\title{
À LUZ DO CANDEEIRO E O CONSTRUCTO DO ‘EU' FONTE: EDUCAÇÃO PELA ARTE, CIÊNCIA E POLÍTICA
}

\author{
http://dx.doi.org/10.5902/2318133866773
}

\author{
Edilson Fernandes de Souza ${ }^{1}$
}

\section{Resumo}

Esta tese de natureza autobiográfica intenta responder ao seguinte questionamento: Qual é a percepção que tenho da minha trajetória de vida desde as séries iniciais à universidade, em relação aos campos artístico e acadêmico-científico e as disposições políticas decorrentes entre 1975 e 2020? Para tanto, a temporalidade autobiográfica corresponde ao início do processo de escolarização numa instituição pública, Escola Municipal de 1ำ Grau Marechal Arthur da Costa Silva, na cidade de Jaboatão dos Guararapes/PE, com o fechamento correspondendo a um ciclo político experimentado na Universidade Federal de Pernambuco - UFPE - e o processo de ritual de passagem para o estágio mais elevado na carreira docente no Brasil: o de professor titular, motivação central deste estudo. A trajetória é demarcada por campos que envolvem a educação, a arte, o ambiente acadêmico, a ciência e a política, cuja hipótese diz respeito a minha transmigração do campo artístico ao acadêmico-científico. Para confirmação dessa hipótese, estabeleci três objetivos, sendo: 1) contribuir com o debate acerca do método (auto)biográfico enquanto instrumento de pesquisa e seu impacto em memoriais discursivos; 2) construir e analisar a autonarrativa, focando nas ações que perpassaram a minha ambientação escolar, artística, acadêmico-científica e política e 3) levantar e analisar diferentes tipologias de fontes que evidenciam a minha mudança de trajetória e a imersão nas atividades científicas e participação na política institucional. Considerando o método (auto)biográfico, em momentos diferentes, gravei $5 \mathrm{~h} 20 \mathrm{~min}$. de áudio, mediante roteiro por mim previamente estabelecido, e utilizei da entrevista que havia concedido anteriormente ao Laboratório de História Oral e da Imagem, em 2009, com tempo aproximado de $2 \mathrm{~h} 14 \mathrm{~min}$. Além disso, trouxe para análise massa documental e iconográfica do arquivo pessoal e de diferentes acervos institucionais - escolas, universidades, plataforma do CNPq/currículo Lattes, blogs e jornais online -, bem como a minha produção acadêmica: livros, capítulos de livros, artigos em periódicos científicos e anais de congressos. A análise foi realizada a partir dos seguintes marcos conceituais: configuração, sublimação, campo de produção, habitus, individualização, outsider, estratégia e tática, objetivação e subjetivação; que corroboraram a autonarrativa, cujo resultado é o diagrama constructo do 'eu' fonte desenvolvido por meio da linguagem científica na transmigração que consegui realizar no itinerário entre a escola, a arte e a vida acadêmica.

Palavras-chave: autobiografia; itinerário; vida acadêmica; habitus negro; memórias; constructo do 'eu' fonte.

\section{IN THE LIGHT OF THE LAMP AND THE CONSTRUCT OF THE 'I’ SOURCE: EDUCATION THROUGH ART, SCIENCE AND POLITICS}

\section{Abstract}

This thesis of an autobiographical nature attempts to answer the following question: What is my perception of my life trajectory from the initial grades to the University, the artistic, academic-

\footnotetext{
1 Universidade Federal de Pernambuco, Brasil. E-mail: edilson.souza@ufpe.br.
} 
scientific field and the political dispositions that ensued between 1975-2020? Therefore, autobiographical temporality corresponds to the beginning of the schooling process at a public institution, Municipal School of 1st Degree Marechal Arthur da Costa Silva, in the city of Jaboatão dos Guararapes/PE, as well as the closing of a political cycle experienced at the Federal University of Pernambuco - UFPE - and the ritual process of moving to the highest stage in the magitery career in Brazil, Full Professor, central motivation of this study. The trajectory is demarcated by fields involving education, art, the academic environment, science and politics, whose hypothesis concerns my transmigration from the artistic field to the academic-scientific one. To confirm the hypothesis, three objectives were estabilished: 1) contribute to the debate about the (auto) biographical method as an investigation tool and its impact on discursive memorials; 2) build and analyze self-narrative focusing on actions that went through my school, artistic, scientific and political environment and 3) survey and analyze different types of sources that show my change in trajectory and immersion in scientific activities and participation in institutional policy. Considering the (auto)biographical method, at different times, I recorded 5 h20 (five hours and twenty minutes) of audio using a script I had previously established, and used the interview I had previously given to the Oral History and Image Laboratory, in 2009, with an approximate time of $2 \mathrm{~h} 14 \mathrm{~min}$. In addition to this, I brought for analysis a documentary and iconographic mass of the personal archive and of different institutional collections - schools, Universities, CNPq platform/curriculum Lattes-, blogs and online newspapers -, as well as my academic production: books, book chapters, articles in scientific journals and congress proceedings. The analysis was carried out from the conceptual frameworks configuration, sublimation, production field, habitus, individualization, outsider, strategy and tactic, objectification and subjectivation, which corroborated with the selfnarrative, the result of which is the constructive diagram of the ' $l$ ' source developed by through the scientific language in transmigration that I managed to accomplish in the itinerary between school, art and academic life.

Key-words: autobiography; itinerary; academic life; black habitus; memories; construct of the 'I' source. 


\section{Para começo de conversa}

luz do candeeiro e o constructo do 'eu' fonte: educação pela arte, ciência e
política passou a ser escrita a partir do momento em que recebi a confirmação
de que estaria apto à classe de Professor Titular ${ }^{2}$. Todavia, para o acesso a essa classe de professor na Universidade Federal de Pernambuco -UFPE -, exige-se um memorial descritivo ou uma tese acadêmica inédita ${ }^{3}$. No primeiro caso, o candidato relaciona por ordem cronológica e por grupos de atividades de ensino, pesquisa, extensão e gestão, o que for possível e mais relevante num determinado interstício com documentação comprobatória de sua atuação na carreira.

Para ser um Professor Titular - à lente do termo latino legente, que lê -, normalmente, o docente faz de maneira sucinta um preâmbulo de natureza conceitual a respeito da memória ou o próprio método da história de vida, como forma de explanar sequencialmente as atividades realizadas no decorrer de seu ingresso e permanência na instituição. Entretanto, sem demérito, pela própria natureza do instrumento, no memorial descritivo não há necessidade de aprofundar questões teóricas, os procedimentos, as questões centrais a serem resolvidas como num projeto de pesquisa científica, que requer um modelo de estudo, com os objetivos, as hipóteses de trabalho e as teorias.

Por outro lado, além desses aspectos formais de uma pesquisa, segundo a resolução n. 03/2014, art. 22, da UFPE, a exposição do candidato a esse título por meio da defesa pública da tese terá que cumprir três requisitos básicos fundamentais, sendo: I Domínio do tema que tenha dado sustentação ao trabalho; II - Ineditismo, mérito e originalidade da tese apresentada e III - Contribuição da tese ao desenvolvimento científico da área do docente.

Considerando esses elementos, a tomada de decisão para escrever uma tese e não o memorial descritivo se deve ao fato de querer propor ao ambiente administrativoinstitucional algo que possa ser compreensivo à luz dos aspectos teóricos, bem como possa trazer um conjunto de informações documentadas acerca de uma trajetória de vida iniciada em 1965 e impactada pelo ambiente escolar e acadêmico entre 1975 e 2020, marcada por vários momentos importantes, relacionados com a arte, a ciência e a política.

Boa parte dessa trajetória também pode ser lembrada a partir do meu ingresso, por concurso público, numa instituição de ensino superior como professor auxiliar na Universidade Federal de Uberlândia, em Minas Gerais, em 1993. Foi nesse período que passei a compreender e a me firmar em campos ainda pouco experimentados, notadamente da ciência e da política institucional.

É óbvio que alguns acontecimentos antecedentes a 1993 fazem parte do que foi possível desenvolver nos primeiros anos nessa universidade, ou seja, têm impacto no modo e na forma de agir em relação a determinados problemas e a ver, em certa medida, com alguns percalços encontrados no próprio campo acadêmico nos meus primeiros anos de atividade, seja por não compreender o que de fato seria uma instituição universitária de natureza pública federal, seja por falta de informações por parte da própria instituição ao postulante/ingressante no cargo de docente.

\footnotetext{
2 Refiro-me à portaria de nomeação da progressão funcional de professor associado III para Professor Associado IV, da Universidade Federal de Pernambuco, possibilitando, dessa forma, a última progressão vertical, o acesso à classe de professor titular.

${ }^{3}$ Esses dois instrumentos são os pré-requisitos exigidos pela Resolução 03/2014, Consuni/UFPE.
} 
Para quem vive neste campo, não é nenhuma novidade dizer que a gente aprende a ser professor no exercício do ofício, é algo que se aprende no dia a dia, sendo, fazendo e partilhando sentimentos, reflexões e problemáticas institucionais. No entanto, trazemos à universidade muitas coisas que incorporamos do senso comum, mas que não funcionam no campo acadêmico. Nesse ambiente, todo mundo é sabedor, autônomo, independente, experto e dono de um pequeno pedaço: sala, laboratório, equipamentos, alguns livros etc.

Destarte, foi pensando no tempo vivido em ambientes escolares, artísticos e acadêmicos e nos contratempos a eles conferidos que resolvi escrever uma tese para submissão ao processo ritual de passagem para a categoria mais elevada na carreira docente a partir da autobiografia. Inspirado em Eco (1994), para quem uma experiência pode ser tratada cientificamente, procurei fazer este trabalho na perspectiva autobiográfica, não como gênero literário, mas como teoria de uma narrativa de mim mesmo a partir do meu discurso e de um conjunto de documentos arrolados que desenrolaram a minha estada, sobretudo no campo acadêmico, e tornaram possíveis a ocupação de cargos, afastamentos funcionais para participação em eventos e a realização de doutorado, pós-doutorado etc.

Não obstante, Eco (1994) também adverte para o fato de que uma tese terá sempre um caráter original, de descoberta de novos sentidos, especialmente no campo das Ciências Humanas, em que a partir do manuseio de documentação pode ser encontrada "a identificação de um manuscrito que lança nova luz sobre a biografia de um autor" (p. 2). E é dessa forma, portanto, que pretendo apresentar este estudo, jogando luz sobre a minha própria trajetória.

Comumente, vemos trabalhos biográficos acerca de grandes homens e mulheres, pessoas que são reconhecidas socialmente e relevantes no mundo, que são conhecidas ou reconhecidas no meio artístico, como as celebridades; meio acadêmico, como grandes intelectuais; ou, ainda, no campo empresarial, como os milionários. Normalmente, nós não vemos biografias publicadas de pessoas desconhecidas, anônimas, como eu.

Contudo, qual seria a importância da minha autobiografia se eu sou conhecido apenas por mim mesmo? Eu me conheço e me reconheço como um indivíduo, mas não sou conhecido e muito menos reconhecido pela maioria da população brasileira, por um conjunto de intelectuais de outras universidades e nem pelo trabalho que desenvolvo, até porque poucas pessoas realmente sabem o que faço no meu cotidiano.

Então, por que vale a pena conhecer a minha vida, a minha trajetória? O que as pessoas poderiam aprender com a minha fala, os meus gestos ou com a percepção que tenho sobre as coisas da vida, da minha trajetória escolar e acadêmica, minha vida artística e política? Seguindo esse raciocínio, esta e outras autobiografias, talvez, sirvam para muito pouco, principalmente quando Bourdieu (2005) diz que a biografia é trivial e enganosa. Entendo o trivial no sentido de que a maioria de nós fala constantemente o que faz e como faz determinadas coisas, e enganosa porque boa parte do que falamos sobre nós mesmos, 'inventamos e fantasiamos', embora não seja possível inventar e fantasiar sempre, a menos que se seja esquizofrênico. Mas, guardadas as devidas proporções, uma vida, seja ela qual for, a de um analfabeto, grande intelectual, empresário ou celebridade, é sempre única; portanto, é essa unicidade, esse caráter singular, que me possibilita a falar como experiência pessoal, única, e de forma científica. 
Nessa perspectiva, este estudo se justifica pela própria natureza do método biográfico. Pelo fato de que se encontram na literatura consideráveis investigações acerca da vida de professores, sua trajetória e construção de identidade, muito importantes para a compreensão desse profissional. $\mathrm{O}$ estudo em tela é um modesto, mas significativo contributo à produção científica sobre esse tipo de assunto, que a biografia tem levado muitos pesquisadores a se interessarem pela vida desses profissionais da educação, quando não eles próprios, como faço agora, tentam alimentar o espírito científico escrevendo acerca de sua própria vida.

Outra justificação plausível para a produção deste trabalho marca a extraordinária oportunidade que tenho de agradecer a escola pública e a comunidade acadêmica, que contribuíram para o sucesso da minha trajetória, causando mudanças em minha vida profissional e, em muitos momentos, trazendo impactos importantes na vida pessoal, no acúmulo de capital social, cultural e simbólico. Fiquemos por aqui, porque do capital financeiro pouco ou nada consegui até o momento.

Não obstante, esta também é uma oportunidade que tenho de olhar para trás e ver o quanto consegui fazer por outros indivíduos em seu processo de mudança na aquisição de saberes na graduação e, especialmente, na pós-graduação. No exato momento de escrita deste parágrafo, construído no amanhecer do dia 24 de novembro de 2018, às 5h30min., contabilizo junto ao Currículo Lattes a orientação de 32 mestres, 18 doutores e uma supervisão de pós-doutoramento. A maior parte dessas orientações advém da minha inserção no Programa de Pós-Graduação em Educação, no Núcleo de Teoria e História da UFPE. Essa é uma boa razão para aliar pesquisa científica de natureza biográfica em resposta ao que já venho desenvolvendo, por meio da instituição universitária na formação de recursos humanos de excelência.

Em certa medida, escrever esta tese é um ato político - lato sensu do termo -, uma vez que compartilho de ideias e sentimentos, buscando despertar o sentido que a educação tem na transformação de indivíduos, ao mesmo tempo que apresento um quadro das relações sociais no âmbito das instituições educativas, no meio artístico e no campo acadêmico por onde passei.

Dessa maneira, posso garantir que o leitor tem em mãos um estudo de autonarrativa, com documentação comprobatória e analisada à luz de teorias sociais de dois autores que têm me orientado nessa trajetória: Norbert Elias e Pierre Bourdieu. Cada um a seu modo influenciou o que tenho discutido nos meus alfarrábios e o que fiz junto aos estudantes, que me concederam a excelente oportunidade de tê-los como interlocutores de saberes populares, acadêmicos e científicos. As teorias desenvolvidas por esses autores, junto a Michel de Certeau, outro autor de minha preferência, estruturam esta tese ao fornecerem categorias ou marcos conceituais como habitus, campo, capital cultural, capital social, configuração, sublimação, estratégia e tática.

$E$, considerando os marcos conceituais e pressupostos desses e de outros pesquisadores das Ciências Humanas e Sociais, apresentarei ao final deste estudo um diagrama, que chamo de constructo do 'eu' fonte, para reafirmar as evidências percebidas em meu percurso, e o farei no intuito de refletir sobre as 'falas por mim escritas' e por indivíduos e instituições que falaram ao meu respeito, na dispersão e unicidade durante a minha trajetória. 
Então, motivado em me compreender enquanto indivíduo na sociedade de meu próprio tempo, percebo que até a conclusão desta tese decorreram 27 anos de trabalho nesse mundo de densas e profícuas reflexões, devaneios e algumas produções científicas que, sinceramente, espero que tenham servido para despertar nos estudantes de graduação e pós-graduação algum interesse em se tornarem seres mais humanos e com o espírito científico aguçado para transformarem a sociedade. Aliás, este foi o principal e único motivo pelo qual decidi escrever esta tese e produzir um pouco mais de conhecimento para as futuras gerações, ou que possa servir no mínimo de inspiração.

Nesse contexto, o objeto de estudo neste momento é a minha própria trajetória escolar e acadêmica, recortada e contada, dividida entre arte, ciência e a política. Utilizo, para isso, o método autobiográfico, capaz de produzir uma fonte de grande importância e que eu chamo aqui e ali de autonarrativa, culminando no constructo do 'eu' fonte enquanto resultado desta experiência científica. A autobiografia é a própria marca deixada pelas tramas da vida, é a narrativa dos registros intransponíveis, sentidos incorporados num contexto sociocultural específico e numa determinada condição de produção de um discurso. Ou seja, é a escrita de minha própria história, centrada em instituições escolares e acadêmicas, no campo artístico e político.

Contudo, aliei os meus ditos, minhas falas, à pesquisa documental por entender que havia a necessidade de outras evidências sobre as minhas experiências profissionais para a composição deste estudo, não apenas porque os elementos comprobatórios são de grande valor na administração pública e exigidos pela comunidade acadêmica, mas também pelo prazer em rever os registros do meu passado distante e recente e a satisfação de poder dar uma destinação conceitual, assim como a devida visibilidade histórica ao que fiz.

A decisão em utilizar o método autobiográfico se deve às evidências sentidas na minha forma de pensar e de agir, ao autoconhecimento e reconhecimento do que foi possível alcançar nessa trajetória que seguirá nas próximas páginas e que poderia chamar de processo individual, ou seja, mudanças sentidas e evidenciadas não apenas no meu próprio discurso e no meu comportamento, mas também no meu corpo e no meu Currículo Lattes.

A decisão em defender esta tese a partir da autobiografia sugere que há um esforço na diferenciação fundamental entre literatura e ciência, o que, por ora, diga-se de passagem, é deveras difícil pela intrigante relação sujeito-objeto aqui estabelecida. Entretanto, a possibilidade de se ter um projeto científico e não literário caracteriza-se pelo plano de redação e, sobretudo, pelos procedimentos delineados, seja na captação do relato propriamente, na utilização da biografia secundária como evidência na análise ou no arcabouço teórico, apresentado como elemento interpretativo.

Gostaria de registrar que eu já havia tentado experimentar essa perspectiva biográfica anteriormente, na dissertação do mestrado em que gravei a história de vida de 20 dançarinos-atores residentes no Rio de Janeiro (Souza, 1995). Na época, a orientadora Regina Feltran, a quem agradeço neste momento, sugeriu a inclusão de minha própria história como evidência empírica, uma vez que também era participante 
daquele campo - refiro-me à prática artística da dança afro -, no entanto, não tive sucesso, talvez por não compreender o método e não ter conseguido estabelecer, naquela época, o mínimo de distanciamento na relação sujeito-objeto como tentarei fazer neste estudo.

Há de se considerar, contudo, que a utilização da autobiografia para tratar de progressão ou promoção acadêmica não é nenhuma novidade. Silva (2015) apresenta uma infinidade de terminologias e maneiras de se fazer uma escrita de si para galgar status acadêmico, exigida por diferentes instituições. Então, a autobiografia não representa algo novo do ponto de vista acadêmico-científico. A forma não é nova e o método não é novo, nem para ciência e muito menos para a literatura. Outros intelectuais também escreveram à luz desse método para efeito de elevação de seu status acadêmico-institucional. É provável que os primeiros leitores desta tese, que no momento tentam buscar brechas de imperfeições, também tenham elaborado semelhante redação.

Todavia, o que é novo neste trabalho, obviamente, é o conteúdo. O conteúdo é original, e é o que garante a possibilidade da tese. A submissão deste conteúdo a um determinado aporte teórico, bem como um conjunto de entradas ou interpretações também podem justificar o aspecto inovador deste estudo. Aliás, posso garantir também que os escritos que se seguem contam com uma razoável dose de subjetividade construída e constituída nas diferentes relações interpessoais travadas ao longo da minha trajetória. Negar essa subjetividade da minha fala, dos meus gestos, parafraseando Eakin (2019), seria negar a minha identidade narrativa, e essa identidade é única.

Desse modo, às vezes, chegamos a um determinado nível de conhecimento que desejamos criar palavras para melhor expressar os sentimentos, afetos, desafetos e expectativas, mas, na impossibilidade de criá-las, procuramos atribuir novos sentidos às palavras existentes. Por isso, a importância de uma narrativa construída e estruturada com base em nossa própria existência humana, profissional, sobretudo, quando decorridos 27 anos de atividades docentes. Assim, considerando as lembranças que possuo e a documentação mobilizada na perspectiva do constructo do 'eu' fonte, a questão que se coloca é a seguinte: qual a percepção que tenho da minha trajetória de vida desde as séries iniciais à universidade, envolvendo o campo artístico, acadêmicocientífico e as disposições políticas daí decorrentes entre 1975 e 2020 ?

O recorte corresponde a minha primeira matrícula numa escola pública municipal. Foi o início do meu processo de escolarização oficial, de onde parte a documentação com as evidências do antigo curso de $1^{\circ}$ grau, que hoje corresponde ao $1^{\circ}$ ao $9^{\circ}$ ano. Embora o documento escrito e memória estejam em desacordo, o que demonstrarei mais adiante, é o registro oficial da minha entrada no campo da escolarização. E considero 2020 como o ano do fechamento de um ciclo político na Universidade Federal de Pernambuco, bem como a preparação decisiva para a defesa desta tese, numa perspectiva de uma outra 'formatura' acadêmica, de um grau nunca antes pensado (Eco, 1994). Logo, essa temporalidade autobiográfica está pautada entre a experiência vivida e a reconstrução da experiência na escrita que faço sobre mim mesmo em defesa pública.

Contudo, esse é um recorte temporal de médio prazo, demarcado por momentos importantes que precisam ser explicitados no decorrer do trabalho, ou seja, tempos e espaços, datas e cenários que evidenciam mudanças pontuais e estratégicas na forma e no conteúdo de atuação na trajetória. Entretanto, o recorte temporal em estudos 
biográficos tem sido um elemento de razoável questionamento, por isso Goodson (2015) tem advertido para os procedimentos que possam demarcar metodologicamente os estudos dessa natureza.

Segundo ele, a periodização pode ser compreendida em conformidade com a Escola dos Annales, numa perspectiva de longa duração, ou de característica que marcaram uma determinada geração, a exemplo da Segunda Guerra Mundial. Ou entre nós, brasileiros, eu acrescentaria de uma forma muito específica, a Ditadura Civil-Militar. Além disso, a periodização pode ser demarcada pelos ciclos da vida, como nascimento e morte, ou ainda delimitada como o próprio indivíduo enxerga os marcos de sua trajetória, "o tempo pessoal - o modo como cada pessoa delimita fases e desenvolve padrões de acordo com sonhos, objetivos ou imperativos pessoais ao longo do curso da vida" (Goodson, 2015, p. 16).

Considerando esses aspectos, para nortear as evidências autobiográficas, levanto a hipótese de que minha transformação de artista para cientista e político de porte médio na comunidade acadêmica ocorre a partir dos primeiros escritos sobre a dança afro num concurso de monografia promovido pelas Faculdades Integradas Castelo Branco/RJ, em 1990, quando percebi que poderia escrever sobre esse tema mediante à apropriação de uma linguagem diferenciada em relação ao meio artístico em que atuava.

Deste modo, mesmo com a escrita ainda meio tosca, cambaleante na construção das ideias centrais do que seria a arte por mim desenvolvida até aquele momento, começou, então, o processo de distanciamento do campo artístico. O processo de mudança para o campo acadêmico foi lento e só se confirmou mais densamente ao término do mestrado na Universidade Gama Filho/RJ, em 1995, e com o doutoramento na Universidade de Campinas, em 1998.

A consolidação desta mudança aconteceu pelas escolhas e imersão na vida universitária como professor, orientador na pós-graduação, gestor e candidato a reitor da Universidade Federal de Pernambuco. Logo, a transformação ocorreu por meio do desenvolvimento de um habitus acadêmico-científico em contraposição ao habitus artístico, cujos campos se estruturam por meios diametralmente distintos. Embora a criatividade esteja presente nos campos em que esses habitus se consolidam, o método de elaboração, exposição, avaliação crítica e a finalidade dos projetos executados são diferentes.

$\mathrm{Na}$ medida que fui adquirindo capital cultural e social no campo acadêmico, é possível compreender que também fui deixando meus impulsos artísticos e desenvolvendo táticas de sobrevivência no novo campo, o que é facilmente percebido pelos vestígios deixados durante a trajetória. Fui deixando as representações partilhadas por anônimos no campo da arte, para compartilhar ideias, sentimentos e percepções num campo muito específico das ciências e vida acadêmica.

Contudo, reconheço que os dois habitus em algum momento estiveram entrelaçados na interdependência funcional, no processo de compartilhamento sensível das experiências artísticas, científicas e políticas, e transmigrei de um campo onde mantinha torço na cabeça, facão e cobra jiboia nas mãos para o campo onde a caneta e papel, computador e teclado passaram a ser as principais ferramentas de trabalho. 
Como em toda área, no campo acadêmico também há disputa pelo controle do poder. Entretanto, esta autobiografia revela que neste a disputa foi mais acirrada, tensa, velada, desonesta que em outros, tornando-se em alguns momentos, disputa pública, levada, inclusive, às redes sociais. Apesar disso, como estamos numa democracia, boa parte do conteúdo da disputa foi realmente saudável.

Nesse contexto, enredado no campo acadêmico, já tendo desenvolvido o habitus que the é peculiar, minha trajetória de artista e agora cientista foi conferindo maturidade nos avanços e retrocessos, a possibilidade do constructo de uma fonte viva para a composição de um estudo científico. Assim, é na aquisição de uma consciência política e na materialização dos registros das ações acadêmicas em que esse constructo se confirma enquanto experiência autobiográfica.

Nesse sentido, esta tese se explicita por dois eixos distintos e complementares, sendo eles: 1) eixo teórico-metodológico, em que busco situar historicamente a biografia, seu significado, nuances e problemáticas, sua relação com a literatura, método e fonte de pesquisa, além de explicitar de maneira descritiva os aspectos técnicos do estudo, os meus procedimentos e as minhas fontes; 2) eixo autobiográfico, traçado pela construção da narrativa registrada, gravada e materializada a partir das memórias antecedentes e posteriores a 1975, impulsionadas no meu trajeto escolar e acadêmico até 2020, construída exclusivamente para ancorar o projeto desta tese.

Além disso, o último eixo traz um levantamento documental, ou biografia secundária, referente a minha participação como personagem principal da narrativa, estruturado na periodização definida e submetido à análise na corroboração das lembranças no campo da configuração escolar, artística e acadêmica. Chama-se biografia secundária por não ter sido produzida inicialmente com a finalidade de pesquisa.

É óbvio que a documentação aqui arrolada faz parte de uma seleção dos momentos mais relevantes, pelo menos a meu julgamento, e que pode realçar o enredo representado na minha trajetória. Os capítulos que se seguem não apresentam uma cronologia ou sequência lógica linear, a não ser o impulso das minhas lembranças e da própria escrita, meu estilo. Aliás, como tenho feito nos meus trabalhos acadêmicos, seguindo sempre meus impulsos, o resultado são trabalhos escritos de uma só vez que não ultrapassam dois anos.

Esses impulsos também se apresentam na simultaneidade das minhas ações. Foi, inclusive, de forma simultânea, por meio do impulso, que consegui escrever em três meses as primeiras 164 páginas desta tese. Todavia, em resposta às questões centrais e os eixos aqui estabelecidos, formulei os seguintes objetivos:

1) Contribuir com o debate acerca do método (auto)biográfico enquanto instrumento de pesquisa e seu impacto em memoriais discursivos. Assim, pretendo obter informações relevantes sobre a origem do método, sua inserção em trabalhos acadêmicos e os procedimentos usados no momento da construção da narrativa enquanto fonte que me constituo.

2) Construir e analisar a autonarrativa, focando em ações que perpassaram a ambientação escolar, artística, científica e política, entre 1975 e 2020. Este é o momento em que colaboro com a gravação e transcrição das minhas memórias, e o faço a partir da 
exposição completa, para que o leitor compreenda as nuances da minha fala, veja as lacunas, o não dito e identifique as táticas necessárias para a minha permanência nos campos pelos quais passei.

3) Levantar e analisar diferentes tipologias documentais que evidenciem a minha mudança de trajetória, a imersão nas atividades científicas e a participação na política institucional. Os documentos impressos, fotográficos e os fragmentos da narrativa oral permitem vislumbrar um enredo contado pelo indivíduo que sou, sujeito e objeto de mim mesmo, que corroboram o constructo do 'eu' fonte.

Nesse contexto, em atendimento aos objetivos, o primeiro capítulo, Do quadro teórico figuracional no campo e dos procedimentos (auto)biográficos, está subdividido em quatro seções: Pequeno ensaio para efeito de interpretação; Biografia: do discurso panegírico à fonte historiográfica; Teses (auto)biográficas e a natureza da narrativa de si; O campo e os procedimentos (auto)biográficos.

Assim, ancoro uma rápida discussão acerca dos autores que sustentam a análise e interpretação da minha trajetória de vida e faço um breve levantamento da literatura sobre o método biográfico, indicando os aspectos históricos, autores e problemáticas pelos quais passa esse tipo de abordagem científica. Analiso, ainda, as situações ancoradas em narrativas elogiosas, sobretudo do discurso panegírico, que devota respeito e admiração por um indivíduo em especial, bem como sua importância à construção de fonte para a pesquisa historiográfica.

Nesse capítulo também recorro à descrição dos momentos da escrita desta tese, ou seja, faço um breve relato de como procedi na construção da autonarrativa, na qual tempo, lugar e lembranças ganham força nos registros para posterior transcrição e reescritas. Além disso, mostro detalhadamente outras fontes utilizadas, como a biografia secundária e sua análise. Todo esse material não aparece para confrontar, mas para corroborar as lembranças da trajetória, embora eu perceba que às vezes a memória seja mais fidedigna do que o impresso ${ }^{4}$.

No segundo capítulo, À guisa das memórias, precisei subdividir em cinco seções: Antecedentes autobiográficos: sete escolas públicas, uma formação humana; Um parêntese na memória: arte e ciência; No Rio de Janeiro: teatro, academia de dança; Em Uberlândia/MG: teatro, academia, universidade; Em Pernambuco: permanência e mudança de habitus.

Nessas seções, as experiências educacionais, artísticas e políticas são narradas para explicitar os meandros de uma trajetória no que diz respeito à formação humana, aos desafios encontrados e superados no próprio percurso e como isso se soma às astúcias na tomada de decisão para a manutenção do trajeto, que levou ao meu ingresso no campo acadêmico.

\footnotetext{
${ }^{4}$ Refiro-me ao histórico escolar do curso de $1^{\circ}$ Grau, onde constam notas relativas à $1^{\text {a }}$ série realizada na Escola de 1ํㅡㅁau Centro Educativo Operário Agamenon Magalhães, em 1973, bairro de Água Fria, no Recife, quando, na verdade, minhas lembranças dão conta de que nesse ano eu iniciava a $3^{\underline{a}}$ série na Escola Municipal Marechal Arthur da Costa e Silva, bairro de Prazeres, em Jaboatão dos Guararapes/PE.
} 
O capítulo é construído basicamente pela autonarrativa gravada, transcrita e reescrita, para permitir melhor compreensão da trajetória de vida entre a arte, a ciência e a política. Portanto, é um capítulo de base autobiográfica, produzido especialmente para a finalidade desta tese, de modo que os capítulos seguintes sejam cotejados pelas informações constantes nessa fonte oral.

O capítulo está periodizado de forma cíclica-linear e, embora considere 1993 o marco de entrada na vida acadêmica, quando comecei como professor universitário, precisei fazer recuos temporais táticos, para compreender as frustrações e os desafios superados no processo de escolarização desde as séries iniciais, o que só foi possível por meio de uma narrativa que chamei de antecedentes autobiográficos, anteriores a 1975, ano da primeira matrícula numa escola domiciliar num bairro pobre de Jaboatão dos Guararapes/PE e, posteriormente, numa escola pública desse município.

O terceiro capítulo, Do capital escolar-cultural aos penduricalhos institucionais, foi dividido em duas seções: Aquisição de capital escolar-cultural e Penduricalhos: capitais em processo de aquisição. Assim, faço uma análise de diferentes fontes sobre a minha vida escolar e acadêmica, e o que foi possível agregar valor ao capital cultural adquirido durante a trajetória. A análise traz importante reflexão acerca da relação ensinoaprendizagem e os pequenos desafios enfrentados a partir das disciplinas escolares, conceitos e formas de avaliação numa direção específica de alcance a estratos mais elevados da escolarização.

O capítulo é bastante inspirador, no que se refere ao método aqui empregado, porque ele foi construído a partir de fontes oriundas do meu arquivo pessoal no intercruzamento com arquivos institucionais das escolas e universidades, o que fortalece a ideia de interfaces ou interdependências estabelecidas em ambientes diversos, tendo o indivíduo autobiografado como o epicentro das evidências. Foi no manuseio de diferentes arquivos da minha trajetória de onde partiu a ideia do constructo do 'eu' fonte, elemento central da tese.

No quarto capítulo, O campo e os quadros autobiográficos do Lattes, a análise se concentra no suporte de registro das atividades acadêmicas e artísticas-culturais exigido pelo Conselho Nacional de Desenvolvimento Científico e Tecnológico - CNPq. Como o Currículo Lattes tem um caráter essencialmente autobiográfico, analiso a forma como tento me inserir na comunidade científica e a relação estabelecida com outros pesquisadores das Ciências Humanas e Sociais.

Nesse capítulo, apresento, ainda, as primeiras publicações da minha entrada mais efetiva no campo acadêmico, em 1993, bem como as últimas produções de 2018, que estabeleci como marco para efeito de análise dessa importante documentação autobiográfica.

No quinto capítulo, Dos livros e capítulos da minha trajetória, apresento resumidamente algumas publicações que fiz durante o percurso no campo acadêmico, individualmente ou em parcerias, mas sempre visando a circulação das minhas ideias por meio desse tipo específico de publicação. Esse é o ambiente em que escrevo e me inscrevo como intelectual atento aos diversos temas da História e Sociologia, reafirmando essas áreas de impacto na minha formação e intervenção profissional. Nesse capítulo também falo rapidamente o que me levou a publicar essas obras, bem como o meu sentimento em relação aos conteúdos que fiz circular em determinado momento. 
No sexto capítulo, Habitus negro em território branco, tento mostrar como me vejo, como os outros me veem e como reajo aos percalços da vida. Inicio essa parte do trabalho com dois poemas que aprendi quando tinha uns 17 anos de idade. Aqui, os documentos utilizados são: uma matéria de jornal publicada sobre minha história de vida, uma crônica escrita por uma ex-orientanda de mestrado e doutorado, fotografias, bem como uma entrevista que concedi a um projeto de pesquisa sobre a negritude pernambucana na década de 1980.

Nesse capítulo, também analiso o conceito de habitus e como compreendo sua aplicação na trajetória que construí. Mesmo que seja um capítulo curto, na verdade, foi por onde comecei os primeiros escritos desta tese, ponto de inspiração para o que consegui elaborar teórica e empiricamente no conjunto geral deste estudo.

Para o sétimo capítulo, $O$ campus em disputa: da ciência à política institucional e as teias do poder, foram necessárias três gravações em momentos distintos, e faço o manuseio de documentos que marcam os registros da política institucional em que tive a experiência enquanto docente na Universidade Federal de Uberlândia e Universidade Federal de Pernambuco. Além disso, trago os registros relacionados a minha participação como gestor público e como candidato a reitor por duas vezes. Essa é uma parte do trabalho onde tento, sem sucesso, ser menos emotivo, em que exponho os êxitos e os equívocos das decisões em que tomei em nome de um projeto de universidade, articulando junto a um grupo de intelectuais outsiders.

Mesmo com as dificuldades próprias da voz embargada, o capítulo está subdividido em três seções: Para voar mais longe!; SomosTodosUFPE de mãos dadas! e Largaram as minhas mãos! As razões desses títulos são óbvias.

Apesar dos tópicos tratarem do mesmo tema política-institucional, os momentos aos quais se referem são distintos, com flagrantes tensões e discórdias entre os personagens mobilizados para o desvelar da trama política. Desse modo, foi necessário arcar com a ideia da privacidade, mais do que em outros capítulos. Assim, os indivíduos receberam nomes fictícios para o resguardo de suas identidades.

No oitavo e último capítulo, O campo autobiográfico e o constructo do 'eu' fonte, dividido nas seções Aspectos gerais do constructo e Do constructo às fontes, analiso a minha trajetória a partir de vários conceitos teóricos com vistas a fortalecer a hipótese da tese e formular a ideia do indivíduo enquanto fonte de análise de si mesmo, por meio dos seus produtos e patrimônios historicamente construídos e adquiridos num campo determinado. É o momento em que apresento uma tipologia de fontes fornecidas pelos diferentes arquivos de um 'proprietário' na escrita de si. Além disso, considerando as transmigrações de território e de campo de produção, explicito a hipótese levantada de um habitus acadêmico que se reafirma no constructo do 'eu' fonte, a partir de uma dispersão documental em busca da sua unicidade.

Destarte, enquanto desfecho da recordação de uma trajetória de vida, ponho em destaque um diagrama do constructo das fontes que me constituem na dispersão pelos campos por onde passei, resultado, portanto, da percepção adquirida por meio da relação teórica e empírica e da consciência despertada por uma temporalidade narrativa, onde me faço sujeito e objeto deste estudo. 


\section{Capítulo 1 - Do quadro teórico figuracional no campo e dos procedimentos (auto)biográficos}

Compreender a gênese social de um campo, e apreender aquilo que faz a necessidade específica da crença que o sustenta, do jogo de linguagem que nele se joga, das coisas materiais e simbólicas em jogo que nele se geram, é explicar, tornar necessário, subtrair ao absurdo do arbitrário e do não-motivado os actos dos produtores e as obras por eles produzidas. (Bourdieu, 1989, p. 69)

Este capítulo tem por objetivo apresentar uma discussão geral acerca das questões teóricas que envolvem a análise deste estudo autobiográfico. Além disso, o capítulo é cotejado por um conjunto de informações e interpretações relativas ao método aqui empregado a partir dos procedimentos da pesquisa e as tipologias das fontes utilizadas, seja no contexto da autonarrativa, seja para efeito da biografia secundária, enquanto composição da minha trajetória de vida no campo escolar, artístico, político e acadêmico. Para tanto, trago para a discussão autores contemporâneos e autores clássicos da História e da Sociologia que tentam elucidar os meandros envolvendo o método aqui desenvolvido e os procedimentos e decisões tomadas no campo, para efeito da construção de uma fonte.

\section{Pequeno ensaio para efeito de interpretação}

Para efeito de análise e interpretação do corpus documental ou outro artefato conjugado para a finalidade de estudo, como a autobiografia aqui definida e como objeto de estudo desta pesquisa, sempre nos deparamos com as teorias no sentido de jogar luz aos diferentes problemas afetos ao método científico. Pensando nesses elementos, Almeida e Pinto (1995), de maneira muito particular, expõem os aspectos centrais da Sociologia do Conhecimento e da Epistemologia. Os autores supracitados sinalizam o impacto que a produção científica recebe das condicionantes histórico-sociais e propriamente teóricas. Das primeiras, eles inferem a força das múltiplas estruturas e práticas sobre o exercício científico e, consequentemente, sobre os agentes responsáveis pela produção do conhecimento. Ou seja, como as condições sócio-históricas afetam a produção e o produto daí decorrente: o conhecimento.

Já as condições teóricas dizem respeito a duas questões fundamentais de maneira articulada. Por um lado, a formulação de problemas elencados por uma formação científica em particular e, por outro, os diferentes métodos, técnicas e modelos de análise desenvolvidos por uma dada formação científica, coloraria das próprias formulações demandadas pela sociedade e, consequentemente, pelos indivíduos que nela estão imersos.

Baseado numa linguagem mais eliasiana, as condições histórico-sociais da produção do conhecimento, bem como as condições teóricas desenvolvidas pelos cientistas, são funcionalmente interdependentes e podem ser traduzidas pelo conjunto de desenvolvimento social mais geral atingido pela sociedade. Ou seja, essas transformações e mudanças são possíveis de compreensão a partir do que Elias e 
Dunning (1992) chamam de a tríade dos níveis de controle básicos, sendo: a) o controle sobre os aspectos da natureza, da ciência e tecnologia; b) o controle que os indivíduos exercem uns sobre os outros; e c) o desenvolvimento do autocontrole, o mais decisivo no processo civilizacional.

Numa alusão mais explícita às questões postas por Elias $(2005,1994 a)$, não há cientistas e produto de seu trabalho de um lado e sociedade que demanda as problemáticas do outro, de forma antagônica e sem a devida interveniência das ferramentas utilizadas pelos primeiros a partir e, conjuntamente do desenvolvimento social atingido por uma dada configuração, aqui, nomeadamente, configuração social ou científica.

Dessa maneira, compreender o conceito de figuração é fundamental para se ter uma ideia mais precisa do indivíduo e da relação interdependente com a sociedade. Aliás, esse conceito contribui para se eliminar as dicotomias existentes no pensamento da Sociologia Clássica, porque ele está voltado para o ser humano e sua interdependência funcional (Elias, 2001). Trata-se, portanto, de se ter não apenas uma mera reflexão teórica, mas, sobretudo, uma questão de método, que pressupõe um conjunto de procedimentos requeridos frente aos problemas empíricos nessa relação imbricada do indivíduo enquanto sociedade:

Caso se chegue a efetuar o procedimento do distanciamento, fica-se em condições, nos degraus da escada espiral da consciência, de se reconhecer a si próprio, aparentemente no degrau precedente, enquanto homem entre outros homens, e de reconhecer a sociedade como uma figuração constituída de numerosos indivíduos fundamentalmente interdependentes, ou seja, tributários e dependentes uns dos outros; só então se é capaz de superar intelectualmente a polarização entre indivíduo e sociedade. (Elias, 2001, p. 149)

O autor chama a atenção para o nível de consciência atingido pelos indivíduos numa determinada sociedade, mas, sobretudo, a consciência que os pesquisadores precisam ter de si mesmos na elaboração de suas pesquisas, no sentido de se compreender enquanto indivíduos partícipes de uma determinada figuração social, ou seja, um indivíduo entre tantos outros de seu tempo, tributário e interdependente, conforme Elias (2001).

A Sociologia, enquanto ciência que estuda os indivíduos em sociedade (Elias, 2005), é constituída por procedimentos metódicos amparados fortemente por uma reflexão densa que procura compreender as regularidades e intermitências das múltiplas relações interpessoais e intergrupais. Antecipadamente, ela parte de um modelo explicativo da realidade social, seja por meio de marcos conceituais elaborados por um determinado pesquisador frente à realidade empírica, seja por aquisição presente, historicamente, na própria tradição do fazer sociológico.

Na vasta obra publicada pelo autor, que não cabe destrinchá-la aqui, pelo propósito e limitações desta tese, é possível verificar sua preocupação com os problemas de seu tempo, como também as questões observadas na digressão de um processo social a longo prazo. No fundo, problemas teórico-práticos que lhes eram apresentados e que 
situavam-se no campo da história da humanidade, envolvendo seu desenvolvimento e sua evolução. Não no sentido do progresso tecnológico, mas na amplitude e complexidade do comportamento, da emoção e da violência social; aliás, elementos esses tão presentes na sociedade contemporânea.

Nesse aspecto, o conjunto de sua obra problematiza a polidez das condutas, da formação da personalidade social e do caráter e a criação dos Estados-nacionais, bem como as formas organizativas das diferentes práticas e funções dos indivíduos em comunidades humanas (Elias, 1993). Parte de seu esforço no processo de produção do conhecimento sociológico se direciona para a eliminação das dicotomias, ou, como ele próprio explicita, dos conceitos reificantes (Elias, 2005), que mais ofuscam do que evidenciam as relações estreitas do indivíduo e sociedade, os processos sociais, as transformações e mudanças no comportamento dos indivíduos e as alterações nas estruturas sociais específicas, que podem nos fazer compreender a sociogênese e a psicogênese de determinadas sociedades, por exemplo:

A sociologia trata de pessoas; as interdependências que ocorrem entre elas são o seu problema central. O termo 'relações humanas' evoca muitas vezes ideia do dia a dia, da experiência de hora a hora, que se processa dentro do círculo restrito que nos inclui a nós, à nossa família e ao nosso emprego. Mas temos consciência do problema criado pela possibilidade de centenas, milhares e milhões de pessoas poderem estar relacionadas umas com as outras e dependentes umas das outras, mesmo que isto possa acontecer no mundo moderno. (Elias, 2005, p. 109)

Com essas reflexões, o autor tenta fazer um alerta para o fato de que a infinidade de relações humanas, especialmente a interdependência funcional estabelecida entre os indivíduos agindo numa determinada direção, sem, no entanto, causar individualmente e deliberadamente transformações e mudanças, é o objeto de estudo da Sociologia. Cabe, portanto, ao sociólogo estudar essa multiplicidade de relações dentro de um grupo ou sociedade determinados. Contudo, para Elias (2005), essa compreensão só é possível mediante a digressão social, especialmente a longo prazo, e a eliminação de determinados conceitos preconcebidos pela Sociologia clássica.

Assim, desvelar a trama das múltiplas relações sociais é uma das principais tarefas da Sociologia, é o que Elias (2005) chama de configuração. Para ele, uma configuração existe em virtude da interdependência funcional das pessoas que dela tomam parte, de modo que, no conjunto dessas relações, não é possível valorizar apenas o indivíduo ou, por outra parte, apenas a sociedade. Aliás, esse conceito é introduzido para expressar que o indivíduo e a sociedade não deveriam ser analisados separadamente, como se um existisse contrário e independente do outro.

Uma análise sociológica mais consequente, que não trouxesse prejuízo a esse ramo da ciência, deveria considerar que não é possível estudar uma pessoa separadamente e depois incluí-la no que se pode chamar de sociedade, como se aquela fosse um objeto diametralmente diferente do conjunto de pessoas vivendo de maneira interdependente. Logo, "o conceito de configuração serve, portanto, de importante instrumento conceptual que tem em vista afrouxar o constrangimento social de falarmos e pensarmos como se 0 
'indivíduo e a sociedade' fossem antagônicos e diferentes” (Elias, 2005, p. 141). Ou seja, como se a existência de um desses 'objetos' só se consolidasse em contraposição ao outro. No fundo, para o autor, o indivíduo e a sociedade são inseparáveis nesse mundo humano.

Compreender essa relação é o que vai demonstrar que não é possível a existência do Homo clausus, um indivíduo vivendo independentemente de outros tantos indivíduos da sociedade. Desse modo, a atenção da Sociologia deve se voltar para o fato de que, inevitavelmente, uma pessoa interdepende de outras, mesmo considerando uma sociedade moderna, que requer vários níveis de unidade e de relações interdependentes, justamente porque os indivíduos são valências abertas e, por várias razões, ligam-se e desligam-se de outros membros da sociedade.

Nessa perspectiva, os indivíduos formam configurações porque são capazes, enquanto valências abertas, de se ligarem e desligarem a outros indivíduos de maneira interdependente. $E$ tais ligações podem ser de várias formas e características, podendo assumir feições numa situação perigo, como questões que envolvem a economia, emoções e afetos, artes, ciência e literatura, bem como as questões acadêmicas e políticas etc.

Pensando nesses aspectos, dois outros conceitos se apresentam na obra de Elias (1998) e que são de grande importância para a pesquisa científica: o envolvimento e a alienação. Esses conceitos são desenvolvidos para a reafirmação do nível de controle e, consequentemente, distanciamento que um indivíduo atinge ou é capaz de suportar frente aos desafios, tensões sociais e, em certa medida, algumas intempéries da natureza. Assim, com relativa consciência, é possível 'predizer' ou prever a real situação pelo qual passa uma determinada realidade social, como uma situação perigo, de vida e morte, por exemplo. "Entretanto, há também processos críticos que já avançaram tanto, que, para os envolvidos neles, não resta qualquer possibilidade de manter intacta sua integridade física e mental nem de assegurar sua sobrevivência" (Elias, 1998, p. 167).

Os conceitos de envolvimento e alienação são interdependentes, relacionais, produtos e processos ao mesmo tempo, o que pode garantir, em certa medida, a sobrevivência de um indivíduo ou de um grupo, mediante o controle emocional disposto num determinado momento. Um dos exemplos clássicos do envolvimento e distanciamento diz respeito aos pescadores no turbilhão do Maelströn, que se envolveram nas ondas circulares do redemoinho sem ter, momentaneamente, onde se agarrar. No entanto, em situações como essas, é preciso um pouco de distanciamento e controle de suas emoções para enxergar o problema em sua complexidade:

Enquanto o irmão mais velho se encolhia desesperadamente no bote, paralisado pela vizinhança do desastre, o mais jovem acalmou-se e começou a observar tudo à sua volta, com certa curiosidade. Foi então, enquanto tudo considerava, quase como se não estivesse envolvido, que notou certa regularidade de movimentos nas peças que estavam sendo arrastadas em círculos, juntamente com o bote. (Elias, 1998, p. 165)

O exemplo é importante porque o autor faz uma explícita referência à formulação de uma teoria a partir do que foi observado por um dos envolvidos no naufrágio, especificamente o irmão mais jovem, mesmo sem muita experiência de vida. Assim, essa 
tomada de consciência de si, juntamente com as regularidades com que o redemoinho movimentava outros objetos flutuantes, levou o irmão mais jovem a se salvar no turbilhão.

Compreender as relações estabelecidas entre o envolvimento e o distanciamento é o que vai levar a compressão de outro marco conceitual de grande importância para a Sociologia eliasiana, o autodistanciamento, o despertar à consciência de si, o que Elias (2001) chama de o lugar ocupado pelo indivíduo no degrau em espiral e, consequentemente, seu olhar para a interdependência funcional em relação a outros indivíduos.

De modo geral, na perspectiva dos processos de longo prazo, na tomada da consciência de si e dos outros, de envolvimento e alienação, o autor está preocupado em compreender o controle dos impulsos, que variam desde os escarros junto à mesa do jantar, durante a Idade Média, por exemplo, à utilização dos talheres nas refeições e, sobretudo, a polidez necessária à vida pública e privada, a partir da disseminação de formas polidas enquanto traços de civilidade e de uma boa educação.

Assim, Elias (1993) também se detém na centralidade dos impostos, no uso da força física enquanto legitimidade de uma configuração específica junto à cortenização dos guerreiros, bem como na capacidade de os seres humanos adquirirem a provisão e previsão dentro da cadeia produtiva, com o alargamento das funções sociais e processos de integração das sociedades pré-estatais. Embora pareça bastante distante para a sociedade contemporânea, esses elementos são passíveis de verificação empírica, na medida em que as instituições sociais são formadas por um conjunto de indivíduos que se mantêm mais ou menos em tensão, com forças "centrífugas e centrípetas" no interior de dada configuração (Elias, 2005).

Ainda no esforço de eliminar as dicotomias e o pensamento reificante, que insiste em colocar as relações sociais independentes sempre em oposição, como o de indivíduo e sociedade, o autor concebe o conceito de outsider, o que está de fora, mas intrinsecamente relacionado com aqueles que estão dentro, os established. De modo que ser outsider não é apenas uma condição ou posição que o indivíduo ocupa num determinado território, participando de determinadas situações. Ser outsider é, além disso, ter o sentimento de estar fora, de fazer parte de outro ambiente, mas sem deixar de ser interdependente de outros indivíduos established. Assim, esse sentimento reflete inevitavelmente na autoimagem do indivíduo de fora de um determinado processo, de um grupo social.

Esses elementos são empiricamente possíveis de aplicação, na medida em que é perceptível indivíduos outsiders conviverem com os estabelecidos, participando do mesmo culto religioso, trabalhando e tendo a mesma remuneração, mas, cuja diferença fundamental de intocabilidade se concentra no fato de os outsiders serem recémchegados numa determinada comunidade, como foi o caso estudado por Elias e Scotson (2000), numa comunidade fictícia que eles chamaram de Winston Parva.

Em outras reflexões acerca dos conceitos reificantes, que enxerga no pensamento sociológico, e na tentativa de resolver a problemática espaço-temporal, além de escrever uma pesquisa sobre a construção social do tempo, Elias (1994a) lançou mão do conceito de habitus, para compreender as formas organizativas a partir de uma história enraizada 
no grupo social de origem dos indivíduos. Talvez por isso, ao escrever a história dos costumes e a formação do Estado-nacional, foi rascunhado o livro que levou 50 anos para ser concluído: $A$ sociedade dos indivíduos.

Nessa obra, é sinalizada a relação intrínseca entre o indivíduo e a sociedade, o singular e o plural, processos que são traduzidos conceitualmente por habitus e individualização. Esses conceitos são possíveis de serem compreendidos mediante a familiaridade com investigações sociológico-processuais em longo prazo, para explicar as diferenças dos seres humanos que vivem na América Latina, na Europa, na África ou na Ásia, por exemplo.

É extremamente útil o emprego de conceitos não dicotômicos para compreender e explicar as relações sociais dos indivíduos, bem como o emprego de termos que melhor deem indicativos de determinados comportamentos e sentimentos desses mesmos indivíduos em determinadas sociedades. Assim, "o conceito de habitus social ainda não faz parte do repertório básico de conhecimentos teóricos que os professores de sociologia e das outras ciências sociais transmitem às gerações mais novas ao lhes darnuma perspectiva da sociedade humana" (Elias, 1994a, p. 172). De modo que a complexidade das relações construídas entre os indivíduos também é cotejada, em última instância, pela estrutura da personalidade social, especialmente quando se trata de níveis de integração das sociedade pré-estatais e de Estados-nacionais.

Segundo o autor, somente a partir de uma metodologia de longo prazo é possível compreender a identidade-nós, o eu social dos povos que habitam determinados territórios, para apresentar soluções de impacto na vida em comunidade. Nesse contexto, Elias (1994a) põe em destaque o conceito de habitus para reafirmar o impacto do passado sobre o presente, e isso não é feito como uma relação puramente causal, mas como processo de continuidade. Esse marco conceitual é extremamente complexo, pois se apresenta à teoria como aquilo herdado pelo indivíduo de seu grupo social de origem, é o que o prende definitivamente a uma coletividade de muitas gerações passadas. É, portanto, o plural, o 'nós' no indivíduo (Elias, 1994a).

Dessa maneira, o habitus pode ser melhor compreendido quando aplicado ao lado de um outro igualmente complexo, que indica singularidade. Ou seja, a individualização. Então, se habitus é o 'nós', que demarca as características identitárias de um grupo social ou coletividade, a individualização é o que difere indivíduos do mesmo grupo entre os seus membros. Assim, a individualização é como o indivíduo se distingue dos demais, é a sua característica psicossocial específica, irrefutável e intransferível.

Considerando esses aspectos, se o habitus é o 'nós', a identidade coletiva de grupos sociais ou de uma sociedade inteira, a individualização é o singular, é a minha identidade, minha forma única de pensar e agir. Todos somos brasileiros, mas a minha forma específica de ser, a maneira com que construo minha trajetória e como sou construído por ela, difere-me de todos os outros brasileiros.

Há, no entanto, quem encontre similaridade entre o habitus eliasiano e o conceito de habitus defendido por Bourdieu (1989). Eu diria que esse conceito é bastante complexo e aparece de maneira muito diferente para os autores. Na síntese eliasiana, a ideia é eliminar as dicotomias estabelecidas pela Sociologia tradicional, em que se conjuga o conceito de habitus a um correspondente para indicar a singularidade. Então, se habitus 
indica o que é o nós num determinado indivíduo e comum a uma sociedade, a individualização indicará o que é peculiar, o que the é próprio, ou seja, aquilo que distingue o indivíduo de seu grupo de origem.

Por outro lado, o habitus, definido por Elias (1994a) permite compreender ainda que, embora haja processos sociais importantes, de transformações e mudanças, algo permanece intacto enquanto composição da sociogênese e psicogênese e da relação entre o indivíduo e sociedade. Então, ao mesmo tempo em que os processos sociais permitem, a partir dos planos e ações individuais, a construção de uma singularidade, daquilo que é próprio ao indivíduo, algo continua, como elementos ou traços da coletividade. Aqui, portanto, o 'nós' e o 'eu' estão imbricados, mesmo considerando que esse 'nós' se expresse eventualmente em contextos bastante específicos, como foi o caso estudado por Elias (1997), na perspectiva do surgimento de um personagem como Hitler.

É compreensível, portanto, que o habitus apresentado pela síntese eliasiana seja cotejado por um outro conceito igualmente importante para demonstrar empiricamente que a estrutura social tem impacto decisivo na personalidade do indivíduo, mas que seus planos e ações são regulados e orientados pela sua singularidade, por aquilo que herdou de sua sociedade de origem, bem como por aquilo que permite expressar a idiossincrasia,

e esse fato, o de cada 'eu' estar irrevogavelmente inserido num 'nós', finalmente deixa claro porque a entremeação dos atos, planos e propósitos de muitos 'eus' origina, constantemente, algo que não foi planejado, pretendido ou criado por nenhum indivíduo. [...] Vez após outra, os atos e obras de pessoas isoladas, entremeados na trama social, assumnuma aparência que não foi premeditada. (Elias, 1994a, p. 57)

Nesse contexto, não importa muito onde esse indivíduo esteja, pois sempre trará consigo o 'nós' indeterminado com ele. Isso explica como indivíduos de sociedades africanas, por exemplo, mesmo tendo sido arrancados e escravizados no processo de expansão dos países europeus, até o final do século XIX, conseguiram ressignificar as culturas concretas de suas origens nas diásporas e manter o 'nós' de seus grupos sociais de origem em outros territórios. Assim, o habitus é compreendido como aquilo que permanece, um contínuum indeterminado. Esse aspecto é fundamental para se compreender que, numa determinada configuração, o indivíduo não está sozinho e sempre trará consigo o 'nós' de seu grupo de origem.

A ideia que reside na teoria configuracional sugere que os indivíduos são interdependentes, orientados uns para os outros, o que reforça a compreensão da intrínseca relação estabelecida entre o indivíduo e a sociedade. Ainda que os indivíduos possuam status ou alguma diferenciação no espectro social, todos são funcionalmente interdependentes. Assim, "cada pessoa nesse turbilhão faz parte de um determinado lugar. Tnuma mesa à qual come, uma cama em que dorme; até os famintos e sem teto são produtos e componentes da ordem oculta que subjaz à confusão" (Elias, 1994a, p. 21).

É nessa perspectiva de compreender a confusão submersa entre os indivíduos e a sociedade e, sobretudo, a relação interdependente dos indivíduos no espectro social que a pesquisa configuracional se apresenta. De modo que, para o autor citado, todos estamos ligados de uma forma ou de outra, ainda que seja no processo de recordação ou 
memória, amigos vivos, perdidos ou mortos, estamos ligados e orientados uns para os outros porque o ser humano é constituído por valências abertas que se ligam e se desligam com outros indivíduos.

Com o desejo de deixar mais evidente a compreensão do 'eu' e 'nós', bem como a ideia de que estamos sempre unidos uns aos outros, é oportuno levantar "o conceito de valências emocionais abertas, orientadas para os outros, [que] ajuda à substituição da imagem do homem como Homo clausus, pela imagem de - indivíduo aberto" (Elias, 2005, p. 148). É, então, a partir desse indivíduo aberto, orientado um para outro, que se materializam os planos e ações individuais, assim como os processos de transformação e mudança, cujo resultado é imprevisível, sem necessariamente, ter sido intencionado por um indivíduo em particular:

Só se pode chegar a uma compreensão clara da relação entre indivíduo e sociedade quando se inclui o perpétuo crescimento dos indivíduos dentro da sociedade, quando se inclui o processo de individualização na teoria da sociedade. A historicidade de cada indivíduo, o fenômeno do crescimento até a idade adulta, é a chave para a compreensão do que é a 'sociedade'. (Elias, 1994a, p. 30)

Considerando essas reflexões do autor, num trabalho biográfico, o pesquisador não apenas pode compreender os planos e ações individuais, a historicidade do indivíduo, mas também pode passar a compreender melhor e com mais propriedade a sociedade que forjou aquele indivíduo em particular, por suas relações interdependentes. A partir dessas reflexões, percebe-se que é extremamente importante a preocupação da síntese eliasiana para eliminar ou diminuir os discursos reificantes e dicotômicos que pairam sobre a Sociologia clássica, que são alvo, inclusive, de uma das principais críticas realizadas por Elias (2005) num dos seus livros, Introdução à sociologia.

Todavia, essa não é apenas a preocupação do sociológico alemão, mas também de um pesquisador francês que apresenta conceitos importantes para superar algumas dicotomias expostas pela Sociologia. Para Bourdieu (2004) há um certo perigo nas divisões conceituais que colocam os pesquisadores em oposição, no sentido de que as dicotomias mais ofuscam do que elucidam os problemas sociais concretos.

Essas oposições são divisões reais do campo sociológico; elas têm um fundamento social, mas nenhum fundamento científico. Tomemos as mais evidentes, como oposição entre teóricos e empiristas, ou entre subjetivistas e objetivistas, ou ainda entre estruturalistas e certas formas de fenomenologia. Todas essas oposições (e há muitas outras) parecemme absolutamente fictícias e ao mesmo tempo perigosas, porque conduzem a mutilações. (Bourdieu, 2004, p. 49)

Como pode ser observado, a preocupação do autor é fundamental não só para o avanço das teorias sociológicas como também para os procedimentos na pesquisa científica que trata dos problemas dos agentes sociais e suas relações. Assim, é fundamental evitar as oposições aparentes e, por conseguinte, as mutilações que colocam os pesquisadores numa situação de perigo por levá-los a enxergar apenas parte dos problemas da sociedade, ou seja, observar apenas um dos lados das questões 
apresentadas. Conseguimos verificar isso, por exemplo, nas análises estatísticas, quando os sociólogos testam modelos matemáticos para compreender as diferentes situações concretas.

Todas as competências de que pode servir a Sociologia raramente estão concentradas num único indivíduo, e essa talvez seja a razão pela qual os sociólogos tentam imprimir apenas o modelo que lhes parecem mais acessível aos problemas sociais. De modo que é preciso entender a sociologia da Sociologia, diz Bourdieu (2004),

para se ter uma ideia mais realista dos problemas pelos quais passa essa disciplina acadêmica, "e uma análise do campo da sociologia certamente mostraria que há uma estreita correlação entre o tipo de capital de que dispõem os diferentes pesquisadores e a forma de sociologia que eles defendem como a única legítima" (Bourdieu, 2004, p. 50).

Da mesma maneira que o autor é crítico em relação à Sociologia, advogando, inclusive, por uma sociologia para a Sociologia e identificação dos modos de trabalho dos próprios sociológicos, faz uma crítica à História e aos historiadores. Para Bourdieu (2004), a história de longo prazo, por exemplo, traz vantagens para os pesquisadores que dela fazem uso, mas prejuízos à ciência. Por essa razão, diz ele, "fazer sociologia como eu a concebo, seria preciso renunciar a essas vantagens. A história que eu precisaria para meu trabalho muitas vezes não existe" (Bourdieu, 2004, p. 58).

Destarte, o autor está preocupado com a gênese das estruturas sociais capazes de forjar intelectuais e artistas autônomos. Segundo suas reflexões, as generalizações baseadas em documentos, compilações estatísticas ou de outra ordem qualquer não dão conta de explicar o essencial. Desse modo, "é evidente que uma sociologia plenamente acabada deveria englobar uma história das estruturas que são num dado momento o resultado de todo o processo histórico" (Bourdieu, 2004, p. 58).

Considerando essas reflexões, a ideia central que reside no pensamento de Bourdieu (2004) diz respeito à história das estruturas, das lutas e forças que atuaram para conservar ou manter estruturas anteriores, bem como as transformações daí consequentes. Assim, é preciso uma análise minuciosa para compreender os indivíduos, ou agentes sociais, no contexto dos campos em que estão inseridos, no centro do qual disputam o controle do poder.

Nesse sentido, Bourdieu (2002) percebe que a história de um determinado campo, bem como de seu produtor e as relações por ele estabelecidas, pode constituir evidência do funcionamento desse ambiente no centro do qual são travadas as lutas pelo seu controle. Assim, o autor considera que a estrutura de um campo é determinada pelo estado de relações dos agentes ou instituições que interferem na própria luta desse campo. E o que está em jogo no campo de produção é um conjunto de forças que atuam para a manutenção ou conversão de poder.

Dessa forma, a teoria de campo pretende eliminar as dicotomias ou mais precisamente as mutilações, conforme pensa Bourdieu (2004). Segundo o autor, essa teoria faz aproximações entre a biografia individual e a obra literária, como os aspectos intertextuais e a classe social de seu criador, por exemplo. De modo que um estudo sociológico que toma como referência a teoria de campo deve analisar a complexa relação dos agentes sociais, sua produção e condições de produção, ou seja, "existe uma 
correspondência bastante rigorosa, uma homologia, entre o espaço das obras consideradas nas suas diferenças, nos seus desvios [...] e o espaço dos produtores e das instituições de produção, revistas, editoras etc" (Bourdieu, 2004, p. 117).

Destarte, essa teoria é bastante fértil. $E$ coloca as instituições escolares como um campo, tal qual as outras de natureza similar, ou seja, que advogam algum tipo de iniciação cultural, na esfera estética: música, dança, artes visuais; e são capazes de emitir certificados ou diplomas, garantindo, assim, a eficácia da autodidaxia como legítima, na medida em que assegura uma certa competência a seus agentes, dotados, hipoteticamente, de uma cultura geral, tanto mais extenso e importante o prestígio do documento emitido. De maneira que tudo é efetivamente tomado na análise simultânea:

Nada há, portanto, de paradoxal no fato de que a instituição escolar defina, em seus fins e seus meios, o esforço de autodidaxia legítima pressuposta pela aquisição de uma 'cultura geral', aliás, empreendimento cada vez mais fortemente exigido à medida que alguém se eleva na hierarquia escolar (entre as seções, disciplina e especialidades etc., ou entre os níveis). (Bourdieu, 2007a, p. 28)

Esses elementos são fundamentais para se compreender a distinção sobre a qual incide o que o autor chama de classificação, desclassificação, reclassificação, de onde pode-se presumir os efeitos das transformações sociais e a relação estreita entre o campo escolar e o próprio campo social. É, na verdade, ainda que relativa, não apenas as formas de aquisição de capital cultural, no contexto da própria distinção, mas, também, a legitimidade dessa aquisição.

De todos os campos teorizados por Bourdieu (2002), o campo intelectual tnum significado muito especial por estar articulado inevitavelmente com outros campos, o da cultura, da produção da esfera estética e até mesmo com uma gama de projetos do autor que dizem respeito ao sistema educacional francês - mais especificamente, à formação de uma elite intelectual naquele país - e às questões que envolvem as artes visuais, por exemplo.

O campo intelectual é relativamente autônomo dos sistemas de produção simbólica porque pode se referir tanto à produção de um determinado autor em particular, quanto a uma obra específica. Contudo, mesmo resguardada sua autonomia, esse campo é intrinsecamente relacional, pela constante relação interdependente da criação intelectual com a própria obra, ao mesmo tempo em que a obra é afetada pelas relações sociais que a produzem. Para Bourdieu (2002), tudo isso age como um sistema de comunicação entre os agentes, por meio dos quais se legitimam posições relativamente hierarquizadas.

Considerando esses aspectos, ao surgirem os agentes, inevitavelmente, são constituídas forças que se opõem ao mesmo tempo em que convergem para a estrutura do próprio campo num determinado espaço-temporal. Aliás, um dos principais indícios da existência de um campo, diz o autor, é a compreensão de que há um corpo de agentes conservadores, notadamente biógrafos, os chamados "conservadores de vidas - os biógrafos - e de obras - os filólogos, os historiadores de arte e de literatura, que asseguram aos recém-chegados ao campo o que está em jogo a partir do passado do próprio campo, conservado, conservando-se" (Bourdieu, 2002, p. 122). 
Nesse contexto, o campo institui, a partir das relações que nele são praticadas, um habitus específico que the caracteriza, sendo, inclusive, um elemento que traduz não apenas um sentimento dos agentes do campo, mas o comportamento e as subjetividades a ele atribuídos. Um exemplo disso é dizer que "ser filósofo é dominar o necessário da história da filosofia para saber se comportar como filósofo dentro do próprio campo filosófico" (Bourdieu, 2002, p. 125).

Sendo o habitus assim compreendido, como um elemento que representa e faz os agentes representarem as marcas do campo, a disposição a ele conferida é aprendida de maneira objetiva e subjetiva, e de vez em quando pode servir de mecanismo para corroborar os interesses dos agentes de um determinado campo. É óbvio que a utilização do habitus para atingir determinados interesses pode ser utilizado pelo agente social de forma consciente ou inconsciente, como advoga Bourdieu (2002):

O habitus, como sistema de provisões adquiridas por meio de aprendizado implícito ou explícito, que funciona como sistema de geração de esquemas, gera estratégias que podem estar objetivamente conformes aos interesses objetivos de seus autores, sem que tenham sido expressamente concebidas para esse fim. (p. 125)

Como explica o autor, o habitus aqui é aprendido, logo, há necessidade de participação constante do agente no campo para que, a partir das relações históricas com outros agentes desse campo, se possa apreender o que está disposto nesse sistema de provisões e, se possível, utilizar essas disposições como estratégias no alcance de seus interesses. "O habitus torna-se gerador de práticas imediatamente ajustadas ao presente, e mesmo no futuro inscrito no presente (daí a ilusão de finalidade)" (Bourdieu, 2002, p. 130).

O conceito de habitus é extremamente útil, e chama especial atenção o fato de que tanto Elias, quanto Bourdieu o aplicam na perspectiva de eliminação das dicotomias no que diz respeito à relação do indivíduo, ou agente, com sua composição social, numa determinada configuração ou na estrutura de um campo determinado. Assim, alguns pesquisadores tentam fazer aproximações teóricas e empíricas desses dois autores, chegando, inclusive, a afirmar que determinados conceitos são similares em seus projetos sociológicos.

Nesse contexto, autoras como Dendasck e Lopes (2016) e Setton (2002, 2018) tentam fazer aproximações teórico-conceituais entre Norbert Elias e Pierre Bourdieu, em relação ao modo com que compreendem e fazem as análises sociológicas, levando em conta as semelhanças apresentadas por esses sociólogos. Entretanto, de todos os conceitos apresentados, como configuração, campo, indivíduo, agente social, outsider etc., o conceito de habitus é o que mais me intriga, por considerar que há significativas diferenças, entre os autores, na maneira de aplicá-lo, como também em seu conteúdo.

Ao entrar em contato com o que pretendo comparar, chamo especial atenção a alguns aspectos fundantes que podem alimentar a diferenciação entre os respectivos autores, sendo: a forma de aquisição do habitus; a compreensão que os autores têm sobre o conhecimento histórico, desenvolvido quando aplicado ao objeto sociológico, bem como outros conceitos que são aplicados paralelamente ao do próprio habitus em relação aos pronomes 'nós' e 'eu'. Desse modo, tentarei apresentar as diferenças que residem no modo desses autores da Sociologia contemporânea pensarem o referido conceito. 
Quadro 1 -

Quadro sintético comparativo do conceito de habitus em Norbert Elias e Pierre Bourdieu.

\begin{tabular}{|l|l|}
\hline \multicolumn{1}{|c|}{ Norbert Elias } & \multicolumn{1}{c|}{ Pierre Bourdieu } \\
\hline $\begin{array}{l}\text { Numa configuração pode ter muitos habitus } \\
\text { entrelaçados, podendo se tornar mais } \\
\text { proeminente em determinados momentos } \\
\text { entre um ou mais indivíduos. }\end{array}$ & $\begin{array}{l}\text { O habitus surge do campo enquanto expressão } \\
\text { do agente social representante do próprio } \\
\text { campo: político, artístico, científico etc. }\end{array}$ \\
\hline $\begin{array}{l}\text { O habitus tem raízes muito profundas, é } \\
\text { socialmente herdado e passa de gerações } \\
\text { em gerações de indivíduos. }\end{array}$ & $\begin{array}{l}\text { O habitus é apropriado, incorporado na história } \\
\text { do indivíduo por meio de suas práticas, a técnica } \\
\text { corporal, por exemplo. }\end{array}$ \\
\hline $\begin{array}{l}\text { O habitus é a composição social do } \\
\text { indivíduo. Sua identidade 'nós'. }\end{array}$ & $\begin{array}{l}\text { O habitus é a expressão individual do capital } \\
\text { cultural acumulado pelo agente social. }\end{array}$ \\
\hline $\begin{array}{l}\text { Segunda natureza; composição social: } \\
\text { sociogênese e psicogênse. }\end{array}$ & $\begin{array}{l}\text { Desenvolve a partir de suas práticas num campo } \\
\text { determinado, como o político, esportivo, } \\
\text { científico, artístico etc. }\end{array}$ \\
\hline $\begin{array}{l}\text { O habitus deve ser compreendido e } \\
\text { aplicado na perspectiva da História de longo } \\
\text { prazo. }\end{array}$ & $\begin{array}{l}\text { O habitus pode ser compreendido e aplicado na } \\
\text { perspectiva da História do tempo presente. }\end{array}$ \\
\hline Saber social incorporado em longo prazo. & História incorporada a curto prazo. \\
\hline $\begin{array}{l}\text { O habitus não tem relação direta com a } \\
\text { configuração. }\end{array}$ & $\begin{array}{l}\text { O habitus tem relação direta com o campo de } \\
\text { produção. }\end{array}$ \\
\hline $\begin{array}{l}\text { O habitus é a segunda natureza do } \\
\text { indivíduo, que age independentemente a } \\
\text { vontade de seu 'proprietário'. }\end{array}$ & $\begin{array}{l}\text { O indivíduo pode decidir lutar pela sua aquisição, } \\
\text { por incorporar essa ou outra técnica corporal, } \\
\text { esse ou aquele comportamento. }\end{array}$ \\
\hline $\begin{array}{l}\text { Difícil compreensão empírica pelos } \\
\text { processos sociais, planos e ações } \\
\text { individuais. }\end{array}$ & $\begin{array}{l}\text { Fácil verificação empírica a partir da análise de } \\
\text { determinados campos. }\end{array}$ \\
Fon antor
\end{tabular}

Fonte: autor (2020).

Considerando essa breve análise comparativa entre os autores no que se refere ao conceito de habitus, é perceptível a maneira como sua aplicação pode resultar em ideias muito diferentes, especialmente quando se toma as ações dos indivíduos, ou agentes sociais, em campos específicos da arte, da política ou ciência. É evidente que, tanto Elias, quanto Bourdieu, pensam esse conceito para minimizar as dicotomias da Sociologia clássica, mas, inevitavelmente, sua aplicação precisa ser justificada para não confundir camadas profundas da identidade coletiva a longo prazo, em relação aos procedimentos ou técnicas próprias de grupos sociais facilmente identificados no tempo presente.

Desse modo, mesmo considerando que Elias (1994a) enraíza o conceito de habitus nas tradições e produções sociais dos saberes de longo prazo, cujos componentes étnicoraciais, por exemplo, podem reverberar com bastante densidade, o que foi pertinente no meu estudo dos batuques e o controle das emoções (Souza, 1998). Para esta tese, no entanto, fico mais à vontade em aplicar o habitus a partir do pensamento de Bourdieu por levar adiante as minhas participações em vários campos que tomo como referência a arte, a ciência e a política, que resultam, portanto, em habitus específicos desses ambientes.

Além da aplicação do habitus, os dois autores se complementam para dar sentido às possíveis interpretações da minha autobiografia, não apenas no que concerne às falas por mim recordadas, mas a uma massa documental que se avolumou no decorrer do estudo, necessitando, portanto, de uma reflexão tanto sociológica como histórica, na minha percepção. Então, além desses dois autores da Sociologia contemporânea, que se 
complementam no entendimento de que as dicotomias e os discursos reificantes devem ser eliminados, sobretudo, no que diz respeito ao indivíduo e à sociedade, outro autor que contribui significativamente para as tomadas de decisões teóricas e empíricas neste estudo é o Michel de Certeau.

A contribuição desse 'operador da história' é incontestável para esta pesquisa autobiográfica porque, num de seus escritos, o autor reafirma o seu ofício de historiador e a condição desse campo do conhecimento enquanto técnica, levada, inclusive, ao caminho da interpretação em virtude de sua organização espaço-temporal. Ou seja, para ele é preciso atitudes e gestos pragmáticos "sem se prender mais à situação epistemológica que, até aqui, foi desvendada pela sociologia da história" (Certeau, 2002, p. 78). Assim, em certa altura, ele põe em destaque a importância da relação estabelecida entre a escrita enquanto condição da História e a oralidade como estrutura da Etnologia.

Essa relação, diz o autor, fundamenta-se no fato de que o que se escreve é produto do que se escuta, do que é falado. Logo, é possível pensar que a História e o domínio da interpretação da escrita, por consequência, são produtos do que se fala num determinado campo de produção, ou seja, um lugar socioeconômico e culturalmente delimitado, em que a História está atrelada. Assim, fazer história é praticar a interpretação (Certeau, 2002) e, por conseguinte, interpretar os caminhos percorridos pelos personagens de um determinado enredo.

Ao interpretar a trajetória de um personagem frente a um lugar, "o percurso visa o retorno a este ponto de partida. O próprio itinerário da escrita conduz à visão do lugar: ler é ir ver" (Certeau, 2002, p. 277). Contudo, fica evidente que o autor está se referindo às hagiografias, isto é, às biografias dos santos, e à ideia de ir e vir dos personagens santificados entre uma cidade específica e o deserto, entre o milagre e a devoção num lugar. Entretanto, em certa medida, é fundamental se pensar nos percursos traçados por diferentes personagens e a contação de seus traçados em diferentes campos de permanência e de atuação. Digo isso porque compreendo que os indivíduos "traçam 'trajetórias indeterminadas' aparentemente desprovidas de sentido, porque não são coerentes com o espaço construído, escrito e pré-fabricado onde se movimentam" (Certeau, 1998, p. 97). Assim, numa configuração determinada, num campo específico, há sempre a possibilidade de um indivíduo elaborar o saber mediante a sua interdependência funcional. Não obstante, a luta pela conservação, transformação ou mesmo aquisição do saber-poder resulta muitas vezes em importantes evidências, que, a partir de uma análise histórica, é possível representar o mais próximo possível da realidade espaço-temporal de seu próprio campo de produção.

Destarte, o poder, que resguarda em sua intimidade o saber, tem a "capacidade de transformar as incertezas da história em lugares legíveis" (Certeau, 1998, p. 100) e, por sua extensão, também legítimos. É oportuno o reconhecimento desse tipo de estratégia, na medida em que o fundamental desse saber é a sustentação de um tipo muito específico de conquista, seja militar ou científica, o que se assemelha "à constituição de campos 'próprios' (cidades autônomas, instituições 'neutras' ou 'independentes', laboratórios de pesquisas 'desinteressados' etc." (Certeau, 1998, p. 100). Logo, o poder é o suporte desse saber institucional, corolário das estratégias militares ou científicas.

O conceito de estratégia pode ser compreendido como o efeito do poder instituído e instituinte, a figura matriz de um discurso já referido e consolidado. É, de certa forma, a 
senhora do tempo e a arma dos fortes e dos vencedores articulados num espaço determinado. Por sua vez, pode-se chamar de tática "a ação calculada que é determinada pela ausência de um próprio [...] por isso deve jogar com o terreno que lhe é imposto tal como o organiza a lei de uma força estranha" (Certeau, 1998, p. 100).

Sendo a tática os procedimentos desenvolvidos em terrenos que não lhes são próprios, portanto, movimento num campo inimigo, ela corre contra o tempo, para que a situação ali estabelecida seja favorável a ela, mesmo que por um instante, e permita movimentos rápidos e precisos para que haja alteração organizacional da estratégia. Logo, a tática sempre perseguirá o fortalecimento dos mais vulneráveis, porque não tem a visão globalizante e totalizante da força que lhe é imposta pela estratégia.

Pelas características peculiares do indivíduo astucioso, do desprovido de poder, a tática é "a arte do fraco" (Certeau, 1998, p. 101), que deve agir com urgência para ultrapassar as barreiras impostas pelas forças distribuídas pelos indivíduos que detêm a estratégia. Sem a urgência da aplicação de sua arte, o indivíduo permanecerá na mesma posição até encontrar outras brechas nesse jogo de forças. Esses são apenas alguns exemplos que permeiam o nosso cotidiano, passíveis de verificação empírica em várias esferas das atividades humanas, na ciência, na política e na própria arte.

Nesse contexto, é fundamental compreender que "o privilégio detido pela problemática da repressão no terreno das pesquisas não surpreende: as instituições científicas pertencem ao sistema que estudam" (Certeau, 1998, p. 105) e resguardam em si a estratégia, a senhora do tempo. Parafraseando Bourdieu (2004), estudar a universidade é objetivar o sujeito objetivante. Ou seja, há nesse sentido, uma conformidade das instituições e da produção do conhecimento, uma vez que as instituições permitem o desenvolvimento da própria ciência. De modo que, para Certeau (1998), toda a crítica científica é apenas 'aparência' do terreno da qual pertence e só ocorre em virtude da permissão do próprio agente objetivante.

Nesse sentido, as práticas cotidianas, que Certeau (1998) chama de procedimentos, assim como a manipulação das técnicas, podem ser compreendidas como aquisição das disposições desenvolvidas pelos indivíduos num campo determinado, ou seja, o que poderíamos interpretar como o habitus, em Bourdieu (2004).

Levando em consideração as reflexões de Certeau (2002), no campo das Ciências Humanas é fundamental o estabelecimento criterioso de um lugar e da relação sujeito e objeto do conhecimento. Normalmente, elevamo-nos do status de objeto e nos posicionamos frente aos desafios de iniciar um projeto de pesquisa tendo o outro indivíduo, membro da nossa própria sociedade, do grupo social ou instituição que pertencemos, como um objeto de análise, ou seja, como algo a ser conhecido por meio do método científico.

No entanto, se isso pode parecer estranho, por onde começar um estudo quando o pesquisador tem por objeto o sujeito que é? Ou melhor, quando somos sujeitos e objetos de nós mesmos a partir de um lugar socioeconômico e culturalmente determinado, carregado de emoções, afetos e expectativas?

Nessa tensão sujeito/objeto, por exemplo, é preciso expor, de forma bem definida e territorialmente delimitada, os pontos de vista, o campo ou o lugar de fala, no estabelecimento dessa relação construída num determinado tempo. É necessária a 
tomada de consciência sobre o campo de onde faz emergir as intencionalidades dessa relação intrigante do sujeito/objeto, para que haja a construção de uma narrativa plausível e respeitável no próprio campo em que a relação foi historicamente construída.

Essas reflexões estão relacionadas ao manuseio de evidências, sendo, portanto, uma questão de método, relacionado a um lugar determinado. Assim, "é em função deste lugar que se instauram os métodos, que se delineia uma topografia de interesses, que os documentos e as questões, que lhes serão propostas, se organizam" (Certeau, 2002, p. 67). A organização de que fala o autor é um dos pressupostos fundamentais de trabalho no ofício do historiador, como ele mesmo refere, em sua operação histórica. Trata-se, pois, dos procedimentos de pesquisa a partir das evidências encontradas ao longo de um percurso determinado.

Dessa forma, é preciso compreender a importância dos métodos, seu valor e o porquê nós os praticamos, sobretudo o método científico. De maneira que "o método tem o valor da iniciação a um grupo (é preciso aprender ou praticar os 'bons' métodos para ser introduzido no grupo), ou sua relação com uma força social" (Certeau, 2002, p. 73). Assim, o método, diz o autor, é a forma mais segura de proteção que os mestres e doutores encontraram para se afastar das falsas convicções, é a nossa forma peculiar de lidar com a resolução de problemas científicos.

É também por meio dos métodos e das teorias por onde os discursos operam para legitimar determinadas práticas sociais e científicas: "um discurso manterá, portanto, uma marca de cientificidade explicitando as condições e as regras de sua produção e, em primeiro lugar, as relações de onde nasce" (Certeau, 1998, p. 110). É nesse sentido que as teorias e os métodos vão paulatinamente legitimando-se e recompondo-se numa configuração social específica.

Considerando esses aspectos, foi a busca de um caminho que me permitiu trazer esses três autores para o conjunto das reflexões que farei mais adiante, principalmente para as que se constroem a partir das memórias dos ambientes em que construí a minha experiência de vida. Os autores são muito diferentes nas abordagens e nos seus procedimentos, mas, reconhecidamente, não são excludentes na forma de pensar as atitudes de sobrevivência dos indivíduos no contexto social; seja pensado a longo prazo, nas disposições que emergem de suas práticas, seja nas táticas por eles empregadas.

Nesse sentido, foi pensando num caminho seguro que fiz a escolha do método autobiográfico para desenvolver esta tese com muitos desafios, especialmente por a minha própria experiência de vida e os meus itinerários serem o objeto de estudo, que pautam, obviamente, a autobiografia também enquanto técnica, fonte de pesquisa e inspiração de minhas memórias. Assim, em menor ou maior grau, esses autores vão corroborar a análise e interpretação que tentarei fazer de minha própria experiência, ao falar, escrever e refletir acerca da minha trajetória. Então, a Sociologia e a História, que neste momento emprego, justificam-se na modelagem de um método que tem avançado consideravelmente por meio de vários trabalhos científicos de autores nacionais e estrangeiros, e é o que tentarei apresentar resumidamente na próxima seção.

\section{Biografia: do discurso panegírico à fonte historiográfica}

$\mathrm{Na}$ seção anterior fiz uma breve discussão de três autores clássicos fundamentais para análise e interpretação do modelo de sociedade e perspectiva de estudos, conforme 
pensamos a relação imbricada entre o indivíduo e a sociedade e sua produção de sentido no processo histórico, o que pode fundamentar diferentes discussões epistemológicas acerca da relação sujeito/objeto. Dessa maneira, esta seção tem por objetivo apresentar, de forma resumida, as contribuições de alguns autores sobre um tipo de pesquisa onde 0 indivíduo fala de suas experiências ou de sua trajetória de vida.

Nesse contexto, compreende-se por método biográfico a narrativa oral, visual ou, notadamente, escrita, acerca dos diferentes momentos ou fases da vida de uma pessoa. Entretanto, durante algum tempo, Borges (2015) "não tinha ideia de que esse termo tivesse surgido tão tarde, oriundo do grego bios = vida e graphein = escrever, inscrever acrescido de ia, um formador de substantivo abstrato" (p. 204). A biografia também pode ser compreendida, assim, como descrever, desenhar a vida de uma pessoa, desenhar a sua trajetória.

A autora reconhece que havia no mundo grego antigo uma preocupação em distinguir a história da vida de uma só pessoa da história coletiva, política, considerada a história verdadeira, em contraposição, obviamente, à memória. A história de vida de uma pessoa, servia, naquele momento, como realce às questões morais e éticas, fosse positiva ou negativa, portanto, diferente do que poderia ser considerado como conhecimento científico, tratando-se a fala sobre um indivíduo de um discurso panegírico.

Nessa perspectiva, é salutar o esclarecimento acerca dos estudos historiográficos e da biografia no que dize respeito ao papel desempenhado pelos indivíduos nos contextos sociais em que essas duas áreas do conhecimento se inserem. Para Borges (2015), durante todo o período do século 19, a Filosofia da História, preocupada em ter como tema as "instituições, trabalhando com objetos de estudo como meio, raça, nação, e não com a vida particular - levou à redução da importância do indivíduo na História" (p. 206). Esse aspecto é fundamental não só do ponto de vista teórico como também para procedimentos investigativos, mas, em certa medida, se apresenta como um problema de método na abordagem. De qualquer forma, a história nacional escrita nessa época valorizava os grandes heróis e figuras também importantes para a literatura.

Diante disso, se o indivíduo é tomado como objeto de pesquisa, portanto, seu discurso e suas práticas, assim, inverte-se a lógica historiográfica tradicional, positivista. Todavia, "o debate sobre o papel do indivíduo e da biografia, realizado nesse século, ainda se prolonga" (Borges, 2015, p. 206). O prolongamento desse debate diz respeito não só à necessidade do aprofundamento de novas descobertas sobre o método, como também ao papel desempenhado pela biografia para a história em seus diferentes subcampos.

Considerando os aspectos de um discurso Perelman e Olbrechts-Tyteca (1996) assinalam que "Aristóteles e todos os teóricos nele inspirados incluem em seus tratados de Retórica, ao lado dos gêneros oratórios deliberativo e judiciário, o gênero epidíctico" (p. 53). Este gênero não pretendia estabelecer debate político ou de natureza jurídica, em que se espera alguma decisão, mas a afirmação vigorosa de atributos do personagem central, objeto da retórica. 
Os autores ressaltam, ainda, a importância dada ao discurso epidíctico pelo filósofo grego Górgias e o ateniense Isócrates, que faziam constar em suas obras aspectos elogiosos e panegíricos nas solenidades e celebrações na Grécia antiga. O gênero epidíctico, no entanto, não se aplicava apenas aos indivíduos, mas também às cidades, a uma profissão, à história e a um mito.

Normalmente, o epidíctico era proferido por um orador muitas vezes sem aparição pública, fazendo circular o discurso pelos seus escritos, que, de maneira incontestável, devia ser lido ou ouvido pelos participantes das solenidades. De modo que esse gênero discursivo não apresentava dúvidas sobre o dito acerca de seu objeto ou de seu personagem:

Que se tratasse de um elogio fúnebre ou do elogio de uma cidade diante de seus habitantes, de um tema desprovido de atualidade, tal como a exaltação de uma virtude ou de uma divindade, os ouvintes nele só representavam, segundo os teóricos, o papel de espectador. Após ouvir o orador, tinham apenas de aplaudir ou ir-se embora. (Perelman; OlbrechtsTyteca, 1996, p. 53)

Para Franchi (2007) o discurso panegírico foi amplamente utilizado entre os gregos e no Império Romano para ressaltar as qualidades e atitudes políticas dos imperadores. Essa é a razão pela qual, segundo a autora, vários pesquisadores se utilizaram do discurso panegírico como fontes para a análise histórica. Em muitos desses discursos, o orador enfatizava aspectos particulares do personagem central, revelando, inclusive, o que podemos chamar atualmente de biografia. Assim, "o orador permitirá o conhecimento, entre outros elementos, de sua cidade natal, a provável data de seu nascimento e de funções administrativas ocupadas por ele, seu filho e seus discípulos" (Franchi, 2007, p. 106).

A utilização dos discursos panegíricos por pesquisadores para análise histórica é um bom indicativo da densidade política e das relações de poder estabelecidas no próprio discurso enquanto representação social do soberano. É, em certa medida, fazer uso de uma percepção particular que um indivíduo tem sobre o outro, ainda que esse outro seja ocupante de uma determinada posição na hierarquia social.

Não obstante, penso que ainda hoje a biografia serve não apenas como gênero literário, para que o cidadão comum tenha acesso a algumas celebridades, mas também enquanto método científico para conhecer a vida de alguém. Sendo de uma forma ou de outra, certamente, em muitos casos, deve servir de modelo de como um indivíduo precisou conduzir a sua trajetória na sociedade a qual constrói e pertence, de como o indivíduo superou suas dificuldades e manteve as expectativas dentro da própria trajetória, de como aprendeu a vivê-la.

Para Leite e Carvalho (2018), no entanto, o discurso panegírico apresenta fortes conotações argumentativas baseadas na exaltação a um determinado indivíduo. Um texto de caráter elogioso, que assume a responsabilidade de mostrar a consonância desse indivíduo com a sociedade e sua observância à ética, bem como alguns acréscimos às virtudes. Os autores afirmam que os oradores latinos, ao utilizarem do panegírico, diferente de Aristóteles, tentam empregar uma função mais didático-pedagógica do que propriamente de sistematização ou de um ordenamento para se obter os resultados esperados. 
$\mathrm{Na}$ retórica latina os panegíricos desviam o foco do personagem central do discurso para retirar de seus personagens os ensinamentos necessários aos ouvintes. Ou seja, o foco se desvia de algum modo para a figura persuasiva do orador e, nesse caso, concentra-se no suporte do próprio discurso.

Enquanto discurso sobre o outro, o panegírico se apresenta exaltando as qualidades morais e éticas de um indivíduo que ocupa ou passa a ocupar um cargo de destaque na sociedade. De modo geral, o discurso panegírico pode servir como uma espécie de alimento para a identificação do espírito público de determinados atores sociais e as funções que porventura venham a ocupar. É provável que, para proferir tal discurso, seja necessário um breve levantamento acerca da vida de quem esteja mudando seu status na mobilidade social ascendente. É preciso compreender não apenas a vida do indivíduo, mas também o lugar social que ele ocupa ou passa a ocupar em determinado momento.

Nesse contexto, por fazer referência sobre o outro, pode-se dizer que a biografia possui uma epistemologia significativa, pois busca, em última instância, compreender a imbricada relação entre sujeito e objeto na construção do conhecimento científico. Assim, no método biográfico, tem-se um sujeito reflexivo pensante que se debruça sobre um objeto móvel, igualmente pensante e reflexivo. Entretanto, esse sujeito não está distante do objeto a ser conhecido, ele está nas proximidades do próprio objeto, já conhece a priori seus sentimentos, suas vontades. São exatamente esses aspectos que permitem especulações sobre o fazer ciência com base nesse método, carregado de sentimentos, desejos e afetos.

Essa relação entre sujeito e objeto, provavelmente, intrigou os historiadores positivistas durante todo o século 19, que valorizavam o escrito em detrimento ao oral. Então, o que chamamos hoje de História Oral era à época "identificado como anedótico, com as sociedades sem escrita e, portanto, 'sem História'” (Alberti, 2015, p. 163). Há nessa premissa a ideia de que o passado poderia ser compreendido com o devido distanciamento do pesquisador ou parcialidade, em contraposição a temas contemporâneos, sob os quais, para essa visão de ciência, haveria imparcialidade.

Mesmo considerando as diferenças metodológicas ou a compreensão do que seja história, mesmo fugindo do positivismo da ciência, a Escola dos Annales, nos seus primórdios, idos de 1929, utilizava-se de todas as fontes seriais nas pesquisas de processos de longa duração, e não dava a devida importância ou "espaço ao papel do indivíduo na História" (Alberti, 2015, p. 163).

Somente a partir da década de 1980 temas considerados contemporâneos foram incorporados aos projetos de pesquisa histórica, em que a chamada História Do Tempo Presente passa a valorizar a experiência contada por indivíduos como interpretação possível na representação coletiva de acontecimentos sociais num determinado campo social.

Nesse sentido,

os historiadores passaram a se interessar também pela vida cotidiana, pela família, pelos gestos do trabalho, pelos rituais, pelas festas e pelas formas de sociabilidade - temas que, quando investigados no 'tempo presente' podem ser abordados por meio de entrevistas de História oral (Alberti, 2015, p. 163). 
Com base nessas reflexões, é cada vez mais frequente o uso do método da História Oral em práticas pedagógicas junto a estudantes de ensino médio, levando-os, em seus trabalhos escolares, a entrevistar os mais velhos da família ou os mais velhos de seu bairro, de sua comunidade, para conhecer um pouco da dinâmica familiar, sua trajetória de sucesso ou insucesso, de construção de patrimônios ou de visibilidade em todas as camadas sociais. Em todos os casos, o que se verifica é que "o documento escrito deixou de ser o repositório exclusivo dos restos do passado" (Alberti, 2015, p. 164).

Para essa autora, no método biográfico, os pressupostos do indivíduo têm valor em si mesmo, assim como a personalidade única, cuja singularidade se revela nas ações, nas práticas cotidianas fundamentais para a compreensão das sociedades contemporâneas. Aliás, essas características de valorização do indivíduo são, na visão da Alberti (2015), produto das próprias sociedades ocidentais na contemporaneidade, e executar um projeto de pesquisa com esse método é reforçar tais valores individuais.

Essas reflexões são fundamentais na perspectiva da História da humanidade, pois, desde os gregos até o presente, segundo Cunha (2018), o ser humano se define e se orienta individual e coletivamente e traz, obviamente, elementos objetivos e subjetivos em suas relações interpessoais. Assim, uma das formas de apreensão do mundo é narrar sobre si mesmo ou sobre outros indivíduos de sua sociedade, o que acontece desde a antiguidade, como bem chama atenção o autor, ao escrever que o "que consideramos a base da chamada civilização greco-romana e judaico-cristã ocidental, a própria mitologia grega, associada à intencionalidade de formatação da sociedade humana, cultural e política, tem um caráter claramente biográfico" (Cunha, 2018, p. 239).

De qualquer modo, é preciso compreender que não apenas nos orientamos pelo conhecimento adquirido sobre os outros, mas, em certa medida, produzimos conhecimento ao narrar sobre a nossa própria vida, sobre o mundo que nos cerca. $\mathrm{E}$ a possibilidade de narrar sobre o mundo é fundamental na apreensão do próprio mundo, dos valores, códigos e rituais importantes à convivência em sociedade. Todavia, é preciso registrar, ainda, que o método biográfico e, por consequência, a produção das fontes orais estão entrecruzados com vários campos das Ciências Humanas e Sociais, como a Antropologia, a Sociologia, a Ciência Política etc., o que tende a conferir a eles importância e impacto significativo na produção do conhecimento de forma interdisciplinar.

Nesse contexto, devota-se à chamada Escola de Chicago, especialmente ao seu Departamento de Sociologia, os primeiros estudos relacionados à História Oral. Pesquisas como da Alberti (2015) destacam os trabalhos de William Thomas e Florian Znaniecki, que, entre 1918 e 1920, desenvolveram um estudo bastante significativo e inovador, à época, sobre a história de vida de poloneses residentes nos Estados Unidos da América. Com esse estudo também se ampliou a ideia de laboratório, na qual o pesquisador deve explorar o campo para o encontro de seu objeto empírico.

Percebe-se que os avanços do método da História Oral também são acompanhados pelo desenvolvimento da tecnologia, de modo que a invenção do gravador a fita, em 1948, por exemplo, possibilitou os registros de entrevistas por meio eletrônico e estabeleceu uma relação bastante clara e objetiva entre o entrevistador e o entrevistado, considerando o objeto ou tema a ser tratado. 
Essa foi uma época bastante profícua para essa linha de pesquisa porque "formouse o Columbia University oral History Research Office, programa de História oral da Universidade de Columbia fundado por Allan Nevins e Louis Starr em Nova York" (Alberti, 2015, p. 156), cuja preocupação era a de deixar registrado para as gerações futuras, na história norte-americana, os depoimentos de nomes destacados na política, na cultura e na economia.

No entanto, para Levi (2006) a biografia, ao ocupar boa parte das reflexões dos historiadores, enseja em seu cerne certa ambiguidade. Por um lado, entende-se o cuidado para não reduzir os indivíduos aos pressupostos normativos a partir de suas experiências, mas, por outro lado, ao contrário, utilizam-se os pressupostos para sustentar hipóteses da materialidade das leis e normas que se efetivam no comportamento social do biografado. Essa ambiguidade da biografia também se expressa, em certa medida, no debate do que é ciência e literatura, embora já seja de domínio acadêmico farta produção sobre o assunto.

Seja como for, é possível reconhecer os limites impostos às pessoas em suas relações sociais, políticas, culturais, geográficas etc., ainda assim, não é possível que os historiadores, em suas cadências teóricas e metodológicas, consigam cobrir a fertilidade total da vida em sociedade, visto que as fontes também impõem limites de várias ordens, inclusive, teóricas. É por essa razão que a biografia tende a assumir um status considerável no campo das Ciências Humanas, na cobertura mais completa e complexa de uma vida.

A biografia é a escrita sobre um determinado indivíduo e, por extensão, a autobiografia é uma escrita sobre si mesmo. Diz respeito à memória, autoimagem e representação do próprio indivíduo que a escreve acerca de sua trajetória em determinado ambiente social. Essa escrita sobre si mesmo pode revelar suas confissões, motivações, interesses, expectativas, suas manifestações frente aos desafios encontrados em sua trajetória, em seu processo individual.

Em certa medida, uma pesquisa de base biográfica procura compreender o comportamento social do indivíduo. Aliás, o próprio indivíduo vai em busca de sua identidade social, construída e compartilhada, parafraseando Elias (1998), num processo de 'envolvimento e alienação' de si mesmo. A autobiografia também pode se fazer compreender pela relação interdependente que se estabelece entre indivíduo e sociedade, relação esta que é necessária para a superação das dicotomias apresentadas pelo autor em seus vários estudos.

Dessa maneira, a autobiografia é também a possibilidade de um indivíduo exprimir seus sentimentos a partir do que ele vivenciou em sua relação com outros membros de sua sociedade. Baseado nisso, em certa medida, é possível perceber como o autor e biografado desenvolve determinados padrões na sua forma de pensar e falar sobre essas experiências, trazendo, inclusive, formas específicas de recordação:

O modo como os membros individuais de um grupo vivencia qualquer coisa que afete seus sentidos, o significado que isso tem para eles, depende dos padrões de lidar com esses fenômenos que gradualmente se desenvolvem em suas sociedades, bem como de pensar e falar sobre eles. (Elias, 1998, p. 109) 
Embora Elias (1998) não tenha se debruçado em tratar do método que ancora esta pesquisa, ou tenha assumido publicamente os estudos (auto)biográficos, é importante se ter em mente que, na perspectiva do 'envolvimento e alienação', o que está em jogo é a habilidade relativamente alta dos indivíduos de pensar e representar os diferentes conceitos a partir de suas experiências e, ao mesmo tempo, o que foi possível incorporar dos padrões coletivos. Assim, na elaboração de uma biografia, é possível, a partir desse método, compreender como um indivíduo é afetado pelos padrões sociais e subtrair as condicionantes históricas de sua representação a partir dos conceitos que elabora.

Esse método de pesquisa é realmente bastante instigante, pois possibilita o intercruzamento de diferentes áreas do conhecimento. Assim, Halbwachs (1990) chama atenção para o fato de que não há contradições entre a autobiografia e a história e que, na experiência humana, é possível que duas memórias estejam em conexão de forma complementar. Para o autor há uma memória individual, pessoal e outra memória coletiva, histórica, e que ambas, certamente, oferecem ao indivíduo uma espécie de porto seguro no processo de recordação.

Para ele a memória individual é inevitavelmente autobiográfica e se apoia na memória coletiva, sem a qual não há possibilidade de uma história individual, ou de vida. De modo que "toda história de nossa vida faz parte da história em geral" (Halbwachs, 1990, p. 55). Ou seja, uma história de vida só tem sentido dentro do espectro geral da vida em sociedade, e é esse arcabouço do todo social onde assenta a nossa memória. Além disso, é salutar a compreensão de que sem um lugar determinado não há como fazer emergir a memória, as recordações.

Entretanto, mesmo o autor reconhecendo que a memória histórica é mais ampla, ela não dá conta de representar o passado do indivíduo, a menos que seja de maneira tópica e esquemática. Em contrapartida, a memória individual, que o autor chama de autobiográfica, daria um quadro mais denso e contínuo sobre o próprio indivíduo. Dessa forma há em sua compreensão uma memória interior e outra memória exterior, o que permite um rico contraste compreensível daquilo que é pessoal, portanto, singular, e o que é coletivo.

A memória pessoal não está fechada em si mesma, um indivíduo, para fazer emergir suas recordações, terá que obrigatoriamente buscar referências nas lembranças dos outros, especialmente nos diferentes grupos sociais por onde passou e interagiu. Logo, a sociedade em seu espectro mais amplo e geral é o ponto de apoio das recordações, onde foram gerados os símbolos, os sentimentos, as realizações, ou seja, os pensamentos e resultados de um espaço e tempos vividos.

Nessa perspectiva, cotejada pela memória coletiva, essa memória individual pega de empréstimo lembranças de acontecimentos, fatos ou eventos lembrados pelos outros, bem como incorpora a história adquirida pela leitura ou pela simples conversa cotidiana com quem testemunhou aqueles acontecimentos ou, ainda, com quem participa de uma instituição que resguarda determinadas tradições nacionais.

Para Halbwachs (1990) toda memória, desde a mais tenra idade, é cotejada pelo conjunto de memórias 'preparadas' ou disponíveis ao indivíduo por uma coletividade. Não há uma memória individual sem a sua conexão correspondente coletiva, de maneira que 
uma criança, ao formular sua ideia ou percepção de algum objeto, estará, de certa forma, compartilhando ideias e percepções de uma coletividade, sem a qual não teria sentido sua visão que elabora do próprio objeto percebido:

Desde que a criança ultrapasse a etapa da vida puramente sensitiva, desde que ela se interessa pela significação das imagens e dos quadros que percebe, podemos dizer que ela pensa em comum com os outros, e que seu pensamento se divide entre o conjunto das impressões todas pessoais e diversas correntes de pensamento coletivo. (Halbwachs, 1990, p. 62)

Com essas reflexões do autor é possível compreender que a memória cumpre um papel importante no contexto das relações interpessoais, pois, por meio dela, o indivíduo não é apenas socializado e recebe do grupo ao qual pertence os códigos e o valores produzidos e disponibilizados pelas gerações mais velhas, como também vai paulatinamente construindo sua singularidade. Esses aspectos são importantes porque, num método de estudos como o aqui proposto, o autobiográfico, o fundamental é verificar a relação estabelecida pelo indivíduo em seu processo singular com os diferentes grupos sociais de uma trajetória.

Nesse sentido, é por meio da memória, do processo de recordação, que as trajetórias de vida são de alguma maneira definidas. E estudar essa relação do singular e plural, do indivíduo e os grupos sociais de suas referências, é o que traz para o campo desse tipo de estudo um certo encantamento ao próprio processo (auto)biográfico, na medida em que o pesquisador desperta o interesse em descortinar uma trajetória de vida e entende como a partir dela o indivíduo construiu e estabeleceu seus vínculos com os diferentes grupos sociais.

Entretanto, não é apenas a relação com os grupos sociais que interessa a uma pesquisa com essas características. A relação do indivíduo com o lugar e os diferentes objetos também entram nesse processo de recordação. Logo, a imagem exterior do lugar e também dos objetos parecem apoiar a memória individual, conferindo-lhe segurança e estabilidade na recordação. Por isso, é necessário revisitarmos os lugares de nosso passado, às vezes fisicamente, às vezes por meio de fotografias de uma carta recebida por parentes etc.

Segundo Halbwachs (1990) o indivíduo não tem apenas uma relação de comodidade e estética com os móveis, utensílios e outros objetos em sua residência. Há uma relação afetiva construída sem dúvida, mas também porque esses objetos em geral trazem à memória a imagem de famílias e de amigos com os quais está fixada a própria memória. De modo que as imagens com as quais nos relacionamos nos diferentes espaços por onde costumeiramente passamos e convivemos no dia a dia, têm um papel crucial no contexto da memória coletiva.

No contexto dessas reflexões podemos dizer que todos os quadros, móveis, utensílios e, de alguma maneira, as imagens com que interagimos resguardam uma memória individual e ao mesmo tempo coletiva, pois sua construção será sempre uma construção com outros membros de um determinado grupo social. Há também nessa relação com objetos e lugares, com esses elementos, importantes maneiras de lidarmos com as recordações da nossa infância. Assim, o indivíduo ao recordar, seja a partir de 
objetos ou lugares, seja de imagens, sempre despertará nos outros membros de sua sociedade a curiosidade de identificar formas fundamentais de uma experiência de vida numa trajetória.

Para Carino (1999), no entanto, existe um certo fascínio na biografia, especialmente por ela resguardar, até certo ponto, uma espécie de modelo de vida a ser seguido, o que estaria, a meu ver, o mais próximo do discurso panegírico, uma espécie de instrumentalização educativa, na perspectiva do que ele chama de pedagogia do exemplo. Isso, inclusive, remonta aos momentos iniciais da biografia, quando os discursos panegíricos buscavam, e ainda buscam, ressaltar as qualidades morais dos indivíduos, os aspectos positivos de sua existência.

O fascínio que temos pela trajetória de um indivíduo pode decorrer de sua singularidade enquanto pessoa e sua relação com os outros membros da sociedade, das suas características únicas irrefutáveis e irreplicáveis. Isso remonta para Carino (1999) à origem da própria Filosofia, no sentido do único contraposto ao múltiplo. Assim, esse Uno remete à ancestralidade, situado, portanto, nos esforços metafísicos do ser.

De qualquer modo, biografar alguém significa tentar estabelecer conexões de sua trajetória com a de outros indivíduos, seja para confirmar seu modus operandi, sua moral e ética, seja para dar exemplos às avessas, demonstrando a não conformidade com seus princípios. O autor reafirma o caráter indispensável da biografia na medida em que "tais finalidades e intenções fazem com que retratar vidas, experiências singulares, trajetórias individuais transforme-se intencionalmente ou não, numa pedagogia do exemplo. A força educativa de um relato biográfico é inegável" (Carino, 1999, p. 154). Por isso, não se lança mão do método biográfico de maneira fortuita, haverá sempre uma finalidade prática ou, como refere o autor, uma instrumentalidade educativa que sirva de exemplo.

A autobiografia é a apresentação pública do próprio biografado. É o discurso oficial do indivíduo partícipe de uma instituição que a ela se faz reconhecer. Assim sendo, parafraseando Bourdieu (2005), o mesmo conjunto de leis que rege e orienta o habitus social a um determinado território de trocas simbólicas, rege o discurso de um indivíduo proferido sobre a sua própria existência.

Para efeito de reflexão linguística, pode-se afirmar que a autobiografia tem a ver com o nome próprio, isto é, com o antropônimo, que identifica uma pessoa específica, e a ela cabe o desvendar de sua subjetividade, interesses, afetos, emoções etc. Desse modo, com o método autobiográfico, o indivíduo se concede a voz, se permite aos questionamentos que vê nos outros as perguntas de interesse e retoma a trajetória a partir dos conceitos e representações das próprias experiências.

Dito isso, Bourdieu (2005) apresenta um esboço de sua trajetória enquanto intelectual preocupado inicialmente em compreender o campo no qual se inseriu, embora negando que se tratava de uma autobiografia. Ele ainda expõe um conjunto de conceitos relativos a seu método sociológico, bem como conceitos fundamentais para se compreender o próprio método biográfico, apesar de, em sua visão, ser uma coisa comum e não passar de algo enganoso.

Essa percepção acerca da biografia é bastante inspiradora, na medida em que não há realmente algo mais trivial do que um indivíduo falar de si mesmo, dos seus feitos, seu heroísmo, de sua forma 'positiva' de ver o mundo, o que às vezes não passa de um 
profundo devaneio. No entanto, quando um indivíduo fala espontaneamente para um colega de classe, um vizinho etc., não se coloca mediante um método, eis a diferença fundamental.

Desse modo, é bastante significativo a forma como Bourdieu (2005) se posiciona na construção de sua trajetória, vencendo seus problemas, suas barreiras num processo de interrelação com outros intelectuais. Ou seja, à medida que sua trajetória toma corpo no campo acadêmico, ele vai se firmando enquanto intelectual e sociólogo e lentamente se diferencia de outros profissionais e intelectuais. Então, ele se coloca na posição de pesquisador, mas também de sujeito e objeto da análise.

Todavia, não se pode de modo algum, segundo Bourdieu (2006), compreender os mecanismos sociais que autorizam a experiência ou a trajetória de vida como unidade e ao mesmo tempo como totalidade, sem estar atento aos limites impostos pelo campo sociológico. Isto posto, "podemos encontrar no habitus o princípio ativo, irredutível às percepções passivas, da unificação das práticas e das representações [historicamente situadas e constituídas]" (Bourdieu, 2006, p. 186).

Produzir uma história de vida, tratar a vida como uma história, isto é, como relato coerente de uma sequência de acontecimentos com significado e direção, talvez seja conformar-se com uma ilusão retórica, uma representação comum da existência que toda uma tradição literária não deixou e não deixa de reforçar. (Bourdieu, 2006, p. 185)

Assim, ao relatar sobre os acontecimentos acadêmicos, o agente vai se tornando aquilo que está presente nas hipóteses de trabalho relativo à biografia, ou seja, conforme Bourdieu (2006), vai tornando-se o ideólogo de sua própria vida, consequentemente, construindo a prospecção estratégica de sua existência e subsistência material a partir das relações institucionais que se trava durante a trajetória:

Essa propensão a tornar-se o ideólogo de sua própria vida, selecionando, em função de uma intenção global, certos acontecimentos significativos e estabelecendo entre eles conexões para Ihes dar coerência, como as que implica a sua instituição como causas ou, com mais frequência, como fins, conta com a cumplicidade natural do biografado, que, a começar por suas disposições de profissional da interpretação, só pode levado a aceitar essa criação artificial de sentido (Bourdieu, 2006, p. 184)

Considerando as reflexões de Bourdieu (2006), a cumplicidade do biografado tende a ser completa e irredutível, na medida em que sua relação de sujeito e objeto está intimamente comprometida, seja nos aspectos subjetivos ou corpóreos, seja na seleção dos acontecimentos para realçar os limites pelos quais trilhou em determinado espaçotempo. A esse sujeito objeto de si mesmo, cabe também refletir acerca dos significados atribuídos aos acontecimentos e suas conexões estratégicas, no sentido de verificar as mudanças bruscas ou mais lentas das trajetórias institucionais que ocorreram.

Destarte, uma trajetória de vida não se encerra em si mesma. Logo, uma história de vida, mesmo que centrada na trajetória de uma vida, é cotejada inevitavelmente e intercruzada por outras trajetórias, seja de maneira direta ou indireta. Uma trajetória de vida é, por conseguinte, o mapeamento sensível e relacional de outras trajetórias dentro ou conformadas num determinado cenário ou campo específico, pode ser uma instituição escolar, religiosa ou universitária. 
A trajetória representa o reposicionamento ou deslocamento das diferentes espécies de capital (Bourdieu, 2006) que estão disponíveis no próprio campo de ocorrência, sob as escolhas do indivíduo. Assim, diferente do envelhecimento biológico, o envelhecimento social representa um amadurecimento das ideias, dos afetos, expectativas etc., e seu desenrolar é permitido a partir do "conjunto das relações objetivas que uniram o agente considerado" (p. 190).

O discurso do biografado, ou o discurso na autobiografia, é, em última instância, não apenas uma representação oficial do indivíduo, mas, sim, a produção oficial de si mesmo (Bourdieu, 2006). Essa produção, obviamente, remete às condições sociais, culturais e políticas circunscritas ao campo em que o biografado está inserido e de onde emergiu para proferir e oficializar sua fala, seu discurso.

Nesse sentido, a autobiografia é a apresentação pública. É o discurso oficial do indivíduo partícipe de uma determinada instituição a ela fazendo-se reconhecer. Assim sendo, as mesmas leis que orientam o habitus a um determinado território de trocas simbólicas regem o discurso proferido sobre sua própria existência "socialmente reconhecida de totalizar essas manifestações em registros oficiais, curriculum vitae, cursos honorum, ficha judicial, necrologia ou biografia, que constituem a vida na totalidade finita, pelo veredicto dado sobre um balanço provisório ou definitivo" (Bourdieu, 2006, p. 187).

Todavia, sem deixar de considerar os discursos anedóticos, elogiosos sobre o outro ou sobre si mesmo, dentre as possibilidades da biografia está a de se compreender as 'saídas' dos embaraços do indivíduo no cotidiano. Ou seja, está a possibilidade de o pesquisador identificar, num campo mais geral da sociedade, bem como num bairro, comunidade classista ou numa instituição, a predominância do indivíduo em resolver os conflitos, sua tomada de decisão, a construção de seus saberes, suas táticas, conforme Certeau (1998). Nesse aspecto, está também a possibilidade de o biografado estabelecer um balanço de sua vida, levantar hipótese de regozijos ou fracassos de sua trajetória num determinado campo de produção.

A esse respeito, pode-se dizer que é no campo onde se estruturam determinadas posições sociais, de onde advém a produção e o consumo de bens simbólicos, sua classificação, seus valores culturais, as disputas para as melhores posições dos indivíduos ocupantes desses espaços e onde o indivíduo mantém, inclusive, suas trocas simbólicas (Bourdieu, 2006, 2011). Nele, isto é, no campo, os diferentes capitais são distribuídos de forma desigual.

Trilhando um caminho parecido ao de Bourdieu (2006), Calligaris (1998) apresenta alguns argumentos importantes na intencionalidade e sinceridade de quem fala para si ou para um conjunto de interlocutores a partir da autobiografia. Suas considerações reconhecem que há sempre por parte dos interlocutores a escuta da verdade, ainda que 0 autobiografado tente esconder algo relacionado à sua vida:

A partir dessas premissas, não é difícil imaginar que o escrito autobiográfico ou o diário sejam em nossa cultura documentos privilegiados. Falar ou escrever de si - como reparou Foucault (1976) - é um dispositivo crucial da modernidade, uma necessidade cultural, já que a verdade é sempre e prioritariamente esperada do sujeito - subordinada à sua sinceridade. (Calligaris, 1998, p. 45) 
Para o autor, há um valor intrínseco no ponto de partida da fala do indivíduo, na medida em que já se espera sua intenção em falar e escrever a verdade, posto que o escrito autobiografado já revela que o indivíduo se situa acima de seu grupo social ou da comunidade a qual faz parte para expor, com sinceridade, suas motivações, desejos, expectativas etc., assim como o desejo do próprio indivíduo em construir uma história autônoma e independente da história oficial.

Calligaris (1998) afirma ainda que tanto a biografia, quanto a autobiografia estão imbricadas, em que uma dá sentido à outra. Essa premissa reside no fato de que sempre se contou histórias de vida, mas a ideia de que a vida é uma história é produto da sociedade moderna. Assim, "entende-se, desse ponto de vista, a simultaneidade históricocultural da aparição da biografia, da autobiografia e, naturalmente, do romance” (p. 48).

Nesse contexto, o método biográfico se revela de grande importância para a produção do conhecimento científico e não se contrapõe ao método historiográfico, justamente porque a biografia pode ser construída e constituída para um projeto de estudo, como um documento elaborado, e o pesquisador pode se valer da biografia secundária, que seria um conjunto documental produzido com outra finalidade, mas agora pode servir de análise complementar à representação do enredo do indivíduo biografado.

A autobiografia pode ser compreendida como um monumento, na medida em que é elaborada para fins práticos, ou seja, serve de modelo exemplo, para ser vista, observada e lida, mediada pelo interlocutor de sua própria existência e construção. Esse monumento da fala só é possível porque é construído a partir das relações sociais, que em suas disposições alteradas durante a própria trajetória, o indivíduo desenvolve uma autopercepção e acaba 'encontrando-se' com a sua própria identidade.

A autobiografia é também a representação que o indivíduo faz da instituição em que se forjou enquanto membro efetivo ou profissional. E pode ser, normalmente, narrada em primeira pessoa do singular, representando uma espécie de confissão social, pois os atos descritos na narrativa são a demonstração clara do que foi feito, realizado de forma positiva ou negativa, mas agora declarado como a 'sujeição' do indivíduo num determinado momento de sua vida.

Esse método se assemelha à conciliação dos 'pecados' para com um outro ser que não se encontra necessariamente no oratório. Enquanto ato confessional, as coisas ditas são assumidas como de responsabilidade pessoal e intransferível, mantidas para registro e possível divulgação, de maneira que apontam um caminho, se não da verdade, pelo menos dos compromissos assumidos durante uma existência e permanência do indivíduo num determinado campo.

Enquanto experimentação de um método, a autobiografia parece ser uma revisão da própria vida, porque, à medida que se conta a própria história, o indivíduo lembra e revê cenários, personagens, tensões, crises e também as atitudes tomadas para sair desses momentos. É no encontro com a sua identidade onde essas pequenas partes de sua trajetória são remontadas num tempo e num espaço enquanto lembrança, mas trazida e conciliada para os momentos atuais.

De acordo ainda com Calligaris (1998) espera-se um determinado resultado da autobiografia, na medida em que o ato autobiográfico é a ocasião em que o indivíduo faz algo para si mesmo ao desvelar sua trajetória na construção da narrativa. Nesse sentido, a autobiografia pode ser compreendida, ainda, como um projeto político, em que, ao se 
colocar acima de seu grupo e, às vezes, de seu tempo, o indivíduo se lança a dizer algo para os outros e para si mesmo, seja como objeto de inspiração, seja como modelo a orientar outras trajetórias.

O ato autobiográfico a que Calligaris (1998) se refere também pode ser interpretado como um momento em que o indivíduo se reconhece em meio aos desafios a serem vencidos, justamente porque "a vida do sujeito moderno já é um ato narrativo, uma autobiografia performativa" (p. 50), ou seja, na sociedade moderna, o indivíduo sempre estará em busca de ações para alterar a realidade. Logo, para o autor, o que está em jogo nesse ato autobiográfico não é metalinguagem, mas a narração e a reflexão acerca da própria trajetória de vida.

Há no ato autobiográfico um valor intrínseco pelas afirmações que constam da narrativa, isso configura seu caráter de verdade a partir dos caminhos por onde 0 indivíduo decidiu caminhar. Assim, do ponto de vista de um método, duas questões aparecem nessa decisão: o que consta da narrativa propriamente dita? $\mathrm{E}$ qual a motivação por contar de uma forma e não de outra, com suas pausas, inflexões, emoções, bem como os aspectos de sua vida pública e privada?

Nesse contexto, o livro Confissões, de Jean-Jacques Rousseau (2008), representa um clássico da autobiografia, que inaugurou, inclusive, para alguns autores, o sentido do homem moderno. O livro traz, do ponto de vista técnico, toda uma densidade autobiográfica inspirada e vivida em meados do século 18. A narração em primeira pessoa do singular faz o leitor adentrar em seu cotidiano, suas particularidades, tensões e erotismo experimentados desde a tenra idade para com mulheres mais velhas.

Esse exemplo clássico da autobiografia inaugura o espírito do homem moderno, ou a sensação de vazio construído por si mesmo e seu desejo de preenchê-lo, contrapondose aos destinos da vida ancorada na tradição. Assim, o indivíduo se impõe pela subjetividade causada pelo discurso proferido acerca de sua trajetória enquanto expressão de sua singularidade no mundo: "Dou começo a uma empresa de que não há exemplos, e cuja execução não terá imitadores. Quero mostrar aos meus semelhantes um homem em toda a verdade da natureza; e serei eu esse homem." (Rousseau, 2008, p. 29)

É desse modo que o autor inicia a escrita acerca de sua vida e avança decididamente, reafirmando a solidão de seus pensamentos e de sua memória, dizendo que conhece a si mesmo e também a outros humanos, que é semelhante àqueles que com ele convive, mas, ao mesmo tempo, difere diametralmente de todos os outros, por isso a execução do que pretende empreender não será passível de imitação. Ou seja, o autor reafirma com seus pensamentos a escrita de si, a singularidade de sua existência, e o fará com a sinceridade que lhe for possível, por testemunhar os acontecimentos, vivenciá-los ou, pelo menos, por trazer à memória aquilo que lhe pareceu acontecer.

De linguagem clara e direta, Rousseau (2008) desperta a curiosidade e o interesse nos meandros de sua vida mais íntima. Num diálogo sincero com o leitor, o autor apela, inclusive, para que não seja julgado antes de terminar o que teria para dizer, 'confessar', sobre as formas com que se viu na solidão, distanciamento do seus pais, os castigos recebidos pelos cuidadores, o aprendizado das primeiras letras até sobre os pensamentos eróticos despertados por mulheres mais velhas. 
Nesse contexto, para Malatian (2015), há um interesse especial em relação à vida das pessoas, suas intimidades e participação em algumas atividades, cujas evidências podem estar, além da fala, nas cartas pessoais, escritas e compartilhadas com amigos, familiares ou profissionais. Assim, seja por meio de cartas ou biografias publicadas amplamente na década de 1980, a vida privada vai tomando contornos acadêmicoscientíficos por meio de estudos que se interessam em conhecer motivações, desejos e afetos do indivíduo ocupante de uma determinada classe social.

Para a autora supracitada, a autobiografia tem aberto um campo expressivo para os historiadores e, ao lado das palavras, as cartas também ocupam um espaço entre as fontes privilegiadas para representar as pessoas, embora, segundo ela, esse suporte da escrita tenha sido substituído pelos e-mails, blogs e perfis no Facebook etc., onde ainda é possível compreender um conjunto de representações do indivíduo, porque "trata-se de escrita de si, na primeira pessoa, na qual o indivíduo assume uma posição reflexiva em relação à sua história e ao mundo onde se movimenta" (Malatian, 2015, p. 195).

Esse procedimento da 'cultura epistolar', segundo Malatian (2015), remonta ao século 19, que, além de ser o século da História, foi o período em que os indivíduos desenvolveram uma postura educativa diante de si mesmo, isto é, à medida que introjetavam determinados padrões sociais, normas de etiqueta, também refletiam sobre seus sentimentos e experiências.

Há nas diferentes tipologias de carta um conjunto de coisas dizíveis aos padrões sociais esperados, portanto, no realce da escrita constam elementos artísticos embutidos, que podem ser considerados verdadeiros instrumentos de educação formal, na medida em que modulam comportamentos. E, "longe de serem espontâneas, as cartas ocultam e revelam seus autores conforme regras de boas maneiras e de apresentação de si, numa imagem pessoal codificada" (Malatian, 2015, p. 197). Além disso, exigem e exigiam reciprocidade nas respostas, quando não solicitavam que fossem destruídas devido ao assunto tratado, às vezes, confidenciado.

Por outro lado, Goodson (2015) chama atenção para o amplo desenvolvimento de investigações realizadas na Inglaterra na perspectiva da história de vida. Para ele, já se alcançou certa maturidade no que diz respeito às abordagens, sobretudo na etapa das entrevistas da história de vida. Assim, "em Inglaterra, os métodos de história de vida estão cada vez mais a ser utilizados nos estudos, ajudando-nos a compreender melhor o percurso de vida adulto e as estratégias de aprendizagem ao longo da vida" (p. 24).

O autor considera que está havendo uma considerável mudança de paradigma, pelo surgimento das pequenas narrativas como um contraponto às grandes narrativas dominadas pela historiografia. Segundo ele, a questão central que se apresenta nesse novo gênero de abordagem passa pelo processo de individualização em que as sociedades humanas estão vivendo na atualidade. Dessa maneira, esse gênero narrativo, construído socialmente, expressa a própria trajetória da humanidade, e isso pode gerar a sensação de uma onda que atravessa diferentes interesses pela pequena narrativa.

Para o autor, "na atual sociedade individualizada, a nossa arte, cultura e política refletem cada vez mais um deslocamento para narrativas altamente individualizadas ou de interesse particular, que muitas vezes recorrem à literatura de terapia e de desenvolvimento pessoal" (Goodson, 2015, p. 8). Embora não concorde integralmente com o autor, no que concerne aos aspectos terapêuticos da narrativa, ele se refere a um 
dos aspectos fundamentais do que é realizado no tipo de pesquisa biográfica, o fato de que, subjacente à narrativa individualizada, há o impacto da sociedade geral, da história social sobre o próprio indivíduo que narra e sobre os cientistas que, porventura, valorizam esse tipo de produção de conhecimento.

Concretamente, o desenvolvimento tecnológico alcançado pela sociedade num determinado momento da história acaba por criar mecanismos fundamentais de interesse em áreas antes não observadas, como, por exemplo, a invenção do gravador e da fita magnética, que contribuíram para que as pesquisas sociais pudessem ter uma forma específica de construir fontes de conhecimento a partir da narrativa oral, que passou a ser registrada num instrumento para posterior análise.

Há também na narrativa individual uma espécie de orientação advinda da sociedade mais geral e de sua história que fixa o indivíduo, ou melhor, que traça uma trajetória para ele a partir de determinados modelos sociais, seja de comportamento, de estética ou política. Assim, é preciso advertir que "os guiões sociais que as pessoas empregam na narração de sua estória de vida derivam de um número reduzido de arquétipos aceitáveis na sociedade em geral" (Goodson, 2015, p. 16). Ou seja, o que se conta enquanto indivíduo e personagem central numa biografia está irremediavelmente em conexão com figuras de símbolos sociais que favoreçam uma linha de raciocínio e de comportamento de modelo exemplar.

Nesse sentido, o autor tenta distinguir o que vem a ser estória e história de vida. Para ele, a estória passa necessariamente por uma experiência pessoal construída a partir do relato de um indivíduo; já a história de vida, embora se baseie na estória contada, "o objetivo é desenvolver um eixo de análise intertextual e intercontextual" (Goodson, 2015, p. 57). Assim, envolve uma gama significativa de outras elaborações, que levam em conta informações acerca daquela experiência de vida, bem como a abrangência sob a qual a estória é contada.

Nessa transição de estória para história de vida, texto, intertexto e contextos são fundamentais para a compreensão mais geral do cenário em que o narrador está inserido, de modo a conectar a experiência individual no conjunto dos acontecimentos e situações as quais uma vida está submetida. Dito isso, a história de vida é uma reconstrução do investigador junto ao seu colaborador, sem, no entanto, perder de vista fatos e acontecimentos históricos que envolvem o conjunto mais geral da sociedade.

Contudo, na esteira dessas reflexões e modulado de certa forma por personagens importantes socialmente, resguarda-se a autobiografia de professores. Assim, Nóvoa (2013) discute de maneira aprofundada as múltiplas abordagens autobiográficas relacionadas a esse profissional do conhecimento. $O$ autor adverte que, no interior do movimento de estudos biográficos, nascido de preocupações pedagógicas, têm aparecido interesses bastante difusos em relação às realidades profissionais e educativas, bem como as formas e procedimentos com que os professores se organizam no dia a dia de sua profissão.

Nesse contexto, tem-se percebido, numa vasta literatura, aproximações da Psicologia, interessada no estresse, tensões e saúde mental dos professores, e da Sociologia, com interesse nos aspectos relacionados ao universo social e a memória, por exemplo. Mas, para Nóvoa (2013), sejam quais forem os campos de interesse teórico ou 
empírico, "uns e outros esquecem as necessidades de saber e de ação que estiveram na gênese contemporânea das abordagens (auto)biográficas, dificultando a configuração de uma reflexão especificamente pedagógica" (p. 19).

Todavia, é importante se ater aos objetivos e as dimensões concernentes às diferentes abordagens. Assim, tem-se objetivos teóricos versus a prática dos professores, objetivos teóricos versus a profissão do professor, entre outros objetivos emancipatórios que envolvem a investigação-formação, práticas e o professor e sua dimensão pessoal (Nóvoa, 2013).

Com essas reflexões, é preciso compreender também que a autobiografia e as narrativas quando analisadas têm demonstrado a complexidade de elementos que envolvem os saberes e as ações dos personagens e seus respectivos cenários. De modo que há de se conjugar diferentes olhares sobre as trajetórias, uma vez que se trata de um ser humano contando e recontando suas ações, limites e desafios ultrapassados.

Como uma dessas importantes experiências, Holly (2013), no texto Teorizando com coragem, conta de uma pesquisa que analisou a escolha dos professores por um diário para falar sobre suas vidas profissionais e pessoais. Essa opção corajosa reflete, de certa forma, na observação de si mesmos, uma autodescrição de seu cotidiano, que possui características comuns presente em outros educadores, mesmo essa experiência tendo profissionais de diferentes níveis de ensino, do secundário ao ensino superior, seja início ou final de carreira.

Portanto, são muitas as perspectivas analíticas que podem envolver a autobiografia, além de algumas das técnicas empregadas no método, isso porque "a escrita de diários biográficos e autobiográficos inclui, geralmente, a reconsideração e a reconstrução da experiência a partir da história de uma vida, quer seja a sua própria (autobiografia) ou de outras pessoas (biografia)" (Holly, 2013, p. 101).

A autora adverte que, do ponto de vista da teorização, escrever sobre a própria história requer muito mais tempo, porque envolve escolhas a partir dos sentimentos e ações observadas. As decisões pressupõem a exploração de sequências narrativas que podem entrar na trajetória de muitas maneiras, seja corroborando ou refutando sentimentos. Isso a autora categoriza como desconforto: o desconhecido e o incerto na própria narrativa; distanciamento: a investigação de si mesmo e a análise da trajetória por diferentes ângulos; transformação de perspectiva: a partir do desconforto, deixar de escrever ou de narrar os acontecimentos.

Além dessas categorias, que se apresentam de maneira comum nos diários escritos por educadores e observados por Holly (2013), a atenção focalizada e a voz complementam a perspectiva analítica da autora sobre os dois mundos em que esses profissionais se veem no cotidiano, entre compreender as pessoas que ensinam e a obrigatoriedade de transmitir o conhecimento, entre a demonstração de confiança e o estabelecimento de padrões de comportamento mais adequados à própria profissão de professor.

Se por um lado esses diários representam a experiência contada pelos educadores em seu cotidiano, portanto, autobiografia, por outro, essas fontes também podem servir para a construção historiográfica, para aquilo que Aróstegui (2006) compreende como 
fiabilidade e adequação, ou seja, autenticidade e origem da fonte, como a possibilidade de se ter uma fonte em quantidade suficiente para responder a uma infinidade de questões de um determinado projeto de pesquisa.

Considerando todos os aspectos que envolvem as questões relacionadas ao método aqui empregado, há de se distinguir a história de vida, a biografia e a autobiografia. Embora tenham um tronco comum, que acompanha, de certa forma, segundo Pereira (2000), a valorização da História Oral, dos usos dessa fonte enquanto método ou técnica de pesquisa, esses gêneros são diferentes em alguns aspectos e semelhantes em outros, como as características multidisciplinares que envolvem a Sociologia, a Antropologia e a própria História.

Pelo que se percebe, os gêneros são realmente distintos, embora a distinção apareça de forma muito sutil, quando considerada a abordagem com que a trajetória da vida do indivíduo é ancorada pelo pesquisador. Assim, a história de vida se distingue por concentrar a análise no contexto em que aquela vida está inserida; ou seja, concentra-se no evento enquanto contexto da narrativa.

De fato, ao escrever sobre as representações sociais de dançarinos-atores a partir da história de vida, num trabalho que publiquei (Souza, 2008), minha preocupação estava em descobrir o que levou aqueles agentes sociais ao ingresso na dança e quais foram os eventos que marcaram a entrada daqueles indivíduos no campo artístico. De modo que a ideia de contexto estava sempre presente enquanto elemento a ser considerado na análise e, mesmo solicitando inicialmente que o entrevistado falasse sobre sua história de vida, realizava pequenas intervenções de acordo com o meu interesse geral na explicação/explicitação dos fatos narrados.

Já a "biografia se define como a história de um indivíduo redigida por outro. Existe, aqui, a dupla intermediação que se aproxima da história de vida, consubstanciada na presença do pesquisador e no relato que se segue" (Pereira, 2000, p. 118). A autora deixa implícito que, na biografia, trata-se de alguém vivo ou já falecido cuja vida é narrada e redigida por outros agentes sociais, utilizando-se de arquivos e depoimentos de terceiros.

Dessa maneira, "uma autobiografia consiste na narrativa da própria existência [...] nela foi o próprio narrador quem se dispôs a narrar sua vida, deu a ela o encaminhamento que melhor the pareceu e deteve o controle sobre os meios de registro" (Pereira, 2000, p. 118). Dito isto, está garantida a totalidade da narrativa, desde a produção do discurso, das escolhas, das cenas e personagens censurados até as edições e recortes das falas para publicação.

Por outro lado, também há de se pensar nas fronteiras entre os métodos da história oral, história de vida e biografia (Silva, 2002), especialmente quando se pode arcar com o método biográfico independentemente da história oral, ao mesmo tempo que se pode ter um projeto de história oral acerca de um evento coletivo, portanto não biográfico, a depender, inclusive, dos aspectos teóricos envolvidos, se de matriz sociológica ou histórica.

Segundo Silva (2002), a biografia remonta ao século 19, amplamente utilizada pelos historiadores ao reposicionar os feitos dos 'grandes homens', pondo-os num papel de destaque em seu lugar na história. Mas, a partir da década de 1920, quando a biografia é 
sumariamente descartada pelos historiadores, o método ressurge nas Ciências Sociais, na perspectiva de compreender a relação do indivíduo e a sociedade. Esse ressurgimento acaba pondo em relevo a história de vida de forma imbricada à biografia (Silva, 2002).

De qualquer maneira, o ressurgimento da biografia nesse campo das ciências altera significativamente o olhar do pesquisador, o que "significa que não mais o relato de vida de um indivíduo, uma autobiografia comporia a pesquisa, mas um número suficiente de histórias de vida pudesse dar conta da explicação do grupo" (Silva, 2002, p. 28).

Parece óbvio que, a partir desse ressurgimento do método, tem-se conceitualmente uma biografia histórica e uma biografia sociológica, ambas com interesses difusos em relação ao personagem relatado, seja no contexto mais específico de participação e interveniência do indivíduo, seja em relação aos aspectos mais gerais do movimento de um grupo social. Ou melhor, "enquanto a primeira centra o interesse no indivíduo, a segunda procura desvendar o grupo; enquanto a primeira não estabelece prioridade de fonte, a segunda privilegia o relato de vida e a autobiografia" (Silva, 2002, p. 29). Esse debate se assemelha, portanto, ao que frequentemente a historiografia se deparava ao tentar diferenciar Literatura e História, o que é gênero de discurso, retórica e método científico.

Outro autor que também partilha dessas ideias relacionadas à biografia histórica é o Silveira (2016). Para ele, esse gênero busca "articular a narração e explicação, reguladas pelas regras de pesquisa e produção escrita comuns à área da História" (p. 472). Desse modo, a ideia de contexto também sempre estará presente na interpretação da narrativa de si, sendo necessário que o pesquisador aborde questões mais gerais dentro do recorte espaço-temporal em que o biografado viveu. Além desses aspectos, há de se considerar o manuseio de diversas fontes documentais e bibliográficas para se construir um conjunto de representações daquilo que se pode chamar de história-problema. Nesse sentido, o autor reconhece que a "microanálise e biografia histórica se aproximam" (p. 474).

Para além da diferenciação entre história de vida e biografia, há de se pensar na História Oral também como um método bastante explorado pelas Ciências Humanas e Sociais. De surgimento bastante remoto, sua força acadêmico-científica foi impulsionada, notadamente, a partir da publicação de Paul Thompson (1992), A voz do passado, que é, na verdade, uma contraposição à história positivista, linear, que ancorava os feitos da elite burguesa.

Nessa perspectiva de uma história vista desde baixo, o autor põe em relevo a voz do indivíduo, do seu grupo social e das experiências particulares daí decorrentes. Com esse método, a relação sujeito-objeto fica bem clara e definida num projeto de engajamento político, o que tem suscitado inúmeros trabalhos vindos dos movimentos sociais, ou como o cidadão comum enxerga sua sociedade e seu papel na história.

Thompson (1992) levanta várias questões relacionadas à História Oral, mas uma das que mais se sobressaem é a procura por aquilo que entendo por 'porões' do inconsciente. Segundo o autor "toda fonte histórica derivada da percepção humana é subjetiva, mas apenas a fonte oral permite-nos desafiar essa subjetividade: descolar as camadas de memória, cavar fundo em suas sombras, na perspectiva de atingir a verdade oculta" (Thompson, 1992, p. 197). É evidente que a verdade a ser encontrada é um dos objetivos fundamentais da pesquisa científica, muito embora saibamos que essa verdade será sempre relativa e conjuntural. 
Esse 'cavar fundo' apresentado por Thompson (1992), lembra bem as reflexões feitas por Velandia Mora (2010) ao tratar das questões relacionadas à autobiografia e de uma das ferramentas fundamentais para a compreensão da narrativa de si mesmo: a autoetnografia. Em sua perspectiva, a autoetnografia pode servir, inclusive, como elemento educacional, pois pode ajudar os intelectuais a entenderem os preconceitos referentes a determinadas minorias e minimizar os impactos das superstições, equívocos e mentiras relacionadas a grupos vulneráveis, por exemplo.

Segundo Velandia Mora (2010), numa perspectiva autoetnográfica, o pesquisador é levado a fazer um duplo movimento, ou seja, ao mesmo tempo em que analisa um determinado objeto, o próprio método é submetido à análise. Dessa maneira, há nesse ambiente um processo em que o autor chama de 'reflexividade', que, no fundo, é próprio das pesquisas sociais e humanas, onde o pesquisador pode fazer uma densa reflexão acerca das condições do próprio ambiente da pesquisa científica e verificar seus efeitos e impactos sociais.

Desse modo, a categoria da 'reflexividade', assegura Velandia Mora (2010), diz respeito a todo o processo desenvolvido pelo pesquisador na confecção de um estudo sobre si mesmo, ou seja, envolve a compreensão da estrutura e dinâmica da escrita sobre sua vida, seus procedimentos no campo em que decidiu empiricamente investigar a sua existência, de maneira a criar um ambiente favorável a essa categoria analítica. Entretanto, "as razões para escrever uma autobiografia podem responder a qualquer motivação interna e externa e a diversidade de autores e temas atualmente dificultam os tipos de classificação"5 (Velandia Mora, 2010, p. 64).

$\mathrm{O}$ que as pesquisas têm indicado, diz o autor, é que o autobiógrafo, também narrador e protagonista, acredita no que narra, expõe o que fala enquanto verdade de sua trajetória porque sua ação é a própria forma de existir e sentir (Velandia Mora, 2010). Logo, o narrador é o que fala com grandes possibilidades de transformação, justamente porque somos mutáveis na mesma medida em que recebemos as clivagens sociais e culturais em que estamos imersos.

As pessoas agem de acordo com os sistemas sociais a que pertencem. Mas através de suas ações, embora condicionadas por esses sistemas sociais, também eles podem mudar esses sistemas sociais. Isso também pode ser afirmado em relação a cultura. Nós nos acostumamos como pessoas do sistema de relacionamentos que mantemos com os outros, isto é, que somos componentes de um sistema social mais amplo: o idioma." 6 (Velandia Mora, 2010, p. 69)

Essa fala do autor é bastante significativa porque considera que, mesmo o indivíduo fazendo parte de um sistema social que lhe impõe valores, há possibilidades de transformar a realidade em que ele está inserido. Assim, ele advoga uma autobiografia

\footnotetext{
5 "Las razones para escribir una autobiografía pueden responden a cualquier motivación interna o externa y la diversidad de autores y de temas dificulta actualmente cualquier tipo de clasificación."

6 "Las personas actúan de acuerdo a los sistemas sociales a los que pertenecen. Pero a través de sus acciones, aunque condicionadas por estos sistemas sociales, también pueden cambiar tales sistemas sociales esto igualmente pude afirmarse con relación a la cultura. Nos constituimos como personas desde el sistema de relaciones que mantenemos con los demás, es decir, que somos componentes de un sistema sociales más amplio: el lenguaje."
} 
fundamentada em processos educacionais, que pode provocar transformações, mesmo 0 indivíduo submetido às condições culturais que mantém os mesmos códigos linguísticos, por exemplo. É óbvio que essa é apenas uma das muitas conceituações e reflexões teóricas a que os pesquisadores estão dispostos a fazer em relação ao método (auto)biográfico.

Não obstante, o autor se propõe a fazer algumas incursões conceituais sobre o método, inclusive, reconhece a relativa dificuldade em determinar se a escrita sobre si, autobiografia, memórias e história de vida são exatamente as mesmas coisas, ou se tratam dos mesmos objetos, pelo menos por parte de sociólogos e antropólogos. Aliás, esse tem sido um debate bastante profícuo, seja na Espanha, origem dos estudos de Velandia Mora (2010), seja aqui no Brasil.

Em sua perspectiva, dependendo do olhar de quem escreve, há três possibilidades de se pensar os estudos que possuem essas características sendo, "primeiro, narração da vida de outro (biografias); segundo, as histórias baseadas em aspectos da vida das pessoas (história de vida); e, terceiro a narração da própria vida (autobiografia)"7 (Velandia Mora, 2010, p. 73).

Seja como for o encaminhamento dado aos aspectos conceituais de diferenciação de um método, a literatura consultada ainda parece insuficiente para diferenciar a história de vida da biografia. Por enquanto, o que parece mais óbvio é que o tronco genealógico comum das histórias de vida, biografia e a própria autobiografia tem suas origens na tradição oral, sob a qual se assentaria um conjunto de procedimentos extraídos da experiência dos indivíduos e da coletividade.

Não obstante a problemática que envolve esse campo de interesse acadêmico, nossa fala sobre nós mesmos é recorrente no que diz respeito aos planos, aos sentimentos e ações, bem como aos possíveis projetos próprios de uma experiência. Em última instância, esse discurso de si pode servir de orientação para um estudo científico, caso isto ocorra, no entanto, o projeto da pesquisa precisa ter regras que o (auto)biógrafo não pode escapar:

Contamos histórias sobre nós mesmos diariamente. Às vezes conseguimos que alguém as escute, mas, mesmo quando não é o caso, este processo de autonarração constantemente se desenrola em nossas mentes, mesmo que de maneira frouxa e desordenada. Em certo sentido, estamos sempre falando sobre nós pelo menos para nós mesmos, fazendo planos sobre o que iremos fazer, revendo o que fizemos, o que pensamos, o que sentimos. (Eakin, 2019, p. 17)

Essa fala recorrente é fundamental para que o indivíduo autobiógrafo se compreenda na teia das relações sociais. Logo, segundo Eakin (2019), à medida que a fala se desenvolve, construímos a nossa identidade na narrativa. Essa fala de si sempre obedecerá a um conjunto de regras que fundamentam a construção da narrativa e de onde emerge vários personagens, entre os quais o autobiógrafo, em suas relações amistosas, afetuosas, tensas etc.

\footnotetext{
7 "Primero, la narración de la vida de otro (biografías); segundo, las narraciones que se basan en aspectos de las vidas de las personas (relatos de vida); y, tercero, la narración de la propia vida (autobiografías)."
} 
O autor sugere que temos o direito de falarmos o que quisermos sobre nós mesmos, mas, seja o que for dito, ao envolver outros indivíduos, podemos ser responsabilizados pelo que dissermos, especialmente ao envolver a vida privada. Mesmo não estando escritas enquanto um manual, as regras serão sempre cobradas em virtude das relações sociais que mantemos no cotidiano. Desse modo, Eakin (2019) chama a atenção para três regras importantes "sobre as quais autobiógrafos têm sido chamados a se explicar: 1) distorção da verdade histórica ou biográfica; 2) infringência do direito à privacidade; 3) incapacidade de exibir padrões de pessoalidade" (Eakin, 2019, p. 46).

$\mathrm{O}$ autor adverte que transgredir essas regras pode levar a algumas sanções, que variam desde o desabono público e contenda jurídica ao isolamento institucional; ou seja, pode prejudicar o posicionamento do autobiógrafo e colocá-lo à margem dos grupos sociais que pretensamente poderiam lhe conferir autenticidade e garantias de boa-fé. Aliás, segundo Eakin (2019), a primeira regra parece assegurar que determinada pessoa é digna de contar e ter uma história de vida de acordo com os padrões culturais da sua sociedade.

Embora haja a ideia de regras e pactos, estes colocados pelo autor em outro momento, como garantias de veracidade autobiográfica, o que incide nessas reflexões é o fato de que falamos sobre nós mesmos todos os dias e com muita frequência; logo, a escrita autobiográfica é apenas uma pequena parte para corroborar a construção da identidade do indivíduo. Assim, o exame mais preciso de Eakin (2019) diz respeito ao "que se espera de um indivíduo, manifestado numa narração de si, para que ele ou ela 'sejam considerados' uma pessoa" (p. 48).

Desse modo, o autor compreende que as regras autobiográficas funcionam como 'regras identitárias' e, se infringidas, expõem, por conseguinte, a identidade do próprio autobiógrafo enquanto pessoa. A identidade do indivíduo, seja no texto ou na fala, está sempre em suspeição, sob a reação e o questionamento público se de fato se trata de um indivíduo com as prerrogativas identitárias do grupo social a que diz pertencer.

A partir dessas reflexões, é possível presumir que o autobiógrafo fala e escreve para um determinado grupo e se vê capaz de predizer suas intenções, afetos e expectativas, mas, é claro, sem infringir suas regras, sua moral e ética. Assim, a lealdade ao grupo ao qual escreve deve ser preservada, sob pena de se tornar à margem por sua desconstrução identitária.

A primeira regra aqui exposta por Eakin (2019) não diz respeito apenas à veracidade do que foi escrito ou à capacidade de o autobiógrafo se mostrar por inteiro, mas, mesmo sendo os fatos narrados verdadeiros, eles devem referir-se também irremediavelmente ao próprio indivíduo objeto da fala. Ou seja, o autobiógrafo deve referir-se aos fatos vividos e ou testemunhados por si mesmo, sob pena de estar transgredindo uma das regras.

A segunda regra, do direito à privacidade, parece mais óbvia do que as demais e transgredi-la é uma infração grave, na medida em que a autobiografia deve ser demarcada a uma narrativa de si, onde o dizer desse indivíduo precisa estar circunscrito a suas próprias tensões, expectativas, medos e anseios, sem causar danos à terceiros. Quebrar essa regra é o que vale, em muitos casos, a arcar com demandas judiciais, além da opinião pública. 
Para Eakin (2019), há de se tomar muito cuidado na observação dessa regra do direito à privacidade, na medida em que essa regra pode ser incompatível à primeira, contar a verdade, ou simplesmente falar de si, porque envolverá inevitavelmente outros personagens na mesma trama. Segundo o autor, "se autobiografia implica inescapavelmente expor o privado, autobiografados acabam levando vidas arriscadas, moralmente falando, gostem eles ou não; alguns, no entanto, são bem recompensados por violar a privacidade - e essa é uma óbvia razão para fazê-lo" (p. 54).

De qualquer modo, o direito à privacidade é a garantia de que o autobiógrafo não revele aspectos de sua vida privada que sejam 'momentos a dois', isto é, que envolvam outro indivíduo e sua respectiva identidade. Transgredir essa regra pode desrespeitar a integridade física ou moral de terceiros em sua singularidade.

A última regra examinada pelo autor, a "incapacidade de exibir padrões normativos" diz respeito ao que a pessoa realmente é, não o que foi capaz de fazer. A pessoa do autobiógrafo "é julgada pelos outros como alguém que não possui a natureza do próprio ser, de maneira profunda e incapacitante" (Eakin, 2019, p. 56). Essa regra pressupõe os gestos de normalidade que devem estar contidos na narrativa de si, o contínuo identitário, ou melhor, a ausência de distúrbios que coloquem em suspeição a integridade mental do autobiógrafo. Sendo assim, o descrédito pode levar ao inconformismo do leitor em relação ao objeto narrado:

A responsabilização social nos condiciona, desde a mais tenra infância, a acreditar que nosso reconhecimento enquanto pessoa deve ser negociado através da troca de narrativas identitárias. O veredito das pessoas para quem nós nos apresentamos é praticamente axiomático: não havendo narrativa satisfatória (ou narrativa nenhuma), não há um eu (Eakin, 2019, p. 57)

Esses aspectos aludidos pelo autor dizem respeito à normalidade na narrativa. Embora saibamos que pessoas que apresentem distúrbios narrativos tenham sido com certa frequência institucionalizadas, os distúrbios dessa ordem não trazem punições jurídicas ao transgressor, mas, colocam, em certa medida, uma suspeição na credibilidade do autobiógrafo.

Seja como for as questões relacionadas à credibilidade da narrativa, não se pode presumir quais das três regras podem trazer mais prejuízos ao autobiógrafo, caso sejam transgredidas, mas, seja como for, o espectro identitário deve ser sempre resguardado, sob pena de sofrer as mesmas punições apresentadas pelo autor. Desse modo, "o que estou sugerindo é que existe uma punição potencial para as pessoas que falham em exibir um modelo normal de identidade narrativa. Essa possibilidade está latente em qualquer aplicação das normas" (Eakin, 2019, p. 58).

Realmente pode ser muito danoso o fato de algum indivíduo em seu ato autobiográfico ser identificado como portador de algum distúrbio na narrativa, por conseguinte, distúrbio identitário. Talvez, essa seja a razão pela qual, ao ter que apresentar memoriais acadêmicos, por exemplo, os docentes não queiram imprimir seus aspectos subjetivos à narrativa, sob pena de "acusação" de subjetivismo ou distorção da realidade. 
Contudo, há grandes possibilidades de se encontrar nesse subjetivismo algo a mais do que simplesmente erudição desnecessária. Talvez, seja possível identificar nessas narrativas algo que seja compreensível, como entende Franklin (2009), no sentido de uma cultura acadêmica em processo de construção, que pode representar os atores sociais que vivem em instituições universitárias, por exemplo. Aliás, para a autora, a crítica literária tem dado pouca importância às memórias de professores, mesmo considerando que, ao contar suas histórias de vida, o produto da narrativa faça parte de um gênero da literatura amplamente aceito.

Franklin (2009) adverte, no entanto, que, para os críticos da literatura, quando o professor escreve sobre sua vida acadêmica, não passa de "crise da meia-idade" ou de tomada de consciência de sua aposentadoria etc. Outro aspecto apontado pela autora diz respeito à valorização das áreas tecnológicas, seu financiamento público e consequentemente, à falta de financiamento e bolsa de estudos para as áreas de humanidades, que tem atingido a escrita dos memoriais acadêmicos. De qualquer modo, ainda há um movimento sobre a escrita desses memoriais e o impacto de diferentes fatores sobre essa narrativa de si é o objeto de estudo a que se propõe Franklin (2009).

As preocupações da autora são importantíssimas para o objeto desta tese, especialmente numa perspectiva autobiográfica, em que tenho de expor, de alguma forma, minha subjetividade e ainda submetê-la ao crivo de um processo de aprovação por membros da comunidade científica. Dito isto, Franklin (2009) identifica em seus estudos um engajamento político do narrador, na medida em que reivindica mudanças institucionais, diz ela: "outras memórias que eu discuto postulam um humanismo abrangente que insistentemente não procura transcender, mas sim fazer uso e transformar as instituições acadêmicas e outras em que todos estamos desigualmente localizados"8 (p. 3).

Essas reflexões são bastante significativas, uma vez que as memórias acadêmicas são escritas, normalmente, a partir de um certo tempo de permanência institucional, especialmente quando 0 docente já adquiriu uma certa dose de experiência na profissão e, sobretudo, adverte Franklin (2009), após os 50 anos de idade e após adquirir o status de professor titular.

Além de sua preocupação com o movimento das memórias acadêmicas, a autora também tnuma preocupação com os estudos sobre a brancura e a autobiografia institucional, em que faz uma razoável reflexão acerca dos problemas étnico-raciais enfrentados por professores e estudantes universitários. É óbvio que, ao narrar sobre suas memórias acadêmicas, a autora considera que, ao contrário das instituições, que só demonstram uma preocupação teórica, os professores acabam tratando de temas ásperos.

Todavia, Silva (2015), ao analisar memoriais acadêmicos apresentados por docentes para ingressar por concurso na instituição ou para efeito de titulação, mostra a dificuldade encontrada pelos autores em falar sobre si. Mas, em meio às dificuldades, é

\footnotetext{
8 "Other memoirs I discuss posit a wide-reaching humanism that insistently seeks not to transcend, but rather to make use of and transform the academic and other institution in which we are all unequally located." (Franklin, 2009, p. 3).
} 
importante compreender a riqueza de terminologias e abordagens com que os autores de suas narrativas encontram na distinção desse importante instrumento exigido por diferentes instituições:

O estudo das narrativas de vida de educadores tem sido abordado por uma extensa diversidade de entradas e terminologias de pesquisa, sintoma de uma flutuação terminológica em torno das histórias e relatos de vida, biografias e autobiografias que refletem a riqueza e a dificuldade de se expressar distintas vivências e temporalidades. (Silva, 2015, p. 108)

É impressionante como professores de diversas áreas do conhecimento sofrem da mesma angústia ao terem, em algum momento de suas vidas acadêmicas, a necessidade institucional de falar sobre suas realizações, seus feitos e efeitos consoantes a uma trajetória. Pelo que o autor analisou, as experiências relatadas variam consideravelmente em relação ao conteúdo, mas a forma direta, objetiva, portanto, descritiva, não muda. Mesmo assim, se está diante de um relato de vida, de uma trajetória, cujas características centrais se assentam na autobiografia.

Com algumas exceções, ainda se encontram narrativas de si de uma maneira mais subjetiva, ou melhor, um alinhamento dos dados objetivos aos aspectos subjetivos da vida em família, da casa e outros eventos do convívio interpessoal. Mesmo não sendo o mais comum de se encontrar, esse tipo de narrativa de si expressa uma relação imbricada entre a profissão e a vida cotidiana. Logo, há um caminho bastante movediço ao tentar fugir das narrativas que se mostram mais objetivas.

Quem se lança à aventura de contar-se na forma de uma narrativa nãoesquemática é porque se dispõe a colocar em meio ao esforço reflexivo boa dose de impressionismo, a correr o risco da nostalgia ou da indignação, a assumir litígios ou vindicações, e outros contrastes de luz e sombra, afirmação e negação, lembrança e esquecimento que tornam a vida mais do que um currículo. (Silva, 2015, p. 133)

Os riscos apontados pelo autor tendem a movimentar o campo dos estudos autobiográficos, no qual é possível mapear diferentes perspectivas teóricas e metodológicas, aquilo que ele próprio chama de entradas e terminologias, para situar a fertilidade com que os memoriais têm sido produzidos no interior das instituições universitárias.

Sendo considerado que a vida é mais do que um currículo, como de fato é, a biografização pode se expressar para além das questões da formação escolarizada e levantar, a partir da memória, os aspectos identitários da profissão docente ou relacionados às questões étnico-raciais, por exemplo. Aliás, o problema da identidade, bem como da alteridade, é um dos aspectos fundamentais na construção da narrativa de si, segundo Souza Elizeu (2008). Essas preocupações são pontos de confluências de grupos de pesquisa que têm investido no processo de "investigação-formação docente" por meio da autobiografia.

O que tem mobilizado os pesquisadores nessa vertente é considerar o momento de formação inicial e continuada um dos elementos essenciais para a construção da identidade profissional, o que leva a hipótese de que o processo de formação deixa marcas fundamentais na história de vida dos indivíduos, na qual o método de narrar 
cumpre alguns papéis importantes, seja enquanto método de pesquisa, na construção de fontes, seja na autorreflexão sobre a própria formação em andamento (Souza Elizeu, 2008).

$\mathrm{Na}$ perspectiva autobiográfica, portanto, é possível identificar também as formas e modelos de aprendizagens do próprio professor. Ou seja, como o professor aprendeu o que sabe e de que maneira esse saber é transposto aos educandos. Com isso, estamos tratando da Sociologia do Conhecimento e das condições históricas em que o saber circula num determinado ambiente social a partir de registros autobiográficos.

Nesse contexto, Passeggi, Souza e Vicentini (2011) situam as narrativas autobiográficas como parte importante do que chamam de "virada biográfica em educação", no interior da qual emergem estudos preocupados em verificar "as razões da escolha profissional, as especificidades das diferentes fases da carreira docente, as relações de gênero no exercício do magistério, a construção da identidade docente, as relações entre a ação educativa e as políticas educacionais" (p. 370).

Além desses aspectos, os autores apontam alguns avanços sobre esses estudos na Alemanha, na França e nos países anglo-saxões, por exemplo, e compreendem que, nesses lugares, como também em Portugal e no Brasil, não se busca uma verdade do autobiógrafo, e sim o modo como o "professor-narrador-autor" se situa no contexto histórico ou "como constrói a consciência histórica de si" (Passeggi; Souza; Vicentini, 2011, p. 371). Assim, no bojo desses estudos e suas diferentes abordagens, também se encontra a preocupação com as representações sociais do docente, bem como os aspectos de seu imaginário.

Estudos que apresentam essas características quase sempre levam em consideração os aspectos socioeducacionais ou o ambiente em que o biografado recebeu suas marcas institucionais, que provavelmente têm impacto na formação do docente, na maneira como ele enxerga a vida e dilui seus percalços durante a trajetória. "Essa trajetória se inicia na graduação e se conclui pela ascensão ao nível de professor titular, considerado o ápice da carreira docente, na maioria das universidades brasileiras" (Passeggi; Souza; Vicentini, 2011, p. 373).

Desse modo, esses estudos têm se firmado de maneira interdisciplinar, intercruzando a Sociologia, a Antropologia, a História e a História da Educação, para o fortalecimento e abrangência das próprias investigações, que têm como objeto de pesquisa a narrativa sobre si e o professor como seu principal elemento de interlocução. Os autores admitem que houve uma considerável expansão de estudos com essas características a partir dos anos 2000 , sobretudo oriundos da produção de dissertações e teses que emergiram da pós-graduação brasileira.

Outro aspecto relevante no contexto da estruturação do movimento biográfico apresentado pelos autores diz respeito aos eventos nacionais e internacionais que alimentam a discussão e a disposição de pesquisadores brasileiros e estrangeiros. Como exemplos desse movimento encontram-se: os congressos internacionais sobre pesquisa (auto)biográfica - Cipa -, a Associação Brasileira de Pesquisa (Auto)Biográfica - Biograf e a Associação Norte-Nordeste das Histórias de Vida em Formação, além da constituição da Rede Narrativas Autobiográficas - Rednaue. Tudo isso apenas para citar alguns elementos da estruturação desse campo. 
Além das associações nacionais e internacionais, outras iniciativas também são importantes na composição de uma rede de interesses acadêmicos acerca da (auto)biografia. Parte das produções elaboradas entre os pesquisadores tem circulado por meio de dossiês ${ }^{9}$. E já faz algum tempo do surgimento de um veículo específico. Em janeiro de 2016 a Revista Brasileira de Pesquisa (Auto)biográfica teve seu primeiro número publicado. Esse veículo é de suma importância para os estudos que pretendem se desenvolver com essas caraterísticas teóricas e metodológicas, especialmente no campo educacional.

É com essa dimensão do campo que as pesquisas brasileiras avançam nas perspectivas das diferentes correntes e tendências temáticas, caracterizando-se com a diversidade na produção de novos conhecimentos a respeito da narrativa de si. Essa dimensão também é concernente à representação do indivíduo docente como sua inserção na cultura e, às vezes, nas negociações pautadas pelas relações profissionais. De qualquer maneira, a pós-graduação, com seus grupos e linhas de pesquisa nas diferentes universidades, tem demonstrado a estruturação desse campo de investigação.

Desse modo, Costa (2016) apresenta, em seu artigo, a perspectiva de que os docentes submetidos ao método autobiográfico estão sujeitos também a uma autohermenêutica, ou seja, sujeitos a uma análise de seus próprios enunciados e, portanto, a interpretar suas palavras. Além disso, ao falar de sua trajetória, o 'agente social' realiza, segundo seus achados, dois movimentos importantes, sendo a objetivação e subjetivação, ou melhor, a transformação de coisas abstratas em algo concreto, bem como a introjeção dos valores expostos numa relação interpessoal tornando-se sujeito, respectivamente.

$\mathrm{Na}$ medida em que reflete sobre o que foi dito na narrativa sobre si, o indivíduo se posiciona favorável ou desfavorável a determinados enunciados ou situações, permitindo ou interditando os registros de sua fala. Tal procedimento ocorre em virtude de o agente reconhecer-se num determinado lugar de fala, ocupar um espaço - institucional, por exemplo - e não querer revelar os segredos, pessoas e acontecimentos que poderiam implicar numa situação vexatória.

Por outro lado, a autora adverte que esse processo de auto-hermenêutica só é possível frente a indivíduos que possuem consciência não apenas de seu papel social, ou lugar de fala, mas também das reais condições com que está submetido na relação com o entrevistador. Assim, Costa (2016) apresenta as seguintes reflexões:

Enfim, a "auto-hermenêutica" é praticada por sujeitos que detêm amplas condições de se comportarem conscientemente em situações de entrevista, no que tange à seleção, interpretação, ordenação e modo de exposição dos conteúdos oferecidos como dados para uma pesquisa sobre a qual todos foram informados previamente acerca do objeto e de seus objetivos. (p. 79)

Nesse contexto, a subjetivação acontece quando o indivíduo introjeta ou incorpora conhecimentos e valores expressos num determinado momento enquanto adesão ao que foi devidamente produzido na relação entrevistador-entrevistado. Adesão esta

9 Disponível em: Educação e Revista. Editorial, Belo Horizonte, v. 27, n. 1, abr. 2011. 
incorporada e manifestada enquanto representações do seu modo de ser e pensar. Logo, a narrativa de si pode evidenciar uma série de questões relativas ao autoconhecimento que se desenvolve em cadeia, numa espécie de socioanálise das condições de produção de um discurso (Costa, 2016).

Em certa medida, as considerações de Costa (2016) assemelham-se às preocupações de Delory-Momberger (2016), especialmente por se perguntar qual o papel ocupado pela biografia, bem como qual o saber que tenta alcançar as pesquisas biográficas, ou seja, preocupações relacionadas à epistemologia e à metodologia da pesquisa nesse campo de conhecimento. Aliás, o problema epistemológico é recorrente quando se trata de diferenciar projetos biográficos das demais áreas das ciências sociais e humanas.

Ao considerar esses aspectos, "o projeto fundador da pesquisa biográfica inscrevese no quadro de uma das questões centrais da Antropologia Social, que é a da constituição individual: como os indivíduos se tornam indivíduos?" (Delory-Momberger, 2012, p. 523). Responder a essa pergunta parece ser um dos problemas enfrentados pelos biógrafos ao desenvolver a escuta atenta às narrativas dos indivíduos ou ao levantar uma série documental a respeito de quem investigam. Aqui também está implícito a compreensão ou a explicação da relação entre indivíduo e sociedade.

Tal perspectiva existencial, por assim dizer, submerge o biografado num conjunto de relações sociais, interpessoais, culturais, econômicas, políticas etc., ao mesmo tempo que - leva a construir uma representação de si próprio nas interfaces mantidas em diferentes campos, onde mantém suas experiências de vida. Essa construção também está relacionada com a temporalidade, ou seja, as demarcações espaço-temporais e a diversidade de cenários possíveis e imagináveis de atuação do biografado.

Num projeto de investigação dessa ordem "o objeto de pesquisa biográfica é explorar os processos de gênese e de devir dos indivíduos no seio do espaço social, de mostrar como eles dão forma a suas experiências, como fazem significar as situações e os acontecimentos de sua existência" (Delory-Momberger, 2012, p. 524). Ou seja, o objeto é intrínseco à própria dimensão do indivíduo, na medida em que o que se busca compreender são as formas e maneiras de o indivíduo superar suas crises, tensões, seus problemas e, sobretudo, como produz e reproduz o seu meio social.

Desse modo, o projeto epistemológico da pesquisa biográfica deve se concentrar no processo de "individuação, de construção de si, de subjetivação, com um conjunto de interações que esses processos envolvem com o outro e o mundo social" (DeloryMomberger, 2016, p. 136). Esses processos são partilhados com outros ramos das Ciências Humanas e Sociais, como a Sociologia e a Psicologia Social.

Contudo, a diferença do objeto de investigação da biografia e as demais áreas de investigação está na construção do tempo pelo indivíduo e, especialmente, na relação que o indivíduo estabelece com a sua experiência e o ato de narrar, o que poderia ser chamado de temporalidade biográfica: "Essa temporalidade biográfica tem sua gramática ou sua sintaxe fundamentada na sequência narrativa matricial que representa a trama da vida entre o nascimento e a morte" (Delory-Momberger, 2016, p. 136). Uma vez reconstruída a trama, essa temporalidade é inevitável, pois a demarcação temporal constituirá o sentido daquilo que a autora chama de fato biográfico, pela construção e constituição do tempo ser responsabilidade do indivíduo biografado. 
Ao construir a temporalidade biográfica na narrativa, o indivíduo também constrói e mostra sua forma de viver o mundo, demarcando, por vezes, a sua relação intrínseca com a realidade social. Compreender esses aspectos é fundamental para se ter categorias de análise capazes de identificar a relação entre o indivíduo e a sociedade de seu tempo ou, pelo menos, no tempo em que a narrativa de si foi construída. Numa perspectiva sociológica configuracional eliasiana, poderíamos dizer que o objeto da biografia é a sociogênese e a psicogênese de um indivíduo determinado, como Elias (1995) demonstra ao escrever Mozart: sociologia de um gênio.

Nessa pesquisa em particular, além de se ter um quadro histórico do tempo em que Mozart viveu com seus pais e no mundo da música, com as turnês de concertos, são verificados os aspectos individuais, ou seja, os sentimentos que o gênio da música devotava em relação às mulheres, por exemplo. Nessa teia de relações também é possível identificar todo um aspecto de sublimação desenvolvida a partir da música, o que permite dizer que Mozart tentou, sem sucesso, pelo menos aos seus próprios olhos, dar significado à música que fazia para outros indivíduos e despertar na sociedade de seu tempo o artista autônomo que desejava ser.

Assim, é nessa relação entre indivíduo e sociedade, o singular e a coletividade de seu tempo, que a biografia se apega enquanto objeto de investigação. É esse processo que a literatura apresenta como individuação e subjetivação o que interessa ao biógrafo na realização de seu ofício. De modo que o indivíduo organiza os saberes que vai acumulando em seu percurso, em sua trajetória, construindo o que Delory-Momberger (2016) chama de biografias típicas, que diz respeito aos diferentes grupos sociais em que o indivíduo participa.

Considerando esses aspectos, as biografias típicas podem ser compreendidas também como uma sucessão de acontecimentos partilhados num espaço-tempo, ou seja, no ambiente familiar, nas instituições educativas ou profissionais. E essa construção temporal proporcionada pela biografia causa um impacto na percepção do indivíduo. Com efeito, é possível compreender, ainda, que essa "temporalidade biográfica", objeto de reflexão de Delory-Momberger (2016), "provoca uma transformação na percepção e na construção do mundo social, organizado não mais segundo regras abstratas e formais, mas segundo o ponto de vista e a temporalidade daquele que o atravessa" (p. 138).

Outro aspecto a ser levado em consideração, é o fato de que biografar é uma das formas de estar e apreender o mundo social e que o indivíduo que mantém a experiência de narrar seus pequenos atos cotidianos, com começo, meio e fim, o faz com construções bastante significativas, num processo que Delory-Momberger (2016) chama de biografização.

A esse respeito, Alheit (2011) compreende que o indivíduo na sociedade moderna tem sempre a impressão de que sua vida está em suas mãos, de que sua vida é organizada segundo seu planejamento e, ainda que as coisas não saiam exatamente conforme o planejado, é resguardada a sensação de que tudo foi previsto. Assim, todos esses elementos podem ser compreendidos a partir da ideia segundo a qual sempre temos uma expectativa positiva diante da nossa biografia. No entanto, essa expectativa positiva não se refere apenas ao futuro distante, mas também às pequenas ações e planos a curtíssimo prazo, como assistir a um filme, ir à escola, comprar um livro etc. 
Desse modo, o autor chama atenção para o fato de que a organização, o planejamento e as ações dos indivíduos se fundamentam numa espécie de código de referência sob o qual tudo o que é feito passa necessariamente por esse parâmetro, porque "dispomos de um conhecimento de fundo biográfico que em princípio nos coloca em posição de preencher e também de explorar o contexto social no qual nos movemos" (Alheit, 2011, p. 36). Todavia, é óbvio que nem tudo é previsível e imaginável no transcurso de uma vida, mas esse conhecimento do qual se refere o autor é um dos fundamentos importantes para as transformações estruturais dos indivíduos, bem como das instituições as quais fazem parte por meio de seus planos e ações.

Considerando esses aspectos, para Alheit (2011), a biografização é uma competência desenvolvida pelo indivíduo para processar e combinar impulsos internos e pressões externas advindas dos diferentes grupos e instituições. Ela é uma exigência da sociedade moderna, gera aprendizagem e molda os múltiplos ambientes nos quais o indivíduo mantém suas interrelações sociais.

Por outro lado, o gênero biográfico tem sido fundamental para a compreensão e reconhecimento do papel dos indivíduos em vários contextos sociais, práticas e profissões, especialmente para a vida e relato de professores, retirando-os da condição de silenciamento. Assim, esse gênero se situa também enquanto "fonte de produção da escrita histórica para o reconhecimento do papel e da atuação dos indivíduos" (Corrêa, 2018, p. 94). E é exatamente na constituição enquanto fonte histórica em que se presta um conjunto de trabalhos (auto)biográficos, alimentando a produção de conhecimento na perspectiva, muitas vezes, da História Cultural, a partir da experiência concreta dos indivíduos e seu cotidiano, conforme Corrêa (2018).

A autora também nos faz refletir acerca das diferentes linhas e tendências da historiografia da educação no Brasil, sobretudo no intercruzamento entre os aspectos sociais e culturais, nos quais os indivíduos, especialmente professores, passam a figurar enquanto temas de estudo e, com esses novos temas, certamente, fontes, que podem apreender "suas trajetórias pessoais, profissionais e em suas inserções no mundo sociocultural, como focos reveladores do modo de viver, sentir, pensar e produzir" (Corrêa, 2018, p. 35).

No âmbito dessa produção do conhecimento, a autora verifica que, no intercruzamento historiográfico, surgem novos temas, problemas e um conjunto de fontes documentais que permitem uma análise e interpretação mais próxima possível do "lugar social", seja dos indivíduos ou instituições educacionais. Assim, a historiografia da educação que toma como fonte as trajetórias de professores tem identificado as "inflexões da atuação intelectual dos educadores, das memórias das práticas educativas, como também, dos estudos sobre a cultura material pela produção de textos, dos livros escolares e outros artefatos culturais produzidos por educadores" (Corrêa, 2018, p. 39).

De modo geral, outros pesquisadores também corroboram esse pensamento em relação aos aspectos culturais que envolvem os estudos (auto)biográficos, inclusive, os que pensam esse tipo de investigação como parte da História Cultural, o que coloca os pesquisadores numa situação intrigante frente aos diferentes documentos a serem analisados sobre a trajetória da vida de professores, por exemplo. Assim, ao "recorrer a 
materiais empíricos diversos como documentos escritos, fotografias e narrativas de memória, [...] em articulação com o referencial teórico" (Hass da Silva; Duarte; Grazziotin, 2019, p. 110), é possível compreender as múltiplas dimensões de uma vida.

Os autores estão se referindo a um estudo que desenvolveram acerca de um professor e as especificidades de sua trajetória de vida como fundador, gestor e docente de uma instituição educativa. Para desvelar o que eles chamam de nuances, os pesquisadores foram em busca de uma massa documental com diferentes características, mas, mesmo assim, não concebem o biografado como sendo um objeto de investigação. Não obstante concordar com parte de suas reflexões, há de se ter clareza que, qualquer que seja a abordagem que se tenta enveredar no campo interpretativo, especialmente numa pesquisa científica, sempre teremos diante dos estudos (auto)biográficos a necessidade de diminuir a distância relacionada entre o sujeito e o objeto da investigação, mas não eliminar a ideia de objeto da análise que se pretende, mesmo que de uma vida humana.

A análise do relato de vida ou a narrativa sobre si diz respeito não apenas às subjetividades que emergem das memórias, mas, até certo ponto, revela a produção material e as práticas educativas em que o docente se debruçou na construção de sua própria trajetória. Assim, a análise da produção material do docente pode revelar aspectos fundamentais da formação e desenvolvimento de uma carreira profissional, além de legitimar o contexto mais geral da própria trajetória, "isso porque a premissa básica deste tipo de estudo é ter em vista a pluralidade de significados de uma vida" (Hass da Silva; Duarte; Grazziotin, 2019, p. 111).

É nessa perspectiva também que Marques e Satriano (2017) fazem uma discussão em torno da ideia de o pesquisador narrar sua própria vida e analisam em que medida haveria validade científica nesses procedimentos. Para as autoras, as Ciências Humanas e Sociais já têm discutido consideravelmente as questões que envolvem seus métodos de investigação, exatamente porque os pesquisadores desse campo de estudo investigam a sociedade em que estão inseridos sendo, portanto, um de seus membros, tentando compreender e resolver os problemas de seu tempo.

A preocupação que reside nas reflexões das autoras é de suma importância porque se trata de uma questão não apenas de método ou procedimental de pesquisa, mas uma questão de ética, na medida em que os estudos dessa natureza têm como premissa verificar a relação entre 0 indivíduo e a sociedade. Então, do ponto de vista epistemológico, como o indivíduo pesquisador pode reconhecer e analisar suas próprias subjetividades ao se deparar com os meandros de uma investigação científica, onde a relação entre sujeito e objeto os transformam numa unidade indissociável?

Não obstante a preocupação das autoras, uma das principais saídas para esse problema é dada pelas próprias reflexões que fazem acerca da narração e do que é efetivamente narrado. Para tanto, elas ampliam "a conceituação de narrativa e a [consideram] como construção de um enunciado (expressão de si e da realidade), texto verbal e não verbal que anuncia um enredo no qual transparece o mundo interno de seu narrador em interação com o mundo externo" (Marques; Satriano, 2017, p. 372).

No entanto, se isso parece óbvio para os estudos que enveredam pela autobiografia e sendo, neste caso, o pesquisador também narrador, há de se pensar nas questões procedimentais que advêm de uma análise com essas características. Logo, é necessário, 
segundo elas, o reconhecimento e a declaração de que "o autor e o espectador estão reunidos na mesma figura. Mesmo assim, garante-se o aspecto relacional visto que o eu é formado por vários 'eus' e o 'outro' não nasce sujeito, se constitui um” (Marques; Satriano, 2017, p. 373).

A superação dessa tensão entre narrador e pesquisador, uma relação de unidade inseparável, por serem o mesmo indivíduo, pode se fazer a partir do diálogo entre quem narra os episódios e quem escuta e interpreta segundo seus parâmetros, posto que, para Marques e Satriano (2017), do ponto de vista da hermenêutica, só vê e escuta quem sabe e conhece. Isto posto, sendo o pesquisador o próprio narrador, estariam resguardadas as semelhanças e as diferenças no processo dialógico necessário a um estudo (auto)biográfico, e é em razão de outras pesquisas sobre o tema, que preparei a próxima seção.

\section{Teses (auto)biográficas e a natureza da narrativa de si}

$\mathrm{Na}$ seção anterior fiz um breve levantamento sobre as publicações de livros e artigos científicos que circulam acerca do método (auto)biográfico, para identificar os principais aspectos debatidos entre os pesquisadores no que se refere à origem, aos procedimentos e ao manuseio da escrita de si enquanto fonte historiográfica. Com esses elementos procurei entender, nesta seção, como o campo de capital cultural (auto)biográfico vem se formando, a maneira pela qual as universidades, enquanto pontos estratégicos de indução desse produto do conhecimento, estão distribuídas geograficamente no Brasil, como as pesquisas oriundas das pós-graduações se avolumam e como os pesquisadores, por sua vez, mostram-se entre os documentos por eles mesmos produzidos.

Compreender essa produção de sentido é fundamental no contexto dos estudos que estou desenvolvendo, porque é daí que possivelmente decorre aquilo que Bourdieu (1998) chama de gênese de um campo, sustentada, obviamente, pelas crenças dos agentes que o produzem e reproduzem por meio dos bens materiais simbólicos do jogo, desenvolvido nesse próprio campo.

Nesse contexto, para me inteirar dos estudos realizados por pesquisadores brasileiros e ter uma ideia de como essas produções poderiam me inspirar e impactar nos procedimentos que descreverei numa seção mais adiante, realizei uma busca ${ }^{10}$ na plataforma da Biblioteca Digital Brasileira de Teses e Dissertações - BDTD -, o que me rendeu a satisfação de pertencer a um campo bastante propício à inovação das Ciências Humanas e Sociais.

É bom lembrar que até o momento em que realizei essa busca, a referida plataforma concentrava 117 instituições participantes, 438.268 dissertações e 157.381 teses produzidas, ou seja, 592.647 documentos disponíveis a partir de diferentes assuntos e problemáticas de diversas áreas do conhecimento. Os dados mencionados são importantes porque demonstram o fortalecimento da comunidade científica brasileira, pelo menos, nos últimos vinte anos.

\footnotetext{
10 Essa busca contou com a colaboração da professora dra. Roseane Silva de Souza, minha esposa, que, com a sua experiência recente de doutoramento, auxiliou-me na compreensão do sistema, podendo, assim, oferecer ao leitor algo mais palatável em relação ao tema aqui investigado. A página de acesso à plataforma está disponível em: http://bdtd.ibct.br.
} 
Desse modo, no cômputo geral, entre os anos 2000 e 2019, a plataforma registrou 455 dissertações e teses (auto)biográficas, o que, reconheço, seria um exagero tentar analisar toda essa produção para efeito deste estudo. Porém, com o manuseio do sistema, restringi a busca a apenas teses defendidas entre 2015 e 2019, o que foi razoável para identificar o que outros pesquisadores estavam pensando acerca do tema.

Então, frente ao que estava disponível, com os meus modestos procedimentos ${ }^{11}$, identifiquei 66 teses, distribuídas institucionalmente da seguinte forma.

Quadro 2 -

Número de teses (auto)biográficas por instituições - 2015 a 2016.

\begin{tabular}{|c|c|c|c|c|c|}
\hline $\begin{array}{c}\text { Cinco } \\
\text { teses }\end{array}$ & $\begin{array}{c}\text { Quatro } \\
\text { teses }\end{array}$ & Três teses & Duas teses & Uma tese & Total \\
\hline USP & UFMG & Ufrgs & $\begin{array}{c}\text { UFBA, UFC, } \\
\text { UFSCAR }\end{array}$ & $\begin{array}{c}\text { PUCRS, PUCSP, UCSAL, } \\
\text { UEPB, Ufes, UFG, UFMS, } \\
\text { UFRN, UFCS, UFSM, } \\
\text { Unesp, Unicamp }\end{array}$ & 30 \\
\hline
\end{tabular}

Fonte: http://bdtd.ibct.br/vufind - Adaptado pelo autor, 2020.

Como pode ser percebido, as universidades com maior número de teses (auto)biográficas nesse período são: a Universidade de São Paulo; a Universidade Federal de Minas Gerais e a Universidade Federal do Rio Grande do Sul. Juntas, essas instituições concentram 12 produtos de um total de 30 teses defendidas nesse período. A Universidade Federal da Bahia, a Universidade Federal do Ceará e a Universidade Federal de São Carlos apresentam-se com dois produtos cada e as demais instituições colaboram, cada uma, com uma defesa de tese com método autobiográfico, conforme identificado pelo descritor.

As universidades públicas estão mais presentes na oferta desse produto, especialmente as federais, com onze instituições, e as estaduais, com 4quatro. No total, há 23 teses com esse método. Embora apenas com uma única produção, também se destacam, nesse período, as universidades católicas, como a de Salvador e as PUC de São Paulo e do Rio Grande do Sul.

No próximo quadro apresento o número de produtos no período entre 2017 e 2018 , que é um pouco menor em relação às instituições que expuseram seus produtos entre 2015 e 2016, mas se mantém características institucionais parecidas, ou seja, produtos oriundos da pós-graduação de universidades públicas federais e estaduais, com a exceção das universidades católicas e outra também de caráter privado, a Universidade La Salle - Unilasalle.

\footnotetext{
11 Buscas avançadas: acessos em 05 de janeiro de 2020, às 9h30; 07 de fevereiro de 2020, às 07h; e 08 de fevereiro de 2020 , às 06h30.
} 
Quadro 3 -

Número de teses (auto)biográficas por instituições - 2017 e 2018.

\begin{tabular}{|c|c|c|c|c|}
\hline Seis teses & Três teses & Duas teses & Uma tese & Total \\
\hline USP & $\begin{array}{c}\text { UFBA, UFF, UFRN, } \\
\text { Unesp. }\end{array}$ & UFPB & $\begin{array}{c}\text { PUC-SP, UFCG, UFMG, } \\
\text { UFRGS, UFSM, UNB, } \\
\text { Unilasalle, Unioeste. }\end{array}$ & 28 \\
\hline
\end{tabular}

Fonte: http://bdtd.ibct.br/vufind - Adaptada pelo autor, 2020.

Conforme o quadro acima, mais uma vez, a Universidade de São Paulo concentra o maior número de teses (auto)biográficas defendidas entre 2017 e 2018, com seis defesas. Em seguida aparecem as universidades federais da Bahia, Fluminense e do Rio Grande Norte e a Universidade Estadual Paulista com três pesquisas sobre o assunto no mesmo período.

Como se percebe, foram vários acessos à plataforma para identificar as instituições, temas e autores referentes às teses (auto)biográficas, o que revela uma produção bastante significativa pela complexidade metodológica que modela esse tipo de produção. Assim, no próximo quadro, é possível identificar as instituições que favorecem as teses sobre o assunto em 2019. ${ }^{12}$

Quadro 4 -

Número de teses (auto)biográficas por instituição - 2019.

\begin{tabular}{|c|c|c|}
\hline Três teses & Uma tese & Total \\
\hline UFMG & PUC-RS, UFBA, UFJF, UFS, Unesp & 8 \\
\hline
\end{tabular}

Fonte: http://bdtd.ibct.br/vufind - Adaptado pelo autor, 2020.

Curiosamente, pela primeira vez, a Universidade de São Paulo não aparece no quadro das instituições que investiram em teses (auto)biográficas em 2019, pelo menos, não até os dias em que acessei a Biblioteca Digital. No entanto, quando comparamos com os anos anteriores, essa instituição apresenta números expressivos em relação aos trabalhos sobre este assunto, especialmente com as teses defendidas na Pós-graduação em Educação, Letras e Meios Audiovisuais, como será facilmente identificado mais adiante.

Conforme consta nos quadros referentes às origens institucionais das teses (auto)biográficas defendidas entre 2015 e 2019, todas as regiões brasileiras estão representadas por 26 universidades, com a exceção da região Norte, que não apresentou nenhuma ocorrência em seus programas de pós-graduação. Aliás, mesmo o Nordeste sendo representado por instituições como a UFBA, a UFRN, a UFPB e a UEPB, a UFPE não aparece nos indicadores; pelo menos, não até a realização dessa consulta, ocorrida em fevereiro de 2020.

${ }^{12}$ Acesso ocorrido em 08 de fevereiro de 2020, às $06 \mathrm{~h} 30$. 
Contudo, no cenário nacional, pode-se afirmar que o método aqui estudado está bastante difundido como um subcampo do conhecimento de áreas como Educação, Letras, Literatura, Linguagem, Educação Matemática, Artes, Música, Ciências Sociais, História e Saúde Pública.

Para melhor visualização, inseri os quadros abaixo, nos quais é possível ter uma ideia mais geral das 26 primeiras teses que aparecem quando é buscado na plataforma o descritor "autobiografia". Dessa vez, já com a exposição do título, ano de defesa, instituição e autoria, no período entre 2015 a 2019.

\section{Quadro 5 -}

Teses (auto)biográficas defendidas entre 2015 e 2016.

\begin{tabular}{|c|c|c|c|}
\hline Ano & Título & Instituição & Autoria \\
\hline 2016 & $\begin{array}{l}\text { (Des)arquivar biografemas: a } \\
\text { biblioteca de Cora Coralina }\end{array}$ & $\begin{array}{l}\text { Universidade Federal de } \\
\text { Santa Catarina - Programa } \\
\text { de Pós-graduação em } \\
\text { Literatura }\end{array}$ & $\begin{array}{l}\text { Grants, Andréa } \\
\text { Figueiredo Leão }\end{array}$ \\
\hline 2015 & $\begin{array}{l}\text { "Você quer me ouvir"? Narrativas } \\
\text { (auto)biográficas de professoras } \\
\text { da rede municipal de Vitória/ES } \\
\text { aposentadas por invalidez } \\
\text { (décadas de } 1980 \text { a 2000) }\end{array}$ & $\begin{array}{l}\text { Universidade Federal do } \\
\text { Espírito Santo - Programa de } \\
\text { Pós-graduação em Educação }\end{array}$ & $\begin{array}{l}\text { Azevedo, Karla } \\
\text { Veruska }\end{array}$ \\
\hline 2015 & $\begin{array}{lrr}\begin{array}{l}\text { Entre o } \\
\text { indizível: }\end{array} \quad \text { autobiografia } & \text { e } \\
\text { autorretrato em Aveux } & \text { non } \\
\text { avenus, de Claude Cahun }\end{array}$ & $\begin{array}{l}\text { Universidade Federal de } \\
\text { Minas Gerais - Programa de } \\
\text { Pós-graduação em Letras } \\
\text { (Estudos Literários) }\end{array}$ & $\begin{array}{l}\text { Gambi, Henrique } \\
\text { do Nascimento }\end{array}$ \\
\hline 2016 & $\begin{array}{l}\text { Dor compartilhada é dor } \\
\text { diminuída: autobiografia e } \\
\text { formação identitária em blogs de } \\
\text { pessoas em condição de doença }\end{array}$ & $\begin{array}{l}\text { Universidade Federal do Rio } \\
\text { Grande do Sul - Programa de } \\
\text { Pós-graduação em Educação }\end{array}$ & $\begin{array}{l}\text { Silveira, } \\
\text { Rocha }\end{array}$ \\
\hline 2016 & $\begin{array}{l}\text { Estética da confluência: ficção e } \\
\text { autobiografia na prosa literária e } \\
\text { no Diário do último ano de } \\
\text { Florbela Espanca }\end{array}$ & $\begin{array}{l}\text { Universidade Federal do Rio } \\
\text { Grande do Norte - Programa } \\
\text { de Pós-graduação em } \\
\text { Estudos da Linguagem }\end{array}$ & $\begin{array}{l}\text { Silva, Lígia } \\
\text { Mychelle de Melo }\end{array}$ \\
\hline
\end{tabular}

Fonte: http://bdtd.ibct.br/vufind - Adaptado pelo autor, 2020.

Para melhor visualização e sem correr o risco de ser exaustivo nessa busca, apresentarei quatro quadros com as primeiras 17 pesquisas que aparecem na plataforma quando solicitado o tema (auto)biografia, com as aspas ou com o parêntese, entre 2017 e 2018. 
Quadro 6 -

Teses (auto)biográficas defendidas entre 2017 e 2018.

\begin{tabular}{|l|l|l|l|}
\hline Ano & \multicolumn{1}{|c|}{ Título } & \multicolumn{1}{|c|}{ Instituição } & Autoria \\
\hline 2018 & $\begin{array}{l}\text { Ars longa, vita brevis: uma } \\
\text { proposta simbiótica entre arte e } \\
\text { vida }\end{array}$ & $\begin{array}{l}\text { Universidade de Brasília, } \\
\text { Instituto de Artes, Programa } \\
\text { de Pós-Graduação em Artes }\end{array}$ & $\begin{array}{l}\text { Vega Júnior, Paulo } \\
\text { Ivan Rodrigues }\end{array}$ \\
\hline 2018 & $\begin{array}{l}\text { Memória, espaço e símbolos na } \\
\text { narrativa de Marcel Pagnol }\end{array}$ & $\begin{array}{l}\text { Universidade Estadual } \\
\text { Paulista - Programa de Pós- } \\
\text { graduação em Estudos } \\
\text { Literários }\end{array}$ & $\begin{array}{l}\text { Morgado, Marina } \\
\text { Lourenço }\end{array}$ \\
\hline 2018 & $\begin{array}{l}\text { Relatos de artistas quando } \\
\text { jovens, das caminhadas pelas } \\
\text { margens aos projetos de vida } \\
\text { centrados na música }\end{array}$ & $\begin{array}{l}\text { Programa de Pós-graduação } \\
\text { em Educação - PPGEdu }\end{array}$ & $\begin{array}{l}\text { Sanches, Roberto } \\
\text { Cordeiro }\end{array}$ \\
\hline 2017 & $\begin{array}{l}\text { A opressão da criança em } \\
\text { Graciliano Ramos e Charles } \\
\text { Dickens }\end{array}$ & $\begin{array}{l}\text { Universidade Federal do Rio } \\
\text { Grande do Norte - Programa } \\
\text { pós-graduação em } \\
\text { Estudos da Linguagem }\end{array}$ & $\begin{array}{l}\text { Santos, Elizabete } \\
\text { Maria Alves dos }\end{array}$ \\
\hline 2018 & $\begin{array}{l}\text { Veredas da lembrança no Vale do } \\
\text { Açu }\end{array}$ & $\begin{array}{l}\text { Universidade Federal do Rio } \\
\text { Grande do Norte - Programa } \\
\text { de Pós-graduação em } \\
\text { Estudos da Linguagem }\end{array}$ & $\begin{array}{l}\text { Silva, } \\
\text { Moreira da }\end{array}$ \\
\hline
\end{tabular}

Fonte: http://bdtd.ibct.br/vufind - Adaptado pelo autor, 2020.

Como pode ser percebido, ao menos pelos títulos, as teses se fundamentam em narrativas de outros agentes enquanto construção de um objeto de análise, o que pressupõe uma pesquisa biográfica, pelo fato de os autores estudarem a vida de um outro indivíduo ou personagem de seu interesse. 
Quadro 7 -

Teses (auto)biográficas defendidas entre 2017 e 2018 - continuação, parte 1.

\begin{tabular}{|c|c|c|c|}
\hline Ano & Título & Instituição & Autoria \\
\hline 2017 & $\begin{array}{l}\text { Fabulário Oswald de Andrade: } \\
\text { memórias de um homem sem } \\
\text { profissão }\end{array}$ & $\begin{array}{l}\text { Universidade de São Paulo - } \\
\text { Programa de Pós-graduação } \\
\text { em Letras (Teoria Literária e } \\
\text { Literatura Comparada) }\end{array}$ & $\begin{array}{l}\text { Maio, } \quad \text { Sandro } \\
\text { Roberto }\end{array}$ \\
\hline 2018 & $\begin{array}{l}\text { Simultaneidade indissolúvel entre } \\
\text { o factual e o ficcional na obra } \\
\text { Beim Häuten der Zwiebel de } \\
\text { Günter Grass }\end{array}$ & $\begin{array}{l}\text { Universidade de São Paulo - } \\
\text { Programa de Pós-graduação } \\
\text { em Letras (Língua e } \\
\text { Literatura Alemã) }\end{array}$ & $\begin{array}{l}\text { Pedro, Elisandra } \\
\text { de Souza }\end{array}$ \\
\hline 2018 & $\begin{array}{l}\text { A vida e a obra de Agnès Varda } \\
\text { em As Praias de Agnès (2008) }\end{array}$ & $\begin{array}{l}\text { Universidade de São Paulo - } \\
\text { Programa de Pós-graduação } \\
\text { em Meios e Processos } \\
\text { Audiovisuais }\end{array}$ & $\begin{array}{l}\text { Souza, } \quad \text { Tainah } \\
\text { Negreiros } \text { Oliveira }\end{array}$ \\
\hline 2017 & $\begin{array}{l}\text { Uma casa azul de memórias: } \\
\text { escritas de Frida Kahlo }\end{array}$ & $\begin{array}{l}\text { Universidade Estadual do } \\
\text { Oeste do Paraná - Programa } \\
\text { de Pós-graduação em Letras }\end{array}$ & $\begin{array}{l}\text { Fachin, } \\
\text { Cesar }\end{array}$ \\
\hline 2018 & $\begin{array}{lr}\text { A relação } & \text { sujeito-língua } \\
\text { (portuguesa): } & \text { identidade em } \\
\text { contexto de } & \text { intercâmbio } \\
\text { universitário: } & \text { autobiografias } \\
\text { linguageiras } & \end{array}$ & $\begin{array}{l}\text { Universidade de São Paulo - } \\
\text { Programa de Pós-graduação } \\
\text { em Letras (Língua e } \\
\text { Literatura Francesa) }\end{array}$ & $\begin{array}{l}\text { Valentim, Amarílis } \\
\text { Aurora Aparecida }\end{array}$ \\
\hline
\end{tabular}

Fonte: http://bdtd.ibct.br/vufind - Adaptado pelo autor, 2020.

Mesmo os autores dessas teses colocando outros agentes como objetos e fontes para análise, ou seja, abstraindo-se do lugar de sujeito-objeto de estudo, essas pesquisas são muito importantes em vários aspectos, desde a abordagem sociológica ou histórica, os procedimentos até os resultados acerca da relação entre indivíduo e sociedade, reposicionando, inclusive, as questões epistemológicas especificas desse tipo de estudo.

Quadro 8 -

Teses (auto)biográficas defendidas entre 2017 e 2018 - continuação, parte 2.

\begin{tabular}{|c|l|l|l|}
\hline Ano & \multicolumn{1}{|c|}{ Título } & \multicolumn{1}{|c|}{ Instituição } & \multicolumn{1}{c|}{ Autoria } \\
\hline 2018 & $\begin{array}{l}\text { Morrer, gestar, renascer: } \\
\text { estetização e autorrepresentação } \\
\text { nos documentários Elena e Olmo } \\
\text { e a gaivota }\end{array}$ & $\begin{array}{l}\text { Universidade Federal da } \\
\text { Paraíba - Programa de Pós- } \\
\text { graduação em Letras }\end{array}$ & $\begin{array}{l}\text { Silva, Suéllen } \\
\text { Rodrigues Ramos } \\
\text { da }\end{array}$ \\
\hline
\end{tabular}




\begin{tabular}{|l|l|l|l|}
\hline 2018 & $\begin{array}{l}\text { Do segredo ao sagrado: o } \\
\text { autoconhecimento nas narrativas } \\
\text { autobiográficas de C. G. Jung }\end{array}$ & $\begin{array}{l}\text { Universidade Federal do Rio } \\
\text { Grande do Norte - Programa } \\
\text { de Pós-graduação em } \\
\text { Ciências Sociais }\end{array}$ & $\begin{array}{l}\text { Alves, Adeilton } \\
\text { Dias }\end{array}$ \\
\hline 2018 & $\begin{array}{l}\text { Narrativas autobiográficas de } \\
\text { professoras que atuam na } \\
\text { modalidade de creche: saberes } \\
\text { necessários à profissão }\end{array}$ & $\begin{array}{l}\text { Universidade Estadual } \\
\text { Paulista Júlio de Mesquita - } \\
\text { Programa de Pós-graduação } \\
\text { em Educação (Processos }\end{array}$ & $\begin{array}{l}\text { Santos, Haís } \\
\text { Formativos Infância e e } \\
\text { Juventude) }\end{array}$ \\
\hline 2018 & $\begin{array}{l}\text { Práticas corporais na saúde: nós, } \\
\text { tangências e saídas }\end{array}$ & $\begin{array}{l}\text { Universidade de São Paulo - } \\
\text { Programa de Pós-graduação } \\
\text { em Saúde Pública }\end{array}$ & Warcos \\
\hline
\end{tabular}

Fonte: http://bdtd.ibct.br/vufind - Adaptado pelo autor, 2020.

É curioso como as teses aparecem às vezes numa sequência crescente e às vezes decrescente - ordem invertida do ano da defesa, como foi o caso dos quadros aqui expostos. Mas, como pode ser visto, foram três pesquisas produzidas em 2017 e onze em 2018, distribuídas em várias universidades e pós-graduações diferentes, com a predominância da área de Letras, Literatura e Educação, mas com ocorrência de outras áreas, como Saúde Pública e Artes. Os temas e títulos também variam consideravelmente, aliás, com expressiva criatividade de seus autores. A seguir, apresento um quadro sintético das teses defendidas em 2019 que, aparentemente, possuem as mesmas características dos estudos até aqui expostos.

Quadro 9 -

Teses (auto)biográficas defendidas em 2019.

\begin{tabular}{|l|l|l|}
\hline \multicolumn{1}{|c|}{ Título } & \multicolumn{1}{|c|}{ Instituição } & \multicolumn{1}{c|}{ Autoria } \\
\hline $\begin{array}{l}\text { Uma teoria ovidiana da literatura; os } \\
\text { Tristia como epitáfio de um poeta- } \\
\text { leitor }\end{array}$ & $\begin{array}{l}\text { Universidade Federal de Minas } \\
\text { Gerais - Programa de Pós- } \\
\text { graduação em Estudos Literários }\end{array}$ & $\begin{array}{l}\text { Avellar, Júlia Batista } \\
\text { Castilho de }\end{array}$ \\
\hline $\begin{array}{l}\text { As memórias alinhavadas de rui } \\
\text { Spohr: moda e distinção a partir de } \\
\text { Porto Alegre }\end{array}$ & $\begin{array}{l}\text { Pontifícia Universidade Católica } \\
\text { do Rio Grande do Sul - Programa } \\
\text { de Pós-graduação em História }\end{array}$ & $\begin{array}{l}\text { Noronha, Renata } \\
\text { Fratton }\end{array}$ \\
\hline $\begin{array}{l}\text { Estranho que habita em mim: } \\
\text { narrativas de vida e formação de } \\
\text { professores gays no semiárido baiano }\end{array}$ & $\begin{array}{l}\text { - Pniversidade Federal de Sergipe } \\
\text { Educação }\end{array}$ & $\begin{array}{l}\text { Rios, Pedro Paulo } \\
\text { Souza }\end{array}$ \\
\hline
\end{tabular}




\begin{tabular}{|l|l|l|}
\hline $\begin{array}{l}\text { Militância em Ferréz: uma discussão } \\
\text { sobre a relação do modo de narrar } \\
\text { com a intenção de representar a } \\
\text { realidade }\end{array}$ & $\begin{array}{l}\text { Universidade Federal de Juiz de } \\
\text { Fora - Programa de Pós- } \\
\text { graduação em Letras (Estudos } \\
\text { Literários) }\end{array}$ & $\begin{array}{l}\text { Valle, Lígia Gomes } \\
\text { do }\end{array}$ \\
\hline $\begin{array}{l}\text { "Diário de uma pai(chão)": discutindo } \\
\text { de Pespaço, Lugar e território num Grupo em construção }\end{array}$ & $\begin{array}{l}\text { Universidade Estadual Paulista } \\
\text { Júlio de Mesquita -- Programa de } \\
\text { Pós-graduação em Educação }\end{array}$ & Silva, Stella de Melo \\
\hline $\begin{array}{l}\text { Espacialidades no romance } \\
\text { experimental brasileiro: Serafim Ponte } \\
\text { Grande, de Oswald de Andrade, e } \\
\text { confissões de Ralfo, de Sérgio } \\
\text { Sant'Anna }\end{array}$ & $\begin{array}{l}\text { Gniversidade Federal de Minas - Programa de Pós- } \\
\text { graduação em Estudos Literários }\end{array}$ & $\begin{array}{l}\text { Pimentel, Daiane } \\
\text { Carneiro }\end{array}$ \\
\hline $\begin{array}{l}\text { Os significados de uma visita a um } \\
\text { observatório astronômico: um estudo } \\
\text { baseado nas memórias e emoções de } \\
\text { estudantes }\end{array}$ & $\begin{array}{l}\text { Universidade Federal de Minas } \\
\text { Gerais - Programa de Pós- }\end{array}$ & $\begin{array}{l}\text { Linhares, Fernando em Educação } \\
\text { Roberto da Costa }\end{array}$ \\
\hline $\begin{array}{l}\text { Para além do visível: princípios para } \\
\text { uma audiodescrição menos } \\
\text { visocêntrica }\end{array}$ & $\begin{array}{l}\text { Universidade Federal da Bahia - } \\
\text { Programa de Pós-graduação em } \\
\text { Educação }\end{array}$ & $\begin{array}{l}\text { Silva, Manoela } \\
\text { Cristina Correia } \\
\text { Carvalho de }\end{array}$ \\
\hline
\end{tabular}

Fonte: http://bdtd.ibct.br/vufind - Adaptado pelo autor, 2020.

No conjunto, considero que esses são na realidade trabalhos biográficos, em virtude de os agentes sociais, objeto de interesse dos respectivos projetos, concederem entrevista falando de suas vidas ou serem analisados a partir de suas obras autobiográficas. No entanto, consegui identificar teses onde o pesquisador se posicionava como sujeito-objeto do próprio estudo, conforme o quadro 10.

Quadro 10 -

Teses autobiográficas clássicas defendidas entre 2015 e 2019.

\begin{tabular}{|l|l|l|l|}
\hline Ano & \multicolumn{1}{|c|}{ Título } & \multicolumn{1}{|c|}{ Instituição } \\
\hline 2015 & $\begin{array}{l}\text { Mo(vi)mentos autoria } \\
\text { historiando fragmentos narrativos de } \\
\text { experiências de vida docente e e } \\
\text { discente em artes visuais }\end{array}$ & $\begin{array}{l}\text { Universidade Federal de } \\
\text { Goiás - Programa de Pós- } \\
\text { graduação em Arte e Cultura } \\
\text { Visual }\end{array}$ & $\begin{array}{l}\text { Ferreira, Luiz } \\
\text { Carlos } \\
\text { Pinheiro }\end{array}$ \\
\hline 2016 & $\begin{array}{l}\text { Pelos olhos de Alice: ancestralidade } \\
\text { afro-ameríndia, ambientalismo e e } \\
\text { formação - uma tese de ficção } \\
\text { autobiográfica }\end{array}$ & $\begin{array}{l}\text { Universidade de São Paulo - } \\
\text { Programa de Pós-graduação } \\
\text { em Educação }\end{array}$ & $\begin{array}{l}\text { Caffagni, } \\
\text { Carla } \\
\text { Wanessa do } \\
\text { Amaral }\end{array}$ \\
\hline
\end{tabular}




\begin{tabular}{|c|c|c|c|}
\hline 2016 & $\begin{array}{l}\text { Histórias de vida e narrativa como } \\
\text { possibilidade da escuta de si }\end{array}$ & $\begin{array}{l}\text { Universidade Estadual } \\
\text { Paulista Júlio de Mesquita - } \\
\text { Programa de Pós-graduação } \\
\text { em Educação }\end{array}$ & $\begin{array}{l}\text { Sousa, Vera } \\
\text { Luísa de }\end{array}$ \\
\hline 2016 & $\begin{array}{l}\text { Imaginário e formação de educadores: } \\
\text { a narrativa de si }\end{array}$ & $\begin{array}{l}\text { Universidade de São Paulo - } \\
\text { Programa de pós-graduação } \\
\text { em Educação }\end{array}$ & $\begin{array}{l}\text { Fonseca, } \\
\text { Elisabete } \\
\text { Martins da }\end{array}$ \\
\hline 2016 & $\begin{array}{l}\text { A autobiografia como metodologia para } \\
\text { uma história da disciplina arte no Brasil: } \\
\text { vida e formação de uma arte/educadora }\end{array}$ & $\begin{array}{l}\text { Universidade Estadual } \\
\text { Paulista Júlio de Mesquita - } \\
\text { Programa de Pós-graduação } \\
\text { em Educação }\end{array}$ & $\begin{array}{l}\text { Lanzi, } \\
\text { Lucirene } \\
\text { Andréa Catini }\end{array}$ \\
\hline 2017 & $\begin{array}{l}\text { Atuação de um guitarrista em Salvador: } \\
\text { pesquisa autobiográfica docente }\end{array}$ & $\begin{array}{l}\text { Universidade Federal da } \\
\text { Bahia - Programa de Pós- } \\
\text { graduação de Música } \\
\text { Popular }\end{array}$ & $\begin{array}{l}\text { Costa, Alex } \\
\text { Augusto } \\
\text { Mesquita }\end{array}$ \\
\hline 2016 & $\begin{array}{l}\text { FLORianopólisNoSãojosédosCAMPOS: } \\
\text { na mala autobiografemas: sonoro, } \\
\text { imagético e verbal }\end{array}$ & $\begin{array}{l}\text { Universidade } \quad \text { Estadual de } \\
\text { Campinas - Programa de } \\
\text { Pós-graduação em Educação }\end{array}$ & $\begin{array}{l}\text { Guerra Filho, } \\
\text { Raulito Ramos }\end{array}$ \\
\hline 2017 & $\begin{array}{l}\text { Estudei a vida e a vida ofereceu-me o } \\
\text { ensino: trajetórias identitárias de uma } \\
\text { professora-pesquisadora que ensina } \\
\text { Ciências }\end{array}$ & $\begin{array}{l}\text { Universidade Federal da } \\
\text { Bahia - Instituto de Física - } \\
\text { Programa de Pós-graduação } \\
\text { do Ensino de Filosofia e } \\
\text { História da Ciência }\end{array}$ & $\begin{array}{l}\text { Silva, Patrícia } \\
\text { Petitinga }\end{array}$ \\
\hline 2017 & $\begin{array}{l}\text { Eu, uma professora de matemática em } \\
\text { jornada narrativa em busca de meus } \\
\text { eus-professores em autoformação }\end{array}$ & $\begin{array}{l}\text { Universidade Estadual } \\
\text { Paulista Júlio de Mesquita - } \\
\text { Programa de Pós-graduação } \\
\text { em Educação Matemática }\end{array}$ & $\begin{array}{l}\text { Brião, } \\
\text { Gabriela Félix }\end{array}$ \\
\hline
\end{tabular}

Fonte: http://bdtd.ibct.br/vufind - Adaptado pelo autor, 2020.

Conforme apresentado no quadro 10, nesse cenário da produção científica entre 2015 a 2019, do total de 66 teses, encontrei nove trabalhos em que os pesquisadores se colocam como sujeito-objeto de estudo e se posicionam, portanto, enquanto interlocutores de si mesmos submetidos ao método autobiográfico na contação e recordação de suas lembranças. Ao tomarem essa atitude, investindo nesse método sobre si e para si mesmos, eles se mostraram dispostos à interpretação teórica-empírica de suas percepções.

Nesse contexto, Ferreira (2015) procurou articular sua história de vida, seu tempo escolar e seu trabalho docente às experiências em sala de aula com estudantes da licenciatura em Artes Visuais e, ao tratar a vida como um movimento, articulou suas 
fotografias $3 \times 4$, fotografias de seu cotidiano quando criança e já docente, junto a estudantes universitários, para apresentar os fragmentos da sua trajetória de vida. Dessa maneira, sua autobiografia também traz os episódios de suas aulas, na medida em que seus estudantes e colaboradores falam da experiência que tiveram com o referido docente.

De maneira ousada, Caffagni (2016) já destaca no título do estudo que se trata de uma tese de ficção autobiográfica e que, para tanto, elegeu como o suporte de análise 0 conto de fadas Alice no país das maravilhas, intercruzando os momentos das personagens no mundo fantasmagórico com os episódios de sua própria trajetória de vida. A autora enfatiza que a ideia de fazer um estudo com essas características partiu de seu memorial acadêmico na perspectiva de se construir um entendimento que ela admite ser de 'um eu-aprendiz'.

Essas reflexões partem do fato de que a Alice, personagem do conto, por onde passou, aprendeu e viu várias coisas com alguns mestres. Assim, Caffagni (2016), de posse desses elementos, subsidia sua interpretação intercruzando a própria experiência de vida com o conto de fadas e reconhecendo que sua identidade de professora também foi adquirida a partir das conversas e exemplos dos professores que teve durante sua formação.

Já considerando o estudo de Sousa (2016), narrar sobre a própria trajetória serviu como um importante instrumento de estilo de vida, de cuidado de si mesma enquanto ser e estar professora, como mulher e profissional. Assim, para atender aos objetivos do método, a autora se utilizou de entrevistas, narrativas orais e escritas com base na experiência de quatro professoras para desencadear a tomada de consciência de sua própria trajetória, especialmente a tomada de decisão e de escolhas profissionais e pessoais. Além disso, a autora reconhece que, com esse procedimento, foi possível compreender o seu processo de subjetivação e o autoconhecimento que adquiriu. Ao finalizar o estudo, ela espera colaborar com outros profissionais para que eles também possam submeter-se ao método da narrativa de si.

Semelhante a Sousa (2016), Fonseca (2016) compreende que é na autobiografia que o pesquisador pode deixar e reconhecer suas marcas a partir de seu imaginário, sendo uma das forças impulsionadoras do processo de criação. É também por meio da narrativa de si que o pesquisador se reconhece autor do próprio percurso experimentado durante a formação profissional, ressignificando, inclusive, a sua própria história, enquanto obra inacabada.

Contudo, na base de interpretação da narrativa sobre si de Fonseca (2016), estão poesias e contos de várias culturas, desenhos e experiências pedagógicas, além das brincadeiras lúdicas e práticas esportivas das recordações de infância. A autora registra que seus primeiros contatos com a autobiografia foram ainda na graduação, frente à necessidade de construir seu portfólio durante a formação de pedagoga.

Por outro lado, Lanzi (2016) inicia seu trabalho com a hipótese de que narrar sobre sua experiência de arte-educadora contribui para a compreensão do ensino da arteeducação no Brasil, e isso se articula com a história de vida de outros profissionais dessa disciplina escolar. De maneira consciente, a autora assume a responsabilidade de seu relato autobiográfico, como ela mesma chama, que contribui para a compreensão do 
entrecruzamento de sua história familiar com as questões mais gerais da sociedade brasileira, bem como a importância de seus professores, ainda na educação infantil, participarem ativamente no estímulo e na descoberta de seu processo criativo.

Para corroborar a narrativa de si, a pesquisadora lançou mão de relatos de familiares acerca de sua trajetória, relatos sobre a experiência da própria família e juntou a um levantamento bibliográfico sobre a situação política e social brasileira, com o intuito de contribuir com alternativas do ensino da arte-educação. Dessa maneira, penso que Lanzi (2016), a partir de sua autobiografia, apresenta-se com o desafio de criar meios para a compreensão e melhoria da atuação docente dessa disciplina escolar.

Por sua vez, Costa (2017) apresenta, como um dos seus objetivos, promover a reflexão acerca de sua trajetória profissional ligada ao processo de ensino-aprendizagem do violão enquanto um dos instrumentos da música popular. Sua autonarrativa também intenta identificar o seu perfil na atuação pedagógica, no ensino superior, e enquanto artista. Para o autor, sua pesquisa tem uma característica transdisciplinar e interdisciplinar e possui, entre outros, aspectos descritivos e históricos com o objetivo de levantar documentação de sua vida, especificamente, em relação ao campo da música.

Desse modo, Costa (2017) constrói uma narrativa de si tomando por base a experiência artística e formação docente, entre a guitarra e o violão, e reflete a possibilidade de compreender sua trajetória explorando o sentido que a música instrumental tem enquanto elemento para a educação inclusiva.

De maneira criativa e ousada, Guerra Filho (2016) defende sua tese a partir de autobiografemas, que se desdobram em textos, fotografias e microdocumentários, acerca de sua trajetória como músico e assume, na narrativa de si, a postura de artista-educador. A pesquisa é justificada pelas suas próprias composições gravadas em CD, o que permite a análise de uma documentação constante de uma mala artesanal de onde saem as pérolas da objetivação e subjetivação. Assim, o principal intento do autor é desnudar e desvendar os encontros e desencontros que se estabelecem durante o seu processo de composição musical, o que é facilmente identificado no relatório final de sua pesquisa.

No jogo das narrativas de si e semelhante à base de inspiração de Caffagni (2016), o conto de fadas Alice no país das maravilhas, Silva (2017) reflete a possibilidade de múltiplas identidades como professora-pesquisadora do ensino de Ciências. Além do conto de fadas, a autora traz como base de sua análise e interpretação Lewis Carroll que, em o Espelho, por meio de um processo de biografização, procura dar forma à sua trajetória de vida.

Ao assumir a experiência de vida e a biografização como elementos fundamentais da imaginação, Silva (2017) procura interpretar a narrativa, o que ela chama de autopoética, a partir de teorias sociais da aprendizagem, como de Etienne Wenger. Desse modo, a autora reconhece que todo esse processo reflete significativamente as situações de construção e desconstrução de múltiplas identidades a partir da imaginação.

Em contexto bem diferente do que foi apresentado até agora, em especial a origem das investigações autobiográficas e a formação dos respectivos pesquisadores em Artes, Pedagogia e História, Brião (2017) constrói sua narrativa a partir da docência em Matemática. Para a autora, que se percebe no processo de autoformação, a narrativa tem 
base em vários episódios críticos de sua trajetória, em que reconhece, inclusive, as contradições e insubordinações vividas no processo identitário enquanto sujeito da própria experiência.

Brião (2017) entende que sua autobiografia pode colaborar e encorajar outros professores de Matemática, que, por possuírem uma formação técnica especializada, carecem de contato com conteúdo mais humanizado; por essa razão, estão ainda silenciados no paradigma cristalizado. Assim, para construir a narrativa, a autora utilizou de áudios produzidos num curso de extensão, outros artefatos, como e-mails e fotografias, e de intervenções de colegas em várias experiências que estiveram juntos durante a trajetória.

Não obstante encontrar essas teses e ler atentamente seus resumos para ter a certeza de que se tratava da escrita do pesquisador sobre si mesmo, fiquei decepcionado em ver que alguns deles ainda se colocavam em terceira pessoa, somente com o adiantamento da leitura e, às vezes, na introdução da tese, percebi que o 'eu' do pesquisador se mostrava mais fortemente. No entanto, reconheço o mérito dessas escritas e as dificuldades dos autores, na medida em que, a meu julgamento, a utilização desse método ainda é complexo de ser feito e aceito em instituições acadêmicas.

Considerando a perspectiva tática ou a arte do fraco em Certeau (1998), alguns pesquisadores, mesmo desenvolvendo autobiografias clássicas e falando de si mesmos enquanto sujeitos e objetos, construíram um discurso em terceira pessoa. Isso é importante para ser observado porque, ao que parece, no entendimento de quem assim procedeu, há uma complexidade entre a ciência e a literatura quando o assunto é o método aqui empregado. Contudo, há de se observar também que esse campo é bastante fértil no contexto das dissertações e teses, guardadas as devidas proporções, os autores sempre interpretam suas objetivações e subjetivações a partir de autores clássicos da Sociologia e da História; inclusive, com aprovações de bancas assim constituídas, mediante defesa pública.

Para lembrar de Elias (1998), de modo geral, o que se pode apreender dessas teses é o problema do envolvimento e distanciamento, processos em que, em muitos casos, o pesquisador criou um substrato de seus episódios para se manter distante enquanto objeto de si mesmo, na medida em que se inspira em contos de fadas na construção da narrativa.

Todavia, para efeito de síntese, nessa breve revisão entre 2015 e 2019, como disse, encontrei 66 teses defendidas nesse período e, de acordo com a literatura consultada e esse pequeno estado da arte que desenvolvi, só identifiquei como autobiografia clássica 9 teses, ou seja, pesquisas realizadas tendo por sujeito-objeto o próprio pesquisador, que é o autobiógrafo e se posiciona dessa maneira, falando sobre si mesmo e sua trajetória, constituindo-se, assim, como fonte.

Dos trabalhos encontrados, a meu julgamento, identifico 57 em que o pesquisador é uma outra pessoa, outro agente social diferente do biografado. Portanto, é um interlocutor que se aproxima de um indivíduo - o colaborador do estudo, que por alguma circunstância detém um saber a ser conhecido cientificamente - e capta o áudio ou os escritos desse agente social e, ao fazê-lo, capta sua biografia, 'autobiografia de quem fala'. Após esse procedimento, o pesquisador interpreta a narrativa do 'falante' e, por alguma razão, expõe 
nos títulos das teses ou extratores o termo (auto)biografia. Entretanto, isso também pode ser validado na medida em que essa forma de trabalho pode estar servindo à fonte historiográfica.

Nesse contexto, mediante essa breve análise das produções, resolvi aprofundar e radicalizar no encontro de minhas evidências enquanto sujeito/objeto, o que possibilitou o reforço da hipótese inicialmente formulada de um constructo do 'eu' fonte para efeito dos procedimentos do método científico, onde os acervos recordados, até o presente momento, poderiam corroborar a escrita acerca da minha trajetória.

Desse modo, é a partir desse esboço teórico que esta tese se apresenta para reforçar os trabalhos dos pesquisadores interessados no método (auto)biográfico, que há muito tem permeado diferentes áreas do conhecimento, circulando entre a História, a Sociologia, a Literatura, a Psicologia Social, a Antropologia, a Arte e a História da Educação. Assim, para avançar na perspectiva das questões empíricas que envolvem este estudo, na próxima seção, aponto alguns elementos que justificam a inserção desta pesquisa nas discussões dos autores até agora referenciados, bem como a dinâmica de trabalho que permitiu a escrita sobre a minha trajetória de vida, esta própria vida construída enquanto fonte.

\section{O campo e os procedimentos (auto)biográficos}

$\mathrm{Na}$ seção anterior fiz uma pequena revisão de literatura acerca da (auto)biografia para mostrar ao leitor como diferentes autores têm se comportado diante das múltiplas possibilidades de interpretação e execução de um método. Em continuidade ao que realizei, esta seção está concentrada nos aspectos tanto teóricos, quanto metodológicos, para responder ao seguinte questionamento: qual a percepção que tenho da minha trajetória de vida desde as séries iniciais à universidade, envolvendo o campo artístico, acadêmico-científico e as disposições políticas daí decorrentes entre 1975 e 2020 ?

Destarte, ao pensar em escrever na perspectiva autobiográfica, fui em busca de meu pequeno acervo nas estantes de minha própria residência e depois o que dispunha no Laboratório de Sociologia do Esporte - UFPE/CNPq, que coordeno há 20 anos. Embora estando também na universidade, o pequeno acervo foi adquirido com meus próprios recursos, certamente, do mesmo modo como fazem os colegas que estão lendo esta pesquisa.

Em sua totalidade, com exceção dos livros emprestados e quase nunca devolvidos, o pequeno acervo é constituído de aproximadamente 2.000 títulos, entre livros, dissertações e teses. Curiosamente, sobre o tema biografia, encontrei apenas cinco livros, alguns capítulos e três teses que abordam o assunto rapidamente. Assim, fui tomado pelo desafio em pesquisar alguma literatura sobre a teoria que dá suporte a este estudo e verificar as brechas que permitem uma compreensão identitária acerca do tema. Desse modo, tentei costurar aspectos teóricos e elementos empíricos, buscando sentido na autonarrativa e na documentação produzida num determinado momento da minha trajetória, como apresentarei mais adiante.

Nesse contexto, o que estou chamando de autonarrativa é a fala gravada, compromissada na busca da memória, das minhas lembranças e de fatos sobre minhas experiências de vida escolar e acadêmica, nas artes e na política, entrelaçadas com outros personagens das minhas relações interpessoais, profissionais etc. Diante da 
construção da autonarrativa, segui as reflexões de Marques e Satriano (2017), segundo as quais é necessário escolher autores e teorias para que o pesquisador-narrador possa estabelecer um diálogo e fazer, na medida do possível, a descrição e interpretação de suas emoções e motivações. Então, estamos diante de um método que pressupõe fazer escolhas para produzir conhecimento.

Frente às orientações teóricas e na perspectiva do marco temporal estabelecido nesta tese, 1975 e 2020, divido esta autobiografia em quatro partes episódicas, pelo menos do ponto de vista da recordação e documentação mobilizadas para o estudo, conforme explicitado mais adiante no quadro 11. Então, no cômputo geral, fui em busca das evidências relacionadas à trajetória na periodização definida, com o objetivo de identificar, na biografia secundária, elementos que pudessem fortalecer a hipótese levantada. Essa documentação se reveste basicamente de históricos escolares, certificados, diplomas e outros objetos que serviram para o reforço da memória e elemento de interpretação. Novamente, recorro às orientações de Marques e Satriano (2017), para quem a autonarrativa possibilita uma infinidade de registros cognitivos e afetivos-sociais a partir de um número razoável de objetos.

Desse modo, considerando a razão narrativa, que, segundo Delory-Momberger (2016), são momentos episódicos elencados pelo indivíduo no processo de recordação, comecei a gravar minhas memórias tendo como ponto de partida e motivação 1993, momento em que ingressei como professor auxiliar de ensino na Universidade Federal de Uberlândia, em Minas Gerais. Nessa minha fala, registrei o que consegui produzir do ponto de vista científico, ou seja, a dissertação de mestrado e uma tese de doutorado, com suas particularidades, e falarei mais sobre essas produções depois, porque cada uma a seu modo teve uma história à parte, sobretudo, porque se transformaram em publicações em forma de livro.

O propósito de recordar sobre essas produções não é o de fazer uma análise da dissertação e da tese, mas é de situar o leitor acerca dos primeiros momentos da minha transmigração dos dois campos de interesse, a arte e a ciência, que se evidencia mais fortemente nas duas pesquisas. Penso que esses trabalhos se explicam por si só se observado pelo ponto de vista do conteúdo, assim como forma e escrita. O primeiro, em primeira pessoa, e o outro, em terceira pessoa do singular, respectivamente, cujo conteúdo versa sobre afrodescendência e os aspectos corpóreos da dança afro no Rio de Janeiro.

Assim, apenas para efeitos didáticos, apresento o resumo, no quadro 11, a temporalidade autobiográfica e a razão narrativa correspondente às recordações e a busca da documentação referente à trajetória. Essa é uma forma simples de tentar fazer o leitor entender a predominância do conteúdo no tempo vivido durante o percurso e as recordações correspondentes.

Quadro 11 -

Temporalidade autobiográfica e razão narrativa 1975 a 2020.

\begin{tabular}{|c|l|}
\hline Temporalidade & \multicolumn{1}{c|}{ Razão narrativa/episódios } \\
\hline $1975-1980$ & Episódios escolares \\
\hline $1981-1993$ & Escola; artes; universidade; docência \\
\hline $1994-1999$ & Mestrado; doutoramento; docência \\
\hline $2000-2020$ & Docência; política institucional; defesa da tese para professor titular \\
\hline
\end{tabular}

Fonte: autor (2019). 
Como disse, essa é apenas uma demonstração para efeito didático, sobretudo, quando considerado os áudios gravados num processo de recordação, os assuntos acabam se misturando, embora haja predominância de um tema em detrimento de outros numa determinada experiência temporal. Esses aspectos são importantes na medida em que estamos ancorados nas reflexões de Halbwachs (1990) para quem "não reconstituímos o quadro temporal senão depois que a lembrança foi restabelecida e então somos obrigados, a fim de localizar a data do acontecimento, dele examinar em detalhes todas as partes" (p. 101).

É exatamente seguindo essas orientações do autor supracitado que criei quadros e tentei reconstituir as temporalidades da minha trajetória. Com efeito, reafirmo por meio das recordações os principais ambientes por onde passei, resistindo, inclusive, ao tempo e transpondo os pequenos obstáculos encontrados por entre as linhas curvas e, às vezes, circulares da minha própria trajetória. Essas lembranças chegam pelo exercício da autonarração e também pelo constante manuseio de diferentes arquivos que liberam fontes documentais nesse ato autobiográfico.

Desse modo, a partir da temporalidade apresentada no quadro 11, fui em busca de documentos que pudessem evidenciar alguns momentos fundamentais da minha passagem e transmigração de um campo a outro, especialmente da arte para a ciência. Assim, entre 1994 e 1995, tive uma das mais importantes recordações sobre uma disciplina que criei na Universidade Federal de Uberlândia: Teoria, Prática e Metodologia da Dança, que era uma disciplina eletiva, quando ainda não se falava de conteúdos sobre a história e cultura afro-brasileira, a exemplo da lei n. 10.639/2003, que é bastante recente.

Utilizo as recordações e documentos dessa época para indicar o início do impulso acadêmico intercruzado com as inspirações artísticas trazidas do Rio de Janeiro. É também uma forma de dizer que trabalho há bastante tempo com as questões étnicoraciais na instituição universitária, essa foi durante muito tempo a minha causa prioritária na instituição.

Além disso, recorro também as atas provenientes das reuniões do Departamento de Educação Física e Desportos da Universidade Federal de Uberlândia. Não é uma documentação muito extensa, mas nela é possível verificar a minha transferência para o Recife e uma das principais tensões experimentadas no ambiente universitário, que foi um processo de sindicância no período probatório, relatado com alguns detalhes por meio das recordações.

As atas evidenciam as autorizações para viagens em congresso e o afastamento para o doutorado na Unicamp por 24 meses, concedido pelo pleno do Departamento. E, em seguida, a liberação, ou redistribuição, concedida para a Universidade Federal de Pernambuco. Aliás, essa documentação já consta na pasta de assentamento funcional que veio para a instituição pernambucana em 2000.

$\mathrm{Da}$ análise da biografia secundária, eu analiso ainda o meu Currículo Lattes e verifico os primeiros registros dessa plataforma, iniciado na UFPE, porque até 2000 não se ouvia falar do Lattes em Uberlândia. Os primeiros registros foram feitos numa das salas da Pró-Reitoria de Pesquisa e Pós-graduação da UFPE. Até hoje, entro com a 
mesma senha e me sinto muito orgulhoso do que consegui avançar na vida acadêmica. Assim, afirmo que foi na Universidade Federal de Pernambuco onde ingressei efetivamente no mundo acadêmico-científico e político-institucional.

Em seguida, entre 2000 a 2020, o período mais extenso, tenho basicamente 20 anos de atuação dedicados exclusivamente à UFPE. É desse ambiente de onde saem as pérolas desta narrativa, que me enchem de orgulho pela construção e reconstrução da trajetória fincada na graduação, pós-graduação, administração e política institucional. Embora reconheça que na Universidade Federal de Uberlândia também tenha experimentado algo semelhante, foi na UFPE que a entrada no campo acadêmico se deu de maneira mais efetiva na ciência e na política institucional.

Assim, considerando o que havia de produção nesse campo, copiei todo o conteúdo da minha pasta de assentamento funcional, arquivada no Setor de Registro e Movimentação, da Pró-Reitoria de Gestão de Pessoas e Qualidade de Vida da UFPE, e fui tentar entender as circunstâncias que foram produzidas as informações contidas a meu respeito, bem como o que representa esse tipo de documentação para a distinção institucional, considerando ainda a forma e o conteúdo da mensagem.

Essa pasta de assentamento contém 198 documentos, que variam desde uma ficha de caráter pessoal - data de nascimento, filiação, local de lotação, estado civil - à portarias diversas das progressões, nomeações e exonerações, ofícios dirigidos à instituição universitária para redistribuição, publicações do Diário Oficial da União, extrato de férias, fichas financeiras de vários anos, formulário de declaração de dependentes para imposto de renda, cópia de Diário Oficial da União, histórico de classificação na carreira do magistério superior, certidão de tempo de serviço, memorandos internos da UFU, informes de redistribuição e ofícios entre reitores da UFU e UFPE no diálogo sobre a minha redistribuição. Além desses documentos, constam ainda atas de reuniões da Faculdade de Educação Física da UFU e de reuniões do Departamento de Educação Física da UFPE que tratam da minha redistribuição, ofício endereçado ao Ministério da Educação sobre a decisão da vaga para efeito da redistribuição e vários pareceres sobre a pontuação nas minhas progressões funcionais.

Assim que tomei a decisão de utilizar a (auto)biografia secundária, ou seja, documentos que produzi e foram produzidos por terceiros sobre a minha vida profissional e acadêmica sem a finalidade desta pesquisa, tratei de dar um print, impressão completa, 58 páginas, no Currículo Lattes, o que foi realizado no dia 24 de novembro de 2018, às 6h30min., horário de verão, Brasília.

Nesse contexto, meus arquivos também se encontram no Portal da Transparência, do Governo Federal, e na plataforma Siga ${ }^{13}$, da UFPE, que se desdobra em Plano de Atividade Docente - Paad - e Relatório de Atividade Docente - Raad. Ambiente semelhante ao que podemos chamar de Siga Acadêmico, tenho o Siga Processo, onde constam todos processos que impetrei na UFPE, dos afastamentos para viagens a congresso ou para o pós-doutorado, recursos financeiros etc., totalizando, até o presente momento, 122 processos, incluindo este para o cargo de Professor Titular.

Um dos arquivos institucionais de grande importância diz respeito às escolas onde estudei. Sempre tive a curiosidade de retornar a essas instituições, por isso, após mais de

\footnotetext{
${ }^{13}$ Nesse endereço somente eu tenho acesso ao meu perfil, mediante CPF e senha individual.
} 
40 anos, voltei a esses ambientes aos quais sou muito grato. Num só dia visitei três escolas: a Escola Professor Pedro Augusto Carneiro Leão; a Escola Estadual Santo Inácio de Loyola e o Centro Educativo Operário Agamenon Magalhães, já extinto. Em seu lugar atualmente está o prédio do Senai, também sem funcionamento.

Fui muito bem recebido nas escolas, inclusive, na Escola Pedro Augusto, na qual o diretor me levou à secretaria do colégio e pediu para que um dos funcionários fosse buscar a minha ficha, minha documentação de 1977. De forma rápida e inusitada, prontamente obtive em minhas mãos vestígios de um passado bastante importante em minha formação humana.

O funcionário perguntou o meu nome completo, digitou no computador, retirou-se e voltou com uma caixa de plástico onde constavam várias fichas com o nome Edilson, numa delas estava a documentação referente à minha passagem por três anos naquela escola. Dessa ficha também constava a documentação do Colégio Agamenon Magalhães, especialmente o certificado de conclusão de série, certamente, motivado pela transferência de instituição e mudança da 4⿳a para a 5 a $^{\text {a }}$ série. Esse documento, em particular, me trouxe algumas surpresas.

Considerando a emoção que me tomava conta, folheei rapidamente o que foi possível, vi minha fotografia com 12 anos, mas fiquei sem saber o que fazer com aquele material, até porque o técnico-administrativo, meu xará Edilson, ao me entregar a pasta disse: "Aqui está toda a sua vida escolar. Toda sua vida está aqui". Então, eu o avisei que voltaria num outro dia para pegar uma cópia daqueles registros e doar alguns exemplares dos livros que eu havia escrito sobre alguns assuntos como as memórias da Copa do Mundo, a história da Educação, o samba e a civilização etc.

Além da visita à secretaria da Escola Pedro Augusto, percorri duas ou três salas e fui apresentado aos estudantes. Numa das salas, acho que do $8^{\circ}$ ano, ao ser apresentado à turma, embora não tenha falado absolutamente nada naquele momento, fui aplaudido pela garotada. Em seguida, fui até a quadra poliesportiva, a mesma onde tive a primeira aula de Educação Física. Os olhos até lacrimejaram!

No dia seguinte, fui buscar a cópia da minha ficha escolar e a minha curiosidade era imensa para saber o que havia registrado sobre minha estada naquele ambiente educacional, desde as notas, os conceitos até a matéria que me saí melhor - seria Português, Matemática, História? Enfim, um pouco do que havia deixado para trás e o que havia avançado entre os assuntos que trato atualmente.

Ah! Ao entrar nas escolas, meu sentimento era de respeito para com as pessoas que lá trabalhavam, a mesma sensação de quando era criança. A memória afetiva reagiu ao me aproximar dos ambientes administrativos, pois sempre tive respeito e, às vezes, medo, especialmente por aqueles que detinham o poder: diretores, supervisores etc.

Essa sensação de medo e respeito aconteceu principalmente na Escola Pedro Augusto. Acho que a razão é óbvia, afinal foi lá onde tive um pequeno embate com a diretora, Dona Malévolas, um dos nomes fictícios neste estudo, que me chamou a atenção por duas vezes no mesmo dia, ameaçando-me de expulsão da escola. Não obstante essa sensação, até porque passado tanto tempo, agora a lida era com um diretor, no geral fiquei feliz em voltar à escola. 
Nesse contexto, a principal mensagem que fica é a importância de um arquivo bem cuidado nessas instituições escolares. Digo isso porque meus documentos estão bem conservados e, provavelmente, há uma política de preservação desse acervo, bem como do estado geral das próprias escolas, pelo menos no Pedro Augusto e no Colégio Estadual de Beberibe, onde estudei apenas por seis meses, em 1980.

Os documentos encontrados foram bastante significativos e representativos de uma época escolar, seja de ordem pessoal, porque revelam uma parte da minha trajetória na educação formal, seja porque identificam, sobretudo, a política de escolarização a que uma sociedade está submetida. Afirmo isso porque, além de verificar o que consta acerca dos meus registros pessoais, é possível, em certa medida, analisar a legislação que regia as instituições nesse período, especialmente os pequenos dribles institucionais para ajustar a idade dos estudantes à série. Os documentos podem revelar, ainda, os currículos exigidos e a formação esperada de meninos e meninas das classes populares, por exemplo.

Além de tudo isso, um aspecto importante é saber que todas essas escolas fazem parte de um sistema integrado, mas são instituições diferentes entre si, pois possuem uma política própria de preservação e socialização de documentos. Logo, a imagem que tive da Escola Pedro Augusto e da Escola Técnica Estadual Almirante Soares Dutra, a presteza com que recebi meus documentos, não foi a mesma com que obtive a documentação de outras escolas, inclusive, as mais recentes.

No entanto, embora tenha recebido a ata dos resultados finais, já na primeira visita à Escola Técnica Estadual Almirante Soares Dutra, quando perguntei sobre a ficha escolar do ano de 1983, ou seja, alguns documentos relativos ao acompanhamento que a instituição fazia ao meu respeito, recebi a resposta de que todo o material relacionado ao que precisava havia sido destruído por cupins. Mesmo assim, fui convidado a entrar na sala de apoio técnico e verificar em locus os gavetões de aço e os respectivos períodos aos quais a documentação se referia, neste caso, atas dos anos 1976 a 1983 e minha pasta, Enf/83, que continha a relação dos concluintes do curso de Enfermagem em 1983.

Todavia, o leitor deve saber que, por vezes, o método de pesquisa difere da forma de exposição de seus resultados, por isso gostaria de registrar que a visitação às escolas foi feita uns nove meses eu ter gravado as memórias, e isso pode ter afetado as minhas sensações. É como se eu estivesse ido às escolas, como fui, antes da presença física, o que pode ter mitigado as emoções a elas devotadas. É evidente que isso é apenas uma percepção, mas, ao recordar e depois visitar fisicamente, parecia que tudo estava exatamente no mesmo lugar, os móveis, o cheiro da cozinha e da merenda, as pessoas que lá trabalhavam, inclusive a diretora.

Documentação sob a guarda das escolas pode evidenciar vários elementos importantes acerca do estudante, como notas, conceitos e matérias que clivaram o indivíduo durante um percurso escolar; fotografias oficiais, para efeito de identificação do tempo da escola; endereços antigos do estudante; membro da família responsável pela matrícula numa determinada escola etc. Além disso, pode-se encontrar ainda evidências das características socioeconômicas e demográficas da família, seu tamanho e formas de parentesco, profissão e grau de escolaridade do pai e da mãe. Com esses dados, a escola e a própria rede de ensino podem traçar políticas específicas e mais eficazes no atendimento de seus estudantes. 
Numa visita aos arquivos e documentação escolar ainda é possível identificar que, sendo de uma mesma rede, municipal ou estadual, as escolas se comunicam entre si e dão informes importantes de seus ritos, como, por exemplo, uma escola em que passei apenas seis meses, informou à escola subsequente que a avaliação na disciplina de Religião era organizada de tal forma em que 0 ' $B$ ' equivaleria a nota 7,0 .

Além disso, mesmo com essa informação, a escola que recebe o estudante, poderia não ter a referida matéria ou professor responsável, o mais provável. $\mathrm{Na}$ minha documentação escolar, por exemplo, na medida em que progredi às séries subsequentes, percebi de maneira bastante expressiva a presença de conceitos em disciplinas julgadas importantes para a época, como a chamada 'A Formação Especial', prevista na resolução n. 3/1973. do Conselho Estadual de Educação, do Estado de Pernambuco. Ainda há o caso da lei de n. 5.692/1971, das diretrizes e bases da educação, em seu artigo $7^{\circ}$, que previa disciplinas como: Programa de Saúde, Educação Moral e Cívica, Educação Artística, Educação Física e Ensino Religioso.

Outro aspecto que gostaria de registrar, além da comunicação documental entre as escolas, mesmo numa rede estadual, como foi o caso, é que o corpo docente e administrativo tem relativa autonomia para avaliar seus estudantes. Além do mais, por alguma razão, seja pelo número de professores de determinada área, seja pela própria relação que aquela escola tem com os discentes, áreas de determinado conhecimento estão presentes numa série e, em outra escola, essa mesma área sequer aparece como elemento da formação educacional. Essa constatação foi possível porque tive acesso à ficha individual do estudante das escolas, a partir da qual foi possível comparar esses elementos.

Se as instituições onde estudei me permitem enxergar por meio de um arquivo os meus progressos educacionais, outro ambiente que não pode de maneira nenhuma ser negligenciado é o meu arquivo pessoal, aliás, é a minha pequena bagunça, como acontece em qualquer família nuclear formada há pelo menos 23 anos de 7 membros, com papéis espalhados que se encontram em muitos lugares, entre armários, estantes e gavetas, mas esse arquivo precisou ser revisitado.

Nele, pude encontrar uma infinidade de documentos, entre boletos bancários, extratos de cartões de crédito já pagos, registros de casamento e nascimento, históricos escolares e de cursos de graduação e pós-graduação, declarações, documentos de veículos antigos, certificados, declaração de conclusão de disciplinas cursadas na Especialização em Psicomotricidade e Pedagogia do Movimento Humano, diplomas de todos os níveis de escolaridade, graduação, mestrado e doutorado, ainda encontrei meu cartão de imunização e o crachá da Associação dos Cronistas Desportivos de Pernambuco.

Essa massa documental de diferentes naturezas resguarda também surpresas agradáveis, como convites de casamento, de formatura, cartão de aniversário ou de lugares visitados por amigos, cartão de natal e ano novo e fotografia do churrasco após defesa de doutorado, em Campinas/SP. Entre esses documentos de grande satisfação, encontrei ainda um recibo do Centro Educacional Nova Cultura de Uberlândia, Minas Gerais, referente a um mês de pagamento do Jardim III, novembro de 1993. Nessa ocasião, chorei ao constatar que esse documento é referente ao início da educação de minha filha mais velha, que hoje é doutoranda em Educação na UFPE. 
Além disso, também encontrei outros documentos oficiais de instituições educacionais. Da minha época na Universidade Federal de Uberlândia, por exemplo, encontrei a solicitação de prestação de contas das diárias de uma viagem a Salvador; um manuscrito da mesma instituição respondendo à minha solicitação de transferência do mestrado de Educação Física da Universidade Gama Filho para o mestrado em Educação Brasileira da UFU; uma procuração que passei a um colega da Unicamp para realizar minha matrícula no doutorado, em 1997; um ofício em que solicitei ingresso, já como professor, para o mestrado em Educação Brasileira da UFU em 1999; um ofício do Departamento de Educação Física da UFU liberando-me por 20h semanais para ministrar aulas no referido mestrado; ofício resposta do então coordenador do mestrado negando a minha solicitação, infelizmente, o documento encontra-se com algumas avarias; ofício do Programa de Pós-Graduação em Educação da Universidade Metodista de Piracicaba Unimep -, convidando-me para compor o que seria a minha primeira banca de mestrado em 1999; documento da UFU concedendo remuneração compatível ao título de especialista em 1993; contracheques da UFU, julho e agosto de 1993, e documento da mesma instituição concedendo remuneração compatível ao título de doutor a partir de 1998.

É importante registrar também que apenas um ou outro documento desse arquivo foi utilizado nesta tese, até porque tive que separar o que havia de interesse para a composição das temáticas aqui abordadas daquilo que servia apenas para recordação e futuros trabalhos, o que fiz conforme Certeau (1998) e, de maneira mais drástica, Saviani (2006), com suas reflexões sobre a política de fontes. De qualquer modo, um fundo documental de família requer, sem sombra de dúvidas, um tratamento especializado no contexto da política de fontes para diferentes perspectivas historiográficas, pensando no campo econômico, da cultura da família, na relação com a própria memória e na história da educação, por exemplo.

Nesse contexto, penso que qualquer relato que possamos fazer em relação à nossa profissão ou outros interesses políticos tem a ver, inevitavelmente, com a documentação encontrada nos nossos porões, nas bagunças deixadas entre caixas, sacolas, pastas, armários, gavetas e, eventualmente, algumas estantes. Até porque, ao vasculhar esses ambientes, também vêm à memória cenas e situações da vida que talvez não viessem à tona se não houvesse esse movimento a partir de um pouco de contato com esses móveis e utensílios:

Nossa casa, nossos móveis e a maneira segundo a qual estão dispostos, o arranjo dos cômodos onde vivemos, lembram-nos nossa família e os amigos que víamos geralmente nesse quadro. [...] Nossa cultura e nossos gostos aparentes na escolha e na disposição desses objetos se explicam em larga medida pelos elos que nos prendem sempre a um grande número de sociedades, sensíveis ou invisíveis. (Halbwachs, 1990, p. 131)

Considerando essas reflexões, há de se concordar com Halbwachs (1990), porque tudo está irremediavelmente encadeado, os objetos e utensílios, os móveis que fazem parte de uma mesma teia de relações carregadas pelo indivíduo que recorda, o autobiógrafo em ação. Assim, tudo parece fazer recordar, trazer à memória situações experimentadas por mim num simples gesto de aproximação desses objetos, até brinquedos esquecidos pelos filhos agora adultos. 
É óbvio que um arquivo pessoal, como o meu, que resolvi abrir e vasculhar, tem relevância na medida em que autobiógrafos precisam de algum documento que possam corroborar algumas informações, complementando ideias que possam puxar pela própria memória em decorrência do tempo; como uma carta de amigos, uma mensagem de apoio, um quadro sujo e desprezado, uma fotografia em família ou de pessoas que já se foram.

Os objetos expostos em nossos lares trazem traços importantes da distinção social e, às vezes, também trazem a recordação de algum momento importante em que foi produzido ou adquirido, uma moda já antiga de seu uso, de sua relação com a sociedade mais ampla. Logo, num projeto autobiográfico, como estou a desenvolver, o pesquisador deve ficar atento para o fato de que o indivíduo recorda sua trajetória a partir e conjuntamente de um lugar e na sua relação com pessoas, objetos e imagens.

O autobiógrafo nunca estará sozinho em suas lembranças. No fundo, qualquer acervo da família tem origem num tempo diferente da própria existência, é fruto de algum de seus membros, filhos, entes que já se foram, outros que estão por vir, pedaços de uma família e complementos de outras, a exemplo, arquivos provenientes de casamentos anteriores, como foi o meu caso. Assim, encontrei documentos de quando ainda era casado com a minha primeira esposa, documentos da nossa filha e da dissolução de nossa união num acordo judicial. É que documentos provenientes do acervo de uma família podem ter inevitavelmente conexão com outras famílias, às vezes, desfeitas.

Em outros casos, filhos constituem suas próprias famílias nucleares e deixam por alguma razão documentos dos mais diversos com seus pais. Foi o que aconteceu comigo. Logo após o falecimento da minha mãe, encontrei documentos meus ou objetos relativos à minha vida de quando morei no Rio de Janeiro e em Uberlândia. Entre esses objetos estavam cinco cartas, minha carteira estudantil e várias fotografias de conteúdos variados, de festas, atividades de trabalho e mais de uma simples visita aos domingos.

Não obstante identificar a importância de se pensar numa política de fontes documentais provenientes de acervos da família, não pretendo fazer uma discussão exaustiva pelas próprias limitações deste estudo, mas cabe, por enquanto, dizer que só em 1990 esse tema de arquivo pessoal adquire status acadêmico-científico no rol das preocupações dos arquivistas (Britto; Corradi, 2017). Esse debruçar tardio sobre os arquivos pessoais talvez se deva à diversidade tipológica dos próprios documentos ali conservados:

A questão sobre as atividades produzidas está relacionada a tudo o que a pessoa fez, não apenas a sua carreira profissional. Nesse sentido, faz nexo encontrarmos documentos de caráter religioso, recreativo, associativo, político, de formação educacional, beneficentes entre outros num arquivo pessoal. (Britto; Corradi, 2017, p. 155)

De qualquer modo, é intrigante a complexidade documental que pode ser encontrada num arquivo pessoal. Há de convir que um indivíduo tem relações estreitas com vários espectros da estrutura estatal, logo, podem ser encontrados nesse tipo especial de arquivo não apenas documentos pessoais, mas também, e em grande parte, documentos oficiais da relação do indivíduo com o Estado, seja em resposta ou em reclamação, assim como na outorga em função de um diploma de uma universidade pública, por exemplo. 
Ao fazer uso do arquivo pessoal precisei separar o que era efetivamente do titular do arquivo, ou seja, separar os meus próprios objetos dos daqueles pertencentes a outros membros da minha família. Entretanto, boa parte dos documentos são mesmo produtos das minhas relações institucionais e interpessoais e envolvem outras pessoas que igualmente devem ter seus arquivos com a minha conexão. No entanto, mesmo verificando essa interrelação que os objetos têm e mantêm com outros indivíduos, seja da minha família, seja de outros lugares, analisei apenas uma pequena parte daquilo que considerei essencial para a compreensão mais geral deste estudo e, inevitavelmente, foi isso que me levou a pensar na hipótese de trabalho do constructo do 'eu' fonte, que constará no último capítulo desta tese.

Entretanto, a utilização desse arquivo pessoal em trabalhos científicos, essa exposição de parte do acervo, é também a conexão complementar das memórias que, na maioria das vezes, compreendemos apenas com os registros orais. Por isso, tratei nesta tese a gravação da minha fala, que passará de agora em diante a fazer parte também de meu arquivo pessoal na relação de arquivos públicos, na medida em que esta tese constará no repositório institucional da Universidade Federal de Pernambuco.

Nesse contexto, ao gravar a narrativa, fui simultaneamente narrador e observador da narração, sujeito e objeto desse tempo social e histórico da trajetória escolar, artística, acadêmica e política que experimentei. Além de compreender que sou o próprio destino da minha fala, dos meus gestos e atitudes, as gravações originais, bem como as transcrições do meu discurso produzido para esta tese, têm como comunidade de destino o repositório da UFPE, especialmente o Memorial Denis Bernardes, localizado na

Biblioteca Central, onde já se encontra um conjunto de materiais e objetos relacionados aos 10 anos em que me dediquei à produção e apresentação do programa de televisão Cabeça de área: penso, logo assisto.

Considerando que "um discurso manterá portanto uma marca de cientificidade explicitando as condições e as regras de sua produção e, em primeiro lugar, as relações de onde nasce" (Certeau, 1998, p. 110), para se apresentar no campo acadêmico de forma satisfatória e atender minimamente aos requisitos de uma hipótese, registrei os diferentes momentos retrospectivos da minha trajetória que "corresponde[m] ao transcurso mais autêntico da vida real, repleta de: multiplicidades, avanços, recuos, tropeços, encruzilhadas, bifurcações, ruas sem saída, atalhos, acidentes de percurso e tantos outros fatores" (Costa, 2016, p. 78), utilizados na autonarrativa.

As gravações do que chamo autonarrativa ocorreram em minha própria residência. Gravei as falas em várias etapas e dias diferentes, que ocorreram sempre entre $5 \mathrm{~h} 30 \mathrm{~min}$. e 7 h, na sala de tevê. A sala fica na Pousadinha, próximo à piscina. A primeira ocorreu no último domingo de 2018, dia 30 de dezembro. Foram 52:08,16 (cinquenta e dois minutos, oito segundos e dezesseis milésimos de segundos). Tive duas interrupções: a primeira porque minha esposa precisava sair e pediu que eu fechasse o portão eletrônico, a uns 200 metros de distância, e a segunda foi em virtude do meu atrapalho com o aparelho celular da Samsung que utilizei, de forma que não consegui dar o ok para continuar a gravação 
A segunda gravação ocorreu no dia 31 de dezembro de 2018, com tempo de 44:11,34 (quarenta e quatro minutos, onze segundos e trinta e quatro milésimos de segundos). Estava apreensivo, pois senti que deveria gravar antes do ano novo, talvez para deixar realmente para trás algumas lembranças ou angústias que me afligiam em 2018, sobretudo a possibilidade de não concorrer à eleição para a reitor em 2019, porque a situação da força política em que atuava naquele momento estava realmente muito tensa. A terceira gravação fiz no dia 2 de janeiro de 2019, já havia me recuperado da ressaca e rendeu 53:05,47 (cinquenta e três minutos, cinco segundos e quarenta e sete milésimos de segundos). Acordei no mesmo horário de sempre, 5 horas, tomei um café meio frio do dia anterior e fui até a Pousadinha, para gravar no segundo dia do ano.

A quarta gravação foi realizada no dia 11 de janeiro de 2019, com o tempo de 55:18,71 (cinquenta e cinco minutos, dezoito segundos e setenta e um milésimos de segundos). Decidi fazer esses registros após a leitura do Memorial do professor Edson Hely Silva, foi muito instigante a forma com que ele abordou alguns aspectos de sua vida escolar, o que me impulsionou a também tratar desse assunto.

Além da inspiração vinda do professor Edson Silva, senti-me obrigado a dar uma resposta e visibilidade às escolas por onde passei. Como não estava no roteiro original, precisei fazer um breve rascunho para guiar minimamente a minha fala, até porque os registros sobre as escolas por onde passei foram os mais emocionantes. Alguns momentos fiquei com a voz embargada por dois motivos: as lembranças das escolas e o fato de à época minha mãe já estar hospitalizada, com difícil recuperação.

Já a quinta gravação ocorreu no dia 12 de janeiro de 2019, com um tempo de 41:13,73 (quarenta e um minutos, treze segundos e setenta e três milésimos de segundos). Decidi fazer esse registro para complementar alguns elementos que faltaram na gravação anterior, sobre a escola, e para escrever o penúltimo capítulo da tese, que trata sobre a política. Outra gravação foi realizada para um projeto da professora Inaldete Pinheiro sobre Memórias negras pernambucanas. Essa gravação ocorreu em 23 de janeiro de 2019, cujo tempo foi de 42:25,62 (quarenta e dois minutos, vinte e cinco segundos e sessenta e dois milésimos de segundos).

A gravação do dia 23 de janeiro de 2019 foi uma das mais difíceis de se realizar porque a minha mãe havia sido sepultada três dias antes. Mas, pela disciplina de estudo, que sempre tive durante a trajetória de vida, sabia que precisava gravar, transcrever e entregar todo esse material à Inaldete Pinheiro, para a composição de seu projeto/livro. Entretanto, acabei utilizando todo o material inédito nesta tese e contarei as razões desse procedimento mais adiante.

Durante o processo de escrita do trabalho e revendo o que já havia produzido, senti a necessidade de fazer mais duas gravações para efeito de compreensão de dois momentos importantes da minha trajetória na UFPE. Então, resolvi gravar no dia 19 de julho de 2019 um áudio que durou 13:57,98 (treze minutos, cinquenta e sete segundos e noventa e oito milésimos de segundos) ${ }^{14}$ e no dia 24 de julho de 2019 o último áudio, que teve a duração de 08:87,00 (oito minutos, oitenta e sete segundos).

\footnotetext{
14 Essa foi a única gravação realizada em horário diferente das demais, às 10h50, após eu ter chegado do simpósio temático Trajetórias e (auto)biografias: modelos, limites, desafios e possibilidades, da $30^{\underline{a}}$ reunião anual da Anpuh, Recife, 2019.
} 
Nesse contexto, foram oito áudios que serviram de suporte para o projeto geral desta autobiografia, são as minhas memórias que ganharam força e serviram de esteio para a elaboração deste trabalho. Tecnicamente, o tempo de gravação e o número de páginas das transcrições depende da velocidade da voz, das emoções contidas e, obviamente, dos detalhes que se pretendeu explicitar. Assim, percebi que gravar minhas recordações não era mais necessário e que deveria, portanto, partir para a redação do texto.

Como todos os dias às $5 \mathrm{~h}$, também fui acompanhado pelo meu cachorro, já idoso, o Spike, que estava sempre por perto. Entre uma cochilada e outra, ele ficava atento ao que eu dizia, às vezes resmungando, fazendo 'pum', e às vezes roncando. Era muito bom ele estar por ali, principalmente porque a sala que elegi como estúdio fica na parte de fora da casa, a Pousadinha, a uns 31 metros da casa principal. É sempre bom mesmo ter o pulguento por perto, mesmo sonolento.

Pensei, inicialmente, que uma única gravação seria o suficiente para dar conta do que pretendia realizar, mas, ao perceber que teria um pouco mais para contar da trajetória, comecei a nomear os registros da seguinte forma: 1. (Primeira gravação); 2. (Biografia, fala 2); 3. (Biografia, fala 3); 4. (Escola, gravação 1); 5. (Escola e política); 6. (Para Inaldete Pinheiro - Memórias Negras Pernambucanas). 7. (Largaram a mão 1); 8. (UFU, Eleição diretor). Com esse procedimento, foi possível diferenciar os temas centrais abordados em cada momento, o que facilitou as transcrições realizadas por um profissional (depois revisadas por mim, para que pudesse utilizar como fonte). Entretanto, fiz as transcrições das duas últimas gravações.

Essa atitude de gravar com espaços de tempo muito próximos - apenas com duas gravações separadas das outras por meses - e ainda com um tempo razoável de narrativa em cada uma, fez eu me lembrar de que "os biografados são capazes de narrar suas vidas durante muito tempo - horas -, frequentemente sem vacilações, apesar de lhes ser pedido que façam de um modo muito geral" (Rosenthal, 2006, p. 195). Nesses momentos de contação de história, o tempo é precioso e leva aos desfechos das experiências, porque abrimos e fechamos cenas que aparentemente estão desconexas por ocorrerem em momentos diferentes, mas estão irremediavelmente conectadas, mesmo com o espaçamento da lembrança e da própria experiência física.

Considerando todos esses aspectos, neste estudo me impus um roteiro, mas o fato é que, se o projeto trata de um outro indivíduo ou de nós mesmos, temos razoável interesse na nossa própria história. Falamos e ouvimos sobre nós mesmos e isso nos dá uma agradável sensação de dever cumprido, seja por conta da vida enquanto experiência, e o relato registrado tenta confirmar isso, seja pelo compromisso com a pesquisa científica, razão deste ritual.

De qualquer modo, gravei as narrativas com o roteiro nas mãos. Sempre falei para um outro, talvez para o meu ego ou para o Spike. Ao ouvir as gravações, percebi que havia lapsos de memória na narrativa, datas, nomes de pessoas e alguns cenários pareceram se impor pela fuga das lembranças. Por alguma razão, falhei ao tentar lembrar. Decidi, então, que, depois das transcrições e leitura do documento, deveria completar a retórica e deixar mais evidente o que queria realmente dizer com as palavras gravadas, na verdade, esquecidas. 
O cenário das gravações, a Pousadinha, fica próximo à piscina, ao terraço e à cozinha gourmet. É um cômodo de aproximadamente $27 \mathrm{~m}^{2}$, possui porta e três janelas de madeira. No seu interior, encontram-se uma estante com 350 títulos, entre livros, dissertações e teses, dois sofás velhos, um aparelho de televisão sobre o rack, um tapete de palha, onde o Spike costuma ficar deitado, uma cadeira de plástico, duas quartinhas de enfeite de argila, a mesa e ferro de passar roupa, um pufe preto e branco e vários enfeites de cerâmica e madeira, alguns desses provenientes da Guiné-Bissau, na África. Há também um ventilador de mesa, porque, depois do meio-dia, o calor é insuportável, mesmo com a piscina de frente e um pé de manga espada ao lado.

Quadro 12 -

Aspectos gerais dos áudios da pesquisa.

\begin{tabular}{|l|c|c|c|c|}
\hline \multicolumn{1}{|c|}{$\begin{array}{c}\text { Título da } \\
\text { gravação }\end{array}$} & $\begin{array}{c}\text { Tempo de } \\
\text { gravação em } \\
\text { minutos }\end{array}$ & Local da gravação & $\begin{array}{c}\text { Data da } \\
\text { gravação }\end{array}$ & Páginas \\
\hline $\begin{array}{l}\text { Primeira } \\
\text { gravação }\end{array}$ & $00: 52: 08,16$ & Residência/Pousadinha & $30 / 12 / 2018$ & 10 \\
\hline Biografia, fala 2 & $00: 44: 11,34$ & Residência/Pousadinha & $31 / 12 / 2018$ & 9 \\
\hline Biografia, fala 3 & $00: 53: 05,47$ & Residência/Pousadinha & $02 / 01 / 2019$ & 11 \\
\hline $\begin{array}{l}\text { Escola gravação } \\
1\end{array}$ & $00: 55: 18,71$ & Residência/Pousadinha & $11 / 01 / 2019$ & 8 \\
\hline Escola e política & $00: 41: 13,73$ & Residência/Pousadinha & $12 / 01 / 2019$ & 7 \\
\hline $\begin{array}{l}\text { Memórias } \\
\text { Pegras }\end{array}$ & $00: 42: 25,62$ & Residência/Pousadinha & $23 / 01 / 2019$ & 2 \\
\hline Largaram a mão & $00: 13: 57,98$ & Residência/Pousadinha & $19 / 07 / 2019$ & 1,5 \\
\hline $\begin{array}{l}\text { UFU, eleição } \\
\text { diretor }\end{array}$ & $00: 08: 87,00$ & Residência/Pousadinha & $24 / 07 / 2019$ & \\
\hline
\end{tabular}

Fonte: autor.

Conforme pode ser visto no quadro 12 foram oito gravações, que renderam um tempo aproximado de cinco horas no total, resultando em 59,5 páginas. É importante ainda observar que essa paginação se refere ao parágrafo único e espaçamento simples com a fonte Times New Roman, tamanho 12. Após as transcrições fui reelaborando seu conteúdo e editando palavras ou frases inteiras para melhor compreensão do contexto da recordação, também corrigi, após verificação, as datas, nomes de personagens, cenários dos episódios etc.

Mesmo arcando com as responsabilidades éticas que envolvem um projeto autobiográfico, uma vez que você não fala apenas de si mesmo, é praticamente impossível a identificação nesta tese dos trechos extraídos das gravações e o que consegui elaborar a partir de uma vasta documentação iconográfica e impressa. Por enquanto, é importante que o leitor tenha em mente que a base fundamental do que está escrito, pelo menos $50 \%$, foi produzido a partir das gravações. Contudo, para efeito de identificação, quando a referência for extraída do Currículo Lattes, aparecerá a sigla EFSLattes, seguida do ano e páginas.

Do mesmo modo, ao ler "Souza", seguido de um determinado ano e, às vezes, letras para diferenciação, posso estar me referindo a algumas das minhas publicações que, a partir de citações diretas ou indiretas, chamarei a atenção para alguma informação relevante enquanto autor. De outro modo, ainda considerando minhas próprias citações, 
por exigência dos entrevistadores, quando o leitor estiver diante de Souza (2009b), saberá que diz respeito às referências ao depoimento concedido ao Laboratório de História Oral e da Imagem - Lahoi/UFPE. Essa entrevista foi concedida em 22 de junho de 2009 e teve a duração de 2:14:13 (duas horas, catorze minutos e treze segundos).

Embora eu tenha utilizado parte significativa desse material por se tratar de conteúdo da minha história de vida, não expus no quadro 12 porque não possui as mesmas características dos áudios que produzi especificamente para esta tese. Então, a soma total de áudios para a modelagem deste estudo é de aproximadamente oito horas e a paginação das transcrições do Lahoi/UFPE renderam aproximadamente 62, já considerando as intervenções dos entrevistadores, os professores Isabel Guillen e Ivaldo Marciano.

Nesse contexto, para a recordação e gravação, mantive os nomes reais dos personagens, mas, no processo de escrita do enredo que o leitor tem em mãos, tomei a iniciativa de resguardar alguns personagens que entraram e saíram da minha trajetória, principalmente de forma positiva num determinado momento e negativa em outro. Logo, ao serem citados como membros integrantes desse campo, as referências que, por ventura, faço a eles textualmente, será seguida por nomes abreviados e às vezes fictícios. Uma forma carinhosa e divertida de apresentá-los nesta estrutura narrativa, ainda que sua aparição na vida real tenha sido de muitas tensões e desagrados.

Percebo que na autonarrativa, entre uma lembrança e outra, um esquecimento e outro, preservei alguns personagens que fizeram parte dos campos em que atuei. Às vezes, omiti algumas informações relevantes sobre eles, inclusive a minha percepção acerca de sua integridade ética e moral. Em alguns momentos, omiti informações relacionadas às faltas graves que me atingiram frontalmente, minha percepção. Em

outros, ressaltei algumas qualidades desses indivíduos. De modo que os enganos da biografia, que Bourdieu (2005) aborda, às vezes, são omissões propositais; ou melhor, são parte das orientações de Eakin (2019) quando trata das regras da autobiografia e do direito à privacidade.

Desse modo, resguardei essas pessoas de suas idiossincrasias humanas até porque elas estão vivas, ainda fazem parte do meu convívio, da mesma instituição em que trabalho, volta e meia estamos numa mesma reunião, evento etc. Por outro lado, permiti e liberei o acesso a informações sobre determinadas pessoas e situações que julguei relevantes sem a necessidade de cometer alguma interferência na integridade ética ou moral, ainda que alguns dos personagens não mereçam tamanho sacrifício.

Numa narrativa como a que me submeti, interdita-se ou libera-se informações. Isto posto, a autobiografia tem entre outras, a função relacional do sujeito-objeto. Quem se submete a esse processo autobiográfico sabe que não se trata de associação livre, como a de um tratamento psicanalítico, ou de um registro psicológico, do ponto de vista da saúde mental. Trata-se, portanto, de um ponto de vista histórico-social, onde os personagens entram e saem da história com certa possibilidade de atuação positiva ou negativa na trama, ou mais provável, funcionalmente interdependente, para me servir das orientações de Elias (2005). 
Há na contação dessa história um resguardo do outro. Então, nessa minha autobiografia, chamo para narrativa, para os registros que o leitor tem em mãos, as pessoas que julguei mais importantes para aquele momento que está sendo descrito, aquela cena, aquela passagem, aquele período curto da história. Por outro lado, mesmo chamando a atenção para certos personagens, ao fazer seus registros na trajetória, lembrei de outros personagens que também participaram do mesmo momento, da mesma cena, mas não registrei ou não registrei devidamente, de forma que fiz uma rápida seleção dos personagens e respectivos episódios.

A memória realmente é seletiva e a autobiografia quando submetida ao processo da recordação também tem esse caráter de conceder ou não o registro de pessoas ou cenas, são as escolhas que você faz desse registro. Um caráter de interditar ou permitir a participação de outros agentes sociais nessa trajetória. Foi assim que procedi e só tomei ciência desses aspectos quando resolvi escutar as gravações. Outro aspecto diz respeito, de fato, ao esquecimento daquele tempo histórico, daquele cenário, nome de pessoas, objetos, lugares ou situações que foram vividas e aparecem na narrativa às vezes de forma parcial; e só no momento que você vai escutar as gravações, o que foi dito, é que acaba lembrando que de fato o nome exato das pessoas não era aqueles ou que as cenas ocorreram, mas em outro momento ou lugar. São as imperfeições do método.

Assim, o leitor pode estar se perguntando onde estaria a verdade nesse tipo de estudo, uma vez que se trata de uma pesquisa científica. Então, leitor, todos sabemos que não existe a verdade absoluta, mas, se há alguma neste trabalho, ela existe na própria contação das falhas, dos ditos e interditos sobre temas, cenários e personagens. Os equívocos e omissões próprias de uma narrativa de si. Entretanto, esses aspectos são fundamentais no rigor do método aqui empregado, considerando o que Velandia Mora (2010) trata acerca da reflexividade na autoetnografia ou Eakin (2019) sobre direito à privacidade.

De qualquer maneira, diante desses elementos técnicos de exposição e registro da trajetória, você é levado a fazer alguns consertos na narrativa, é um processo técnico de edição da fala. A edição da narrativa, onde se fará alguns complementos, ajustes para que aquele tempo histórico esteja condizente com a cena descrita, ou a cena descrita esteja condizente com aqueles personagens e tempo histórico. Às vezes, os fatos são narrados fora da sequência que ocorreram e quando relatados oralmente têm um certo sentido, mas quando transcritos precisam ser realinhados na representação gráfica.

Nesse processo de edição, foi possível cortar frases e palavras repetidas e preencher lacunas ou acrescentar palavras, frases, às vezes, até ideias inteiras para realçar a lembrança. Como o relato gravado e transcrito ocorreu num determinado momento e a reescrita em outro, foram imprimidas várias emoções no texto que chega ao leitor. Digo isso porque, nesse processo de edição da fala, eu estava realmente vivendo outro momento de quase perda e a perda propriamente dita da minha mãe. Por isso, o leitor pode deparar com situações que mais se parecem com 'fita travada' de áudio ou imagem, em que num determinado tópico há a morte e depois seu sofrimento na UTI. Coisa inversa da vida e de uma transcrição sucedida.

De modo que essas interdições, essas idas e vindas, esses quase contratempos da narrativa e da vida são fundamentais porque mostram as nuances. Mostram essas ondas de memória que chegam e você libera para a exposição ou registro. Não que você queira 
esquecer propositalmente, mas é o fato de não querer registrar, pelo menos naquele momento. Logo, a autobiografia é uma construção política, na medida em que você decide o que quer conectar com a história, com a trajetória, o que você deseja influenciar e como pretende influenciar a partir dos registros da fala.

Assim, é entre uma tomada de decisão e outra, entre um posicionamento político e outro, que você vai construindo e reconstruindo cenas, imagens, cheiros e gostos. Vai personificando e atribuindo sentido ao que está sendo dito e interditado simultaneamente. E esse trabalho é fundamental para a construção de um 'todo da trajetória' trazido à lembrança, bem como a concretização de um desfecho hipotético, ou seja, a verificação instantânea de onde você chegará com aquelas palavras e frases ditas.

Também está presente nessas idas e vindas das cenas, para montagem do repertório, a ideia de contexto. Muitas vezes, ao iniciar uma narrativa sobre a lembrança das escolas, por exemplo, repeti o nome de lugares e pessoas, talvez, para deixar irrefutável o que pretendia realmente tratar; talvez, para buscar no fundo da memória essas recordações e ter um 'retrato' mais apropriado da realidade distante, mesmo que esse retrato possa ser retocado posteriormente, ou seja, observado sob outros ângulos para a realização de alguns complementos essenciais à compreensão da trajetória.

Nesse contexto, tentei também o máximo que pude diminuir os problemas éticos que envolvem normalmente a relação sujeito-objeto, pesquisador e colaborador. Parafraseando Goodson (2015), aqui possuí a informação privilegiada, controlei os testemunhos e o relatório final da pesquisa, tive também o cuidado expresso pelo autor, no sentido de garantir o "fluxo" e "focagem" da narração, a "abrangência" e a "profundidade": "De certa maneira, esta fluidez não nos deve surpreender - os humanos são animais narradores. Estamos constantemente a reaprender as nossas próprias estórias, a experimentá-las com os outros e conosco. A nossa estória é uma parte ensaiada de nós mesmos." (Goodson, 2015, p. 36)

Para realçar um pouco mais a biografia secundária, resolvi desenvolver um capítulo acerca dos livros que publiquei. Na verdade, trago a esta tese apenas o que julguei mais importante para o estudo aqui desenvolvido, porque, até o presente momento, eu publiquei três livros como autor, um livro como coautor e cinco livros como organizador, onde em cada um deles escrevi pelo menos um capítulo.

A escolha não foi aleatória, exponho apenas os livros e capítulos que dão sentido aos pressupostos da análise do resumo do meu Currículo Lattes, onde o leitor terá a oportunidade de verificar as minhas preocupações iniciais e situar-se nos estudos que desenvolvo numa determinada corrente de pensamento ou em algumas áreas específicas da produção científica. Logo, os livros e capítulos que ora descrevo, ora analiso, são resultados da minha representação acadêmica, ou melhor de como gostaria de ser visto e percebido academicamente.

Com o objetivo de trazer para o texto algumas imagens, fotografei com a câmera do celular as capas e os capítulos de minha preferência e prossegui com a análise-descritiva do porquê de publicá-los, bem como de onde partiram as ideias iniciais dos temas abordados. Tal iniciativa tenta reverberar não apenas a importância de produzir, mas também de situar a produção, sobretudo, livros e capítulos, enquanto elementos de uma pequena história de nossas vidas. 
Um procedimento mais descritivo do que discursivo foi a utilização das capas dos livros enquanto fonte de análise da biografia secundária juntamente com parte de seu conteúdo. Assim, tomei o cuidado de explicitar, em nota de rodapé, seus registros junto à Biblioteca Nacional, e os termos, extratores, utilizados na indexação. Embora não sendo usual, tal procedimento dá uma certa garantia à existência material que foi publicado e também pode remeter à peculiaridade de um olhar técnico da biblioteconomia, sobre a própria produção do conhecimento.

De modo que os extratores expressos nas fichas catalográficas permitem assegurar que aquela produção específica está situada/indexada num determinado campo de conhecimento e é isso que pretendo mostrar: como profissionais de outras áreas acadêmico-científicas enxergam o que escrevo. Isso pode parecer algo sem importância, mas pode revelar como tenho direcionado as minhas pesquisas e publicações, como me situo no campo e luto para permanecer nesse ambiente com os capitais que adquiri.

A internet foi uma outra aliada deste trabalho, especialmente porque fotografava as capas, enviava para o e-mail pessoal e depois fazia o download no notebook. Além disso, alguns materiais foram encontrados por meio de redes sociais ou blogs. Nesse sentido, em relação às fotografias, sei que há um debate significativo acerca dos estudos historiográficos e esse suporte na composição de trabalhos científicos, especialmente nas reflexões de Mauad (1996).

A autora reconhece que a utilização de fotografias na composição de estudos historiográficos advém da abertura desse campo para novos temas e problemas, o que reposiciona a imagem não apenas como fixação do tempo, mas, sobretudo, como um registro importante do cotidiano das famílias, movimentos sociais e do próprio indivíduo. De modo que sempre se deve levar em consideração as especificidades da fotografia ao usá-las para o conhecimento científico, especialmente no campo da História (Mauad, 1996).

Diante do conjunto documental e na construção das diferentes fontes, como o Currículo Lattes, procedi à análise seguindo as orientações de Aróstegui (2006) com vista a duas categorias: a fiabilidade e a adequação. Para esse autor, a fiabilidade diz respeito à originalidade da fonte, sua datação, sua história, autoria e as condições sociais de sua produção, e eu acrescentaria constituição do acervo e conservação. Logo, o que foi aqui constituído para efeito de análise documental está em conformidade com a originalidade exigida pelo autor, sobretudo, quando a minha consciência de pesquisador permite identificar não apenas a natureza das fontes, mas, especialmente, a relação da construção de fonte comigo enquanto sujeito e objeto de pesquisa.

Já a adequação é abundância documental, a quantidade e a qualidade da fonte capaz de responder a números razoáveis de perguntas na representação de um espaçotemporal. Nesse sentido, a ideia central de Aróstegui (2006) diz respeito à organização documental e sua constituição para análise, o que só é possível a partir do esforço que o pesquisador faz na busca exaustiva das evidências em função de seu objeto de estudo.

Destarte, nesta pesquisa, a adequação, essa abrangência e massa documental, foi extraída de vários arquivos, o que acabou impactando de uma forma bem específica a construção de fonte e resultando, inclusive, na afirmação da hipótese formulada 
inicialmente e que analiso no último capítulo desta tese. Além disso, chamo a atenção para um arquivo bastante significativo, a Pasta de Assentamento Funcional da UFPE, nunca antes alvo de nossas visitas e manuseio para trabalhos acadêmicos.

Esses aspectos são importantes porque a documentação da Pasta de Assentamento foi produzida independentemente das finalidades desta pesquisa, em outro tempo histórico, e foi mobilizada neste momento para dar conta de algumas explicações acerca do campo em que me inseri a partir de 1993, por exemplo. Esse procedimento se assemelha ao que Certeau (2002) chama de operação historiográfica, em que o pesquisador muda os objetos de lugar para organizá-los de outra maneira a fim de que eles proporcionem as respostas necessárias aos problemas apresentados pelo próprio cientista.

Pensando ainda na adequação, como dito anteriormente, eu trouxe para a análise as gravações realizadas em diferentes momentos da construção desta tese, bem como na concessão de entrevista para um projeto de história oral já mencionado e, na medida do possível, submeti o dito, a fala, à análise documental semelhante ao que está previsto por Aróstegui (2006).

Embora o meu esforço neste momento seja o de reafirmar que este trabalho se trata de uma pesquisa científica e não de literatura, vejo que os aspectos procedimentais deixarão algumas lacunas. E mesmo que essas lacunas sejam reparadas no decorrer da narrativa, não conseguirei eliminar o todo das minhas subjetividades, até porque um estudo como este tenta verificar exatamente os aspectos subjetivos do pesquisadornarrador em sua trajetória.

Considerando todos os elementos até aqui descritos, para efeito de síntese, o quadro 13 mostra o tipo de fonte utilizada, bem como o tipo de arquivo ao qual recorri para aportar na dinâmica deste estudo autobiográfico.

Quadro 13 -

Tipos de fontes e tipos de arquivos.

\begin{tabular}{|l|l|}
\hline \multicolumn{1}{|c|}{ Tipologia das fontes } & \multicolumn{1}{c|}{ Tipo de arquivo } \\
\hline Fontes orais & $\begin{array}{l}\text { Arquivo vivo } \\
\text { Arquivo institucional on-line, do Lahoi }\end{array}$ \\
\hline Jornais & Arquivo institucional físico, arquivo on-line \\
\hline $\begin{array}{l}\text { Certificados; históricos escolares, carteiras } \\
\text { estudantis e crachás }\end{array}$ & $\begin{array}{l}\text { Arquivos institucionais físicos; arquivo pessoal, } \\
\text { arquivo da família }\end{array}$ \\
\hline $\begin{array}{l}\text { Portarias, nomeações, progressões e e } \\
\text { processos }\end{array}$ & Arquivo institucional físico; arquivo pessoal \\
\hline Artigos científicos & Arquivo on-line; arquivo pessoal \\
\hline Currículo Lattes & Arquivo institucional do CNPq on-line \\
\hline Capas de livro & Arquivo pessoal \\
\hline Fotografias & $\begin{array}{l}\text { Arquivos institucionais físicos; arquivo pessoal, } \\
\text { arquivo da família }\end{array}$ \\
\hline Print de programa de tevê & Arquivo on-line, no Youtube \\
\hline Fotografias & $\begin{array}{l}\text { Arquivo pessoal; arquivo da família, arquivos } \\
\text { institucionais físicos e on-line }\end{array}$ \\
\hline Livros, monografia, dissertações e teses & Arquivo pessoal; arquivo institucional on-line \\
\hline
\end{tabular}

Fonte: autor (2019).

Regae: Rev. Gest. Aval. Educ. 
Como está posto no quadro acima, este estudo está baseado num conjunto de procedimentos, cujas principais perspectivas dizem respeito à trajetória que puxei pela memória e o constructo do 'eu' fonte enquanto principal elemento de aglutinação da própria percepção aqui verificada. Desse modo, a documentação aqui analisada terá impacto decisivo no último capítulo da tese, onde confirmarei a hipótese que se revelará na transmigração do campo arte para ciência, meus itinerários e a minha construção e constituição enquanto fonte de recordação, e que terá início no próximo capítulo.

\section{Capítulo 2 - À guisa das memórias}

Diríamos voluntariamente que cada memória individual é um ponto de vista sobre a memória coletiva, que este ponto de vista muda conforme o lugar que ali eu ocupo, e que este lugar mesmo muda segundo as relações que mantenho com outros meios. Não é de admirar que, do instrumento comum, nem todos aproveitam do mesmo modo. Todavia, quando tentamos explicar essa diversidade, voltamos sempre a uma combinação de influências que são, todas, de natureza social. (Halbwachs, 1990, p. 51)

Considerando as reflexões de Halbwachs (1990), a memória que faço emergir neste momento é uma percepção muito particular daquilo que consegui manter nas minhas relações interpessoais, das minhas interdependências funcionais, do meu envolvimento e distanciamento possíveis e necessários (Elias, 1998, 1994a). Embora seja uma memória individual, sob minha responsabilidade, conta e risco, a minha percepção é produto de uma combinação entre o singular e o coletivo. De modo que minha memória também é aquilo que foi disponibilizado e, em certa medida, passível de ser lembrada por outros indivíduos membros do meu tempo, ainda que possa ser o reverso do que agora recordo.

Assim, este capítulo tem por objetivo apresentar a minha narrativa, gravada e transcrita em meio eletrônico, que servirá como evidência de uma trajetória de vida. Tratase de expor cenas, personagens, atividades e motivações nas escolas em que estudei, no contexto do campo artístico, acadêmico-científico e político, com a aplicação de táticas de sobrevivência e desenvolvimento dos respectivos habitus desses campos.

No cômputo geral, este é um capítulo baseado nas recordações em que, na medida do possível, trago alguns elementos iconográficos, bem como fontes manuscritas e impressas para a composição e interpretação de uma temporalidade e razão narrativas, ou seja, para a delimitação de espaços temporais e episódios de um itinerário marcado por emoções, sentimentos, tensões e sublimações. A este respeito, uma das bases de sustentação dessas memórias é a minha própria biografização, que, segundo Alheit (2011) e Delory-Momberger (2016), é uma das chaves importantes para a aprendizagem, uma competência desenvolvida pelo indivíduo da sociedade moderna que articula seus impulsos internos aos problemas mais gerais de seu tempo.

\section{Antecedentes autobiográficos: sete escolas públicas; uma formação humana}

À luz do candeeiro nasci em casa, na madrugada chuvosa do dia 31 de março de 1965. Minha mãe sempre contou que eu não dei trabalho para nascer. Naquela madrugada, mais ou menos às $4 \mathrm{~h}$, estava chovendo e ela sentiu vontade de fazer xixi, o que descobriu logo depois que era a bolsa d'água, que havia estourado. Às pressas, meu pai teve que chamar a comadre Quitéria, a parteira, que ainda conseguiu me amparar. A 
casa ficava na rua Jundiaí, bairro de Jardim São Paulo, subúrbio do Recife, Pernambuco, mas fui registrado num cartório de Olinda, razão pela qual consta que sou olindense e não recifense.

Só conheci minhas avós Euclídia, mãe da minha mãe, e Benvenuta, mãe do meu pai. Meus avôs eram homens muito simples: o Severino, pai da minha mãe, era açougueiro; e o pai do meu pai, o Dindo, vendedor de miúdos bovinos e depois arrumador no cais do Porto do Recife. Conheci também a avó da minha mãe, eu ainda bem pequeno a chamava de vovó. Engraçado que, vez ou outra, entre as tragadas no cachimbo, vovó me chamava de 'doutorzinho'. Talvez, fosse em virtude das roupas de saco de açúcar lavadas à água sanitária que mamãe mandava fazer para nos vestir, ou seria premonição de vovó, uma 'nêga veia', que junto aos meus pais, certamente, devotava alguma esperança?

Figura 1 -

Retrato dos meus pais - montagem de 2002.

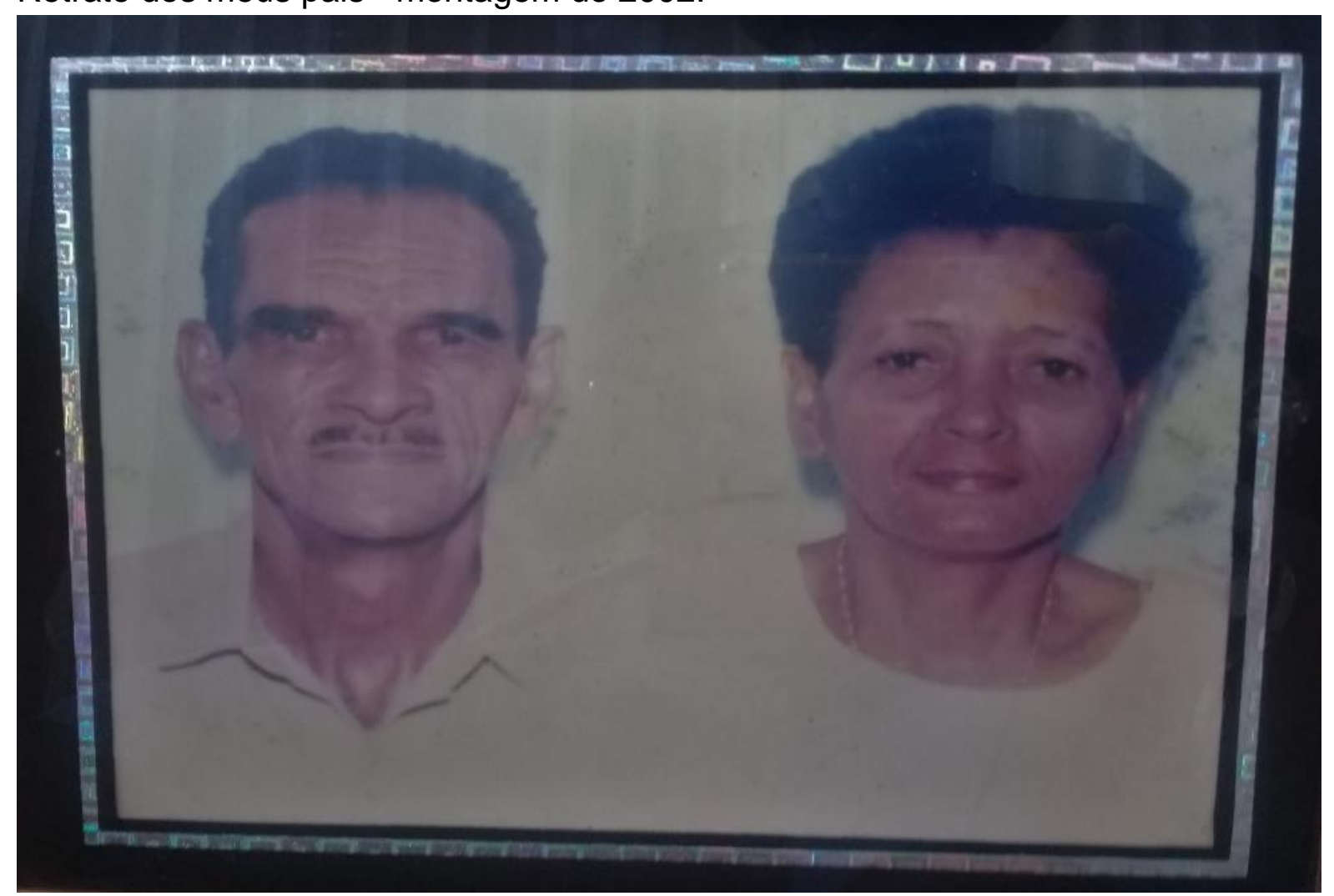

Fonte: acervo da minha mãe, Lídia Pinto de Souza.

Ao trabalhar na edição dessa fotografia, não pude conter a emoção e as lágrimas. Esses são os meus pais, já falecidos. Editar essas imagens foi muito difícil, mas necessário para quem pretende escrever sobre si mesmo e apontar alguma direção por onde transcorreu sua trajetória.

Esse retrato dos meus pais é resultado da união de duas fotografias $3 \times 4$ que estavam separadas. Após cinco anos do falecimento de papai, em 1997, mamãe resolveu unir as duas fotografias nesse formato, algo que pudesse representar um casamento de, aproximadamente, 40 anos. A moldura é de madeira, rodeada por um friso de alumínio e 
com pequenos vidros espelhados no entorno das imagens. No verso, o registro a lápis, no dia 28 de setembro de 2002, certamente, o dia em que o trabalho foi entregue pelo fotógrafo desconhecido.

Esses são os recuos mais densos que consigo fazer neste momento para alcançar meus antepassados. Contudo, fica aqui minha gratidão e homenagem aos homens e mulheres das gerações anteriores que fizeram com que nossa família pudesse chegar até onde chegou, e eu possa contar um pouco de como cheguei.

Papai era portuário, ganhava pouco e por produção, às vezes faltava carga para tombar até o navio. Minha mãe sempre me contou que, para ajudar no orçamento doméstico, vendia mão-de-vaca, sarapatel e outras comidas numa barraca que havia na parte da frente da casa onde nasci. Comigo ainda bebê ela me colocava debaixo do balcão, numa pequena cama improvisada com alguns lençóis, enquanto servia aos fregueses, moradores da rua e da circunvizinhança.

Com muito orgulho, posso dizer que sou oriundo da escola pública. Na verdade, sou a construção humana das sete escolas públicas municipais e estaduais em que estudei, de forma ininterrupta, dos 9 aos 18 anos. Nesse período nunca fui reprovado e sempre me considerei um estudante médio.

Quando me perguntam sobre escola, a primeira lembrança que me vem é de dentro de minha própria residência quando observava uma prima minha, que é minha madrinha de fogueira ${ }^{15}$, a Florinha. Ela ministrava aulas para cinco ou seis crianças do bairro, mas nunca tive aulas com ela, eu só via um pouco do seu comportamento quando ministrava aquelas atividades para as crianças, ensinando a cartilha do $A B C$, às vezes, usando a palmatória. Depois, uma outra imagem que me vem à cabeça, entre 1972 e 1973, é quando eu ia para uma escolinha de bairro com meus três irmãos, sendo dois hoje já falecidos. Lembro, inclusive, o nome da escola: Escola Dona Lígia. Então, nós íamos para a Dona Lígia, meus irmãos iam estudar e eu, o mais novo, apenas acompanhava. A lembrança que tenho dessa escolinha é que era na casa da Dona Lígia, na Sapucaia, em Olinda. E a primeira imagem da minha madrinha é em Jaboatão dos Guararapes, uma residência da família há bastante tempo.

Ao acompanhar meus irmãos para a escolinha, a imagem que eu tenho é que Dona Lígia era vermelha, na verdade, uma negra vermelha. Acredito que foi o pai dela quem fez um buraco atrás da casa para a construção de uma fossa, ou cacimba, coisa que o valha. Lembro que tiramos uma fotografia próximo desse buraco no dia das crianças, onde também tinha um pé de carambola próximo. A fotografia era exibida por um monóculo ${ }^{16}$. Não sei se temos ainda esse monóculo e gostaria de perguntar a minha mãe sobre ele, mas, infelizmente não posso, pois, no exato momento de escrita desta lembrança, 18 de janeiro de 2019, às 7h30, com 79 anos, ela está na UTI entre a vida e a morte. ${ }^{17}$

15 Costume antigo em que parentes ou vizinhos tomam as crianças como afilhados na noite de São João, num ritual que cruzam várias vezes as brasas das fogueiras.

16 Durante muito tempo, as famílias eram fotografadas por um retratista, que revelava as imagens e as exibiam por meio de um objeto pequeno monocular, o monóculo, que possuía uma pequena lente através da qual era possível enxergar as figuras. Famílias mais pobres só podiam adquirir os monóculos e não as fotografias reveladas em papel, portanto, impressas.

17 Mamãe morreu em 19 de janeiro de 2019, às 12h40, madrugada do sábado. 
Uma outra imagem que eu tenho da escola é de uma outra atividade também do dia das crianças, que me parece uma espécie de um clube, onde as crianças foram para falar um pouco sobre uns poemas. Não, não, aliás, eu acho que era Dia das Mães, porque eu falei um poema - batatinha quando nasce... - no lugar do meu irmão, que tinha vergonha do público, ou coisa assim. Mesmo sem estudar nessa escola, eu pensava que tinha aprendido o $A B C$ lá em Dona Lígia, até descobrir que, na verdade, eu não sabia o $A B C$.

Considerando a formalidade de uma escolinha, mesmo de bairro, a Escola de Dona Lilia foi onde comecei os estudos, isso já era em Jaboatão dos Guararapes, no bairro Guararapes, nas proximidades do nosso imóvel herdado da família. Aliás, nós nos mudamos muito, eu costumo dizer que a minha família, sobretudo meu pai e minha mãe, mas eu também, somos nômades urbanos, mudamos de residência com muita frequência.

As mudanças de residência feitas pelos meus pais têm muito a ver com as escolas que estudei, porque nunca desisti dos estudos. As mudanças ocorreriam a qualquer momento. Até parecia que não pagávamos aluguel, mas, às vezes, voltávamos para o mesmo imóvel com o mesmo proprietário. Não era o aluguel, então. Mas minha mãe foi me matricular e Dona Lilia perguntou se eu sabia ler a cartilha do ABC.

Antes da minha mãe responder eu confirmei, disse que sim. Disse que sabia porque achava que tinha aprendido em Dona Lígia, como disse anteriormente, mas então ela abriu a cartilha e pediu que eu lesse. Eu comecei a ler do A e continuei até o Z. Quando terminei, ela me parabenizou, pegou uma folha de caderno em branco, na qual fez um buraco no meio, e abriu a cartilha novamente. Dessa vez, colocou o papel em cima da cartilha de modo que eu só via o ' $A$ ', e eu lhe disse corretamente qual era a letra. Ela continuou e, na próxima, mostrou um 'B', ao qual também respondi corretamente. Até que ela mudou a estratégia e percorreu a cartilha com o papel, parando numa letra que eu não sabia identificar. Logo em seguida, ela me mostrou outra, e eu também não a identifiquei, assim como uma terceira letra e uma quarta, sem sucesso de minha parte. Então ela explicou que eu não sabia o $A B C$, apenas pensava que sabia e disse que eu tinha que aprender. Ela tinha razão, e até hoje eu tenho a mania de pensar que sei alguma coisa!

Contudo, fiquei com vergonha e muito frustrado com o resultado do teste, porque eu tinha dito na frente da minha mãe que sabia o $A B C$ e não era a realidade. Mesmo assim, comecei a estudar em Dona Lilia. Era uma turma que tinha umas 15 crianças, mais ou menos. A casa dela ficava num sítio, e ela ministrava as aulas na única sala da casa, que era enorme, com uma mesa de madeira e um banco de madeira onde as crianças ficavam sentadas escrevendo e outra mesa no terraço, se a memória não me falha. Como era um sítio, tinha jaqueira, cajueiro, cajazeira, coqueiro e mangueira, e nós nos divertíamos muito por lá, pelo menos, quando não tínhamos que dar a mão à palmatória.

Dona Lilia tinha sete filhos, ou coisa assim, ela fazia a comida e logo em seguida ia nos ensinar. Muitas vezes, testemunhei Dona Lilia batendo e gritando com os filhos. $O$ marido dela, acho que sr. Davi, era um caçador, volta e meia ele chegava em casa no momento das aulas, por volta das $11 \mathrm{~h}$, às vezes, meio-dia quando estávamos terminando as aulas. Às vezes ele trazia uns animais mortos para eles comerem: tinha macaco, teju, acho que cobra também, e nós fazíamos uma festa em torno desses animais mortos, animados com a espingarda do sr. Davi, que caçava tudo que via. 
Nessa escolinha consegui fazer algumas amizades, inclusive com um menino que tinha o cabelo liso, cortado feito índio. Ele suava muito nas mãos e no rosto, especialmente na hora de escrever, porque tinha muita dificuldade e acabava ficando muito nervoso, especialmente quando Dona Lilia chegava para checar a lição. Eu lembro que dizia para ele: 'Tem calma, tu tem que escrever com calma, tu tá muito nervoso'.

Naquela época, década de 1970, era comum as professoras dos bairros andarem com palmatória ou régua para punir as crianças que não lessem bem o $A B C$ ou que não fizessem o dever corretamente. Eu nunca passei por isso, mas tinha bastante medo de levar à palmatória, talvez por isso eu tenha aprendido rapidamente a ler o $\mathrm{ABC}$ com Dona Lilia, de modo que, no final do ano ou início do outro, entre 1974 e 1975, minha mãe foi procurar saber com Dona Lilia onde eu iria estudar e Dona Lilia Ihe disse para me matricular em outra escola, onde eu pudesse cursar a $2^{\text {a }}$ série, porque eu tinha passado de ano. Que alívio!

Diante dessa informação minha mãe prontamente agradeceu, feliz, já que de outro modo ela teria que passar o próximo ano pagando mensalidade em Dona Lilia e em outro lugar, onde meus irmãos estudavam. Logo, fomos procurar uma escola pública, certamente, municipal. Eu lembro que foi o meu irmão Ednaldo, já falecido há algum tempo, o responsável por me matricular no Colégio Municipal Costa e Silva, em Prazeres, Jaboatão dos Guararapes.

Um colégio que ainda tenho admiração enorme e que sempre me emociono ao falar dele, meu primeiro e importante colégio. Encontro nesta tese uma oportunidade de render homenagem a ele e a todos os colégios que estudei, sem os quais não estaria escrevendo este trabalho. Bem, mas a fila para matrícula no Costa e Silva estava enorme e ainda estávamos no sol escaldante. Reflito agora que o ritual para conseguir uma vaga nas escolas públicas mudou bastante. Naquela época, não havia obrigatoriedade de estudo para as crianças e, ainda assim, faltavam vagas que acolhessem a todas. Se não fosse possível matricular a criança, teria que tentar no outro ano ou ir a uma escola particular, e eu lembro que não queria voltar para a escola de Dona Lilia. Então, quando meu irmão saiu da fila com a justificativa de comprar um picolé, ou coisa assim, aguardei na fila sozinho, por um longo período, até que chegou minha vez e eu ainda estava sem ele.

Lembro que meu irmão disse que ia comprar um picolé ou coisa assim, e pediu para eu ficar na fila, aguardando a vez. Só que ele demorou muito comprando o picolé, acho que resolveu brincar. Só sei dizer que a fila andou, quando a fila andou eu acabei entrando no colégio. Na porta de uma das salas de aula, encontrei a professora que estava fazendo as matrículas, e ela me perguntou quem tinha ido fazer minha matrícula, eu respondi que eu mesmo tinha ido, acompanhado do meu irmão, mas capaz de fazer sozinho. Ela aceitou e quis saber em que série eu iria me matricular. Quando Ihe falei, ela me avisou que não tinha vagas para a $2^{\mathrm{a}}$ série, só a $3^{\mathrm{a}}$ ou a $1^{\underline{a}}$, na qual ela queria me matricular. Eu então insisti pela $3^{\mathrm{a}} \mathrm{e}$, ao saber que tinha estudado na escola de Dona Lilia, aceitou meu pedido e ainda me falou a razão: ela também tinha estudado com minha antiga professora, que morava perto da casa dos pais dela. Mas me avisou: "se você não se der bem na $3^{a}$ série, voltará para a $1^{\text {a". }}$. Lembro agora que essa mulher era irmã do 
vereador Neco. Já vereador naquela época e acho que agora também. Eterno vereador de Jaboatão dos Guararapes. Penso que boa parte dos problemas é exatamente esse: 0 poder nas mesmas mãos sempre.

Voltando a falar da escola, lembro bem que tinha quatro salas e eu já a achava enorme, tinha na frente dela um mastro, onde era hasteada a bandeira brasileira, e não lembro o nome da professora, mas lembro que ela vinha do Cabo de Santo Agostinho num fusquinha branco, achava incrível como ela conseguia dirigir aquele carro. A imagem que tenho da professora era a seguinte: ela interagia pouco conosco, era muito séria, não tinha nenhuma simpatia por nenhum de nós, mas cobrava muito de todos.

$\mathrm{Na}$ sala de aula, tinha um birô, na verdade, era uma mesa pequena, e ela botava a cadeira atrás daquela mesa e sentava. Desatenta, ela ia sempre de saia ou vestido e acabava deixando a calcinha à mostra. Eu, que, apesar de não ser bagunceiro, sempre sentava nas últimas cadeiras - daquelas de madeira, pesadas -, conseguia mesmo de longe ver a calcinha dela. Ainda tenho a lembrança daquela calcinha verde com listras brancas, às vezes azuis. Eu era uma criança e achava um absurdo a professora mostrar a calcinha, eu achava que era de propósito, que ela queria mostrar a calcinha para todo o mundo. Só mais tarde percebi que não era nada disso, que ela sentava e abria as pernas sem imaginar que poderíamos ver.

Nessa escola tenho ainda outra lembrança que quero compartilhar. Numa turma de 40 meninos e meninas, tínhamos todos um lápis preto com a borracha branca em cima, para copiar e responder o dever que a professora passava no quadro de giz, que à época chamava-se quadro negro. Eu lembro que observava muito as mãos dos meninos e das meninas ao copiarem o dever no quadro. Eu ficava olhando as mãos daquelas crianças como se a inteligência passasse pelas mãos, como se as mãos fossem inteligentes, eu lembro que eu tinha essas coisas de olhar para as mãos das pessoas, desenhando as letras, escrevendo etc.

Nesse lugar, foi a primeira vez que participei de uma política de vacinação. Foi um dia em que, depois da aula, fomos para a casa e penso que voltamos à tarde para isso. Lá tomamos a BCG o que, para os parâmetros de hoje, seria tardiamente. Foi, inclusive, praticamente no mesmo birô onde me matriculei que estava uma pessoa anotando o nome das crianças para serem vacinadas. Ao lado dela, uma outra pegava a seringa, esquentava na vela ou num candeeiro, esfriava um pouco e aplicava na gente. Depois, num outro momento, acho que um ano depois, já era uma pistola, ela chegava e dava uma pistolada em você, eu tenho a marca até hoje dessa vacina.

Nessa escola passei um ano mais ou menos, lembro que, um dia, antes de ir para a instituição, fui para o desfile cívico de 7 de setembro, assistir a um dos meus colegas de infância, o José, que era uma espécie de bolsista do Colégio Ascenso Ferreira, no bairro de Porta Larga, entre Jaboatão e Recife, perto do aeroporto internacional. Ele participou com um fardamento bem bonito, que ele sempre ganhava. Eu assisti admirado o desfile.

Eu sempre acompanhava os desfiles e achava muito bonita aquela gente toda marchando. Então, quando eu fui estudar no Costa e Silva, estava animado com a possibilidade de desfilar também, inclusive com fardamento bonito. E aconteceu, mas o desfile foi decepcionante para mim, andamos muito e esperamos por um longo tempo para o desfile começar. Ainda mais quando o desfile começou, não desfilamos no Alto da Igreja Nossa Senhora dos Prazeres, como de costume. O desfile daquele ano foi na 
Estrada da Batalha, uma das avenidas principais de Prazeres, que vai do aeroporto até o Cabo de Santo Agostinho. O dia estava muito quente, as crianças que estavam bem fardadas iam mais à frente, com a banda marcial, a baliza etc., e quem estava com a roupa mais ou menos envelhecida, como eu, ficava lá atrás, ou seja, eu só escutava de longe a orquestra, o que foi muito ruim para mim. No fim, em vez de ser um momento prazeroso, foi muito chato e decepcionante. Daquele dia em diante, eu decidi que não iria desfilar em lugar algum, e foi o que aconteceu. Ainda bem, porque os propósitos dessa época, como acho que agora também, eram outros.

Tenho outra lembrança da data festiva dessa época, mas dessa vez do mês de junho, quando teve a festa junina na minha escola. Lembro que antes do dia da Quadrilha, nos ensaios, a professora que estava conosco, acho que da $4^{\mathrm{a}}$ série, pediu que comprássemos nossa roupa para a apresentação, mais especificamente, calça e camisa quadriculada, mas meus pais não tinham dinheiro para comprar essa vestimenta.

Assim, o tempo foi passando e, no dia da festa, eu fui com a calça rasgada, literalmente rasgada, eu lembro que estava dançando numa sala de aula, foi um dia de sábado e minha mãe tinha ido para feira de Prazeres, quando retornou passou na frente da escola e resolveu assistir à Quadrilha. Eu lembro de vê-la na janela com uma das minhas irmãs, assim como lembro de colocar a mão atrás da bunda para ninguém ver o rombo que estava atrás nem minha cueca, porque, nessa época, nós não tínhamos 'zorba', como se tem hoje, era uma cueca comum, às vezes até cueca de saco, e a minha era de saco, que mamãe tinha mandado fazer há um tempo. Uma experiência de graça e pobreza.

Após um determinado período, minha família acabou se mudando para o Alto Santa Terezinha, no Recife. A gente foi morar numa casa na Rua Guilhermino que, às vezes, chamávamos de Alto Guilhermino. Foi uma casa que meu pai comprou porque recebeu um dinheiro, acho que do Cais do Porto. Até então morávamos na casa da minha avó Euclídia, mãe da minha mãe, que é esse imóvel que temos até hoje de herança. ${ }^{18}$

Chegando no Alto de Santa Terezinha como é que eu ia para a escola? Porque a escola era em Prazeres, Jaboatão dos Guararapes, outro município. Então, resolvi procurar outro colégio para que eu pudesse pedir transferência, mas eu não consegui, inclusive aconteceu um episódio muito ruim comigo, um acidente.

Uma das escolas que eu fui procurar para pedir transferência era no Alto do Pascoal. Para chegar lá, o ônibus que saía do centro do Recife, passava pelo Alto do Pascoal, onde fazia o retorno na frente da escola que tinha interesse em estudar, para seguir para o Alto de Santa Terezinha. De modo que o ônibus de Santa Terezinha que ia para o centro da cidade de Recife também entrava antes no Alto Pascoal e fazia o retorno na frente da escola, só que este descia no sentido da cidade. Ou seja, havia uma espécie de rotatória em frente a escola.

Quando fui nessa escola, peguei o ônibus tranquilamente e, ao chegar, fiz um teste, pois, apesar de eu informar à professora que era da $3^{\underline{a}}$ série, ela quis fazer um teste comigo para ter certeza, isso logo me lembrou do teste que havia feito em Dona Lilia.

18 Pausa para as lágrimas. Esta é uma retomada de escrita após o falecimento da minha mãe na madrugada do dia 19 de janeiro 2019. Como sou realmente disciplinado, interrompi apenas o trabalho por um dia, retomando a reescrita das transcrições na madrugada seguinte, ou seja, 20 de janeiro 2019, às $3 \mathrm{~h} 53$. 
Logo após o teste, ela me disse que eu deveria fazer a $2^{\text {a }}$ série e que ela iria me matricular assim que eu a levasse os documentos. Eu agradeci, mas já sabendo que iria continuar no Colégio Costa e Silva, em Prazeres, para nunca, jamais, voltar à $2^{\mathrm{a}}$ série.

Bem, peguei o ônibus na frente do colégio e o ônibus fez o retorno, mas, em vez de ir para o Alto Santa Terezinha, onde eu morava, ele desceu para o centro do Recife. Quando percebi o percurso diferente, eu me joguei do ônibus, pulei com medo de ir para outro lugar. Besteira minha, porque eu sabia andar na cidade, eu podia pegar um outro ônibus de volta. Acho que ainda estava atordoado com a ideia de fazer a $2^{\underline{a}}$ série. Quebrei dente, arrebentei minha boca, arranhei meus braços... fiquei mesmo com muito sangue pelo corpo. Até hoje fico pensando no fato de as pessoas não me socorrerem, mesmo tendo caído em frente a umas casas. Elas olharam de longe, mas não foram me levantar, nem perguntar se eu queria uma água, nada! E eu saí daquele local até a minha casa a pé, com sangue pela boca e com a camisa cheia de sangue. Quando finalmente cheguei em casa, minha mãe ficou muito preocupada.

Ela não sabia que eu tinha ido procurar uma escola para me transferir e, ao saber, disse que eu ficaria no Costa e Silva mesmo, e eu fiquei. Lembro que as aulas no Costa e Silva começavam às $13 \mathrm{~h} 30$, e eu tinha que pegar dois ônibus para chegar até lá. Nesse período, eu tinha entre 9 e 10 anos de idade e pegava o ônibus do Alto Santa Terezinha, descia na Av. Guararapes, andava até o Cais de Santa Rita, no centro do Recife, depois pegava outro ônibus até Prazeres, em Jaboatão. Para isso, tinha duas opções: o ônibus Prazeres ou o Cajueiro Seco. Por fim, descia próximo ao Colégio Costa e Silva.

Essa minha escola ainda existe e resiste no mesmo lugar de antes. Em frente a ela, foi construído o Mercado da Mangueira, em Prazeres, próximo à estação do metrô e a um viaduto, que foi feito há alguns anos. Na época em que estudei, não havia nada disso. Era apenas um terreno baldio em frente, em seguida, a linha férrea e a estação do trem. Até o presente momento, não tive coragem suficiente para entrar em suas dependências. Sinto uma emoção muito grande; de fato, até dá vontade de chorar só em escrever sobre ela.

Numa dessas viagens em direção à escola, passei por uma situação interessante. Onde é hoje o viaduto Tancredo Neves, na Imbiribeira, já na saída da Avenida Recife, tinha dois casarões e um ponto de ônibus em frente a eles. Um dia, a professora da $4^{\text {a }}$ série, do Colégio Costa e Silva, pegou o ônibus nesse ponto e me viu lá dentro com a farda da instituição. Lembro que ela me perguntou o que eu estava fazendo ali, certa de que eu estava faltando a aula. Quando Ihe falei que, na verdade, estava indo para a escola, ficou curiosa para saber onde morava e, ao saber, preocupada: "mas você vem estudar aqui? você é tão pequeno, tão novo, sua mãe deixa? seu pai deixa?". Eu logo a tranquilizei e nós seguimos viagem. De qualquer modo, terminei a $3^{a}$ série no Colégio Costa e Silva e depois fui procurar uma outra escola. A escolhida foi a Escola Agamenon Magalhães, em Água Fria, já no Recife, atrás do Mercado de Água Fria. Minha professora da $4^{\mathrm{a}}$ série era a Dona Rosete. Era uma professora negra, magra, que vestia sempre uma saia preta e uma blusa branca. Dona Rosete era muito educada, muito afetuosa com todos nós, embora tenha me acontecido um fato em relação a ela que me decepcionou profundamente, no entanto contarei só mais adiante.

Gostaria de ressaltar que meu histórico escolar da $1^{\text {a }}$ a $8^{\text {a }}$ série do $1^{\circ}$ grau registra que, de 1973 a 1975, eu estudava na Escola Agamenon Magalhães, o que retira oficialmente o Colégio Costa e Silva de minha formação educacional. No entanto, as 
minhas memórias, que ainda estão bem vivas, dão conta de que só fui estudar no Agamenon Magalhães em 1976. Acho que tiveram que oficializar as matrículas, nesse colégio, em virtude de eu ter estudado até aquele momento em "escolinhas de bairro"; assim, foi preciso "alterar a realidade" para ajustar a idade/série, uma vez que só fui matriculado na escola pública aos 10 anos de idade, na 3ª série.

Nessa escola, eu tinha um colega chamado Robson, que desenhava muito bem, ele desenhava a cara da gente na escola, desenhava a professora, saía desenhando todo mundo. Esse colega me fez lembrar de quando eu observava as mãos dos outros estudantes ao meu redor como se houvesse inteligência nelas. As mãos do Robson me pareciam muito inteligentes porque sabiam desenhar todo mundo.

Nessa escola, também tenho uma lembrança de festa junina. Dessa vez, meus pais já puderam comprar uma roupa, compraram uma calça jeans e uma camisa verde, que não era quadriculada, mas era de manga comprida e tinha uma estampa muito bonita. Nessa ocasião, participei da festa junina e, mais especificamente, da quadrilha junina, foi uma festa muito boa.

Lá também participei de uma atividade no Dia das Crianças, quando teve uma corrida de sacos, e eu ganhei. O prêmio foi uma bola de futebol de borracha. Essa bola eu deixei, por muito tempo, na casa da minha avó materna, Euclídia, e não deixava ninguém pegar.

Lembro que neste ano, no mês de setembro, foi planejado para que fôssemos assistir ao desfile cívico em frente ao Palácio das Princesas, onde vive o governador do estado de Pernambuco. A escola contratou dois ônibus para levar os estudantes até o centro do Recife. Todos precisavam chegar bem cedo, umas sete horas da manhã, mais ou menos. Eu acordei mais cedo que o de costume para chegar na escola, ser um dos primeiros e sentar atrás da cadeira do motorista, como normalmente eu fazia quando pegava o ônibus para o Costa e Silva. Eu achava muito bonito o avanço metro por metro que fazíamos ao andar de ônibus, especialmente porque eu conseguia ver os carros lá da frente e do alto.

Quando cheguei na escola, os dois ônibus já estavam lotados, com estudantes e professores. Cheguei pensando que estava no horário porque a porta de um dos ônibus ainda estava aberta, mas, quando fui subir, Dona Rosete me disse que eu não iria para o passeio porque estava atrasado. Eu estava sozinho, tinha várias pessoas em pé no ônibus, já que não tinha assento para todo mundo. Ainda insisti, mas a professora continuou dizendo que eu não poderia entrar no ônibus e, a essa altura, todos já diziam que eu não iria. Eu quase chorei nessa ocasião, quando tentei subir, a porta foi batida na minha cara. Foi um momento muito triste para mim, fui o único da escola a ficar fora daqueles ônibus.

Eu era uma criança, tinha apenas 11 anos. Fiquei sozinho na frente da escola vendo os ônibus dobrarem ao final da rua. Frustrado, pensei logo em voltar para casa, mas, como eu conhecia a cidade e desde de cedo apendi a andar por lá, com a avó Euclídia, e também quando estudava no Costa e Silva, passava pelo centro do Recife, resolvi ir para o desfile.

Ao chegar em frente ao Palácio das Princesas, fui meio desconfiado procurar a minha turma da escola. Como todos estavam com o uniforme, sabia que seria fácil a identificação. Assim, peguei uma bandeirinha do Brasil e, quando os encontrei, fiquei 
passando pela frente deles. Nessa hora, meus colegas todos gritavam para que eu fosse para perto deles e até chamaram a atenção da Dona Rosete, que começou a me chamar também, mas eu me neguei. Tinha ido sozinho e iria voltar sozinho. A verdade é que eu queria mesmo estar junto à minha turma porque ficar sozinho era muito chato, afinal ninguém faz nada sozinho. Fiquei andando para lá e para cá, mas o desfile estava bem sem graça para mim. Assim, quando acabou, voltei para casa solitário.

$\mathrm{Na}$ primeira aula que tivemos depois desse episódio, a professora questionou por que eu tinha ido sozinho ao desfile e eu a expliquei. Ela entendeu, mas pediu para eu não fazer mais aquilo porque era perigoso e todos tinham ficado preocupados. Penso que, na verdade, ninguém esperava que eu tivesse essa iniciativa de ir para o desfile sozinho e que eu soubesse andar no centro do Recife.

Quando acabei a 4ª série na Escola Agamenon Magalhães, precisava achar uma outra que tivesse o próximo grau de ensino. Para isso, fui estudar na Escola Professor Pedro Augusto Carneiro Leão, no Fundão, também no Recife. No dia da matrícula, estava com minha mãe nessa escola, enfrentando uma fila enorme. Lá, os comentários entre os pais era de que só se podia matricular as crianças com atestado médico. Mamãe não teve dúvida, me deixou na fila e foi até o Sindicato dos Portuários, na rua Bom Jesus, onde nós íamos ao dentista e médico, e conseguiu um atestado. No último momento, ela chegou e conseguiu fazer minha matrícula.

Figura 2 -

Ficha de Matrícula na 5ª série do 1ํㅡrau, 1977.

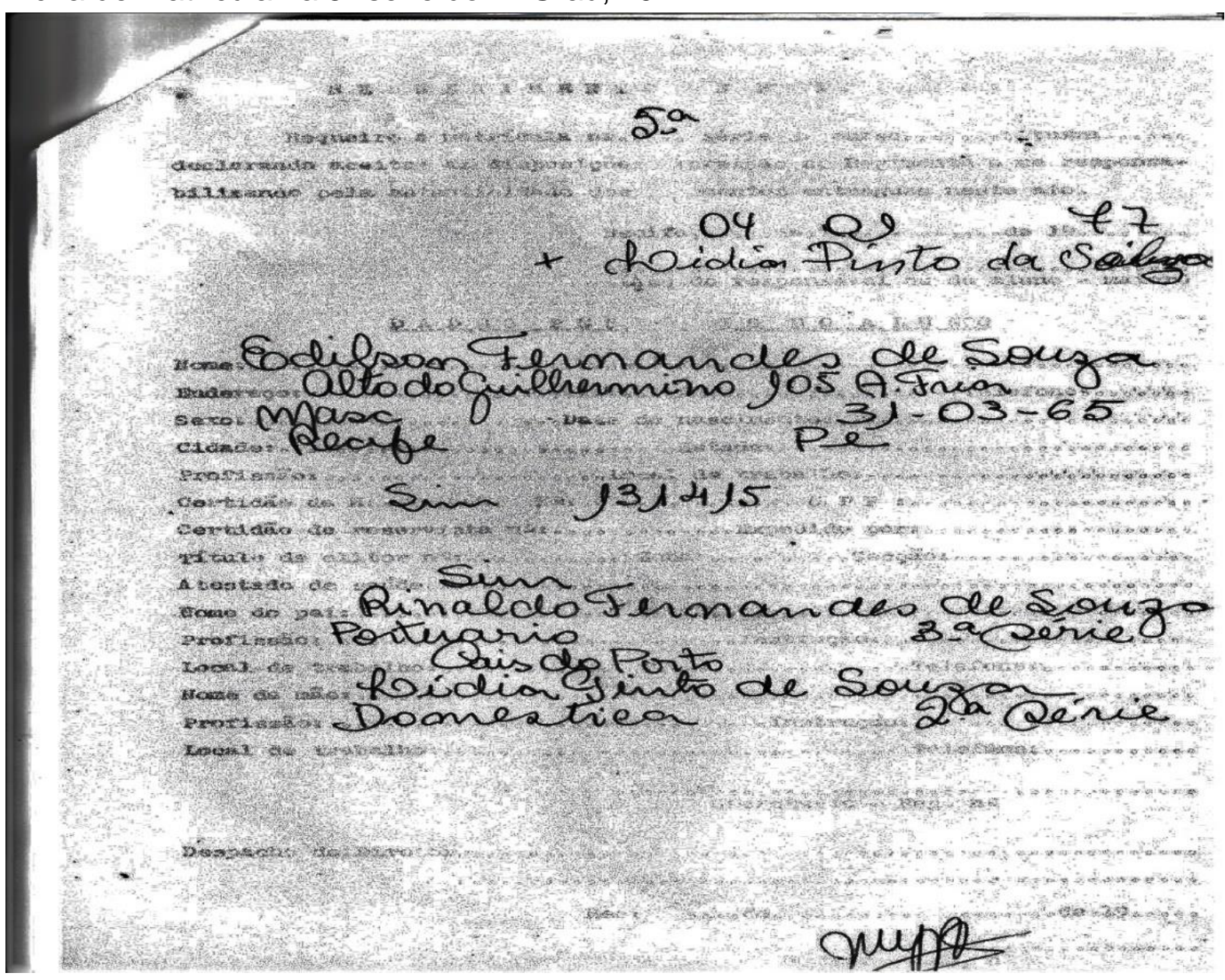

Fonte: Arquivo do Colégio Pedro Augusto, pasta 08, E-02. 
Como o leitor pode perceber, essa é a ficha da minha matrícula na $5^{\underline{a}}$ série do $1^{\text {o }}$ grau, assinada pela minha mãe em 4 de janeiro de 1977. O primeiro 'sim' diz respeito à apresentação da minha certidão de nascimento e o segundo, logo acima do nome do meu pai, diz respeito ao atestado de saúde, o mesmo que exigiu agilidade da minha mãe para buscá-lo, sem o qual, pelos comentários de outros pais, certamente não seria possível matricular as crianças na série pretendida.

As lembranças que tenho da $5^{\text {a }}$ série são lembranças boas, pelo menos a maior parte delas. Inclusive, foi na $5^{\underline{a}}$ série que tive a primeira aula de Educação Física, que a gente chamava de 'vamos ter física'. Meu primeiro professor dessa disciplina foi o professor Valter. Lembro do primeiro dia de aula, em que ele perguntou se nós tínhamos tomado café, porque a aula era no contraturno escolar, logo cedo, umas $7 \mathrm{~h}$, e as outras disciplinas estudávamos às 13h30: "Bom dia, alguém aqui ficou sem tomar café hoje? Porque quem não tomou café ou quem chegar aqui sem tomar café me avise, eu vou pagar um café para você, não pode fazer Educação Física sem tomar café da manhã”.

O professor Valter tinha uma voz firme, estatura alta, acho que uns dois metros - era realmente muito alto e muito falante também. Eu gostava de estar em suas aulas, mas as atividades de Educação Física eram bem simples, o que me parece ser um problema de nossa área até hoje. Então, à época, tinha futsal - futebol de salão -, para os meninos, e queimada, para as meninas. De vez em quando, também ficávamos correndo no quarteirão da escola, pelas ladeiras de paralelepípedo.

Tenho outras lembranças desse tempo da $5^{\text {a }}$ série, uma delas envolve um desejo. A professora Denise, de História, sempre levava a passeio os estudantes que tiravam a nota máxima em sua matéria. Ela fazia prova escrita e oral, e os estudantes que fizessem com excelência poderiam ir ao museu, biblioteca, inclusive com o lanche pago. Eles iam no próprio carro da professora, um Corcel $^{19}$ amarelo de capô e teto pretos. Vários colegas se empenhavam para se sair bem na matéria de História, do Colégio Pedro Augusto.

Nessa escola, tinha um professor chamado Davi, nunca entendi realmente qual a função que ele exercia e isso me fazia ter um pouco de medo dele. Normalmente, 0 professor Davi ia de calça social de cor preta, camisa branca de manga curta e, por baixo dessa última, uma camiseta branca, acho que da marca Hering. O professor Davi colocava todos nós, em fila indiana, para ensinar ou cantar o hino nacional; antes, porém, tínhamos que rezar o Pai Nosso e a Ave Maria.

Se na Escola Agamenon Magalhães, ainda vestia calça curta, sapato Conga azul, camisa branca, no Pedro Augusto, o fardamento era calça comprida de tergal azulmarinho, com vinco bem feito, às vezes, boca-sino, camisa branca, sapato Conga azul ou Kichute. Eu ainda ia com um sapato cavalo de aço que ganhei de uma amiga da minha mãe, Dona Lourdes, penso que foi parte do pagamento mensal que mamãe recebeu por lavar as roupas dela.

Eu gostava muito da Escola Pedro Augusto. O prédio era enorme, limpo e estava em boas condições físicas. ${ }^{20}$ Lá tinha um palco, logo numa das entradas laterais, por onde entravam os artistas, ensaiados pela professora lêda, de Geografia. Pena que a

\footnotetext{
19 Esse automóvel, estilo sedan, foi produzido pela Ford no Brasil até 1986.

20 Nos dois dias em que estive na escola para solicitar e pegar os documentos, o ambiente estava muito limpo. Aliás, a documentação fotocopiada foi entregue no outro dia da solicitação.
} 
professora lêda só ensinava na $7^{\mathrm{a}}$ ou $8^{\mathrm{a}}$ série. Ela 'mexia' com teatro e lembro a primeira peça de teatro que assisti ali, acho que foi Alice no país das maravilhas. Eu achava muito engraçado e incrível como aquelas pessoas, alunos da escola, decoravam o texto e falavam na sequência correta; de longe, ficava pensando: Será que um dia eu vou conseguir decorar um texto desse também?

A lêda, professora de Geografia, era muito simpática, lembro que mais tarde, já com uns 16 ou 17 anos, revi essa professora, quando comecei a dançar no Balé Primitivo de Arte Negra de Pernambuco. Ela também passou a fazer aulas por lá, num curso de dança afro, e deve ter participado do primeiro afoxé de Pernambuco, Afoxé llê África. Infelizmente, nunca falei com ela.

O Pedro Augusto foi um dos melhores colégios que estudei. Foi lá onde tive a primeira aula de Educação Física, como já disse, e também de Inglês, na $5^{\underline{a}}$ série. Foi lá também onde consegui fazer alguns poucos amigos, porque eu não tinha muita amizade na escola. Até hoje lembro dos amigos que fiz por lá: Daniel, Bruno, José Maria e Torquato.

Como meu pai havia se aposentado do Cais do Porto, passei a ajudá-lo na venda de abacaxi e milho em frente ao Mercado de Água Fria, na pedra do mercado ${ }^{21}$. Terminava as aulas, no Pedro Augusto, chegava em casa, mudava a roupa e voltava para ajudar meu pai. Eu era um menino muito franzino, magro e cabeludo, como o leitor pode ver logo abaixo.

Figura 3 -

Fotografia aos 12 anos de idade, 1977.

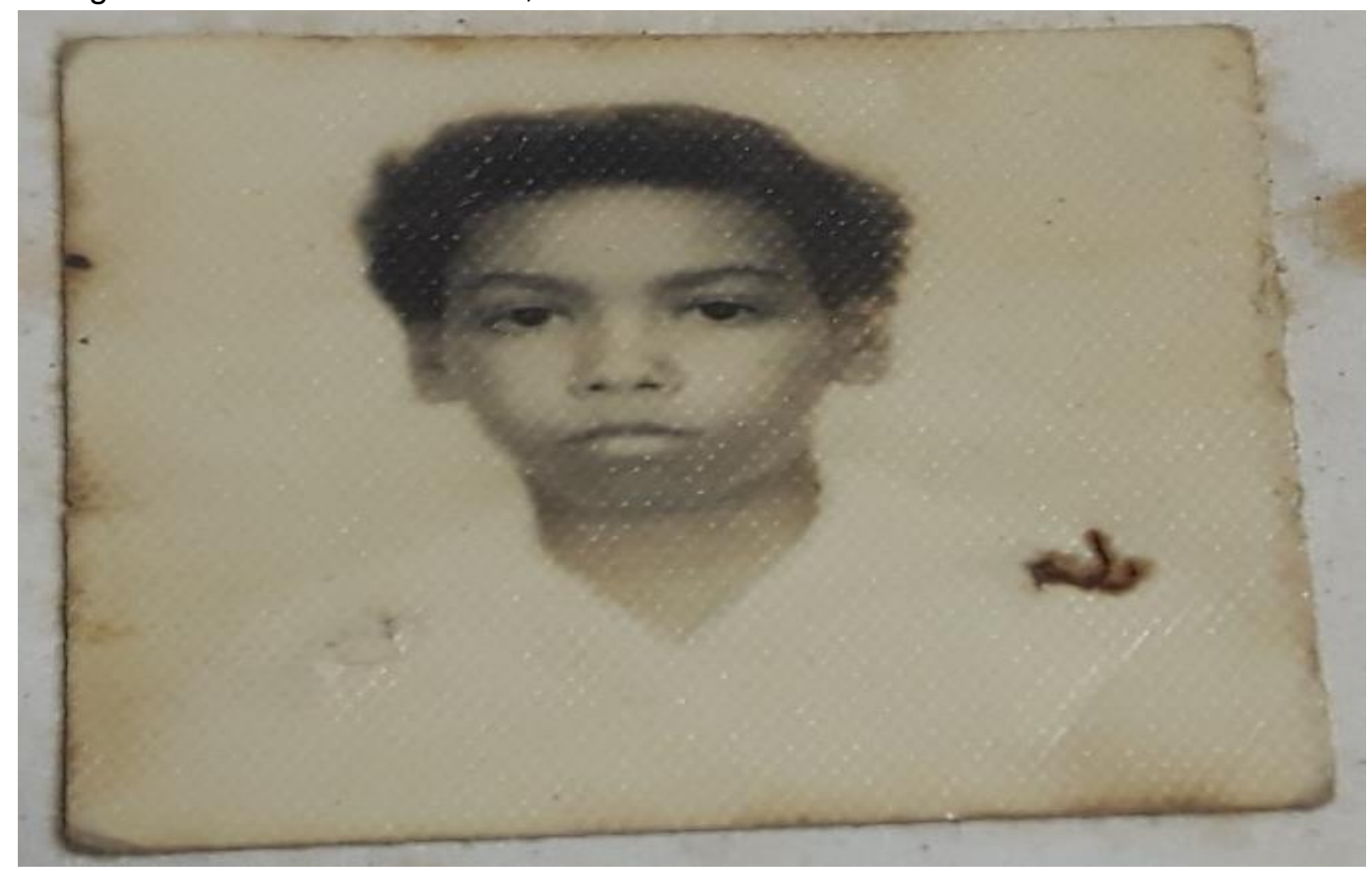

Fonte: arquivo do Colégio Pedro Augusto Carneiro Leão, pasta 08, E-02, 1977.

${ }^{21}$ Trata-se de termo utilizado, à época, pelos comerciantes que expunham seus produtos no estacionamento
do referido mercado. 
Consegui essa fotografia por meio dos arquivos da Escola Pedro Augusto, no dia seguinte à solicitação. Quando a vi, cheguei a me emocionar, pela passagem de tempo, ela foi tirada 42 anos antes! Na verdade, no primeiro dia em que estive na escola, no dia 2 de setembro de 2019, um dos funcionários da Secretaria, meu xará Edilson, com muita presteza, identificou a pasta pelo computador e logo me mostrou os documentos. Como eu não quis atrapalhar a rotina da instituição, pedi para buscar as cópias no dia seguinte.

$\mathrm{Na}$ mesma época dessa foto, ainda na $5^{\mathrm{a}}$ série, ajudava meu pai na frente do mercado de Água Fria e, às vezes, ajudava Dona Lucila, na sua venda de amendoim torrado, nas tardes de domingo, em frente a uma sede-dançante na rua em que morava, no Alto Guilhermino. Dona Lucila tinha um marido e duas crianças, mas seus filhos tinham vergonha, então ela me chamava para vender no tabuleiro com ela. Assim, enquanto seus filhos, juntos a outras crianças, dançavam 'cocota'22 na sede, eu vendia o amendoim nuns pacotinhos azuis e rosa. Lembrando dessa situação, penso que a filha dela havia estudado comigo no Agamenon Magalhães.

Também já vendi uma espécie de pássaro de isopor para seu Pedro e Dona Alta, os padrinhos do meu irmão mais novo. $O$ engraçado é que ninguém me pagava direito. Sempre diziam que a renda era pouca e não podiam me pagar coerentemente com o esforço que eu fazia. Só fiquei um pouco satisfeito, numa certa vez, quando vendi balões de festa para um dos meninos do Circo Garcia. Naquela ocasião, ganhei 10\%. O problema foi que só peguei os balões para vender porque queria entrar no circo. Acabou que assisti mais do que vendi e o menino, meio aborrecido, disse que eu nunca mais iria vender para ele.

Voltando ao assunto da escola, lembro de um momento muito importante que tive com o meu professor de Biologia da época, que também era médico. Não lembro o nome dele agora, mas ele foi o primeiro professor a questionar minha caligrafia - na verdade, a questionar a minha assinatura, porque eu já ensaiava a possibilidade de não escrever meu nome por extenso porque achava muito simples, então resolvi testar uma rubrica exatamente na prova de Biologia, e ele chamou a minha atenção na frente de toda a turma.

Como médico, o professor de Biologia também tirava medidas no corpo de todo mundo da escola e auscultava o nosso coração. Hoje eu sei que ele estava fazendo exames antropométricos conosco, que, normalmente, aconteciam no salão principal e dos quais todas as turmas tinham que passar. Neste momento de escrita da tese, despertou em mim o interesse em voltar à escola e verificar se esses dados ainda se encontram por lá, porque lembro que o professor anotava os dados numa ficha.

A gente tinha aula de Inglês e Matemática com o mesmo professor, Pedro, que era casado com uma professora também de Inglês, Helena. Eu achava incrível o fato de eles serem casados, trabalharem na mesma escola e ainda serem da mesma profissão. Falando de relacionamentos, por volta desta época, na 6 a série, eu me apaixonei por uma menina muito linda, a Rosa, uma negra de olhos verdes. Ela morava no bairro de

22 Dança de salão do final dos anos 1970 em que os pares davam saltitos, giravam levemente, batendo bunda com bunda. 
Campina do Barreto e eu lembro que quando as aulas acabavam, por volta das $17 \mathrm{~h}$, eu seguia a Rosa pelo caminho da sua casa para descobrir onde ela morava, mas nunca tive coragem de falar com ela, muito menos pedi-la em namoro.

A Rosa percebeu que eu a seguia quase todos os dias e falou para a diretora. Com isso, acabei levando um chamado da Dona Malévolas, que era muito ríspida, verdadeira peste; mas, pelo menos, consegui me livrar de uma suspensão, em vez disso, ela preferiu me aconselhar para que não fizesse mais aquilo, que a Rosa não queria namorar comigo. Quando retornei à sala depois dos conselhos da Dona Malévolas, os meninos me perguntaram como foi, como teria sido a minha conversa, e eu disse que foi 'chuchu beleza, foi tranquilo' passando a mão pela boca, gesto muito comum na época por conta do Didi, dos Trapalhões.

Essa situação aconteceu no meio da aula de Matemática da professora Patológica, que era outra professora que eu não era muito afeito. Ao me ver respondendo aos colegas sobre o que tinha acontecido, a professora entendeu que eu estava de deboche $e$ chamou a Dona Malévolas. A professora Patológica aumentou de tal forma que disse até que eu teria dito que tinha levado a diretora 'no papo. Obviamente, a coisa realmente ficou feia dali em diante. Dona Malévolas não teve dúvida, chamou a mim novamente, passou um esculacho, gritou comigo, balançou meu braço e disse que iria chamar minha mãe e me expulsar da escola. Felizmente, nada disso aconteceu.

Eu continuei estudando na escola, apesar dessa situação e de meus pais mudarem frequentemente de endereço. Ainda nessa época, fomos morar no Alto dos Coqueiros, no Recife, e, em seguida, em Águas Compridas, já subúrbio de Olinda. Essa época foi de dificuldade para minha família, muitos problemas financeiros, sobretudo para mim, que andava aproximadamente seis quilômetros até a Escola Pedro Augusto.

Continuei estudando no Pedro Augusto à tarde e saía de Águas Compridas até o Fundão todos os dias a pé, ida e volta, aproximadamente $12 \mathrm{~km}$. Tinha dia que era uma minimaratona porque ia para a Educação Física às $7 \mathrm{~h}$, voltava para casa, tomava banho e, às vezes, sem almoço, retornava para a escola. Em outros dois dias da semana ainda ia para a aula de datilografia, que era na metade do caminho, na Av. Presidente Kennedy, em frente à Escola Santo Inácio de Loyola, onde acabei estudando tempos depois.

Com essa rotina, voltava sempre à noite e raríssimas vezes eu pegava ônibus, porque eu já era grandinho, deveria pagar passagem, e nem sempre o cobrador me deixava passar por baixo da 'borboleta' - catraca. O problema era quando chovia; nessas horas, eu enrolava o caderno num plástico e o colocava entre a camisa e a barriga. Como morávamos num sítio, lembro que, em dias de chuva, o lamaçal tomava conta dos meus pés.

De qualquer modo, esse período foi muito difícil, meus pais estavam com muita dificuldade financeira, morávamos dentro de um sítio, em Olinda, numa casa pequena e eu dormia no chão, uma situação realmente muito ruim. No entanto, para meu alívio, meus pais se mudaram novamente para o Alto dos Coqueiros, numa casa que ficava de frente a anterior, e depois para as proximidades, na rua São Sebastião. Assim, passei novamente a andar por volta de um quilômetro e meio apenas até o Colégio Pedro Augusto. 
Em frente à casa que fomos morar na rua São Sebastião, morava uma menina chamada SCM Primorosa, ela era $7^{\underline{a}}$ série, e eu era $6^{\underline{a}}$ série. Eu estudava ainda no Pedro Augusto e ela na Escola Estadual de Beberibe. Eu me apaixonei por ela, queria estudar com ela, para me aproximar e pedi-la em namoro, mas como? Eu era 6 ${ }^{\underline{a}}$ série e passaria para a $7^{a}$, e ela era $7^{\underline{a}}$ série e passaria, obviamente, para a $8^{\underline{a}}$, além do mais, estudávamos em escolas de bairros diferentes.

No entanto, a paixão era grande, por isso comecei a fazer oração pedindo a Deus para que ela fosse reprovada e eu fosse aprovado. Assim, eu poderia pedir transferência e estudar junto com ela. Alcancei a graça, foi o que aconteceu 'infelizmente', ela foi reprovada e eu aproveitei para me matricular na $7^{a} \underline{a}$ série no Colégio Estadual de Beberibe. Inclusive, tia Zeza era merendeira dessa escola, o que poderia 'facilitar' a transferência, mas não foi preciso nenhuma influência.

No primeiro dia de aula, quando foram distribuir as turmas, descobri que eu tinha ficado numa turma da manhã e ela, numa da tarde. Ou seja, os planos estavam dando errado. Então, fui para a turma dela e sentei por lá. Todas as vezes que os professores faziam a chamada para anotarem as primeiras frequências, perguntavam se alguém não teria sido chamado. Eu dizia: "eu, professor(a), Edilson Fernandes de Souza", e eles anotavam meu nome na caderneta. Resultado, passei a ser da turma e sentava bem ao lado da menina, embora não conseguisse verbalizar o meu sentimento por ela.

$\mathrm{Na}$ nossa turma, tinha um cara chamado Gary, um cara realmente perturbado, discutia com os professores, paquerava todas as meninas, danado demais. Eu ficava incomodado, afinal a gente já tinha 15 anos na época. Mas a verdade é que minha preocupação também era o Gary se interessar pela SCM Primorosa e vice-versa, e isso estragar tudo.

Das aulas dessa época, lembro de algumas, como a de Religião, em que a professora questionava o porquê de ser obrigada a falar do catolicismo. Dizia ela que não tinha que dar aula só sobre catolicismo, que tinha que falar de candomblé, umbanda, espiritismo. Entretanto, ela só reclamava, não fazia nada diferente. Só dava aula de catolicismo.

Tem uma disciplina que até hoje utilizo no meu dia a dia: Técnicas Comerciais. Essa disciplina me ensinou a fazer um ofício, a fazer um pedido a alguém, seja pessoa ou órgão público, instituição etc. Em resumo, aprendi que deveria fazer o pedido de forma clara, objetiva e direta e depois explicar os motivos da solicitação. Foi mais ou menos assim que fiz o pedido a SCM Primorosa, mas, infelizmente, ela não aceitou, disse que preferia continuar como amiga, que não queria estragar o sentimento de amizade. No meu desespero, acabei tentando fazer ciúmes a ela com uma outra garota que morava próximo da nossa casa e também estudava no mesmo colégio. O resultado foi que SCM Primorosa passou a me evitar, deixou de falar comigo até mesmo sobre a escola.

Nesse mesmo período, meus pais se mudaram de novo, dessa vez para o Cabo de Santo Agostinho, ou seja, a gente saiu do Recife para morar em outra cidade. Eu dizia que era 'interior brabo', embora já conhecesse porque uma irmã da minha mãe já havia morado por lá e eu a visitava. Acho que isso aconteceu no primeiro semestre de 1979, e eu não queria abandonar a escola, como nunca abandonei, assim como não queria sair 
de perto da SCM Primorosa, porque, embora ela não quisesse nem falar comigo, eu queria mais uma chance. Para isso, fiquei morando por um tempo na casa da tia Zeza, minha tia que era merendeira da escola.

A memória, às vezes, realmente deixa lacunas, depois que fui pegar a documentação dos arquivos escolares, verifiquei que o ano registrado na Ata de Resultados Finais do Rendimento Escolar, da Estadual de Beberibe, foi o ano de 1980, portanto, esse foi o ano da desilusão amorosa e ao lado do meu nome consta a menção transferido.

Quando chegou o mês de férias, fui visitar meus pais, que agora moravam na Vila da Cohab, no Cabo de Santo Agostinho. Lá, conheci uma moça chamada Ninha. Ela morava num primeiro andar, na rua 56 , e eu morava na rua 58 . Eu a vi pela primeira vez ao passar na rua 56 para conhecer as outras casas e logo me apaixonei. Essa paixão me fez pedir transferência para uma das escolas do Cabo. Foi assim que fui estudar na Escola Técnica Estadual Epitácio Pessoa, popularmente conhecida como Escola Industrial.

No primeiro dia de aula, todo mundo sabia que eu era novato, e um estudante da minha sala apontando para o alto disse: "Desce daí, rapaz", só que a escola não tinha primeiro andar; então, quando eu olhei para cima, o pessoal ficou rindo do trote que ele me passou e tirando sarro comigo. Nesse mesmo dia, resolvi devolver na mesma moeda. A oportunidade veio só no ano seguinte, quando estava terminando a $8^{\mathrm{a}}$ série. Nos últimos dias de aula, disse a mesma coisa para ele. Assim como eu, ele olhou para cima e todo mundo riu lembrando do que havia acontecido comigo no ano anterior.

$\mathrm{Na}$ Escola Industrial, eu aprendi uma palavra que até hoje faz parte do trabalho daqueles que lidam com a ciência. Pela primeira vez, ouvi de um professor de Filosofia a palavra Epistemologia. Fiquei tão fascinado por essa palavra que acabei fazendo uma música. Infelizmente, não lembro mais a letra, só sei que era algo assim: 'Filosofia, a importância da teoria, epistemologicamente inteligente, inteligentemente, o amor e a epistemologia'.

Voltar a morar com os meus pais no Cabo de Santo Agostinho foi um dos momentos mais importantes da minha vida. Por ser uma vizinhança nova, ninguém se conhecia muito bem na Vila da Cohab de forma que, na Associação de Moradores, eram oferecidas muitas atividades, como bordado, crochê, teatro e música, para que pudéssemos interagir de alguma forma. Foi assim que acabei estudando teatro.

Todas as noites, eu ia assistir aos ensaios do teatro na Associação, o nome do cara que ensaiava o teatro era Ramos, eu ficava olhando pela janela da frente, admirando a movimentação do pessoal. $O$ ensaio que eu ficava observando era da peça $A$ revolta dos brinquedos, de Pedro Veiga e Pernambuco de Oliveira. Certo dia, estava chovendo, e o Ramos pediu para que eu entrasse para me proteger da chuva e, no mesmo momento, perguntou se eu gostaria de ajudá-lo nas cenas. Aí fiquei ajudando e pensando em algum personagem.

Bem, esse grupo de teatro teve um impacto muito grande na minha vida e nas minhas escolhas. Nele, conheci algumas pessoas e, tempos depois, virei o diretor do grupo, que passou a se chamar Grupo de Teatro Amador União da Boca Aberta. Passei a 
dirigir e atuar também. Nesse tempo, fiz um personagem chamado Ratinho infame, que era de um esquete, nada a ver com a peça, mas foi a partir dele que ganhei o apelido de Ratinho, o que acabou atrapalhando o meu namoro com a Ninha, da rua 56.

Durante os ensaios e apresentações conheci a Lindóia. Ela era uma dessas pessoas apaixonadas pela música e sempre se apresentava na televisão. Um dia, ela foi cantar imitando uma cantora norte-americana no programa de Paulo Marques, na TV Jornal, onde o Balé Primitivo de Arte Negra de Pernambuco também se apresentava, e conheceu o Zumbi Bahia, um dos diretores-coreógrafos. Nessa ocasião, acabou sendo convidada por Zumbi, para participar do grupo afro. Certo dia, ela me levou a um dos ensaios e eu acabei também entrando no grupo, no qual eu fiquei por cinco anos.

Eu concluí a $8^{\mathrm{a}}$ série na Escola Epitácio Pessoa, em 1980. Contudo, logo em seguida, meus pais se mudaram novamente e dessa vez foram morar no bairro de Linha do Tiro, no Recife. Por causa disso, eu acabei me matriculando na Escola Santo Inácio de Loyola, onde estudei por dois anos, na turma $\mathrm{F}$ no $1^{\circ}$ ano, em 1981, e na turma $\mathrm{B}$ no $2^{\circ}$ ano, em 1982, ambos no terceiro turno escolar.

Nessa escola, passei por uma situação controversa. Acontece que, nessa época, eu já estava no grupo de dança afro junto com Zumbi Bahia e Ubiracy Ferreira, e ia à escola com colares Lágrimas de Nossa Senhora. Quando perceberam isso, fui proibido de entrar com esses adereços. Acabou que eu criei uma confusão muito grande porque achava que não era preciso nada disso, o fato de eu andar com aqueles apetrechos não deveria ser um problema, muito menos me fazer ser proibido de entrar numa escola pública.

Por causa disso, a diretora me chamou em sua sala e passou um sermão danado, dizendo que eu não deveria ter aquele comportamento, que os professores tinham uma boa referência da minha participação nas aulas, que eu era muito inteligente, e não me cabia bem ser chamado na direção da escola por conta de uma bobagem.

Além disso, ela ainda perguntou o que meus pais achariam de meu comportamento. Ou seja, deu sermão com classe, com muita tranquilidade, com a voz muito macia, mas me detonando, com críticas diretas aos adereços afro. No fundo, dizendo mesmo que era para eu não entrar ali com aqueles adereços, que aquilo era incompatível com o ambiente escolar. Achei um absurdo, ela também era negra, eu a via como negra, mas acho que ela não se via assim, não se aceitava.

Contudo, considerando aquelas palavras 'macias', penso que a diretora queria mesmo me ver todos os dias chegando à escola parecido com a imagem que constava na minha Ficha Individual de Aluno na referida instituição, conforme fotografia abaixo. 
Figura 4 -

Fotografia aos 17 anos de idade, 1982.

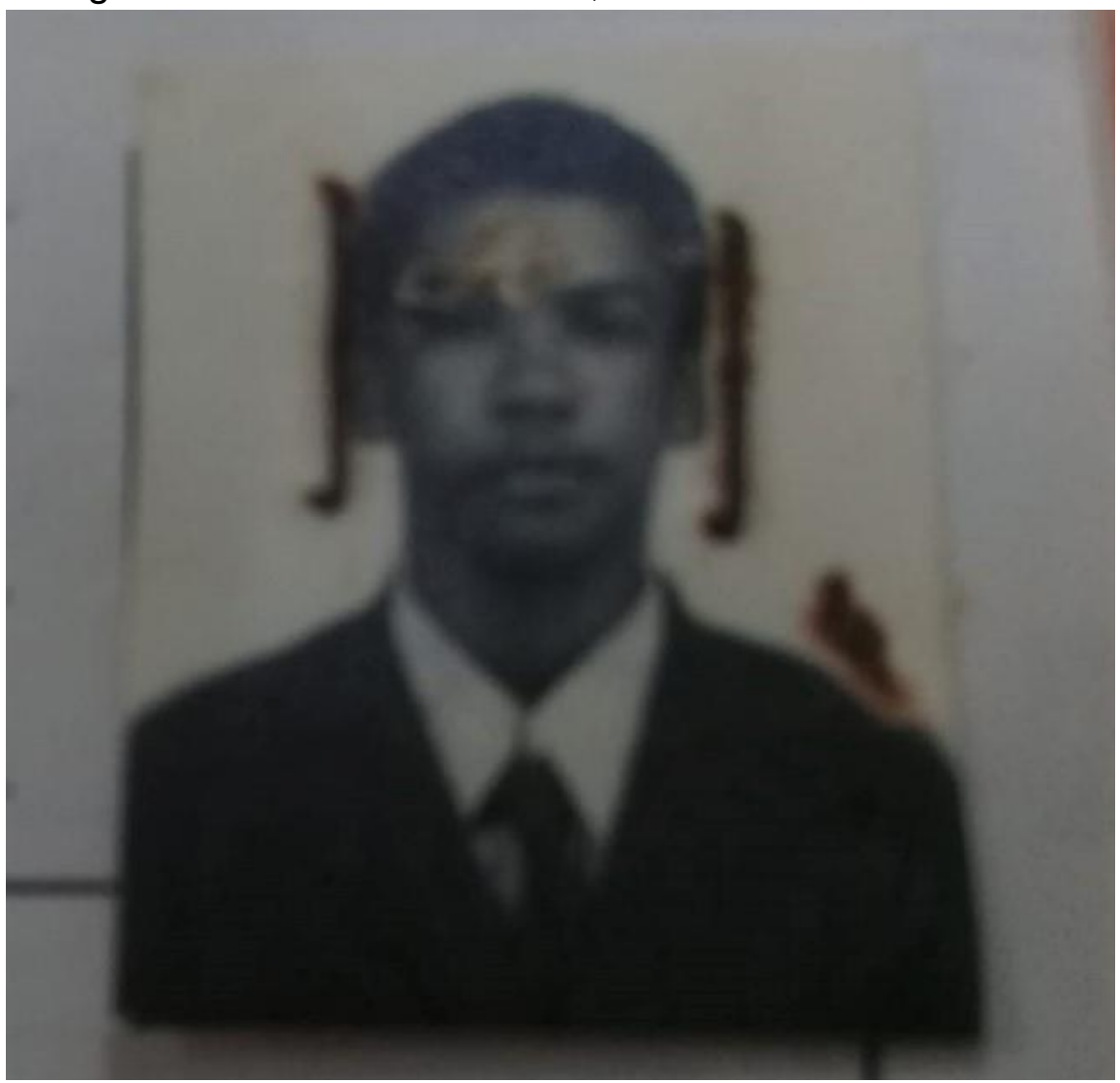

Fonte: arquivo da Escola Estadual Santo Inácio de Loyola. Ficha individual de aluno - bloco do arquivo morto 127, 1982.

Não obstante às críticas aos adereços afro, uma outra recordação que tenho dessa escola é do maracatu. Via de longe os ensaios que a professora Gerusa fazia com os meninos e meninas no pátio da escola. Depois de muito tempo, mais para frente, eu já professor da Universidade Federal de Pernambuco, acabei descobrindo que a professora Gerusa, naquela época, também ensinava no Departamento de Educação Física da UFPE. Infelizmente, mesmo algumas pessoas sabendo que eu dançava num grupo afro, nunca fui apresentado à professora Gerusa; portanto, nunca fui convidado a dançar no maracatu do Santo Inácio de Loyola. Também, pudera, com aquela diretora!

$\mathrm{Na}$ época em que estudava nessa escola, 1981-1982, eu já participava de várias atividades artísticas, estudava música, teatro e ainda a dança afro, motivo dos adereços. Foi uma grande correria para não escapar nada, ou seja, ser aprovado no Ensino Médio, $2^{\circ}$ grau na época, e manter uma certa performance, um determinado nível de excelência no campo artístico, sobretudo, na dança, onde eu já ganhava algum cachê. Aliás, foi com a dança afro que fiz pela primeira vez uma viagem internacional.

O Balé Primitivo de Arte Negra de Pernambuco participou do Festival de Ypacaraí, no Paraguai. Para que eu pudesse viajar, como eu tinha entre 16 e 17 anos, meu pai teve que autorizar e registrar pessoalmente em cartório. Ele trabalhava por produção, vendendo abacaxi, e, às vezes, colaborava na Secretaria do Sindicato dos Trabalhadores de Serviço Portuário de Recife. Ele trabalhava muito, mas, mesmo assim, perdeu um dia de trabalho, fez esse sacrifício por mim. Obrigado, papai. 
Consegui fazer boas amizades no Colégio Santo Inácio de Loyola. Até hoje tenho um amigo de fama internacional, Isaac Duarte, que toca oboé na Orquestra de Zurich. E o René, que depois acabou entrando na Marinha do Brasil, mas na época tocava fagote. Debatíamos muito sobre a vida. Então, nós três, mesmo envolvidos com a arte, resolvemos montar uma chapa para concorrer ao Grêmio Estudantil. A partir daí, íamos de sala em sala para mostrar nossa plataforma de gestão, falávamos sobre os problemas que a escola estava passando, sobretudo, alguns equipamentos quebrados, janelas quebradas, ambiente sujo, o fato de, às vezes, faltar água e a merenda ser ruim.

Até hoje penso que aquela chapa era muito forte, porque queríamos debater com outras chapas, inclusive, uma delas estava há bastante tempo no poder do Grêmio. Entretanto, aconteceu uma coisa muito inusitada, o coordenador do Serviço de Orientação Educação - SOE -, a diretora, a que reclamou dos adereços, e um pessoal pelego, todos acabaram desmobilizando a nossa chapa, baseados no argumento de que nós éramos muito bons, precisávamos nos misturar um pouco com outros estudantes, além disso disseram que, como éramos artistas, talvez não teríamos tempo para dedicação ao Grêmio.

A partir disso, a gente acabou desistindo da ideia de concorrer ou se misturar, e outro grupo ganhou a eleição. Na verdade, os mesmos de sempre, o que é uma pena, já que pensávamos a liderança a partir da arte uma concepção de educação e de escola. $O$ René nunca mais soube dele, nem por onde ele anda, e o Isaque Duarte, embora nunca mais tenha falado, faz parte dos meus amigos nas redes sociais.

Tenho saudade desses momentos na Escola Santo Inácio de Loyola, foi um lugar muito importante para mim, porque foi ali que decidi minha profissão ou as minhas profissões, também foi lá que decidi ir para a Escola Almirante Soares Dutra, que é um capítulo à parte. Foi naquele momento que decidi o que ia fazer do ponto de vista da arte e da vida.

Então, foi basicamente na Escola Santo Inácio de Loyola onde decidi minha profissão. Houve uma Feira de Ciências na Escola Almirante Soares Dutra, no bairro de Santo Amaro, e nós fomos fazer um passeio para lá. Aliás, várias escolas promoveram um passeio para os alunos verem essa Feira de Ciências. Lá, havia pessoas de várias áreas, como Contabilidade, Administração, Enfermagem, Patologia, inclusive durante algum tempo pensei em estudar Contabilidade. Foi ali que vi o pessoal de Patologia apresentando um trabalho, assim como vi um na área de Enfermagem.

Naquela ocasião, eu era bailarino consolidado no Balé Primitivo de Arte Negra de Pernambuco e me apresentava em vários lugares, viajava, mas sabia que precisava terminar o Ensino Médio, que na época era chamado de segundo grau. Então, sabia que precisava terminar o científico, o que popularmente chamávamos de 'terminar os estudos. Então, fiz o primeiro e o segundo ano científico e decidi estudar Enfermagem na Escola Almirante Soares Dutra.

Escolhi esse curso porque, no fundo, queria mesmo uma profissão que pudesse lidar com pessoas, falar com as pessoas, esse foi o meu critério, e Contabilidade certamente só lidava com números, já a Patologia, com dejetos, excreções, exames etc.

Minha vida na Escola Almirante Soares Dutra foi muito interessante, eu era um dos melhores alunos da turma; na verdade, era um dos 10 melhores alunos da escola naquela época. Logo nos primeiros seis meses de curso, por ser um dos melhores alunos, recebi 
uma bolsa de estágio que me permitia pagar algumas despesas. Lembro que, na época, eu recusei a bolsa, porque achava que o estágio remunerado ia dificultar esse meu trânsito pela arte e não queria que nada atrapalhasse, porque, inclusive, eu tinha feito uma turnê pelo Rio de Janeiro e São Paulo. No entanto, no semestre seguinte, a assistente social da escola me chamou e me convenceu a aceitar a bolsa, dizendo que muitos alunos desejavam ter uma oportunidade como aquela e me chamou a atenção para eu não recusar pela segunda vez. Isso me sensibilizou e eu acabei aceitando, assim fui estagiar no Hospital Barão de Lucena; de onde, atualmente, moro próximo.

No meu primeiro dia de estágio, tinha um professor no hall do hospital, esperando para nos acompanhar, ele era o coordenador do estágio, acho que o nome dele era Antônio. Nesse mesmo dia, ele nos chamou para subir até o $6^{\circ}$ ou $7^{\circ}$ andar e apresentou o que faríamos no estágio, os principais desafios dessa jornada etc.

Começamos, então, pela Enfermagem Cirúrgica, ele apresentou um caso de uma paciente que já estava há bastante tempo com choque anafilático. Ela havia feito uma cirurgia, mas se encontrava, infelizmente, de forma vegetativa; além disso, tinha uma traqueostomia, por isso precisava ser aspirada de vez em quando para não morrer asfixiada. A paciente requeria muitos cuidados porque não havia nenhuma possibilidade de recuperação. Como estava há bastante tempo no hospital sob os cuidados da Enfermagem, a principal tarefa era dar uma sobrevida digna, especialmente com medicamentos, limpeza corporal e limpeza das vias aéreas, com procedimentos necessários para uma boa ventilação, ou seja, para que pudesse respirar. Então, o professor Antônio mostrou o procedimento de aspiração na traqueostomia, ele usou uma sonda e ligou o tubo de oxigênio, para fazer a aspiração bem devagar, observando sempre as reações da paciente. Após a apresentação desse procedimento, ele nos alertou que não deveríamos fazer isso sem a autorização ou acompanhamento de um profissional responsável do setor.

Durante a demonstração, todos perceberam que para realizar o procedimento era preciso uma certa técnica, só que eu era muito danado e queria aprender muita coisa ao mesmo tempo e de forma rápida. Então, no outro dia, acho que estávamos em cinco alunos, resolvi chamar os colegas e fazer esse procedimento na paciente.

Foi desesperador, a gente fez o procedimento, mas não sabia a técnica correta, e a paciente começou a tossir, a se afogar com a própria saliva e ficar vermelha. Nesse momento, uma parte da sonda de borracha começou a aumentar e ficou como uma 'bola de festa', como falam no Rio de Janeiro e no Recife, inclusive, quase explodiu com parte da saliva da paciente. Com total despreparo, desligamos o tubo de oxigênio que ajudava na sucção, corremos para uma das enfermarias e ficamos tremendo de medo. Dali em diante, percebemos a responsabilidade que tínhamos com as pessoas e com a vida humana. Felizmente a paciente não morreu, pelo menos não pelas nossas mãos.

No Almirante Soares Dutra, aprendi a cuidar das pessoas, porque a Enfermagem tem como princípio o cuidado do outro, é a profissão do cuidado. No estágio, aconteceram coisas decisivas na minha vida, inclusive coisas que acabaram criando em mim a capacidade de discernir o que queria como profissão. Algumas coisas erradas que vi no hospital por parte da equipe médica me fizeram entender que ali não era o lugar de pura experimentação ou de brincadeira. 
O primeiro paciente que faleceu sob minha vista, quase morreu em minhas mãos. Normalmente, eu fazia meu trabalho numa das alas do hospital, fazia a admissão dos pacientes, dava a medicação na hora certa, e ia ajudar meus colegas numa outra ala. Um dos dias, cheguei para ajudar um colega e ele estava aplicando numa sonda nasogástrica uma bolsa de soro fisiológico. O paciente era o Jacinto, ele havia sido admitido há algum tempo e, por isso, acabei conhecendo sua esposa e filha.

Após muitas tentativas, meu colega estava cansado. Ele havia colocado o soro da sonda e o que retornava eram raios de sangue, por isso o Sr. Jacinto já estava começando a passar mal. Ele estava quase se afogando no próprio soro. Chamamos o nosso supervisor de estágio, que pediu que eu ajudasse. Baseado no prontuário, começamos a refazer o procedimento e verificar se o retorno viria transparente ou com sangue.

O resultado dessa manobra foi a piora do Sr. Jacinto, porque ele começou a passar mal, complicou o seu quadro clínico e os médicos tiveram que ser chamados. Foi uma correria. O Sr. Jacinto, praticamente, acabou falecendo em minhas mãos. Talvez não houvesse a necessidade de ministrar tanto soro em tão pouco tempo. Então, esse foi o primeiro caso de falecimento que eu vi, o que me sensibilizou. Um outro caso foi o do Sr. Manoel, ele tinha diabetes e estava com muitas feridas nas pernas já necrosadas. Uma médica disse que seria necessário cortar sua perna. E isso foi dito sem rodeios, de uma forma bem brusca, ríspida e sem compaixão, acredito que essa não é a melhor maneira de explicar o procedimento. Na Enfermagem aprendemos a preparar o paciente para conversar determinados assuntos ou realizar determinados procedimentos.

Naquele momento, percebi que o sr. Manoel derramou discretamente algumas lágrimas, porque a equipe já estava preparando a mesa de cirurgia quando ele recebeu a notícia. A amputação ocorreu no mesmo dia, mas, quando cheguei no estágio no dia seguinte, o paciente estava amputado e morto. Infelizmente, não tivemos mais nada a fazer, a não ser prepará-lo e levá-lo ao necrotério.

Houve um outro caso, não lembro o nome do paciente, mas sei que era um rapaz jovem, apesar de já ter, à época, mulher e filho. Num dia de visitas, ele estava caminhando no corredor, eu andava muito, conversava com os pacientes. Quando o vi, fiquei feliz pela sua recuperação e ele disse que recebia alta naquele dia, bastava tomar mais uma bolsa de soro, solicitação feita pelo médico que estava acompanhando-o. Logo em seguida, o paciente foi para a enfermaria, deitou-se para receber o soro, mas, depois de uma hora, ele faleceu. Talvez, tudo isso tenha sido coincidência, mas esses acontecimentos me deixaram um pouco triste.

Naquela época, além do estágio, eu realizava algumas atividades de criação artística. Lembro-me de que conversava muito com os colegas sobre tudo o que acontecia no hospital, inclusive sobre o que gostava mesmo de fazer, que era dançar. Por isso, em alguns momentos de folga, quando estava na enfermaria ou no bloco cirúrgico, tentava "puxar" uns passos de dança para alegrar um pouco o ambiente. Fundamentalmente, eu era bailarino, e era dessa forma que pretendia viver profissionalmente.

Contudo, a decisão em não prosseguir na profissão de Auxiliar de Enfermagem aconteceu em virtude de um erro que cometi que, mesmo ainda sendo um estudante e isso ser comum, é considerado grave: a troca de nomes de paciente. Certo dia, fui dar a 
medicação numa enfermaria que tinha três mulheres dormindo. Sabemos que o medicamento vem com o nome dos pacientes, por isso perguntei qual delas era a dona Maria de Fátima. Uma delas abriu os olhos e chamou minha atenção, afirmando que ela era a paciente que chamei. Então, apliquei a injeção. Após isso, a mulher começou a passar mal, ela era alérgica ao medicamento injetado. Foi uma correria para salvar a paciente, foi aí que percebi que todas elas se chamavam Maria de Fátima, ou melhor, elas eram: Maria de Fátima da Silva e Maria de Fátima Silvia dos Santos etc. Nesse caso, os dois primeiros nomes não eram suficientes para identificar a paciente que deveria tomar aquele medicamento.

Numa emergência, precisamos tomar muito cuidado para não causar danos ao paciente. Foi assim que tomei a decisão de não seguir essa profissão, até passei a ter uma precaução exagerada pelos pacientes, uma espécie de transferência e contratransferência, como se diz na Psicologia. Após isso, fui estagiar nas áreas de Ginecologia e Obstetrícia, Pediatria etc., mas sempre com uma preocupação para além do necessário, como se todos fossem da minha família. Passei, então, a me afastar da profissão; inclusive, também me distanciei do hospital. Hoje, não suporto ver o sofrimento alheio. Neste exato momento em que estou gravando essa fala, minha mãe está hospitalizada, tenho feito visitas muito curtas, pois não suporto vê-la na condição em que se encontra, com dor e sofrendo. Espero que ela compreenda, afinal todas as internações têm sido muito longas, cerca de 10 a 20 dias.

Esse meu comportamento indica que vejo o hospital como um lugar de doentes e de quem cuida deles. Às vezes visita demais atrapalha, inclusive acaba levando mais bactérias para dentro do hospital e contaminando os pacientes. Eu não tenho medo de hospital, só não acho um ambiente agradável. Isso foi um dado que aprendi na minha trajetória, sobretudo na formação de Auxiliar de Enfermagem. Apesar de ter essa visão, fui um bom aluno, terminei o curso e, em seguida, comecei o Técnico em Enfermagem, ainda na Escola Almirante Soares Dutra, e fiquei por volta de quatro meses até perceber que aquela não seria a minha profissão.

Mesmo como estagiário fui contratado para passar uma noite inteira no hospital cuidando de um paciente já idoso. Recebi um bom dinheiro, mas foi muito ruim porque eu queria falar com as pessoas, queria conversar e, à noite, não tinha condições de interagir com ninguém. Enfrentar a madrugada em silêncio foi uma péssima experiência.

Além do curso de Auxiliar de Enfermagem, aprendi coisas corriqueiras na Escola Almirante Soares Dutra, como passar cheques. Isso porque estávamos sempre interagindo com a prática e os projetos de outros cursos. Nesse caso, aprendi por meio de um banco para a prática dos estudantes de Contabilidade. Nele, tínhamos algum crédito para pequenas despesas. Inclusive, às vezes, quando precisava chegar mais cedo e queria comer coxinha de galinha com Leite Cilpe gelado, sempre utilizava do cheque 'especial' do banco da escola. Agora sei que essa coisa de 'especial' não tem nada e que é horrível essa combinação para lanche.

Apesar de tantas andanças e interação no estágio e na própria escola, eu tinha poucos amigos e me sentia só. Sentia uma falta muito grande de amizades, eu tinha 1718 anos e estava preocupado com o futuro incerto na dança e com a "repulsa" que se 
avizinhava pela Enfermagem, uma das mais belas profissões da Saúde. Nessa ocasião, já estava namorando com Aninha; na verdade, esse é o apelido da moça, o nome mesmo é Roseane, minha atual esposa, com a qual me reencontrei e casei depois de 15 anos.

A nossa história merece um capítulo à parte. Quando tinha 17-18 anos, ela tinha 16 . Certo dia, ela falou que gostava de mim, mas não me queria, o que me fez chegar à psicoterapia porque não conseguia entender o motivo disso e ainda hoje continuo não entendendo como você pode gostar de alguém e não querer ficar com aquela pessoa. Às vezes, fico pensando que ela não me queria por causa do futuro incerto da dança, apesar de ela gostar de me assistir quando dançava seminu no Teatro de Santa Isabel.

Nesse contexto das paixões, depois de 15 anos sem nenhum contato, sem saber onde o outro estava ou andava, acabamos nos reencontrando e casamos. Hoje, temos duas meninas e um menino. Além deles, tenho uma menina do primeiro casamento e ela também.

Voltando para a Escola Almirante Soares Dutra, posso garantir que tive bons exemplos, especialmente de duas professoras, a Cristina, que a gente chamava de Cristininha, e a Eliane, que davam bons exemplos da profissão do cuidado - da Enfermagem, seus procedimentos, o respeito pelo outro, a forma de cooperar com a sociedade a partir da saúde. E elas falavam sobre isso com um olhar bastante cuidadoso para com as pessoas, então, é um dado essencial que eu trago como experiência.

A Escola Almirante Soares Dutra foi minha última escola, é uma escola pública que ainda mantém minha profunda admiração. Lá foi onde pensei que tinha "acabado os estudos", como todos nós falávamos de forma equivocada. Na verdade, toda a experiência adquirida nessa escola serviu de porta de entrada, de recomeço. Apesar do sentimento de que havia concluído meus estudos, percebi que tinha que tomar um rumo, decidir se iria continuar como Auxiliar de Enfermagem ou se seria artista-bailarino. Inclusive, até hoje não peguei o meu diploma, mas estou pensando seriamente em ir atrás desse documento para constar nesta biografia.

\section{Um parêntese na memória: arte e ciência ${ }^{23}$}

Algumas pessoas têm a impressão de que eu teria sido um dos integrantes do Balé de Cultura Negra de Pernambuco - Bacnaré - quando era adolescente. Entretanto, eu nunca fui de seu corpo de bailarinos. Na verdade, esse grupo representa uma outra geração de artistas, mais recente, apesar dos seus 30 anos. Fui bailarino do Balé Primitivo de Arte Negra de Pernambuco, o primeiro grupo no Recife a desenvolver a dança afro entre 1979 e 1985.

Como entrei nesse grupo artístico? Bem, eu morava na Vila da Cohab, no Cabo de Santo Agostinho, região metropolitana do Recife, a 32km da capital. Eu devia ter 16 anos de idade, tinha amigos adolescentes. Entre essas amizades, tinha uma amiga chamada Lindóia, uma negra alta de olhos brilhantes. E a Lindóia gostava de cantar. Ela era uma

23 Esse trecho foi originalmente gravado, transcrito e reescrito para o projeto Memórias negras de Pernambuco, cujo texto foi solicitado pela Inaldete Pinheiro, escritora, ativista e uma das fundadoras do Movimento Negro no Recife, numa interlocução com a professora Elizama Messias. Considerando a extensão dos escritos, toda essa fala ficou esperando uma solução editorial por um bom tempo, então, resolvi agradecer ao convite das professoras e incorporar à tese como texto ainda inédito. 
pessoa fascinada pela arte e, de vez em quando, cantava na TV Jornal, no programa de Paulo Marques e, às vezes, no de Jota Ferreira, que eram os únicos programas de auditório na época, década de 1980, com concurso de calouros.

Certa vez a Lindóia foi cantar num desses programas, acho que foi no de Jota Ferreira. Nesse dia o Balé Primitivo de Arte Negra de Pernambuco foi se apresentar e desenvolveu ali uma coreografia, parte de seu espetáculo Ânsia de liberdade, inclusive, assisti sua apresentação pela TV e fiquei impressionado com a destreza dos bailarinoscapoeiristas. Era algo inusitado, um grupo de homens dançando seminus na televisão, coragem enorme. Isso era um dia de sábado, meio-dia, em plena ditadura militar. É importante salientar que, na época, o Balé em questão ainda não tinha o nome que conhecemos hoje.

Na semana seguinte, quando a Lindóia me encontrou, ela disse que havia sido convidada por Zumbi Bahia, um dos diretores-coreógrafos, para ingressar no grupo de dança como cantora num espetáculo chamado Ânsia de Liberdade, que estava sendo montado para estrear num dos teatros do Recife. Então, ela foi ao ensaio e me levou como seu primo. Engraçado que, nesse dia, fui com uma boina azul na cabeça que tinha uma estrela com o nome Sheriff escrito.

Os ensaios aconteciam na rua Gervásio Pires, no centro do Recife, aos sábados. Chegamos cedo e ficamos à espera do Zumbi Bahia, que acabou chegando de microônibus com os integrantes do Balé Primitivo. Pegamos carona e fomos ao bairro de Vasco da Gama, num ensaio com o grupo só de meninas, do SESI.

Ao chegarmos lá, Zumbi foi fazer as apresentações dos componentes do grupo dizendo: "Esse aqui é o 'Tição', esse aqui é o 'Bereguedê', esse é o 'Careca'” etc., na minha vez, ele percebeu que não me conhecia, então uma das meninas se antecipou e disse: "Esse é o Sheriff". A partir daquele dia minha vida se transformou significativamente. Meu apelido na dança acabou ficando Sheriff, que utilizei por muito tempo, inclusive na Universidade Castelo Branco, no Rio de Janeiro, onde estudei a licenciatura em Educação Física.

Lembro-me que o Ubiracy Ferreira e o Zumbi Bahia compartilhavam dois projetos artísticos: um voltado para o Balé Primitivo de Arte Negra de Pernambuco, somente com rapazes, e um no Sesi do Vasco da Gama só com meninas, apesar de ainda haver alguns poucos meninos ali no Sesi. O projeto do Sesi desenvolvia danças populares, então eram várias danças ensaiadas, como Reisado, Maracatu, Caboclinho, Frevo etc.

Já o grupo de dança afro ou, melhor, o Balé Primitivo de Arte Negra de Pernambuco, tinha em seu elenco rapazes oriundos das classes populares e, em sua maioria, capoeiristas. Então, fui lentamente entrando no grupo, fortalecendo-me, participando dos ensaios e algumas apresentações desse grupo, que me ensinou a viver e a me expressar enquanto artista, embora já tivesse participando simultaneamente de um grupo de teatro onde eu morava, na Cohab, o Grupo de Teatro Amador União da Boca Aberta, onde conheci a Lindóia.

Lembro bem que fizemos uma expressiva movimentação artística aqui em Pernambuco, porque volta e meia nós éramos convidados a fazer apresentações em teatros e praças de outros bairros, por exemplo. Houve um projeto da prefeitura que fomos dançar no bairro dos Coelhos, no Coque. Dançávamos seminus. Aliás, acho que a 
primeira vez que dancei com plateia. Na época eu tinha 16 anos, dancei numa praça dos Coelhos, perto do Imip. Também fizemos apresentação em Campina do Barreto, em Campo Grande.

O primeiro teatro que dancei aqui no Recife foi o Teatro do Parque. O teatro estava lotado, não sei qual a lotação total, mas lembro que estava muito cheio durante a nossa apresentação com o espetáculo Ânsia de liberdade. O público era tanto que não conseguíamos nem andar pelo corredor, entre as cadeiras da plateia. Tudo era muito expressivo no espetáculo: ritmo, vestimenta e dança.

\section{Figura 5 -}

Balé Primitivo de Arte Negra de Pernambuco - Teatro do Parque, 1980-1981.

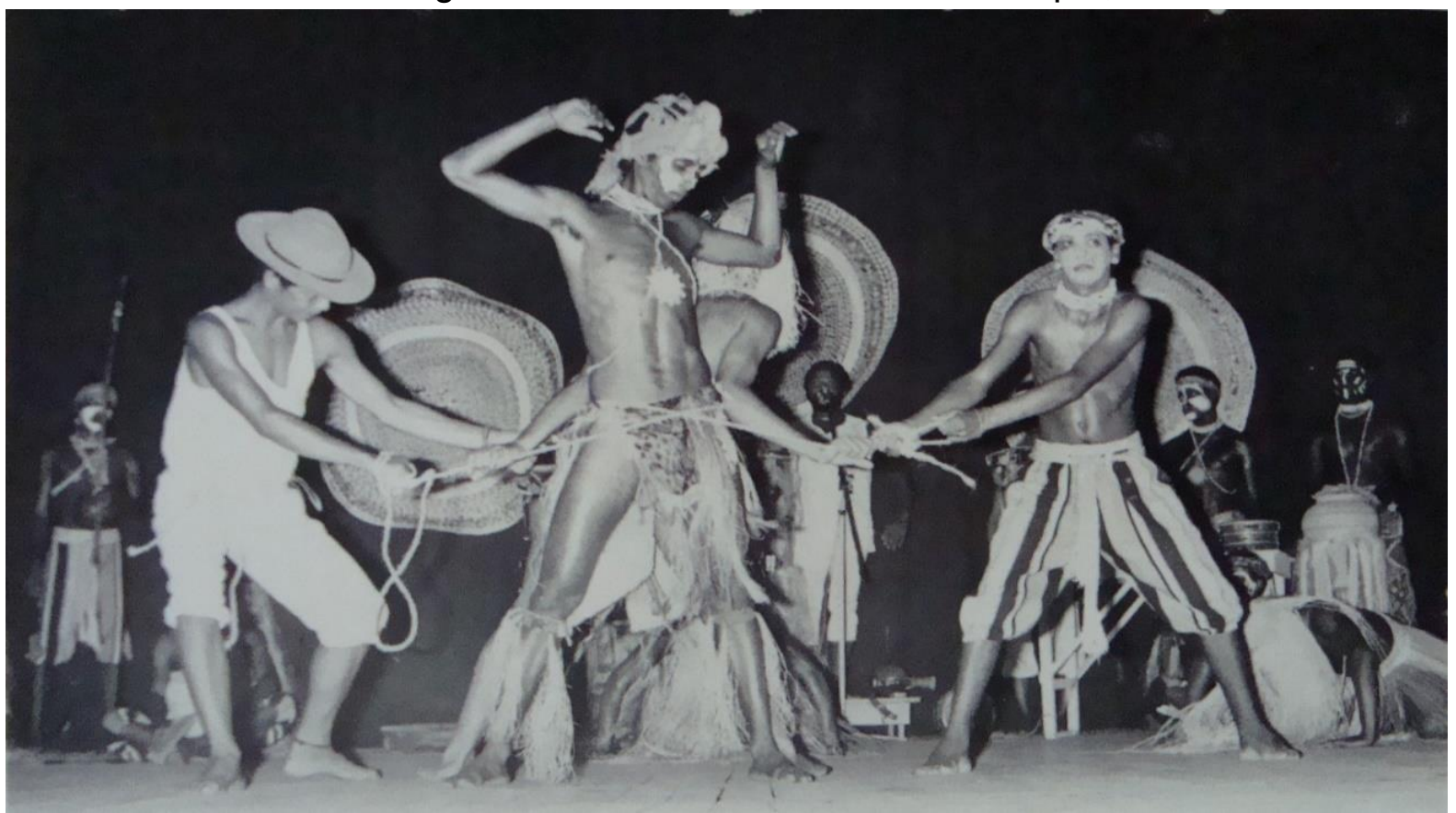

Fonte: Acervo Fundarpe. Projeto Ritmos, Cores e Gestos da Negritude Pernambucana - Lahoi/UFPE. Disponível em: https://www3.ufpe.br/negritude/images/galeria/bale_primitivo/foto\%2027.jpg.

Fotografia n. 50.

Essa cena tenta reproduzir a caçada humana em alguma aldeia africana em que dois exímios dançarinos festejam um acontecimento importante de seu povo e são arrancados de seu território por mercadores de escravos. Este registro foi feito no Teatro do Parque, na década de 1980. Minhas memórias dão conta de que foi a primeira vez que pisei num palco com o Balé Primitivo de Arte Negra de Pernambuco. Foi durante os ensaios para as apresentações nesse teatro que recebi o meu primeiro cachê, na verdade, a primeira passagem de ônibus para retornar para casa depois do ensaio que terminou por volta das $12 \mathrm{~h} 30$ da madrugada.

$\mathrm{Na}$ cena principal desse registro podemos ver quatro dançarinos, sendo: à esquerda, o Gordo, o Bereguedê; no centro e atrás, o Canjica; e à direita, estou eu, com 16 anos. Na composição dessa coreografia, também é possível perceber mais dois dançarinos de joelhos e curvados ao chão. Lá, ao fundo do palco, na rotunda, encontramos o Zumbi Bahia e os demais percussionistas. É emocionante ver essa e outras fotografias desse espetáculo. Foi o começo de minha trajetória no campo da arte da dança. No espetáculo, eu fazia três papéis secundários: tocador de ganzá; segurava

\begin{tabular}{|l|l|l|l|l|l|}
\hline Regae: Rev. Gest. Aval. Educ. & Santa Maria & v. 10 & n. especial & e66773, p. 1-325 & 2021
\end{tabular}


essa corda para conter o dançarino principal, o Bereguedê; e vendia vassoura. Eu tocava ganzá porque não sabia tocar atabaque, aliás, não tocava tão bem o ganzá, mesmo sendo mais fácil. Contudo, não demorou muito para me transformar num dos dançarinosatores principais dessa e de outras produções coreográficas.

Figura 6 -

Balé Primitivo de Arte Negra de Pernambuco - Teatro do Parque, 1980-1981.

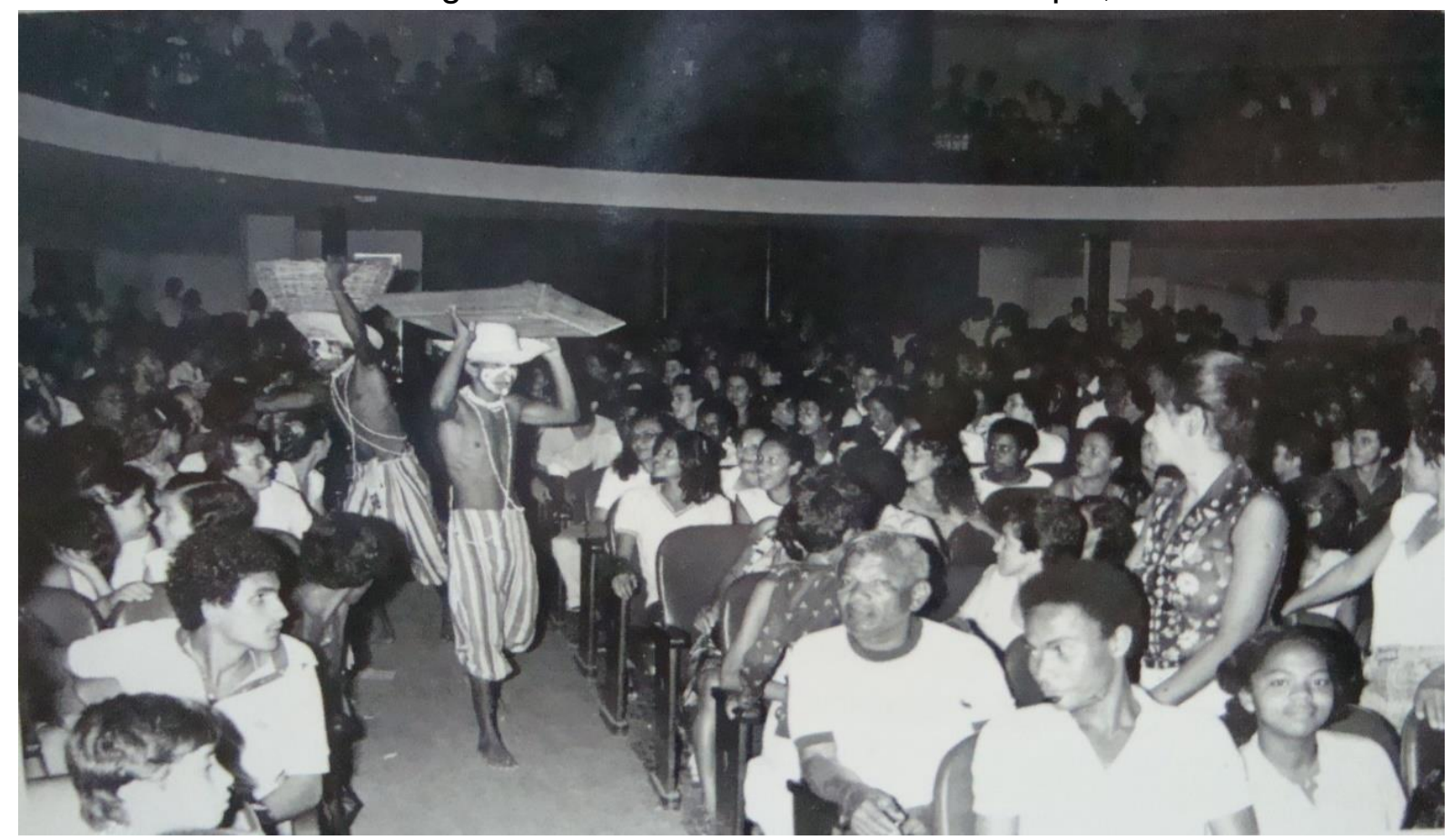

Fonte: Acervo Fundarpe. Projeto Ritmos, Cores e Gestos da Negritude Pernambucana - Lahoi/UFPE. Disponível em: https://www3.ufpe.br/negritude/images/galeria/bale_primitivo/foto\%2027.jpg.

Fotografia n. 31.

Num determinado momento, como mostrado na fotografia acima, o espetáculo falava sobre os Mangaeiros do Recife. Nessa parte, eu vendia vassouras e, literalmente, saía pela plateia gritando "Olha vassoura, olha vassoura". E aconteceu uma coisa bastante curiosa, porque uma pessoa, que depois virou minha amiga, perguntou quanto custava a vassoura. Ela fez isso brincando, mas fiquei preocupado porque eu pensei que ela realmente queria comprar a vassoura, e eu não sabia o preço. Ainda pensei em vender a vassoura, mas depois o que iria usar no espetáculo? Só mesmo um amador iniciante para pensar nisso.

O espetáculo Ânsia de liberdade durou um bom tempo, acho que ficamos uns dois anos elaborando e reelaborando as coreografias. Tínhamos: o Navio Negreiro, que considero uma coreografia clássica da dança afro no Brasil; a capoeira e o Maculelê, realizado com facões que saíam até faíscas. No decorrer desse período fomos nos fortalecendo artisticamente e, consequentemente, apresentando-nos em outros lugares, dentro e fora do Brasil. Na próxima fotografia, é possível ter uma ideia da participação do público ao aplaudir o elenco ao final do espetáculo, que durava cerca de duas horas. 
Figura 7 -

Balé Primitivo de Arte Negra de Pernambuco - Teatro do Parque, 1980-1981.

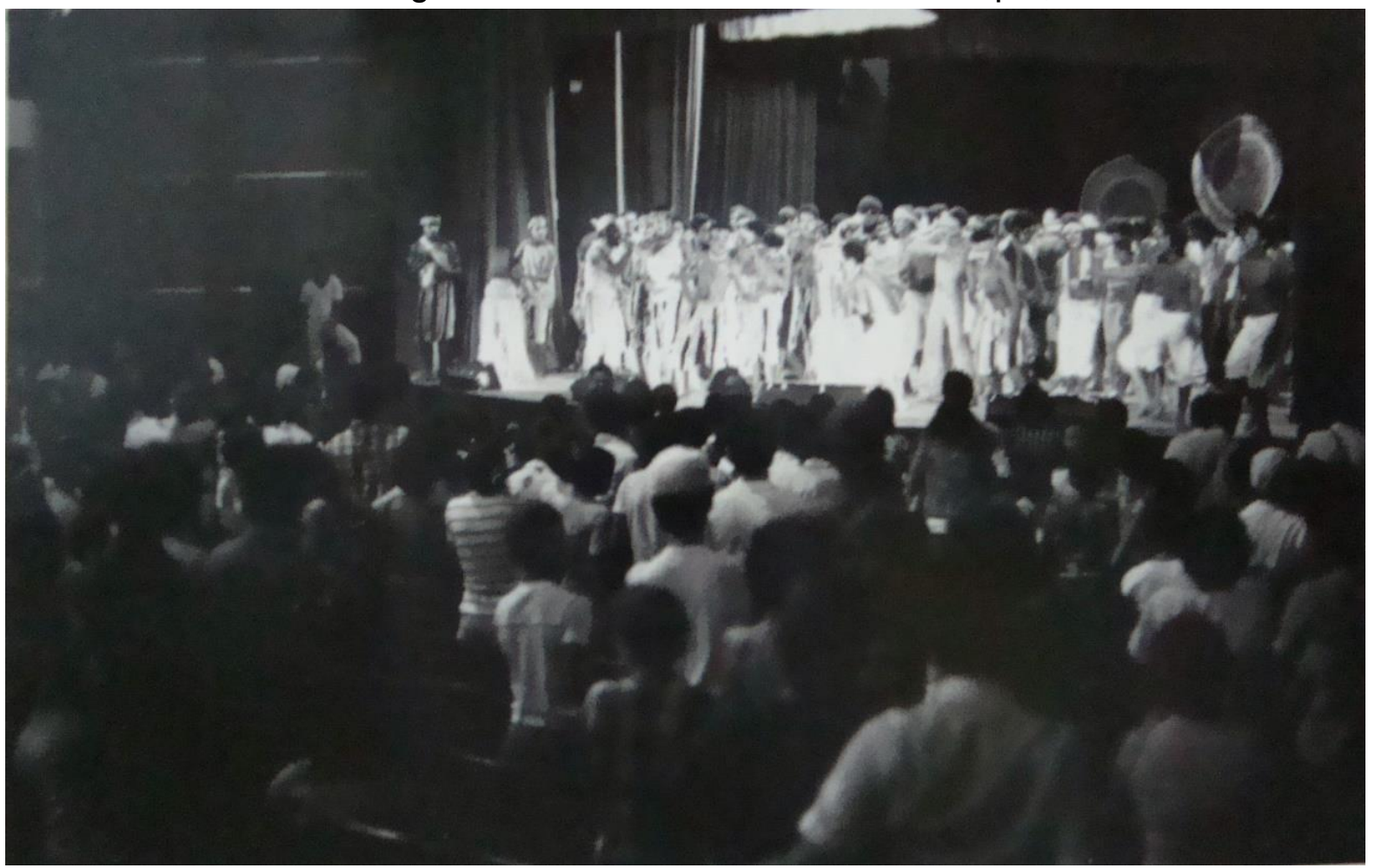

Fonte: Acervo Fundarpe. Projeto Ritmos, Cores e Gestos da Negritude Pernambucana - Lahoi/UFPE. Disponível em: https://www3.ufpe.br/negritude/images/galeria/bale_primitivo/foto\%2027.jpg.

Fotografia n. 48.

Por outro ângulo e provavelmente num outro dia, no final do mesmo espetáculo, pode-se ver mais nitidamente um elenco de jovens dançarinos-atores, alguns oriundos de trabalhos na capoeira e Maculelê e outros, como eu, iniciantes na técnica corporal de matriz africana. Todos eram jovens ávidos e esperançosos por reconhecimento para além da periferia, onde a maioria era originária. Ao ver essas fotografias e recordar o espetáculo, lembro-me que havia muita incerteza no caminho a ser seguido, e o mais importante: se deveria realmente seguir o da arte. 
Figura 8 -

Balé Primitivo de Arte Negra de Pernambuco - Teatro do Parque, 1980-1981.

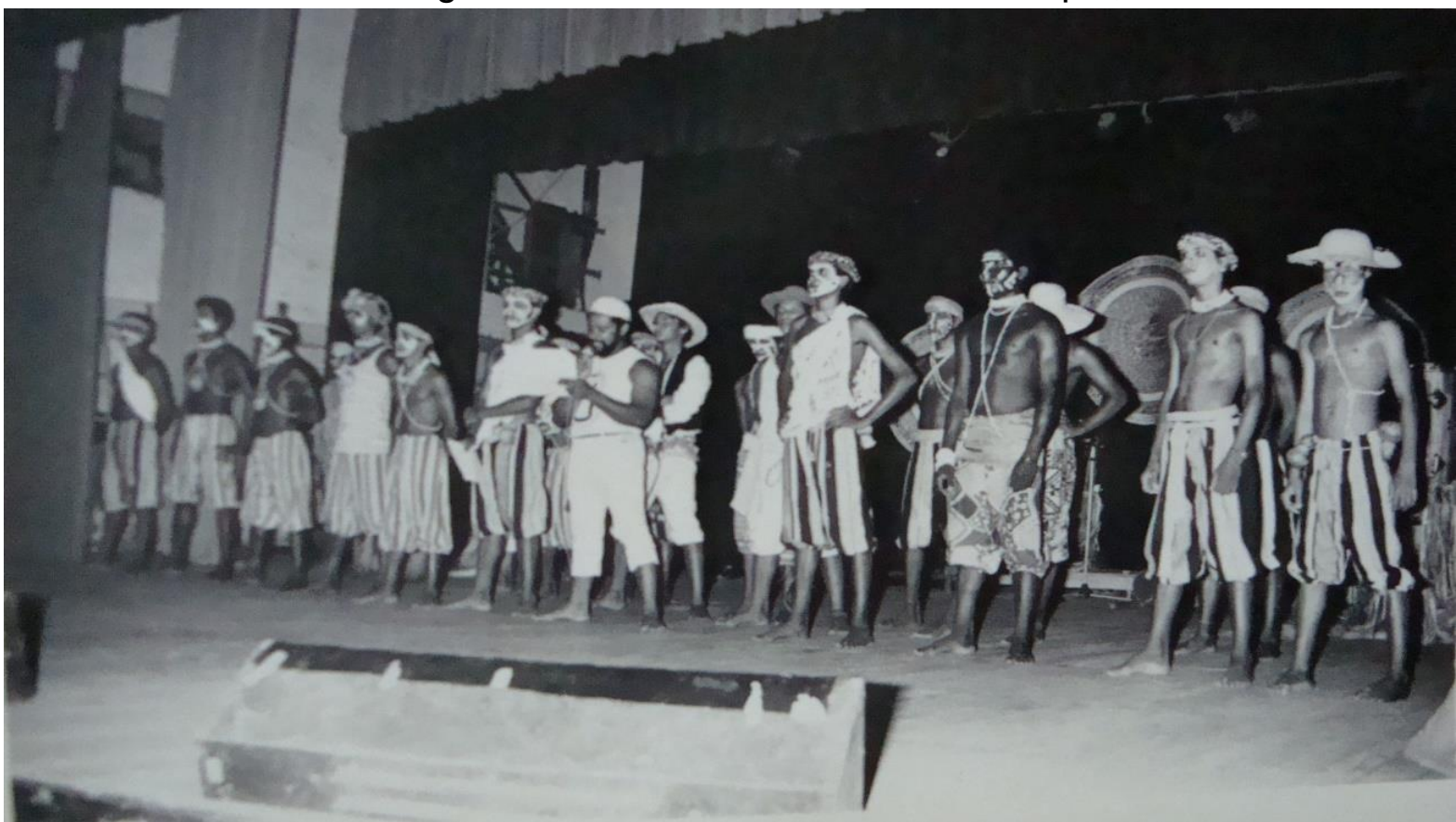

Fonte: Acervo Fundarpe. Projeto Ritmos, Cores e Gestos da Negritude Pernambucana - Lahoi/UFPE. Disponível em: https://www3.ufpe.br/negritude/images/galeria/bale_primitivo/foto\%2027.jpg.

Fotografia n. 27.

Estou na primeira fileira, o segundo, da direita para à esquerda. Com o espetáculo Ânsia de liberdade, nós viajamos ao Paraguai, para o Festival Internacional de Folclore de Ypacaraí. Foi preciso fazer uma movimentação muito grande na cidade do Recife na época, porque o grupo não tinha dinheiro para viajar, então fizemos pedágio em Boa Viagem e fomos até ao governador e ao prefeito da cidade, enfim, isso mais ou menos em 1981-1982.

Finalmente conseguimos arrecadar o dinheiro para viajarmos num ônibus fretado. Passamos praticamente um mês e meio na estrada porque acabamos por fazer uma turnê em São Paulo para levantarmos, obviamente, mais uma graninha para o retorno ao Recife. No Festival Internacional de Ypacaraí, conseguimos o primeiro lugar e a premiação foi em dinheiro, moeda Guarany, mais valorizada do que o cruzeiro na época. Vejam só!

A nossa participação no festival despertou muita curiosidade porque éramos 25 homens dançando, com algumas coreografias que representavam os Orixás, mas a maioria das danças mostrava a relação de trabalho, ou a exploração da mão de obra escravizada. Todo o espetáculo exigia uma alta carga dramática, porque envolvia muito sofrimento, choro e surra.

Logo em seguida, o Zumbi Bahia e o Ubiracy Ferreira resolveram montar um outro espetáculo chamado Corte real de Zumbi. Antes disso, em 1983, havíamos montado o espetáculo $O$ Encontro das Nações, para voltarmos ao festival do Paraguai. Esse espetáculo foi apresentado para angariar fundos. Em $O$ encontro das nações, Zumbi Bahia e Ubiracy Ferreira resolveram costurar as coreografias a partir das danças populares e dança afro, inclusive, uma dessas apresentações foi no SESC de Santo Amaro e outra foi no Museu da Cidade do Recife, no Forte das Cinco Pontas.

\begin{tabular}{|l|l|l|l|l|l|}
\hline Regae: Rev. Gest. Aval. Educ. & Santa Maria & v. 10 & n. especial & e66773, p. 1-325 & 2021 \\
\hline
\end{tabular}


Voltando ao espetáculo Corte real de Zumbi, foram por volta de dois a três anos de muito sucesso no Recife, no Rio de Janeiro e em São Paulo. Lembro-me de que nós ensaiávamos no Teatro Santa Isabel porque tínhamos uma pauta de quinta a domingo durante praticamente um mês. Antes da estreia do espetáculo, nós ensaiávamos à noite, depois que acabava outras produções, algumas de outros lugares e até mesmo de fora do país.

Nossos ensaios, às vezes, aconteciam a partir das $22 \mathrm{~h} 30 \mathrm{~min}$. ou $23 \mathrm{~h}$ e íamos até as $2 \mathrm{~h}$ ou $3 \mathrm{~h}$ da madrugada. Quando terminávamos, pegávamos um 'grude', que é um tipo de cola feita com farinha de mandioca e água, e colávamos os cartazes feitos de papel de jornal pela cidade em muros, tapumes e paredes de prédios. Ou seja, depois do ensaio bastante cansativo, tínhamos mais trabalho com a divulgação do espetáculo, para chamar a atenção e atrair o público para o teatro.

O Zumbi Bahia tinha um papel importante nessa divulgação, ele participava de programas de rádios e das emissoras de televisão de Pernambuco para divulgar o nosso espetáculo. Na época, ainda existia a TV Manchete. Além dela, outras emissoras também davam espaço, como a TV Universitária e a TV Globo, contudo, a TV Jornal era a que mais ajudava, porque abria um espaço em seus programas de auditório, como, por exemplo, o programa do Paulo Marques e do Jota Ferreira, que ainda nos divulgavam em algumas chamadas durante a programação da emissora. Um cara que nos ajudou também foi o Paulo de Castro, conhecido como Paulo Baixinho. Recentemente, eu o encontrei na porta do Teatro de Santa Isabel, quando fui assistir o Bacnaré, num espetáculo montado e dirigido por Tiago Ferreira, chamado de Encontro das gerações.

De qualquer forma a TV Jornal nos ajudou muito na divulgação dos nossos espetáculos e ações do grupo de dança. Penso que o Balé Primitivo de Arte Negra de Pernambuco formou gerações, formou a mim e outras pessoas também, do ponto de vista técnico e humano. Lembro de que tanto Zumbi Bahia como Ubiracy Ferreira nos ensinaram muito, desde a parte técnica-artística da dança ao comportamento à mesa e nos hotéis, porque a grande preocupação dos gerentes era com os utensílios, sempre achavam que nós íamos roubar alguma coisa. Acredito que foi um dos trabalhos mais interessantes e mais perfeitos que eu já vi nessa perspectiva da corporeidade, da estética africana e da estética afro-brasileira.

Dos nossos dirigentes, Zumbi Bahia era o mais ríspido, o mais grosseirão. Já o Ubiracy era mais o paizão, mais sentimento. Então, Zumbi convidava pessoas para fazer parte do grupo de dança, mas quem fazia com que ficássemos no grupo era o Ubiracy Ferreira, porque ele era mais educado, falava com mais tranquilidade. Zumbi queria que nós estivéssemos em cena, ele despertava em nós a coragem de subir no palco; já o Ubiracy Ferreira, pelo menos em minha perspectiva, fazia o refinamento do movimento, da coreografia, a reelaboração estética. Bira, como carinhosamente chamávamos, queria imprimir em todos nós, bailarinos, a ideia de provocar no outro algum sentimento, provocar na plateia uma determinada emoção.

Contracenei com Ubiracy durante muito tempo, porque eu fui corista e depois solista no Balé Primitivo de Arte Negra em Pernambuco. Um dos destaques que ganhei foi justamente num dueto com o Bira: na cena, ele fazia o orixá Oxóssi, um caçador, o orixá 
da provisão, o que buscava alimento para a aldeia, para sua família, e eu fazia o pássaro. Então era uma dramaticidade entre caçador e pássaro; em que eu entrava primeiro e, em seguida, aparecia Oxóssi em busca de alimento.

Com essa dramatização contávamos ali um 'itan', uma história mítica do Oxóssi e sua caça. A trama falava sobre a sobrevivência. Na coreografia o pássaro acabava sendo atingido pela flecha e morria em cena mesmo, em seguida era retirado do palco. A meu ver era uma dramatização simples, mas de grande plasticidade pelos movimentos do pássaro em função do caçador, que dispunha apenas de uma única flecha para atingi-lo.

Lembro de outra coreografia, um cortejo que tinha como personagem central Zumbi dos Palmares. Nessa coreografia um dos vassalos acabava perdendo a cabeça e matando o Zumbi num excesso emocional. Essa dramatização pedia que eu tivesse com o facão na mão. Então eu rolava no chão com os olhos fechados, pegava o facão e, com sua ponta, cravava entre as pernas, jogava próximo a cabeça, próximo ao abdome, de modo que rolando no chão dava ideia de que aquele personagem quisesse se matar, mas logo em seguida me levantava e atingia o líder Zumbi.

Depois que o Zumbi caía morto, a cena seguinte era convertida em poemas de Solano Trindade e Vilmar Alves. Alguns desses poemas sei falar até hoje, aprendi com Zumbi Bahia. O espetáculo Corte real de Zumbi durou bastante tempo, como havia dito. Com ele, fomos para o Rio de Janeiro e São Paulo. Uma dessas apresentações teve início em janeiro de 1985 e foi até final de fevereiro. Em São Paulo, o espetáculo era de quinta-feira a domingo, com duas sessões, no Teatro Maria Della Costa. Essa foi a última turnê e, pela primeira vez, o Ubiracy não viajou conosco, um sinal de que as coisas não estavam indo muito bem. Na verdade, não foi somente ele que não viajou conosco, a sua esposa e seu filho, Thiago, que também tinha uma participação muito especial numa dramatização quando representávamos o Omolu. Nenhum dos três viajou conosco.

Lembro de que essa dança era um momento muito forte do espetáculo. Ubiracy entrava em cena todo coberto de palha da costa e, num determinado momento, o Thiago, que era bem pequenininho, também coberto de palha, entrava em cena agarrado à barriga do Ubiracy e, em certo momento, saía vestido de Omolu mirim; ou seja, saía de dentro da roupa do Ubiracy. Era mesmo um ponto alto do espetáculo. Era muito bonita aquela cena. Por isso era importante a presença do Ubiracy na turnê de 1985.

Voltando a falar da turnê, depois que saímos de São Paulo, do teatro Maria Della Costa, fomos nos apresentar no Teatro Glauce Rocha, no Rio de Janeiro, também em duas sessões, com pautas de quinta-feira ao domingo. Passamos uns quinze a vinte dias exibindo o espetáculo neste teatro; inclusive, isso aconteceu próximo ao carnaval. Então, nessa turnê, ganhamos bastante dinheiro, praticamente uma redescoberta da dança afro no Brasil, com espetáculos que estavam fora do eixo, especialmente do Rio de Janeiro, São Paulo ou Bahia. Para alguns, parecia uma releitura da dança de matriz africana, porque éramos de Pernambuco. Nessa última turnê, chegamos até a gravar uma vinheta nos estúdios da TV Globo Nordeste, assim nos estados onde apresentávamos a emissora divulgava o espetáculo usando essa vinheta de 30 segundos.

Quando retornamos do Rio de Janeiro para o Recife, houve uma reunião no Sesi de Sítio Novo e, naquele momento, ficou muito clara a dissidência, a divisão do grupo. Eu não me sinto à vontade para entrar em detalhes do que aconteceu, os motivos reais da dissidência, até porque eu tinha pouca participação nas questões políticas e 
administrativas, na verdade eu era uma espécie de coringa, porque entrava muitas vezes em cena, também era corista e solista, por isso dançava na maioria das coreografias, tinha mais três ou quatro solos e ainda falava alguns poemas, além de coordenar os ensaios. Essa reunião foi muito dura, porque foi a primeira vez que houve uma discussão muito grande, o que acabou desfazendo um trabalho de anos somente em alguns minutos.

Contudo, mesmo que dolorosa, essa memória é muito importante para minha vida. Sinto muito orgulho dessas lembranças porque elas não são apenas propriedades de Pernambuco, elas estão em vários lugares, estão no mundo. Lembro que naquela ocasião nós queríamos ir para a Europa, queríamos fazer uma apresentação em vários lugares, isso até 1985. Chegamos até a receber um convite, mas não tínhamos dinheiro para viajar à Alemanha.

Percebi que o grupo tinha sido desfeito e aproveitei dois momentos importantes, mas não cabe aqui relatá-los, porque não tem a ver diretamente com a dança. Com a dissolução do grupo fui para o Rio de Janeiro, já que, na turnê de 1985, eu havia sido convidado para ministrar dois dias de aula para um cara chamado Sérgio Silva, um psicólogo (in memoriam) que estava tentando iniciar um trabalho com a dança e pretendia entrar no campo da produção artística. Assim, quando o grupo se desfez, passei a conversar com o Sergio Silva.

É muito engraçada a imagem que as pessoas tinham de nós, especialmente no Rio de Janeiro. Era a de um grupo consolidado de profissionais na área, com 25 homens dançando com muito impulso artístico, muita força e muita energia em cena. $O$ que não imaginavam é que tudo havia sido desfeito. Essa é uma parte tão triste que, em todo o tempo que passei no Rio de Janeiro - oito anos -, não falei que o grupo havia acabado, sempre tive vergonha de dizer e continuo achando que isso me enfraqueceria no mundo artístico numa praça como o Rio de Janeiro.

Cheguei no Rio de Janeiro em 13 de maio de 1985. Logo em seguida, em 1986, voltei para o Recife, para passar férias e brincar carnaval, já voltei com minha ex-esposa. Quando soube da minha chegada, Zumbi Bahia e a Telma Chase, companheira dele, convidaram-me para ficar no Recife e iniciar um trabalho de dança, pois eles estavam sem bailarinos. Isso porque o corpo de baile e percussionistas ficaram com o Ubiracy Ferreira e montaram o Bacnaré. Como disse, o Ubiracy era aquele paizão. Talvez, por isso tem-se a ideia de que participei do Bacnaré. Na época, o Zumbi até pensou em me contratar, mas recusei a proposta, pois já estava com alguns trabalhos no Rio de Janeiro. As pessoas lembravam-se do Balé Primitivo de Arte Negra de Pernambuco e eu fazia um trabalho diferente do que já tinha por lá, diferente da escola MB Kathrin e me sentia muito confortável, profissional e financeiramente.

Com a minha recusa o mestre Zumbi ficou triste, mas agradeceu pela conversa sincera e me desejou boa sorte. Então, voltei para o Rio de Janeiro e continuei desenvolvendo meu trabalho como coreógrafo, bailarino e professor, com aulas de dança afro. Antes da conversa com o Zumbi, já havia montado, com Sergio Silva, o espetáculo Ashanti. Aliás, esse espetáculo está registrado na Biblioteca Nacional. E em meados de 1986, montei com a minha ex-esposa o Heranças de uma cultura. 
Independentemente das minhas produções, sempre pensei e lembrei do Balé Primitivo de Arte Negra de Pernambuco, tentei mostrar a todos e fiz constar no meu currículo que havia sido bailarino desse excelente grupo de arte de matriz africana. No Rio de Janeiro, dentro ou fora dos palcos, as pessoas tinham sempre essa lembrança desse grupo de Pernambuco. No meu currículo a única coisa que constava era que fui o Sheriff, ex-integrante desse grupo artístico. Depois acabei construindo um binômio Edilson Sheriff, inclusive, o pessoal do Instituto Nacional de Artes Cênicas - Inacen - me conhecia com esse nome e já sabia de nosso trabalho por meio do Sérgio Cardoso, um dos diretores de lá. Aliás, as turnês que tínhamos feito em anos anteriores foram justamente fruto dos investimentos do Inacen, que passou a acompanhar o trabalho do Balé Primitivo de Arte Negra de Pernambuco.

Lembro de que nos ensaios antes das apresentações, sempre tivemos a presença de um sensor, a censura assistia. Em Pernambuco isso não acontecia sempre, mas, quando cheguei no Rio de Janeiro e comecei a montar meu próprio espetáculo e a coreografá-lo, percebi a presença maior da censura, era uma apresentação específica que nós fazíamos para que os caras pudessem observar e colocar ali uma faixa etária de espectador.

Fiquei no Rio de Janeiro durante muito tempo. Num certo período o Balé de Arte Negra de Pernambuco, criado e coreografado por Zumbi Bahia, foi ao Rio de Janeiro e lá eu acabei encontrando o pessoal, inclusive fizemos uma apresentação com o Antônio Pompeu, agora falecido, que era ator da Globo e havia feito o filme sobre Zumbi dos Palmares. Pompeu e o Paulão produziram vários eventos no Circo Voador e acabaram contratando o Balé de Arte Negra de Pernambuco.

Essa apresentação do Circo Voador foi muito importante para mim. Nela pude rever várias pessoas, inclusive o Bereguedê, que continuou com o Zumbi Bahia, também revi um cara chamado Gilson - lansã - que morava em Beberibe, próximo à minha antiga residência. O Gilson, jogador, acabou iniciando a dança com o Zumbi Bahia porque, na época, que eu era do Balé Primitivo, ele sabia que eu dançava, mas ele jogava futebol, achei muito engraçado como o cara trocou o futebol pela dança, aliás, era excelente bailarino e depois também virou coreógrafo.

Voltando à apresentação, o Balé de Arte Negra de Pernambuco fez um excelente espetáculo no Circo Voador, eu também fiz uma apresentação boa, apesar de ter me apresentado sozinho, com parte do espetáculo Ogum Onirê. Tentei relembrar uma das cenas que eu fazia no Balé Primitivo de Arte Negra, em 1985, com o facão na mão, um dos meus solos preferidos. Tenho o facão até hoje.

Na época em que Zumbi esteve no Rio de Janeiro acabei perguntando pelo Ubiracy Ferreira, a informação foi que o Ubiracy estava pelo Recife fazendo várias apresentações com o Bacnaré, inclusive, viajando para a Europa algumas vezes. Percebi que ainda existia alguma divergência entre eles e não quis entrar nessas questões, até porque isso em nada acrescentaria em nossas vidas.

Sair do Recife foi realmente algo doloroso e, ao mesmo tempo, reconheço que foi muito bom que isso tenha acontecido, pois foi no Rio de Janeiro que tive a oportunidade de voltar a estudar e foi de lá, por ter feito a graduação em Educação Física, que veio a oportunidade de morar em Minas Gerais, em São Paulo e depois retornar a Minas Gerais. 
Anos depois retornei para o Recife. Entre 2000 ou 2001 assisti a uma matéria na televisão com o Ubiracy Ferreira chamando atenção para um espetáculo no Teatro de Santa Isabel. A reportagem dizia que o Bacnaré iria fazer uma apresentação para angariar fundos em virtude de uma viagem que o grupo faria à Europa. Como eu tinha terminado minha tese de doutorado e escrito o livro Entre o fogo e o vento: as práticas de batuques e o controle das emoções, juntei uns dez exemplares e fiz uma doação ao grupo, com o intuito de que a venda pudesse ajudar de alguma maneira. Não me mobilizei para assistir aquela apresentação. Acho que só fui assistir a um espetáculo do Bacnaré algum tempo depois do falecimento de Ubiracy, em meados de 2018, e depois em janeiro de 2019, quando fui convidado para dançar.

E o que eu posso falar do Bacnaré? Em primeiro lugar, de forma intransponível, é um grupo de grande resistência cultural e representa muitas vozes e corpos, assim como a manutenção estética afro-brasileira com técnicas da dança e do ritmo. Com o seu posicionamento político, tem a coragem de colocar bailarinos e bailarinas em cena, inclusive com idade entre 30 e 40 anos e com o peso acima dos padrões sociais. É importante frisar que é muito difícil a apresentação e montagem de um espetáculo, porque, além desses aspectos, sempre tem muita gente em cena.

Penso que, esteticamente, o Bacnaré está muito acima da média, com suas cores vibrantes e suas indumentárias bem elaboradas; e com um primor na elaboração das coreografias dramáticas, festivas e, às vezes, engraçadas. Seu trabalho sempre leva em conta o comportamento e a gestualidade do povo africano, no intuito de reproduzir com fidelidade algumas de suas comunidades. O Bacnaré tem envidado esforços para 0 desenvolvimento de uma estética de excelência, isso é claro para mim.

$\mathrm{Na}$ atual conjuntura econômica e financeira do país eles ainda conseguem mobilizar alguns percussionistas, e isso não é uma coisa simples, assim como despertar o outro para o ritmo e controle de seus impulsos emocionais não o é. Passei por isso no Rio de Janeiro e sei que colocar muita gente em cena de forma bem-sucedida significa boa liderança a partir do ritmo e da técnica corporal.

Não é fácil colocar, no mínimo, dez percussionistas no palco e ainda despertar o gosto pelo ritmo em duas ou três crianças. Inclusive, no grupo há uma criança que toca atabaque. Então, isso é uma proeza só possível para aqueles que sabem liderar e, mais que isso, há um exemplo para seguir, como é o caso do Thiago Ferreira que, a partir da memória do seu pai, Ubiracy, continua o trabalho ancestral de origem afro. Desse modo, quando a gente fala de memórias negras de Pernambuco, o Bacnaré representa um pouco essa memória artística-dançante que começa mais ou menos em 1979, com a formação do Balé Primitivo de Arte Negra de Pernambuco.

É compreensível que alguns integrantes do Bacnaré talvez não queiram falar sobre esse assunto, mas essa é a minha memória desses momentos; inclusive, um dos momentos importantes de Zumbi Bahia e o Ubiracy Ferreira foi quando eles resolveram ministrar um curso de dança afro, que aconteceu no Sesc de Santo Amaro. Como resultado desse curso, tivemos o primeiro afoxé aqui em Pernambuco, que saiu no carnaval pelas ruas de Olinda, o Ylê África.

O Sesc sempre foi parceiro dos trabalhos que o Ubiracy e o Zumbi faziam, até cedendo espaço para o curso e apresentações. Um desses cursos foi divulgado na apresentação do espetáculo Ânsia de liberdade, que aconteceu no Teatro do Parque, 
lembro-me que neste dia a casa estava lotada. Outra parceria com o Sesc aconteceu para o espetáculo Encontro das nações, que foi pensado com o intuito de angariar fundos para uma segunda viagem ao Paraguai.

A memória é uma coisa realmente curiosa. Aquela pessoa que, alguns meses antes do curso, queria 'comprar a vassoura' que eu vendia como 'mangaeiro' no espetáculo Ânsia de liberdade, era a Jaraine Neves, que é pedagoga e acabou fazendo esse curso. Durante as aulas acabei me tornando um de seus amigos.

$O$ registro, para mim, mais marcante desse curso foi o fato de que os alunos se transformaram nos brincantes do afoxé. Iniciamos os ensaios no Sesc de Santo Amaro e depois no antigo Forró Cheiro do Povo, em Olinda. Várias pessoas importantes da cultura e religião de matriz africana faziam parte do curso e, consequentemente, do afoxé, como, por exemplo, o jornalista Lepê Correia, as irmãs Telma e Vanda Cheese etc. O babalorixá Raminho, inclusive, era um dos integrantes desse candomblé de rua. Lembro-me de que na noite que antecedeu os nossos ensaios no Forró Cheiro do Povo, o Raminho realizou um xirê - festa - para Oxum, a cesta de Oxum. Por isso, o pessoal que estava no curso de dança afro, após a aula, acabou indo à casa de Raminho, no Jardim Brasil, em Olinda. A ocasião foi uma espécie de aula prática, assistimos à festa de Oxum, que acabou pela madrugada. No dia seguinte, teríamos o primeiro ensaio no forró Cheiro do Povo e, como eu não tinha como voltar para casa, resolvi dormir na Praça do Carmo, em frente à igreja, pois o ensaio começaria às $9 \mathrm{~h}$.

Desse modo, o primeiro afoxé no estado de Pernambuco foi o Ylê África. Nesse afoxé, tinha uma personagem que ia na frente da agremiação, o Babalotim, eu era responsável por dançar com esse boneco. Era muito engraçado porque as pessoas não sabiam o que era o afoxé, assim, nós nos misturávamos com outros foliões. Na época, as nações de maracatu já eram consolidadas no Estado, mas o afoxé só existia na Bahia.

Atualmente já vemos vários grupos de afoxé, vemos belíssimos espetáculos com homens e mulheres tocando, vemos em quase toda a esquina que passamos. No entanto, entre 1981 e 1982, só tinha maracatu nação, os tradicionais e o afoxé acabou entrando também nessa onda, nesse movimento negro em Pernambuco. Na segunda-feira de carnaval, quando tem a Noite dos Tambores Silenciosos, no Pátio do Terço, nós participamos com o afoxé. Foi a primeira vez que o grupo participou dessa noite festiva.

Uma outra questão que eu gostaria de deixar explícito aqui é a seguinte: esse grupo de dança afro, o Balé Primitivo de Arte Negra de Pernambuco, teve uma participação muito grande na minha formação profissional e pessoal. Foi a partir dessa movimentação artística com os professores Zumbi Bahia e Ubiracy Ferreira, sob suas influências estéticas, que aprendi a subir no palco, a respeitar os colegas em cena e outros profissionais, outros artistas, e, principalmente, a respeitar o público.

Com o grupo, também aprendi a criar e a respeitar a minha criação, expor minha criatividade a partir dessa memória da africanidade. Mesmo com o trabalho de arte que desenvolvia, com as nossas viagens, as turnês etc., eu sempre estudei; na época, estava no Ensino Médio e tentava articular o que aprendia na dança com o aprendizado escolar, inclusive, quando fui estudar Enfermagem.

Ao participar do grupo de dança, sempre vi uma grande oportunidade de aprender outras coisas, por exemplo, como me comportar nos lugares por onde andávamos. $O$ Ubiracy Ferreira era muito preocupado com isso, com a nossa forma de falar e de lidar 
com outras pessoas nos diferentes lugares por onde passávamos. A nossa grande preocupação era sermos discriminados, vítimas de racismo. Aliás, uma vez aconteceu de sermos proibidos de entrar no Clube Português do Recife para ensaiarmos o espetáculo que aconteceria na mesma noite.

A apresentação aconteceu em virtude das comemorações dos 50 anos do livro Casa grande e senzala, de Gilberto Freyre. Coisa curiosa, infeliz coincidência. O porteiro não nos deixou entrar, apesar dos vários argumentos utilizados. Acho que quem interveio foi a atriz Geninha da Rosa Borges, que se apresentaria também naquela noite. Depois de muita insistência, conseguimos entrar, mas não ensaiamos porque já não havia mais tempo. Fomos direto para a apresentação. Um show, é assim que defino aquele dia. Entramos em cena com muita raiva e apresentamos o espetáculo com todo o vigor estético e profissional.

Ao me envolver com a dança afro, posso garantir que aprendi muito com esses dois personagens, o Ubiracy Ferreira e o Zumbi Bahia. É uma pena que o grupo tenha se desfeito no auge do sucesso. Acho que nós estávamos num momento muito bom, certamente teríamos chegado muito longe se tivéssemos permanecido juntos. $\mathrm{O}$ grupo estava ganhando não só fama e dinheiro, mas também expertise, do ponto de vista da técnica da dança. Como o grupo acabou, mesmo sem querer aceitar, precisei seguir o conselho de meu pai e viajar para outro lugar.

Contudo, considerando os aspectos que envolvem as recordações, especialmente esta seção da memória, consegui identificar com clareza o que Alheit (2011) trata da biografização, segundo o qual "a dimensão estética é uma ponte confiável e ao mesmo tempo surpreendente para aquilo que socialmente costumamos denominar de 'trabalho' e é, simultaneamente, um ponto de partida produtivo para processos de formação" (p. 39). Assim, essas reflexões são importantes porque vivemos biograficamente, vivemos segundo nossas experiências, que se organizam em torno de planos e ações, é como se a nossa vida, segundo o autor, estivesse sempre em nossas mãos.

\section{No Rio de Janeiro: teatro, academia de dança}

Saí do Recife, em direção ao Rio de Janeiro, num ônibus da empresa São Geraldo, no dia 11 de maio de 1985. Na mala de couro cru, comprada na Ciudad del Este, no Paraguai, tinha $1 / 2 \mathrm{~kg}$ de carne verde - carne de boi com farinha -, 11 laranjas e alguns cruzeiros. Cheguei no Rio com três laranjas, alguns pedaços de carne e uns trocados. A promessa era ministrar um curso de dança por duas semanas e receber Cr\$400,000,00, acho que era isso.

Cheguei no dia 13 de maio com o objetivo inicial de ministrar aulas, por duas semanas, para Sérgio Silva e alguns dançarinos-atores. Como já mencionei, na época, o Balé Primitivo de Arte Negra de Pernambuco, que eu era bailarino, havia se desfeito após uma longa temporada em turnê no Rio de Janeiro e em São Paulo. Antes de ter sido convidado para ministrar esse curso eu já havia dado algumas aulas na época em que aconteceu a turnê para ele e alguns de seus amigos e, apesar de ter sido chamado por um período determinado, eu já sabia que ia ficar no Rio de Janeiro, porque não tinha espaço, ambiente e nem condições de continuar no Recife. 
Durante as duas semanas que ministrei as aulas de dança, fiquei no apartamento de uma amiga do Sérgio Silva, a Kátia Barbosa, que morava num condomínio em Botafogo, em frente ao Canecão. A Kátia ministrava aulas de dança na Academia Angel Viana. Aliás, essa é uma oportunidade para agradecê-la por ter me abrigado. Depois fui morar numa quitinete de um cara chamado Mauro, em Realengo, um estudante de Filosofia, que participou das duas semanas do curso e me alugou esse espaço. A casa que ele morava ficava embaixo da quitinete, e eu tinha direito a fazer a minha comida ou filar a comida de alguém, caso deixasse por lá. Preciso agradecer ao Mauro pela colaboração, compreensão e por não ter me cobrado o último mês de aluguel.

Fiquei no Rio de Janeiro, mas com muita dificuldade. Na época, tinha concluído o Ensino Médio em Recife, no curso Auxiliar de Enfermagem. Como nunca exerci a profissão, resolvi ficar no Rio de Janeiro e tentar ministrar aulas, conseguir algum contrato ou um grupo de dança que pudesse me convidar, ou até mesmo ser modelo fotográfico para manter o sustento, como pode ser apreciado na próxima imagem.

Figura 9 -

Ensaio Fotográfico no Rio de Janeiro, 1986.

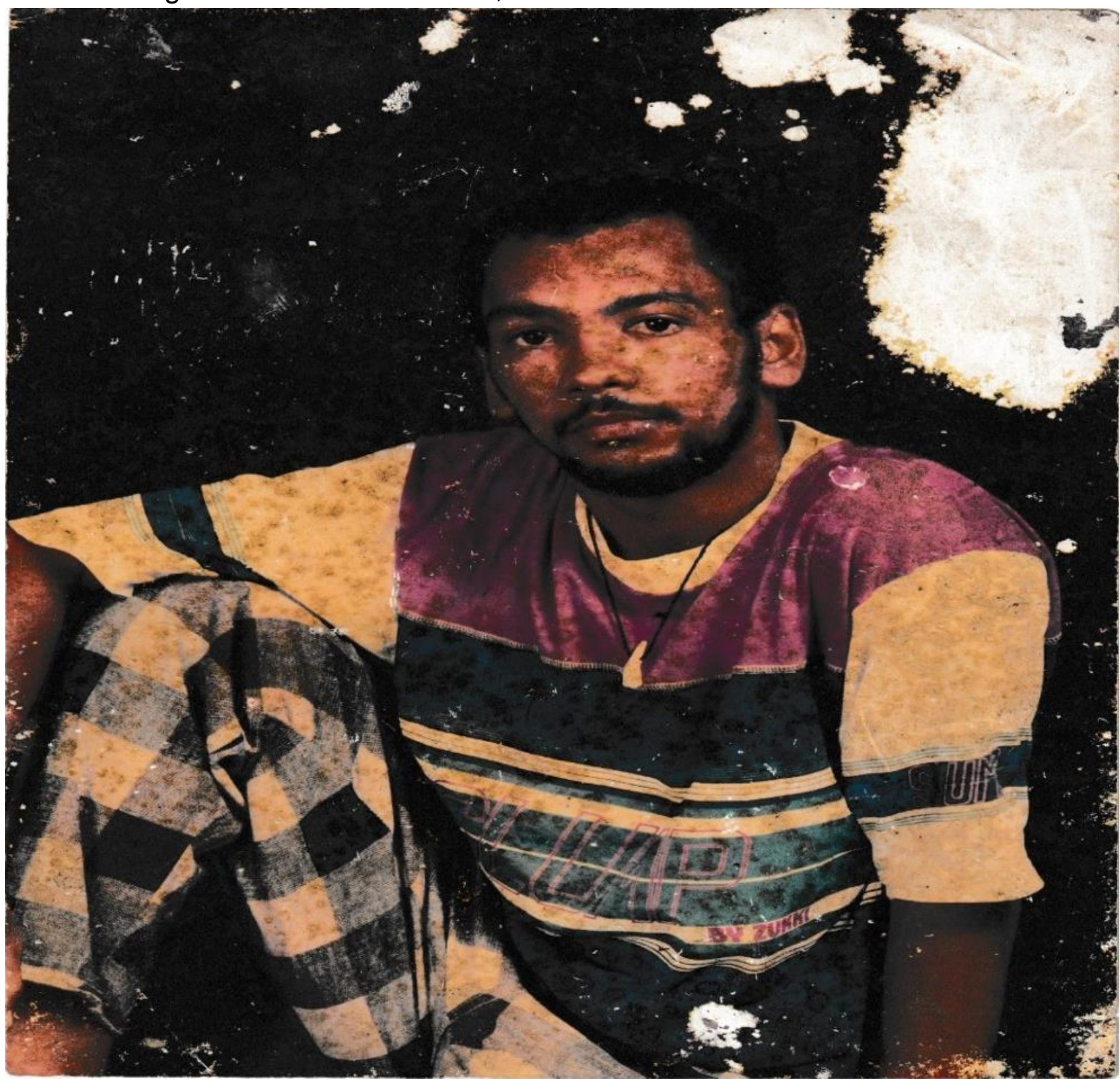

Fonte: Arquivo de mamãe, Lídia Pinto de Souza. 
A fotografia está meio desgastada pelo tempo e modo de conservação, mas ainda é possível perceber o colar de dente de cavalo, pendurado por uma lã de cor preta, e uma argola na orelha direita, que passei a usar assim que cheguei no Rio de Janeiro. Também é possível ver as roupas coloridas, calça de algodão e camisa poliéster, de uso comum desde o Recife. O ensaio foi realizado a convite de um fotógrafo que estava na avenida principal do Méier, zona norte do Rio. Confesso que não fiquei muito animado com o resultado e não acreditava que daria certo, como na verdade não deu, são várias fotografias com a mesma pose, mas algumas, como essa, mandei para minha mãe com um pequeno texto no verso: "Para a família mais linda do mundo! Nadinho [meu apelido de infância], 17.08.86".

Foi a primeira vez que fotografei dessa forma. Durante os flashes ficava pensando na possibilidade de mudar de ramo, ainda que o corpo parado em pose não me atraísse tanto quando comparado a um que se movimentava. No fundo, a arte era o caminho para acalmar o tormento de como sobreviver, principalmente porque minha ex-mulher já estava grávida de uns sete meses da minha primeira filha.

Fiquei de maio até junho ou julho de 1985 ministrando aulas numa academia que se chamava Academia Meier Training Center, que ficava na zona norte da cidade. Nessa academia eu recebia por hora-aula e eu só tinha um aluno, então, o que eu fazia? Como eu recebia por mês pegava uma parte desse dinheiro e pagava a mensalidade desse meu aluno, o Jocelim. Eu tinha uma pequena vantagem, o dinheiro que eu recebia dava para pagar a mensalidade dele e ainda ficar com algum troco. $O$ gerente da academia percebeu que não tinha condição de continuar ministrando essa aula, então me dispensou.

Como nós estávamos montando um projeto, um espetáculo, que estrearia em breve, eu acabei ficando parado depois da dispensa. O nome dado ao espetáculo foi Os Ashantis e, por causa desse projeto, fui convidado a ir na Escola Estadual de Dança Maria Olenewa, pertencente ao Teatro Municipal do Rio de Janeiro, junto com o Sérgio Silva, que era um dos produtores do espetáculo, junto com Jorge Lafond, a Vera Verão, comediante já falecido. Chegando na Escola de Dança fui apresentado a algumas pessoas. Entre todos, um deles me reconheceu, acredito que era o técnico de som, o Ari. Ele afirmou que eu era um grande bailarino e que o grupo que eu fazia parte era um dos melhores do Brasil. E eu fui conversar com Maria Luiza, a diretora na época, e acabei sendo aceito para ministrar aula. Confesso que ministrava as aulas com muita dificuldade, porque eu já não recebia por hora-aula, mas por percentual de alunos, e tinha poucos alunos. No início eram só dois: a Cristina, fisioterapeuta; e o Sérgio Galvão.

Fiquei com esses dois alunos com muita dificuldade, porque eu estava acostumado a trabalhar com ritmos com percussão ao vivo, mas eu não tinha como pagar um percussionista, nem tínhamos instrumento. De qualquer forma, fui ministrando as aulas com fita cassete, já que nessa época ainda existia o gravador e fita. Com muita dificuldade conseguimos chamar um ogã para tocar o atabaque, era um ritmo totalmente diferente do que estava acostumado, mas acabei aprendendo a tocar o instrumento quando não estava expondo os movimentos e o inseri no curso. Depois de algum tempo as aulas tiveram uma certa aceitação, pois o Instituto Nacional de Artes Cênicas do Rio de Janeiro fez uma divulgação sobre o trabalho desenvolvido por mim. 
Por causa disso acabei atraindo alguns estudantes para Escola de Dança e, nesse meio tempo, em 1985, o espetáculo que estávamos montando, Os Ashantis, estreou. Já no próximo ano montei outro espetáculo, chamado Heranças de uma cultura. A partir dele recebi um convite para coreografar uma novela chamada Helena, de Machado de Assis, que foi produzida e exibida pela extinta TV Manchete. Essa gravação teve aspectos curiosos, porque eu não dancei nessa novela, eu apenas coreografei algumas cenas e me rendeu um bom dinheiro, embora eu tivesse consciência de que os dois cavalos que conduziam a charrete da atriz principal ganhavam mais do que eu. De qualquer forma, com o que ganhei nesse trabalho, consegui comprar meu primeiro carro, um Chevette, que eu apelidei de trovão vermelho. Barulho arretado!

Voltando ao Rio de Janeiro de 1985, eu cheguei solteiro à cidade, em maio. Em agosto eu estava apaixonado pela minha primeira esposa. Fomos morar juntos e acabamos fazendo também uma boa parceria artística. Ela estava iniciando o trabalho nas artes e viu ali uma grande oportunidade de também trabalharmos juntos, montarmos um espetáculo. Chegamos a criar uma companhia de dança chamada Edilson Sheriff Companhia de Dança Afro do Rio. Fruto dessa parceria foi também o espetáculo Heranças de uma cultura, porém, com melhor estrutura que o anterior porque fizemos pequenos investimentos no grupo e conseguimos ensaiar por mais tempo, selecionar o corpo de baile etc. Com o espetáculo, andamos por Minas Gerais.

Em 1986, eu já estava firmado no Rio de Janeiro, a Escola de Dança Maria Olenewa já estava dando alguns poucos frutos, já que eu ministrava aulas nas segundas, quartas e sextas-feiras. Na época eu tinha bastante interesse em divulgar minhas aulas, pois era a única fonte de renda que tinha. Por causa disso acabei procurando uma empresa de publicidade, com anúncios em algumas lixeiras do centro do Rio de Janeiro. O pagamento garantia o anúncio por um tempo e o valor era razoável, mais ou menos um salário mínimo. Inclusive, essa história de salário mínimo me acompanha, porque, na época, acabei pagando um livro que tenho até hoje com esse valor.

Naqueles tempos eu não tinha muita informação sobre a cultura afro-brasileira, embora eu já estivesse envolvido com ela há mais de cinco anos. Por não ter muito conhecimento sobre Orixás, dos arquétipos dos Orixás, das lendas etc., eu acabei comprando o livro Orixás, de Pierre Verger. Comprei esse exemplar num evento Ciclo do Livro, se não me engano esse era o nome da feira literária. Eu estava indo para a Escola de Dança Maria Olenewa, quando passei por essa feira e resolvi comprá-lo, e ele realmente era o mesmo preço de um salário mínimo da época, era também o único dinheiro que recebi naquele mês, pelo trabalho com as aulas. Esse livro me rendeu muita coisa boa, foi por meio dele que estudei para montar espetáculos e ministrar aulas com mais segurança e que construí minha dissertação de mestrado.

Voltando à publicidade das aulas, pois é um ponto-chave nessa história, a divulgação ficou por cerca de seis meses na Cinelândia. Era uma placa e ficava muito orgulhoso quando passava e via meu trabalho sendo divulgado. Se não me engano a placa informava: "Dança afro primitiva com professor Edilson Sheriff", usei meu pseudônimo, pois era conhecido dessa forma. 
Sempre que chegava alguém para se matricular eu perguntava se tinha chegado até lá por indicação ou pelo anúncio e as pessoas geralmente diziam que tinha sido indicação de um ex-aluno ou só que ouviram a batucada e resolveram entrar. Eu acho que a divulgação não causou o impacto desejado, mesmo tendo sido um investimento alto.

No entanto, certo dia, recebemos uma pessoa chamada Geny Togun e o seu filho, o James, um garoto que acredito ter 12 anos na época. Finalmente uma pessoa tinha sido atraída pela bendita placa da Cinelândia. Essa pessoa era professora na Universidade Estadual do Rio de Janeiro e ministrava a disciplina de Voleibol, no curso de Educação Física. Acabou que ela gostava tanto das aulas que me convidou para ministrar um curso de extensão na universidade, mas eu não tinha um currículo acadêmico, logo, não poderia ministrar o curso. Naquele momento, ela me incentivou a cursar Educação Física dizendo que eu não iria ficar com o corpo bonito para sempre e nem poderia "bater bunda" para cima e para baixo por toda minha vida, ainda afirmou que eu me daria muito bem no curso.

Confesso que fiquei um pouco chateado com essa fala, isso já era perto do final de 1986, inclusive minha filha tinha acabado de nascer em outubro. De fato, eu estava ganhando um certo dinheiro e até pagava uma espécie de motorista para me levar aos lugares num Fusca. O motorista se chamava Fernando, era cobrador de ônibus e falava inglês. De qualquer modo, eu e minha ex-esposa tínhamos feito um pequeno investimento num salão de cabeleireiro e era desse salão que nós tirávamos parte de nosso sustento e investíamos no grupo de dança.

Nessa mesma época, eu estava ensaiando um grupo chamado Os Catastróficos, idealizado pela própria Geny. Esse grupo saiu da Escola de Dança, ou seja, eram pessoas que faziam aula comigo nas segundas, quartas e sextas-feiras e, aos sábados e domingos, eles ensaiavam comigo, inclusive a Geny, quem mais me incentivou a criar esse grupo. $O$ engraçado é que algum tempo depois, junto com a Geny, eles me convidaram a sair do processo coreográfico. Isso mesmo, me descartaram!

Ainda continuei nesse trabalho por algum tempo, mas fui estudar Educação Física nas Faculdades Integradas Castelo Branco. Fiz o vestibular numa faculdade privada, mas gostaria de ter sido resultado das cotas raciais, acredito que, se fosse, seria um professor melhor do que sou hoje, com ensinamentos de docentes de uma universidade federal, por exemplo, além, é claro, de talvez ter me envolvido com algum projeto de pesquisa.

Para entrar no curso de Educação Física naquela época, nós tínhamos de fazer um teste de habilidades específicas, que consistia em correr, saltar e nadar. Aliás, nadei estilo borboleta e os avaliadores pensavam que eu ia morrer afogado, mesmo assim passei no teste, tinha uma boa coordenação, força e agilidade. Nas provas de Inglês e de Português, já não fui bem, tirei notas baixas. Lembro como se fosse hoje de quando saiu o resultado do vestibular e eu fiquei procurando meu nome no mural. Todos os dias ia na faculdade, mas meu nome não aparecia nas listas. Não apareceu na primeira chamada, nem na segunda e muito menos na terceira. Meu nome só veio aparecer exatamente na quinta chamada. Eu tinha feito 510 pontos, acho que fui o último a ser chamado na última chamada.

Comecei a fazer o curso, mas confesso que eu queria ter feito Psicologia Social também. A primeira disciplina teórica que tive foi Estudos de Problemas Brasileiros com o professor Carlos Venceslau, certamente já falecido. Achava a aula muito interessante, 
pois era uma espécie de aula-seminário com as turmas ingressantes de outros cursos também. Depois, comecei a ter aula de Sociologia com o professor Augusto, apelidado pelos veteranos de Durkheim, porque ele só falava Durkheim, Durkheim, Durkheim, Durkheim, tá? Gostei muito da disciplina. Inclusive, perguntei a ele como era dar aula de Sociologia, e ele me respondeu: "a lei te faculta isso, você pode ministrar aula de Sociologia, se especializar em Sociologia e trabalhar com essa matéria". Acho que segui seu conselho, até hoje ministro essa disciplina.

Gostei muito também da disciplina de Psicologia, até me apaixonei por uma das professoras, chegando ao ponto de me declarar a ela, a TCOT Linda. Então, essas disciplinas sempre tiveram um certo interesse da minha parte, e isso foi muito bom, pois sempre me motivaram a continuar cursando Educação Física, mesmo que fosse um curso que não desejava ter feito e não gostava muito, embora nunca tivesse sido reprovado em nenhuma disciplina, pois sempre fui um aluno médio. Ficava aqui e ali numa prova final, mas reprovado nunca fiquei.

$\mathrm{Na}$ faculdade as pessoas começaram a me identificar como um profissional da área de dança. Lembro de que muitos alunos tinham dificuldade com a disciplina Rítmica e Dança. Depois de Fisiologia essa disciplina era a que mais reprovava. $\mathrm{E}$ eu, felizmente, consegui ajudar vários colegas da minha turma e de outros períodos também. Inclusive, montei espetáculos, mesmo no final do semestre, quando cursava a disciplina e, depois, quando estava em períodos mais avançados, passei a ajudar outros estudantes.

$\mathrm{Na}$ verdade eu cobrava uma espécie de mensalidade para exercer esse trabalho, no qual ajudava-os com as dificuldades de coordenação motora e ritmo. Ministrei algumas aulas e fiz apresentações num evento chamado Painel de Dança. Normalmente eu juntava turmas inteiras de 40 a 70 estudantes num só espetáculo e, em determinados momentos, ainda me apresentava fazendo um ou dois solos. Foi, portanto, durante a minha graduação na licenciatura em Educação Física, em que pude experimentar, simultaneamente, o meu impulso artístico e um pouco do conhecimento acadêmico que me era disponibilizado pelos professores.

Por coincidência, num dos momentos escavando o que tinha dessa época de faculdade para registrar nesta tese, acabei encontrando uma fotografia de uma das apresentações no Painel de Dança, nas Faculdades Integradas Castelo Branco; hoje, Universidade Castelo Branco. Posso garantir que foi uma das melhores épocas da minha vida, os primeiros passos no processo de transmigração do campo arte-ciência. 
Figura 10 -

Dança afro, painel de dança nas Faculdades Integradas

Castelo Branco, Rio de Janeiro, 1989.

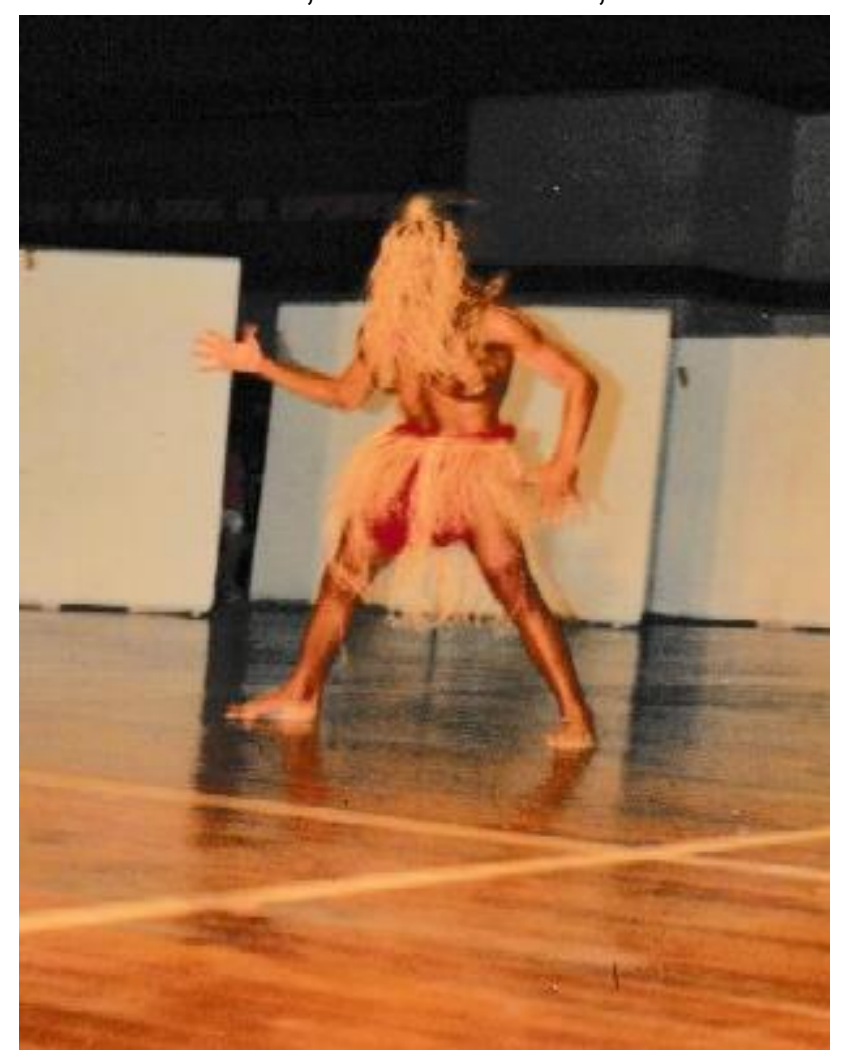

Fonte: acervo do autor.

Esse registro é de junho de 1989. Observa-se que estou com o Esculápio, a cobra jiboia que durante muito tempo me acompanhou nos espetáculos de dança afro. Ela foi um presente que ganhei de uma das minhas alunas de dança, a Vera, que era farmacêutica da Fundação Oswaldo Cruz. Sei que isso pode parecer um tanto engraçado e por vezes repugnante, mas também já fui chamado de o 'homem da cobra'.

De volta à fotografia, esse foi um dos dias mais importantes em que passei na faculdade, além da consagração do solo com a jiboia, o momento foi propício para novos contatos profissionais. O meu campo artístico precisava ser ampliado, para que eu pagasse a minha graduação, e esses eram os momentos em que eu podia mostrar minhas habilidades artísticas e reorganizar as agendas de shows.

A próxima fotografia também é desse mesmo ano, em Uberaba, Minas Gerais, quando ministrei um curso para os alunos de uma academia de ginástica. $O$ convite veio depois que a professora Cleidimar, proprietária da academia, que estava fazendo um curso de especialização na Castelo Branco, assistiu a esse momento no Painel de Dança. 
Figura 112 -

Apresentação de dança afro, Praça Rui Barbosa, Uberaba/MG, 1989.

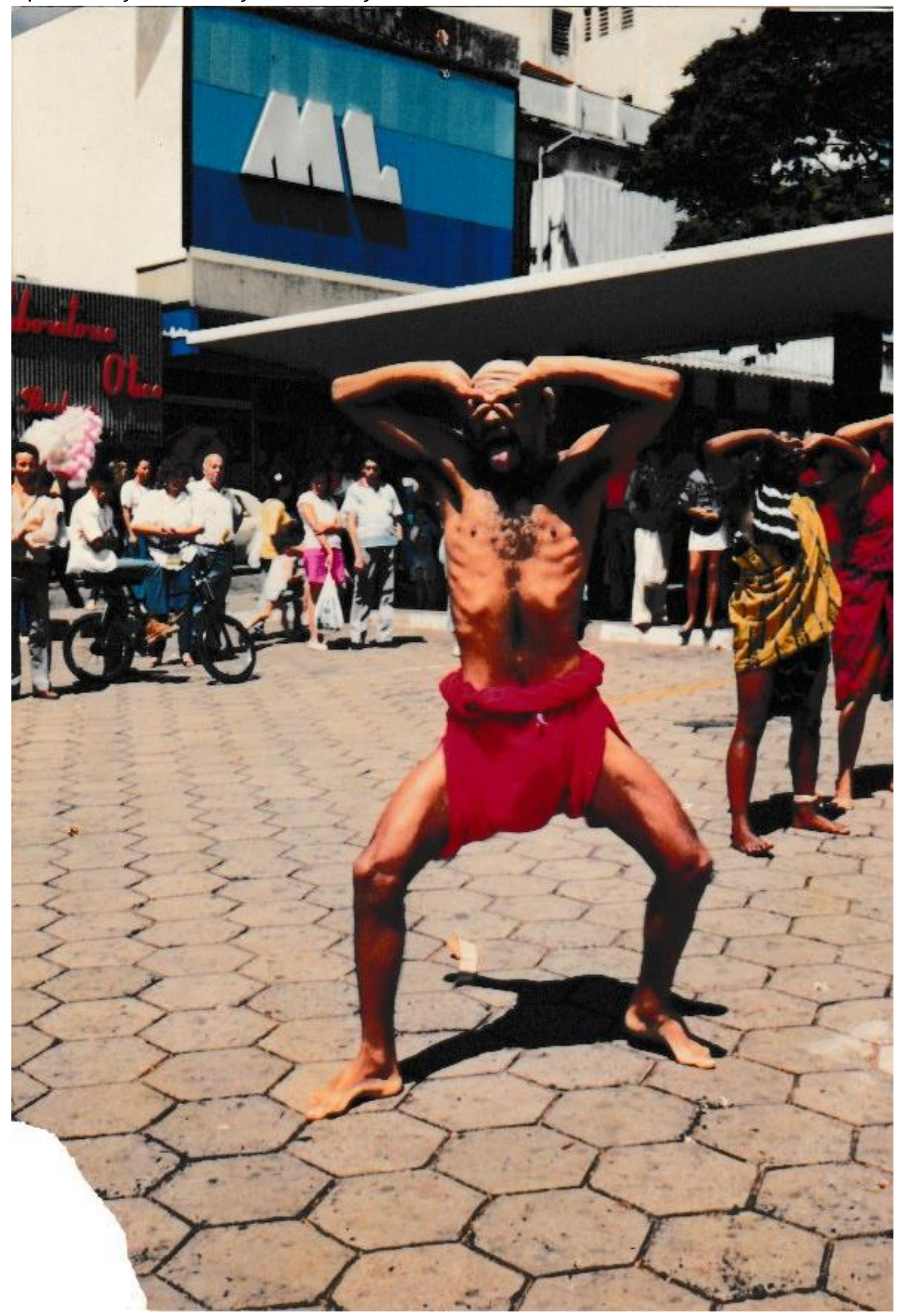

Fonte: acervo do autor. 
No primeiro plano estou executando um gesto meio animalesco, tentando passar a ideia de um olhar por trás de uma máscara 'animal humano. Aqui também tento mostrar as tensões corporais, no sentido de causar impressão de susto e medo que esse 'animal' pode provocar. No segundo plano, à direita, estão duas alunas do curso, tentando repetir os mesmos gestos, numa apresentação final do referido curso, que aconteceu no intervalo para o almoço, às $12 \mathrm{~h}$.

No verso da fotografia, a professora Cleidimar, minha anfitriã e fotógrafa, escreveu o seguinte: "Lembrança do $1^{\circ}$ curso em Uberaba - Academia Studio Baila - 23/08/89, e hoje estamos juntos, e amanhã estaremos mais [...]. Local, Pça. Rui Barbosa em frente à Academia", e assinou em seguida.

Durante a época de faculdade ajudei muitos colegas a se formar porque eu investia profissionalmente nessas pessoas. $O$ investimento foi tão alto do ponto de vista da Faculdade Castelo Branco que um professor chamado Eugênio, da disciplina de Estágio Supervisionado Curricular, me convidou para ministrar aulas no curso de especialização quando eu ainda estava no $6^{\circ}$ ou $7^{\circ}$ período. A faculdade havia criado o curso recentemente e muitos dos meus professores eram alunos. Naquela época era um pouco mais fácil, você terminava a graduação e podia dar aula na faculdade. Lembro que tinha um professor que havia acabado de ministrar aula de ginástica para a minha turma de graduação e foi ser meu aluno nesse curso de especialização. Eu achava interessante e meio absurdo como eu, que tinha sido seu aluno há alguns semestres, passei a ser professor dele naquela disciplina. É provável que o professor Eugênio, coordenador do referido curso, tenha criado alguns problemas lá, porque várias pessoas achavam que era exagero da parte dele me contratar ainda enquanto estudante de Educação Física para ministrar aulas num curso de pós-graduação lato sensu, na disciplina Educação Física e Ritmos.

Quando estava terminando o curso de licenciatura em Educação Física, um colega de faculdade chamado Carlos me mostrou a divulgação de um curso de especialização que aconteceria em Cabo Frio, Região dos Lagos do Rio, pela empresa Palestra Sport. Eu decidi fazer esse curso também, que era de Psicomotricidade e Pedagogia do Movimento Humano e, por causa disso, após colar grau, eu já era praticamente um especialista.

Lembro que antes de colar grau houve um concurso de monografia. Na época, não era obrigatório e a faculdade resolveu fazer um concurso. A minha monografia foi sobre a dança afro primitiva e foi orientada por uma professora que não lembro o nome neste momento, mas o método dela era interessante e engraçado. Ela pediu para que eu escrevesse no caderno e realocasse algumas frases ou parágrafos que estavam no final da página para o começo, e eu tinha que cortar esses trechos e literalmente colar com cola tenaz onde tivesse melhor fluência. Dizia ela que era para encaixar melhor as ideias. É curioso como hoje isso é feito em frente ao computador e de forma virtual, basta pressionar algumas teclas, cortar e colar.

Enfim, eu ganhei o concurso, fiquei em primeiro lugar, ganhei uns $\operatorname{Cr} \$ 38.000,00$, que usei para pagar a especialização em Psicomotricidade e Pedagogia do Movimento Humano. Então passei janeiro e fevereiro de $1991 \mathrm{em}$ Cabo Frio. Este foi um momento 
muito importante da minha vida. Para a conclusão da especialização, aproveitei um pouco dos conteúdos da monografia e ampliei o texto. Isso me rendeu um trabalho interessante e eu decidi continuar escrevendo.

A minha motivação em escrever aconteceu um pouco antes disso. Antes mesmo de concluir a graduação, participei de um festival de dança do qual, na verdade, eu não queria participar, mas minha ex-esposa insistiu. Se tivéssemos ganhado o festival, ganharíamos também algum dinheiro. Era um festival com todas as modalidades de dança, aconteceu no Teatro João Caetano, no centro do Rio de Janeiro.

De dança afro eram somente dois espetáculos: um com CHN Grajau e o nosso, com a coreografia $O$ reinado do rei negro, tinha facão, cobra e fogo em cena. $O$ resultado aparentemente não foi muito bom do ponto de vista artístico. Por quê? Porque o CHN Grajau ficou em $3^{\circ}$ lugar, eram premiados os $1^{\circ}, 2^{\circ}$ e $3^{\circ}$ lugares, e o nosso grupo de dança não se classificou em nenhum lugar, o que me trouxe certa revolta, sem falar que não ganhamos nada.

Depois fiquei sabendo que o júri era constituído por cinco pessoas e, coincidentemente, na noite da dança afro, estavam presentes entre seus membros a matriarca da dança afro no Rio de Janeiro, MB Kathrin, e um de seus melhores ex-alunos, GDA Palhares, algo que que parecia normal às vistas de quem não conhecia o campo artístico na cidade maravilhosa, mas o que se tinha mesmo era a presença de duas pessoas que haviam ministrado aulas para o CHN Grajau e que poderiam ser chamados de avó e pai do coreógrafo. Sei que isso pode parecer leviano de minha parte, mas foi o que circulou na ocasião.

De qualquer forma, essa questão foi ruim do ponto de vista artístico, mas muito boa para minha escrita, pois me impulsionou a escrever um texto. Lembro muito bem que 0 que escrevi foi muito curto, meia lauda praticamente, dizendo o que era a dança afro primitiva, onde eu havia aprendido e que havia sido integrante do Balé Primitivo de Arte Negra de Pernambuco. Com essa escrita tentei dar uma satisfação com esse trabalho, porque fiquei revoltado. As Faculdades Castelo Branco, na época, imprimiram esse texto gratuitamente e eu fui distribuir na porta do Teatro João Caetano.

Quero deixar registrado que essa pequena revolta me impulsionou nos meus primeiros escritos sobre a dança afro. É óbvio que estou lembrando aqui também de momentos anteriores a esse, quando ainda estava aqui no Recife e fui convidado para mostrar o que eu sabia fazer, acredito que eu tinha que escrever alguma coisa do candomblé, não me recordo direito, mas esse fato no Teatro João Caetano foi importantíssimo, porque foi desse panfleto que surgiu a ideia de escrever a monografia para a conclusão da minha graduação, que me fez ganhar o concurso, como havia dito, e foi ampliada para a especialização.

Naquela ocasião, era a Vera, a aluna de dança que me presenteou com o Esculápio, a cobra jiboia, quem digitava os meus manuscritos e depois líamos juntos para sanar algumas dúvidas e, consequentemente, ampliar o meu trabalho. Então, o que eu quero dizer na verdade é o seguinte: foi com o dinheiro do concurso que paguei a minha especialização, um dos instrumentos necessários ao avanço dos meus estudos.

Além dessa importante evidência de capital cultural em processo de aquisição e os futuros efeitos daí decorrentes, o passo para a transmigração de campo arte-ciência foi testemunhado por várias pessoas no Teatro João Caetano, inclusive, pelos meus pais, 
que viajaram de ônibus do Recife para o Rio de Janeiro. Assim, não basta apenas o canudo nas mãos, é preciso testemunhas dessa aquisição, principalmente para um indivíduo e sua família, oriundos de um ambiente desfavorável, às margens das instituições universitárias.

\section{Figura 12 -}

Fotografia de Formatura em Educação Física, 1991.

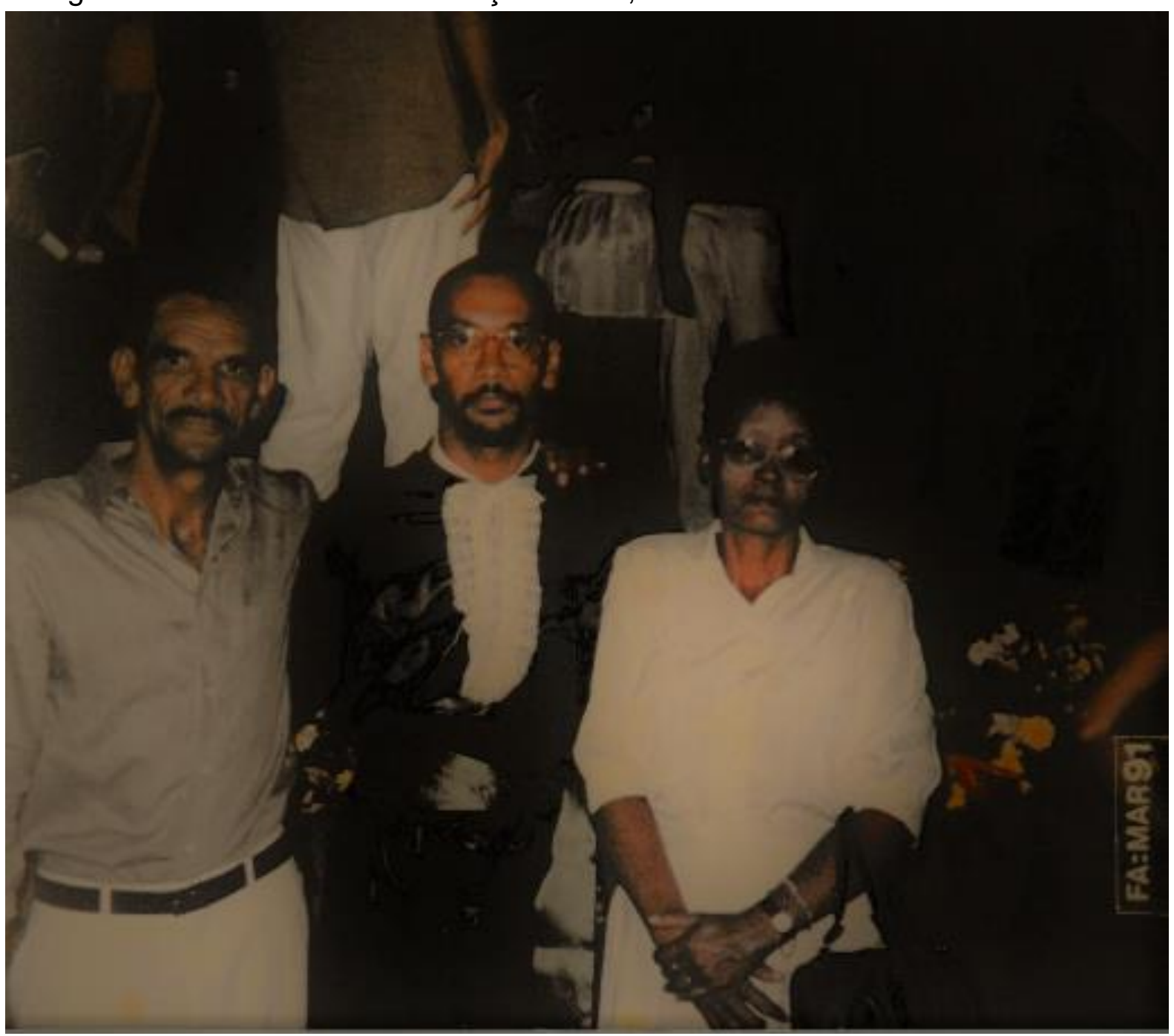

Fonte: arquivo de mamãe, Lídia Pinto de Souza.

A fotografia estava entre outros documentos guardados numa caixa de papelão, que, após o falecimento de mamãe, tive a curiosidade de ver para descobrir o que ela havia guardado de correspondência de quando eu morava no Rio de Janeiro. Na verdade, esse é apenas um dos registros de um pequeno álbum de sete fotografias relacionadas ao dia da minha formatura. Nesse registro fotográfico, provavelmente, feito pela empresa responsável pela cerimônia, estou entre meus pais, que acompanharam minha diplomação. Como se pode verificar ao lado direito e abaixo da fonte, o registro é identificado pela sigla FA:MAR91, ou seja, formatura, março de 1991.

Como já disse, a colação de grau foi após eu ter cumprido com os créditos das disciplinas na pós-graduação lato sensu, promovida pela empresa Palestra Sport e chancelada pela Faculdade de Filosofia Ciências e Letras, de Arapongas, no Paraná, em 
janeiro e fevereiro de 1991. Após a finalização desse curso, fui convidado por um dos professores, o Sirdley para ministrar algumas aulas de dança como atividade de extensão nas Faculdades Clarentianas, em Batatais, São Paulo. Com apenas dois dias lá, alguém conseguiu fazer o registro que se segue.

Figura 13 -

Faculdades Clarentianas, Batatais, São Paulo, 1991.

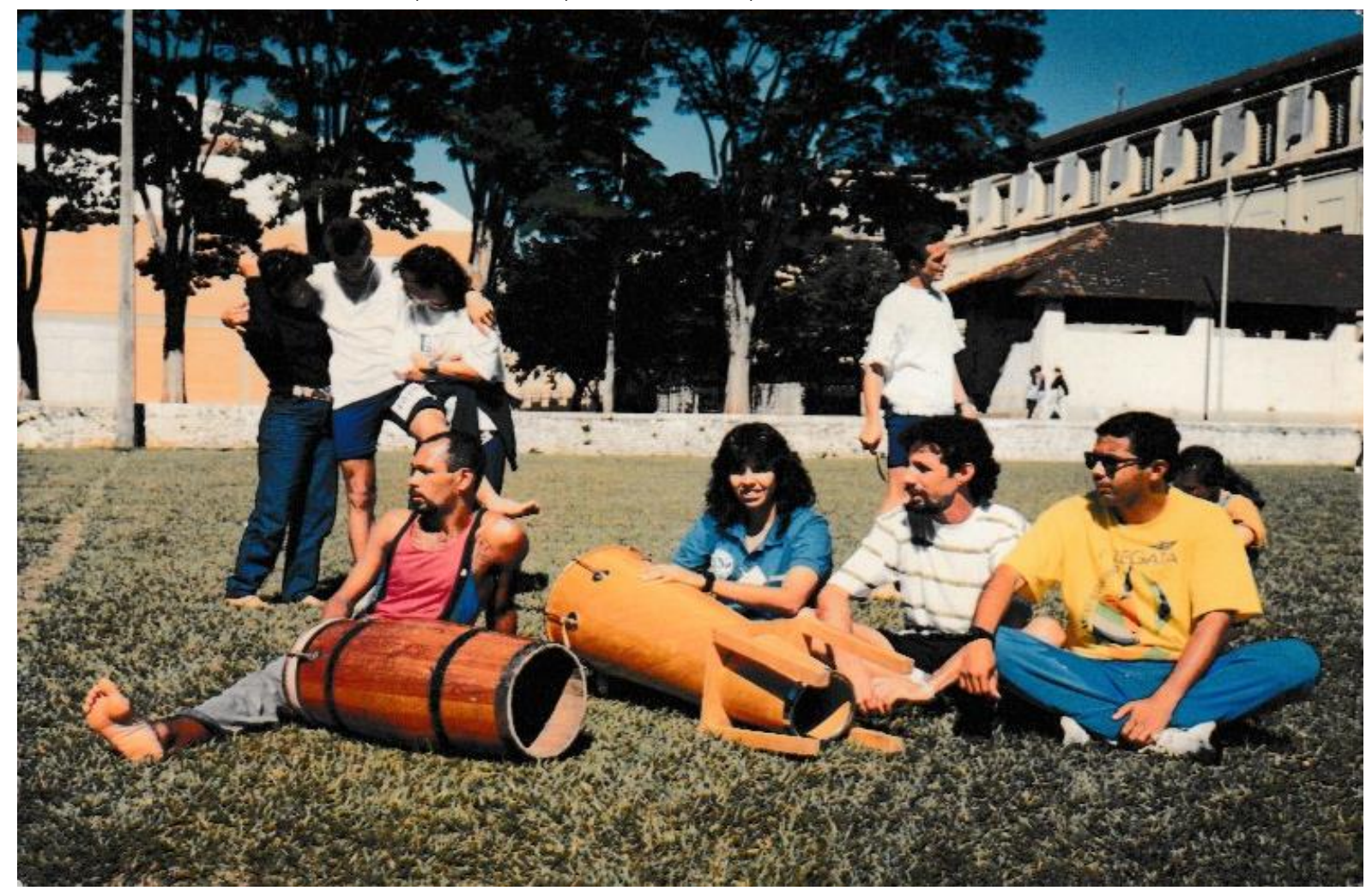

Fonte: acervo do autor.

Nessa ocasião, estávamos esperando os estudantes chegarem de outras atividades realizadas na Semana de Educação Física das Clarentianas. Da esquerda para à direita, estou eu, uma aluna do curso, o Carlos e Sirdley. Ao fundo, estão mais cinco alunos do curso, um deles havia torcido o pé esquerdo. Carlos foi meu contemporâneo nas Faculdades Castelo Branco, nós não estudamos juntos, mas nos conhecíamos em virtude das nossas preocupações comuns em progredir na carreira. Aliás, foi ele quem me incentivou a fazer o curso de especialização. Mais adiante, esse mesmo amigo acabou me informando que as inscrições para o mestrado em Educação Física na Gama Filho haviam começado e questionou se eu gostaria de tentar, eu o respondi que não.

No fundo, queria ir para o Museu Nacional fazer o mestrado em Antropologia pela Universidade Federal do Rio de Janeiro. Lembro-me de que o projeto seria uma análise comparativa entre a dança afro-brasileira e a dança afro de Angola, por meio do Balé Nacional de Angola, que tinha acabado de chegar ao Brasil. Eu havia assistido a uma das apresentações no Rio de Janeiro e fiquei muito interessado em fazer uma análise comparativa, do ponto de vista técnico da corporeidade e gestualidade, ou seja, questões relacionadas à técnica corporal e técnicas propriamente ditas, baseado na teoria desenvolvida por Marcel Mauss. 
A ideia era ousada, penso que nem hoje eu conseguiria fazer essa pesquisa, considerando o financiamento, que envolveria viagens a Angola. De qualquer forma, foi isso que apresentei no Museu Nacional e até passei nas primeiras etapas do mestrado, porque o projeto realmente tinha a ver com Antropologia, mas não passei na prova de francês, na verdade, acho que não passei nem no francês nem no inglês, que eram prérequisitos para garantir a aprovação. Então, peguei o projeto de volta e fui fazer minha inscrição para o mestrado que o Carlos tinha me dito, na Gama Filho.

Fiz a inscrição e passei. Na verdade, fiquei antes numa espécie de fila de espera e minha entrada condicionada à minha aprovação na prova de inglês, que eu tentaria novamente se houvesse vaga, o que aconteceu porque o Alexandre Vaz, que é professor hoje na Universidade Federal de Santa Catarina, um cara bastante conceituado na nossa área, acabou optando por outra instituição. Isso me permitiu ingressar no mestrado da Gama Filho. Obrigado, Alexandre!

Já como aluno do mestrado em Educação Física da Universidade Gama Filho, acabei conhecendo a Dinah Vasconcelos Terra e a Alda Lúcia Pirolo, que estavam muito empolgadas com o mestrado, afinal havia poucos cursos de stricto sensu em Educação Física no Brasil. A Dinah me reconheceu e perguntou se eu era o Sheriff: ao ter minha confirmação afirmou que eu dançava muito e que deveria prestar o concurso para ser professor na Universidade Federal de Uberlândia, onde ela era professora.

$\mathrm{Na}$ ocasião não dei muita atenção porque eu achava que não era muito a minha praia ser professor universitário e funcionário público, achava que estava longe de mim, que isso estava muito distante de minha capacidade, da minha condição. Além disso, eu já estava bem situado no Rio de Janeiro e era uma referência no campo artístico, mas a Dinah me encontrou mais umas duas ou três vezes no mestrado, até fizemos uma disciplina juntos, e ela continuou insistindo e me incentivando, dizendo que tinha um concurso para a área de dança que ninguém havia sido aprovado e que a "vaga era minha".

Ao chegar no final do semestre perdi o contato com a Dinah, mas, numa certa noite, na Escola Estadual de Dança Maria Olenewa, a secretária me chamou e informou que havia uma pessoa que estava ligando insistentemente para falar comigo. Segundo ela, essa pessoa falou sobre um concurso em Uberlândia. Assim, consegui falar com a Dinah, que foi minha procuradora e, após o envio da minha documentação, fez a minha inscrição no concurso. Inclusive, fiquei na casa dela quando fui realizar as provas.

Ao fazer o concurso, percebi uma coisa curiosa. Eu havia me preparado por cerca de dois meses, li vários livros sobre dança, um deles chamado $A$ pequena história da dança, de Antônio José Faro, pensei em ver algumas coisas sobre ballet clássico, dança contemporânea, moderna etc. Tudo isso com o objetivo de fazer uma boa prova, afinal achava que não passaria, eu conhecia, inclusive, um professor, o RM Claro, que havia feito a prova por duas vezes, ele até era um ex-aluno do curso de Educação Física de Uberlândia e não havia sido aprovado.

Para esse concurso havia nove pessoas concorrendo a uma única vaga. Eu passei na primeira etapa e o RM Claro também, era a prova escrita. Uma questão curiosa é que a prova escrita foi sobre ritmo e cultura, e aí, meu caro, [me referindo ao cachorro Spike], acabei fazendo uma excelente escrita, escrevi umas três laudas sobre essa questão, que fundamentei com Marx Weber, com o texto A esfera estética. 
Logo em seguida tivemos a prova de didática. Nela caiu um ponto similar, acho que foi a interveniência da cultura no ritmo ou algo parecido. Nessa parte falei bastante, abordei os ritmos da Bahia, Pernambuco e falei até sobre Daniela Mercury. Passei novamente e fui para a parte da entrevista. Nessa fase a banca era composta por três professoras e uma delas, a presidente, disse que me conhecia, que tinha me visto quando dancei com uma cobra. Perguntei, assustado, onde ela tinha visto e a resposta foi que ela tinha ido ao Encontro Nacional de Recreação e Lazer - Enarel -, em Brasília, quando apresentei um vídeo em que dançava com uma jiboia. Ela ainda me disse que, mesmo que eu fosse formado em Educação Física, eu era um artista e que eu desenvolvi um trabalho bonito e de referência no Rio de Janeiro. Ela ainda apontou para uma das professoras e disse que aquela também conhecia o meu trabalho. Após isso, perguntou se eu estava disposto a ficar em Uberlândia e ajudar na formação profissional dos estudantes ou se estava apenas testando como me sairia no concurso. Fiquei sem saída e tive que responder algo. Após 27 anos, posso dizer que o que afirmei, para aquele momento, era uma mentira, que estava disposto a passar no concurso e ficar em Uberlândia.

Depois da entrevista foi análise do currículo, passei também nessa fase. Nesse período, ainda estava fazendo o mestrado na Universidade Gama Filho. O tema da dissertação era relacionado à dança, óbvio. O problema é que continuar o mestrado, no Rio de Janeiro, e trabalhar em Uberlândia, em Minas Gerais, não daria certo, eu sabia que não teria condições físicas e financeiras para tantas idas e vindas. Assim, corri para tentar adiantar meu trabalho de mestrado.

Meu orientador na Gama Filho, foi o antropólogo Selo Miranda. Lembro que fui procurá-lo já perto de me mudar para Uberlândia e pedi algumas dicas para iniciar o meu trabalho. Estávamos numa fila no que eu acho que era o Banco do Brasil quando ele me sugeriu que eu procurasse alguns profissionais da dança, já que meu trabalho era nesta área, entrevistasse-os com um gravador, para uma entrevista piloto, e, se desse certo, fizesse mais, com outros profissionais, para que falassem sobre suas vidas e, provavelmente, a dança estaria num dos assuntos principais.

E aí, meu caro, [gravando e falando para o Spike], eu não tive dúvida, fiz logo nove entrevistas, porque eu não tinha tempo para ficar fazendo testes. Então mostrei a ele a entrevista piloto, e ele disse que o caminho era aquele. Assim, pediu que eu fizesse mais quatro e acabei realizando 11. Na verdade, fiz 21 entrevistas. Entretanto, a piloto foi destruída por minha ex-mulher, porque a entrevista foi concedida por uma ex-namorada, que também era do universo da dança afro. Eu até tentei recuperar o material, mas não teve jeito. O ciúme venceu a fita.

De qualquer forma fui para Uberlândia em 1993, cheguei no período de férias e fiquei na casa da professora Dinah, que já era considerada uma amiga. Ela estava de férias em outra cidade e eu fiquei, em sua residência, esperando ser oficialmente chamado para tomar posse. Enquanto esperava fiquei lá, sozinho, sem emprego, sem trabalho, sem dinheiro, mas fiz uma coisa que estou fazendo neste exato momento, eu gravei um pouco da minha história até ali, das dificuldades que eu estava encontrando para analisar 20 fitas, gravações importantes da dança. Gravei uma fala, inclusive, falando um pouco da minha representação acerca da dança afro e sobre a relação da dança afro e a religião, por exemplo. Fiquei com aquele material durante muito tempo. 
Quando resolvi tomar posse em Uberlândia tive que suspender o mestrado na Gama Filho, mas sabia que seria só temporariamente, que terminaria o mestrado em algum momento. Foi aí, então, que tive a ideia de me transferir da Universidade Gama Filho para a Universidade Federal de Uberlândia e isso significava passar de um mestrado em Educação Física para um mestrado em Educação Brasileira. Fui até a coordenação do mestrado em Educação da UFU, apresentei o projeto e fui aceito, conforme parecer do Colegiado.

Figura 14 -

Parecer do Colegiado do Programa de Pós-Graduação da Educação Brasileira da UFU, 1993.

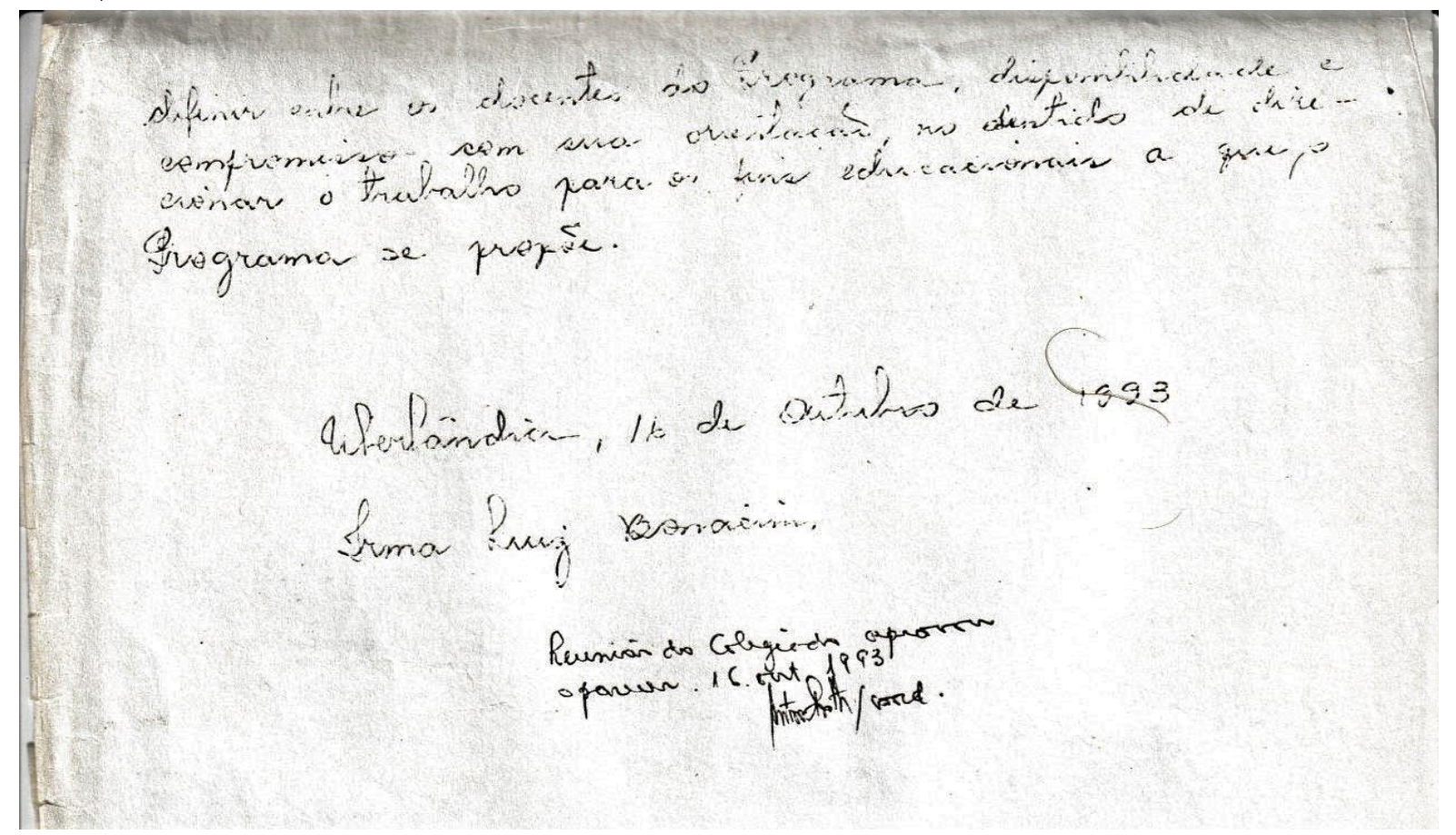

Fonte: acervo do autor.

Conforme consta no parecer, em reunião no dia 16 de outubro de 1993, o Colegiado do Mestrado em Educação Brasileira da UFU foi favorável à minha transferência. A parecerista, professora Irma Luz, numa de suas considerações, destacou o seguinte: "o aluno está envolvido com um tema de estudo que privilegia o aspecto cultural ligado ao fator étnico, o que deveria ser valorizado pelo Programa".

De fato, o parecer foi bem fundamentado e muito favorável ao meu ingresso ao curso, o que me deixou feliz naquele momento por estar sendo valorizado pelo que fazia há bastante tempo. Além disso, nas considerações finais, a professora fez um apelo para que um dos docentes do mestrado pudesse me acompanhar nas orientações da pesquisa.

Assim, encontrei no mestrado de Educação Brasileira a professora Regina Feltran, que me orientou nesse trabalho. Eu informei a ela dos desafios que já tinha encontrado, as fitas que tinha gravado, e ela me sugeriu a utilização da análise de conteúdo de Laurence Bardin. Segundo ela, por meio dessa análise, eu ia conseguir fazer meu trabalho, e fiz de fato. Regina Feltran me sugeriu ainda que eu incluísse no texto da 
dissertação a minha história de vida, minha própria história, e eu achei curioso, até fiquei tentado realmente a fazer isso, mas depois vimos que esse procedimento poderia inviabilizar o projeto, já que a banca talvez não aceitasse.

Chegado próximo do tempo de conclusão do curso, já que na época o mestrado durava em torno de três anos, eu tinha que fazer a qualificação do projeto, mostrando o que já havia escrito. Naquela ocasião, eu já havia concluído alguns créditos, algumas disciplinas, tudo aparentemente normal. Qualifiquei-me em Uberlândia, mas, na hora de defender a dissertação, o coordenador do mestrado na época, professor Antonio Chizzotti, disse que era impossível defender aquele texto porque havia uma incompatibilidade entre carga horária e as disciplinas que eu tinha feito na Gama Filho com as disciplinas que eram ofertadas no Programa de Pós-graduação em Educação Brasileira da Universidade Federal de Uberlândia. Isso me revoltou profundamente porque, se ele sabia disso, se era esse o problema, por que me aceitaram? Diante dessa negativa do Chizzotti tive que fazer um recuo tático e acabei voltando à Gama Filho para defender a dissertação. Na época, ainda tive que pagar uns $\mathrm{R} \$ 500,00$. Hoje, ao orientar meus mestrandos e doutorandos tenho muito cuidado com isso, para não os prejudicar em seus percursos acadêmicos. De qualquer modo, eu me sinto mestre em Educação Brasileira pela UFU.

Outro episódio desagradável foi protagonizado por meu ex-orientador da Universidade Gama Filho na banca de defesa da dissertação, porque ele aceitou meu convite, mas fez grandes, profundas e densas observações. Na verdade fez um arrazoado destruindo todo o trabalho que nós tínhamos feito junto à Regina Feltran. Achei deselegante da parte dele. Sei que isso tudo é um pouco chato, mas eu precisava contar essa história, essa experiência do campo acadêmico. É importante registrar que não é o conteúdo dos arrazoados que incomoda, mas é a forma como as coisas foram ditas. Durante algum tempo, guardei esse documento e acho que, até certo ponto, ele tinha razão para um determinado contexto, mas exagerou na dose do recalque.

Contudo, mediante o arrazoado apresentado, o que nós fizemos? Reaproveitamos o trabalho, demos uma outra dinamicidade ao texto, reorganizamos a dissertação e mandamos para ele. Isso foi feito em duas semanas apenas. Em seguida, ele me ligou num domingo, me parabenizou e avisou que na quarta-feira já iria defender o trabalho. Fui pego de surpresa, como iria convidar as pessoas para assistir à apresentação? Segundo ele, não poderia ser outro dia, pois iria viajar para Itália, para fazer o pós-doutorado. Em meu pensamento, questionei o motivo de sua participação, afinal, provavelmente, ele sabia que precisaria viajar.

Mediante esse diálogo num domingo logo cedo, agradeci, pedi desculpas e informei que não poderia defender o trabalho no dia estipulado por ele, pois realmente precisava ter algumas pessoas assistindo. Pedi a ele que indicasse uma outra pessoa para avaliar e ele indicou o Helder Guerra, coordenador do mestrado na época. Então, fiz uma excelente apresentação na defesa, gostei muito do resultado. Fui aprovado com louvor e indicado para publicação, embora depois tenha um desdobramento da publicação do livro, que conto mais adiante.

De qualquer modo, isso é um pouco da história da minha passagem pelo Rio de Janeiro e uma parte dela em Minas Gerais. Assim que terminei o mestrado, em dezembro de 1995, fui fazer uma disciplina como aluno especial na Unicamp, no primeiro semestre 
de 1996. Fui de carona com um colega que pretendia fazer o mestrado, o Sérgio Sérvulo. Minha pretensão era ser aluno especial na Faculdade de História e depois apresentar um projeto de doutorado nessa área, confesso que não queria nada com a Educação Física. No entanto, logo descobri que, naquele ano, a pós-graduação de História não estava oferecendo disciplinas para alunos especiais. Então, voltei para a Faculdade de Educação Física para esperar meus amigos, o Bertulino e o Sérgio Sérvulo, ambos professores de Educação Física, resolverem a vida deles: quais disciplinas eletivas que iam fazer como alunos especiais. Mas, cansado de esperar, aproximei-me do balcão da secretaria da pósgraduação em Educação Física da Unicamp e passei a folhear as disciplinas ofertadas naquele semestre. Vi uma disciplina chamada História da Educação Física no Brasil, com Ademir Gebara, na qual acabei me inscrevendo e, a partir dela, resolvi me inscrever também em Metodologia Científica, com Paulo Sales de Oliveira.

Naquele primeiro semestre de 1996 comecei a cursar essas duas disciplinas. Foi um momento muito difícil, eu estava me separando da primeira esposa e estava preparando, simultaneamente, um projeto de doutorado para História e outro para Educação Física. O plano era me inscrever para a seleção que saísse primeiro. Saiu a de Educação Física. No dia da defesa do projeto já fui com a namorada nova, minha atual esposa. Nesse momento, estamos com 23 anos de casados. Isso é outra história complexa, porque ela já havia sido minha namorada há 15 anos. Na defesa do projeto a banca foi constituída por três professores bastante renomados da Sociologia e História do Esporte, Lazer e Educação Física: Ademir Gebara, Heloisa Bruhns e Nelson Marcellino. Na hora da defesa Ademir Gebara perguntou se algum membro tinha interesse naquele projeto, e eles disseram que não. Então, ele disse: "se vocês não têm interesse no projeto, eu tenho". E afirmou que colaboraria com a minha pesquisa. Eu fiquei muito feliz, muito satisfeito. Já saí de lá sabendo que eu tinha passado no doutorado.

Voltei para o Departamento de Educação Física da Universidade Federal de Uberlândia e solicitei imediatamente minha saída, em licença capacitação, porque no mestrado não tive afastamento, nem bolsa. Entretanto, o Departamento me concedeu apenas 24 meses, sob o argumento de que outros professores também estavam saindo para o doutoramento naquele ano.

Apesar do pouco tempo, fiquei feliz. Eu sabia que ia para o doutorado com tranquilidade, faria minha matrícula e conseguiria a tão sonhada bolsa da Capes, cursaria as disciplinas obrigatórias e depois voltaria para Uberlândia para escrever a tese. Entretanto, não foi nada disso que aconteceu. Na verdade, eu estava saindo de um casamento e entrando noutro, minha mulher já estava grávida, e eu fui morar numa cidade mais barata, Americana, em São Paulo, além disso, meu pai faleceu em janeiro de 1997, exatamente nos primeiros sete dias que havíamos chegado na nova cidade. Com a morte de papai, tive que voltar às pressas para o Recife. Sem dinheiro voltei de carro, passando cheques na estrada, mas, infelizmente, não consegui ver o sepultamento do meu pai. Até hoje tenho remorso por não ter chegado a tempo.

Por fim, fiquei preocupado em perder a primeira matrícula do doutorado e, por consequência, perder a bolsa da Capes. Contudo, consegui fazer a matrícula por meio de uma procuração a um colega que fazia mestrado à época, o que me tranquilizou em relação ao início do doutoramento. 
Figura 15 -

Procuração que outorga matrícula do doutoramento na Unicamp, 1997.

PROCURACTOO

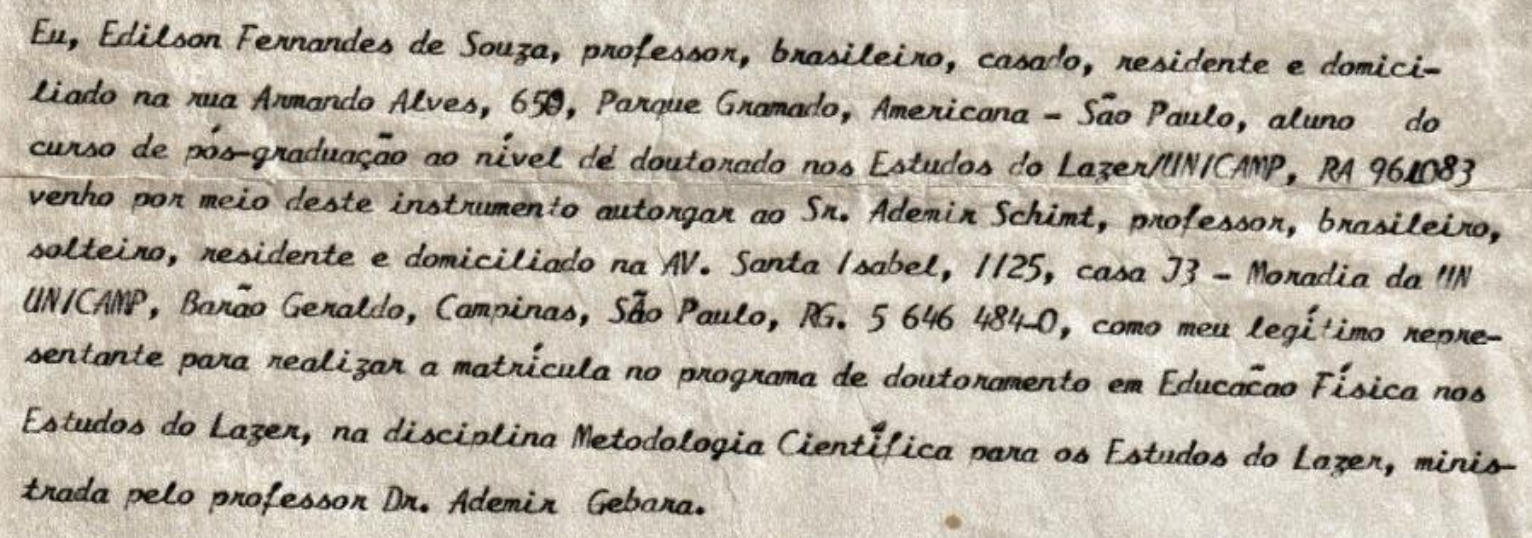

Recife, 31 de janeiro de 1997.

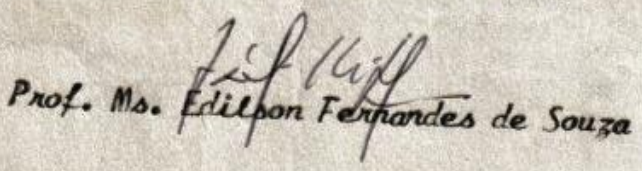

Fonte: acervo do autor.

Esse documento foi encontrado no acervo pessoal após as gravações dos áudios que servem de suporte para o enredo deste trabalho. Curioso foi encontrá-lo no exato momento em que me preparava para viajar à cidade de Americana com a minha esposa $\mathrm{e}$ a nossa primeira filha, para mostrar a maternidade e possivelmente a nossa residência no interior de São Paulo. De posse desse documento, conseguimos encontrar o imóvel e conversar com os atuais moradores. Assim, os arquivos pessoais, às vezes, nos resguardam surpresas agradáveis e muito úteis para a elaboração de algumas pesquisas, especialmente autobiográficas.

\section{Em Uberlândia-MG: teatro, academia, universidade}

Nas seções anteriores foi possível recordar parte do que envolveu a estreita relação entre o meu trabalho artístico de matriz africana e a transmigração para o campo acadêmico-científico, inclusive, com algumas tensões de natureza administrativa em programas de pós-graduação stricto sensu, o que serve não apenas para guardar na memória, mas, sobretudo, de experiência e aprendizagem. 
Contudo, depois de toda a turbulência no momento da matrícula do doutorado, expresso em documento na seção anterior, e problemas familiares, pensei em ir para Unicamp, fazer os créditos do doutorado por dois anos, depois retornar para o Departamento e, obviamente, escrever a tese. Mas não aconteceu nada disso. Já morando em Americana, na região de Campinas, e cursando o doutoramento, fui visitar minha filha mais velha, fruto do primeiro casamento, que morava em Uberlândia. Também resolvi dar uma chegada no meu ambiente de trabalho na UFU, onde encontrei o professor Silvio Soares, afastado para cursar doutorado na Alemanha, e o Gabriel Munhoz, acho que na PUC de São Paulo.

Numa das nossas conversas o Silvio mostrou-se muito feliz por estarmos estudando e recebendo a bolsa e ele ainda estava aperfeiçoando seu estudo na língua alemã. Eu também estava feliz, mas, naquele momento, ele me fez refletir, pois em seu discurso ficou claro que ele queria cursar o mais rápido possível para voltar ao Brasil. Isso me serviu como um conselho. Se o Silvio que tem mais tempo de afastamento que eu, quer voltar, então, por que não adiantar a minha tese? A partir daí, comecei a trabalhar fortemente para terminar o meu doutorado.

Gostaria de falar um pouco sobre minha chegada em Uberlândia. Cheguei lá em 1993, como eu já falei, foi uma chegada de muita apreensão porque eu estava saindo de uma situação em que era autônomo no Rio de Janeiro para ser funcionário público federal. Assim que cheguei em Uberlândia, os primeiros anos foram anos muito intensos, comecei a desenvolver um projeto de extensão chamado Grupo de Dança Afro da UFU, na verdade, antes disso, antes desse projeto de extensão, fui convidado por um estudante na época, o Neil Franco, que hoje é professor da Universidade Federal de Juiz de Fora, para encenar uma peça de teatro.

$\mathrm{Na}$ época $\circ$ Neil era estudante do $6^{\circ}$ período. Ele e os colegas estavam desenvolvendo um trabalho de teatro e, como soube que eu tinha passado no concurso para as disciplinas Rítmica e Dança, na Federal de Uberlândia, ele acabou me convidando para dirigir um espetáculo que ele estava participando. Se não me falha a memória, o nome do espetáculo era Tudo isso e o céu também, do dramaturgo Azir Bajour.

Comecei a dirigir esse espetáculo e depois dirigi um outro, um monólogo, com João Cardoso, a peça Apareceu a margarida, do dramaturgo Roberto de Athayde. É engraçado porque o Neil nunca foi meu aluno na universidade, mas era uma pessoa que estava muito próxima, um monitor voluntário. E logo ele entrou para o meu projeto de extensão, o Grupo de Dança Afro da UFU. A estreia foi em Salvador, na Universidade Federal da Bahia, na Faculdade de Dança, a mais antiga, criada em 1958.

Nosso último espetáculo, aliás, o último que criei no projeto de extensão, foi Os deuses também amam. Dele, participavam 22 pessoas, entre estudantes de graduação e da comunidade. O espetáculo trazia o $\operatorname{itan}^{24}$ de Xangô e suas três esposas: lansã, Oxum e Obá.

Fico feliz em saber que hoje o Neil é professor da Universidade Federal de Juiz de Fora, inclusive, professor de Dança. Então, fico muito feliz de saber que encontrei um pouco do resultado do meu trabalho na UFU, da mesma maneira com o Adriano Ribeiro,

${ }^{24} \mathrm{Em}$ iorubá, um itan diz respeito à história de uma determinada divindade. Uma história mítica. 
que hoje é cantor, mas que entrou no Grupo Afro da UFU e depois foi para o curso de Artes Cênicas. Então esse trabalho foi muito interessante dentro da universidade. Eu estava naquela intermitência artística e acadêmico-científica, professor universitário e dançarino no grupo, nos espetáculos, da mesma forma que fazia no Rio de Janeiro, com a mesma vestimenta, seminu, porque eu entendia que era um trabalho de arte. Isso para mim não era um problema moral ou ético; pelo contrário, era um trabalho de grande valor estético.

Nesse contexto a ideia era promover e valorizar parte da estética africana, afrobrasileira. O curioso é que, assim que cheguei na Universidade Federal de Uberlândia fui convidado para participar de um projeto de extensão para portadores de necessidades especiais, com deficientes ou mobilidade motora reduzida. Na época, a UFU era e ainda é referência nesse tipo de trabalho voltado para a pessoa com deficiência, tendo, inclusive, participações diversas em competições nacionais e internacionais.

Vários professores do Departamento de Educação Física participaram do projeto, inclusive, um dos gestores do Centro de Ciências Biomédicas, os professores Esquivo Grosso e Cowboy do Sirradoo. Acredito que esse tenha sido o primeiro embate que tive na universidade, pois agradeci o convite, mas não aceitei, disse que já tinha planos de desenvolver um projeto de extensão. Eu não posso aqui ser leviano para qualquer coisa antiética, mas alguns colegas já antigos acharam que o processo que eu passei de sindicância, logo no primeiro ano de trabalho na UFU, foi em virtude de não ter aceitado o convite para participação nesse importante projeto institucional.

$\mathrm{Na}$ época eu estava em estágio probatório, que duraria por dois anos, e poderia perder o cargo público. Ser demitido. Mas por que passei pelo processo de sindicância? Acho que é importante dizer que a minha cabeça estava centrada na arte negra, africana. Eu entendia que a universidade era um ambiente de expressão, de experimentação e desprovido de preconceitos, mas, infelizmente, foi um ledo engano. Hoje tenho clareza disso. Acredito que a universidade reproduz os mesmos valores da sociedade que ela é parte, estruturada pelas tensões e disputas entre indivíduos e grupos, que jogam consciente e inconscientemente, mas também estruturando-a como a concebem.

O que eu entendia, de fato, era sobre dança afro, eu era profissional coreógrafo dessa modalidade. As danças populares, tampouco, eram um problema, mas eu precisava desenvolver outras técnicas; por exemplo, da dança contemporânea, do jazz etc., modalidades muito difíceis para minha formação. Assim, comecei a me interessar por dança-teatro.

A aplicação dessa técnica nas aulas que ministrava na universidade me trouxe um problema sério porque os estudantes que cursavam a disciplina tinham que desenvolver algum conteúdo baseado nessa técnica para as avaliações. Inicialmente, precisavam debater e escolher um tema, além de roteirizar as cenas. Depois disso, precisavam desenhar todo o percurso dos personagens previstos no roteiro e, por último, tinham que representar corporalmente, com ou sem música. Tudo feito por eles mesmos.

Um grupo de estudantes escolheu desenvolver um tema que chamaram de amor, sexo e paixão ou amor, sexo e traição, e a história que criaram foi a de um homem e duas mulheres. $\mathrm{O}$ homem estava em casa quando chegavam as duas mulheres. Uma delas era 
a sua esposa. Enquanto a esposa ia para outro cômodo, o homem beijava a outra mulher. No entanto, lembro que, no momento da apresentação, isso não ficou muito explícito e houve uma confusão em relação a quem era a esposa e a visitante.

Questionei o desenvolvimento da coreografia e disse que tecnicamente a história não estava clara. O que deveriam ter feito era demarcar o papel de cada personagem ao chegar na cena, darem os sinais importantes da teatralização para dizer quem era a esposa desse homem, quem ele realmente estaria traindo. Então, quando as duas mulheres chegam à casa, o homem teria que ter um dos dois comportamentos: beijar uma das mulheres e apertar a mão da outra ou apertar a mão da moça que ele era amigo e, em seguida, desenvolver a cena. Assim a plateia saberia quem seria a esposa, ao beijála, e quem seria a visitante. Foi dessa forma que expliquei aos estudantes e foi o suficiente.

De qualquer modo, eu ainda pensava como um artista tentando despertar no outro algum interesse pelas formas de representação. Além da dança-teatro, eu tentava fazer com que os estudantes experimentassem com vários exercícios outras habilidades corporais. Numa outra aula, pedi para que os alunos deitassem no tablado, um ao lado do outro, ombro a ombro, de modo que um pudesse servi" de ponte, passando por cima, como se fosse um rolo compressor. Isso é uma coisa muito simples. Várias técnicas trabalham com isso, como teatro, dança, expressão corporal. No ensino fundamental, trabalhamos com isso, não tem nenhuma conotação sexual.

Outro fundamento da dança que desenvolvemos foi a suspensão e elevação. É você ter a capacidade de levantar realmente um indivíduo, seja homem ou mulher, sobre a cabeça. É um dos mais importantes fundamentos da dança. No entanto, foi a partir dessas atividades, especialmente com a dança-teatro que surgiu uma denúncia. Uma denúncia anônima de que eu estava atentando contra a moral e bons costumes da sociedade uberlandense, da universidade, porque "estava estimulando os estudantes a pegarem na virilha das meninas".

Fui processado! Um processo de sindicância muito doloroso em que tive que prestar esclarecimentos à Procuradoria da Universidade. Alguns professores foram chamados para falar sobre os meus procedimentos pedagógicos e estudantes tiveram que dar depoimentos no caso, inclusive, favoráveis ao meu comportamento, afirmando que era normal e aceitável o tipo de aula ministrada para uma instituição universitária.

Em meio a essa confusão, eu declarei que considerava que aquela situação gerada era própria de uma normalidade pedagógica, inclusive, a disputa de narrativa sobre o ocorrido. Afinal, o tema tinha sido criado pelos próprios alunos. Mais tarde, fiquei sabendo que alguns professores do Departamento viveram, na vida real, algo semelhante ao tema criado pelos estudantes.

Algumas pessoas mais antigas me contaram que, um tempo antes dessa situação, três professores se envolveram em confusão parecida: um casal de professores e um outro também casado com uma ex-aluna. Prefiro não entrar em detalhes, por acreditar que foge do assunto deste trabalho, mas disseram que essa representação dos meninos acabou levantando a história negativa daquele ambiente.

Nesse contexto complicado, colegas do próprio Departamento disseram que o que estava passando era uma retaliação pelo que eu "havia feito". Não consegui entender, mas é como se eu tivesse feito algo realmente muito errado, como se quisesse provocar 
um rebuliço no Departamento a partir dessa história institucional de traições. De qualquer modo, eu fui à Procuradoria e prestei esclarecimentos. Nesse momento, eu apelei, porque vi que a situação estava muito difícil, muito grave mesmo, no nível de não quererem me aprovar no estágio probatório, o que, consequentemente, seria demitido do serviço público.

A história que contei aos procuradores foi de quando ainda ensinava no Rio de Janeiro e o fiz com a intenção de que meu trabalho sempre foi de experimentação, respeito e debate com opiniões divergentes.

Em 1992, eu trabalhava no projeto Recriança, na quadra da escola de samba Estação Primeira da Mangueira, no Rio de Janeiro. No projeto, tinha atividades esportivas, de recreação e lazer, eu ministrava as atividades de dança e teatro, o mesmo trabalho que desenvolvia na UFU, na época. Numa determinada ocasião, uma bola de vôlei sumiu e sua ausência só foi notada na segunda-feira, pelos professores de Educação Física. A partir desse momento, começaram a questionar os estudantes e a procurar a bola de vôlei. Em certo momento, na quadra, era possível ver muitas bolas espalhadas - bola de gude, bola de meia, bola de futebol e de borracha -, mas a de vôlei não apareceu de jeito nenhum.

Quando menos esperávamos, desceram do Morro da Mangueira certamente algumas pessoas do tráfico e se dirigiram para a quadra do projeto. Todos estavam encapuzados, com armas e com pedaços de paus nas mãos. Assim, colocaram os meninos e meninas numa fila indiana e perguntaram um a um quem teria roubado a bola de vôlei. Então, as crianças, que tinham entre 8 e 13 anos, diziam que não sabiam, mas, mesmo assim, tomaram uma paulada numa das mãos. Em seguida, tinham que se dirigir a outra fila, ao lado. Na fila também estava um outro bandido que dizia à criança: "se você souber quem roubou a bola, não diga a ninguém!". E dava outra paulada.

Nós, professores e alguns estagiários, ficamos perplexos, chegamos a chorar assistindo àquela cena deplorável, mas não podíamos fazer absolutamente nada. Era a ética do morro agindo sobre seus agentes.

Então, dei esse exemplo para a Procuradoria da Universidade para tentar mostrar que o mesmo trabalho que desenvolvi no Morro da Mangueira, na Escola Estadual de Dança Maria Olenewa, na Escola do Teatro Municipal do Rio de Janeiro e em vários lugares por onde passei, trouxe para a universidade, sempre acreditando que ali era um ambiente importante para a experimentação, para o debate de opiniões divergentes.

Depois de uns três anos, acabei recebendo um documento, que até pouco tempo estava comigo, informando que o processo de sindicância havia sido anulado e que estava sendo arquivado, pois não havia sido constatado que eu, de fato estava cometendo alguma imoralidade. Além disso, o documento salientava que casos como aquele não deveriam chegar até a Procuradoria da Universidade, pois o próprio Colegiado de Curso poderia ter resolvido, conversando com a turma ou o próprio professor.

Quase todas as turmas em que eu ministrava aulas tiveram alunos que prestaram depoimento, e todos disseram que meu comportamento era um dos melhores da universidade e que aquilo se tratava de uma acusação inócua, sem necessidade. Isso me alertou para uma questão dentro da instituição universitária, comecei a entender que ela é um ambiente que, ao entrar, você passa por alguns rituais de iniciação, ainda que dolorosos. É óbvio que essa minha iniciação foi muito difícil, mas entendi que, embora 
seja um ambiente de experimentação e de grandes debates de ideias, você tem que preparar o campo para poder jogar. Eu comecei a jogar sem o devido preparo do campo, acho que é mais isso, essas relações de poder dentro da universidade. Precisei ficar mais atento a partir daquele momento.

Outra questão interessante que gostaria de registrar é que em 1995, próximo de terminar o mestrado, com o texto que falava das representações sociais de afrobrasileiros de dançarinos-atores, ofereci ao curso de Educação Física da UFU uma disciplina chamada Teoria Prática e Metodologia da Dança Afro.

Essa disciplina era eletiva e comecei com sete alunos, que depois aumentou para 25 estudantes. O Colegiado do curso de licenciatura em Educação Física da UFU, na época, recebeu mais duas disciplinas para incluir no currículo como eletivas, foram: Teoria Prática e Metodologia da Dança Afro e uma sobre o ensino de Alemão especificamente para a área da Educação Física, razão pela qual foi criada uma disciplina diferente da que era ofertada pelo Departamento de Letras.

O fato é que essa disciplina eletiva de Alemão demorou pouco tempo para ser aprovada no Colegiado, acho que não demorou nem um mês. Entretanto, a de dança afro demorou uns cinco ou seis meses e o Colegiado me fez várias exigências, queria saber, por exemplo, o que era a disciplina e qual a importância dela para a Educação Física. Eu tive que apresentar uma quantidade razoável de elementos para justificar essa disciplina no curso, até precisei ir numa das reuniões para apresentar mais argumentos. Depois de vários meses, a disciplina finalmente foi aprovada e a gente pôde trabalhar de forma tranquila e sem muitos problemas.

É fato que, assim que cheguei na UFU, comecei a desenvolver uns conteúdos de dança afro, mas logo percebi que, mesmo de grande importância, esse conteúdo não deveria ser hegemônico. Embora eu justificasse que a disciplina de Rítmica, no curso de Educação Física, tem sempre a predominância da dança moderna, dança contemporânea, de acordo com a formação técnica do professor. Essa foi, inclusive, a razão pela qual iniciei o trabalho com a dança-teatro, para tentar fugir da hegemonia de outras técnicas.

Um outro aspecto importante de minha estada em Uberlândia foi a minha participação na Associação dos Docentes da Universidade Federal de Uberlândia. Assim que tomei posse como professor já me associei e participei de algumas greves; na verdade, participei de todas as greves daquele período, de 1993 a 1996. Todo ano nós tínhamos uma greve, até porque foi o período em que o Fernando Henrique Cardoso estava no poder e nós ficamos por vezes sem salário. Na verdade, não foi Fernando Henrique Cardoso, acho que foi Itamar Franco e depois Fernando Henrique Cardoso.

Nessa época ficamos sem reajuste e pudemos perceber que havia um projeto de sucateamento da universidade. Por esse e outros motivos, em 1996, fizemos uma greve longa. Lutávamos não só por mais recursos para a universidade e pelo reajuste salarial como também pela modificação da Lei de Diretrizes e Bases da Educação Nacional. Eu e a professora Dinah Vasconcelos Terra, éramos do Conselho de Representantes da Associação Docente e representávamos o Departamento de Educação Física.

No período de greve ficávamos responsáveis em fazer o boletim diário, era uma coisa muito interessante porque acordávamos muito cedo, líamos os jornais de circulação nacional e local, víamos os telejornais e, em seguida, fazíamos uma síntese dos informes 
de Brasília e rodávamos o boletim lá mesmo no sindicato. Além disso, saíamos para distribuí-lo nos campi de Santa Mônica, Educação Física e Umuarama, que até hoje sediam, entre outros, os cursos de Engenharia, Educação Física e Medicina, respectivamente.

Era um trabalho muito intenso e foi nesse período que participei do Sindicato Docente, fui para alguns eventos nacionais, um deles foi o Conad, quando estive pela primeira vez na Universidade Federal de Pernambuco. Quando cheguei na UFPE, pela primeira vez, em Recife, para participar do Conad, chorei de emoção.

A emoção foi porque, no ensino médio, fiz o curso de Enfermagem e estagiava no Barão de Lucena. Na época, saía de Beberibe para o Barão de Lucena, depois, para voltar para casa, ia pegar o ônibus na Avenida Caxangá. Durante todo o tempo que fiz esse percurso, nunca imaginei que a UFPE estava praticamente do lado do hospital, inclusive que era possível ir caminhando. Essa lembrança me trouxe uma nostalgia, uma sensação de perda de algo que nunca tive. Estar pela primeira vez numa das melhores universidades do Nordeste me fez pensar que eu gostaria de trabalhar ali, mas isso só aconteceu em 2000. A minha primeira visita à universidade foi entre 1994 e 1995.

Durante o tempo em que passei na UFU participei ativamente do sindicato e ainda havia o mestrado e as apresentações artísticas, tudo ao mesmo tempo. Também participei de algumas discussões em Uberlândia sobre a sucessão da Reitoria. Na UFU é tradição ter uma chapa para reitor, ou seja, equipe completa: vice-reitor e pró-reitores concorrem numa chapa e quem ganha conduz a universidade por quatro anos. Numa dessas discussões, um amigo meu, o Gabriel Munhoz Palafox, quase virou pró-reitor, mas depois decidiu que deveria concorrer ao cargo de diretor estudantil, que estava desocupado há algum tempo.

Depois da eleição ele me convidou para ser chefe de setor e foi a primeira vez que eu tive um cargo na universidade. E qual era a minha função? Eu costumo dizer que eu não sabia o que era e ainda hoje continuo sem entender, porque eu era chefe de mim mesmo, eu não tinha outros servidores próximos, nem outro professor para elaborar um plano de ação. O que eu tinha era mais ou menos dois ou três estudantes bolsistas que acabavam me ajudando, ou seja, acompanhando-me aos sábados, domingos e feriados no Centro Esportivo Universitário, localizado no campus Educação Física, na abertura e fechamento do acesso à piscina, ao campo de futebol e às quadras poliesportivas; inclusive, às quadras de tênis e à pista de atletismo. Era basicamente isso que eu fazia como chefe.

Ao terminar o mestrado na Gama Filho pensei em fazer o doutorado, fui para a Unicamp como aluno especial, como mencionei anteriormente, e foi aí que tive reajustes salariais, na verdade, sempre tive aumentos no salário, pois assumi o cargo como professor auxiliar de ensino, mas, um ano e meio depois, quando estava terminando o mestrado, tive um reajuste, em que comecei a receber como um professor assistente. Quando terminei o mestrado, não tive a progressão funcional como mestre, que seria Assistente 1, 2, 3 e 4, e isso aconteceu porque fui diretamente para o doutorado, no qual passei apenas dois anos. Dessa forma, deveria solicitar a progressão para Assistente 2, mas já era doutor, ou seja, progredi verticalmente na carreira e fiz a progressão como Adjunto I. 
A verdade é que atrasei minha progressão porque, entre 2000 e 2004, fiquei basicamente sem produzir nada, foi nesse momento que pedi a redistribuição para Universidade Federal de Pernambuco. Foi interessante porque aproveitei a dificuldade que eu estava tendo com minha ex-esposa e com a minha filha. Eu queria que a minha filha viesse morar comigo, então acabei pegando uma discussão no meu Departamento. O chefe aceitou a minha redistribuição para a UFPE, inclusive agradeço enormemente por terem me liberado. É importante salientar que, antes disso acontecer, participei de um processo eletivo, pois o Departamento de Educação Física estava se transformando numa faculdade por conta da reforma estatutária e teve eleição para diretor, a qual concorri.

Os professores queriam que essa eleição fosse entre os funcionários do Departamento, técnicos e professores, ou seja, que fosse restrito aos que participavam das reuniões do nosso pleno. Se fosse nesse âmbito eu ganharia a eleição com folga, mas achava que tinha que ser um processo mais democrático, no qual os estudantes também participassem. Em alusão ao livro de Leonardo Boff, o meu slogan foi: O voo da águia 2000, Edilson diretor!

Então, colocamos a eleição para os três segmentos e eu perdi. Quem ganhou foi o Sílvio, nós competimos, disputamos, foi uma perda ruim naquele momento, mas, por outro lado, foi uma coisa boa porque, a partir dali, comecei a pensar seriamente em voltar para Pernambuco. Foi quando pedi redistribuição para a UFPE. Hoje, estou aqui pleiteando a promoção na careira para Professor Titular, mas isso constitui outra história.

Quando perdi as eleições para diretor da UFU fui visitar minha família no Recife, passar férias. Encontrei uma amiga e resolvemos passear pelo campus da UFPE, quando decidi entregar no Departamento de Educação Física uma revista que ajudei a criar quando era estudante de doutorado da Unicamp, a Revista Conexões, que ainda hoje é editada pela Unicamp.

Nessa visita, encontramos o professor Laranjeiras, e a minha amiga Jaraine Neves, pedagoga, que me apresentou ao professor dizendo que eu era pernambucano, mas trabalhava em Uberlândia, perguntou se ele teria uma vaga para mim. A resposta do professor Laranjeiras era que havia, sim, uma vaga, só era preciso levar os documentos necessários. Ainda questionou se eu era doutor, e eu confirmei. Segundo ele eu seria o primeiro homem doutor do Departamento, pois havia uma doutora, a Celi Taffarel, mas ela estava indo para UFBA.

Assim, dei entrada na documentação e fiquei aguardando a resolução dessa transferência, só que demorou bastante tempo e eu fiquei apavorado, porque a Faculdade em Uberlândia já havia me concedido a remoção, mas somente com a condição de que o Departamento de Educação Física da UFPE liberasse uma vaga. Comecei a ligar para ter algum retorno sobre o processo e não conseguia uma resposta satisfatória. Nesses diversos contatos, falei com a Prazeres, secretária do Departamento na época, que virou minha amiga. Além dela, entrei em contato com o professor Jorge Rocha, conhecido como Bocão, chefe do Departamento, que me informou que o processo estava caminhando.

Apreensivo com tanta demora, busquei ajuda. Quando estamos com problemas de saúde, buscamos ajuda médica, mas quando é um problema que não encontramos uma saída, buscamos a religião. Procurei um pai de santo para jogar búzios e ver o que estava 
acontecendo. Ele me disse que o processo estava engavetado e que somente eu poderia mudar isso. E, para tanto, precisaria viajar para o Recife e ficar de uma vez resolvendo a transferência.

Confiei no pai de santo e segui seus conselhos. Vendi as coisas que tinha, pois estava montando minha casa, afinal era recém-casado. Com apenas dois anos meus móveis estavam 'um brinco', como diz o ditado popular. Com o curto tempo para a venda, acabei doando a maioria dos meus móveis. Na época eu tinha um Fiat Uno 1997, pus algumas malas no carro e voltei para Recife em maio de 2000 , conforme previsto nos búzios.

Ao chegar no Recife fui direto ao Departamento. Assim que me viu, o professor Jorge perguntou se eu estava passeando. Neste momento informei que não, que tinha chegado para ficar, aproveitei a oportunidade para perguntar sobre o meu processo de transferência. Segundo ele ainda estava na Reitoria. Não perdi tempo, fui até a administração central e, de fato, o processo estava engavetado e, se continuasse esperando, provavelmente não teria uma resposta até hoje. Montei um outro processo, que provavelmente vai constar nessa biografia porque acho que é um documento importante. Após isso, dei entrada de novo e tive ajuda de algumas pessoas, técnicoadministrativos da universidade, e o processo começou a correr. Dessa vez, passei a acompanhar o processo de redistribuição até finalmente sair no Diário Oficial.

Então, entre maio e outubro de 2000, fiquei basicamente sem produzir nada, nenhum texto ou sequer uma linha, muito menos ministrar aula, era somente preocupação, pois não estava em Uberlândia e nem oficialmente na UFPE. Então, foi um momento muito crítico. A pedido da minha mãe, comecei a fazer campanha para um candidato a vereador de Jaboatão dos Guararapes, amigo da família. Ele era do Partido Comunista do Brasil, ganhou a eleição e até colaborei em alguns momentos no seu gabinete. Esse foi o único trabalho que desenvolvi por praticamente um ano, pois a redistribuição não saía.

Em Uberlândia as pessoas estavam acreditando que receberiam rapidamente o código da vaga, mas não foi bem assim. Porém, quando isso aconteceu, as coisas correram às mil maravilhas. Se estou aqui hoje contando essa história que acho importante, é para dizer que foi por meio da Universidade Federal de Uberlândia que ingressei de fato na carreira acadêmica, no campo acadêmico. Nessa universidade me dediquei mais à graduação e extensão.

Embora tenha me dedicado mais intensamente à extensão, também tentei ser docente do Mestrado em Educação Brasileira da UFU. Apresentei toda a documentação, um projeto de pesquisa, meu currículo, mas não fui aceito. Então, recebi um ofício dizendo que "embora minha produção fosse muito boa, extensa" etc. e tal, "compatível com a vida acadêmica", os trabalhos desenvolvidos por mim eram incompatíveis com as pesquisas desenvolvidas naquele programa de pós-graduação da UFU. Essa rejeição também contribuiu para que eu tivesse a atitude de voltar para o Recife. Mesmo com orientação de dois bolsistas de iniciação científica, pensei que na UFPE poderia trilhar um outro caminho para minha vida acadêmica. Assim, minha estadia em Uberlândia e, consequentemente, na UFU havia encerrado ali, daquela forma. 


\section{Em Pernambuco: permanência e mudança de habitus}

No tópico anterior falei de maneira resumida acerca do tempo em que trabalhei na Universidade Federal de Uberlândia, minha chegada na instituição, meus projetos e participação no movimento docente. Agora, nesta seção, meu foco será no trabalho iniciado na Universidade Federal de Pernambuco, meus projetos de pesquisa e extensão, além da minha inserção na política institucional.

Nos primeiros anos de atuação na UFPE comecei a ministrar aulas na disciplina de Sociologia do Esporte, sempre foi um desejo atuar com disciplinas de caráter mais teórico, porque, em Uberlândia, eu trabalhava com as disciplinas de Rítmica e Dança e lembro muito bem que exigia dos estudantes uma leitura após a outra, muitas vezes desnecessária, que causava muito estresse a todos.

Hoje reconheço a situação desagradável que eu impunha logo nos primeiros dias de aula. No início de cada semestre entrava na sala dizendo que naquela turma de 60 estudantes cerca de $90 \%$ seriam reprovados. Na verdade, o que construía esse número bastante alto de reprovação era o fato de eles atrasarem as leituras exigidas. Eu passava um texto de 10 laudas, em seguida, um de 30 e depois mais um de 60 laudas. Como eles não liam, acabava gerando um acúmulo de material para leitura. Além disso, passava um livro que gosto muito chamado $A$ história do corpo, de Jorge Crespo, que é caracterizado por ser um texto denso e extenso, 400 e poucas páginas, e era um dos materiais para a prova, junto com os demais textos, que ocorria no primeiro mês de aula. Uma vez iniciada essa contenda, empurrava até o final do semestre várias 'cascas de banana', assim tudo caminhava para a reprovação da maioria da turma. A vida de todo mundo virava um pequeno inferno, a do estudante e a minha. $O$ que era pior é que poucos estudantes gostavam de mim, pois sabiam que aquele comportamento era proposital, uma forma de punir quem não acompanhava o material de leitura. Embora a exigência seja um norte na vida acadêmica, reconheço que eu tinha mesmo o desejo de reprovar, talvez uma demonstração de poder, aliás, o único poder que exercia, pelo menos na minha cabeça.

Hoje mudei, ainda bem. Entro na sala, no primeiro dia de aula, e digo exatamente o contrário. Tento reforçar sempre a ideia de que trabalho com o sucesso de todos, dou garantias de que estou ali para colaborar com a formação dos melhores profissionais de que a universidade terá notícia, portanto a aprovação será de $90 \%$ dos estudantes. Tento também ser o mais simpático possível para despertar a confiança do discente e trazer para nosso convívio o desejo de transformar a realidade a partir do conhecimento. Dessa forma, trabalho fortemente para que todos sejam aprovados e com notas acima da média. Afirmo sempre que trabalho com e para o sucesso do estudante, e que isso reverte no meu próprio sucesso enquanto professor. É evidente que continuo sendo exigente com a leitura, mas acompanhando-os mais de perto em suas dificuldades na compreensão e na produção de texto. Trabalhando dessa forma percebo que, ao final do semestre, tenho estudantes mais felizes, despertos para o conhecimento e, sobretudo, com desejo de estar na monitoria da disciplina que ministro, Sociedade: Teoria e História da Educação Física, Esporte e Lazer, ofertada para o primeiro período do Bacharelado.

Frente a essa atitude em relação aos estudantes, ao chegar em Pernambuco, mudei meu paradigma, minha pedagogia e didática. Foi a partir daí que comecei a fazer um investimento no Laboratório de Sociologia do Esporte/CNPq. Embora hoje esteja com 
poucas atividades porque atualmente só estou com uma bolsista de iniciação científica, em virtude de outras prioridades como mestrado e doutorado na Educação e mestrado em Gerontologia, esse Laboratório já deu muitos e bons frutos.

Ele foi criado logo nos primeiros anos de trabalho na UFPE e foi a partir dele que passei a desenvolver uma pesquisa sobre violência e lazer nos bairros do lbura e Nova Descoberta, em 2001. Então juntei ali em torno de 10 estudantes, entre bolsistas e voluntários, para fazer essa pesquisa de muito impulso acadêmico, porque a ideia original era fazer uma pesquisa-ação, inclusive com a montagem de um observatório nesses bairros para acompanhamento do cotidiano de jovens. O recorte estabelecido cobria jovens entre 16 e 24 anos, considerados grupo de risco.

A ideia era verificar qual a percepção que eles tinham sobre a violência no ambiente em que viviam, uma vez que a Prefeitura do Recife havia divulgado os índices de violência e os bairros mais violentos da cidade. A pesquisa divulgada pela imprensa tinha uma metodologia bastante interessante a partir do Datasus, e tentei contrapor esses dados, cuja metodologia não registrava o bairro onde teria acontecido de fato o homicídio, mas o bairro em que a vítima residia. Cheguei, inclusive, até a publicar um livro em coautoria sobre o assunto, falarei disso mais adiante. O Laboratório de Sociologia do Esporte teve um papel importante na minha vida acadêmica e de vários voluntários e bolsistas que passaram por aquele ambiente, desenvolvendo a pesquisa principal sobre a violência, como uma espécie de tema aglutinador naquele momento, bem como outros projetos de pesquisa e extensão.

Hoje observo, com orgulho, que temos na história do Laboratório pessoas como o Henrique Gerson Kohl, o Tchê, ex-aluno e atual chefe do Departamento, que passou por lá no $3^{\circ}$ ou $4^{\circ}$ período. Também temos a Maria Helena Câmera Lira, professora da Universidade Rural de Pernambuco, que também foi minha orientanda desde a graduação até o doutorado. Há outros ex-alunos que agora são professores como o Haroldo Moraes de Figueiredo, professor da UFPE, campus Vitória, e Márcio Eustáquio (in memoriam), que era técnico-administrativo e foi meu aluno de graduação no $3^{\circ}$, quando o incentivei a entrar no mestrado, onde foi orientando do Flávio Brayner, e no doutorado, orientado por mim.

O Márcio Eustáquio terminou o doutorado mas, infelizmente, aconteceu algo muito ruim com ele depois de uma frustração político-administrativa dentro da universidade. Penso que ele acabou entrando em depressão, ficou muito doente, com uma série de complicações e acabou falecendo. Um dos livros que publiquei, Representações da violência e lazer nos bairros do Ibura e Nova Descoberta, foi assinado por mim, Márcio e Haroldo em coautoria.

Nos primeiros anos de minha estada na UFPE eu acabei sendo coordenador do curso de licenciatura em Educação Física, isso em 2002. Aconteceu também uma coisa inusitada, porque, quando cheguei aqui em Recife, o coordenador era o professor Antônio Maria, já falecido, inclusive, faleceu ministrando aula de Basquete, sua grande paixão, numa de nossas quadras.

O Antônio Maria foi um dos primeiros professores a me receber, ele me tratava tão bem que, quando chegava em sua sala, ele dizia que precisavam providenciar um espaço para eu ficar, porque eu era um doutor. Inclusive, profetizava, dizia que um dia eu ocuparia o seu lugar de coordenador e outros altos cargos da universidade. Ele não era 
doutor, era especialista e, naquela ocasião, havia um desconforto entre o coordenador e o então pró-reitor acadêmico, o Roberto Coutinho, porque este não recebia professores e coordenadores que não fossem mestres ou doutores; pelo menos, é o que diziam. Como o Antônio guardava um ressentimento pelo Roberto Coutinho, isso acabava prejudicando o curso de licenciatura. Houve uma situação que não concordei, mas que, infelizmente, aconteceu. O falecido professor Rômulo Lacerda, o José César, o Plic, também falecido, e outros professores acabaram tensionando para que Antônio Maria renunciasse ao cargo de coordenador, para que houvesse uma eleição, basicamente uma das primeiras eleições para a coordenação da licenciatura em Educação Física.

Infelizmente a pressão para que ele desistisse foi tanta que aconteceu. Assim, eu me inscrevi como chapa única e acabei tornando-me coordenador do curso de licenciatura, meu vice-coordenador era o Nairton Sacour, atualmente aposentado. Assim que assumi o cargo, minha principal tarefa foi dar visibilidade ao curso dentro da UFPE, porque durante algum tempo os estudantes e professores eram discriminados dentro da universidade, pelo menos essa era a minha percepção.

Ao chegar aqui sempre ouvi comentários de que os estudantes não eram bem recebidos no Centro de Educação e em outros lugares. Às vezes não tinham disciplinas pedagógicas para que eles se matriculassem e o índice de reprovação em várias disciplinas pedagógicas era muito grande. O curso de Educação Física faz parte do Centro de Ciências da Saúde e poucas vezes nós tínhamos acesso aos auditórios como o Jorge Lobo, que é o principal auditório do CCS. Por isso, eu tinha como principal objetivo dar visibilidade ao curso e promover o que fazíamos no ensino, pesquisa e extensão.

Foi então que fiz algo que já havia experimentado em Uberlândia. Lá eu fazia o Painel de Dança, aqui fiz o Painel Acadêmico. Foram duas edições desse evento, o que acabou dando visibilidade ao curso, além do fato de o professor Roberto Coutinho me receber com muita tranquilidade, conversávamos sobre o curso, como fazer melhorias etc. Assim, o curso realmente ganhou outro impulso acadêmico dentro da instituição. Atualmente, também temos o Bacharelado, mas, na época, era somente a licenciatura, que assumiu uma estatura compatível com um curso superior. Então esse foi o trabalho que desenvolvi na coordenação.

Quando fui redistribuído para Pernambuco estava decidido a não me envolver com política, diferente de quando estava em Uberlândia, onde tinha um trabalho de extensão e um trabalho muito intenso com a política institucional, com a política docente, além disso frequentava muito a Associação dos Docentes da Universidade Federal de Uberlândia. Na UFPE não queria nem mesmo ter um projeto de extensão, pensei apenas em me dedicar ao ensino, que é a nossa obrigação principal. Depois, logo pensei em desenvolver a pesquisa, quem sabe poderia entrar no programa de pós-graduação, especialmente no mestrado em Antropologia, já que não tínhamos mestrado em Educação Física.

Nessa mesma época o professor Ricardo Lucena, que tinha sido transferido da Universidade Federal do Espírito Santo para a UFPE, acabou se aproximando do mestrado em Educação e queria que eu fosse junto, para desenvolvermos algum trabalho. As considerações do Ricardo, muito prudentes, como sempre, eram de que ficaríamos um tempo e depois poderíamos pensar em outro mestrado como de História, 
Sociologia etc. Acabamos ministrando juntos uma disciplina chamada Pesquisa em Teoria e História da Educação. Aliás, disciplina que ministro até hoje, após o Ricardo pedir redistribuição para a Universidade Federal da Paraíba por razões pessoais.

Nos primeiros anos em que Ricardo esteve pela UFPE ele foi convidado para ser diretor de um órgão suplementar, o Núcleo de Educação Física e Desportos - NEFD. Depois, eu acabei sendo também gestor desse mesmo órgão, pois, após o falecimento de sua esposa Rosana, a Rô, que era professora substituta na época, ele acabou pedindo redistribuição para a UFPB, voltar para João Pessoa, sua cidade natal.

Foi na pós-graduação em Educação, especialmente no Núcleo de Teoria e História, que iniciei minhas primeiras orientações de mestrado, minha primeira orientanda foi uma professora chamada Amélia e a segunda foi lolanda, se não me falha a memória. As primeiras orientações foram muito difíceis, eu discutia muito com as orientandas, inclusive, até hoje, ao encontrar a Amélia em algum evento, 'trocamos algumas farpas', mas de uma forma muito carinhosa.

No começo, obviamente, achava que seria muito fácil orientar, mas, na verdade, não tinha ideia de como começar. Com o tempo acabei descobrindo o fio condutor, considerome hoje um dos melhores orientadores da pós-graduação em Educação da UFPE. Até recebi o apelido de $O$ homem que orienta paixões, que tratarei mais adiante. Pensei em ficar na pós-graduação apenas uns oitos anos no máximo, mas estou desde 2002 e, de lá para cá, já orientei um número razoável de mestrandos e doutorandos, próximo a 60 . Em 2013 e 2014 recebi um convite para participar do Mestrado em Gerontologia, confesso que não queria aceitar, mas o convite veio de duas pessoas que tenho enorme consideração dentro da UFPE, as professoras Ana Paula e Márcia Carrera, e eu acabei aceitando.

Essas professoras são muito aguerridas, empenhadas e dedicadas no que se propõem a fazer, seja na pesquisa, seja na extensão, especialmente quando o assunto é envelhecimento. Então, coloquei meu currículo e tenho colaborado razoavelmente com essa pós-graduação do CCS. Sei da grande importância desse programa de pósgraduação, mas, verdadeiramente, eu não me identifico com o trabalho, como me sinto na pós-graduação em Educação. De qualquer forma, eu colaboro com esse programa também, já orientei três ou quatro pessoas.

Então, voltando rapidamente para 2002-2004, eu fui coordenador do curso, depois fui coordenador administrativo do Núcleo de Educação Física e Desportos, mesmo eu não querendo me envolver com a política. No entanto, na época em que estava esperando oficializar a redistribuição, como havia dito, fiquei quase um ano sem realizar qualquer tipo de trabalho. Neste período acabei coordenando uma campanha para vereador em Jaboatão dos Guararapes e o candidato acabou sendo eleito.

Ainda cheguei a colaborar com o seu gabinete por cerca de seis meses, quando resolvi me filiar ao partido e manter o mínimo de coerência política partidária. Como filiado participava das reuniões do Comitê Municipal e cheguei a ser membro da Comissão Política do partido em Jaboatão dos Guararapes, um espaço de discussão e tomada de decisões importantes.

$\mathrm{Na}$ Universidade iria ter eleição para reitor. Nessa época havia um debate para PCdoB e PSB apoiarem o candidato que tinha proximidade com o PT, que era o AHPL. Embora o AHPL nunca tenha dito que fazia parte de algum partido político - nunca diga 
isso a outras pessoas -, chegou até a ser Secretário da Sesu no MEC, ou seja, foi um dos secretários de Aloiso Mercadante, ministro da Dilma. Portanto, uma relação estreita com o PT, de muita proximidade partidária.

Nesse contexto acabei fazendo campanha para AHPL, junto com o Ricardo Lucena e outros colegas, que compunham a base do partido na UFPE. Ao término da campanha o Ricardo foi convidado para ser diretor do Núcleo de Educação Física e Desportos e meu desejo, na verdade, era ser diretor da TV Universitária, tanto é que fiz um investimento muito alto do ponto de vista das discussões. Na época da transição, participei do grupo que discutia sobre o NEFD e sobre a TV Universitária, que estava sendo dirigida por Jardel Filho, ex-funcionário da Globo Nordeste, e isso causava certo desconforto porque o Jardel não era funcionário público.

$\mathrm{Na}$ verdade eu queria ser diretor porque achava que poderia fazer um bom trabalho por lá, mas o AHPL me convidou para ser um colaborador do Ricardo Lucena, uma espécie de conselheiro. Eu achava que, pelo meu empenho na campanha, poderia ter sido diretor de algum órgão suplementar. Depois, em conversa com o Ricardo, acabei me tornando por algum tempo coordenador administrativo do Núcleo de Educação Física e Desportos; e o Ricardo, diretor.

Eu não sabia qual o papel a ser desenvolvido como coordenador administrativo. De qualquer modo, logo em seguida, começamos a promover o Encontro Nacional de História da Educação Física, Esporte e Lazer. Como muitos colegas da área sabem, esse congresso já é uma tradição no campo historiográfico. Então, eu e o Ricardo trabalhamos na coordenação geral do evento. Considerando as nossas características políticas administrativas e as pressões dos congressistas, conseguimos conduzir bem o evento.

Não é exagero reafirmar que esse tipo de atividade docente precisa de um olhar mais cuidadoso por parte das instituições. Entretanto, mesmo com as tensões próprias de quem quer fazer algo e não tem dinheiro nem financiamento de algum órgão fora da UFPE, o congresso aconteceu. Assim, as pró-reitorias de graduação e pós-graduação ajudaram bastante com passagens, hospedagem e alimentação. O congresso foi um sucesso! Não obstante tudo ter corrido bem com o evento, um episódio desagradável e marcante aconteceu na vida pessoal do Ricardo Lucena, o falecimento de sua esposa. Em virtude disso, como já mencionei, ele foi para João Pessoa, e eu acabei me transformando, durante algum tempo, no diretor do Núcleo de Educação Física e Desportos.

Como diretor, em 2005, eu queria divulgar as atividades do NEFD, essa era uma das ações que Ricardo pensou em implementar por meio da mídia: rádio e tevê. Nessa tentativa de divulgação fui até um programa de rádio chamado Caminhos do turismo, a convite de Rizo Trindade e Flávio Soares, que conheci lá mesmo e que até hoje são meus amigos, a Rizo Trindade e o Flávio Soares

O Flávio Soares tem um vozeirão, o que combina com sua função na rádio. Seu empenho e o da Rizo Trindade em fazer o programa me chamou muita atenção. São dois técnicos-administrativos da universidade, negros, empenhados em desenvolver um trabalho bom durante todos os sábados, na Rádio Universitária. Acabei ficando apaixonado pelo trabalho desenvolvido e pedi ajuda para as divulgações das ações, projetos e programas esportivos do Núcleo de Educação Física e Desportos, da mesma maneira que o Ricardo havia pensado. 
$\mathrm{Na}$ conversa sobre os elementos comerciais que envolveriam a divulgação, um deles, acho que a Rizo, sugeriu que eu fizesse um programa de esporte na rádio, o que aceitei. Por coincidência, na época, também estava discutindo na disciplina de graduação de Sociologia do Esporte, a teoria de campo, de Pierre Bourdieu, e as questões configuracionais, de Norbert Elias. Sobre Bourdieu, especificamente, vi a possibilidade de, a partir de sua teoria, fazer o mapeamento do que acontecia nos esportes em Pernambuco, verificar e divulgar o que estrutura essa importante atividade humana em nosso Estado.

Então, partimos para a elaboração e concepção do programa de rádio a partir da teoria de Bourdieu. Desse debate criamos o programa Saber esportivo: a sua conexão com o esporte amador. Era um programa que ia ao ar todas as terças-feiras, ao vivo, de $11 \mathrm{~h}$ às $12 \mathrm{~h}$. Era muito divertido porque tínhamos entrada ao vivo por telefone, aliás, no início produzíamos os telefonemas, ou seja, pedíamos para que estudantes ou amigos telefonassem e fizessem perguntas aos especialistas. Depois, não havia mais a necessidade disso, o programa ganhou força e a própria comunidade esportista e cidadãos comuns passaram a ligar espontaneamente.

No começo eu era apenas um articulador das ações do NEFD com a rádio e uma espécie de produtor iniciante. Em seguida, passei a ser produtor, criador de pauta e até fiz reportagem e locução. A diversão estava nas matérias que fazíamos, inclusive, mandávamos os bolsistas para o interior de Pernambuco, chegamos até em outros lugares, como Alagoas e Goiás. Ao vivo chegamos a fazer inserções nos jogos escolares etc.

A primeira matéria foi no Campo do 15, na Av. do Forte, bairro do Cordeiro. Lembro bem que foi com um dos organizadores do campeonato do Cordeiro, o Edson Rato, que falou sobre as primeiras iniciativas do campeonato, quando começou, quantos times participavam e o regulamento. Na verdade, a matéria queria chamar a atenção para 0 Congresso técnico, do qual deveriam participar os treinadores e os 'donos dos times. Então, um dos objetivos era 'cobrir as peladas' de final de semana e algumas solenidades e eventos que tivessem algo relacionado aos esportes amadores.

A brincadeira ficou séria e, então, eu e a Rizo resolvemos nos inscrever num curso de extensão de jornalismo esportivo, com Álvaro Filho, cronista, comentarista e escritor conceituado em Pernambuco. Uma das atividades do curso era visitar estádios de futebol, assistir gravação ou transmissão de programas de rádio e tevê. Um dia, fomos à TV Jornal e lá assistimos ao debate de um programa apresentado pelo Marciel Júnior. Gostamos muito das entradas dele, a segurança nas perguntas e comentários, a posição cênica no estúdio etc.

A partir dali, combinei com a amiga Rizo que iríamos fazer e produzir um programa de TV e chamaríamos o Álvaro Filho para apresentá-lo sob a nossa supervisão. E foi isso que aconteceu, só que já na estreia nós resolvemos que o Álvaro não ia apresentar sozinho o programa. O Álvaro Filho era um cara muito bom, um excelente profissional da mídia esportiva, inclusive, também professor universitário da Unicap, portanto, sempre muito ocupado, por isso ficamos preocupados em iniciar o programa e, já na primeira semana ou primeiro mês, não termos apresentador.

Então decidimos que eu iria apresentar junto com o Álvaro Filho, porque, se ele faltasse o programa, não seríamos prejudicados, mesmo considerando que tudo era 
gravado, tinha um tempo específico de montagem de cenário, de preparação do estúdio para gravar e disponibilidade da equipe técnica da emissora. Tudo isso não deveria ultrapassar 3 h de relógio e subtrair 30 minutos para exibição, porque o estúdio deveria ser liberado de imediato por conta de outros programas, inclusive o Opinião Pernambuco, transmitido ao vivo de segunda à sexta-feira, dia da nossa gravação.

Iniciamos a gravação e o nome dado ao programa foi sugestão do próprio Álvaro Filho. Cabeça de área: penso, logo assisto foi o nome escolhido. A ideia do programa era convidar profissionais de diferentes áreas do conhecimento para falar sobre o esporte, na perspectiva da História, da Filosofia, da Fisiologia, enfim. Ficamos no ar por 10 anos. E o Álvaro Filho ficou apenas por dois meses, talvez nem isso. Participei de quase tudo na equipe, fui motorista, cinegrafista, repórter e apresentador, o que se tornou minha principal função.

Entrevistei muita gente no estúdio, foram mais de 350 programas produzidos e exibidos, foi de fato uma grande e excelente experiência. Mantivemos bom relacionamento com todos da emissora, inclusive, a cada gravação servíamos uma pizza para a equipe técnica e de produção, o que ajudou no relacionamento. Lembro que numa das gravações, para minha surpresa, acho que após uns cinco anos já fazendo o programa, pelo ponto de comunicação, o diretor de imagem/corte disse que eu tinha uma prima que trabalhava na emissora, no setor administrativo, a Kátia Chacon. Foi emocionante.

Alguns programas podem ser assistidos pelo Youtube, mas os CDs, com todos os programas, estão guardados em nosso repositório institucional, que é o Memorial Denis Bernardes, onde pode ser encontrado também esse material que estou gravando e as transcrições dos áudios da pesquisa. Então, conseguimos passar 10 anos na televisão. $\mathrm{Na}$ época, meus projetos de extensão eram esses, no rádio e na televisão. Abaixo, é possível ver a imagem do nosso cenário no momento da gravação de um dos programas.

Figura 36 -

Programa Cabeça de Área, TV Universitária, 2013.

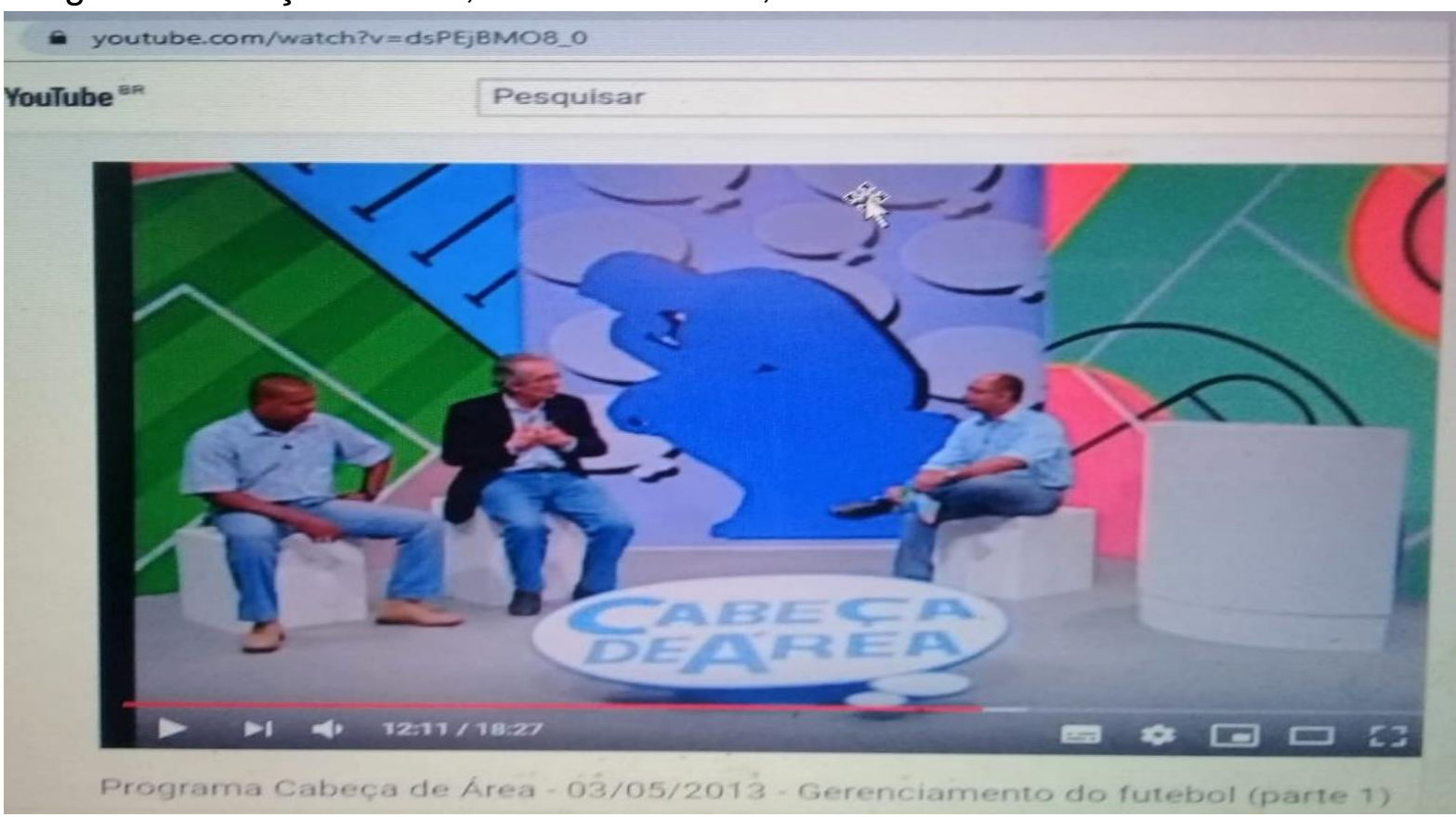

Fonte: Youtube. Disponível em: https://www.youtube.com/watch?v=dsPEjBMO8_0. 
Esse foi o programa de número 300 , exibido no sábado dia 03 de maio de 2013 . O tema discutido foi o Gerenciamento do Futebol, com a participação do professor Iberê Caldas, da Universidade Federal de Pernambuco, e Antônio Carlos Valença, que estava desenvolvendo um estágio pós-doutoral no Centro de Informática, também da UFPE. $O$ início da discussão girou em torno do trabalho do Antônio Valença acerca de uma comunidade reflexiva de monitoramento de projeto e de que maneira a teoria da ação poderia construir estratégias para o alcance de sucesso. Esse foi o primeiro programa de 2013, após alguns meses de férias, com direito a novo cenário.

Gostaria de registrar também duas experiências que envolvem a comunicação e a arte. Em 2006 resolvi fazer um curso de teatro numa escola no bairro da Madalena, com o professor Almir Martins, na Hyperion. Acabei revivendo os bons momentos em que estudei teatro no Sesc, com José Manoel, no início da década de 1980. No final do curso, a prova era a montagem de uma peça. Foi aí que estreamos no Centro Cultural Benfica, da UFPE, com a peça $O$ beijo no asfalto, de Nelson Rodrigues. Foi uma excelente experiência porque estava sentindo falta dos palcos, embora meu objetivo principal fosse exercitar a interpretação para ter um melhor desempenho no meu programa de televisão.

Depois disso fui convidado a fazer uma pequena participação num curta-metragem, no papel de um delegado. O personagem só chegava na última cena do filme, falava apenas uns 30 segundos, mas, quando começamos os ensaios, o diretor do filme resolveu me reposicionar e acabei representando um dos personagens principais, o Dr. Ricardo. Gostei muito de ter feito essa participação, foi um desafio participar desse filme.

O filme se chamava Mulher da vida e a primeira cena se passa num motel, com os dois personagens principais deitados na cama. Para dar mais realidade à cena, resolvi ficar nu, sem cueca, debaixo do lençol. Parte das gravações ocorreram na rua Bom Jesus, no centro do Recife. Aliás, na mesma rua, até hoje fica o Sindicato dos Portuários de Pernambuco, o 'Sindicato do meu pai', local onde frequentei muitas vezes quando era criança.

Voltando à extensão, vejo que esses projetos deram considerável contribuição à formação profissional de jornalistas e repórteres. Hoje, em 2019, o assessor de comunicação do governador do estado de Pernambuco foi nosso estagiário, Gilberto dos Prazeres. Na TV Clube, temos o repórter Bruno Araújo e o Álvaro Bezerra, cinegrafista; Patrícia Costa foi comentarista da TV Globo/Asa Branca; ainda temos gente fazendo mestrado e doutorado, como Tulane Souza, doutoranda em Educação da UFPE.

Fico muito feliz por ter colaborado com a formação dessas e outras pessoas, gente que hoje trabalha em assessoria de imprensa em vários lugares e certamente se beneficiou dos projetos de extensão que desenvolvi, coisa que, quando cheguei à UFPE, nem mesmo queria fazer. $\mathrm{O}$ Cabeça de área também me rendeu muita experiência, conheci pessoas, construí amizades na TV Universitária, aprendi a linguagem televisiva etc.

Esse projeto na emissora educativa foi muito profissional e nos rendeu um bom relacionamento institucional com outros colegas da imprensa esportiva. A partir do programa, conseguimos viajar a Brasília, fazer matéria em Buenos Aires, na Bombonera, e em vários lugares. Inclusive, entrei sem pagar na Bombonera porque eu tinha a carteira/crachá da Associação dos Cronistas Esportivos de Pernambuco. E aqui em 
Pernambuco, nos jogos do Campeonato Brasileiro e jogos do Pernambucano, sempre ia para os estádios. Às vezes, acompanhando a equipe de reportagem, na produção, ou apenas para assistir aos jogos.

Figura 17 -

Crachás da Associação dos Cronistas de Pernambuco, 2006 e 2010.
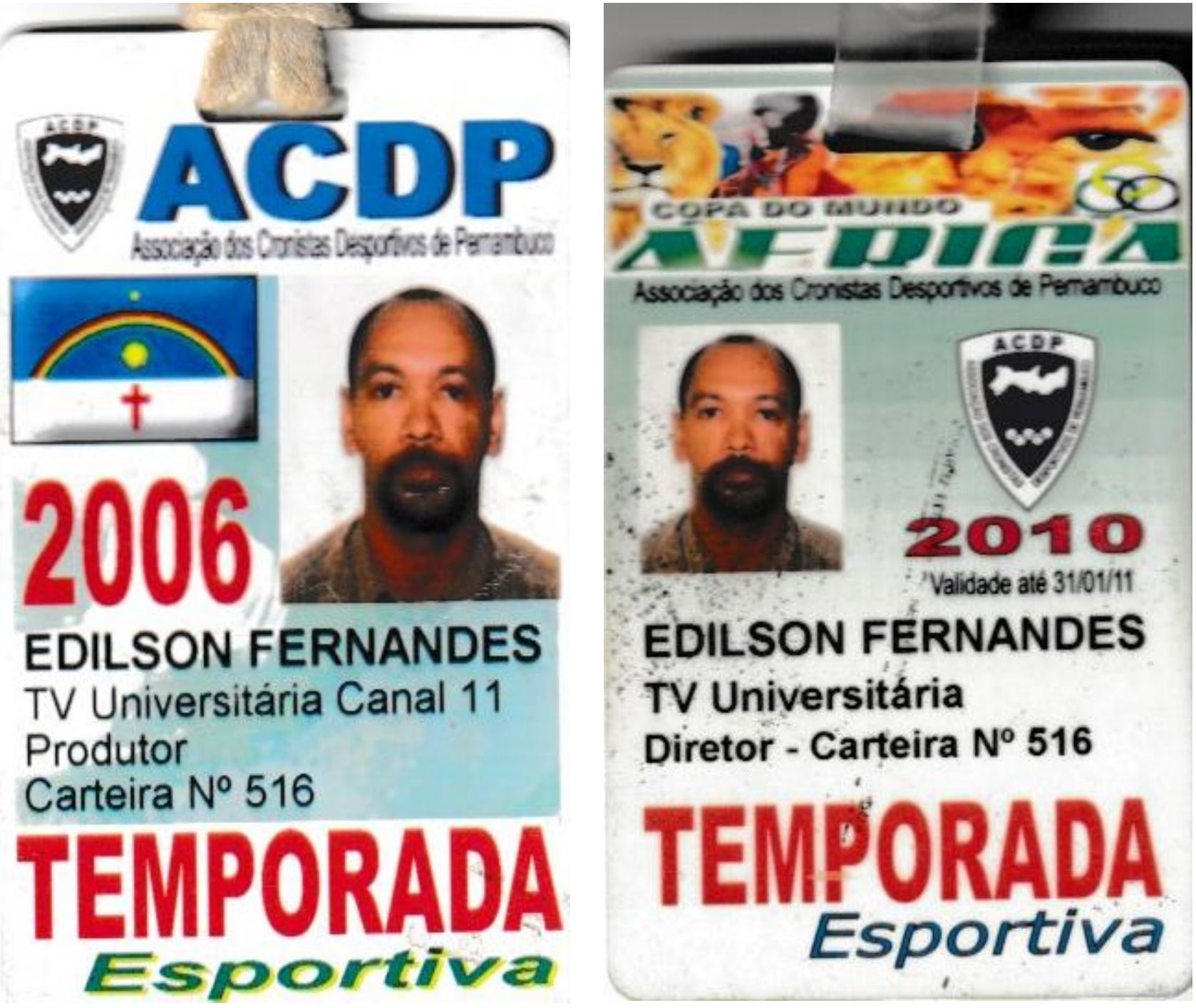

Fonte: acervo do autor.

Todos os anos tínhamos que renovar a nossa inscrição entre os cronistas. E essas duas fontes são importantes porque somente por meio desses crachás era possível a nossa entrada nos estádios e sala de imprensa, bem como ter acesso a outras atividades desenvolvidas pela Federação Pernambucana de Futebol. Com esse documento, eu tinha a impressão de que fazia parte do time esportivo e fazer as críticas próprias das resenhas, com as devidas ressalvas do conhecimento em sociologia e história do esporte, bem como as questões que envolviam a esfera estética das atividades corporais.

No contexto geral da minha ambientação na universidade, a ideia de não me envolver com a política não deu muito certo. Como havia dito, acabei me envolvendo não só com o AHPL, na sua primeira campanha de gestão, entre 2003 e 2007, mas também na segunda campanha. E, em seguida, houve um movimento para que eu fosse 0 candidato a vice-reitor na chapa do DBDA, em 2011. 
Nessa ocasião eu era diretor do Núcleo de Educação Física e Desportos e estava fazendo estágio de pós-doutorado em Sociologia, em 2010/2011, na Universidade do Porto, em Portugal. Quando retornei houve um movimento para que eu fosse candidato a vice-reitor na chapa do DBDA, o que não deu certo. O DBDA não aceitou a parceria, mas nós fizemos um acordo para que eu o ajudasse na eleição, ele se elegeu no primeiro turno e eu acabei sendo pró-reitor de extensão.

Confesso que não era a intenção ser pró-reitor de extensão, pois há muita dificuldade e pouca valorização desse setor em várias universidades. De todo modo, a Pró-Reitoria de Extensão da UFPE era um lugar onde as pessoas trabalhavam há muito tempo, algumas oriundas da Sudene, outras de um órgão federal também extinto que não lembro o nome agora.

Penso que a permanência de determinados indivíduos num lugar por muito tempo, especialmente no serviço público, faz com que tenham a sensação de que são donos do pedaço, proprietários legítimos do patrimônio. Mesmo considerando o empenho e a dedicação de todos, eram pessoas que trabalhavam há bastante tempo, fui para um ambiente que parecia hostil no começo. A sensação que me dava, e hoje tenho a certeza, é que o DBDA me colocou nessa pró-reitoria para que eu não ficasse lá por muito tempo. Ele conhecia bem o ambiente porque já havia sido pró-reitor de extensão e depois da pesquisa. Como dizem os mineiros, ele sabia que o pessoal de lá era mesmo custoso.

Os três primeiros meses foram muito difíceis, muitos discursos inflamados, retóricas inconformadas etc. Eu tive muita paciência. As pessoas alteravam a voz, gritavam e até batiam na mesa. Fui compreendendo o porquê de tudo aquilo. Talvez aquelas pessoas, que trabalhavam lá há bastante tempo e eram competentes no que faziam, estavam frustradas com a perspectiva e resultado do trabalho que faziam ali. Ou porque estivessem esperando a nomeação de um outro gestor para a condução daquele ambiente institucional, o que parecia o mais provável.

Então acho que muita gente desejava que eu abandonasse a Proext nos primeiros dias. Mas não foi o que aconteceu! Muito pelo contrário, comecei a fazer um investimento no trabalho da extensão. Quando eu cheguei nós tínhamos um orçamento de $R \$$ $1.900 .000,00$, que já era alto para os padrões das universidades públicas federais. Quando saí de lá, o nosso orçamento era de $R \$ 17.000 .000,00$, fizemos investimentos altíssimos, conseguimos desenvolver trabalhos estruturantes, trabalho de publicação de resultados de pesquisa. Só na perspectiva étnico-racial publicamos 32 títulos de uma só vez, a única universidade que possui essa experiência no Brasil, pelo menos até o momento.

Iniciamos uma série chamada Brasil África, junto com o programa de pós-graduação em Serviço Social. Fizemos dois documentários, sendo um deles um curta-metragem chamado Camões dos Lusíadas, Camões brasileiro com o pessoal da TV Universitária, produzido e dirigido por Valdir Oliveira e, logo em seguida, nós participamos de um projeto com a ONG Força Guiné, presidida, à época, pelo doutorando Arnaldo Sucuma. Com essa parceri, acabei indo para a Guiné-Bissau. Passei por lá 11 dias e me empenhei na realização de um documentário sobre as questões de economia e cultura do país. Os investimentos para esse documentário giraram em torno de $R \$ 250.000,00$, custo baixo para a dimensão do projeto. 
Além do documentário a equipe da TV Universitária ministrou oficinas para o pessoal da tevê estatal da Guiné-Bissau, a TGB, e o sistema de rádio da mesma emissora. Interessante é que alguns profissionais, técnicos e jornalistas da emissora, foram exalunos da UFPE, uma coisa realmente inusitada e de grande impacto na perspectiva da cooperação internacional via projetos de extensão.

Outro exemplo foi o investimento em Fernando de Noronha a partir da Associação das Pousadas Domiciliares. A ideia central era capacitar mão de obra para o receptivo, bem como as questões que envolvem hotelaria e os cuidados com o meio ambiente. Fernando de Noronha é um lugar maravilhoso, especialmente para quem visita por alguns dias. Para os jovens, viver na ilha, sem opções de lazer e entretenimento, emprego etc., representa um dos grandes problemas a serem enfrentados pelo poder público. Então, pensei em aportar os projetos e programas de extensão pelo arquipélago, mas, infelizmente, já foi nos momentos finais da minha gestão.

De qualquer modo, junto com a equipe, percorri vários interiores de Pernambuco com o programa Diálogo com os municípios. Em cada lugar verificávamos quais projetos poderiam ser desenvolvidos com professores e estudantes; inclusive, fizemos um projeto para recuperação da rabeca, instrumento de corda confeccionado no município de Ferreiros, que precisava de um incentivo para melhorar seu design e valor agregado. Ainda pelo interior, sobretudo, no sertão de Pernambuco, houve razoável investimento nas tecnologias apropriadas para a captação de água e geração de energia a partir dos dejetos de animais domésticos.

Não vou fazer aqui um balanço da gestão na Proext, até porque não é o espaço adequado, mas levanto essas questões para reafirmar o modo de pensar da instituição e como consegui me virar e transpor as dificuldades iniciais encontradas quando estive na gestão do DBDA. Aliás, mesmo com o boicote de alguns pró-reitores, às vezes do próprio reitor e seu vice, consegui levantar a prima pobre da UFPE e colocá-la no patamar bastante significativo dentro da instituição. Inclusive promovendo vários eventos nos três campi: Recife, Caruaru e Vitória de Santo Antão. Além disso, mesmo não tendo participado de nenhuma das várias reuniões sobre a SBPC, de última hora, faltando apenas cinco meses, nos foi dada a missão de administrar os recursos para esse importante evento acadêmico-científico.

Em virtude da irresponsabilidade de quem só 'sabia falar bonito' e não entendia nada de gestão, coordenar administrativa e financeiramente a SBPC foi realmente um grande desafio que experimentei com a equipe maravilhosa, já conquistada, da Proext. Tive, inclusive, que argumentar muito com os membros da equipe para cumprir com essa missão, porque eles estavam se sentido preteridos por não terem sido chamados em nenhum momento durante um ano e meio de discussão sobre o evento, só envolveram nas discussões as pró-reitorias de Pesquisa, de Graduação, de Comunicação e até a estudantil.

Faltando cinco meses para que o evento acontecesse na UFPE fui chamado pelo reitor para administrar o evento. Acho que ele fez isso para que desse errado e, consequentemente, pudesse culpar a Proext, porque ele disse que tudo estava nas minhas mãos. Penso que ele fez isso de propósito, para dar errado mesmo, mas se enganou, o evento foi um sucesso, teve até transmissão ao vivo, com debates e 
reportagens que conseguimos fazer com a TV Universitária. Mesmo assim, preciso agradecer ao DBDA pela coragem em abrigar um evento de tamanha importância acadêmica e a confiança depositada em nosso trabalho.

Posso garantir que a Pró-Reitoria de Extensão foi uma grande experiência políticoadministrativa. Foi uma experiência de muito empenho, tanto é que as pessoas primeiro tinham as ideias, falavam sobre elas comigo e, logo em seguida, faziam um projeto para receber o financiamento, considerando a confiança depositada no nosso trabalho. Fizemos a descentralização dos recursos financeiros, ou seja, os recursos financeiros dos projetos de $R \$ 3.000$ ou $R \$ 5.000$ caíam diretamente na conta do coordenador do projeto. Também construímos uma engenharia de modo a que todos os projetos de extensão tivessem pelo menos um bolsista, recebendo mensalmente sua bolsa, cujo valor fosse próximo ao da bolsa de pesquisa. Tinha um projeto de extensão que possuía, às vezes, 10 bolsistas, outros, 15 bolsistas, porque havia de fato a necessidade da locação das bolsas nesses projetos. Dessa forma, fomos crescendo tanto em termos de visibilidade administrativa na instituição que um grupo de colegas acabou me incentivando a ser candidato a reitor da universidade.

Ser candidato a reitor foi uma outra batalha. Primeiro para me convencerem a ser candidato, passaram pelo menos um ano e meio tentando me incentivar, hoje reconheço que em alguns momentos foi excessivo, porque queriam que eu saísse já no primeiro ano de gestão do DBDA. Penso até que, dependendo do professor que me incentivava, no fundo, queria mesmo era ocupar o meu lugar na Pró-Reitoria de Extensão.

Hoje, com certo distanciamento, consigo ver isso com mais clareza, mas o fato concreto é que, guardadas as proporções, a maioria queria mesmo que eu fosse candidato a reitor porque achava que eu era um bom gestor pelos investimentos que foram feitos nos inúmeros projetos e pelos recursos financeiros que fui buscar dentro e fora da instituição. Inclusive, no Ministério do Esporte, eu e o já falecido Márcio Eustáquio, diretor do Núcleo de Educação Física, na época, captamos $R \$ 6.500 .000$ para a construção da atual pista de atletismo.

Depois da captação dos recursos o Márcio Eustáquio, com uma boa equipe do Núcleo de Educação Física e Desportos, o Leonardo, a Camila e o Laudiélcio, desenvolveram o projeto básico. Hoje a pista de atletismo tem qualidade internacional. Captei outros recursos do Ministério de Ciências e Tecnologia, em torno de $R \$ 2.000 .000$ para a torre de atracamento do Zepelim. A única torre remanescente no Brasil. Internamente na UFPE também captamos os recursos das pró-reitorias que não desenvolviam seus projetos e, consequentemente, deixavam dinheiro sobrando. Por isso que a Proext virou uma das pró-reitorias mais ricas daquele período na universidade, até hoje vejo livros que foram publicados com a marca da Proext.

A Proext estava preparada para receber as demandas da comunidade universitária, especialmente no que se refere aos eventos. Mandei fazer umas sacolas para eventos, nas quais era possível colocar livros, caneta, bloco de anotação etc. Fizemos mais de 40.000 e guardamos, porque, quando as pessoas chegavam dizendo que tinham um evento, já saíam com as sacolas e, às vezes, canetas e blocos de anotação, isso era o básico, padrão Proext. 
Nessa mesma ocasião eu era pró-reitor de extensão, professor do mestrado e doutorado em Educação, professor do mestrado em Gerontologia e ainda apresentava o programa de televisão, com gravações todas as sextas-feiras. Então eu participava de tudo, foi um momento muito intenso da minha vida acadêmica e política. Participava ainda de todos os eventos da universidade, representando a Reitoria. Algumas vezes o reitor não encaminhava a representação, mas eu ia assim mesmo. Outras vezes a organização dos eventos não convidava nenhum outro membro da gestão, mas me convidava, em virtude da minha participação ativa.

Assim, com tanta coisa acontecendo, acabei atendendo aos pedidos e comecei a construir minha saída da Pró-Reitoria de Extensão para ser candidato a reitor. Esse é um capítulo bastante doloroso, confesso que não queria sair da pró-reitoria porque estava fazendo um bom trabalho, mas não podia continuar na gestão por dois motivos: primeiro, a minha impressão é que já havia um boicote do reitorado, ou por alguns membros da equipe, em relação à Proext, visto que eu havia recebido uma homenagem de bons serviços prestados, inclusive, pelo Fórum dos Diretores, que me concedeu esse certificado; segundo, como todos da universidade acabavam pedindo a colaboração da Proext para várias ações, havia de fato uma inveja por parte de alguns, uma espécie de ciúme coletivo. De forma que eu não queria sair, mas não tive outra escolha. Um outro motivo é que o grupo que estava me incentivando a sair era o mesmo grupo que, em 2011, me incentivou a ser candidato a vice-reitor na chapa com DBDA. Era também parte do grupo que tinha uma articulação político-partidária com setores de fora da universidade.

A candidatura a reitor foi uma experiência excelente porque foi possível agregar muitos valores. À medida que participei dos debates nos departamentos, fui aprendendo e também ensinando. Conheci a instituição universitária por dentro, nos meandros, com seus problemas e as possíveis soluções, as táticas que os profissionais, os professores, técnicos e estudantes vão criando para sair dos embaraços da própria instituição, como fugir da burocracia, por exemplo.

Do ponto de vista da disputa propriamente dita,foi uma das disputas mais difíceis que já vi, infelizmente, também senti na pele, por causa da divulgação de fake news, a falta de diálogo entre os pares no esclarecimento de algumas proposições. Alguns absurdos, como imprimir em mim a ideia de que era desonesto. Inclusive, chegaram a dizer que peguei $\mathrm{R} \$ 190,00$ da Adufepe para bancar minha candidatura.

Acontece que, como pró-reitor de extensão, eu fazia parceria com vários órgãos da UFPE e também com a Adufepe. Uma dessas parcerias foi uma competição esportiva entre os professores do campus Recife, que queríamos levar para Caruaru e Vitória. Então, fui no meu carro para Caruaru junto com o presidente da Adufepe, à época, o Arguto Silvério. Fui às minhas custas, sem diárias da universidade, e dei uma carona ao Silvério.

Chegando em Caruaru, após a reunião com o coordenador setorial de extensão e depois do jantar, o Arguto Silvério achou por bem ficar na cidade porque já era noite. Eu disse que era melhor voltar, afinal, apesar de estar oficialmente por lá, estava sob minhas próprias custas. Por sua vez, ele informou que, devido a carona, a Adufepe pagaria as 
diárias. Então, foi isso o que aconteceu, eu sou associado da Adufepe, não houve nenhum mal nisso, não houve nenhuma desonestidade nesse procedimento. Ou seja, a Adufepe, por intermédio de seu presidente, o Silvério, pagou uma diária de hotel em Caruaru.

Com toda essa panaceia, certamente, houve desonestidade em quem tentou transformar isso num problema ético, financeiro e político. A reunião para formalizar a competição em Caruaru aconteceu no mês de maio de 2015. Como houve eleição para a Adufepe em nosso grupo político, nós, inclusive, apoiamos o professor $\mathrm{GCNH}$, que passou a ser o presidente a partir do mês de junho do mesmo ano. Nós fomos traídos pelo $\mathrm{GCNH}$, porque essas falsas denúncias foram feitas por ele, num acordo, certamente, feito com os nossos adversários. $\mathrm{E}$ isso foi levado aos tribunais pelo Arguto Silvério, processando a Adufepe e o seu então presidente GCNH pela publicação da nota oficial, para nos atingir, a mim e ao Arguto Silvério.

Tudo ainda está nos tribunais, não sei como está o andamento disso, eu não processei ninguém porque achava que deveria ter outro tipo de saída, embora essas pessoas merecessem ter sido processadas. Além disso, houve um empenho muito grande dos adversários e, especialmente do DBDA, que acabou ganhando a eleição. Aliás, todos os diretores de centro que me concederam o 'preito de agradecimento pelos serviços prestados na Proext' estavam com o DBDA. Fiquei sabendo, inclusive, que houve um debate muito intenso para que eu não fosse eleito, porque eu era associado ao PCdoB, mas ele também era associado, só que ao PT, que investiu muito fortemente em sua candidatura.

Alguns colegas dizem que o senador Humberto Costa, do PT, ligava para os conhecidos da universidade para pedir votos para o DBDA. Não sei em outras instituições, mas, na UFPE, todos os reitores têm alguma relação político-partidária, ou é filiado ou tem uma relação tão estreita que não precisa fazer filiação oficial. Lembro do candidato DSO, que não era filiado ao PSB, mas passou aproximadamente sete a oito anos no governo de Pernambuco, na época do Eduardo Campos, e parece que ainda ficou uns meses no governo de Paulo Câmara.

Uma pessoa que fica oito anos na gestão de um determinado governo tem uma relação estreita com a política. Ele foi uma das pessoas que mais me acusaram de ser de partido político. Outra candidata, MMJL, dizia que não era filiada a nenhum partido e realmente não era, mas flertava, de vez em quando, com o PT, com o PSB e com o PCdoB. Na ocasião da campanha, ela tinha saído da Editora Universitária, mas durante sua gestão recebeu várias emendas de parlamentares ligados a esses partidos em virtude, obviamente, de sua relação e porque desenvolvia um excelente trabalho por lá.

Outro candidato, o DDR, ele não sabe disso, mas nos bastidores era conhecido como o 'candidato sabão'. Ele havia se desfiliado do Psol, um ano e meio ou dois anos antes da eleição para ser candidato a reitor, mas até hoje se organiza com o Psol. Então, eu, o DBDA, a MMJL, o DSO e o DDR, todo mundo tinha um pé na cozinha de partido político, ou uma relação político-partidária de alguma forma. De qualquer modo, eu não ganhei a eleição, mas, desde 1987, que não havia segundo turno na UFPE e naquela eleição houve, foi muito difícil inclusive. Acho que todo PT veio fazer disputa eleitoral e eu tive apenas a importante colaboração da Associação Nacional dos Pós-Graduandos, na época, dirigida por camaradas do PCdoB. 
No segundo turno, nós crescemos em torno de 10\% e o DBDA diminuiu próximo de $9 \%$, mas, no resultado final, o DBDA conseguiu 7.600 votos e eu, aproximadamente, 5.650, nessa eleição de 2015. Portanto, foi para mim uma grande vitória, com grande êxito político e é esse o grande ensinamento da eleição de reitor na Universidade Federal de Pernambuco, ambiente de disputas pelo conhecimento, pelos laboratórios que mais produzem e, finalmente, pelo poder e controle institucional.

Naquela ocasião houve um debate na imprensa, nos jornais, blogs e televisão. Eu mesmo fui entrevistado por duas emissoras, isso durante o primeiro e o segundo turnos, até porque a universidade é grandiosa, conhecida como uma das maiores do país, a primeira do Norte e Nordeste e com um orçamento de mais de um bilhão de reais. Então não é uma coisa pequena, ela representa o terceiro maior orçamento do Estado e tem um impacto considerável no Norte e Nordeste porque possui o maior número de cursos de mestrado e doutorado. Além disso sua história remonta a 1827, com a criação da Faculdade de Direito.

De qualquer modo, foi uma eleição muito difícil e dolorosa, saí triste não porque tinha perdido a eleição, mas pelo fato de alguns dos nossos colegas terem investido em estratégias baixas para ganhar, inclusive, mostraram o seu lado sombrio, preconceituoso e racista. Uns chegaram a dizer que eu incorporava a vitimização do negro no Brasil; outros, que eu não era pesquisador e não dispunha de produção científica compatível com a vida acadêmica.

Um dos meus apoiadores, o professor Wellington Pinheiro, é engenheiro e fez um levantamento da produção científica de todos os candidatos. Na época a maior produção era a minha. Se juntasse todos os candidatos, os cinco contando comigo, eu tinha mais produção que os quatro juntos, desde livros, capítulos e artigos publicados, investimento na pós-graduação e na formação de recursos humanos até a orientação de mestrado e doutorado.

Se você for verificar, até hoje, tenho uma boa produção acadêmica em relação aos colegas que disputaram a eleição em 2015, inclusive, maior produção do que o próprio reitor da época. Então, a questão não era simplesmente acadêmica, era e ainda é outra, o preconceito e racismo. Observe que, somente em 2019, voltei a conversar com as pessoas sobre a possibilidade de disputar novamente a eleição. Numa dessas conversas um colega disse que não havia votado em mim por um critério acadêmico. Acabei rindo do que ele disse e concordei com o que foi dito.

Concordei dizendo que o critério por ele levado em consideração estava correto, mas a escolha foi equivocada, porque ele não se deu conta de abrir o Currículo Lattes de nenhum de nós. Aliás, quem tinha a menor produção foi exatamente quem ele disse ter votado no primeiro turno. Quando falei isso, ele ficou vermelho de vergonha ou de raiva, saliento que ele é branco de olhos verdes. No fundo, há um preconceito porque eu sou da Educação Física e, certamente, por ser negro. Ele me olhava e achava que eu não tinha produção científica e, portanto, isso era incompatível com um candidato a reitor.

Não obstante essas tensões eu fico feliz de ter fechado um pouco esse ciclo político, mas na esperança de desenvolver outras atividades, novos projetos ou participar de outros pleitos com mais êxito. Assim, neste capítulo, apresentei um panorama geral da minha trajetória entre a vida escolar, artística e acadêmica, com algumas particularidades referentes à política institucional. Espero que o leitor compreenda que a minha razão 
narrativa, minha fala, os meus ditos neste capítulo estratégico servem de referência para os demais capítulos, que terão, além da base autonarrativa, um conjunto de documentos que trarei para análise de vários episódios dos itinerários por mim experimentados, com evidente acúmulo de capitais.

\section{Capítulo 3 - Do capital escolar-cultural aos penduricalhos institucionais}

Toda pesquisa historiográfica se articula com um lugar de produção socioeconômico, político e cultural. Implica um meio de elaboração que circunscrito por determinações próprias: uma profissão liberal, um posto de observação ou de ensino, uma categoria de letrados etc. Ela está, pois, submetida a imposições, ligada a privilégios, enraizada numa particularidade. (Certeau, 2002, p. 66)

Considerando as reflexões de Certeau (2002), este capítulo é dedicado à análise documental da biografia secundária, especialmente diplomas, ofícios, memorandos, portarias e outras evidências em plataformas digitais como a Plataforma Siga, desenvolvida pela Universidade Federal de Pernambuco, onde é possível registrar e encontrar em vários ambientes, ou interfaces, os planos de aula, projetos de pesquisa, de extensão ou de ensino, carga horária semestral e avaliação docente pelo discente. É o que chamamos na UFPE de Paad e Raad, respectivamente, plano e relatório das atividades docentes.

Embora possa parecer coisa menor, o dicionário grafa penduricalhos como adorno, provavelmente símbolo ou objeto ritual de passagem. Logo, este capítulo tem por objetivo apresentar sucintamente alguns documentos relativos à burocracia institucional que tornam possíveis ritos de passagens e progressões horizontais e verticais, sem os quais a vida escolar e acadêmica, a carreira docente numa universidade pública federal, por exemplo, ficaria deveras sem graça.

Parte dessa documentação o leitor pode considerar como evidência do capital escolar-cultural e simbólico adquiridos durante uma trajetória e num campo de produção determinado (Bourdieu, 2002) que, na minha operação historiográfica (Certeau, 1998), as construí como uma das fontes fundamentais para o início da minha entrada no campo das instituições educativas, num primeiro momento, e depois nas instituições universitárias por onde transitei.

Não vou expor toda a documentação referente a esse tema, pois seria necessária uma outra pesquisa, colocarei apenas o suficiente para identificar uma das formas de aquisição de um tipo específico de capital, bem como outros registros, penduricalhos, que agregamos ao nosso habitus em determinados itinerários.

\section{Aquisição de capital escolar-cultural}

Considerando o que propõe Certeau (2002) sobre a articulação da pesquisa historiográfica num determinado lugar social e sua conexão com aspectos econômicos e culturais ligados, inclusive, a uma determinada instituição, analiso uma documentação que evidencia a minha presença e permanência no campo educacional e acadêmico, o que reflete inevitavelmente um tipo muito específico de capital acumulado durante 45 anos aproximadamente. 
Nesse sentido, analiso algumas evidências de documentos provenientes do arquivo pessoal e institucional, ou seja, documentos guardados na minha residência e arquivados nas escolas e universidades. É óbvio que, durante muito tempo, guardei documentos que considerava superados pela força do fechamento de um ciclo, sobretudo, escolar, mas que agora essas fontes me revigoram em busca de mais conquistas. Assim, alguns dos documentos que já dispunha mostraram-me o caminho institucional já percorrido, especialmente a visitação às escolas onde estudei. Outros documentos, como os diplomas, também encontrei na minha própria residência, mas as portarias e ofícios, objetos de análise da próxima seção, só foram possíveis na atual instituição de trabalho, a Universidade Federal de Pernambuco.

Todavia, tendo em vista esses aspectos, no processo de aquisição do capital escolar-cultural a primeira fonte que exibo com todo o meu orgulho de cidadão brasileiro, oriundo das classes populares, diz respeito aos registros de frequência da primeira instituição pública onde estudei a 3ª série do Ensino Primário, em 1975. Trata-se de um registro de frequência do mês de novembro daquele ano, inclusive único registro encontrado da Escola Municipal de 1ํ Grau Marechal Arthur da Costa e Silva, em Jaboatão dos Guararapes, Pernambuco.

Figura 18 -

Registro de Frequência da Escola Municipal de 1ํㅡrau Marechal Arthur da Costa e Silva, 1975.

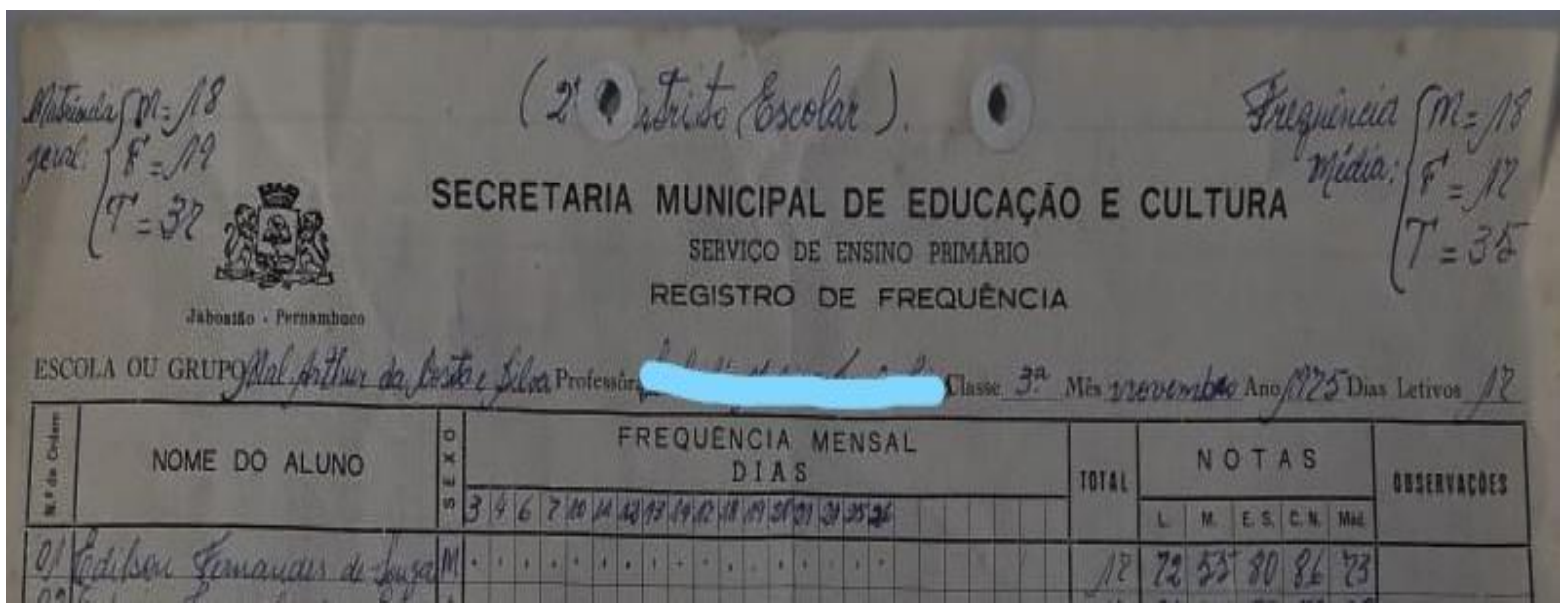

Fonte: acervo permanente da Escola Municipal de 1ํㅡrau Marechal Arthur da Costa e Silva.

Encontrar esse documento foi de grande importância para este projeto autobiográfico, porque essa escola é a que mais me emociona ao falar dos momentos em que estive numa de suas salas, lembro também que fiquei bastante emocionado ao visitá-

la em 2019, quando estava realizando minhas buscas por documentos. Não tive como conter as lágrimas diante da diretora que me recebeu muito bem, de alguns funcionários e de uma das minhas filhas, Viviane Souza.

Foram muitas recordações agradáveis chegando ao mesmo tempo, inclusive o voto de confiança no ato da minha matrícula em 1975. Como já disse anteriormente era para eu ter me matriculado na $2^{\mathrm{a}}$ série mas, como não havia mais vaga, a pessoa responsável 
confiou na minha palavra e me deu uma chance na turma da $3^{\text {a }}$ série. Acho que não decepcionei. A confiança da professora e o meu compromisso resultaram numa boa aprendizagem, algo que reafirma aspectos importantes defendidos por Alheit (2011), que é a biografização.

De volta ao documento, por questões éticas, o leitor pode verificar que passei uma tarja no lugar que corresponde ao nome da minha professora, bem como recortei o documento, para garantir a privacidade dos meus 18 colegas de turma. Essa é uma ficha que registra o nome só dos meninos, embora me recorde de ter meninas naquela turma de 1975. Aliás, conforme está descrito no canto acima, à esquerda da fonte, podemos identificar o total de alunos: "Matrícula geral $\{M=18 ; F=19 ; T=37$ "; ou seja, 18 meninos e 19 meninas, totalizando 37 estudantes.

Os nomes estão em ordem alfabética e, curiosamente, o primeiro da lista, à esquerda, sou eu. No meio da ficha, consta "Frequência Mensal - Dias" e na parte final do documento, na mesma linha do meu nome, à direita, o leitor pode observar a palavra "total", correspondendo ao número de presenças. Logo em seguida, é possível observar as letras L, M, E.S, C.N, Med., que correspondem às disciplinas Língua Portuguesa, Matemática, Estudos Sociais, Ciências Naturais, respectivamente, e a Média.

Fiquei sem saber ao certo se são notas do final do ano ou apenas as notas referentes ao mês de novembro de 1975. A memória aqui não consegue dar conta. De qualquer modo, a minha média foi 73 . Não sei se esse indicador tem realmente alguma importância para a história que estou desenvolvendo, mas o fato concreto é que fui bem nos resultados, pois fiquei com 73 pontos, quando a nota mínima era de 50 pontos.

Ao olhar para o documento, onde só tinha nomes dos meninos, procurei as meninas e recordei que uma delas, a Betânia, provavelmente da mesma turma, seguia sempre no mesmo caminho que eu fazia em direção a minha casa. A razão dessa lembrança devese ao fato de pensar no porquê de um registro de frequência só ter meninos. Talvez, tivesse outra ficha semelhante apenas com os nomes das meninas, até porque dos dois lados superiores da ficha, é possível observar a referência ao número total de estudantes matriculados e frequentes. Ou seja, do lado esquerdo 37 (total de matriculados) e do lado direito 35 (frequência), referência clara a presença de meninas na turma, evidentemente, com duas desistentes.

Há um outro documento que me fez emergir não apenas das memórias, mas também de uma classe social popular numa segunda etapa do processo de escolarização. Consegui ter acesso, nos arquivos de outra instituição em que estudei por três anos, uma fonte que evidencia a minha mudança de status escolar, o Certificado de Conclusão de Série, datado de 27 de dezembro de 1976, emitido pela Escola de 1ํ Grau Centro Educativo Operário Agamenon Magalhães, infelizmente uma instituição já extinta.

Fiquei muito feliz em saber que possuía esse certificado, provavelmente o primeiro da minha vida, após a certidão de nascimento. O primeiro certificado de tantos outros que viriam durante meus itinerários na aquisição do capital escolar-cultural. Evidência, portanto, das minhas progressões e promoções na aquisição do saber escolarizado, importante instrumento de ascensão social.

$\mathrm{O}$ fato é que essa fonte chegou em minhas mãos por meio dos arquivos de uma outra escola, Escola de 1ํ Grau Professor Pedro Augusto Carneiro Leão, que guardou a documentação da minha escola anterior, provavelmente ao me receber como novo aluno 
da série seguinte, ou seja, $5^{\mathrm{a}}$ série. Entre todos os certificados recebidos até o presente momento, este tem um significado muito especial, pois foi o primeiro e decisivo na progressão escolar, descoberto apenas agora. Fiquei muito surpreso ao encontrar essa fonte numa outra escola.

Como pode ser verificado, além do preenchimento à mão e dos nomes dos meus pais, o texto trata das exigências necessárias para a referida conclusão da série, no caso específico, $4^{\underline{a}}$ série do $1^{\circ}$ grau. Essas exigências são relacionadas à frequência e notas do ano letivo de 1976, em conformidade com a legislação da época, lei n. 5.692/1971.

Figura 19 -

Certificado de conclusão de série, 1976.

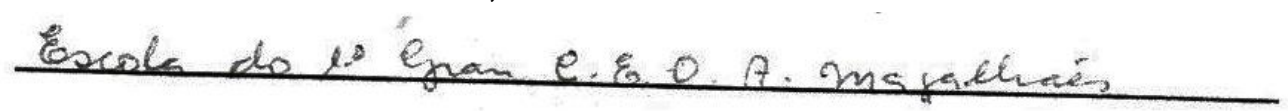

\section{Certificado de Conclusão de Série :}

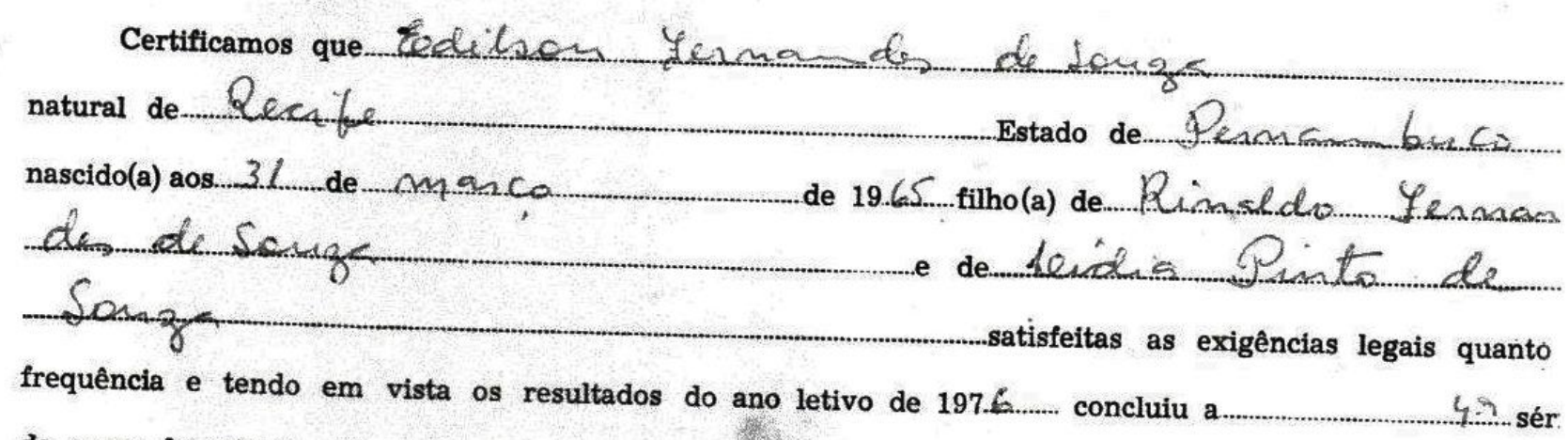

do curso de primeiro Grau de acordo com a Lei 5692 de 11 de agosto de 1971

Fonte: arquivo da Escola de $1^{\circ}$ Grau Professor Pedro Augusto Carneiro Leão.

Após esses dados preenchidos à mão, na parte lateral esquerda consta o título Histórico Escolar - $1^{\circ}$ Grau, com a descrição das atividades ou áreas de estudo da $1^{\underline{a}}$ à $4^{a}$ série. Além desse documento, que certifica a conclusão de um ciclo, foi emitido pela mesma instituição a Ficha de Acompanhamento do Aluno de $1^{\circ}$ Grau - $1^{\underline{a}}$ a $4^{\underline{a}}$ série. Esse documento foi datado dois anos depois do certificado, em 27 de dezembro de 1978, provavelmente por exigência da escola onde eu já estava estudando a $6^{\mathrm{a}}$ série, ou seja, o Pedro Augusto. Essa ficha de acompanhamento revela a minha promoção, com o seguinte trecho grafado num dos versos do documento: "Ao final do ano o aluno foi aprovado. Deverá cursar a $5^{\mathrm{a}}$ série do $1^{\circ} \mathrm{Grau}$ ".

Consta num dos quadros do documento, os tópicos Aspectos: Comunicação e Expressão; Integração Social; Iniciação às Ciências; Matemática; e do outro lado a palavra Aproveitamento, do $1^{\circ}$ ao $4^{\circ}$ período, e as respectivas notas, com espaço para dados relativos à recuperação e ao resultado final. Aliás, sempre fui aprovado.

Curioso foi eu perceber que essa ficha de acompanhamento do aluno de $1^{\circ}$ grau, emitida dois anos após eu ter terminado a $4^{\mathrm{a}}$ série, foi assinada pelo meu pai. Na verdade foram quatro assinaturas relativas a cada período cursado. Não lembrava de papai ter ido 
a alguma escola em que estudei mas, talvez, nesse caso específico, sua assinatura tenha ocorrido porque ele trabalhava a uns cem metros da escola, vendendo abacaxi no mercado de Água Fria, que ficava na frente da escola.

Esse documento tem um significado muito especial, por dois motivos. $O$ primeiro deles diz respeito à própria instrumentalidade de seu suporte, ou seja, certifica a conclusão de um período importante de escolaridade, tendo em vista que, nessa época, muitos colegas apenas concluíam esse grau e não davam continuidade aos estudos. Muitas famílias nordestinas, sobretudo, diziam que seus filhos teriam 'completado' os estudos quando concluíam a 4⿳亠丷a série primária, pelo menos, é assim que eu me lembro.

O segundo motivo trata-se do fato de que o referido documento tem a assinatura do meu pai, além da fiabilidade/originalidade, conforme Aróstegui (2006) trata a análise documental, é uma fonte rara, considerando que o meu pai não se envolvia com as questões relacionadas às instituições onde estudei, embora sempre tenha desejado o meu sucesso escolar.

Além disso, sinto-me muito honrado em ter a assinatura dele num dos meus documentos escolares, haja vista que, sendo portuário aposentado e, nessa época, comerciante para completar o orçamento, papai só havia feito a $3^{\text {a }}$ série do primário. Contudo, vejo com admiração, do lado superior à esquerda, a assinatura correta e letras muito bonitas de meu pai.

Figura 20 -

Ficha de acompanhamento do aluno de 1ํgrau com a assinatura de papai, 1976.
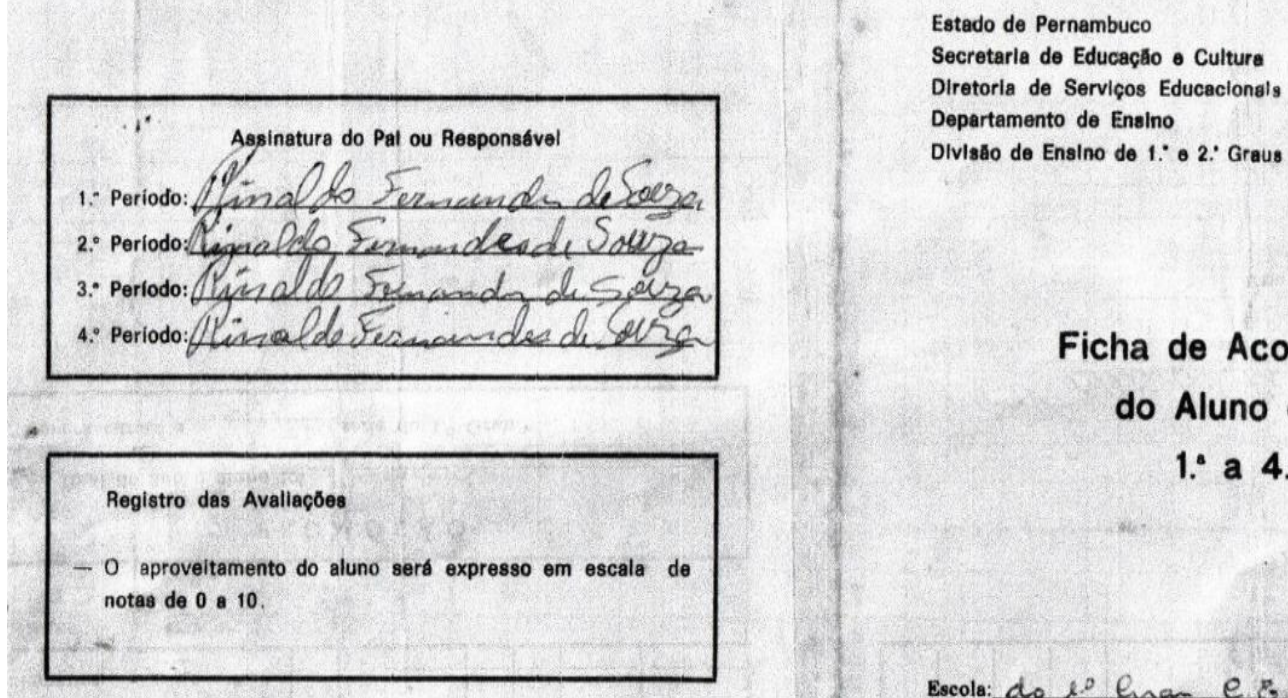

Ficha de Acompanhamento

do Aluno de 1. Grau

1." a 4." série

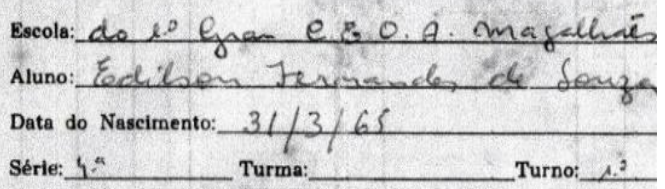

Mad. $301-600.000 \mathrm{fls} .05 / 76$

Fonte: arquivo da Escola de 1ำ Grau Professor Pedro Augusto Carneiro Leão. 
Como pode ser lido, trata-se de um documento da Divisão de Ensino de $1^{\circ}$ e $2^{\circ}$ Graus, da Secretaria de Educação e Cultura do Estado de Pernambuco, que, por existir, expressa a intencionalidade de fechamento do ciclo de ensino ( $1^{\text {a }}$ à $4^{\underline{a}}$ série). Possivelmente, esse era o tipo de documento de porte obrigatório, caso o estudante pretendesse dar continuidade à escolarização ou encerrar os estudos, o mais provável, como a maioria dos meus colegas dos lugares onde morei.

Entre os documentos cedidos e encontrados no arquivo da Escola Pedro Augusto, está a Ficha Individual de 1ํ Grau do ano de 1977. Não vou analisar toda a ficha, mas me chamou atenção o fato de eu ter obtido nas duas primeiras unidades da $5^{\text {a }}$ série os seguintes resultados: Português 3,0 e 3,0; Geografia 7,0 e 9,5; Matemática 5,0 e 9,0. Isso mesmo, 9,0 em Matemática. Acho que foram pouquíssimas as vezes em que obtive um nove em Matemática em toda a minha vida.

Figura 21 -

Ficha Individual de $1^{\circ} \mathrm{Grau}, 1977$.

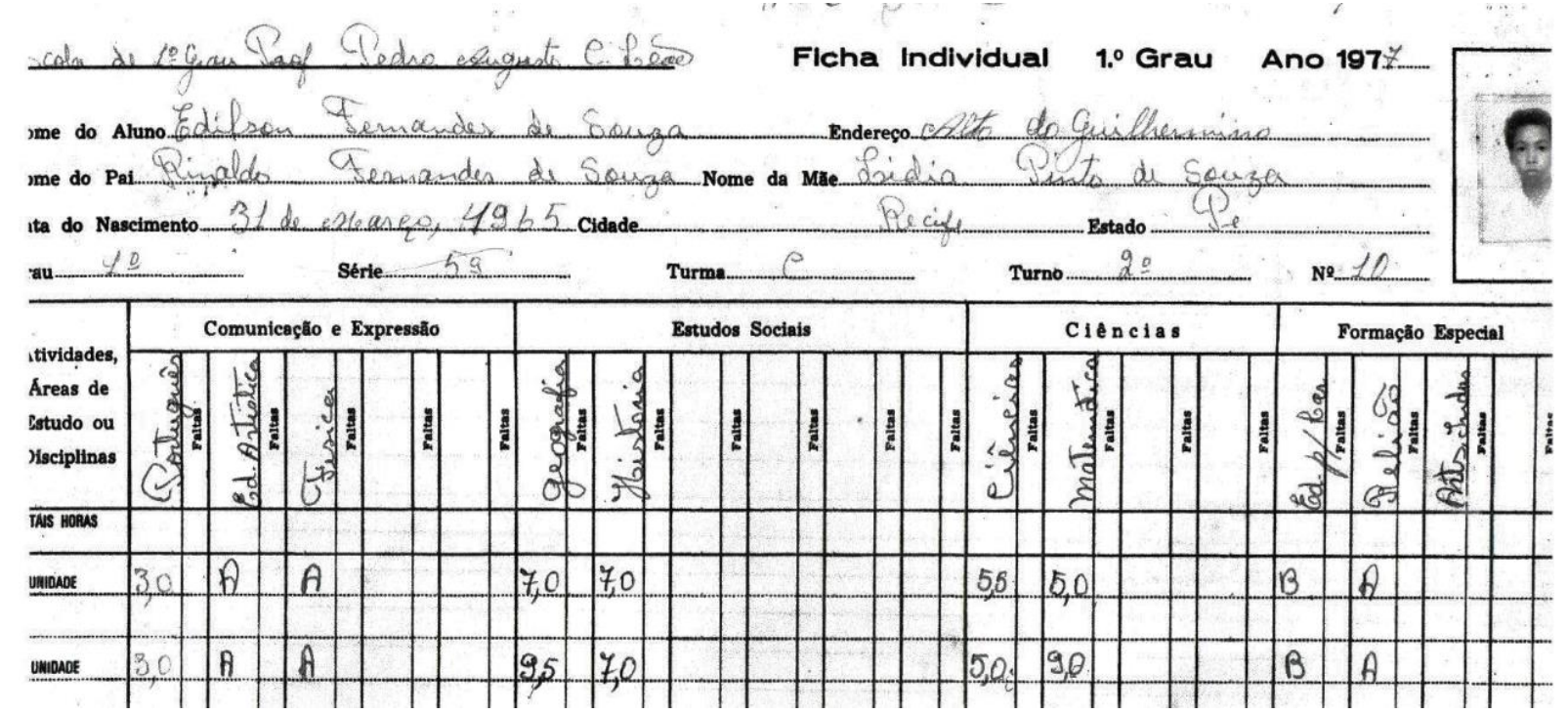

Fonte: arquivo da Escola de 1ำ Grau Professor Pedro Augusto Carneiro Leão.

Além da nota alta em Matemática, outra surpresa foi ter obtido nessas mesmas primeiras unidades o conceito 'B' em Educação para o Lar e 'A' em Religião. Não me lembro de nenhum momento da minha vida escolar que tivesse estudado Educação para - Lar, embora reconheça a importância de algo semelhante na vida de um cidadão: lidar com as finanças do cotidiano em sua casa, fazer comida etc. Entretanto, essa matéria me acompanhou enquanto estive na Escola Pedro Augusto, bem como a matéria Práticas Industriais, que também me foge à memória o seu curso.

Nas buscas pela minha documentação escolar, seja as atas que registraram as notas de todos os estudantes de uma turma ou as Fichas Individuais, objeto de meu maior interesse, tive surpresas agradáveis e desagradáveis em rever notas de disciplinas que sempre julguei que tinha certa afinidade ou que dominava. É o caso dos registros que trarei a seguir, onde aparecem duas notas e um conceito baixos, sendo 2,0 em Física e História e 'C' em Educação Artística, no I Bimestre, da 1aㅡ série do 2ํㅡrau, em 1981. No segundo bimestre, precisei fazer uma rápida recuperação: consegui 9,0 em História e 7,0 em Física. 
Desse modo, no segundo bimestre, tive problemas com a Língua Inglesa, nota 1,0. Mas, por outro lado, houve um feito inusitado que regozija o ego de um estudante: tirei 10,0 em Matemática. Engraçado é que o 9,0 causou mais surpresa em virtude de eu ter tido acesso primeiro àquela documentação e, depois, com avanço da pesquisa, percebi que Matemática não foi um dos meus maiores problemas.

Figura 22 -

Ficha Individual - Curso de 2o Grau, 1981.

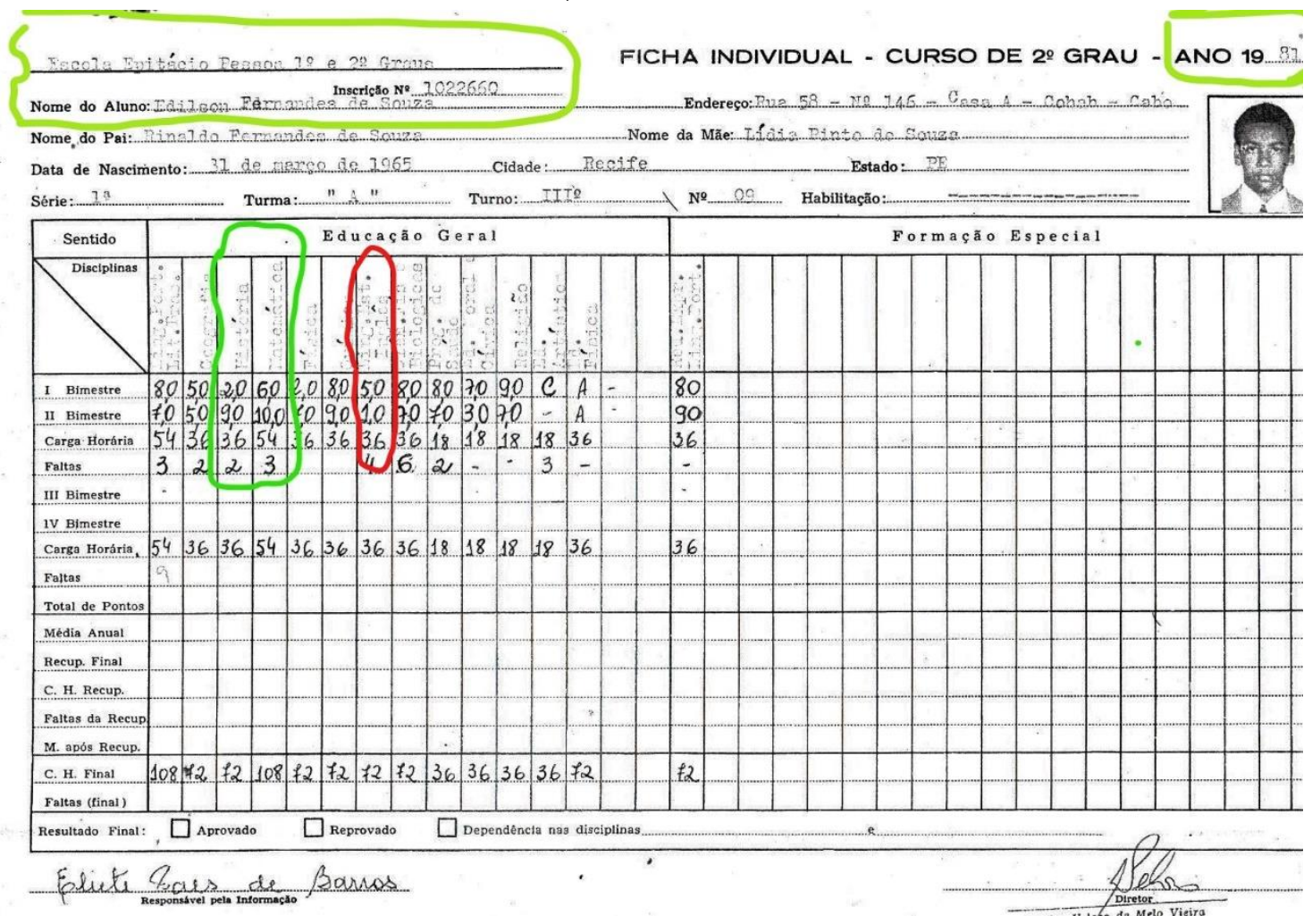

Fonte: arquivo da Escola de 1ํe e 2ํㅡrau Epitácio Pessoa, 1981.

É evidente que essas notas e conceitos servem como indicadores da performance do estudante durante os dois bimestres, mas, também, no cômputo geral da minha Ficha Individual, é perceptível a maneira como vou lidando com as áreas do conhecimento, nas quais, aqui e ali, vou ampliando os indicadores, como 8,0 e 9,0 em Redação e Expressão em Língua Portuguesa, 9,0 em Química. Com isso, vou me recompondo e me reconciliando no trato com as matérias e adquirindo capital cultural-escolar, lenta e paulatinamente.

Nesse contexto, gostaria de refletir acerca das possibilidades de pequenos avanços e retrocessos em que um estudante de porte médio vai adquirindo, driblando e realizando, como diz Elias (2006), seus planos e ações individuais e adquirindo um dos aspectos fundamentais para a formação humana, que diz respeito ao capital escolar-cultural, necessário para alguém oriundo das classes populares como eu. Essas fontes, que por ora tento interpretar seus significados, têm uma importância imensurável no conjunto da minha própria formação profissional.

Como professor, vejo que no processo da formação humana é necessário verificarmos sempre os tropeços dos estudantes e como eles reagem aos desafios das áreas do conhecimento. Já como pesquisador, é fundamental me manter um pouco 
distanciado para refletir mais criticamente acerca dessa mesma formação profissional e também, à luz da documentação aqui analisada, compreender como a instituição escolar lida com esses aspectos avaliativos, que, às vezes, servem muito pouco ou quase nada para justificar as reprovações, evasão escolar e o analfabetismo em nossa sociedade.

Tudo isso pode parecer reflexão vaga e sem sentido, mas o principal objetivo é entender que a médio ou longo prazo no processo de escolarização, o indivíduo vai adquirindo certo nível de capital cultural que, lá pelas tantas, seja ainda na juventude ou quase no final da vida, algo foi se ajustando e alimentando o agente social de capacidades para responder às demandas da sociedade. É, portanto, com base na crença educacional que ainda insisto que a formação é necessária e inadiável a um ser humano.

Todavia, tenho poucos documentos das escolas onde estudei, desses capitais importantes para a permanência e a representação do indivíduo em determinado campo. Um desses documentos se refere ao meu Histórico Escolar da $1^{\text {a }}$ à $8^{\text {a }}$ Série do $1^{\text {o }}$ Grau, sua importância é imensurável, principalmente pelos dribles que uma das instituições educacionais fez para ajustar minha idade-série. Depois, pelas pequenas descobertas que tenho feito na composição desta tese e na reconstrução da temporalidade autobiográfica. Como pode ser visto, leitor, meu histórico escolar revela um estudante de competência mediana, notas apenas para passar de ano, mas revela também a aquisição paulatina do capital cultural disponível para um indivíduo com as minhas características socioeconômicas.

Destarte, o fato é que não nos damos conta desses pequenos registros que uma trajetória possibilita ao longo de uma temporalidade. Às vezes, nem damos tanta importância a esses penduricalhos, como o meu diploma de mestrado, que até agora não fui buscar. Antes, custava caro e eu não tinha dinheiro, conversei até com o decano da universidade, mas não obtive sucesso. Agora, a Universidade Gama Filho fechou, e perdi o interesse.

Dentre os poucos documentos que possuo das escolas em que estudei, está uma carteira de estudante de 1982. Eu a encontrei por um acaso, entre os pertences de mamãe no dia do seu falecimento, quando tive que procurar o seu registro de nascimento ou de casamento para o atestado de óbito. A carteira servia para entrar na escola e para adquirir o passe estudantil, que possibilitava comprar passagens por preços mais baixos. 
Figura 23 -

Carteira estudantil da Associação Pernambucana de Serviços Educacionais, 1982.

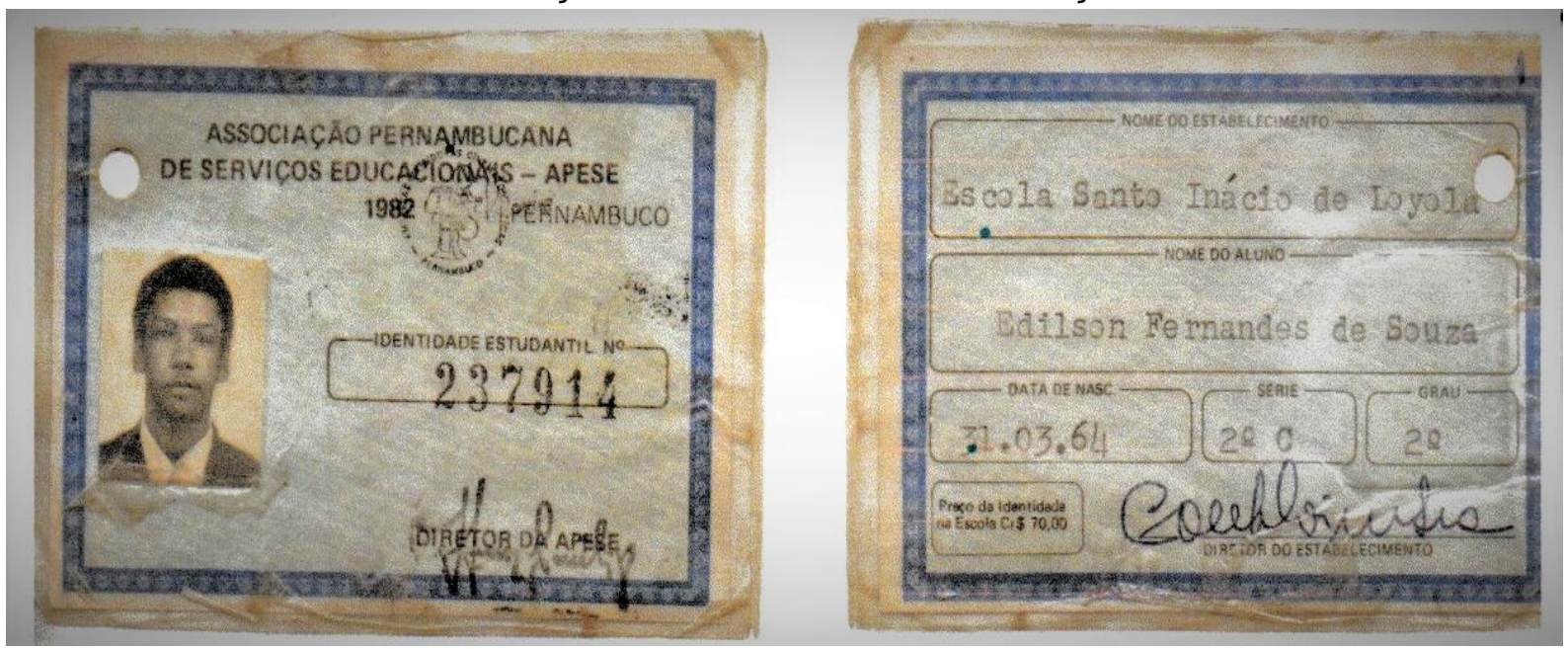

Fonte: arquivo de mamãe, Lídia Pinto de Souza.

Eu, esse menino sério de paletó preto e gravata na fotografia oficial $3 \times 4$, nessa época, já fazia algumas atividades artísticas, como a dança afro no Balé Primitivo de Arte Negra de Pernambuco, estudava música num projeto comunitário de Peixinhos, em Olinda, e também fazia teatro no Sesc, de Santo Amaro, com o José Manuel. Contudo, essa carteira representa a parte mais séria entre as atividades naquela época, porque eu precisava ser aprovado na escola para progredir e atingir o que seriam os níveis mais altos de escolarização, para alguém das classes populares.

Esse documento revela as minhas reais intenções no progresso estudantil, pois, dia após dia, além de ir para as atividades artísticas, mais prazerosas e criativas, por sinal, eu frequentava as aulas do $2^{\circ}$ ano Científico, como diziam à época, na Escola Santo Inácio de Loyola. Naquela ocasião, 1981-82, tomei a decisão de sair do 'científico' e ir para um curso técnico-profissional, no caso, fui estudar Enfermagem. Essa carteira é, portanto, um símbolo de capital cultural em processo de aquisição.

Ao retornar a essa escola 37 anos depois para buscar algum documento daquela época, verifico, na minha ficha individual de aluno, que os históricos escolares das duas séries, $1^{\circ}$ ano, turma ' $F$ ' de 1981 , e $2^{\circ}$ ano, turma 'B' de 1982, representam bem um esforço no sentido de dar pequenos avanços na minha formação educacional. Nunca fui reprovado em nenhuma série, como já disse, mas, ao analisar rapidamente a documentação, agora um pouco distanciado, verifico que passei muitos apertos em algumas matérias. No primeiro bimestre de 1981, por exemplo, fiquei com média 5,0 em Língua Portuguesa Moderna, 6,0 em Matemática e 2,0 em História. No segundo bimestre 1,0 em Língua Portuguesa Moderna, 9,0 em História e 10,0 em Matemática. Ainda bem que tudo foi devidamente recuperado.

Já no $2^{\circ}$ ano, em 1982, a única matéria objeto de minhas preocupações foi a Física, porque, embora também tivesse nota baixa, 5,0, em Organização Social Brasileira -OSPB -, essa era uma matéria de fácil compreensão. A Física, no entanto, me paralisou completamente, no quarto bimestre, as notas foram: 4,0 e 3,0. Fiquei realmente com medo de reprovar e, consequentemente, não avançar para um curso técnico, como era a minha esperança e da minha família: ascender socialmente por meio da educação. 
Contudo, passado esse susto, o meu próprio sentimento indica que sempre fui um aluno de recuperação, provas finais e também de algumas surpresas. Como o leitor pode verificar nos meus históricos de várias séries, tive dois 10,0 em Matemática, embora nunca tenha sido muito afeiçoado à essa matéria. Aliás, considerando o meu perfil intelectual atualmente e diante de uma análise geral dos meus históricos escolares, é interessante perceber que consegui me destacar em Matemática em detrimento de outras matérias, como, por exemplo, História, que nunca tirei 10,0.

No entanto, é sempre bom fazer uma análise mais cuidadosa do processo e resultado da vida escolar, bem como das condições reais pelas quais os estudantes oriundos das classes populares passam, para que não sejam criados estigmas e preconceitos. Ao analisar rapidamente a documentação identifico com facilidade que, durante a minha vida escolar, sempre tive problemas nos primeiros bimestres de cada ano. Talvez por ter dificuldade na adaptação da escola ou nova série, ou ainda por não compreender a dinâmica ou metodologia do professor. Hoje percebo com clareza que estudar não é uma questão apenas de ir à escola. $O$ gesto, a atitude de se dirigir à instituição educacional todos os dias ajuda muito, mas tudo isso é muito complexo para quem não consegue enxergar algum futuro nos ensinamentos que recebe nesses ambientes que, costumeira e erroneamente, dizemos que é do governo. Confesso que eu ia à escola e tinha medo de ser reprovado. Sempre fui à escola como um hábito sadio, mas não porque via como importante para o futuro, infelizmente. Pelo menos até estudar na Escola Santo Inácio de Loyola, onde tive que decidir qual seria a profissão a seguir em outra instituição.

Assim, ao visitar a Escola Estadual Almirante Soares Dutra, hoje Escola Técnica Estadual Almirante Soares Dutra, onde fiz o curso de Auxiliar de Enfermagem para conclusão do antigo $2^{\circ}$ Grau, atualmente, Ensino Médio, achei muito interessante como fui recebido e também como fui alertado para o fato de que a importância não estava somente na conclusão do curso, mas em ter o diploma. De imediato, a funcionária me deixou entrar na sala de apoio técnico e fotografar a ata de resultados finais do rendimento escolar referente ao ano letivo de 1983.

Como se trata de todos os registros dos concluintes daquele ano, com nomes, notas e conceitos, por questões éticas, não vou expor a fonte em sua totalidade, mas de algum modo, tentarei reproduzir alguns dados relativos à minha condição de estudante dessa importante área dos cuidados humanos, em que tive aprovação em todas as disciplinas, inclusive, com uma das maiores notas em Anatomia e Fisiologia, 9,5. 
Figura 241 -

Ata de resultados finais do rendimento escolar referente ao ano letivo de 1983, na Escola Estadual Almirante Soares Dutra.

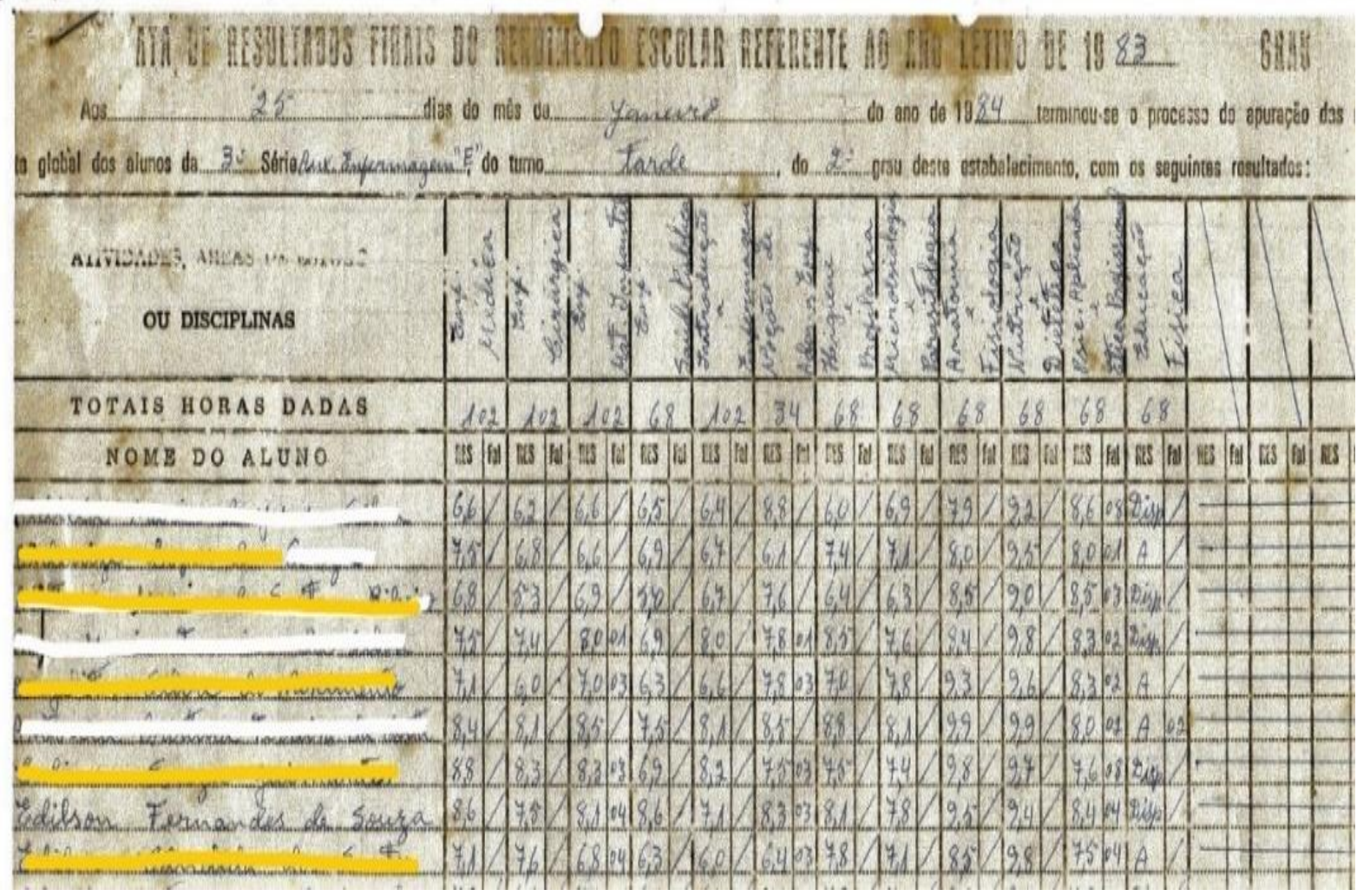

Fonte: Escola Técnica Estadual Almirante Soares Dutra. Sala de Apoio Técnico, gaveta Atas 1976 a 1983. Pasta Enf./83.

Essa ata expressa a perspectiva de Halbwachs (1990), segundo o qual a memória individual e seus vestígios estão sempre em conexão com a memória de um determinado grupo ou memória coletiva. Isso posto, só recordamos aquilo que é possível outros indivíduos também recordarem, embora, o processo e a percepção dessa recordação não seja a mesma de outros indivíduos membros do nosso grupo. De forma que essa ata resguarda pelo menos 40 nomes de estudantes que estiveram juntos em 1983, entre os quais apenas uma desistiu.

A fonte é reveladora das relações interpessoais de jovens em formação técnicaprofissional à espera da aquisição do capital escolar-cultural. Alguns desses estudantes estiveram comigo no estágio no Hospital Barão de Lucena, na verdade, os que obtiveram as melhores notas. Assim, mesmo nunca tendo atuado profissionalmente nessa área, considerando as 11 matérias cursadas, no cômputo geral, obtive uma boa média, 8,3, para receber a bolsa de estágio.

Essa média geral é reflexo das seguintes notas: Enfermagem Médica 8,6, Enfermagem e Saúde Pública 8,6; Nutrição e Dietética 9,4 e, entre outras, Psicologia e Ética Profissional, 8,4, sendo dispensado da Educação Física. Aliás, a dispensa foi em virtude da minha participação no Balé Primitivo de Arte Negra de Pernambuco, que me fez ser considerado apto à atividade física.

Não obstante parecer coisa de menor valor, os penduricalhos muitas vezes te ajudam na transmigração de um território a outro. É o que posso dizer dos documentos relativos ao momento escolar e universitário, como o diploma de graduação em Educação

\begin{tabular}{|l|l|l|l|l|l|} 
Regae: Rev. Gest. Aval. Educ. & Santa Maria & v. 10 & n. especial & e66773, p. 1-325 & 2021
\end{tabular} 
Física. Este é um dos mais importantes, considerando que durante muito tempo eu dizia que não gostava dessa área. Hoje vejo que, seguramente, foi a licenciatura em Educação Física que me permitiu avançar de maneira mais efetiva na transmigração de um campo a outro.

Figura 25 -

Diploma de graduação em Educação Física, 1998.

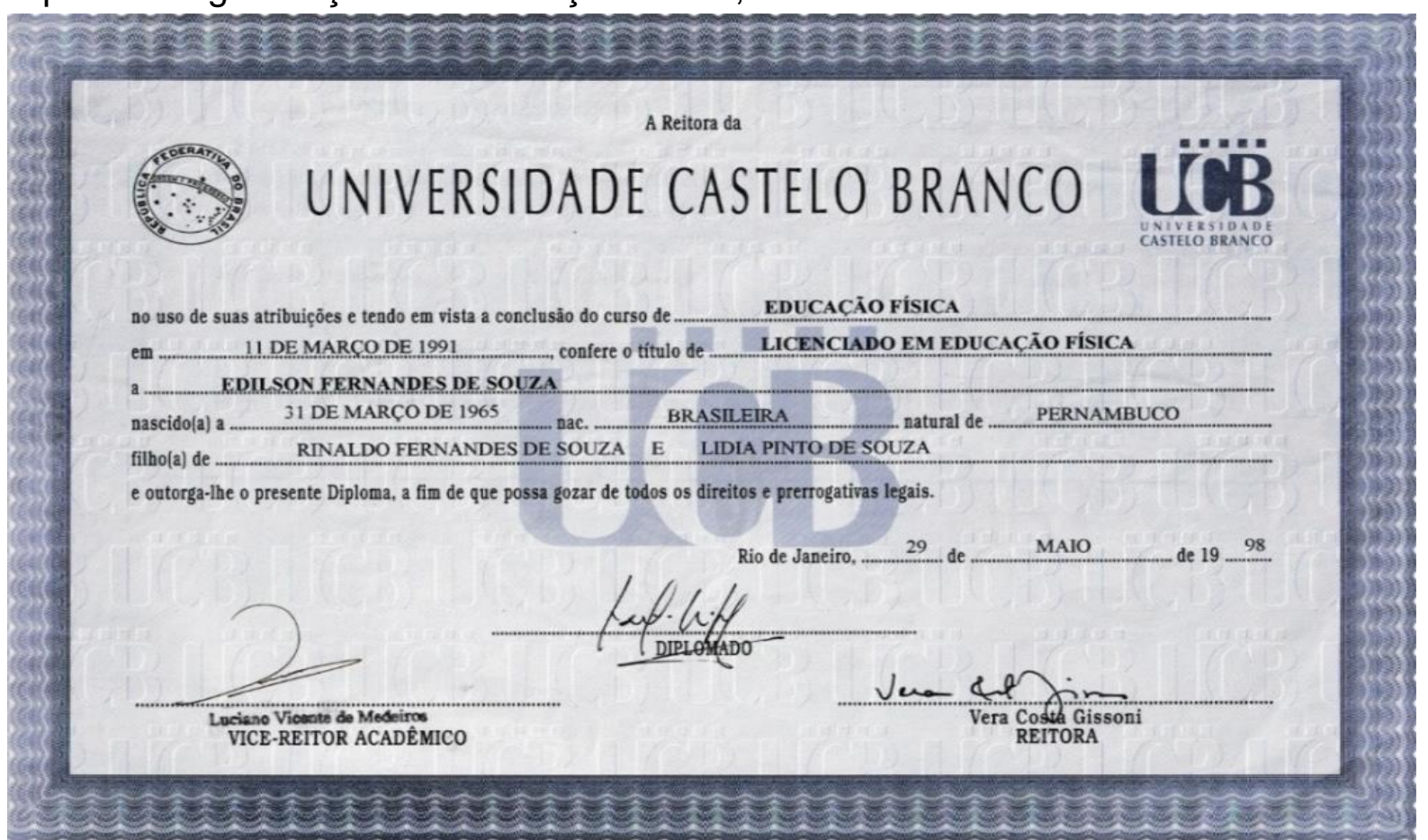

Fonte: acervo do autor.

Desse modo, a transmigração do campo artístico para o acadêmico-científico tem registro de nascimento, fruto de esforços significativos para aprender algo que, até então, não via muito sentido. $\mathrm{Na}$ verdade, não percebia que poderia criar coisas novas e impactantes, porque, àquela altura, 1991, não queria admitir que a vida de artista já estava se esvaindo por entre os textos sobre esporte e didática. Então, mesmo reconhecendo a importância de um curso superior, eu achava que continuaria dançando e nunca atuaria profissionalmente nessa área.

De qualquer modo, só fui buscar o diploma de graduação sete anos depois, quando já estava terminando o doutorado na Unicamp, em 1998, pois, mesmo sem esses penduricalhos definitivos em mãos, sempre consegui fazer as matrículas em concursos que fazia naquele momento, como foi o caso do concurso público para professor auxiliar de Ensino na Universidade Federal de Uberlândia, em Minas Gerais. Então, mesmo sem o diploma, fui aceito num campo bastante específico e recebi a autorização para participar do ambiente universitário fazendo minhas prescrições a partir do meu entendimento acerca de determinados problemas afetos a uma área do conhecimento.

Desse modo, à medida que passei a adquirir o capital escolar-cultural, a partir dos certificados e, mais concretamente, o diploma universitário, passei a lutar mais densamente e com afinco pelo poder de dizer a verdade, pelo menos, as minhas verdades, relativas e provisórias. Até porque "a universidade também é o lugar de uma luta para saber quem, no interior desse universo socialmente mandatário para dizer a verdade sobre o mundo social (e sobre o mundo físico), está realmente (ou 
particularmente) fundamentado para dizer a verdade" (Bourdieu, 2004, p. 116), ou ainda, conforme Bourdieu (2007a), ambiente onde se adquire uma cultura "livre", valorizada pela distinção de um diploma, em contraposição a uma cultura livre que não é legítima adquirida pelo autodidata.

Contudo, antes de ingressar como docente universitário, fui em busca de outros conhecimentos técnico-científicos para melhor atender a uma demanda no campo artístico de meus alunos de dança afro, embora agora reconheça que, nessa ocasião, eu estava mesmo era em busca de outras oportunidades a partir das certificações adquiridas por quaisquer meios, semelhantes aos documentos aqui expostos.

Como pode ser visto mais adiante, o documento de declaração de término do meu curso de pós-graduação lato sensu expõe 13 disciplinas devidamente cursadas que concentram, em sua totalidade, conhecimentos relacionados às áreas de humanas e sociais. Considerando o debate internacional da época, 1991, pesquisadores portugueses, como o filósofo Manuel Sérgio, estavam divulgando em vários lugares a teoria da motricidade humana, o que deve ter incentivado vários empresários a investirem em cursos de curta duração, que pudessem atender a uma demanda crescente, uma vez que ainda eram poucos os cursos de pós-graduação stricto sensu em Educação Física no Brasil.

Apenas por curiosidade, o curso de que trata o certificado e que apresentarei em seguida foi ministrado por dois meses, janeiro e fevereiro de 1991, na cidade de Cabo Frio, Região dos Lagos, no Rio de Janeiro, e teve como alunos vários professores de educação física recém-formados ou prestes a colar grau, como eu, o que nos rendeu uma excelente perspectiva profissional. 
Figura 226 -

Declaração de término do curso pós-graduação lato sensu, 1991.

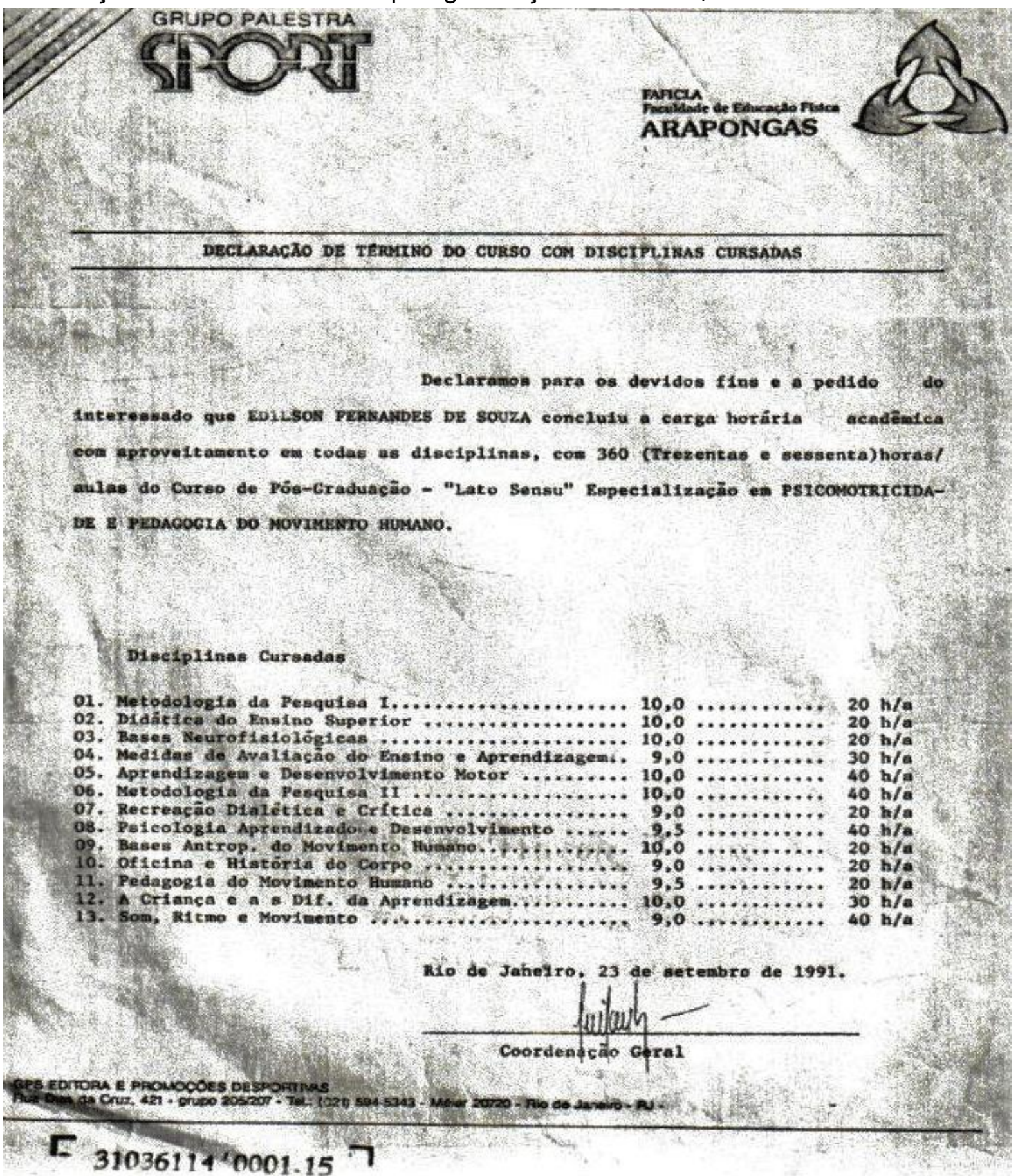

Fonte: acervo do autor.

Não é exagero afirmar que o curso a que esse documento se refere, a especialização em Psicomotricidade e Pedagogia do Movimento Humano, foi de grande importância na minha vida acadêmica, pois, a partir de seu término, escrevi uma monografia sobre a dança afro primitiva, objeto, inclusive, da discussão central desta tese para efeito de análise do constructo do 'eu' fonte no último capítulo. Todavia, ao finalizar esse curso e escrever esse meu primeiro trabalho acadêmico, não imaginava que, em tão pouco tempo, voltaria a estudar, sobretudo, algo mais denso cientificamente, no mestrado na Universidade Gama Filho, no Rio de Janeiro. 
As circunstâncias, o motivo da escolha por esse mestrado e suas intercorrências já expus no segundo capítulo, À guisa das memórias, mas cabe ainda uma observação importante, especialmente sobre a linha de pesquisa, Educação Física e Cultura, onde pude desenvolver o projeto Representações sociais da cultura negra através da dança e de seus atores, cuja defesa rendeu a menção honrosa de ser "aprovado com louvor".

Figura 27 -

Certificado de Conclusão do Mestrado, 1995.

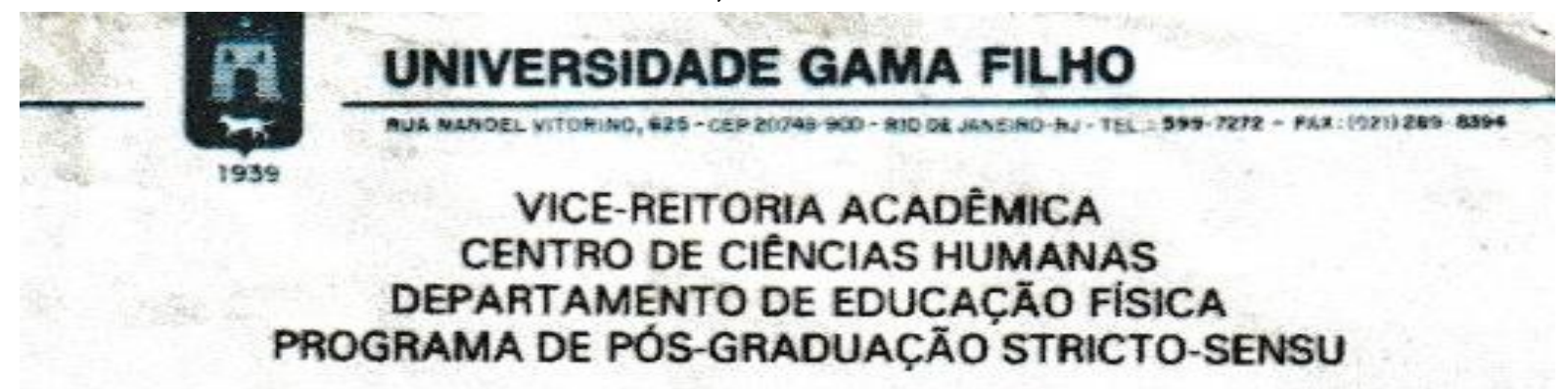

\section{CERTIFICADO DE CONCLUSÃO}

Certificamos, para fins de comprovação, que EDILSON FERNANDES DE SOUZA concluiu em 09 de NOVEMBRo de 1995 o Mestrado em Educaçăo Fisica da. Universidade Gama Filho, Área de Concentração EDUCAÇĀo FisıCA E CULTURA. defendendo a Dissertaçāo intitulada "REPRESENTAÇōes SOCLAIS DA CULTURA NEGRA ATRAVÉS DA DANÇA E DE SEUS ATORES" tendo sido "APROVADO COM LOUVOR".

O Mestrado em Educação Física tem sua aprovação e criação pautadas na Resoluçâo $N^{D} 145 / 84$, do Conselho de Ensino e Pesquisa desta Universidade, bem como é credenciado pelo Conselho Federal de Educação através do Parecer $N^{0} 712 / 91$, publicado no Diário Oficial da Uniâo de 23 de dezembro de 1991.

Rio de Janeiro. 04 de dezembro de 1995.

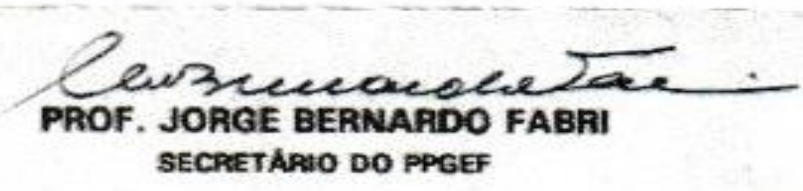

Fonte: Acervo do autor.

O gesto de enaltecimento atribuído pela banca à dissertação representou, naquela época, como ainda hoje, um grande incentivo para eu continuar desenvolvendo as pesquisas acerca das questões étnico-raciais, como também me mostrou a capacidade 
das minhas reflexões sobre o tema diante das dificuldades dos procedimentos empregados, especialmente quando foi abordada a história de vida dos agentes sociais afetados pela técnica corporal de matriz africana. No entanto, cabe ainda um registro sobre esse 'louvor' da banca examinadora que só agora me dou conta. Além das questões do método aplicado e desenvolvido na referida pesquisa, até aquele momento, tinha sido o único mestrando a desenvolver um projeto com essa temática naquele curso.

Guardadas as devidas proporções, de maneira concreta e simbolicamente falando, portar certificados ou diplomas como passei a portar, me permitiu certa qualidade técnica nas experiências corporais que eu já dispunha. Essa distinção, certificada pela universidade, abriu espaço para meu trânsito e permanência no campo intelectualacadêmico, cujo impacto percebi, de imediato, na alteração da minha linguagem, pelo capital simbólico adquirido.

Desse modo, é preciso entender que, na transmigração de campo, como tenho insistido na hipótese desta tese, bem como na aquisição de capital, certamente, continuei o mesmo em essência, um artista; inclusive, na assinatura do registro geral. Embora eu tenha continuado com consciência, também sabia que um diploma como o de doutor representava, como ainda representa, um avanço intelectual importantíssimo, mesmo numa área pouco prestigiada academicamente como a Educação Física.

Figura 28 -

Diploma de doutorado, 1999.

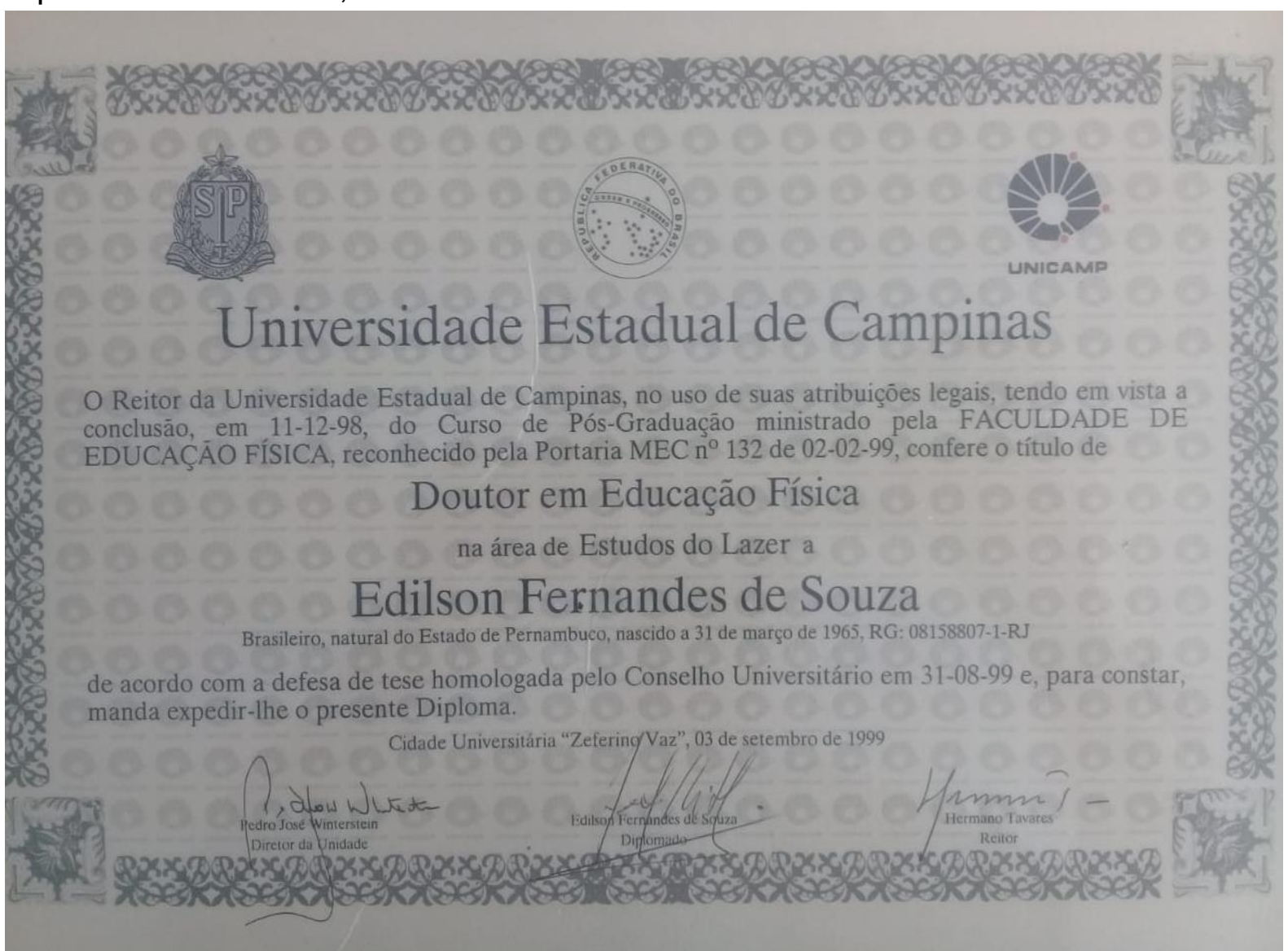

Fonte: acervo do autor. 
É importante considerar que um documento emitido por uma das mais importantes universidades brasileiras, se não determina a vida acadêmica, simboliza, ao menos, a excelência na formação científica de um intelectual vindo de outro campo do saber, nesse caso, do espectro artístico, cuja assinatura oficial ainda resguarda evidência de um campo em transição.

Esses rabiscos fiz também em outros documentos, como o meu termo de posse na Universidade Federal de Uberlândia e no documento que solicito a redistribuição para a UFPE, em 2000, objeto de análise na próxima seção. Assim, ainda é possível verificar esse mesmo tipo de grafia hoje em dia, na qual eu suprimi apenas as letras 'E', 'R', 'l', mas mantive as demais letras do Sheriff. No entanto, não consigo precisar quando de fato suprimi, objetivamente, o Sheriff da assinatura da minha vida, embora ainda permaneça nos garranchos que faço nos documentos, como RG:

Não é por acaso que a assinatura, signum authenticum que autentica essa identidade, é a condição jurídica das transferências de um campo a outro, isto é, de um agente a outro, das propriedades ligadas ao mesmo indivíduo instituído. Como instituição, o nome próprio é arrancado do tempo e do espaço e das variações segundo os lugares e os momentos: assim ele assegura aos indivíduos designados, para além de todas as mudanças e todas as flutuações biológicas e sociais. (Bourdieu, 2006, p. 186)

Essas reflexões de Bourdieu (2006) são fundamentais para a compreensão da mudança ou transmigração dos campos em que passei. Não é exagero afirmar que os documentos aqui expostos, assim como outros da mesma série que não foram utilizados, resguardam interconexões institucionais e dão um tom significativo à minha vida acadêmica enquanto um dos capitais adquiridos na trajetória, como mostrarei sucintamente na próxima seção. Por enquanto, ainda tenho um outro registro acerca de uma aquisição própria do campo em que atuo, trata-se da declaração do estágio pósdoutoral, realizado na Universidade do Porto, em Portugal.

Esse estágio, realizado após doze anos de conclusão do doutoramento, foi fundamental para que eu pudesse repensar as estratégias das pesquisas e orientações até então desenvolvidas no Núcleo de Teoria e História da Educação, do Programa de Pós-graduação em Educação da UFPE. O projeto sugerido aos colegas do Departamento de Sociologia da Faculdade de Letras pretendeu discutir os marcos conceituais eliasianos presentes nos artigos científicos apresentados no Simpósio Internacional de Processos Civilizadores. 
Figura 29 -

Declaração do estágio pós-doutoral, 2010.

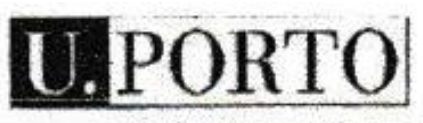

FACULDADE DE LETRAS

UNIYERSIDADE DO PORTO

\section{Deciaracăo}

Para os devidos efejtos se declara que a Doutor Edilson Fernandes de Souza reallzou o programa de investigaç̄o de pós-doutoramento, intitulado "A APROPRIAÇ̄̃o dos MARCos ConcertuAis ELISIANoS MAS PESQUISAS SOBRE EDUCAC̆İo No BRASIL", na Faculdade de Letras da Universidade do Porto, no periodo de Setembro de 2010 a Fevereiro de 2011, sob a onientaçð̄o do Prof. Doutor loð̌o Miguel Trancoso Vaz Teixeira Lopes .

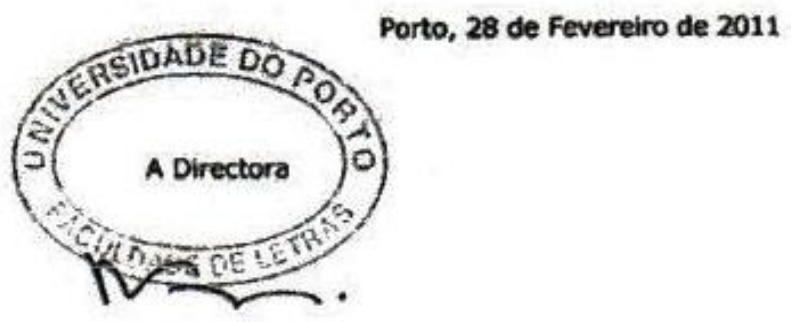

(Prof. Doutora Maria đe Fâtima Aires Perelia Marinho Saraiva)

Fonte: acervo do autor. 
Nesse período percebi que os colegas sociólogos portugueses costumam se separar em dois grupos, os do Norte e os do Sul, ou seja, pesquisadores que lidam com os problemas teórico-empíricos e os que se limitam à teoria. Dito isso, a minha pesquisa tinha como objetivo abordar os estudos de Norbert Elias, que, em sua síntese teóricoempírica, procura eliminar as dicotomias. Assim, eu me senti muito à vontade em discutir meu projeto nas duas frentes.

No entanto, confesso que fiquei um tanto decepcionado ao perceber que, naquele momento em Portugal, eu era somente um autor solitário entre tantos outros que estudavam os escritos de Elias. Ainda assim, consegui alcançar meus objetivos, uma vez que sua biografia não era meu principal foco, mas sim tentar debater exaustivamente a teoria civilizacional. De qualquer modo, consegui realizar o estágio e recebi o certificado, o qual pude incluir como um dos documentos importantes para efeito de promoção na carreira, para professor associado I.

\section{Penduricalhos: capitais em processo de aquisição}

$\mathrm{Na}$ seção anterior tratei de um tipo muito específico de capital por mim adquirido no itinerário educacional e acadêmico, tendo por evidências documentos como certificados, históricos escolares e diplomas. No entanto, há de se considerar também uma tipologia documental que permeia determinadas instituições, como as universidades, e acumula para os agentes que atuam nesses ambientes algum tipo de distinção, como termos de acesso e posse, progressões, promoções e menções honrosas, ou seja, elementos fundamentais de reconhecimento da própria instituição ou de terceiros em conexão com esse ambiente.

Tais documentos, aqui identificados como penduricalhos, sempre estarão em processo de aquisição pelos agentes em sua movimentação no campo, articulando, inclusive, em menor grau, a relação institucional interna com outras instituições exteriores aos indivíduos e seus interesses. Podem fazer parte desses penduricalhos uma infinidade de fontes que, articuladas entre si, representam um determinado espaço-temporal do indivíduo e seu itinerário.

Nesse contexto, alguns desses penduricalhos me permitiram transmigrar de um campo a outro, como meu termo de posse, que oficializou a minha entrada no campo acadêmico, agora como profissional da educação superior. Ou seja, assinei um documento junto à instituição de que desejava expressar minha vontade de participar do jogo daquele campo, ainda que não conhecesse totalmente suas regras explícitas e ocultas, as mais desafiadoras no seu cumprimento. Foi assim, portanto, que entrei num campo onde a luta é travada de diferentes maneiras, inclusive, na produção do conhecimento e na disputa política, como o leitor terá a oportunidade de ver mais adiante, em outro episódio da minha trajetória.

No entanto, de volta aos penduricalhos, o documento que mencionei trata-se do Termo de Posse no D-001, o qual registra que "aos vinte e dois dias do mês de março de mil novecentos e noventa e três", perante a "pró-reitora de Recursos Humanos, da Universidade Federal de Uberlândia (UFU) Sra. Lilian Machado de Sá", eu me apresentei para os cumprimentos da investidura no "cargo de Professor do Grupo de Magistério, na 
classe de Aux. Nível 1". Assim, o referido termo revela fontes anteriores para a condição da posse, ou seja, que foi regulamentado por meio da portaria R n. 472/93, de 17 de fevereiro de 1993, publicada no Diário Oficial da União, em 3 de março do mesmo ano.

O termo, a ser exibido mais adiante, revela, na verdade, uma espécie de contrato firmado entre agentes públicos, representantes do Estado brasileiro, e aqueles que, a partir de sua competência técnico-científica, pretendem entrar no campo específico de uma determinada área do conhecimento para desenvolver atividades de ensino, pesquisa e extensão.

Figura 303 -

Termo de posse, Universidade Federal de Uberlândia, 1993.

001

TERMO DE POSSE $N^{2} D-001$

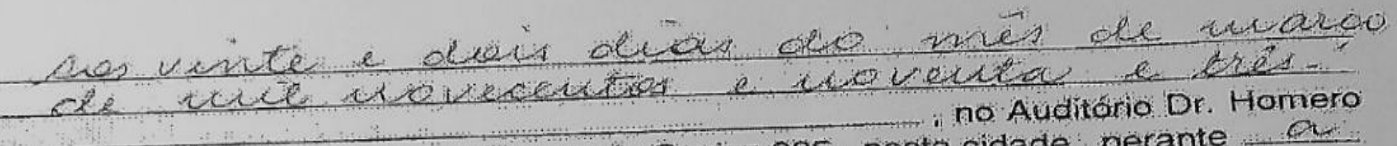

Santos da Reitoria, sila à Rua Duque de Caxias 285. nesta cidade, perante ou

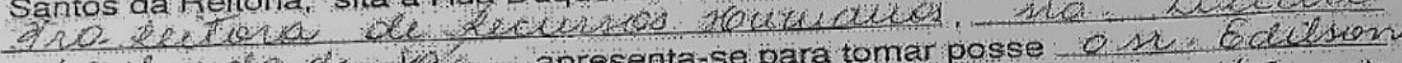

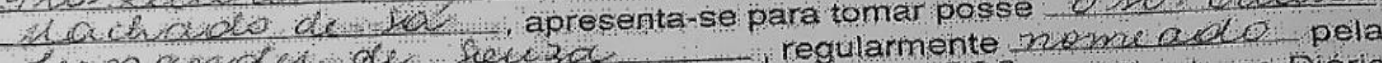

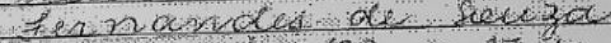
Portaria $A n^{\circ}-472,192$ de 17 de foveredro de 1993 publicada no biario

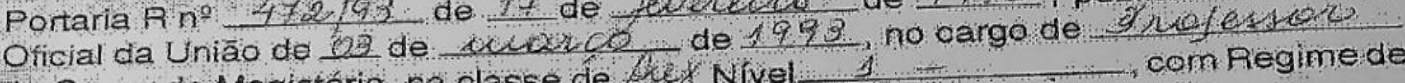
do Grupo de Magistério, na classe de fuex, Nível_................ com Regimede

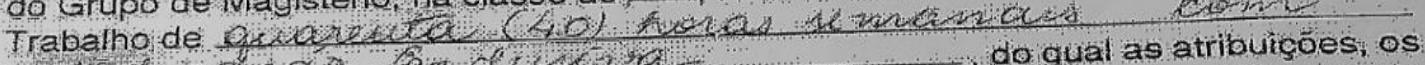

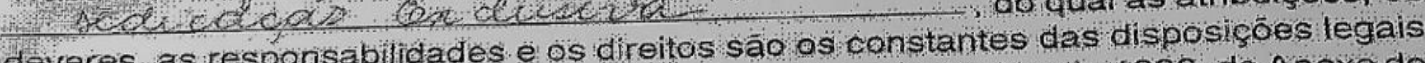
deveres, as responsabilidades e os direitos sa 11 de dezembro de 1990 , do Anexa do vigentes, especificamente, as da Lein $n^{\circ} 112$ de 11 de dezortaria 475 do MEC de 26 de agosto de Decreto 94664 de 23 dejutho de 1987 , da Portaria 475 do Meral de Uberlândia. Além 1987, do Estafuto edo Regimento Geral da Universidade Federal de alo a desempenhar seus deveres disso compromete-se $D$ exns gronocel legais e debem senvira institulçao e ao Pals. Neste ato apresenta declaraçäo dos bens

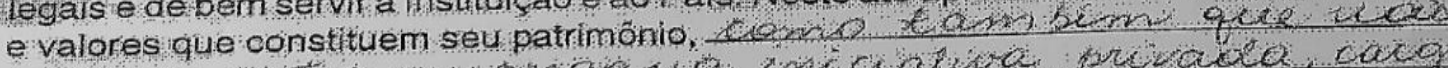

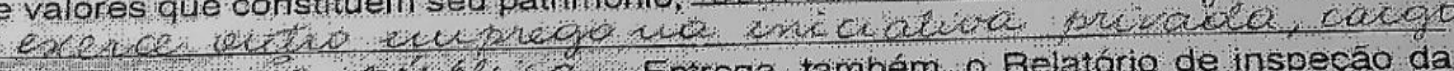

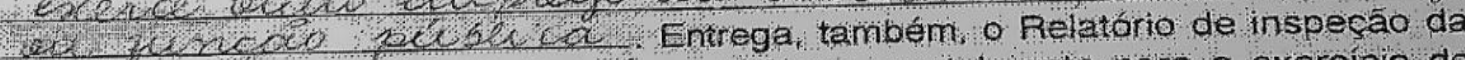
Junta medica que fulgou apto.... física e mentalmente para o exercicio do

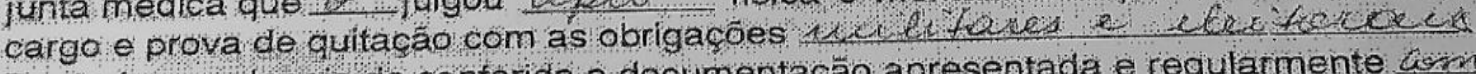
Desta forma, depois de conferida a dooumentaçăo apresentada e regularmente ám

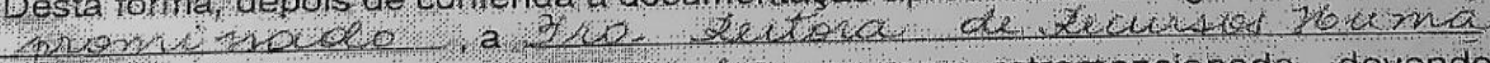
Lof 5 declara en puesex elo no cargo retromencionadio devendo defe, entrar exercíclo no prazo de 30 (trinta) días, contados a partir desta data Uberlândia, 22 de muaves de 1990

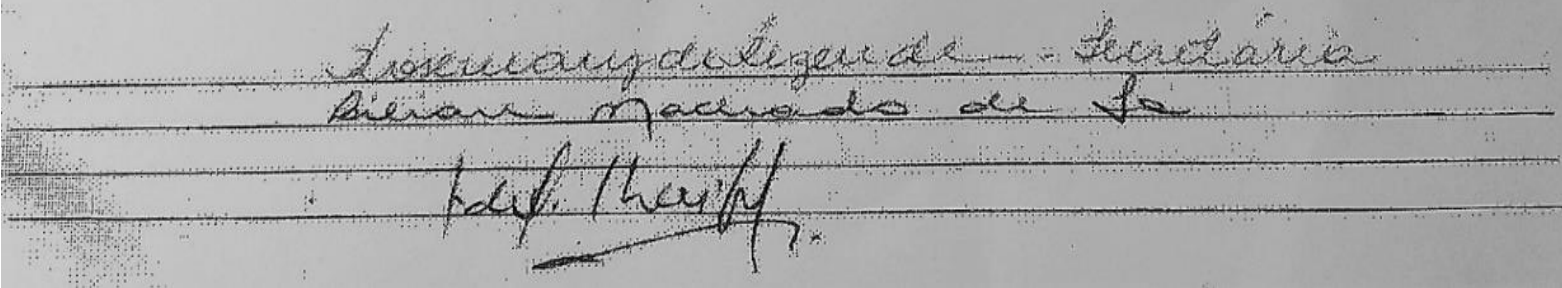

Fonte: pasta do assentamento funcional, Progepe/UFPE. 
Em linhas gerais, o documento trata de leis, decretos anteriores a 1990 que asseguram, entre outras coisas, o cumprimento, por parte do outorgado, do Regimento Geral da Universidade Federal de Uberlândia, provavelmente, o cumprimento das atividades-fim da instituição. No entanto, mesmo com todas as formalidades exigidas para a ocasião, no meu termo de posse, que exibo com orgulho neste momento, ainda é possível observar a assinatura que fiz em transição do campo artístico para o acadêmico.

A grafia não deixa dúvidas de que ainda explicitava, naquela ocasião, o nome próprio Edil (Edilson), atrelado ao pseudônimo Sheriff das academias de ginástica e dos palcos dos teatros. Também é possível perceber que, ao receber o meu diploma de doutor, pela Unicamp, em 1999, a minha assinatura ainda era grafada da mesma maneira, como pode ser vista em outros documentos oficiais.

A partir das reflexões de Bourdieu (2002), no que diz respeito às corporações dos letrados que, ele diz, resguardam, em certa medida, alguns privilégios, há de se pensar na série de documentos que evidencia algum tipo específico de aquisição e pode distinguir os agentes numa mesma instituição social. Essas evidências podem ser resultado dos itinerários, ou melhor, da estrutura básica capaz de produzir determinado sentido, no processo de disputa entre os próprios agentes.

Dessa maneira, outro penduricalho que apresento neste momento diz respeito à uma nomeação como chefe de setor, a primeira de um dos cargos assumidos no serviço público. Os detalhes desse cargo tratarei mais adiante, no penúltimo capítulo, quando abordo as questões relacionadas à política institucional e as relações de poder, mas, por agora, é importante registrar que é muito comum as substituições entre agentes, por meio de disputa ou acordo, especialmente quando são pequenos cargos na estrutura institucional, como o exemplo a seguir, onde substituí um dos colegas do Departamento de Educação Física da UFU, o professor Vander Fagundes. 
Figura 31 -

Portaria de nomeação chefe de setor, UFU, 1993

UFPE

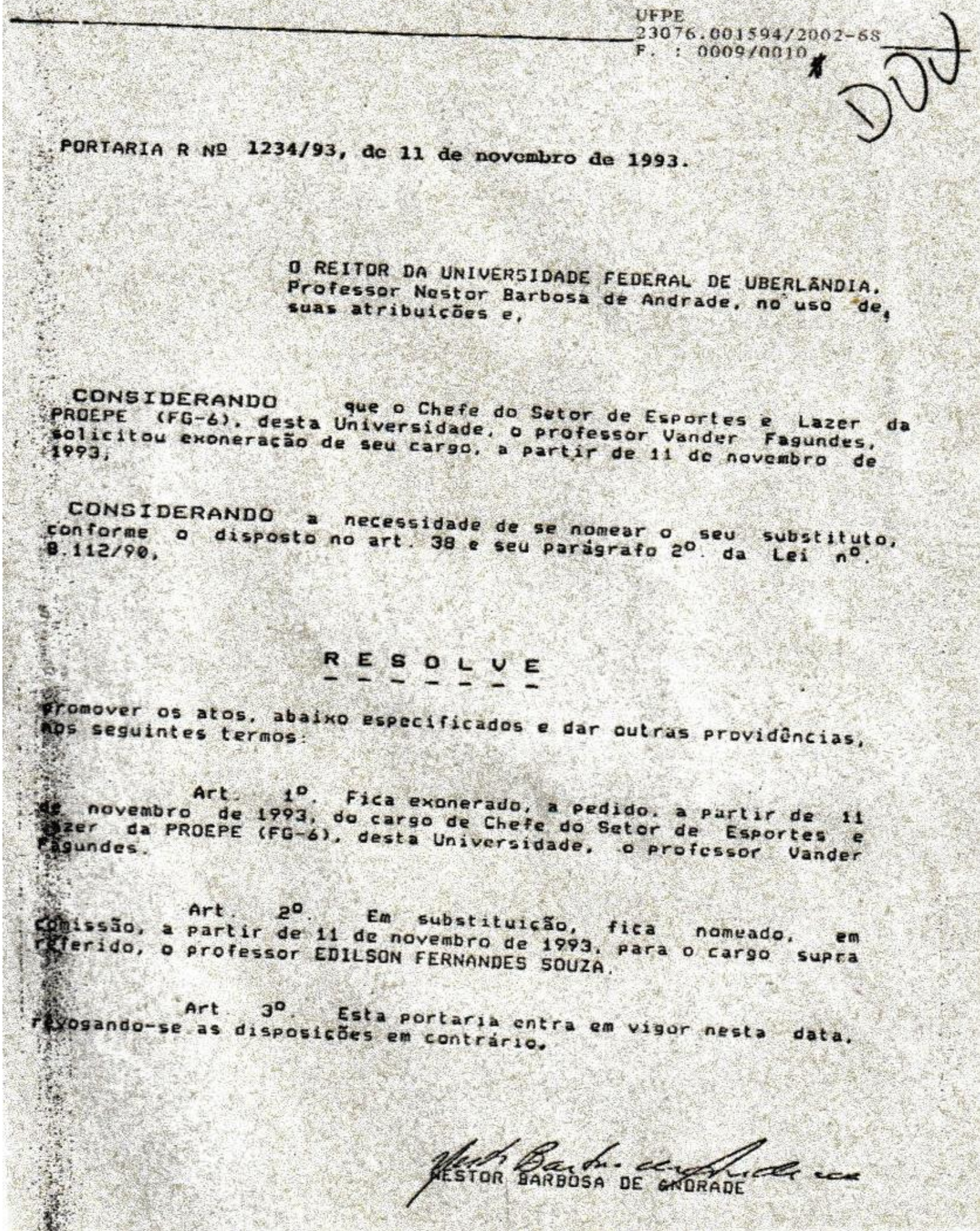

Fonte: Pasta do Assentamento Funcional, Progepe - UFPE.

Como pode ser lido, trata-se da portaria de n. 1234/93, de 11 de novembro de 1993, referente à nomeação a partir daquela data ao cargo de chefe do setor de esportes. É bem provável que esse tipo de cargo tenha sido extinto na universidade, mas é importante dizer que esse chefe de setor, da maneira como está previsto no referido documento, 
distingue os docentes que ministram aulas e desenvolvem suas pesquisa e projetos de extensão daqueles que, além dessas obrigações, atuam na administração da universidade e que, de alguma maneira, estão sujeitos a participar mais ativamente da formulação de políticas para uma determinada área de intervenção institucional.

O cargo para o qual fui nomeado, o primeiro de outros que viriam durante minha trajetória institucional, refere-se a uma FG6, ou seja, uma função gratificada, que hoje me faria ter um bônus de, talvez, não mais do que $R \$ 200,00$. No entanto, tal função me distinguia dos demais colegas, mesmo estando há pouco tempo na instituição universitária.

No conjunto, os poucos documentos aqui expostos simbolizam a minha entrada e permanência no campo, bem como os progressos alcançados nesse ambiente de consideráveis disputas, comprovados por meio dos documentos até aqui apresentados, e mostram também a luta que foi a redistribuição da Universidade Federal de Uberlândia para a Universidade Federal de Pernambuco, processo que teve início em 05 de abril de 2000 e foi finalizado em $1^{\circ}$ de novembro do mesmo ano, pelo menos oficialmente.

As evidências de uma possível disputa funcional, entre outras coisas, são percebidas no tempo de concretização ou conclusão: sete longos meses do processo. Até aqui a luta era entre as instituições, cujas disputas se faziam por códigos de vagas. Isso mesmo, somos apenas um código, que reflete um pedaço de ocupação de um determinado ambiente numa das unidades da federação. Isso me traz a recordação de um dos livros de Erving Goffman (1974), que, ao estudar os atores das instituições totais, percebe que os mesmos são identificados apenas por um número no ambiente onde dormem, no prontuário de suas enfermidades, nas roupas etc.

Apenas a título de curiosidade, ao iniciar meu trabalho na universidade mineira, meu código de vaga passou a corresponder ao n. 323609, e foi objeto de menção no Diário Oficial da União de 17 de agosto de 2000. Quando transcorreu ou se consolidou o meu pedido de redistribuição para a UFPE, o meu código se transformou no n. 0681996. Talvez isso seja importante para lembrar a todos nós, os expertos das intuições de produção do conhecimento, que não passamos de um código entre todos os outros vagos ou já devidamente preenchidos.

É possível que o exemplo acima seja um pouco exagerado, o mais importante é que, naquele momento, eu estava mesmo mudando e não de campo, mas de local de disputa e de competidores, mesmo que o meu objetivo, inicialmente, não fosse a participação ativa que tive na terra fértil - Uberlândia - enquanto ocupante de um cargo ou código de vaga na UFU.

Assim, a transferência de território ou a nova demarcação da disputa deveria ser oficializada em comunicado às instituições envolvidas por meio da solicitação por carta ou ofício do interessado e, posteriormente, por protocolização de processos, via setor de comunicação. Desse modo, encontrei na minha pasta de assentamento funcional, na UFPE, o primeiro ofício que encaminhei para dar início à redistribuição.

No documento, datado de 5 de janeiro de 2000, dou visibilidade aos problemas pessoais que estava passando naquele momento, especialmente as questões que envolviam minha filha mais velha e a disputa com a ex-esposa pela transferência de guarda da criança. Embora as questões pessoais não fossem relevantes, como parecem 
não ser para alguns casos do serviço público, o apelo foi para persuadir os colegas da Faculdade de Educação Física da UFU, representados pelo então diretor e professor Silvio Soares dos Santos.

Contudo, uma vez já redistribuído para a UFPE, passado todo esse tempo, preciso agradecer aos colegas que me concederam essa possibilidade e também pedir desculpas pelos contratempos em algumas de nossas reuniões no meu antigo Departamento da querida 'Educa' que fui levado a explicitar. Espero, inclusive, que as desculpas também sirvam para os pequenos jogos de cena que realizei, necessários ao convencimento desses meus primeiros colegas de campo, que não só entenderam o enredo ali desenvolvido, como subscreveram o documento que redigi.

Então, para dar mais realismo ao que pretendia, construí um texto simples e direto, procurando chamar a atenção para o fato de que, uma vez concedida a redistribuição, a referida faculdade não seria prejudicada porque a UFPE concederia uma de suas vagas para futuro concurso público.

Contudo, para uma movimentação como essa, não basta apenas um documento para oficializar as intenções calcadas nas necessidades. É preciso articular no campo, obter informações acerca de situações semelhantes e observar tendências para lograr êxito. De qualquer modo, o documento seguiu na explicitação do desejo e necessidade, mas, nos bastidores, foi preciso uma boa dose de argumentação para comover os pares daquela instituição. Segue o documento:

Figura 32 -

Ofício endereçado à Faculdade de Educação Física da UFU, 2000.

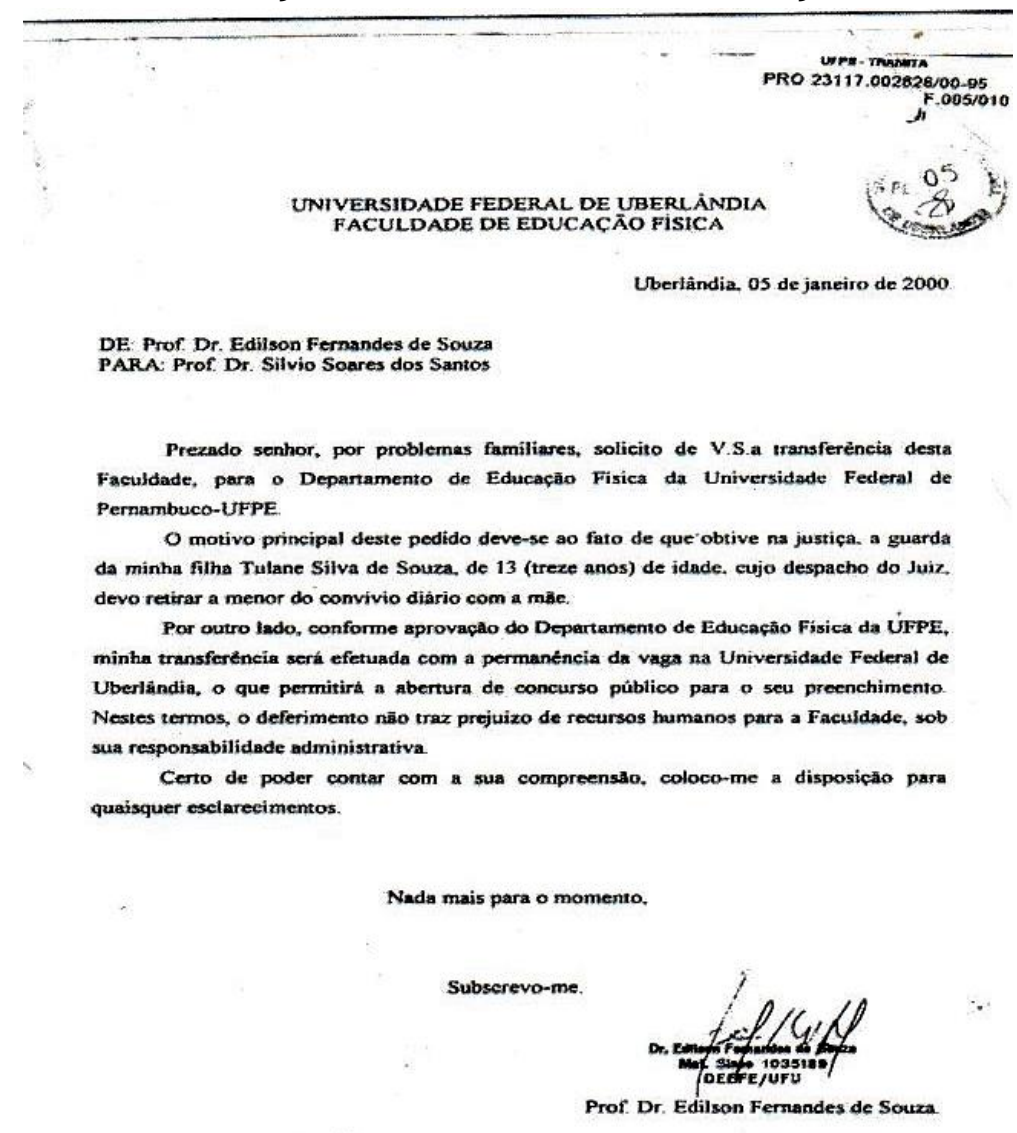

Fonte: pasta do assentamento funcional, Progepe/UFPE. 
O documento acima deu início ao processo de redistribuição sinalizando, como é facilmente percebido, motivo de natureza pessoal. Porém, ao oficializar o desejo de mudança, não do campo, mas do local de disputa, como disse, a instituição de destino, a UFPE, atribuiu a mim, enquanto interessado, um número como participante do campo, algo que pudesse ser de fácil rastreamento e identificasse o objeto de interesse institucional.

Mesmo tendo consciência do que escrevo acerca daqueles momentos turbulentos e os jogos cênicos, táticas para lograr êxito, percebo que há seriedade na forma com que esse tipo de movimento necessita para não dar prejuízos à sociedade brasileira, sobretudo, déficit de pessoal nas Instituições de Ensino Superior, como estava acontecendo naquele momento nas universidades, que estavam há muito tempo sem concurso público. Mesmo assim, consegui oficializar o pedido.

Figura 334 -

Siga Processo, da Universidade Federal de Pernambuco, 2000.

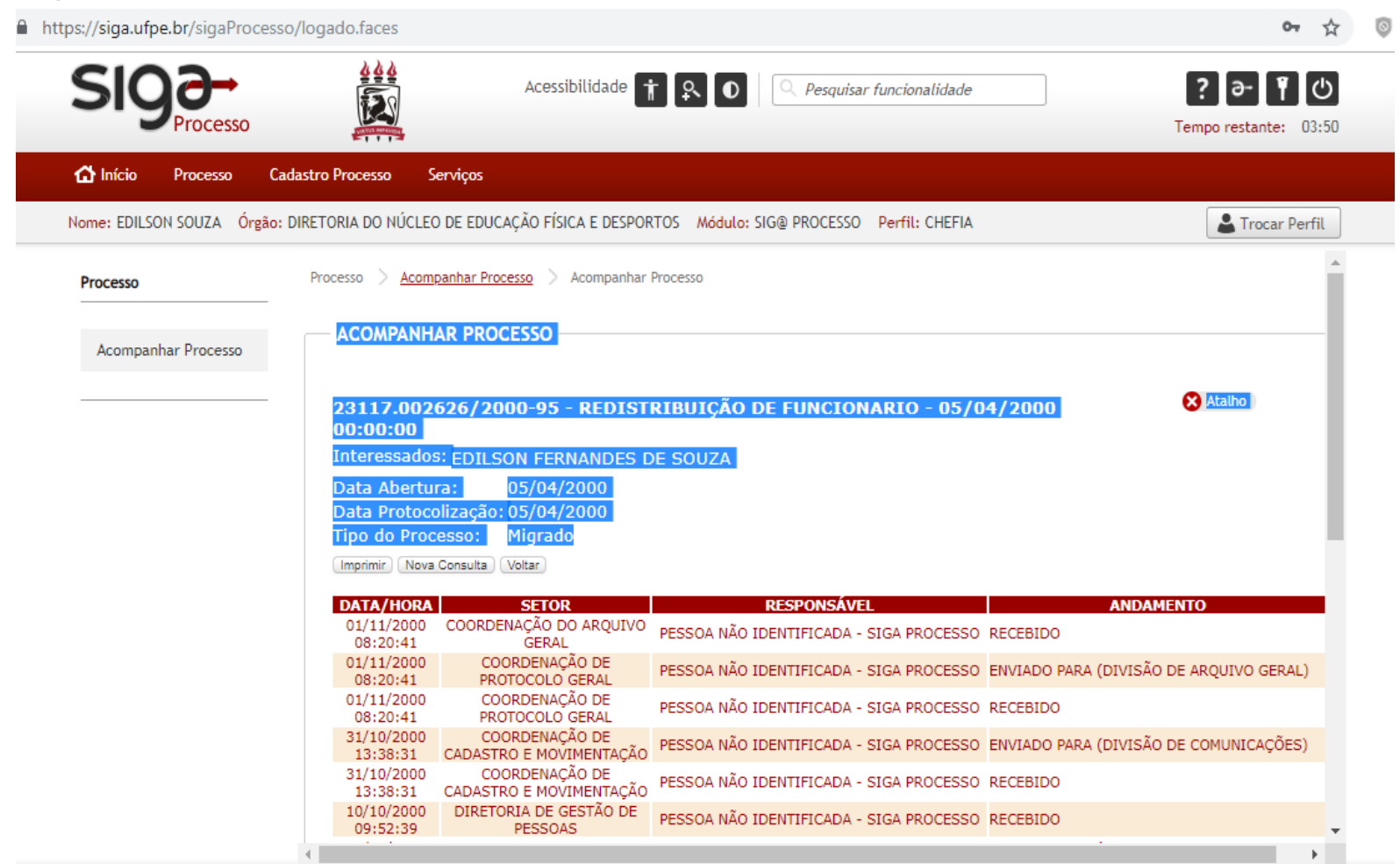

Fonte: Siga Processo. Disponível em: https://siga.ufpe.br/sigaProcesso/logado.faces.

A figura trata do processo de número 23117.002626/2000-95, referente à redistribuição de funcionário. Este foi o primeiro de vários processos em que dei entrada na UFPE. Exibo com orgulho porque, oficialmente, esse documento tornou possível a realização de um desejo e, sobretudo, a materialização mais adiante da minha reentrada no campo onde consegui desenvolver uns $90 \%$ do trabalho que faço, enraizar e fazer florescer o habitus acadêmico-científico, que disponho no momento.

Essa disposição é confirmada durante a trajetória e reafirmada por uma massa documental bastante significativa, vestígios da forma e conteúdo com que enfrentei a instituição ou os dribles que precisei fazer para não ser tragado pelo poder dos outros e o meu próprio poder adquirido, ainda que de forma periférica. 
Guardadas as devidas proporções, nas universidades brasileiras, além das múltiplas reuniões, às vezes sem foco e intermináveis, somos levados praticamente todos os dias a responder ofícios e a deixar registrado o nosso cotidiano para posterior utilização nos diferentes processos de progressão, afastamentos, promoção etc. Esse campo acadêmico é realmente movediço, e precisamos responder com certa astúcia os desafios por ele colocados. No entanto, é a busca pela aquisição e manutenção de capital simbólico que nos faz gerenciar a própria atuação por meio do ensino, da pesquisa, extensão e administração, bem como os penduricalhos que muitas vezes servem apenas para alguns momentos.

Desse modo, ao abrir minha pasta do assentamento funcional, percebi o meu trajeto em meio a diferentes situações institucionais em que fui levado a participar. Logo, a documentação visitada revela a permanência efetiva no campo, o que é muito positivo, considerando a minha transmigração arte-ciência, ou seja, não apenas que sou docente, mas busco corresponder com os princípios que regem o serviço público, especialmente na Universidade Federal de Pernambuco, meu local de trabalho por vinte anos.

Como já descrita nos procedimentos e tendo um ou outro documento analisado, essa pasta do assentamento funcional, minha pasta dos penduricalhos, contém uma infinidade de evidências de um itinerário institucional, recheada de ofícios, de portarias de nomeações e exonerações, bem como portarias de todas as progressões e promoções, de professor auxiliar 2 a professor associado 4. Com aproximadamente 198 documentos, as memórias ali contidas revelam, em síntese, a produção docente e o sentido de uma carreira, além de ser um símbolo de muito esforço na participação ativa da construção cotidiana de uma instituição de ensino superior no Nordeste do Brasil.

Todavia, os documentos que constam na pasta de assentamento funcional revelam interconexões importantes entre as evidências sentidas e experimentadas a partir de 1993 na UFU e na instituição pernambucana, a UFPE. Assim, o meu histórico de classificação na carreira do magistério mostra não apenas o estágio atingido até determinado momento, mas também rememora datas das progressões e promoções funcionais necessárias à continuidade das futuras distinções institucionais.

Ao ter nas mãos esse meu histórico, vieram lembranças dos primeiros dias como docente na UFU, nos quais os colegas me alertaram para que eu procurasse o Setor de Recursos Humanos e solicitasse os meus direitos por ter feito outro curso além da graduação. Ou seja, ganhar alguns outros trocados no salário, porque, logo de início, como consta no documento, meu enquadramento funcional era $A E 1$, que significa professor com especialização. 
Figura 345 -

Histórico da Classificação na Carreira do Magistério, 2000.

\section{UNIVERSIDADE FEDERAL DE UBERLÂNDIA DIVISĀO DE APOIO AO DOCENTE \\ Histórico da Classificação na Carreira do Magistério}

NOME:

UNIDADE ACADÊMICA:

MATRICULA - SIAPE:

CHAPA:

\section{CLASSE FUNCIONAL:}

TTTULAÇÃO:

DATA DE ADMISSÃO:

REGIME DE TRABALHO:

GED - 1999

UED - 1998

ENQUADRAMENTO:

ÚLTIMA PROGRESSÃO:

DATA DO DESLIGAMENTO:

\section{EDILON FERNANDES DE SOUZA}

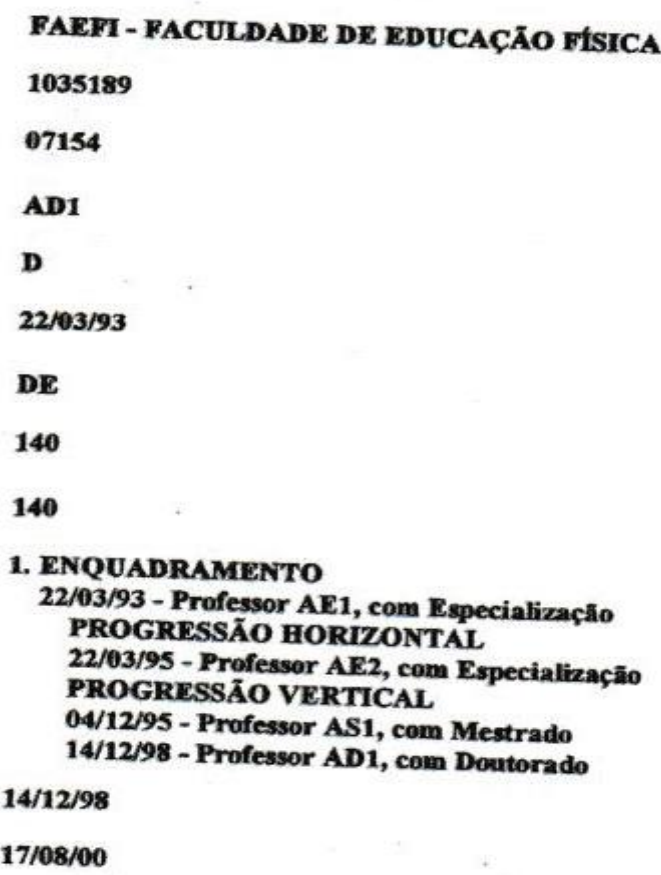

Uberlindia, 17 deOutubro de 2000

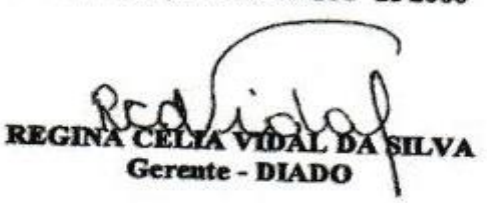

Fonte: pasta do assentamento funcional, Progepe/UFPE.

Essa pasta de penduricalhos pode ser extremamente útil, pois resguarda evidências da vida institucional, documentos que, às vezes, não damos muita importância ou somente em alguns momentos, a partir da necessidade de prova ou contraprova dos poucos direitos ou deveres que temos. assim, de maneira resumida, os penduricalhos na minha pasta de assentamento funcional traduzem momentos importantes da minha experiência em duas universidades públicas federais, articulando, inclusive, elementos de foro íntimo com a própria instituição, a exemplo do Ofício/3VC no 70/01 - Proc. n. 9892/00, da Comarca de Jaboatão dos Guararapes, em Pernambuco, que trata da ação de modificação de guarda com pedido de liminar, referente à suspensão da pensão alimentícia, uma vez que minha filha já havia passado a morar comigo e atingido a idade adulta. 
Tudo isso parece coisa menor para efeito deste estudo, mas o que pretendo mostrar é o que temos de pessoal nas instituições em que atuamos e o que tem de instituição na nossa vida cotidiana, para além do crachá e do salário, até porque um dos motivos alegados para minha redistribuição foram as questões que envolviam a guarda da minha filha, num processo familiar-institucional, como o leitor pôde conferir.

Desse modo, ao vasculhar os 198 documentos que constam dessa minha pasta, além do que encontrei em relação ao âmbito família-instituição, pude identificar uma das maneiras com que se estrutura a nossa condição administrativa, como as exonerações para o ingresso a outro cargo, por exemplo, de coordenador de curso para coordenador administrativo ou diretor de órgão suplementar para pró-reitor; ou ainda, de maneira mais inusitada, a minha exoneração do cargo de pró-reitor, a pedido.

Figura 356 -

Portaria de exoneração do cargo de pró-reitor, 2014.

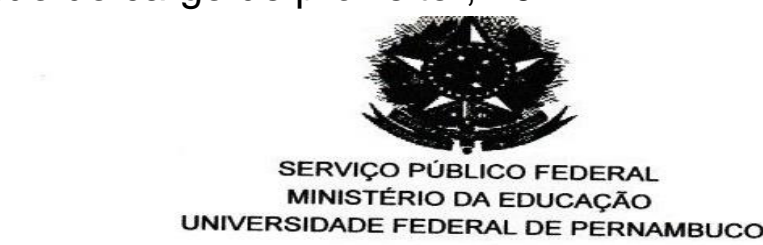

PORTARIA No 5897 de 2 de dezembro de 2014

EXONERAÇÃO

O REITOR DA UNIVERSIDADE FEDERAL DE PERNAMBUCO, no uso das atribuições legais e estatutárias,

\section{RESOLVE}

Exonerar, a pedido, a partir de 02/12/2014, EDILSON FERNANDES DE SOUZA, Matrícula SIAPE $n^{\circ} 1035189$, Professor Associado 2 , em regime de trabalho de Dedicação Exclusiva, lotado(a) no(a) Departamento de Educação Física, do cargo de Pró-Reitor de Extensão, Código CD-02. para a(o) qual havia sido nomeado(a) através da Portaria de Pessoal n ${ }^{\circ} 4072 / 2011$, de $11 / 10 / 2011$.

(Processo $n^{\circ}$ 23076.060183/2014-48)

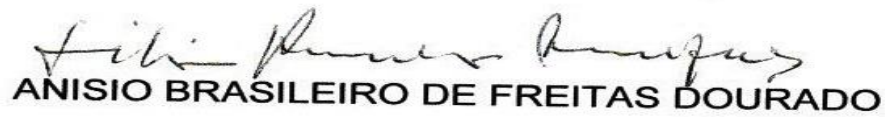

Reitor

Prof. Silvio Romero de Barros Marques

Vi: Vicoreitor no exencicio

Fonte: pasta do assentamento funcional, Progepe/UFPE. 
Essa portaria expressa uma das decisões mais difíceis que tomei no serviço público e que será objeto de discussão em outro momento. Por enquanto, é importante deixar registrado que os documentos aqui analisados dizem respeito à vida institucional e aos agentes que nela disputam espaços de saber-poder, por isso a aquisição de determinadas distinções, seja para a ocupação de espaço político-administrativo, seja para sua desocupação.

De qualquer forma, foi escarafunchando minha pasta de assentamento funcional que encontrei todos os documentos relativos às minhas exonerações, progressões e promoções, inclusive, a última evidência dos meus pequenos progressos institucionais até o presente momento, o que deu início, inclusive, ao processo de escrita desta tese em busca de outra distinção acadêmica-institucional.

Figura 36 -

Portaria de Progressão de Professor Associado IV, de 19 de novembro de 2018.

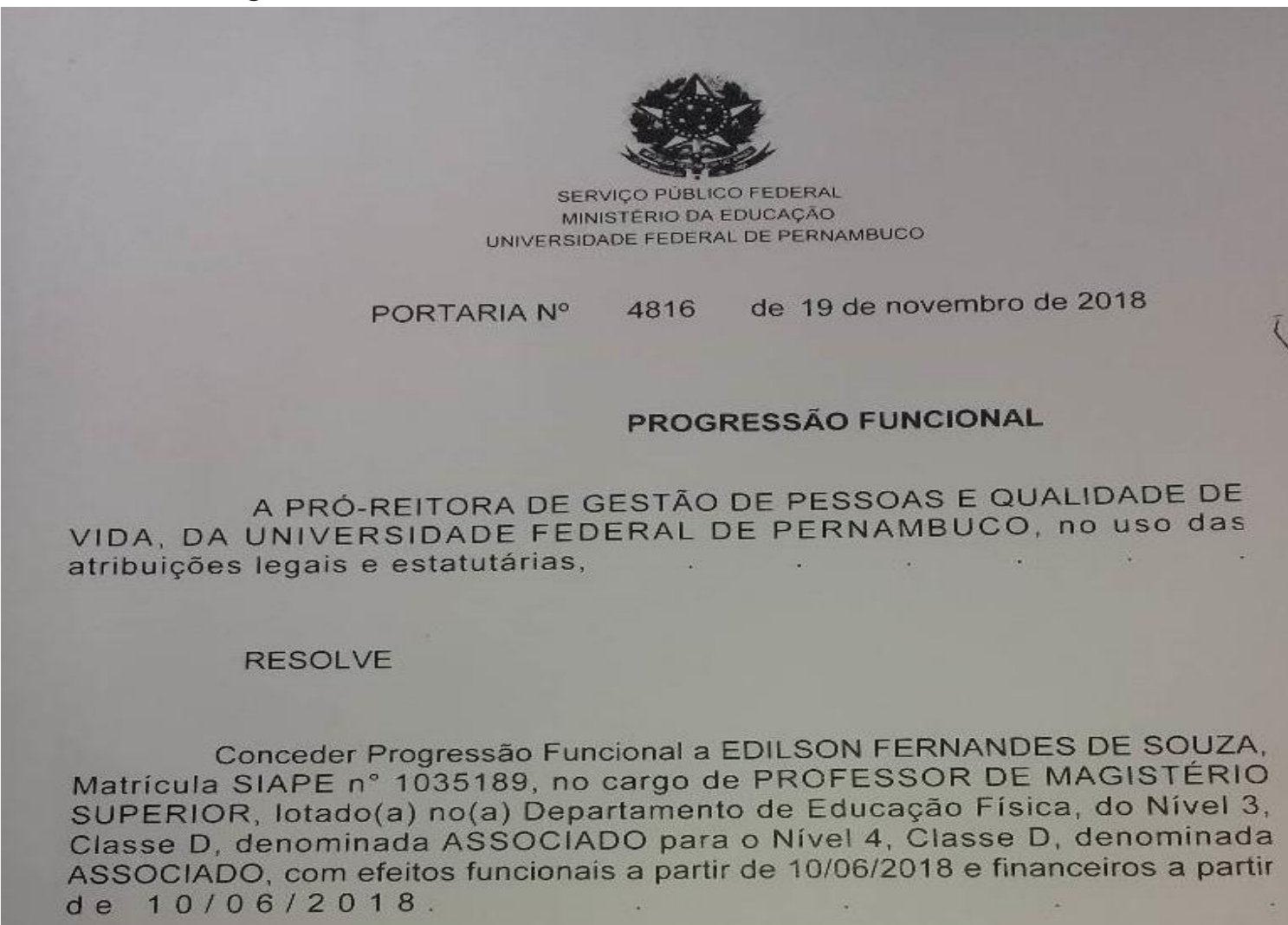

(Processo n²3076.023367/2018-51)

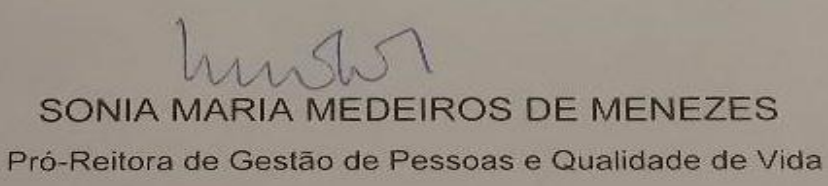

Fonte: pasta do assentamento funcional, Progepe/UFPE. 
Foi com grande satisfação que recebi essa portaria de progressão funcional em 2018. Satisfação semelhante ao receber os títulos de mestre e de doutor, coisa que, para mim, era inusitado. É, por vezes, por meio de um desses capitais referidos por Bourdieu (2004), capital cultural e simbólico, que uma trajetória parece ser justificada. Logo, esse documento congrega ainda um tanto do capital econômico, uma vez que as progressões também representam aumento de salário, ainda que os valores sejam baixos.

Contudo, para além do contentamento de uma progressão, esse documento também me revestiu de certo poder e responsabilidade, porque, enquanto adquiria um capital, precisava ir em busca de mais, que é o que tento fazer neste momento com esta tese: ir em busca de algo que expresse simultaneamente o ponto mais alto da promoção na carreira por meio de um título, símbolo do amadurecimento intelectual e, por isso mesmo, evidência de uma autonomia na trajetória, e que provavelmente irá ser representada por outro penduricalho.

Por outro lado, esse é um dos capitais simbólicos que recebo e tento expandi-lo como emulação para o futuro. Penduricalhos, como a portaria acima, representam, em última instância, uma vida inteira de trabalho, de dedicação, às vezes, reconhecimento silencioso da instituição. Ainda que, para conseguir alguns desses documentos, certificados de um interstício, ou documentos semelhantes, haja sempre a necessidade de determinados ritos processuais e desgaste no ajuntamento de papéis quase inúteis, mas sempre necessários, assim como seu registro em lugar apropriado, como o Currículo Lattes, uma das formas utilizadas por pesquisadores brasileiros de autobiografia, também instrumento de distinção social e institucional e, por isso mesmo, objeto de análise no próximo capítulo.

\section{Capítulo 4 - 0 campo e os quadros autobiográficos do Lattes}

Trata-se, pois, de uma fonte ajustada a um importante paradigma das sociedades ocidentais contemporâneas: a ideia do indivíduo como valor. O indivíduo único e singular, o ser psicológico, dá sentido a uma série de concepções e práticas em nosso mundo, e o pesquisador que opta por trabalhar com a História oral [bem como o método biográfico] deve ter consciência de que está lidando com uma fonte que reforça esses valores.

(Alberti, 2015, p. 169)

Como o leitor já deve saber, a autobiografia é o registro materializado na escrita, na fotografia, no desenho, notadamente, pela própria pessoa biografada. É resultado do encontro do biografado com uma razoável documentação sobre sua trajetória, incluindo a fala gravada e transcrita como uma de suas formas de manifestação.

Acontece que, na vida de professor universitário, você é levado a registrar todas as atividades de natureza acadêmica voltadas para o ensino, a pesquisa, a extensão e a gestão/administração. Você é levado a registrar o que chamam de produção científica que envolve, inclusive, atividades técnicas, como consultorias, avaliações de periódicos, elaboração de projetos e resultados de pesquisa.

Consideradas as observações de Alberti (2015), os principais registros de minhas referências e que servem de parâmetro acadêmico estão no meu Currículo Lattes, baseado na plataforma de mesmo nome. Após dar o print no dia 24 de novembro de 2018 
para posterior análise, percebi que os registros mais antigos que fiz na plataforma datam de 1995, quatro anos antes de ela passar a ser o ambiente oficial/autobiográfico da comunidade científica brasileira.

Lembro bem o momento em que fui informado da necessidade de utilização desse instrumento, já estava na Universidade Federal de Pernambuco, em 2000, e não tomei o devido cuidado em levantar o que já havia realizado e publicado nos eventos acadêmicos anteriores a 1999. Aliás, naquela época, resumos ou textos completos apresentados em congresso tinham algum valor, contrário do que se tem hoje, para efeito de nossa permanência na pós-graduação. É óbvio, também, que a falta daqueles registros trouxe de algum modo prejuízo à memória.

Todavia, antes de analisar essa minha fonte de inspiração e recordação, podemos entender um pouco da história de construção da própria plataforma enquanto um importante instrumento de inserção de um profissional no campo acadêmico, sem a qual hoje é impossível as instituições analisarem o perfil docente que se submete ao crivo institucional numa determinada área do conhecimento científico. Assim, a Plataforma Lattes foi desenvolvida no final da década de 1990 por dois grupos ligados a universidades, sendo o grupo Stela, da Universidade Federal de Santa Catarina, e o grupo C.E.S.A.R, da Universidade Federal de Pernambuco. Esses grupos, juntamente com técnicos da Multisoft e das Superintendências de Informática e Planejamento do CNPq, tiveram a responsabilidade de unificar as versões de currículos já existentes e utilizadas pelos pesquisadores brasileiros.

A plataforma Lattes tem esse nome em homenagem ao cientista brasileiro conhecido internacionalmente por suas pesquisas na área da Física, Césare Giulio Lattes. Ela foi lançada em agosto de 1999 e, desde então, o CNPq tem buscado aperfeiçoar esse instrumento amplamente utilizado por pesquisadores brasileiros, especialmente os que buscam fomento por meio do Ministério de Ciências e Tecnologia e do próprio CNPq.

Essa plataforma é muito abrangente e, além do Currículo Lattes, ainda abriga o Diretório dos Grupos de Pesquisa, que é formado em torno de alguns temas ou objetos de interesse de professores, técnico-administrativos e estudantes de graduação e pósgraduação. Contudo, o próprio Currículo Lattes é uma porta de entrada no campo da vida profissional, sendo ele mesmo autobiografia dos indivíduos que dele fazem uso para fins acadêmicos. É o espaço onde falamos de nós mesmos e, por fé pública, somos levados a registrar apenas o que julgamos mais importante para corroborar a verdade. Uma importante fonte de consulta acerca dos pesquisadores no Brasil, bem como fonte de pesquisa científica para efeito de análise e interpretação, como tentarei fazer neste capítulo.

Como já disse, no dia 24 de novembro de 2018, fiz um print do meu Currículo Lattes por considerar que, a partir daquela data, faria uma análise ou apresentaria uma discussão sobre como me biografei até aquele momento registrando minhas atividades acadêmicas, científicas e técnicas. É evidente que o tal print foi feito como suporte de análise, mas o Lattes ainda continuou sendo preenchido com a continuidade das ações desenvolvidas.

Assim, seria oportuno eu tentar fazer uma "análise sociológica da produção do produtor" (Bourdieu, 2004, p. 118) e mostrar a posição que eu ocupava na estrutura social naquele momento, bem como as possíveis conexões culturais e científicas mantidas no 
campo acadêmico. Contudo, considerando as limitações aqui impostas a um autobiógrafo tateando no autodistanciamento eliasiano e na objetivação de sua própria produção (Bourdieu, 2004), tentarei mais adiante dar sentido à hipótese geral deste estudo, que se fará no último capítulo, no constructo do 'eu' fonte.

Desse modo, o que diz o meu Lattes, quando resolvi escrever esta tese e o congelei para efeito de análise? No currículo eu me descrevo em terceira pessoa do singular, o que parece bastante estranho, reafirmando meu certificado de pós-doutoramento em Sociologia, certamente para recompor, em seguida, a diferenciação entre os intelectuais formados em Educação Física e os estudos continuados. Assim, procuro dizer de qual lugar escrevi ou inscreverei o próprio Lattes, inclusive ao dizer da pós-graduação no mestrado e doutorado e de minhas competências acadêmicas e científicas em áreas mais 'nobres', como a Sociologia, em detrimento da minha formação profissional primeira.

No print, realizado para submissão da análise, foram encontradas 58 páginas, distribuídas entre dados gerais, formação profissional, projetos, produtos, patentes e registros, inovação, educação e popularização da ciência e tecnologia, eventos, orientações, bancas, citações e foto, além, obviamente, da primeira parte do documento onde consta o resumo informado pelo autor, que é de razoável importância para a compreensão geral do perfil de pesquisador e sua produção acadêmica, neste caso, minha apresentação pessoal.

O Lattes é um ambiente academicamente aceito como fé pública e sujeito ao comprobatório da legitimidade documental. Como foi dito, sua ampla utilização pelos pesquisadores brasileiros teve início no final da década de 1990 e expressa uma verdade científica-acadêmica a partir das realizações de seu autor-pesquisador. Não é à toa que esse tipo de autobiografia tenta totalizar de forma provisória ou definitivamente a verdade sobre um indivíduo determinado, conforme reflexões de Bourdieu (2006).

Para dar as primeiras impressões, começo o texto de Resumo do Lattes tentando passar a ideia da diferenciação por ter alcançado um outro grau, embora, todos saibam que o pós-doutorado é apenas um estágio em alguma área de excelência e só confere um certificado e não uma titulação, como tento fazer parecer na abertura do currículo.

Em seguida, falo dos livros, das diferentes temáticas produzidas a partir das publicações que reverberam, de certa forma, a trajetória construída até o presente momento e têm impacto na forma e conteúdo das mais de 50 orientações entre mestrado e doutorado que realizei. Aliás, esse é um detalhe exibido com orgulho, pois desvela o investimento na formação de recursos humanos de qualidade e indica um investimento pessoal e a transmigração para o campo acadêmico-científico, conforme apresentado na hipótese deste trabalho.

Nessa esteira digo das minhas filiações investigativas, da participação como pesquisador no Instituto de Estudos da África (IEAf) da UFPE, no Núcleo de História da Educação UFPE/CNPq, Laboratório de Sociologia do Esporte/CNPq e Grupos de Estudos e Pesquisa de Processos Civilizadores/CNPq, que são uma forte evidência, depois confirmada em publicações, da minha entrada no campo das Ciências Humanas e Sociais.

Percebo que são muitos grupos que registro participação, embora, tenho plena consciência de que sempre privilegiei um ou outro grupo para atuar mais frequentemente. Sei também que alguns colegas que coordenam esses grupos gostam, ou gostavam, de 
ter meus registros em suas fileiras, pois pode servir como uma espécie de "grife acadêmica" me ter por perto. No fundo, essa é uma representação daquilo que construí ao longo desses 27 anos, que o Lattes tende a manter registro/materializar, parafraseando Goffman (1985), numa espécie de "representação do eu" na vida acadêmica.

Figura 37 -

Resumo do Currículo Lattes, 2018.

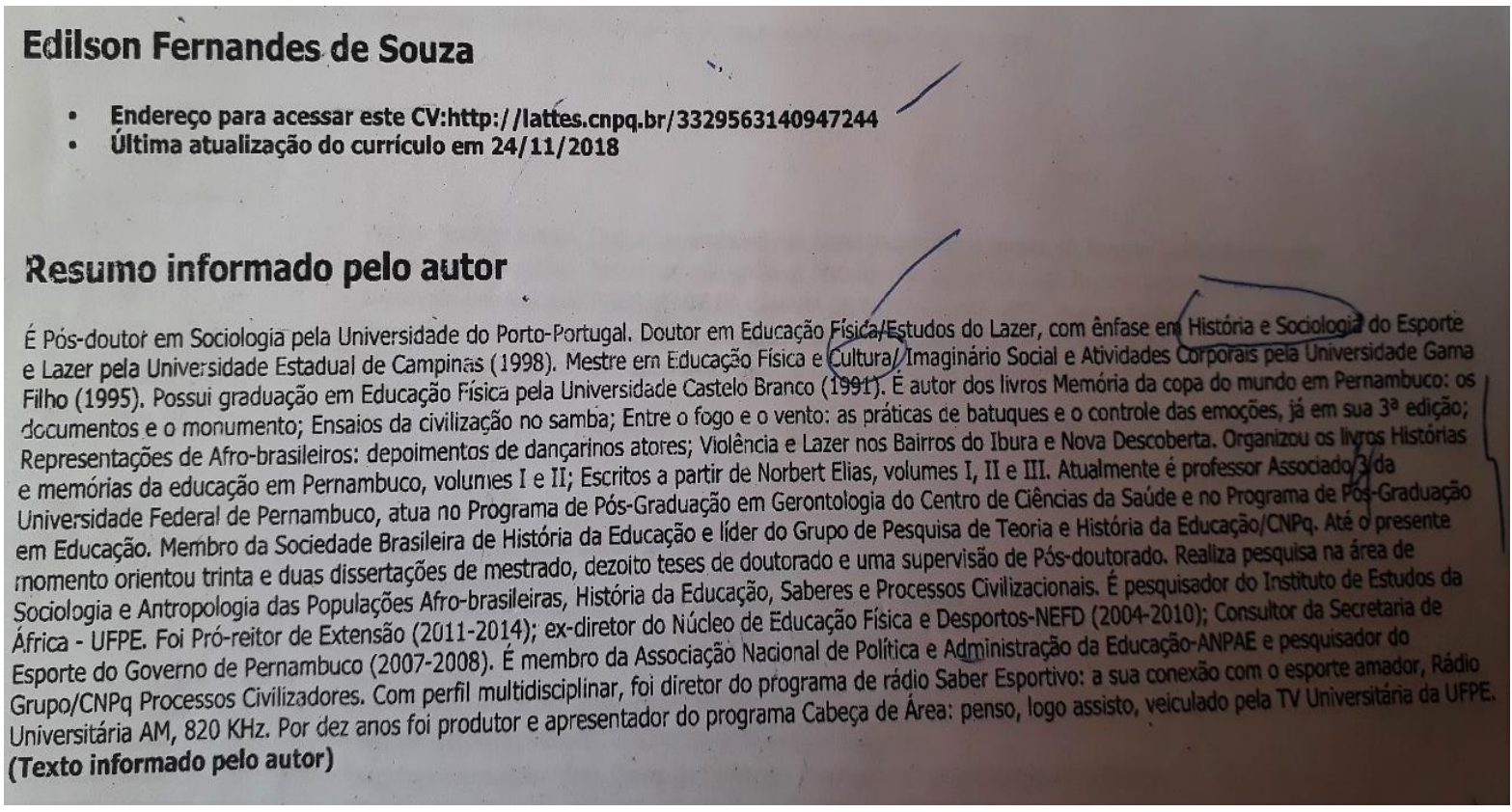

Fonte: http://lattes.cnpq.br/3329563140947244.

Nessa perspectiva de representação, quero também dar a ideia de que sou um profissional que transito por várias áreas do conhecimento e minimizar um pouco do estigma que paira sobre os professores de Educação Física, os 'não intelectuais', pelo menos para alguns preconceituosos. Quero, de certa forma, deixar mais evidente que construí uma trajetória de maneira multidisciplinar por fazer leituras em Antropologia das Populações Afro-brasileiras, Sociologia, História da Educação, além de ter produzido e apresentado programas de rádio e televisão relacionados aos esportes amadores.

No entanto, o registro da passagem por esses programas midiáticos talvez seja uma retomada da minha formação profissional, mas com enfoque nas Ciências Humanas, como está descrito acerca dessas produções: "Saber Esportivo, a sua conexão com o esporte amador, Rádio Universitária AM, $820 \mathrm{KHZ}$, e Cabeça de Área, penso, logo assisto, veiculado pela TV Universitária, Canal 11 da UFPE.” (EFS-Lattes, 2018, p. 1).

Mas do que ser visto da forma como me apresento no texto de abertura do Currículo Lattes, dessa 'representação do eu', é assim que procuro me situar no campo acadêmico e me diferenciar entre outros profissionais da mesma área. No campo, como diz Bourdieu (1989), são estabelecidos um conjunto de forças estruturadas e estruturantes, que produzem sentido para manutenção ou controle do poder e também, como se pode pressupor, o desenvolvimento de um habitus, traduzido numa história incorporada, importante para a construção da identidade de um determinado indivíduo como eu. 
Se, parafraseando Goffman (1985), teríamos uma representação do eu na vida acadêmica, na perspectiva de Bourdieu (2006), teríamos uma ilusão biográfica, centrada no desejo de ser visto e, talvez, ser requisitado como um homem da ciência, que articula diferentes saberes a partir dos seus artigos, livros e investimentos na formação de recursos humanos, como se essa forma de escrita no resumo do Lattes, pudesse traduzir todos os meus itinerários acadêmicos. Ledo engano. Apenas o sentimento de um outsider.

Assim, no resumo, está descrito que aquele é texto informado pelo autor e, assim, se evidencia a utilização tática desse ambiente virtual como um lugar do não poder, como diria Certeau (1998), do "fraco", embora seja exatamente o contrário que pretendo demonstrar nas indicações do estágio pós-doutoral e nas temáticas de pesquisa que oriento, na tentativa de não apenas informar, mas a de passar uma impressão positiva do intelectual que sou.

Nesse contexto, Certeau (1998), ao analisar as tentativas de construção do social pelos indivíduos, traz uma reflexão bastante significativa ao dizer que "as estratégias apontam para a resistência que o estabelecimento de um lugar oferece ao gasto do tempo; as táticas apontam para uma hábil utilização do tempo, das ocasiões que apresenta e também dos jogos que introduz nas fundações de um poder" (Certeau, 1998, p. 102). Assim, é tentando "inaugurar" ou instaurar um certo poder acadêmico-científico que presto as informações necessárias a um campo para consumir um tipo de conhecimento especializado.

Contudo, para efeito das estratégias institucionais, seja na própria Plataforma Lattes, antes de serem publicadas, o informante-autor-pesquisador-autobiógrafo precisa declarar que está em conformidade com os termos de adesão desse ambiente virtual, bem como registrar sua observação ao que consta nos artigos 297-299 do Código Penal Brasileiro, ou seja, sobre a falsificação de documentos públicos ou de inserir informações falsas, no sentido de alterar a verdade.

É importante assinalar que de forma alguma esses artigos contradizem os meus registros, justamente, porque nas páginas seguintes ao texto inicial, encontram-se de fato um razoável fundo documental, biografia secundária, comprobatória por meio de livros e artigos publicados em periódicos nacionais e a minha adesão ao dito, na verdade, registrado na plataforma em questão. Os registros confirmam, portanto, a proeminência de um habitus voltado para a ciência e articulam de maneira bastante significativa a produção acadêmica, técnica e o empenho na formação de recursos humanos a partir de autores, temas e problemáticas sociais.

Essa forma com que me apresento nas páginas iniciais do currículo é uma demarcação de território. Uma espécie de estabelecimento de paradigma para ler e reler a minha produção científica em campo, ou seja, no desenrolar das ideias e do método. A consolidação dessa produção, no entanto, não é, obviamente, de uma hora para a outra; requer cuidados constantes para a manutenção e alimentação dos registros, que serão apreciados por outros membros igualmente do campo acadêmico.

Essa vigilância acadêmica, produção-registro, também acaba me orientando na tomada de decisão no que diz respeito ao que devo ou não fazer circular, e a tática utilizada é muito simples: o que estimula as paixões temáticas dos estudantes e ajuda a construir as narrativas. Ou seja, produzimos sempre em colaboração, mesmo que, para 
as Ciências Humanas e Sociais, isso não seja algo muito comum e ético. Destarte, a autobiografia no Lattes é efetivamente um compromisso com nossos pares. E, para além de me mostrar aos outros do campo, tento refletir uma verdade enquanto princípio da própria atividade científica, até porque os registros também dizem respeito à produção das minhas pesquisas e aos resultados alcançados a partir das elaborações teóricas realizadas até o presente. Boa parte dessa produção faço escoar por meio dos livros e capítulos, que são de mais fácil confecção.

Para que o leitor tenha uma ideia geral do que foi possível produzir nessa lógica das Ciências Humanas e Sociais, e que pretendo continuar nesse campo, trago de forma resumida as primeiras produções realizadas no final de 1990 e as últimas de 2018. O propósito não é exaurir o leitor de informações facilmente encontradas numa busca de currículo na Plataforma Lattes, mas, simplesmente, dar um indicativo de como me comportei no início da entrado no campo acadêmico em comparação a como estou me comportando até o presente momento. Como já foi dito, trago para a leitura o que foi registrado, mas não necessariamente o que foi efetivamente feito, em virtude da minha decisão em registrar no Lattes algumas produções apenas a partir de 1995, começando pela minha dissertação de mestrado.

Nesse contexto, no quadro 14, estão os primeiros e os últimos artigos publicados, e é perceptível como me movimento no campo em que descrevo no texto informado pelo autor, especialmente em 1998, num artigo da Revista Conexões, da Unicamp, em que tento fazer uma análise comparativa entre os sociólogos Norbert Elias e Max Weber. Aliás, essa foi a primeira edição da revista e eu colaborei em sua criação, por uma circunstância bastante peculiar de tensão entre doutorandos da Faculdade de Educação Física, da universidade mencionada, e os organizadores, naquela ocasião, do Encontro Nacional de História do Esporte, da Universidade Gama Filho.

No outro texto, faço um recorte da minha tese de doutorado, que publiquei na Revista do Colégio Brasileiro de Ciências do Esporte (RCBCE), em 1999. Na verdade, é uma publicação oriunda do congresso daquele ano promovido pelo colégio em questão. Essa publicação em particular tem uma razão muito especial e compõe um conjunto de artigos e resumos de congressos de uma fase bastante significativa de transmigração de campo. Esse elemento será melhor explorado no último capítulo da tese, em que tratarei mais especificamente de um constructo do 'eu' fonte.

Entretanto, na outra ponta, ou seja, em 2018, a produção vai buscar inspiração numa das áreas mais significativas em termos de intervenção e produção do conhecimento, sobretudo, das investigações sobre o envelhecimento, mas ainda me mantenho na área de humanas, até porque, embora a Pós-graduação em Gerontologia esteja muito próxima do debate em saúde, a grande área do conhecimento pela Capes é a interdisciplinar. Outro elemento importante diz respeito à minha participação no mestrado na linha de pesquisa de Envelhecimento, Cultura e Sociedade. 
Quadro 14 -

Primeiros e últimos artigos publicados.

\begin{tabular}{|c|l|l|l|}
\hline Ano & \multicolumn{1}{|c|}{ Título } & \multicolumn{1}{|c|}{$\begin{array}{c}\text { Local de } \\
\text { Publicação }\end{array}$} & \multicolumn{1}{|c|}{ Periódico } \\
\hline 1998 & $\begin{array}{l}\text { Weber e Elias: pontos e contrapontos } \\
\text { na metodologia das ciências sociais }\end{array}$ & Campinas/SP & Conexões \\
\hline 1999 & $\begin{array}{l}\text { Proibição de batuques no século XX: } \\
\text { a etiqueta presente em seu discurso }\end{array}$ & $\begin{array}{l}\text { Santa Catarina/ } \\
\text { SC }\end{array}$ & $\begin{array}{l}\text { Revista Brasileira de } \\
\text { Ciências do Esporte (RBCE) }\end{array}$ \\
\hline 2018 & Violência contra a pessoa idosa & Recife/PE & $\begin{array}{l}\text { Revista de Enfermagem on- } \\
\text { line }\end{array}$ \\
\hline
\end{tabular}

Fonte: autor (2019).

Por outro lado, mais adiante, trago ao campo autobiográfico do Lattes minhas primeiras participações em bancas de mestrado, que ocorreram logo após o meu doutoramento na Unicamp. Penso que os dois colegas que me convidaram naquele momento, como também suponho que aconteça agora, viram em minhas reflexões e também na postura de um recém-doutorando, à época, algo que contribuiria com as suas pesquisas. Então, embalado pelas leituras de Norbert Elias, sempre tentei me mostrar como alguém que compreendia a dinâmica metodológica dos trabalhos empíricos, seja com entrevistas, seja por meio da observação participante, como foram as duas primeiras bancas de mestrado em que participei.

Não obstante esse meu interesse, desde o início do meu doutoramento, procurei assistir a defesas de mestrado e doutorado para identificar os melhores arguidores e também aqueles que não condizem com a imagem que construí de um intelectual. Modéstia à parte, até hoje tento dar o melhor nas arguições, mostrar o lado positivo dos erros alheios, inclusive, com elegância, fazer as críticas necessárias para os mestrandos e doutorandos no rito de passagem, em que sempre digo que são os "noivos e as noivas", portanto, os principais personagens desse rito acadêmico.

\section{Quadro 15 -}

Primeiras participações em bancas de mestrado, em 1999, e últimas participações em bancas de mestrado, em 2018.

\begin{tabular}{|c|l|l|l|l|}
\hline Ano & \multicolumn{1}{|c|}{ Título da dissertação } & \multicolumn{1}{|c|}{ Pesquisador } & Instituição & Curso de Mestrado \\
\hline 1999 & Infância: que história é esta? & Magda Sarat & Unimep/SP & $\begin{array}{l}\text { Educação/História } \\
\text { da Educação }\end{array}$ \\
\hline 1999 & $\begin{array}{l}\text { No Circuito dançante de São } \\
\text { Caetano do Sul: liberdade, } \\
\text { juventude, prazer no lazer } \\
\text { noturno }\end{array}$ & $\begin{array}{l}\text { Wilson Luiz de } \\
\text { Souza }\end{array}$ & Unicamp/SP & $\begin{array}{l}\text { Educação } \\
\text { Física/Estudos do } \\
\text { Lazer }\end{array}$ \\
\hline
\end{tabular}




\begin{tabular}{|l|l|l|l|l|}
\hline 2018 & $\begin{array}{l}\text { A educação física no } \\
\text { terceiro ano do ensino } \\
\text { médio: uma análise da } \\
\text { contribuição nas escolas } \\
\text { públicas de Recife diante o } \\
\text { novo ensino médio }\end{array}$ & $\begin{array}{l}\text { Fabiano Swinerd } \\
\text { Gomes da Costa }\end{array}$ & $\begin{array}{l}\text { Centro } \\
\text { Universitário } \\
\text { Faculdade } \\
\text { Guararapes/PE }\end{array}$ & $\begin{array}{l}\text { Inovação e } \\
\text { Desenvolvimento }\end{array}$ \\
\hline 2018 & $\begin{array}{l}\text { A criação da Associação dos } \\
\text { Docentes da Universidade } \\
\text { Federal de Pernambuco no } \\
\text { contexto da abertura política } \\
\text { (1975-1984) }\end{array}$ & $\begin{array}{l}\text { Laudyslaine } \\
\text { de Moura }\end{array}$ & UFPE & $\begin{array}{l}\text { Educação/Teoria e } \\
\text { História }\end{array}$ \\
\hline 2018 & $\begin{array}{l}\text { A pós-graduação stricto } \\
\text { sensu brasileira em } \\
\text { Gerontologia }\end{array}$ & $\begin{array}{l}\text { Fernanda } \\
\text { Tavares Arruda }\end{array}$ & UFPE & Gerontologia \\
\hline
\end{tabular}

Fonte: autor (2020).

Já no quadro abaixo apresento as minhas primeiras participações em banca de doutorado, que tiveram início nos anos 2000, e, curiosamente, fui suplente na defesa de tese de um dos meus colegas do doutorado na Unicamp, o professor Ricardo Lucena, com quem compartilhei as angústias e expectativas profissionais e as leituras da teoria eliasiana durante os dois anos em que estive no doutoramento na Faculdade de Educação Física - FEF/Unicamp. Outra participação como membro titular externo foi em 2002, na Universidade Federal do Rio Grande do Norte, cujo debate girou em torno da vida de professores que escreviam sobre corporeidade.

O quadro também mostra as cinco últimas participações em banca de doutorado em 2018, últimos registros para efeito de análise. Então, o leitor pode observar as temáticas e, consequentemente, a inserção das teses nas áreas das Ciências Humanas e Sociais. Mesmo incipientes, esses dados revelam a minha entrada e permanência no campo acadêmico, sobretudo, no processo de interdependência em que vou construindo entre colegas do mestrado e doutorado que, por alguma razão, vão vendo na minha postura e em algumas intervenções a possibilidade de contribuir com os seus trabalhos de pesquisa.

Quadro 16 -

Primeiras participações em bancas de doutorado, em 2000, e as últimas participações em bancas de doutorado, em 2018,

\begin{tabular}{|c|l|l|l|l|}
\hline Ano & \multicolumn{1}{|c|}{ Título da tese } & Pesquisador & Instituição & $\begin{array}{c}\text { Curso de } \\
\text { Doutorado }\end{array}$ \\
\hline $\begin{array}{c}2000 \\
\text { Suplente }\end{array}$ & O esporte na cidade & $\begin{array}{l}\text { Ricardo de } \\
\text { Figueiredo } \\
\text { Lucena }\end{array}$ & Unicamp/SP & $\begin{array}{l}\text { Educação } \\
\text { Física/Estudos } \\
\text { do Lazer }\end{array}$ \\
\hline
\end{tabular}




\begin{tabular}{|c|c|c|c|c|}
\hline 2002 & $\begin{array}{l}\text { O fenômeno da ludicidade no jogo } \\
\text { crítico e criativo da vida de } \\
\text { professores pesquisadores em } \\
\text { corporeidade }\end{array}$ & $\begin{array}{l}\text { Edmilson } \\
\text { Ferreira Pires }\end{array}$ & UFRN & $\begin{array}{l}\text { Educação/Corpo } \\
\text { e Educação }\end{array}$ \\
\hline 2018 & $\begin{array}{l}\text { O que herdamos de nossos } \\
\text { antepassados? A identidade } \\
\text { nacional brasileira e portuguesa } \\
\text { pela ótica de suas instituições } \\
\text { educacionais }\end{array}$ & $\begin{array}{l}\text { Amanda } \\
\text { Marques de } \\
\text { Carvalho } \\
\text { Gondim }\end{array}$ & UFPE & $\begin{array}{l}\text { Educação/Teoria } \\
\text { e História }\end{array}$ \\
\hline 2018 & $\begin{array}{l}\text { Os saberes da Mata do Engenho } \\
\text { Uchôa }\end{array}$ & $\begin{array}{l}\text { Laudiélcio } \\
\text { Ferreira da } \\
\text { Silva }\end{array}$ & UFPE & $\begin{array}{l}\text { Educação/Teoria } \\
\text { e História }\end{array}$ \\
\hline 2018 & $\begin{array}{l}\text { Ensino superior na Guiné-Bissau: } \\
\text { elementos estruturais e } \\
\text { conjunturais e implicações no } \\
\text { desenvolvimento das } \\
\text { universidades guineenses }\end{array}$ & $\begin{array}{l}\text { Arnaldo } \\
\text { Sucuma }\end{array}$ & UFPE & Serviço Social \\
\hline 2018 & $\begin{array}{l}\text { Quando a polícia chega para } \\
\text { matar nós estamos praticamente } \\
\text { mortos: discursos sobre genocídio } \\
\text { da população negra no cenário de } \\
\text { Recife/PE }\end{array}$ & $\begin{array}{l}\text { Joyce Amâncio } \\
\text { Aquino Alves }\end{array}$ & UFPE & Sociologia \\
\hline 2018 & $\begin{array}{l}\text { Insulamento burocrático e } \\
\text { neoinstitucionalismo: um estudo } \\
\text { sobre os estilos de interação dos } \\
\text { burocratas do nível da rua no } \\
\text { Programa de Bolsa Família }\end{array}$ & $\begin{array}{l}\text { Ronald dos } \\
\text { Santos Oliveira }\end{array}$ & UFPE & Sociologia \\
\hline
\end{tabular}

Fonte: autor (2019).

Como falei anteriormente, as teses para as quais fui convidado a participar das defesas estão na grande área de humanas e, dessa maneira, acabam expressando a minha movimentação nesse campo, mas, sobretudo, a maneira como outros pesquisadores me enxergam com um relativo conhecimento não apenas nas temáticas abordadas, mas a relação teórica e metodológica que possuo com os autores de suas referências. Está evidente que as temáticas são diversificadas, no entanto, o principal argumento para minha participação está na compreensão das teorias que fundamentam as pesquisas. Contudo, não me considero um teórico das Ciências Humanas, longe disso, mas me vejo e tento me representar nesse campo como tenho feito na abertura do Currículo Lattes.

Lembro que passei a registrar minhas atividades em 2000, ano em que conheci a Plataforma Lattes, já na Universidade Federal de Pernambuco. Não obstante os registros pudessem ser feitos antes desse período, por alguma razão, só me motivei a registrar algumas ações a partir de 1995, portanto, ficaram de fora vários resumos de 
congresso e, possivelmente, um ou outro artigo, inclusive, um dos mais importantes, que marca a minha transmigração de um campo artístico para o acadêmico e que servirá de análise no capítulo que trato do constructo do 'eu' fonte.

No cômputo geral, posso afirmar que entre 1995, ano dos meus primeiros trabalhos, os quais foram registrados no Currículo Lattes, e 2018, período em que fixei como limite para análise desse instrumento de apresentação à inserção acadêmica, tenho uma participação bastante ativa e propositiva na orientação de mestrandos e doutorandos, na avaliação em banca de mestrado e doutorado, produção de artigos científicos e, entre outros, na produção de livros e capítulos de livros. Assim, no próximo quadro, mostro de forma sintética a produção que me serve de referência e análise.

Tabela 17 -

Indicadores de produção 1995-2018.

\begin{tabular}{l|c}
\hline Participação em banca de mestrado e doutorado & 132 \\
\hline Orientações de doutorado & 18 \\
\hline Orientações de mestrado & 34 \\
\hline Supervisão de pós-doutorado & 1 \\
\hline Participação em eventos & 111 \\
\hline Artigos publicados em periódicos & 24 \\
\hline Livros publicados & 9 \\
\hline Organização de eventos & 29 \\
\hline Conferências proferidas & 7 \\
\hline Projetos de pesquisa & 13 \\
\hline Projetos de extensão & 4 \\
\hline Capítulos de livros publicados & 15 \\
\hline Trabalhos publicados em anais de eventos & 23 \\
\hline Artes cênicas & 3 \\
\hline
\end{tabular}

Fonte: autor (2019).

Muito embora os dados representem uma inserção acadêmica bastante significativa, onde, por exemplo, o leitor pode verificar 132 participações em bancas de mestrado e doutorado, portanto em média 7 por ano, 24 artigos em periódicos, sendo mais ou menos um artigo a cada ano, bem como os trabalhos publicados em anais de congresso, mas o meu maior orgulho está nas orientações de mestrado e doutorado e na concentração das publicações dos livros e capítulos.

É na atividade de orientação dos mestrandos e doutorandos onde me realizo, onde sinto que meu trabalho enquanto docente tem realmente impacto na sociedade, embora, reconheça que as atividades na graduação sejam fundamentais para a formação humana, técnica e política. Penso que a minha realização nessa atividade seja em virtude das frustrações em não poder pesquisar todos os temas de meu interesse. Aliás, foi em virtude dessas orientações que acabei escrevendo um capítulo $A$ arte de orientar no uso dos métodos e das fontes, num dos livros que organizei (Souza, 2009a).

Nesse contexto, da mesma forma que as orientações de mestrado e doutorado têm um significado especial por seus temas e problemas acabarem corroborando a minha própria formação de pesquisador, os livros têm um significado muito interessante porque 
são onde consigo expor um pouco das minhas ideias, além disso, ainda consigo controlar sua edição e circulação, sem a interferência de um editor, que, muitas vezes, só publica textos dos colegas que circulam entre seu campo de intervenção.

Embora a tabela 1 sintetize bem as minhas participações em eventos, projetos de pesquisa, extensão, publicações etc., gostaria de registrar três ou quatro ações que julgo de suma importância para efeito de minha inserção e percurso na vida acadêmica. A primeira diz respeito à conferência que organizei do professor Dermeval Saviani intitulada Os intelectuais: memória e política, realizada em 2017. Foi realmente um dos maiores eventos daquele ano, onde tivemos a participação de docentes e pessoal administrativo de vários setores da universidade, estudantes e, especialmente, a participação de professores das redes estadual e de diversos municípios de Pernambuco. Foram mais de 1.500 participantes.

Outro registro importante é sobre o artigo proveniente do dossiê Norbert Elias e educação, publicado em parceria com mais dois colegas. O texto Atividades miméticas $e$ dispositivos de controle no Colégio Americano Batista no Recife (Souza; Simões; Nunes, 2017) representou um pouco o meu retorno ao centro de discussão eliasiana, já que há um bom tempo estava sem motivação para participar dos eventos organizados para discutir a teoria de processos civilizadores. Aliás, não só esse artigo me fez voltar à leitura de Elias, como também o livro Ensaios da civilização no samba (Souza, 2018), ou seja, duas produções que revigoraram os meus pensamentos e participação em eventos, que embora importantes, há sempre a necessidade de novos trabalhos teóricos e empíricos.

Por outro lado, é óbvio que os projetos de pesquisa nos mantêm mais experientes no campo acadêmico, inclusive, na pós-graduação, mas são os projetos de extensão que me fazem entender a importância da universidade em sua relação com os problemas sociais. E, mesmo com um número bem reduzido durante toda a trajetória, apenas quatro registros dessas atividades de extensão, passado um bom tempo de atuação nesse setor com projetos que duraram alguns anos, vejo que colaborei com novas discussões e também na formação de alguns estudantes de Comunicação Social, Artes Cênicas, Pedagogia e Educação Física.

Dessa maneira, destaco também o programa de rádio Saber esportivo: a sua conexão com o esporte amador, que existiu por três anos na Rádio Universitária AM/UFPE, e o programa de televisão Cabeça de Área; penso, logo assisto. Esse programa de televisão foi veiculado por mais de dez anos pela TV Universitária/UFPE, e temos dele, sob a nossa responsabilidade, mais de 350 DVDs em processo de catalogação para serem doados ao Memorial Denis Bernardes, na Biblioteca Central da UFPE.

Outro destaque das atividades de extensão é o projeto Capoeira com a UFPE: gingados transformadores ao ritmo de epistemologias críticas, sob a coordenação do professor Henrique Gerson Kohl, o Tchê. Tenho pouca participação nesse projeto em virtude de outros afazeres, mas entendo que estar articulado com a capoeiragem é fundamental para alimentar o espírito resiliente tão necessário na sociedade em que estamos, nos campos onde travamos as nossas lutas. A capoeiragem é uma tática histórica! 
E, por último, por alguma razão não consta nos registros da extensão, mas no ambiente do Currículo Lattes Artes Cênicas, que é o espetáculo Ogum Onirê, datado de 1999, sob a produção do Grupo de Dança Afro da UFU, considerado por mim um trabalho inovador dentro do contexto da época em que fui docente na Universidade Federal de Uberlândia.

Assim, neste capítulo, analisei sucintamente o meu Currículo Lattes, tentando mostrar o mínimo necessário para o leitor compreender de maneira mais abrangente possível o meu comportamento enquanto intelectual na ação e registro das diferentes participações institucionais e produção acadêmica. Em continuidade à circulação da produção científica, no próximo capítulo, apresentarei uma síntese dos livros e capítulos resultantes de pesquisas e reflexões de problemas interpretados à luz da História e da Sociologia.

\section{Capítulo 5 - Dos livros e capítulos da minha trajetória}

Antes de abordar a obra, falarei do seu criador, pois quem conhece o criador conhecerá, ao menos em parte, a criatura. Sou daqueles que acreditam que, ao escrevermos, escrevemo-nos, subscrevemo-nos, inscrevemo-nos. Os leitores que não conhecem pessoalmente Edilson, com esta leitura, terão oportunidade de captar um pouco seu jeito de estar no mundo. (Silva, 2018, p. 11)

Concordo com as reflexões acima, feitas pelo professor José Bento ao prefaciar um dos meus livros. De fato, ao escrever qualquer obra estamos, em última instância, inscrevendo-nos num espaço social determinado, como também projetando-nos, enquanto inscritos, para a história das gerações futuras. E ao ler um livro, conhecemos muito de seu autor. Assim, esta parte do trabalho está dedicada aos livros e capítulos de livros que publiquei como único autor, em parcerias ou como um dos organizadores e tem por objetivo apresentá-los ao leitor para futuras referências de temáticas voltadas às questões étnico-raciais, à sociologia eliasiana, à história da educação, à história e sociologia do esporte, bem como a algumas reflexões acerca do envelhecimento.

O capítulo ajuda a tornar possível minhas lembranças de quando e por que tomei a decisão em publicar essas obras, em parcerias ou como único autor. Pode parecer fortuito, mas é óbvio que cada livro contém uma história própria, especialmente do ponto de vista do conteúdo, forma, diagramação, capa e financiamento. Aliás, a maioria das publicações foi financiada pela Universidade Federal de Pernambuco, por meio de sua editora, uma articulação já não mais possível, seja em virtude da política editorial, seja pela falta de estímulo institucional.

De qualquer modo, seria importante um estudo mais aprofundado acerca das conexões que consegui, até o presente momento, realizar com os livros e capítulos aqui expostos. Tal prudência poderia se sustentar a partir da fala de Bourdieu (2002), para quem a história da literatura tem ignorado o sistema de relações e, por conseguinte, o sistema de produção em que um autor e sua obra estão envolvidos. Assim, o meu interesse neste momento não é o de mostrar a complexidade do meu sistema de relações ou o conjunto de minhas interdependências, para pensar como Elias (2001) em seu processo de autodistanciamento, o que seria praticamente impossível pelas limitações 
espaço-temporais e autobiográficas aqui explícitas. O interesse, na verdade, concentra-se em levantar apenas algumas possibilidades de entrada no campo intelectual, seja na aquisição ou como produtor de capital cultural, sendo este o caso.

Nesse contexto, Silva (2015) apresenta um dado bastante significativo, ao tratar das carreiras docentes, sobre um professor universitário em seus atos de ofício. Além de escolher os livros e textos a serem discutidos com seus estudantes, o docente pode escrever os seus próprios livros e textos para aprofundar com os discentes os problemas levantados numa aula ou conferência. Isso talvez seja uma das grandes vantagens de um professor universitário. Fabricar suas próprias ferramentas de trabalho e exigir dos estudantes sua leitura, levando-os à reflexão e prova.

Considerando esses atos de ofício, para a construção deste capítulo, inicialmente, fui extrair a quantidade de livros da parte final do meu Currículo Lattes, onde constam os indicadores da produção acadêmica. Por surpresa, identifiquei alguns erros em relação à quantidade de artigos e livros publicados. Ora indicava para mais, ora para menos. Então, resolvi contar livro a livro, capítulo a capítulo. Assim, até o presente momento são nove em autoria solo ou parceria e 11 livros organizados, alguns em parcerias com outros pesquisadores. Não vou tratar de cada um dos livros e capítulos, porque seria uma tarefa bastante enfadonha, cabendo, inclusive, uma pesquisa à parte, vou apenas comentar e apresentar alguns que julgo mais importantes para o contexto deste trabalho e me situar enquanto autor e produtor de conhecimento no campo acadêmico ou objetivante, como a universidade (Bourdieu, 2004).

O primeiro livro foi resultado de minha tese de doutorado, a primeira edição data de 2001: pensava que teria sido antes, porque, assim que cheguei na UFPE, em 2000, procurei a diretoria da Editora Universitária, que me cobrou um absurdo para publicá-lo. $\mathrm{O}$ texto ficou muito tempo em processo de análise para verificar a qualidade do conteúdo, mesmo tendo explicado aos técnicos da editora que era resultado de um doutorado na Unicamp. Sua ficha catalográfica dá conta de 2001, mas, efetivamente, o livro saiu do parque gráfico em 2003.

Depois de algum tempo, consegui a aprovação do Conselho Editorial da Editora Universitária da UFPE, já sob outra presidência, da professora Gilda Lins (in memoriam), a quem agradeço a colaboração e empenho em publicar o texto. Assim, Entre o fogo e o vento: as práticas de batuques e o controle das emoções $(2001,2005,2010),{ }^{25}$ considero como uma obra-prima, resultado de muito esforço na elaboração de seu conteúdo, produto da tese, que não sofreu muitas alterações para circular com mais abrangência em forma de livro. Sinto-me realmente orgulhoso pelos resultados da tese e do livro.

Já na primeira edição, recebi um grande presente: o prefácio, Batuque: entre o som e seu sentido, escrito pelo professor Lourival Holanda, do Departamento de Letras da UFPE. "Sempre salutar retorno à autoimagem, à presença étnica. Daí ser tão oportuno o livro de Souza: por pretender dar continuidade histórica à reelaboração das formas culturais negras, ajustando-as às novas pesquisas teatrais de performance corporal." (Holanda, 2010, p. 22)

25 Para efeito de identificação na Biblioteca Nacional: ISBN 978-85-7315-765-9. 1. Cultura - aspectos sociais. 2. Danças afro-brasileiras. 3. Batuque (Música). 4. Negros - Vida e costumes sociais. 5. História e antropologia - Rio de Janeiro - século XIX. Paiva, Gilvando (Ver.). II. Título. 
Essas palavras foram realmente confortantes para quem estava chegando de outra instituição e iniciando uma nova etapa intelectual no campo acadêmico. O mesmo posso dizer dos prefácios das edições posteriores, são formas carinhosas e palavras densas que meus colegas utilizaram para comentar no entorno do fogo e do vento: "O livro de Edilson tem me acompanhado em vários percursos acadêmicos e estéticos, pois trata do corpo de forma presente, viva, existencial, com poesia e profundidade acadêmica" (Nóbrega, 2005, p. 10) e "preocupando-se em entender o sentido do controle dessas práticas, o autor envereda numa trajetória histórica, calcada em pesquisa documental" (Suassuna, 2010, p. 11).

É muito fácil observar que este livro, bem como os próximos, Ensaios da civilização no samba (2018) e Representações de afro-brasileiros: depoimentos de dançarinosatores (2008), têm em comum aspectos significativos da biografia exposta no capítulo anterior. Estão clivados do meu habitus de artista, mesmo já há bastante tempo apenas no campo acadêmico, até porque a tese que originou o livro foi escrita e defendida em dois anos, num só impulso científico - ou artístico?

O texto Entre o fogo e o vento foi construído sob as bases sólidas da sociologia eliasiana, constitui realmente algo de muito orgulho pela modesta e densa aplicação dos marcos conceituais desse autor. Originalmente, ainda como rascunho da tese, foram muitas táticas utilizadas em sua escrita, falando com colegas do doutoramento e perguntando a eles sobre a relevância do tema e também sobre o seu título. Então, desde o momento em que entrei no doutorado, na Unicamp, meus colegas de turma depararamse cotidianamente com esse conteúdo, na medida em que expunha com muita frequência nos seminários demandados pelo Ademir Gebara, nosso orientador.

Para a publicação pela editora da UFPE, foi-me insistentemente perguntado se se tratava de uma obra sobre poesia, pela sonoridade emitida pelo título ao ser pronunciado. Algumas vezes fiquei constrangido em responder sobre a origem da temática, mas, com o tempo, passei a me sentir realmente orgulhoso por despertar esse tipo de curiosidade entre os desavisados. É que uma pesquisa científica também pode ter sua beleza, sem que para isso perca a essência de seu objetivo estratégico, o de produzir novo conhecimento.

Ao falar desse livro, oriundo de uma tese de doutorado em 1998, não posso deixar de chamar a atenção para os projetos gráficos desenvolvidos em cada uma das três edições. Na verdade, é possível fazer um estudo por meio das capas produzidas pelos olhares dos profissionais da Editora Universitária da UFPE, tendo como ponto de partida a densidade do conteúdo.

Curiosamente, ao procurar as edições na biblioteca da minha residência, só encontrei a edição de 2010. No Laboratório de Sociologia do Esporte - UFPE/CNPq -, sob minha coordenação na universidade, depois de muita procura, encontrei a edição de 2005, um exemplar com dedicatória ao professor Márcio Eustáquio, já falecido. Eu não sei como esse exemplar, com o carimbo pessoal do professor, foi parar no Laboratório. Já a primeira edição, foi encontrada na Biblioteca Setorial do Centro de Filosofia e Ciências Humanas - CFCH/UFPE -, disponível à consulta pública.

De qualquer modo, penso que alguém pegou emprestado os exemplares que eu tinha no Laboratório e se esqueceu de devolver. Realmente, perdi o controle enquanto autor, o que é muito bom, mas também significa que devo ter perdido um pouco do meu 
acervo pessoal. Contudo, recuperada a fonte, resolvi expor as capas das três edições para o leitor ter uma ideia mais geral da concepção do seu design e de como os técnicos da editora compreenderam o conteúdo desenvolvido. Penso que o próprio título é muito sugestivo, o que foi devidamente acompanhado pelo projeto gráfico. Seguem as capas:

Figura 387 -

Capas da $1^{\text {a }}$ e 2 ${ }^{\underline{a}}$ edições, Entre o fogo e o vento, 2001 e 2005.
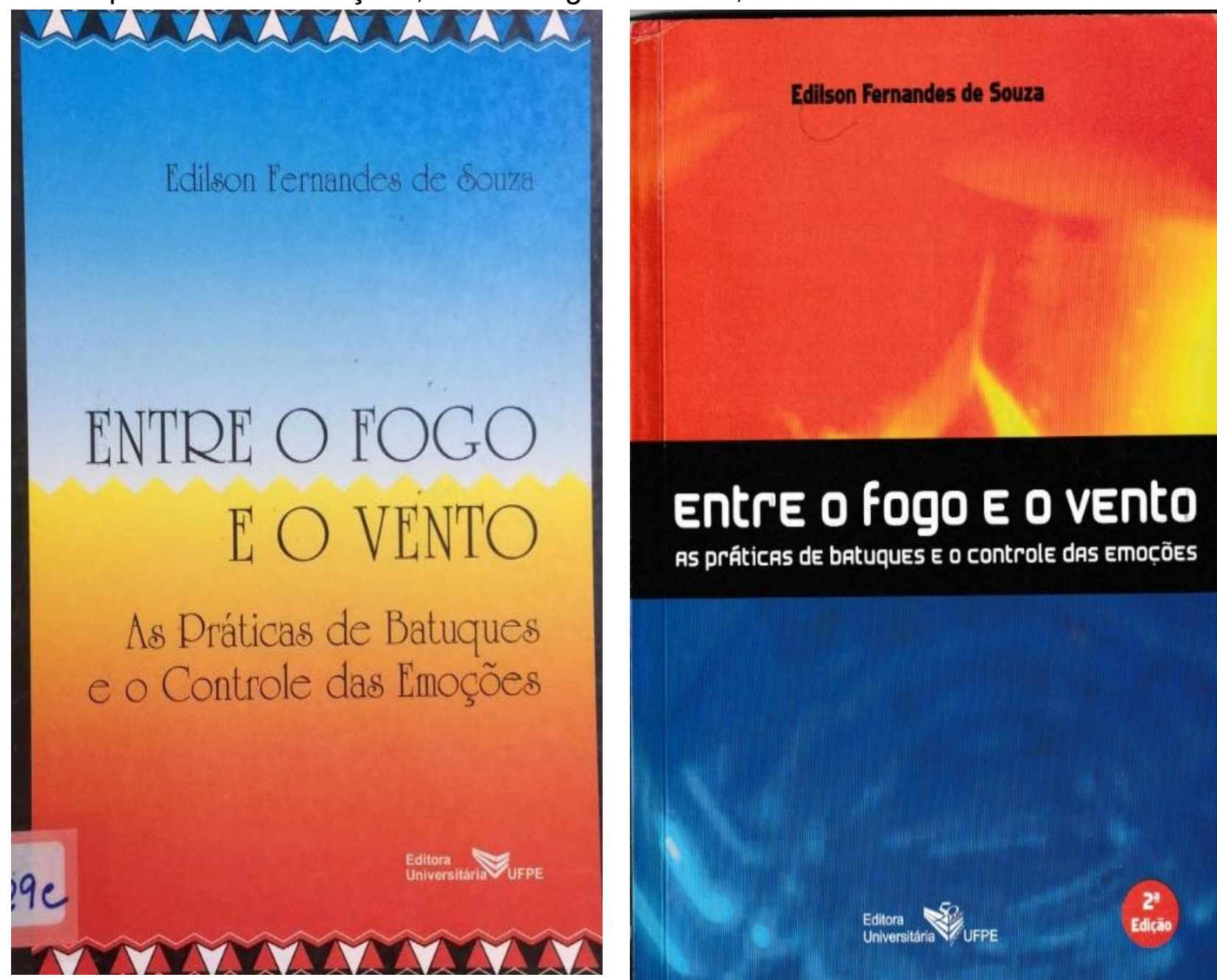

Fonte: acervo da biblioteca da UFPE.

Fonte: acervo da biblioteca do autor.

Como o leitor pode perceber, o exemplar da esquerda, a primeira edição, traz, em letras garrafais, o título "Entre o fogo e o vento", logo, a atenção é desviada do subtítulo, o objeto central da tese. Entretanto, vejo que a diagramação se esforçou para identificar que havia algo de movimento no conteúdo da obra, o que não aparece nas edições posteriores.

Das edições posteriores, sobretudo, a segunda, as cores vermelha e amarela são quebradas pelo azul celeste, uma clara alusão ao céu, que aparece na parte inferior da capa. Na verdade, houve uma inversão de cores entre a primeira e a segunda edição: céu-mar, fogo-terra; fogo-terra, céu-mar.

Confesso que, durante muito tempo, comprei os exemplares para doar aos amigos e às instituições por ocasião de algum evento. A ideia era a de provocar novas edições para sempre ter algo a ser registrado no Currículo Lattes. A terceira edição, por exemplo, quis 
causar uma boa impressão ao meu supervisor de estágio pós-doutoral na Universidade do Porto, em Portugal, em 2010, professor dr. João Miguel Trancoso Vaz Teixeira Lopes, a quem agradeço a oportunidade.

Como disse, a tese que virou livro não sofreu alterações em seu conteúdo, por isso a minha insistência em avançar nas leituras de Norbert Elias e tentar encontrar outros objetos empíricos da afrodescendência para sua aplicação, o que só foi possível algum tempo depois. De qualquer modo, ao comparar as edições do "fogo e do vento"; suas capas, é fácil compreender a perspectiva tomada pelos diagramadores, ao entrarem em contato com o conteúdo ali impresso, e sua tentativa de representação gráfica.

Figura 398 -

Capa, 3a edição, Entre o fogo e o vento, 2010

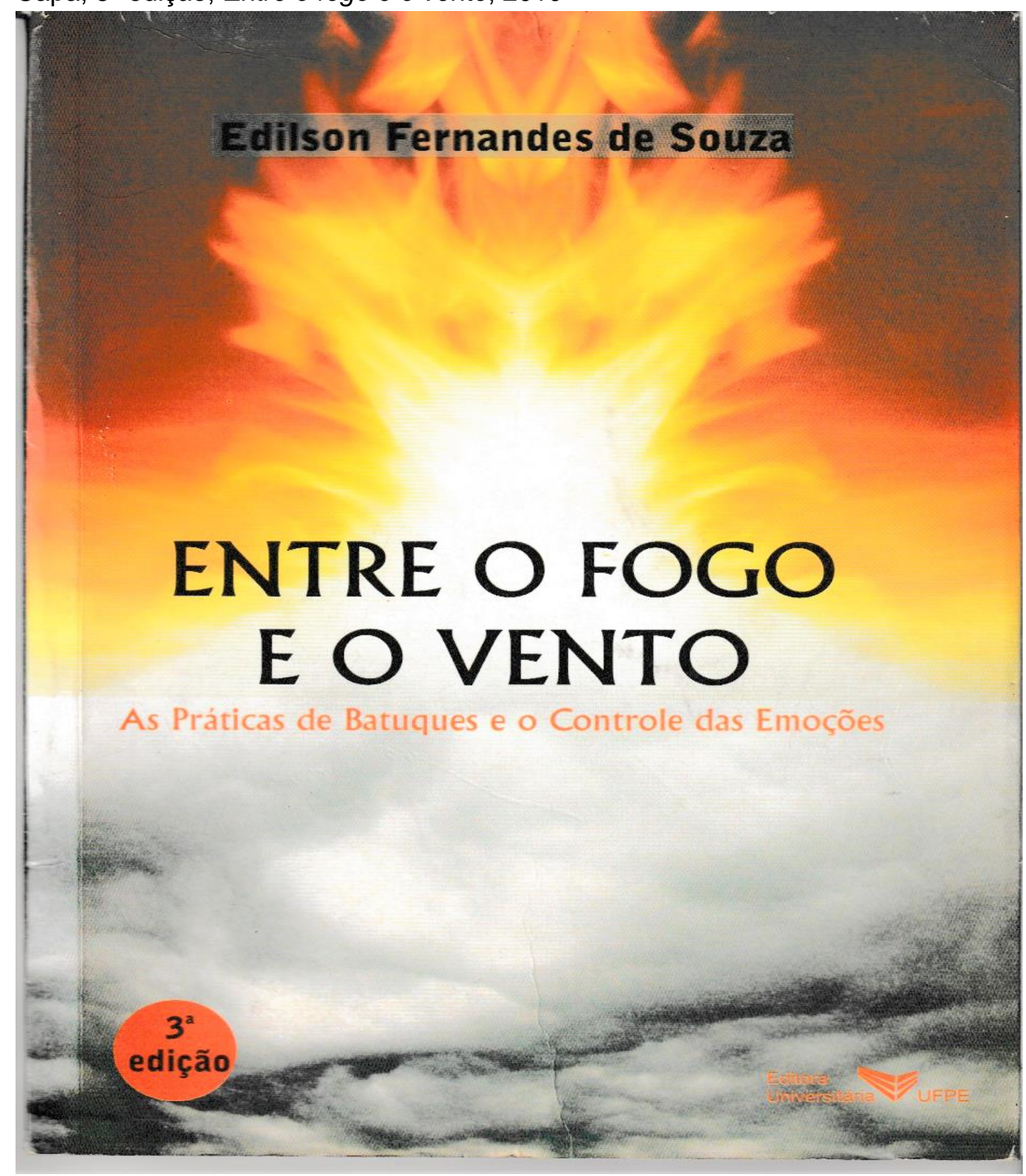

Fonte: acervo da biblioteca do autor. 
Como se percebe, as capas tentam representar o vento soprando o fogo ardente e, de maneira descontrolada, faz soar os batuques, que trazem as emoções dos ancestrais divinizados. Há predominância das cores vermelha e amarela representando o fogo soprado pelo vento e redemoinho das nuvens, especialmente a capa da terceira edição. $\mathrm{Na}$ parte superior, ao centro, sempre vejo uma figura humana soprando ou se aquecendo junto ao fogo.

Interpretação de fogo à parte, com base na teoria eliasiana, a hipótese da tese é sustentada pela argumentação do habitus ${ }^{26}$ revestido de um nós processado em longo prazo. É aquilo que os indivíduos trazem consigo, ou seja, o 'nós' em detrimento do 'eles', e que Elias (1994, 1997b) chama de 'segunda natureza'. Então, na apropriação teórica, ressignifiquei o termo habitus, unindo-o ao conceito de subsaariano, na perspectiva de indicar o processo de continuidade das sociedades africanas na diáspora e suas culturas concretas, defendidas por Munanga (1984) no seu universo cultural africano.

A tese que deu origem ao livro foi escrita num só fôlego, e o livro, enquanto seu resultado, expressa muito do meu pensamento acerca da afrodescendência e o impacto da civilização subsaariana no Brasil. Volta e meia, leio os prefácios das três edições, para me situar enquanto autor/pesquisador percebido por outros cientistas, e leio o último parágrafo das considerações finais, para alimentar minhas inspirações daquilo que considero uma obra-prima.

O título demorou três dias e três noites para eu decidir. Como estava muito estressado, não conseguia dormir só pensando no título: entre o fogo e o vento, entre fogo e vento, entre o fogo e vento. Confesso que a ideia original veio do recorte de jornal do Correio de Uberlândia, que havia publicado uma matéria sobre a minha filha mais velha, do primeiro casamento, Tulane Souza. A matéria dizia: "Como o fogo e o vento, Tulane aprendeu os primeiros passos com os pais".

De qualquer modo, o livro traz uma densa argumentação sobre os batuques praticados pelos afrodescendentes escravizados ou libertos, que circulavam ainda sob o jugo dos senhores de engenho e eram frequentemente acusados de incomodarem os concidadãos da cidade de São Sebastião do Rio de Janeiro, até o final do século 19. No processo de continuidade, esses batuques foram ressignificados em práticas artísticas amplamente desenvolvidas no século 20a denominadas de dança afro:

Apesar de os artistas não passarem pelo processo iniciático, recebem permissão para a espetacularização mítica não só pelos conhecimentos que vão adquirindo lentamente sobre os deuses e suas danças, como também pelo distanciamento que vão tendo dos espaços sagrados onde são implantados os axés. (Souza, 2010, p.147)

Assim, a narrativa tenta passar a ideia de que os dançarinos-atores brincam com duas normas e estéticas diferentes, religiosa do candomblé e artística da dança afro, cuja técnica corporal é que mantém o controle emocional, sem que receba a ancestralidade

${ }^{26}$ O habitus aqui é utilizado na perspectiva eliasiana e é compreendido na perspectiva da longa duração. É aquilo que os indivíduos herdaram de sua sociedade de origem e que atravessa gerações, mesmo considerando os processos sociais. O conceito é extremamente complexo, mas pode ser melhor compreendido a partir do livro do próprio autor (1997b) Os alemães e a evolução do habitus, século XIX e $X X$. 
divina, "contudo, isso concorre também para que a prática dos atuais batuques seja extremamente excitante, onde seus praticantes e seus espectadores estejam sempre entre o fogo e o vento (Souza, 2010, p. 147). Esta é, portanto, a última frase escrita na conclusão do livro e que eu gosto muito de ler e reler quando estou entristecido.

Todavia, na continuidade dessa mesma ideia de ancestralidade impulsionada pelo habitus subsaariano, mas, em outro momento da minha trajetória, passados oito anos da terceira edição do livro Entre o fogo e o vento, escrevi um outro livro que foi produto de uma conferência no Simpósio de Processos Civilizadores, de 2016, na Universidade Federal do Espírito Santo.

Embora eu tenha trabalhado uma hipótese central de argumento similar ao livro anterior, Ensaios da civilização no samba (2018) ${ }^{27}$ é, na verdade, uma brincadeira de razoável inspiração acadêmico-científica que custou muito caro por ter sido pago com o meu cartão de crédito em seis vezes. Foi também um compromisso assumido com meus colegas coordenadores do referido evento, Tony Honorato e Magda Sarat.

Com financiamento pessoal de $\mathrm{R} \$ 3.000,00$ e tiragem de cem exemplares, o livro só possui 81 páginas, já contadas as referências bibliográficas. Foi uma decepção editorial. Confesso que não esperava tamanho prejuízo. O preço de capa não poderia ultrapassar $\mathrm{R} \$ 20,00$, fiquei com vergonha de vendê-lo mais caro, daí já é possível imaginar o desequilíbrio nas finanças.

Em meio à vergonha editorial, o prefácio é um dos maiores alentos que um autor pode ter. Por isso, volta e meia leio o que o professor José Bento Rosas da Silva, do Departamento de História da UFPE, expressou na abertura do referido livro e que consta da epígrafe deste capítulo: "Sou daqueles que acreditam que, ao escrevermos, escrevemo-nos, subscrevemo-nos, inscrevemo-nos. Os leitores que não conhecem pessoalmente o professor Edilson, com esta leitura, terão oportunidade de captar um pouco seu jeito de estar no mundo" (Silva, 2018, p.11). Além dessas palavras confortantes, gosto muito da capa, que chama à atenção para o movimento dançante e remete o leitor a outros tempos históricos.

${ }^{27}$ Para efeito de identificação na Biblioteca Nacional: ISBN 978-85-4442570-1. 1. História do Brasil. 2. Sociologia. 3. Antropologia das populações afro-brasileiras. I. Título II. Série. 
Figura 409 -

Capa, Ensaios da civilização no samba, CRV, 2018.

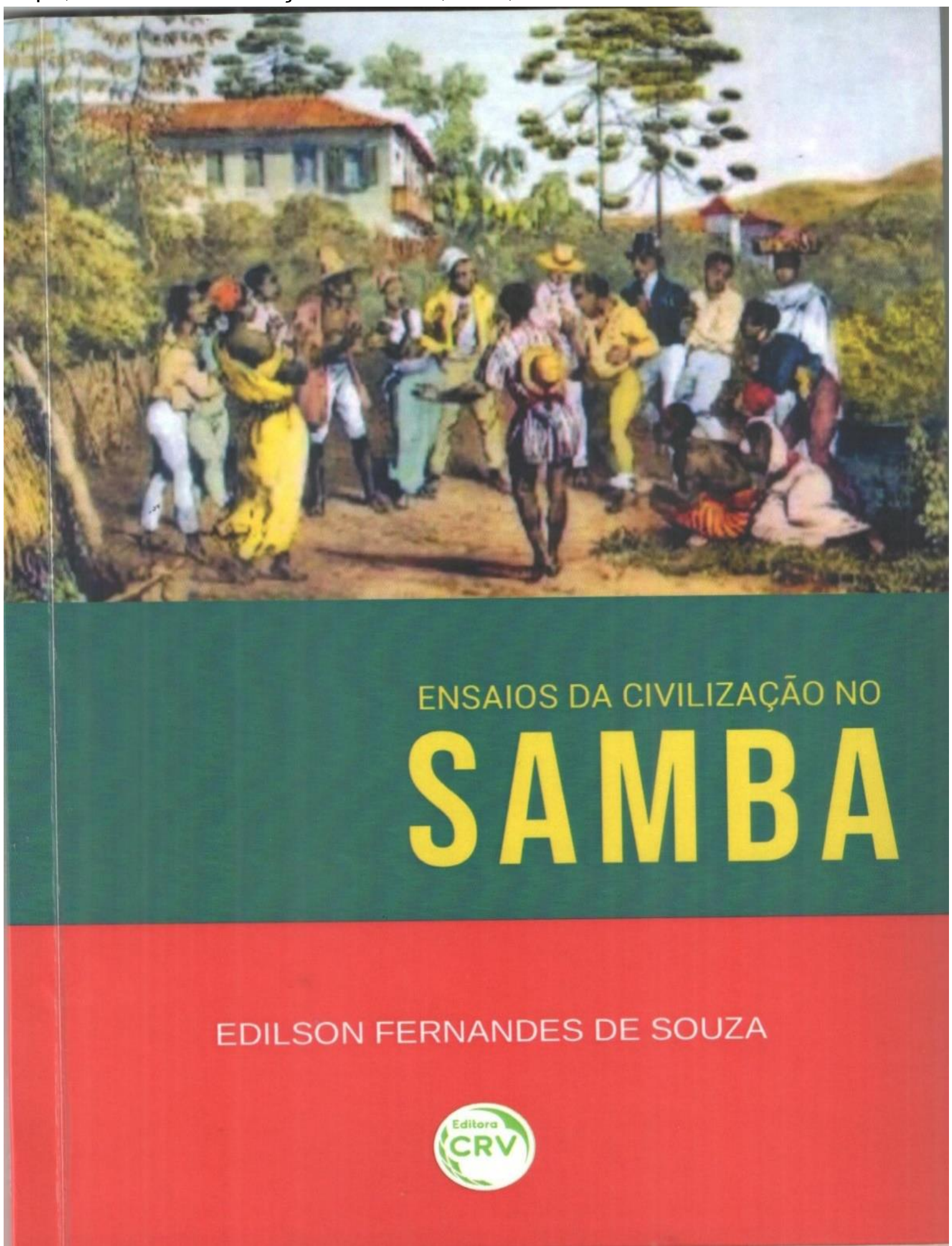

Fonte: acervo da biblioteca do autor.

Não obstante o prejuízo financeiro, a capa é muito sugestiva, trata-se de uma reprodução de internet da pintura de Johann Moritz Rugendas, obviamente, direitos de publicação solicitados pela editora CRV. As imagens são realmente impactantes, um ajuntamento de negros em práticas de batuques, próximo à casa grande. 
O livro é muito gostoso de ler. Nele é possível apreciar os marcos conceituais eliasianos enquanto elementos de interpretação sociológica. Como trago, basicamente, a discussão do habitus subsaariano, tento verificar empiricamente como esse 'nós' africano é incorporado por meio da técnica dançante desenvolvida no Brasil. É realmente um ensaio em sentido duplo, verificação conceitual e experimentação do ritmo samba.

Ao abrir aleatoriamente suas páginas no momento de construção deste parágrafo, olhei o excerto que segue: "Desse modo, essa civilização subsaariana ensaia seu habitus, [...] sua identidade e memória coletiva na performance técnica-dançante do samba, enquanto processo contínuo e de longo prazo, na sociedade brasileira" (Souza, 2018, p. 72). Essa é uma demonstração clara do modelo de interpretação a que submeti as ideias centrais da publicação.

Na perspectiva do fortalecimento da hipótese, apresento o mapa africano numa de suas páginas, localizando a parte subsaariana desse território para indicar a diversidade cultural do que hoje podemos chamar de Estados-nacionais e, ao mesmo tempo, os elementos comuns dessas sociedades, ou seja, apesar da diversidade, há algo o que as unificam. Assim, "reside no território subsaariano o enraizamento e proeminência de um habitus que faz circular a força do gesto, do cântico e da dança entre as famílias nucleares, consanguíneas ou míticas" (Souza, 2018, p. 51).

É, portanto, a circulação cega dessa força que avança na diáspora, se expressa em vários elementos da cultura concreta, como assinala Munanga (1984) e que podemos verificar no maracatu, na capoeira, no candomblé e no próprio samba, o que dá riqueza à análise e interpretação a partir da sociologia eliasiana nesse livro que custou caro, mas que ainda me deixa feliz em ter escrito.

Nesse contexto, percebo que o tema étnico-racial sempre esteve presente entre os meus alfarrábios, seja no início da minha carreira acadêmica, seja hoje em dia. Se os dois livros até aqui apresentados têm em comum a temática, a teoria e o método na perspectiva eliasiana, o livro resultado da dissertação de mestrado, Representações de afro-brasileiros: depoimentos de dançarinos-atores, ${ }^{28}$ revela a minha relação com a etnicidade e com o método de história de vida, próximo ao método biográfico.

Desde a defesa da dissertação na Universidade Gama Filho, em 1995, aprovada com louvor, até a publicação desse livro, passaram-se 13 anos. São muitas as razões que não me motivaram a procurar uma editora, mas depois vi que o resultado ficou muito bom, especialmente a capa, onde é possível ver duas amêndoas. Então, posso dizer que foi uma das melhores capas dos livros que já publiquei. São dois rostos, masculino e feminino, convergindo para o afeto, o beijo.

${ }^{28}$ Para efeito de identificação na Biblioteca Nacional: ISBN 978-857315-490-0. 1. Cultura e sociedade. 2. Cultura negra. 3. Dança na arte-aspectos sociais. 4. Dança afro-brasileira-identidade social. I. Título. 
Figura 10 -

Capa, Representações de afro-brasileiros, 2008

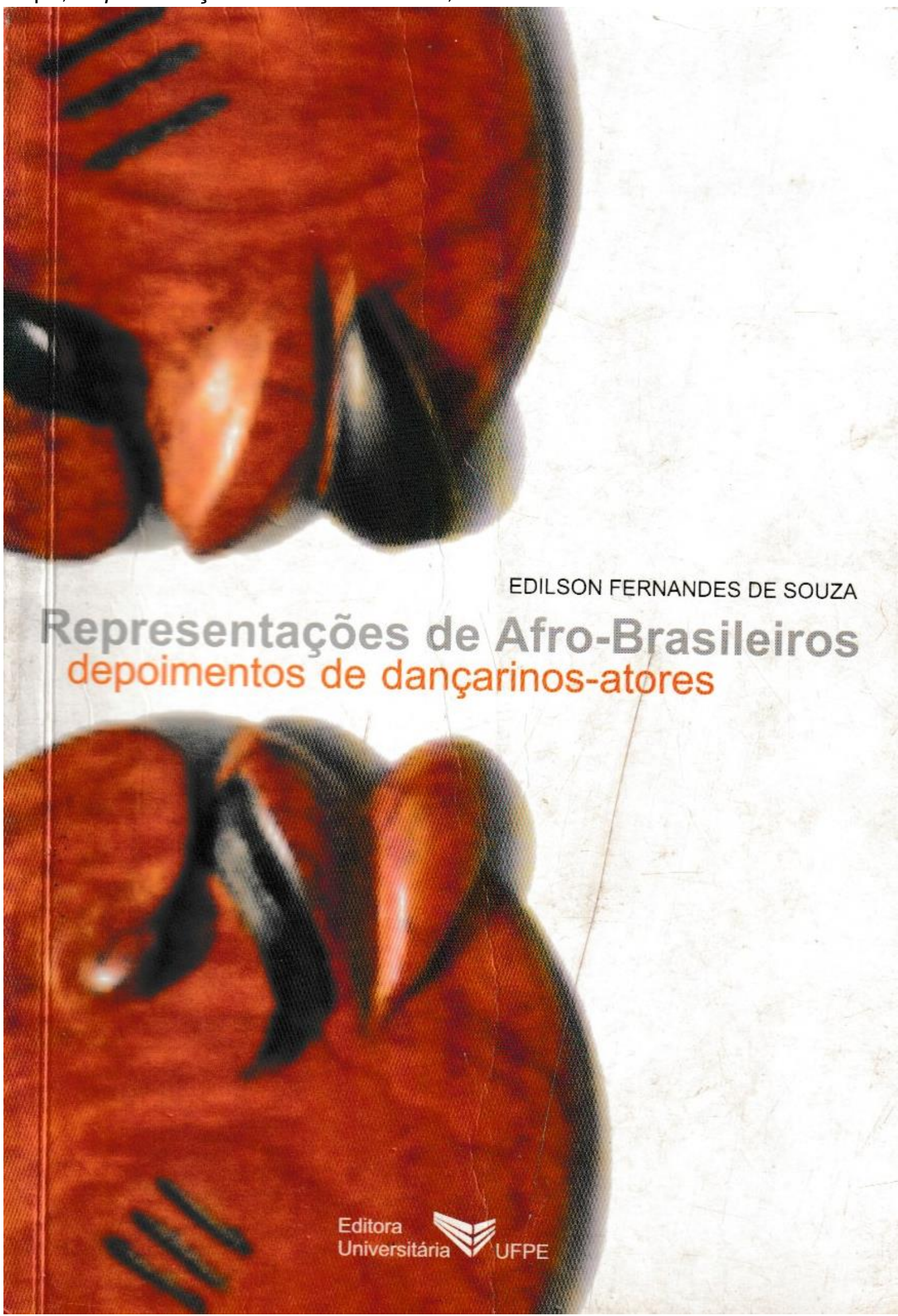

Fonte: acervo da biblioteca do autor. 
As razões pelas quais não queria publicar esse livro devem-se à tentativa de negar o que foi feito em 1995, não pela temática, mas pelas abordagens que usei para interpretar a fala dos entrevistados, à época, 20 pessoas, entre homens e mulheres artistas da dança afro, na cidade do Rio de Janeiro. Penso que fiquei com 'vergonha metodológica', porque, assim que terminei o mestrado, entrei no doutorado, finalizando o curso em dois anos.

$\mathrm{Na}$ época, não tinha coragem de ler o texto do mestrado, muito menos fazer uma revisão para poder publicar. Penso agora que talvez por isso tenha publicado na íntegra sem revisão de conteúdo. Isso porque, ao lembrar deste trabalho, em meus pensamentos vinha sempre um texto frágil, desproporcional ao que já havia adquirido com a tese de doutorado na Unicamp. Na verdade, eu me 'achava' o próprio metodólogo, portanto, inconcebível publicar tal texto.

Entretanto, o livro tem, no capítulo introdutório, o porquê de publicá-lo e depois de tanto tempo. Foi um incentivo internacional, da professora dra. Maria José Mosquera Gonzáles, do Instituto Nacional de Educação Física da Catalunha, na Espanha. Porém, para verificar a opinião da professora Maria José sobre o conteúdo e a forma de exposição do relatório final de pesquisa, é preciso que o livro seja lido.

Ao revisitar a publicação para efeito desta tese, encontro uma escrita muito apropriada que corrobora este momento, senão vejamos: "A abordagem autobiográfica vem crescendo desde os anos 1970 e, na perspectiva de mudança, a autobiografia tem conjugado vários olhares disciplinares ao produzir um rico e diversificado conhecimento" (Souza, 2008, p. 15). Pode-se observar que esse excerto, originalmente retirado do livro em tela, estava próximo de alguns comentários relativos ao Antônio Nóvoa, hoje, reconhecidamente um dos autores clássicos do método aqui empregado.

Assim, quero chamar a atenção para o fato de que esse livro possuía um número razoável de literatura relacionada ao tema da história de vida, e não foi poupado autor para a sustentação das ideias gerais do trabalho original, nos idos de 1995. Guardadas as devidas proporções teóricas e metodológicas, esse foi um livro, tão logo publicado, recebi a solicitação de cinco exemplares para The University of Texas at Austin, nos EUA.

Nesse novo contexto, volta e meia, tenho indicado essa publicação para estudantes de graduação e pós-graduação, porque vejo que o texto apresenta conteúdo e forma bastante interessantes para quem está iniciando algum projeto de pesquisa, sobretudo, para quem pretende aplicar a análise de conteúdo na descoberta dos sentidos da teoria das representações sociais:

Trata-se da análise de entrevistas relativas ao modo como atores sociais representam a cultura negra por meio da dança. Esta análise foi essencialmente temática e qualitativa, constituindo unidade de registro os próprios temas representados nas histórias contadas pelos atores. (Souza, 2008, p. 33)

O livro é bastante didático e, além de ter um razoável levantamento da literatura acerca da história de vida e das representações sociais, também apresenta com detalhes os procedimentos utilizados em várias etapas da pesquisa, desde a captação das fontes orais, as transcrições e a emergência das unidades temáticas até o modo como essas unidades foram interpretadas. Considerando as condições de produção, hoje vejo que a compreensão que se tinha de ciência e o próprio mestrado em Educação Física, à época, deve ter tido algum mérito e deveria mesmo ser publicado. 
Nesse contexto, ao experimentar o sucesso das pesquisas coordenadas no ano de 2009, reuni alguns ex-orientandos de mestrado e organizei e publiquei um dos livros mais simpáticos e lidos até o momento para quem pretende ingressar na linha de Teoria e História do mestrado e doutorado em Educação da UFPE, trata-se do livro Histórias e memórias da educação em Pernambuco ${ }^{29} \mathrm{~A}$ ideia desse texto surgiu quando eu estava sem publicar algo há um tempo, por isso precisava de alguma produção para justificar minha permanência no programa. Seu financiamento foi muito fácil, solicitei os recursos à Pró-Reitoria de Pesquisa e Pós-Graduação da UFPE, que atendeu prontamente.

Essa publicação serviu de inspiração para que outros colegas do Núcleo de Teoria e História do PPGE também reunissem seus ex-mestrandos e fizessem algo semelhante, como foi o caso do professor José Luís Simões, que publicou o livro Teoria e história da educação. Ambos os livros, desde então, têm sido referência para a seleção do mestrado e doutorado do nosso programa.

Todavia, Histórias e memórias da educação em Pernambuco é uma publicação relativamente simples e de fácil compreensão. É um texto didático. Os capítulos são constituídos de resumos das dissertações dos meus ex-orientandos e tratam dos procedimentos, das hipóteses e objetivos de seus temas, relacionados às problemáticas da educação no interior do Estado. Aliás, essa foi uma das principais justificativas que apresentei na abertura do livro.

Ao longo do trabalho que desenvolvo no Programa de Pós-Graduação em Educação, percebi que muitos projetos tinham a preocupação com os problemas educacionais da capital e, às vezes, da Região Metropolitana do Recife. Acabei por orientar um conjunto de pesquisas voltadas para o interior de Pernambuco, o que nos ajudou a refletir um pouco acerca das multiplicidades de temas e fontes de pesquisas ainda inéditas vindas do Agreste e do Sertão do Estado.

Gosto muito do que escrevi como capítulo de abertura e apresentação dos textos dos estudantes, só não gostei da capa do livro. Considerando a abrangência dos assuntos tratados na publicação, achei a capa muito infantil e penso que a Editora Universitária não deu a devida importância a esse detalhe, assim como para seu acabamento, porque as páginas se soltam com frequência, parece que a cola andou faltando por lá.

A capa é a mistura de uma figura abstrata com um desenho animado, pelo menos é assim que a vejo. Não consigo ver outra coisa, embora a ideia tenha sido a de mostrar que são dos livros onde saem as principais memórias. Ou seja, a historiografia da educação em Pernambuco. Pensando bem, o diagramador captou um pouco do que foi escrito, o resumo das dissertações, mas, infelizmente, não conseguiu um bom resultado de capa.

\footnotetext{
29 Para efeito de identificação na Biblioteca Nacional: ISBN 978-85-7315-630-0. 1. Educação-Pernambuco Memória. I. Souza, Edilson Fernandes de.
} 
Figura 42 -

Capa, Histórias e memórias da educação em Pernambuco, 2009.

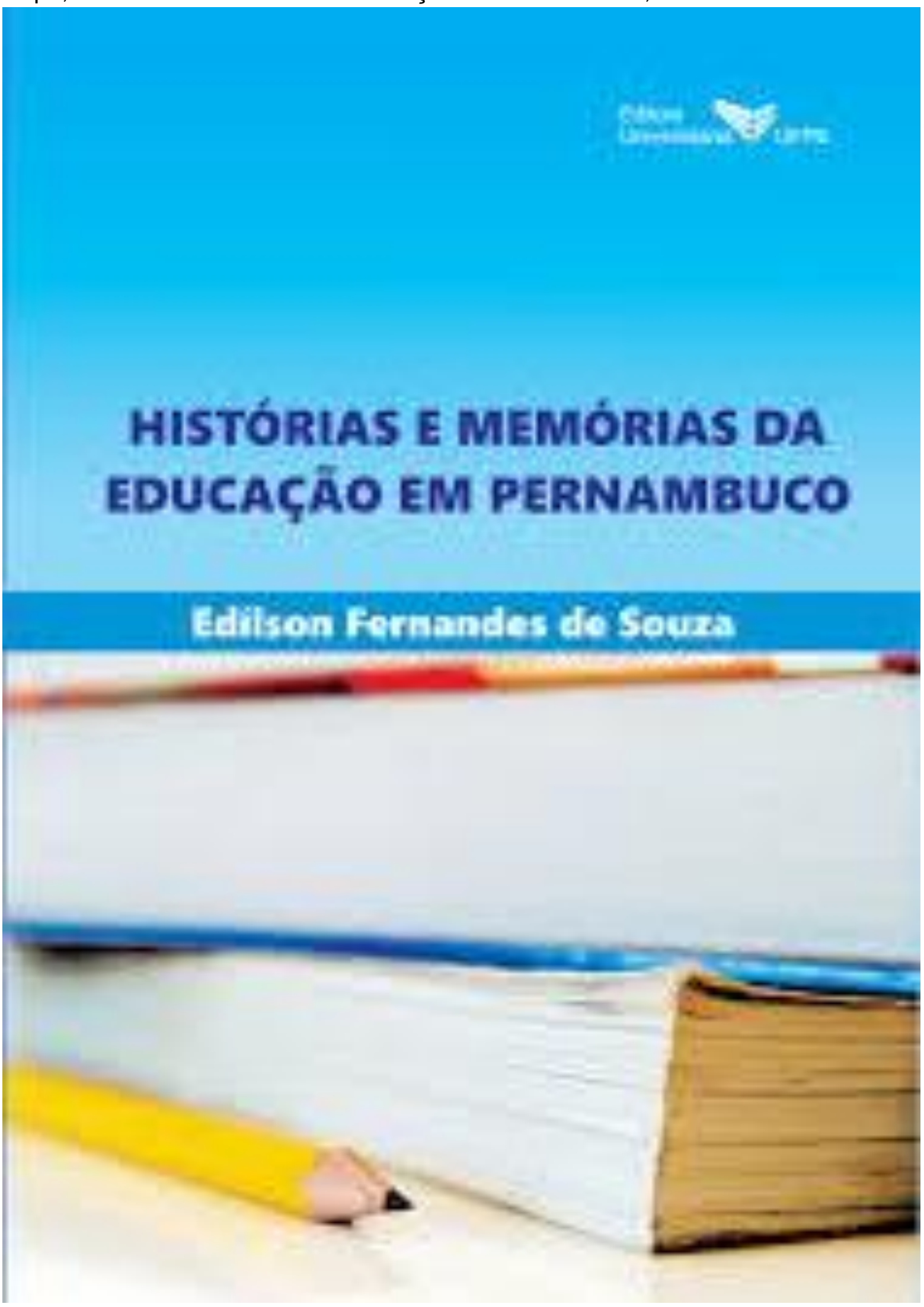

Fonte: acervo da biblioteca do autor. 
O capítulo de abertura, a Arte de orientar no uso dos métodos e das fontes, é uma demonstração de sensibilidade e companheirismo entre orientador e orientando, entre coautores, como falo no texto. Essa relação deve refletir na produção científica desde a abordagem do tema e nos procedimentos até a defesa pública do trabalho. E nós que orientamos, precisamos de um olhar mais despretensioso diante dos desafios de guiar as paixões de professores e professoras que buscam a formação continuada e desejam contribuir com a ciência brasileira, a partir de suas experiências. Também precisamos ser um pouco mais humildes diante do que avançamos e o que é preciso fazer para que outros indivíduos possam avançar em suas produções científicas.

Essa minha atitude frente aos orientandos me rendeu o apelido de 'o homem que orienta paixões', fazendo referência a uma crônica escrita pela Maria Helena Câmara Lira. Mais adiante, falarei dos motivos da crônica e o estado de ânimo em que me encontrava quando foi publicada.

Mas, de volta à história, a publicação desse livro, como já foi dito, suscitou outros colegas a terem atitude semelhante, e eu mesmo fui levado a organizar outra publicação, com novas pesquisas para compor o Histórias e memórias da educação em Pernambuco - volume II, ${ }^{30}$ dessa vez com a Izabel Sena e José Luís Simões, convidados para a colaboração dessa tarefa de divulgação científica.

Diferente do primeiro volume, participaram dessa publicação pesquisadores exorientandos de outros colegas da Pós-graduação em Educação; inclusive, com os temas mais variados, necessitando, portanto, de um arranjo acadêmico ou organização dos temas e problemas apresentados. Assim, o livro está dividido da seguinte forma: Parte I: Memória e formação de identidade; Parte II: Educação e religião; Parte III: Práticas pedagógicas e tempo livre; Parte IV: Educação do corpo e seus ritmos.

A publicação é de 2014, mas até o presente momento o livro não circulou conforme o pretendido. Penso que nós, autores e organizadores, perdemos o interesse na divulgação dos textos ali contidos. Na verdade, houve alguns atropelos na concepção e execução da obra, o que lhe confere uma história particular, especialmente as capas sugeridas pela editora.

30 Para efeito de identificação na Biblioteca Nacional: ISBN 978-85-4150362-5. 1. Educação - Pernambuco Memória. I. Souza, Edilson Fernandes de, 1965 (Org.). II Sena, Izabel Adriana Gomes de (Org.). III. Simões, José Luís (Org.). 
Figura 4311 -

Capas, Histórias e memórias da educação em Pernambuco, Volume 2, 2009, 2014.

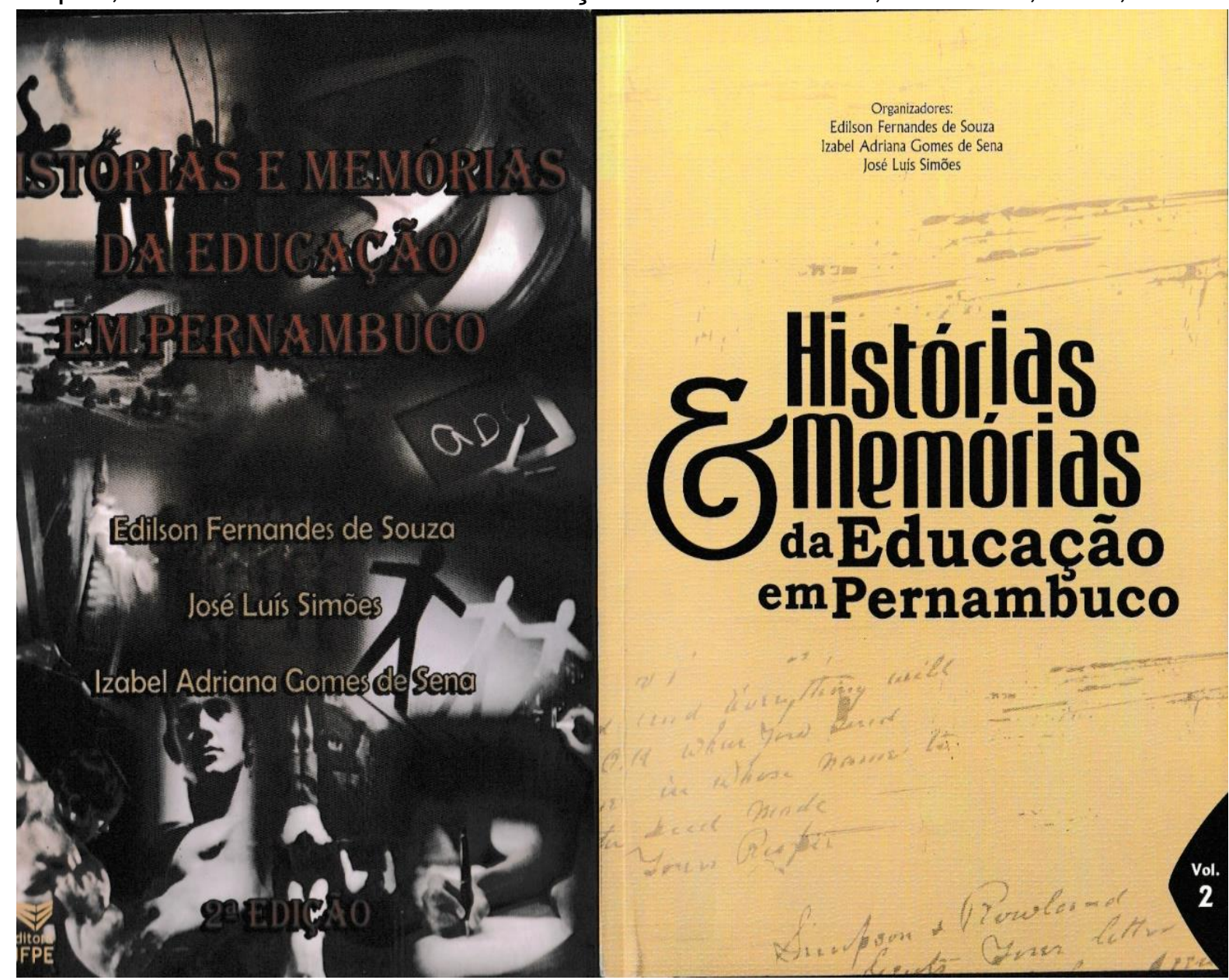

Fonte: acervo da biblioteca do autor.

Como pode ser conferido, esse livro possui duas capas. A primeira, a da esquerda, foi produzida como piloto e, a julgar pelo momento de quem elaborou esse estudo, houve a superposição de ideias e sentimentos em relação ao conteúdo - os textos acadêmicos, especialmente sobre a prática esportiva -, nenhum autor aprovou a forma como se pretendia vender o livro. Aliás, foram feitos dez exemplares para teste como se fosse a segunda edição, outro erro, quando, na verdade, se tratava de um segundo volume.

Mediante a discussão gerada, o livro passou mais de um ano em processo de elaboração, só por conta da capa e a intencionalidade do diagramador, porque internamente o projeto gráfico continuou o mesmo, gerando, inclusive, mais adiamento da publicação. Então, resolvido o impasse, foi elaborada outra capa, a da direita, mais simples e representativa, conforme os autores e organizadores pretendiam. No entanto, até o presente momento, o livro ainda não foi lançado. E, pelo visto, não será.

Todavia, gostaria de destacar o capítulo que escrevi em colaboração com os autores Marcos Roberto C. de Siqueira e Jonathas Eduardo Luna Malta, ex-integrantes do Laboratório de Sociologia do Esporte UFPE/CNPq. Trata-se do primeiro capítulo do livro, intitulado como Memórias de um autodidata: Carmelo de Castro e o culto ao corpo em Pernambuco. O texto é produto de uma pesquisa realizada entre 2002 e 2003 sobre um dos expoentes do halterofilismo pernambucano e brasileiro, o personagem que dá nome ao título: 
O nosso colaborador admite que é mesmo um autodidata e que nunca deixou de se atualizar através de cursos e da leitura constante em revistas especializadas. Em cursos de que participou em São Paulo com o doutor Santarém, estudou anatomia, cinesiologia e fisiologia do esforço, o que, segundo ele, garante o trabalho que realiza em sua "fábrica de campeões", há mais de 40 anos, como é possível observar na placa que compõe a fachada de sua casa. (Souza; Siqueira; Malta, 2014, p. 19)

Com alguma leveza, a narrativa tenta mostrar o saber conferido ao autodidata, bem como seus sentimentos de amor e paixão pelo esporte e pelas artes cênicas, por isso um dos subtítulos: Entre o teatro e os ferros. Então, o texto foi construído basicamente pelos depoimentos de Carmelo, que sempre esteve disposto a falar sobre o esporte que pratica e sobre si mesmo, sempre em terceira pessoa, de forma carinhosa e saudosista.

Um outro livro organizado em parceria foi o Escritos a partir de Norbert Elias, ${ }^{31}$ que tem uma história curiosa. Esse trabalho nasceu de uma insatisfação quando eu estava no Simpósio de Processos Civilizadores, edição Recife, 2009. Na realidade, a insatisfação começou um ano antes, na edição do evento em Buenos Aires, em 2008, quando foi prometida a publicação em forma de livro dos artigos apresentados naquela ocasião.

A capa fala por si mesma, foi escolhida por unanimidade pelos organizadores como forma de pequeno protesto realizado num dos restaurantes das proximidades da UFPE, na Várzea, Recife. Foi uma demonstração clara de que nós não ficaríamos de "fora" do debate científico, as nossas ideias, ou melhor, nossos artigos apresentados em Buenos Aires também virariam livro, para circular na edição do Simpósio no Recife.

Figura 44 -

Capa, Escritos a partir de Norbert Elias, 2009.

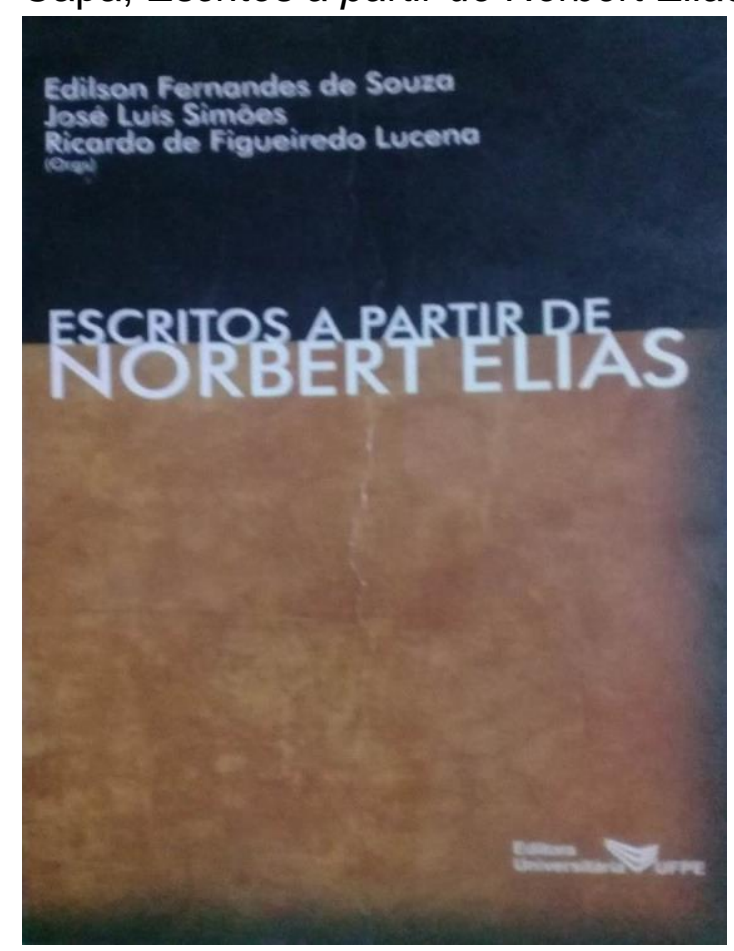

Fonte: acervo da biblioteca do autor.

31 Para efeito de identificação na Biblioteca Nacional: ISBN 978-85-7315-646-1. 1. Sociologia - Norbert Elias. I. Souza, Edilson Fernandes de. II. Simões, José Luís. III. Lucena, Ricardo de Figueiredo. 
A circulação desse livro foi uma surpresa entre os participantes do evento, pois conseguimos publicá-lo em tempo recorde graças ao autofinanciamento. Vendemos alguns exemplares e, eu, pessoalmente, como tenho dificuldade de vender livros, acabei doando a minha cota e dando de presente outros tantos exemplares. A ideia era fazer circular as ideias.

Logo abaixo, o leitor tem acesso ao sumário, onde constam os títulos dos capítulos e seus respectivos autores. O primeiro capítulo foi escrito por mim, especialmente para 0 livro. Aliás, o mesmo texto foi apresentado na primeira mesa do evento e depois me rendeu o projeto de pós-doutorado em Sociologia, na Universidade do Porto, em Portugal, em 2010, o que exibo com orgulho na abertura do meu Currículo Lattes.

Figura 4512 -

Sumário de Escritos a partir de Norbert Elias, 2009

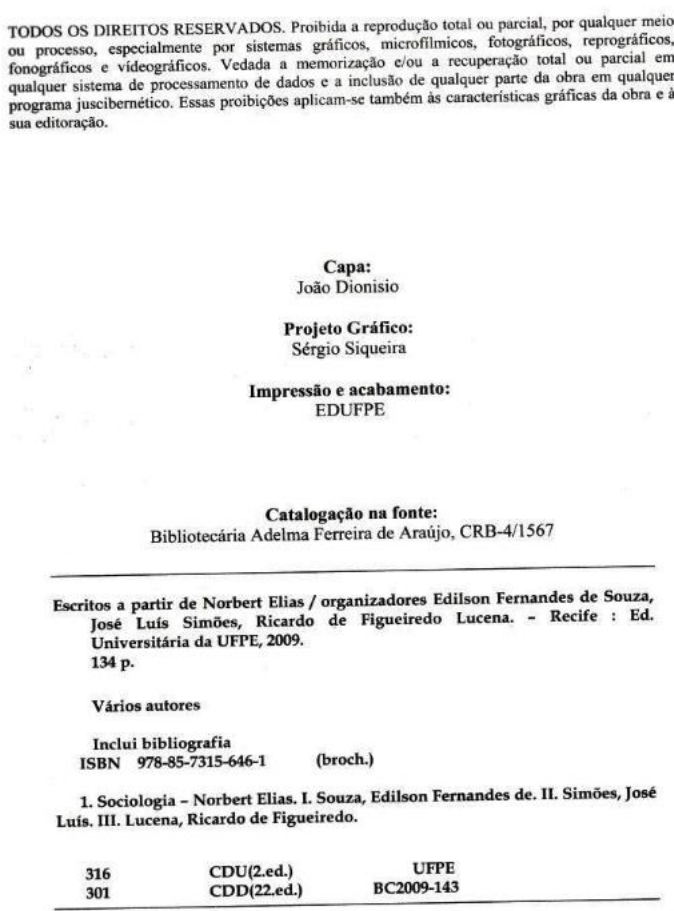

Fonte: Acervo da biblioteca do autor.

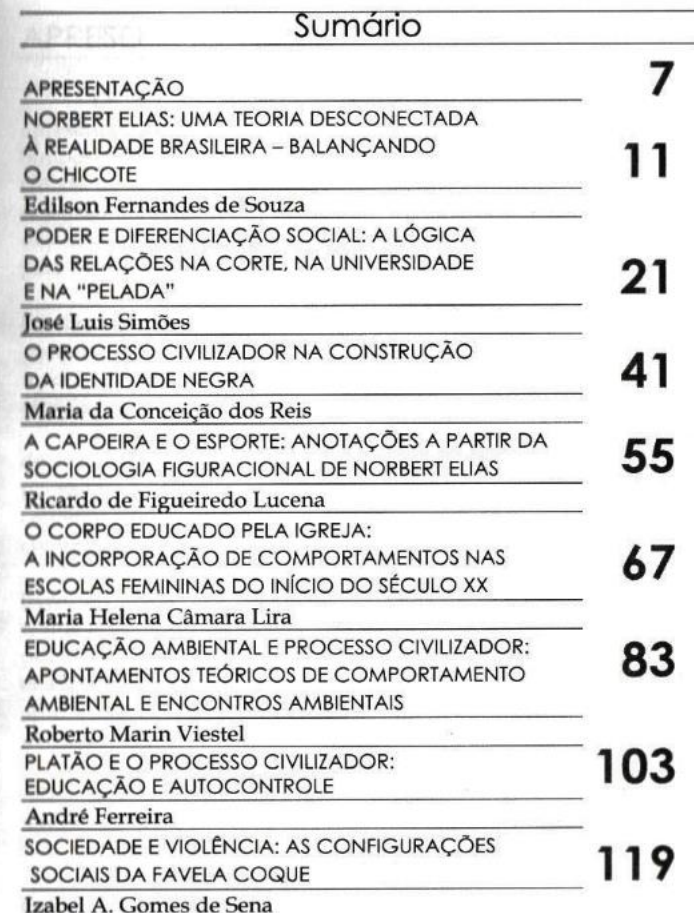

Como pode ser visto, o meu capítulo foi Norbert Elias: uma teoria desconectada à realidade brasileira - balançando o chicote. Nos primeiros parágrafos, o texto fala dos procedimentos científicos e da maneira como uma teoria deve ser tratada, porque só ganha força epistemológica no esforço que o pesquisador faz no momento em que constrói seu objeto de estudo, dando vida à teoria, movimentando-a no campo interpretativo (Souza, 2009c).

Inicialmente, antes de entrar no objeto central da narrativa, pensei em fazer uma discussão mais geral sobre ciência e os procedimentos metodológicos a partir do pensamento eliasiano, ou seja, uma crítica às edições do evento e aos autores ali presentes, uma espécie de 'lavagem de roupa suja' com elegância, onde faria uma crítica aos críticos e leitores assíduos de Elias. 
Figura 46 -

1ํㅡㄴ capítulo, Escritos a partir de Norbert Elias, 2009.

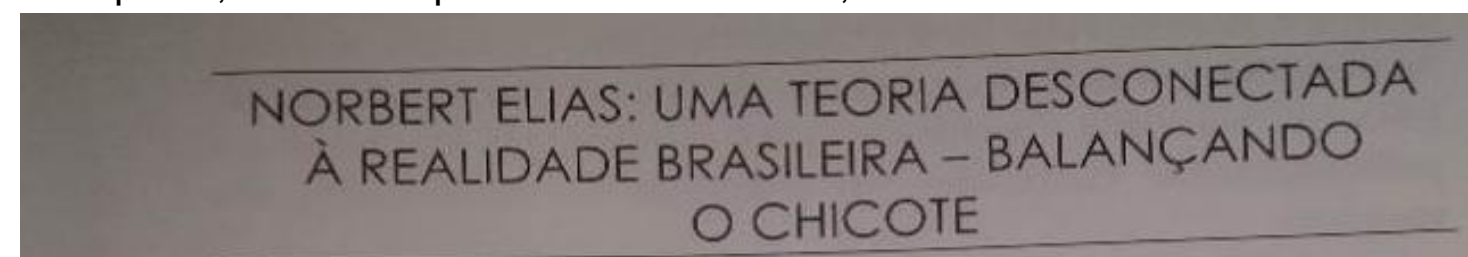

Prof. Dr. Edilson Fernandes de Souza

Universidade Federal de Pernambuco

Programa de Pós-Graduação em Educação

Núcleo de Teoria e História

\section{INTRODUÇÃO}

A ciência é constituida por uma série de procedimentos metódicos, e na perspectiva de compreender a realidade 0 pesquisador formula explicaçōes, ainda que provisorias, reafirmando o seu marco teórico a partir de sua descoberta ou de outros membros da comunidade científica.

Assim sendo, toda teoria é, por força própria, parte da inércia da construção e constituição de um objeto de pesquisa, cabendo, portanto, ao investigador, em seu esforço intelectual, dar vida à teoria e, sobretudo, movimentá-la no campo interpretativo.

Com efeito, podemos acessar uma teoria, pelo menos, de três modos, sendo: primeiro a partir do estudo flutuante em que o pesquisador busca o envolvimento na complexidade das obras publicadas de um determinado autor; o segundo a partir da dissecação dos conceitos ou categorias analíticas apresentadas pela teoria; e o terceiro na aplicaçâo da teoria, pondo-a em movimento interpretativo na elucidação de determinado problema, o que pode gerar conhecimento novo; original.

Considerando essas assertivas, este ensaio tem por objetivo discorrer sobre a tensão gerada no interior das produções acadêmicas no Brasil, especialmente dos artigos publicados nos anais dos Simpósios dos Processos Civilizadores e a estrutura dos

Fonte: acervo da biblioteca do autor.

O balançando o chicote, como ficou conhecido o texto, é na verdade uma crítica ao Simpósio Internacional de Processos Civilizadores e também às produções apresentadas durante algumas edições desse evento, que vi nascer em 1996, na Unicamp. 
Entre outras coisas, o texto chama a atenção para a ausência de pesquisa empírica, bem como a elaboração mais consistente da teoria eliasiana, sobretudo, a tentativa inócua de ler esse autor a partir da lente de autores já consagrados na Sociologia no Brasil.

Outros aspectos da crítica dizem respeito à necessidade que os pesquisadores brasileiros têm em ler rapidamente a obra de Elias, para citar em seus trabalhos como se fosse uma grande novidade. Por isso, tento expor a ponta do iceberg no chicote que movimento nas costas dos pesquisadores inadvertidos. Inclusive, na ocasião do evento, tentei falar mais baixo, para ser ouvido com mais atenção. Assim, construí na chicotada, frases como esta:

Em doze anos desse simpósio, com raríssima exceção, percebemos que há mais publicidade e pouco ou nenhuma pesquisa original em torno da teoria elisiana. Numa frase muito conhecida entre nós, brasileiros, estamos mais tocando o tambor "para inglês ver" do que apresentando resultados de pesquisas originais. (Souza, 2009c, p.17)

É evidente que essa frase lida logo na abertura do evento, causou um desconforto geral, e ainda tem sido, quando a edição do Simpósio no Recife é lembrada. Ao mesmo tempo em que esse capítulo rendeu o projeto de pós-doutorado, também contribuiu para meu afastamento por seis anos das edições do evento. $E$ isso eu conto na introdução do livro Ensaios da civilização no samba, por meio do qual consegui me reconciliar com o grupo de Processos Civilizadores, onde continuo como um dos colaboradores.

Fato é que a crítica só foi possível pelo envolvimento que tenho no campo e nesse grupo de pesquisadores e porque conheço os autores objeto da crítica e o autor de referência. Assim, o campo de produção também emite mensagem para o desequilíbrio das forças que atuam na disputa pelo seu controle. Acontece que, em posse do conhecimento que dispunha da teoria e, inclusive, das fraquezas dos agentes, foi possível tecer o chicote e soltá-lo numa determinada direção. Com essa atitude, também acabei me transformando numa autoridade, apesar de já ter sido o primeiro a defender uma tese com teoria de Elias, entre os seis doutorandos da Faculdade de Educação Física da Unicamp, entre os anos 1996 e 2000.

Nesse contexto, ainda embalados pelo pensamento eliasiano, eu e o professor José Luís Simões organizamos, em 2010, mais um livro, intitulado Escritos a partir de Norbert Elias, volume II. ${ }^{32}$ Além da participação de autores de nosso convívio acadêmico, tivemos a participação de dois pesquisadores internacionais, Françoi Dépelteau e Jason Hughes. A organização desse livro foi relativamente mais fácil do que o anterior, afinal já havíamos criado a tensão necessária ao campo, com o primeiro volume e o chicote. A nossa única preocupação foi em virtude dos autores estrangeiros, com relação à tradução de seus textos e o tempo planejado e determinado pela editora para a publicação.

Ao olhar para a capa desse segundo volume, sempre me vem à mente uma espécie de terra vermelha sobre a qual se arrasta um lagarto ou o pedaço do corpo de uma cobra partindo para o ataque, do lado inferior esquerdo. Mais acima, no lado superior direito, um pedaço do rabo do lagarto. Não sei o porquê, mas não consigo ver elos perdidos nesse

\footnotetext{
32 Para efeito de identificação na Biblioteca Nacional: ISBN 978-85-7315-732-1. 1. Sociologia. I. Souza, Edilson Fernandes de (Org.). II. Simões, José Luís (Org.).
} 
design, embora reconheça que a estética avermelhada chama bastante a atenção do leitor. Aliás, "livro se vende pela capa", frase comum de editores e designers, ou seja, de quem confecciona e comercializa esse tipo de produto.

Figura 47 -

Capa, Escritos a partir de Norbert Elias, volume 2, 2010.

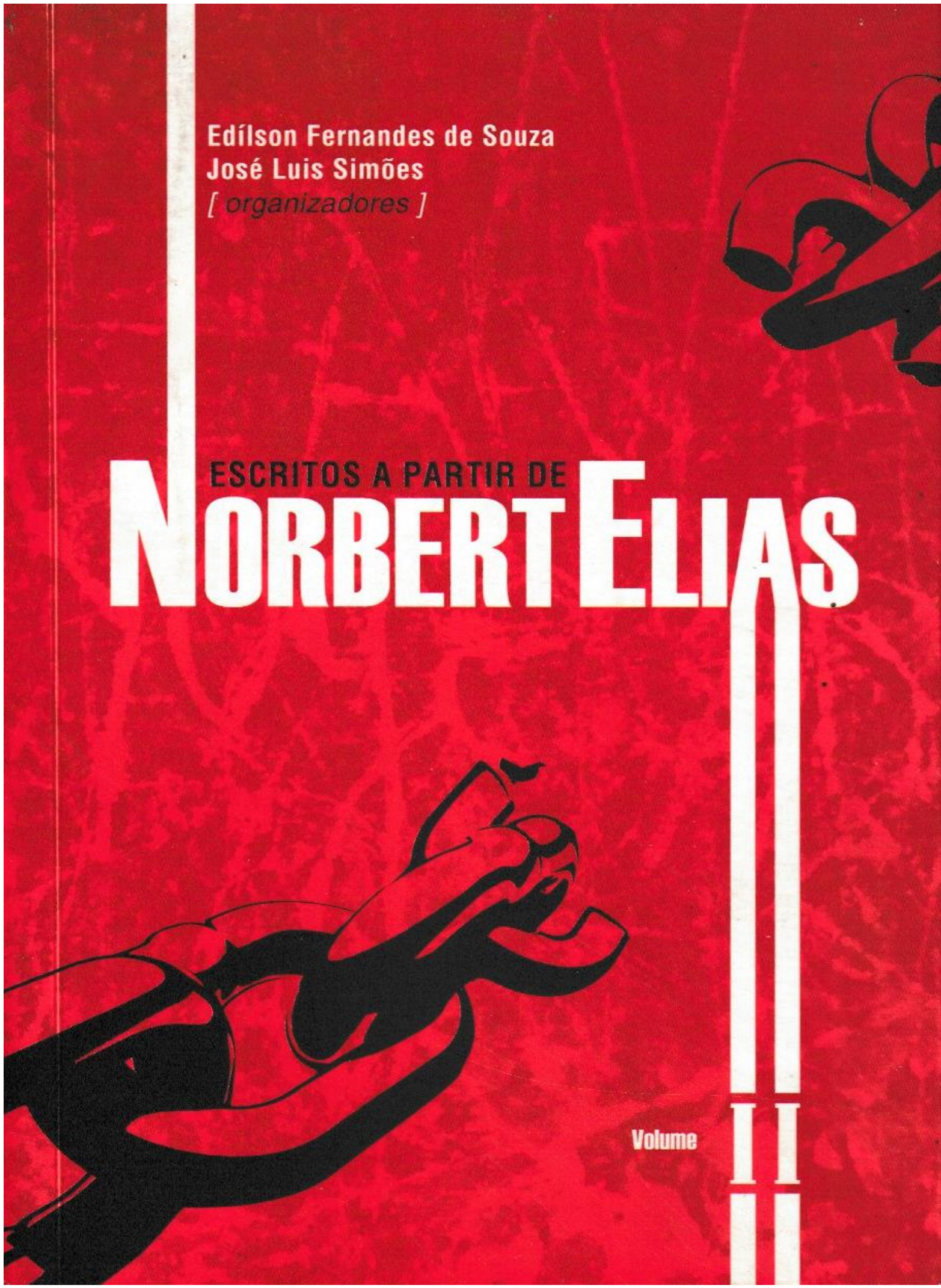

Fonte: acervo da biblioteca do autor. 
Além da organização da obra escrevi dois capítulos com José Luís. Como se sabe, sempre há dificuldades em escrever junto com alguém que possui outros objetos e problemas em mente. O lado positivo disso é que pode ser organizado de tal forma que um ofereça a base do texto e o outro faça os devidos complementos teóricos, como foi o nosso caso. Penso que o resultado ficou bom, o primeiro texto foi As mudanças das regras nos esportes e o segundo intitulamos de Mozart e seu habitus maníaco-depressivo em Viena: uma análise sócio-educacional da depressão. Os dois capítulos são muito instigantes; o primeiro, inicia com a crítica feita por Dunning (1992) aos sociólogos, que não têm dado a devida atenção ao esporte enquanto objeto de investigação científica nesta área do conhecimento.

Diga-se de passagem que esse objeto, quando devidamente investigado, tem demonstrado grande importância para a compreensão dos processos sociais em curso, especialmente no nível de controle e autocontrole atingido pelos indivíduos em determinadas sociedades. Assim, a partir de uma reflexão sócio-histórica, o artigo trata da disputa em jogos esportivos, sobretudo, o desenvolvimento das regras, enquanto estratégia de controle da violência e preservação do poder de um adversário em relação a outro.

Nesse contexto, para manter um certo equilíbrio da contenda, um elemento importante a ser pensado no jogo é a participação da arbitragem que, de posse do regulamento e enquanto representante legítimo das federações e confederações, controla o tempo, a movimentação dos jogadores individual e coletivamente e ainda observa 0 cumprimento das regras nas limitações estabelecidas nos traçados, o que denota um alto nível de organização para eliminar ou diminuir a agressividade entre os participantes.

Não obstante essa rápida compreensão do jogo, o texto traz o argumento de que o desenvolvimento dessas regras, em última instância, acompanha a mudança na estrutura da própria sociedade e o nível de autocontrole atingido pelos indivíduos no processo social a longo prazo. A narrativa traz alguns exemplos de atividades com bola e o nível de agressividade aceito em períodos pretéritos da história da humanidade, como knapan, precursor do futebol, praticado entre os séculos 16 e 19.

Como se pode perceber, não há originalidade nesse tipo de abordagem, mas o dado concreto é pensar o esporte na perspectiva eliasiana e dar continuidade a um pensamento sociológico a partir de marcos conceituais a serem publicados com o olhar de pesquisadores brasileiros e, assim, construir elos acadêmicos no sentido de fazer as possíveis conexões entre a teoria e os dados empíricos. Talvez, tenha sido por isso o desenho da capa.

O segundo capítulo, intitulado de Mozart e seu habitus maníaco-depressivo em Viena: uma análise sócio-educacional da depressão, é um texto recuperado dos anais do Simpósio Internacional de Processos Civilizadores, edição Buenos Aires, em 2008. O texto é uma tentativa de releitura de algumas ideias do livro Mozart: sociologia de um gênio (Elias, 1995). Na releitura o foco se concentra nos aspectos educacionais do gênio da música, especialmente o controle exercido pelo seu pai na transmissão da cultura musical predominante na sociedade aristocrática de corte e nas tournées exigidas à família Mozart em função de sua sobrevivência. Assim, para melhor compreender um pouco do enredo desse capítulo, segue o excerto: 
Desde a mais tenra idade, Mozart foi sócio-educado num ambiente musical para figurar como um dos artistas da corte e ajudar a subsistência da família através das habilidades que dispunha junto às partituras e a interpretação dos mais diferentes temas exigidos pelos membros do grupo establishment. (Souza; Simões, 2010, p. 163)

Nessa perspectiva, a releitura chama atenção para uma possibilidade, embora remota, de que a depressão é socializada a partir de treinamentos excessivos, nesse caso específico, o treinamento musical. Ao lado desse treinamento, estão as exigências sociais impostas aos músicos, que só podiam, na época de Mozart, estar atrelados a uma corte, sem a possibilidade de autonomia do seu gozo estético.

Mesmo sem sucesso, o jovem artista lutou para sublimar seus impulsos criativos e dar significado ao que fazia aos outros, notadamente, membros da corte. Então, "A peculiar forma de sublimar seus impulsos por meio da música não mais correspondia com a educação tradicional que havia recebido de seu pai” (Souza; Simões, 2010, p. 166). Assim, o gênio da música caminhou para a morte social, despedindo-se do afeto e da vida.

Não obstante a agradável releitura em parceria sobre Mozart e as obras até aqui apresentadas, uma das mais importantes publicações teórico-empíricas foi a que consegui realizar pelo Laboratório de Sociologia do Esporte UFPE/CNPq, com dois exestudantes de graduação e orientandos de mestrado e doutorado, Haroldo Moraes de Figueiredo e Márcio Eustáquio Lopes Cavalcante (in memorian). Trata-se do livro Violência e lazer nos bairros do lbura e Nova Descoberta, ${ }^{33}$ texto oriundo de um projeto de iniciação científica em 2001.

A publicação saiu bastante tardia, embora o assunto fosse e ainda seja contemporâneo e atual quando consideramos os aspectos históricos da violência no Brasil que tem como vítima a maioria da população de jovens negros residentes nas periferias das capitais. O projeto original era para ser desenvolvido a partir da metodologia da pesquisa-ação; para isso, teríamos que ir aos bairros considerados mais violentos e estabelecer um observatório por alguns meses, para acompanhar a movimentação dos jovens da localidade e mapear a infraestrutura esportiva e de lazer, entre outros objetivos.

O recorte teórico é versado em Norbert Elias, sobretudo, os aspectos que envolvem as sociedades segmentares e funcionais; mobilidade e controle social da violência; e o desenvolvimento do autocontrole como um traço importante do processo civilizador. Um dos tópicos que abordamos no livro diz respeito à instituição da violência brasileira enquanto dado histórico da nossa formação social, principalmente o processo escravocrata em que fomos submetidos por mais de 300 anos:

\footnotetext{
33 Para efeito de identificação na Biblioteca Nacional: ISBN 978-85-415-0049-4. 1.Violência - Recife (PE). 2. Violência na comunicação de massa. 3. Lazer. 4. Ibura (Recife, PE). 4. Nova Descoberta (Recife, PE). I Figueiredo, Haroldo Moraes de. II. Cavalcante, Márcio Eustáquio Lopes. III. Título.
} 
Como eliminar um comportamento violento se tal impulso constituiu a mola-mestra da nossa personalidade social, em face do tipo patriarcal e sua forma depressiva de dominar indivíduos e grupos, considerados, pelo seu olhar, como bárbaros, a exemplo das comunidades indígenas e os diferentes grupamentos étnicos provindos do continente africano? (Souza, Figueiredo, Cavalcante, 2012, p. 35)

Como é possível verificar, chamamos a atenção para um problema histórico que acompanha a sociedade brasileira e que tem reflexos até o presente momento, afinal jovens das periferias continuam sendo vitimados e oprimidos pelo Estado. A capa do livro é bastante sugestiva. Na parte de cima, faz-se alusão aos aprisionamentos de jovens negros, algemados, e, logo abaixo, crianças e jovens negros em atividades esportivas e de lazer, divertindo-se em praça pública.

Figura 4813 -

Capa, Violência e Lazer nos bairros do Ibura e Nova Descoberta, 2012.

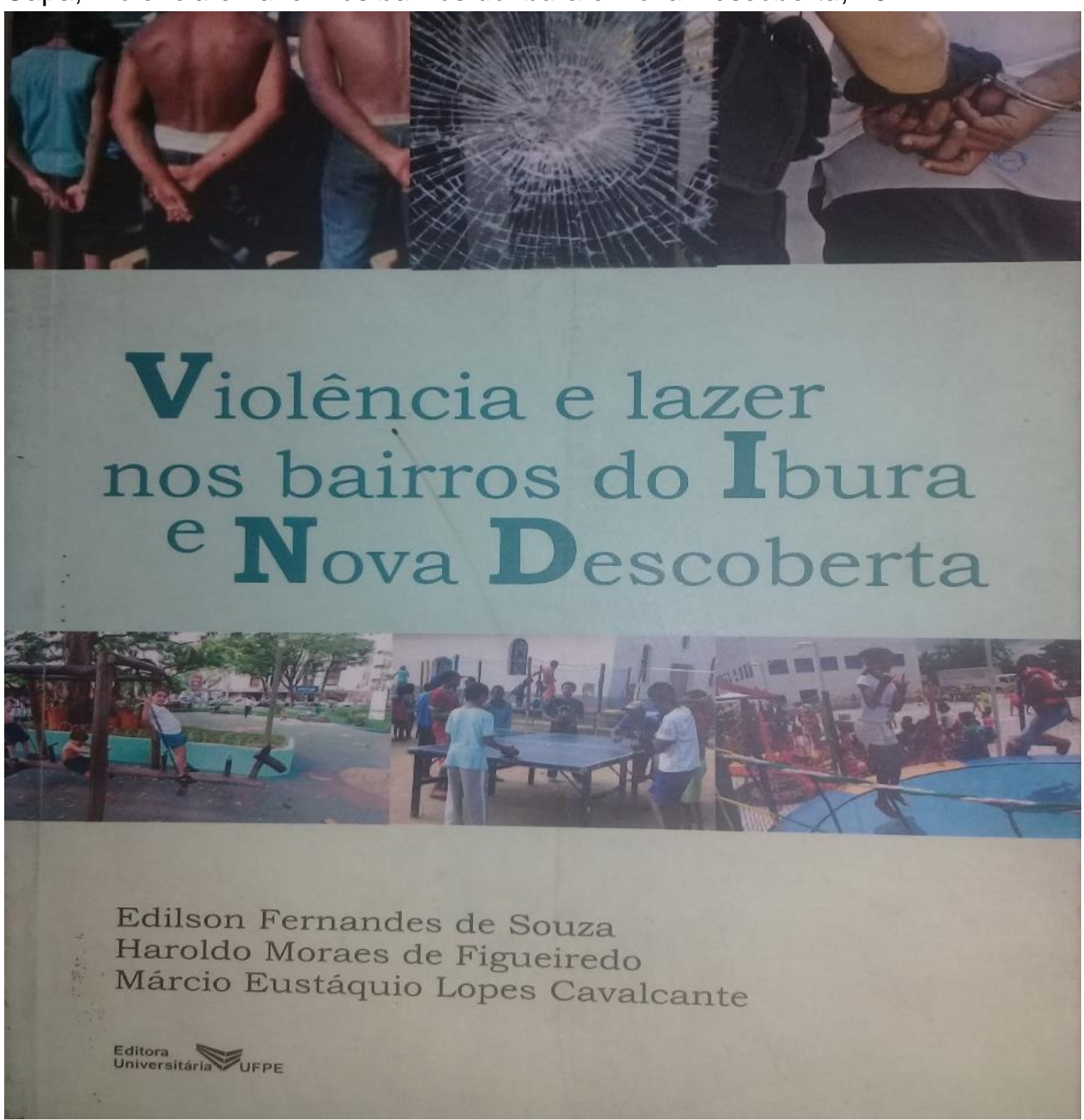

Fonte: acervo da biblioteca do autor. 
O texto mostra uma sequência teórica e argumentativa, além de explicitar a problemática em tela baseada nas reflexões de Norbert Elias. Em seguida, é discutido detalhadamente o modelo empírico, ou a aplicação dos marcos conceituais na realidade que se apresentavam naquele momento, especialmente sobre a violência nos dois bairros da periferia do Recife, que teve ampla repercussão nos meios de comunicação de massa. Assim, até certo ponto, os meios de comunicação também contribuem institucionalmente para a violência contra os jovens, na medida em que as vítimas e seus familiares são estigmatizados por morarem em locais considerados os mais violentos da capital. Esse é um dos aspectos levantados no livro. Mesmo quando os homicídios não ocorrem no local da moradia das vítimas, mas muitas vezes nos bairros mais ricos, como Boa Viagem ou Parnamirim, a metodologia que resulta na contabilidade do Datasus indicava e ainda indica como ocorrência o local de moradia da vítima e não de onde o jovem teve a vida ceifada.

No contexto de coautoria, em 2018, junto com o professor Marcos Nunes, exorientando do doutorado em Educação, publiquei um livro bastante interessante chamado Memória da copa do mundo em Pernambuco: os documentos e o monumento. ${ }^{34} \mathrm{Na}$ verdade foi um convite feito insistentemente pelo Marcos, que, em vários momentos, comentou sobre a possibilidade da publicação, mas eu não dei muita atenção ao projeto. Tanto que a ideia inicial era publicar após o encerramento da Copa do Mundo de 2014, mas, pela minha falta de sensibilidade, o projeto foi finalizado apenas em 2018 , depois de um período de quatro meses de organização.

Como se pode constatar a capa é belíssima e o projeto gráfico bateu todos os recordes da Companhia Editora de Pernambuco, que se empenhou em nos entregar a publicação ainda durante a Copa de 2018. Aliás, quando o texto entrou para ser rodado no parque gráfico, já se tinha a data de lançamento, o que representava, na verdade, um contrato de risco.

Depois que concordei em colaborar com a publicação do livro, discutimos a concepção geral do texto, como seria escrito, inclusive, sua diagramação. Foram duas ou três conversas bastante objetivas sobre os documentos a serem analisados. Em seguida, partimos para os arquivos; na verdade, como o Marcos já conhecia todo o pessoal da Casa Civil do Estado e mantinha boas relações com o Secretário e sua equipe, fiquei com a maior parte no escritório. Escrevi sobre a concepção, formas de entrada no campo e os registros do próprio campo. Esta foi a minha tarefa: escrever quase toda a primeira parte do livro, elaborando e discutindo conceitos da História e da Sociologia.

Em seguida, exponho a capa e um pouco do que discutimos na estrutura narrativa enquanto conteúdo importante para a reflexão da Sociologia e História do Esporte em Pernambuco, sobretudo, os meandros em volta do patrimônio arquitetônico erguido no município de São Lourenço da Mata.

34 Para efeito de identificação na Biblioteca Nacional: ISBN 978-85-7858-645-4. 1. Copa do Mundo (Futebol). 2. Copa do Mundo (Futebol) - Pernambuco. 3. Copa do Mundo (Futebol) PernambucoPlanejamento. 4. Copa do Mundo (Futebol) Pernambuco - Artigos de jornais. 5. Copa do Mundo (Futebol) Pernambuco - Documentos. I. Souza, Edilson Fernandes de. II. Bompastor, Silvio Roberto Caldas. III. Pimentel, Gilberto. IV. Título. 
Figura 49 -

Capa, Memória da copa do mundo em Pernambuco, 2018.

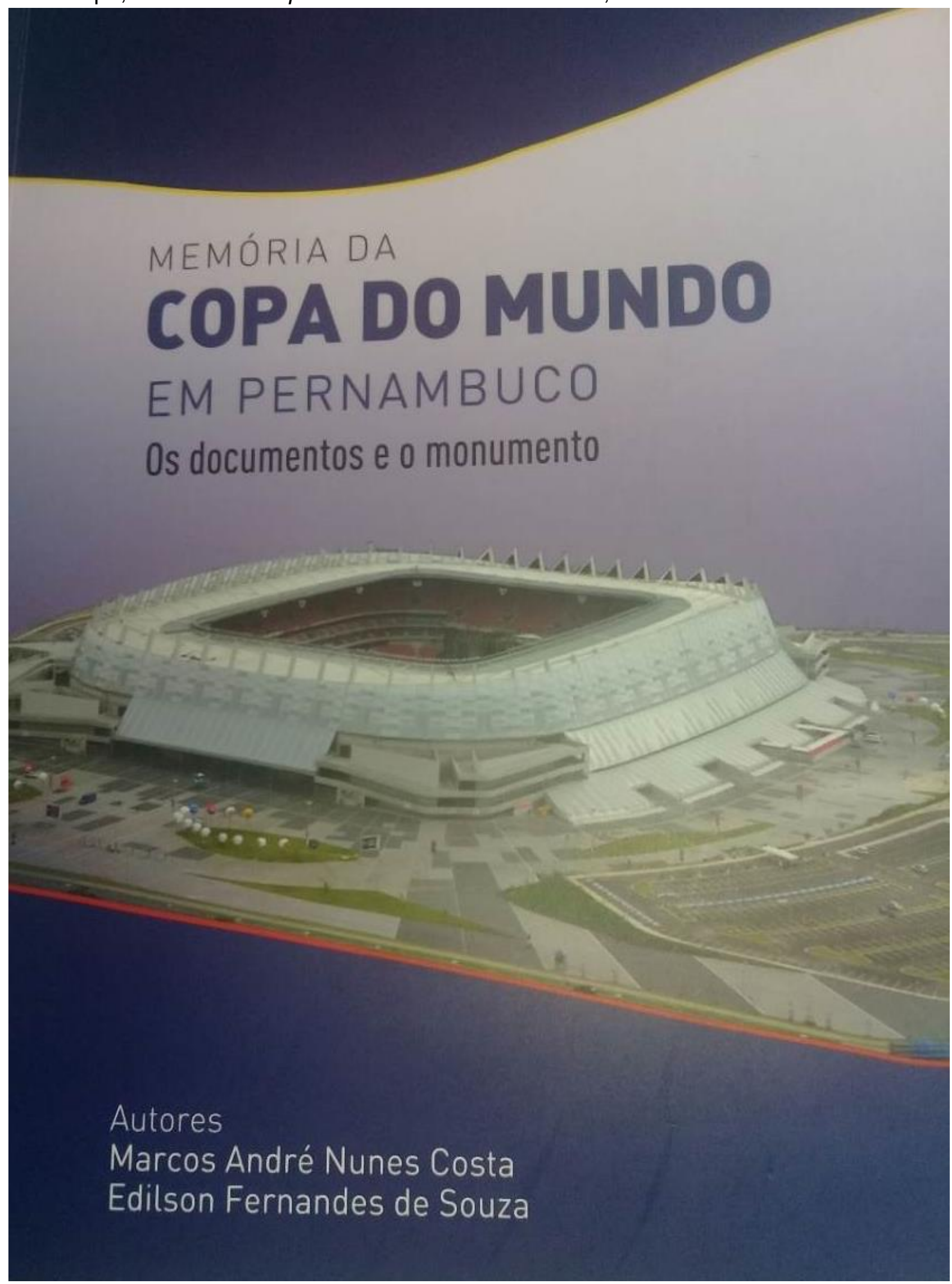

Fonte: acervo da biblioteca do autor. 
O livro fala do empenho e dos investimentos do Governo de Pernambuco ao decidir sediar os jogos da Copa das Confederações e da Copa do Mundo. Trata-se da relação institucional e política com a Fifa e o Governo Federal, bem como o debate travado com os clubes locais - Santa Cruz, Sport e Náutico - e os prefeitos da Região Metropolitana do Recife, que disputavam o apoio para terem a construção do estádio em seus territórios.

No livro chamamos especial atenção aos discursos de agentes públicos, dos detentores dos direitos de realização e transmissão dos jogos e da própria Fifa. O debate é caloroso e a máquina pública pernambucana, por meio do então governador Eduardo Campos, empregou um ritmo acelerado para o cumprimento das metas em função das estratégias de desenvolvimento e atração de empreendimentos estatais. De modo que apresentamos uma farta documentação oficial que circulou sobre o desejo de sediar os jogos de um dos maiores eventos esportivos do mundo:

Há de se considerar que esse campo também permite a aquisição de um considerável capital social por todos os envolvidos, especialmente por parte de uma massa de jogadores oriundos das classes populares, que enxergam no futebol a ascensão social. No caso brasileiro, esses jogadores ainda encontram uma forma de expressão da identidade nacional no jeito de jogar futebol arte, apenas para citar um exemplo. (Nunes; Souza, 2018, p. 14)

Como é perceptível o enredo que desvelamos nessa publicação segue um pouco daquilo que acreditamos ser fundamental para uma análise sociológica. Mesmo diante de uma documentação utilizada como foco da memória, trazemos para a discussão a sociologia de Pierre Bourdieu, cujo instrumento permitiu enxergar a luta travada por diferentes agentes na condução dessa bola em campo, ou seja, seus interesses, necessidades e expectativas.

No enredo também verificamos o debate político entre os agentes que participavam naquele momento, de uma relativa composição ideológica, mesmo campo progressista. No entanto, mesmo nesse compartilhamento e, exatamente por compartilharem desse campo, a luta permaneceu até a conclusão das obras do que chamamos de monumento. Assim, penso que esse livro contribuiu significativamente para a história de Pernambuco no que diz respeito à política pública de esporte e lazer, aos meandros da burocracia que giram em torno das intenções de governantes e beneficiários e à discussão sobre a real necessidade da aplicação do erário em prol de eventos e estruturas de corporações internacionais privadas.

Outra publicação que colaborei na organização foi o livro Tópicos em gerontologia, ${ }^{35}$ com os professores Antônio Carlos Gomes do Espírito Santo e Rafael da Silveira Moreira. A obra é proveniente do Programa de Pós-Graduação em Gerontologia, especialmente dos professores e seus respectivos orientandos. Por se tratar de uma obra coletiva 0 resultado final demorou uns dois anos para se concretizar, sobretudo, por conta do título e da capa, discussão quase interminável via grupo de WhatsApp.

\footnotetext{
${ }^{35}$ Para efeito de identificação na Biblioteca Nacional: ISBN 978-85-444-2111-6. 1. Educação 2. Gerontologia 3. Interdisciplinaridade 4. Saúde 5. Envelhecimento 6. Idosos 7. Velhice 8. Aspectos Biopsicossociais I. Espírito Santo, Antônio Carlos Gomes do. Org. II. Souza, Edilson Fernandes de. Org. III. Moreira, Rafael da Silveira. Org. IV. Título V. Série.
} 
Figura 1450 -

Capa, Tópicos em gerontologia, CRV, 2018.

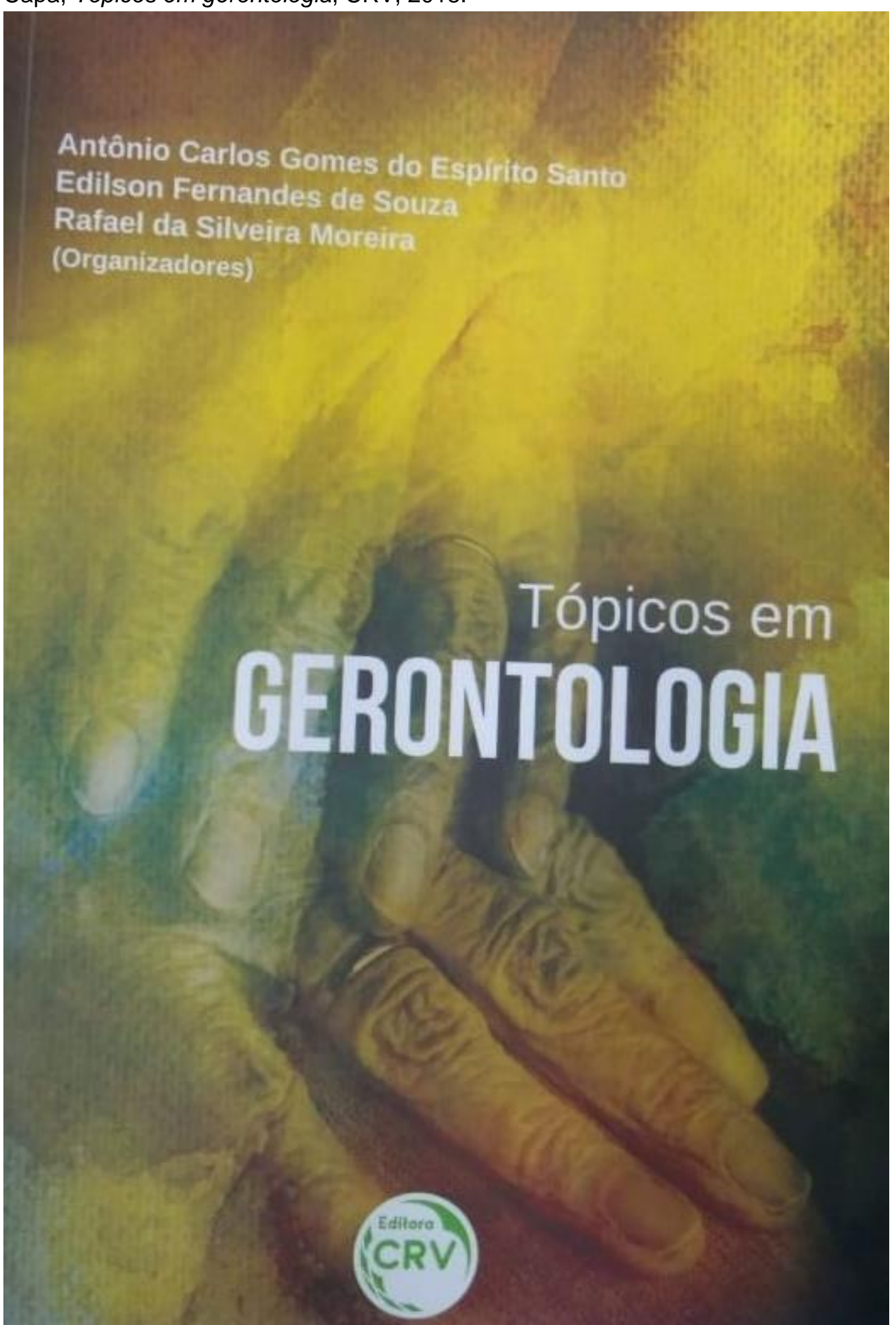

Fonte: acervo do Mestrado em Gerontologia da UFPE. 
Ao mesmo tempo em que colaborava com a organização desse livro, eu escrevia Memórias da copa do mundo em Pernambuco e Ensaios da civilização no samba. O ano de 2018 foi o momento em que foquei na produção de livros e menos nos periódicos, cujo resultado é surpreendente, considerando o campo intelectual das minhas atividades e o processo que estou vivendo das recordações.

Destarte, além da minha participação ativa na organização e seleção dos artigos para o livro do mestrado em Gerontologia, ainda consegui colaborar com dois capítulos, sendo um em parceria com uma orientanda do próprio mestrado, a Laryssa Grazielle Feitosa Lopes, com o título $A$ violência contra a pessoa idosa: entre paradigmas $e$ agravos de notificação; e outro capítulo com a Ana Elisabeth Souza Rocha Carvalho e o José Luís Simões, intitulado Trajetória da educação no Brasil e o Envelhecimento.

Ambos os textos têm como base os aspectos sociológicos e históricos do envelhecimento, as questões demográficas e o impacto da ausência de políticas públicas de educação para esse segmento, especialmente quando parte dos problemas dos idosos têm origem no seio da família, com privações financeiras, violência física e simbólica, acometidos normalmente por parentes próximos, sobretudo, os filhos e as filhas.

Do ponto de vista de pesquisador, uma das preocupações que se deve ter é com a ampliação dos estudos sobre os diferentes assuntos acerca do envelhecimento no Brasil, considerando que atingiremos, em breve, a sexta população mundial de idosos, e isso vai requerer de todos nós, cidadãos, profissionais da saúde e pesquisadores, uma preparação mais condizente com a nossa realidade:

Os grupos de pesquisa localizados na plataforma do CNPq são provenientes de instituições públicas e particulares, e os recortes temáticos também são os mais diversos, ocupam desde as questões de gênero, uso de drogas, populações em situação de risco, inclusão e exclusão, criminologia, políticas públicas, violação de direitos, demografia e, entre outros, geoprocessamento. (Lopes; Souza, 2018, p. 249)

Como pode ser percebido, o texto fez um breve mapeamento dos grupos de pesquisa que têm se ocupado dos estudos sobre o envelhecimento na sociedade brasileira e é muito interessante verificar como as investigações sobre esse tema têm avançado, especialmente, quando há uma relativa mudança de comportamento dos pesquisadores que tentam reclamar a responsabilidade do Estado para investimentos de toda ordem, como no fomento a novas pesquisas, nas políticas públicas educacionais e na infraestrutura, e intervenção mais decisiva nesse setor.

Contudo, confesso que hesitei um pouco em expor minha participação nessa obra porque, a meu ver, o livro difere diametralmente com que venho escrevendo, mas reconheço agora que estava enganado em não falar um pouco de um dos melhores trabalhos coletivos em que participei recentemente, sobretudo, mostrar um pouco a minha inserção institucional a partir dos colegas que compõem o quadro permanente do Colegiado do Mestrado em Gerontologia do Centro de Ciências da Saúde da UFPE, carinhosamente chamado Ppegero. 
De qualquer modo, esse é um dos mais importantes produtos pelo fato de ter sido o primeiro produzido coletivamente entre os professores e estudantes, no primeiro mestrado interdisciplinar em Gerontologia do Norte e Nordeste. Por ser da área interdisciplinar na Capes, os capítulos que colaborei ganham força e sentido no conjunto dessa publicação, pelo menos é como vejo no momento.

Por fim, embalado pela colaboração em livros, em 2019, publiquei um capítulo numa obra financiada pela Associação dos Docentes da UFPE em que tentei expor um pouco o meu pensamento acerca das instituições de ensino superior em nosso país. Por ser um ano de eleição para reitor na UFPE, o texto foi escrito com o objetivo de chamar a atenção da comunidade acadêmica para o projeto que eu pretendia apresentar como candidato naquela ocasião.

Como de costume investi algum tempo na elaboração das ideias centrais que pretendia defender, especialmente os eixos estruturantes e as ações estratégicas necessárias para uma das mais importantes instituições do Norte e Nordeste. Por isso, o capítulo recebeu o seguinte título: Quais desafios resguardam o projeto de universidade que atenda a sociedade brasileira?

Não vou discorrer sobre o texto, até porque espero que o leitor acesse o e-book ${ }^{36} \mathrm{e}$ tire suas próprias conclusões, mas iniciei meus argumentos falando sobre a minha experiência como gestor à frente da Pró-Reitoria de Extensão da UFPE, entre 2011 e 2014 e tentei mostrar um pouco do meu engajamento, compromisso social e conhecimento de história. Segue o excerto:

Quando considerado o cenário político brasileiro, a ideia de Projeto de Universidade tende a aparecer como desafios e perspectivas em resposta às demandas $e$ interesses de diferentes grupos sociais, 0 que naturalmente reverbera no esforço que devemos fazer para responder às crises econômicas e políticas, aos possíveis modelos de financiamento e a governança dessa instituição complexa, símbolo de cultura e civilidade. (Souza, 2019a, p. 193)

Uma vez levantadas essas reflexões, o texto segue falando do processo de federalização das universidades brasileiras, da autonomia reivindicada historicamente pelo movimento docente, estudantil e técnico-administrativo, do modelo de financiamento necessário e possível para essas instituições, bem como a necessidade de se ter uma produção de conhecimento enquanto conquistas sociais. Nessa linha de argumentação, chamei a atenção para a nossa composição étnico-racial, sobretudo, as comunidades indígenas pernambucanas e a população afrodescendente.

Mesmo com tom acadêmico e com uma razoável referência bibliográfica, tentei fazer um apelo para o futuro projeto que iria apresentar nas eleições. Inclusive, mostrei um breve estudo sobre a inovação preceituada no Manual de Oslo. No entanto, hoje vejo que o texto é bastante denso nos argumentos mas, infelizmente, o objetivo central de sua

36 PORTO, Zélia Granja, et. al (orgs.). II Congresso UFPE em Debate; Universidade de ideias e ideias de
$\begin{array}{ccc}\text { universidade. } & \text { Disponível }\end{array}$ iSOjPYSCGBkjQkXjkUm/view. 
confecção não teve impacto e não logrou êxito na política. É o que analisarei na penúltima parte desta tese, como um dos elementos fundamentais da trama que subjaz várias instituições acadêmicas.

Neste capítulo, tentei mostrar um pouco da minha produção científica, particularmente a maneira como enxergo o que foi possível produzir até o presente momento num esforço para me inserir num campo da intelectualidade. Já no próximo capítulo, analisarei a maneira como me vejo dentro do próprio campo acadêmico e a maneira como outros agentes desse campo me enxergam, na controversa trama institucional entre os habitus e seus detentores.

\section{Capítulo 6 - Habitus negro em território branco}

Sou negro, contam que os meus avós vieram de Luanda como mercadoria de baixo preço. O meu avô brigou como um danado nas terras de Zumbi, na capoeira e na faca escreveu não leu o pau comeu. Ele não foi nenhum pai João humilde e manso. Mesmo vovó, vovó não foi de brincadeira, na guerra dos Malês ela se destacou, e na minha alma ficou o samba, o bamboleio, o batuque, a capoeira, o ataque e o desejo de libertação. (Trindade, 2011)

Sou negro, sinto-me como uma ave rara em extinção. Eu devo ser poupado para que no futuro a minha história não morra. Eu tenho ido em casa em sonhos, tenho sentido a negritude bem perto, mas o pior é quando eu acordo que estou nessa terra que não me recebeu de coração aberto. E eu adoro ser negro! A cor negra não representa as trevas, não. Representa a noite, a liberdade, e a juventude deste país. (Pichilinga, $1983)^{37}$

Este capítulo tem por objetivo analisar alguns aspectos relacionados à minha autoimagem, assim como a representação que causo em outros indivíduos nas minhas relações interpessoais, sejam os mais próximos, sejam os mais distantes. Por isso, inicio este momento com esses dois poemas de autores que produziram seus textos em espaços e tempos diferentes para dizer que essas são as falas que me tornam mais forte nos momentos difíceis e delicados de minha trajetória.

Muitas vezes apenas sussurro esses poemas, em outras falo publicamente no final de uma palestra, conferência ou aula em que o tema pede essa interlocução. Também os interpreto para mostrar um pouco da minha veia artística, do meu habitus desse campo, da minha "gênese social dos esquemas de percepção, pensamento e ação" (Bourdieu, 2004, p. 149) que continua pulsando desde o Recife, quando dançava e falava esses e outros poemas nas apresentações do Balé Primitivo de Arte Negra de Pernambuco, no Teatro Santa Isabel, nos idos de 1980 a 1985.

\footnotetext{
37 Poema de Élcio, o Pichilinga, um dos integrantes do Balé Primitivo de Arte Negra de Pernambuco. Certa vez, num dos nossos ensaios, no Teatro Maria Della Costa, em São Paulo, ele deixou escapar que escreveu esse poema inspirado em Solano Trindade, em continuidade ao Sou negro, desse clássico da literatura afro-brasileira. Aliás, penso que esse poema de Pichilinga, na verdade, é a união de dois outros de seus próprios escritos: Romantismo e pelourinho e Encontro com Zumbi. Informação também compartilhada pelo professor Lepê Correia que possui, inclusive, um dos últimos exemplares do livro de Pichilinga.
} 
Foi nos ensaios do referido grupo de dança que os aprendi, ouvindo o mestre de capoeira Zumbi Bahia, por isso peço licença aos poetas por dar essa versão a seus escritos, mas o sentido original, provavelmente, permanece em essência. Quando falo esses poemas, sinto um calor enorme vindo de dentro do meu peito, da minha alma. $E$ isso me dá muito entusiasmo para continuar na luta, em defesa do que acredito na minha relação de alteridade e em defesa da minha vida.

Sobre a minha participação nesse grupo artístico, concedi entrevista ao projeto Ritmos, Cores e Gestos da Negritude Pernambucana, ${ }^{38}$ coordenado pelos professores Isabel Guillen e Ivaldo Marciano, em 2009. Além do meu depoimento, que durou em torno de duas horas, constam em suporte on-line 51 registros fotográficos dos espetáculos apresentados na década de 1980. Realmente, é muito bonito de se ver e trazer à memória um tempo fundamental para minha formação humana e profissional, é algo que me proporcionou muita satisfação.

É óbvio que trago esses poemas, na introdução deste capítulo e em outros momentos, para reafirmar a minha condição irrefutável de ser negro, de um autoencontro com a identidade afrodescendente na superação de muitas dificuldades, mas também o encontro com a minha própria trajetória como faço neste momento. Isso para deixar evidente que artista e cientista têm muitas coisas em comum, especialmente o senso crítico e criativo, entre outros atributos, que revelam a personalidade e o habitus desses profissionais na construção e reconstrução de sua principal obra: a vida.

O habitus, como indica a palavra, é um conhecimento adquirido e também um haver, um capital (de um sujeito transcendental na tradição idealista) o habitus, a hexis, indica a disposição incorporada, quase postural - mas sim de um agente em acção [...] o lado activo do conhecimento prático. (Bourdieu, 1989, p. 61)

Para Bourdieu (2011), a noção de habitus é fundamental para a compreensão da nossa história, justamente porque a história se inscreve no nosso corpo. Assim, as disposições exteriores são internalizadas a partir das condições objetivas da existência. De modo que os valores morais e os nossos princípios estão representados no ethos e a nossa corporeidade, nossa postura e técnicas corporais na hexis. Esses componentes são estruturantes e estruturados a partir da classe em que o indivíduo está inserido, não sendo apenas uma questão de relação de poder e produção dessa classe, mas uma questão fundamentalmente do habitus representativo da própria classe em movimento.

Nesse contexto o principal interesse dos professores Isabel Guillen e Ivaldo Marciano era o de compreender as lembranças e representações da minha passagem pelo Balé Primitivo de Arte Negra de Pernambuco, pelo campo artístico, especialmente o ambiente em que estava forjado a movimentação da negritude pernambucana, e de que maneira eu me inseria naquele contexto, em 1980-1985. A esse respeito, pude colaborar com uma visão bastante técnica e saudosista sobre os espetáculos que mais marcaram a minha vida profissional no campo da dança. Momentos fundamentais de aprendizado e tentativa de retorno às origens afro.

\footnotetext{
${ }^{38}$ A entrevista na íntegra pode ser encontrada no Laboratório de História Oral e da Imagem da UFPE ou no endereço https://www.3.ufpe.br/negritude/.
} 
Ah, o Corte Real de Zumbi eu acho que me marcou mais, porque eu era o mais atuante no espetáculo. Eu dançava uma hora e meia do espetáculo. Saía, mudava a roupa, saía por uma coxia, entrava por outra com outra roupa, já saía de novo. Aí entrava e fazia um solo, tinha um fôlego, uma coisa [certamente que me impulsionava]. (Souza, 2009b)

Atualmente, interpreto esse impulso como sublimado pelas condicionantes de um outro habitus social, que tende a se expressar no campo acadêmico-institucional, mas, naquela ocasião, entre 1980 e 1985, havia de fato uma tentativa de demonstração de força herdada da ancestralidade, cuja dança era mantida pela tensão agradável alcançada por meio dos ritmos dos atabaques e toadas, símbolos do panteão africano no Brasil. Numa linguagem eliasiana, poderíamos dizer que era uma atividade mimética representando a África. Uma África imaginária, sentida no corpo.

Naquela época, como também agora, esse era o meu entendimento enquanto jovem ansioso por um reconhecimento social, pela profissionalização artística. "Às vezes, eu tinha vertigem quando dançava, porque eu não tomava café, não almoçava. la para o grupo cedo. la cedo, saía tarde. Eu tinha um pique muito grande. Então o Corte Real de Zumbi foi o que eu mais dancei" (Souza, 2009b). E, de fato, foi uma grande experiência artística e que eu trago para o campo acadêmico.

Durante muito tempo, eu não tinha a noção de onde poderia chegar com o trabalho que desenvolvia com a dança, principalmente enquanto estava no Balé Primitivo de Arte Negra de Pernambuco. Penso que meus pais, pelo menos a minha mãe, tinha uma preocupação acerca do meu futuro com a dança, se eu dançaria para ganhar dinheiro. Qual seria a minha profissão. Ela sempre me dizia para arrumar um emprego com carteira assinada. Pois era o que se esperava dos garotos da minha idade.

No entanto, meu pai tinha outra visão sobre o meu futuro, ele era mais otimista com a arte que eu fazia. Relembro agora enquanto leio as transcrições da entrevista que meu pai me disse que "esse negócio... isso que você faz, não vai dar certo aqui [no Recife], isso vai dar certo em outro lugar, no Rio de Janeiro" (Souza, 2009b). Ele realmente tinha razão, afinal, quando cheguei ao Rio de Janeiro, minha vida mudou em todos os aspectos.

De fato, seria a antiga capital da República e o antigo Estado da Guanabara o lugar em que tudo daria certo, conforme meu pai havia me dito. Na ocasião eu pensava que ele queria se livrar de mim, mas agora reconheço que ele tinha razão. As oportunidades para mostrar algo diferente à sociedade carioca, talvez o tenham despertado para proferir aquelas sábias palavras. De qualquer modo, era um território dominado por brancos, ainda que a vida cultural durante muito tempo tivesse aflorado por lá. Talvez, a fala de papai tenha sido em virtude de seu conhecimento sobre os movimentos artísticos que ocorriam no sudeste do país. O fato é que ele sempre lia os jornais de domingo e ficava sabendo das novidades do Brasil.

Por outro lado, penso também que papai sempre foi antenado com as questões que envolviam a arte e a dança. Em várias ocasiões, encontrava-o dançando com a minha mãe. Inclusive, ela contava que ele, quando mais moço, andava pelas gafieiras, pelas matinês. Outra lembrança que me vem à mente é que foi ele quem me falou pela primeira vez o que era um atabaque. Eu deveria estar na pré-adolescência quando ele me mostrou num programa de televisão, acho que foi no Chacrinha. 
O Chacrinha era um comunicador popular que animava as tardes de sábado e domingos na televisão. Ele trabalhou em várias emissoras, sempre com programa de auditório e um quadro de calouros. Às vezes lançava e recebia artistas famosos. Certo dia recebeu em seu programa Chico Evangelista e Jorge Alfredo que, com instrumentos de percussão, cantaram uma música que dizia: "rasta pé é moçada, rasta pé é moçada, e no passo dessa dança". Então papai disse: "Caboquinho, [era assim que me chamava às vezes] esse instrumento que eles estão tocando e que faz esse ritmo é um atabaque".

Contudo, considerando a experiência dos pesquisadores Isabel Guillen e Ivaldo Marciano e a percepção que eles detinham sobre a minha capacidade em responder as questões, a entrevista foi bastante ampliada com perguntas de ordem pessoal, familiar, também havia perguntas que envolviam a educação e a profissão dos meus pais e irmãos e as discussões políticas dentro da instituição universitária.

Uma das questões abordadas na entrevista diz respeito à minha percepção sobre a universidade e as relações étnico-raciais, por exemplo. Naquela ocasião, em 2009, como também agora, o posicionamento permanece o mesmo, vejo que há um entrave institucional que parece impedir essa discussão, uma espécie de barreira invisível, que me coloca muitas vezes numa situação bastante crítica diante de alguns colegas, por não denunciar as práticas conservadoras e racistas na instituição.

Por outro lado, também não sou derrotista nem quero mostrar fragilidades ou pieguices para chamar a atenção de que, por ser negro, estou sempre em desvantagens, um coitadinho pedindo reconhecimento acadêmico. Isso porque, no fundo, me sinto mesmo privilegiado por ter conseguido ascender socialmente pelos meus próprios esforços e com a colaboração de alguns, por ter encontrado e aproveitado as oportunidades, as brechas deixadas por esta sociedade preconceituosa e racista. De qualquer maneira, tenho minha própria percepção sobre as instituições universitárias:

Essa universidade, eu vi, não quer discutir certas questões étnicas e raciais, não quer identificar as pessoas, profissionais que trabalham com isso. Algumas pessoas sabem que eu escrevi uma tese de doutorado que trata disso, meu mestrado trata disso, mas não chamam para me ouvir, ouvir minha opinião sobre determinadas coisas. (Souza, 2009b)

No fundo, mesmo sendo sustentadas pela sociedade brasileira, as universidades não são territórios para afrodescendentes, não são construídas para os povos indígenas. Essa relação só mudou tardiamente, a partir de 2012, com a lei n. 12.711/2012, que garante a reserva de $50 \%$ das matrículas por curso e turno a estudantes oriundos das escolas públicas e também a pretos, pardos e indígenas.

Aqui, [na UFPE] apesar de ser mais conservadora, você se sente mais em casa. Em Uberlândia, eu me sentia mais fora do ninho, porque, lá no meu Departamento, era só eu de negro, eu e mais um. Eu falava sobre essas questões e ele não falava sobre absolutamente nada. A maioria dos alunos e dos professores, todos brancos. E os técnicos administrativos, brancos, e os zeladores, negros. (Souza, 2009b)

De qualquer modo a minha percepção é que, na Universidade Federal de Uberlândia, a tensão era maior por alguns motivos. O primeiro pela clivagem socioeconômica que originou a instituição e que, de alguma maneira, ainda a sustenta 
enquanto instrumento de poder entre aqueles que detêm o agronegócio. Inclusive, a UFU está encravada no Triângulo Mineiro, terra do agronegócio. Não sei agora, mas naquele momento, entre 1993 e 2000, eu só via brancos e ricos na universidade. Durante algum tempo, na época, achava que não havia negros na cidade. Depois, com a minha chegada, como professor ainda com um pé muito forte na arte de matriz africana, passei a provocar a universidade com alguns projetos, e isso acabou por tensionar os preconceituosos e racistas entrelaçados na instituição.

Assim que cheguei na UFU, em 1993, apresentei um trabalho no Congresso Brasileiro de Ciências do Esporte, em Belém do Pará, no qual apresentava minhas intenções como docente na realização de alguns projetos relativos à dança afro. Entre eles, estavam um projeto de ensino e outro artístico, que resultou no Grupo de Dança Afro da UFU. Embora houvesse a curiosidade por parte da comunidade em saber o que de fato se tratava, os olhares de desconfiança e com traços preconceituosos eram perceptíveis.

Como o meu habitus negro estava centrado na arte, pouco ou quase nada importava, porque eu queria mesmo era dançar e mostrar a técnica afro-brasileira para estudantes e professores. Tudo ia bem até que fui processado pelo trabalho de dançateatro que estava desenvolvendo junto a estudantes de Educação Física. Os argumentos do processo foram muitos, variaram desde a impropriedade dos gestos e técnicas corporais à minha inabilidade didático-pedagógica. Entretanto, a questão central não aparecia, como não apareceu explicitamente em nenhum documento produzido pela Comissão de Sindicância.

Como relatei nas minhas recordações o que me livrou de uma expulsão da universidade foi eu ter reafirmado minha condição de ser negro trabalhando numa comunidade altamente insalubre e violenta, o Morro da Mangueira, no Rio de Janeiro. Embora com essas características todos respeitavam o trabalho que desenvolvia, com as mesmas técnicas corporais que estava ensinando aos futuros professores. Portanto, eu achava um absurdo você ter uma universidade que não privilegiava a troca de saberes fundamentada em algumas teorias científicas. Esse processo deve ter ocorrido em $1994 \mathrm{e}$ eu já dispunha de algum material bibliográfico para apresentar como importante instrumento de reflexão, porque estava lendo bastante para o avanço do meu mestrado na Universidade Gama Filho.

Apesar de minha fala se referir às universidades federais que trabalhei, tanto a primeira, em que ingressei como professor auxiliar de ensino, a UFU, como a UFPE, que me possibilitou um avanço significativo na carreira docente, as críticas também servem para as instituições em que estudei, como, por exemplo, a Unicamp, por ocasião do meu doutoramento. Lá, em Campinas, volta e meia, percebia os olhares desconfiados, preconceituosos com que me observavam, por ser negro e também por ser nordestino. Sentia que algo de errado pairava quando estava presente em alguns seminários, pelo meu sotaque e também pela velocidade com que escrevia minha tese.

Para minimizar o impacto dessa situação, sempre fiz questão de me impor pela pesquisa que estava desenvolvendo naquele momento. Todas as vezes que tive oportunidade, colocava meu texto para discussão entre doutorandos e mestrandos e isso 
foi muito bom, porque a tese foi se construindo com muita velocidade, ao ponto de defendê-la em dois anos, para a surpresa de todos e o alívio dos preconceituosos, afinal não me teriam mais por perto.

É evidente que eu tinha esse comportamento disciplinar com os trabalhos acadêmicos-científicos porque compreendia bem meu projeto de pesquisa enraizado nos pressupostos étnico-raciais, o que facilitava consideravelmente a aplicação de uma teoria, a de processo civilizacionais, a algo que parecia e era a minha essência enquanto ser humano atento ao que circulava naquele ambiente.

Dito de outra maneira, conforme a minha disposição de origem, "O habitus, que é o princípio gerador de respostas mais ou menos adaptadas às exigências de um campo, é produto de toda a história individual, bem como por meio das experiências familiares da primeira infância, de toda a história coletiva da família e da classe" (Bourdieu, 2004, p. 131). E foi nessa perspectiva da minha experiência e história individual, sobretudo com a dança de matriz africana, que finquei minha posição teórica no desenvolvimento da tese que escrevi naquele momento, entre 1996 e 1998.

De qualquer modo, é um problema de falta de referência, de modelo de sociedade mais entranhado com suas origens étnico-raciais, e que a comunidade universitária reluta em compreender. Parece um contrassenso você ter um corpo negro dentro de uma instituição historicamente construída e ambientada pelas elites brancas do seu próprio país. Então, o que fazer num ambiente como esse? Quais as táticas possíveis e necessárias aplicar em meio às tensões geradas num cotidiano como as instituições universitárias?

Não estou disposto e preparado para detalhar as respostas às perguntas acima formuladas, mas, posso adiantar que é preciso manter a cabeça sempre erguida e ter a consciência de que você está lá para produzir conhecimento e formar pessoas mais humanas, mais preocupadas com a transformação social, de que essa experiência irá servir de inspiração para outras pessoas que, porventura, possam passar pelos mesmos problemas. É fundamental também ter em mente que a pesquisa a que se propõe realizar precisa ser de excelência e superar a média dos estudos desenvolvidos nesse ambiente.

É muito importante falarmos sobre esse assunto, do racismo institucional. Aliás, isso também não é um problema só das universidades brasileiras. Há trabalhos que indicam os problemas étnico-raciais que professores e estudantes enfrentam nessas instituições em outros países como nos Estados Unidos. A professora Franklin (2009) apresentou uma discussão bastante interessante sobre a Universidade do Havaí, em Manoa, ao trabalhar em seu livro a memória, a cultura e a vida acadêmica.

Todavia, do mesmo modo que concedi uma entrevista aos professores Isabel Guillen e Ivaldo Marciano, fui entrevistado pelo jornalista Jailson Paz, do Diario de Pernambuco, em 2015. O principal objetivo da entrevista era o de mostrar um pouco do meu pensamento acerca da universidade e como um negro chegou a ser doutor, mesmo considerando as dificuldades de um menino negro e pobre, conforme título da matéria. 
Figura 451 -

Fotografia de Paulo Paiva, Diário de Pernambuco, 2015.

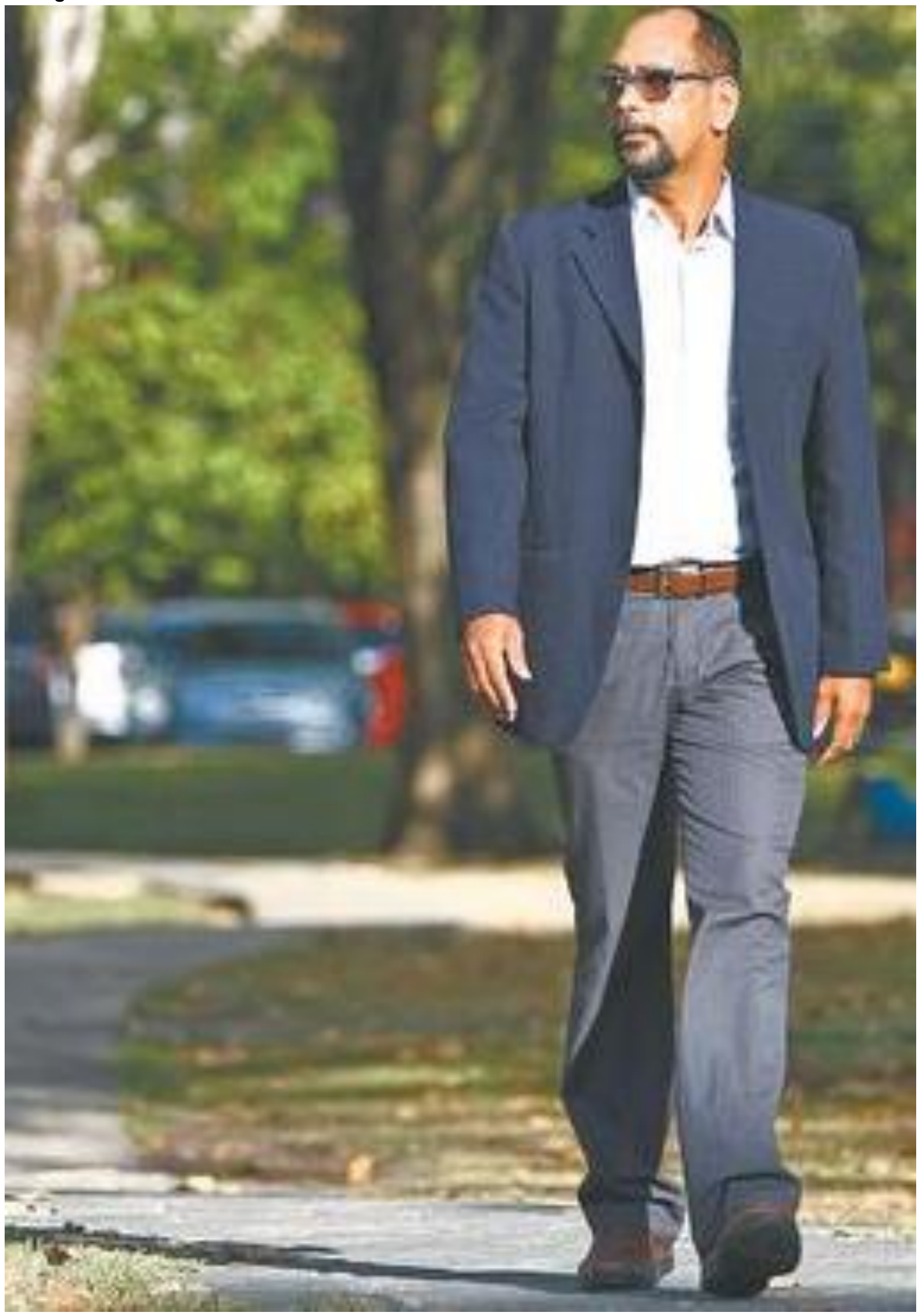


Este é um registro fotográfico do Paulo Paiva, do Diário de Pernambuco, versão online. A matéria faz um brevíssimo resumo da minha história de vida e o meu empenho em estudar, mesmo com as mudanças constantes de residência dos meus pais.

O texto foi publicado em alusão ao Dia Nacional da Consciência Negra, no ano de 2015, e tenta fazer uma reflexão acerca da presença do negro no ensino superior, numa época em que não se tinha as cotas sociais e raciais e estudar, pelo menos para mim e uma boa parte dos negros que conhecia, era um paradigma distante, especialmente 0 ingresso e permanência na universidade, que é um ambiente de muitas tensões, revelador de preconceito e racismo institucional.

Ver e sentir o preconceito e o racismo é muito doloroso, é preciso ter inteligência emocional para não cair nas armadilhas cotidianas. Seja por tática ou covardia, não é possível responder ao racismo e preconceito na mesma proporção que vejo e sinto, justamente porque isso desviaria do foco central de meu trabalho de pesquisador e formador de recursos humanos. Por outro lado, também não dá para fingir que está tudo bem, que não sou discriminado ou vítima de racismo ou que não sofro pequenas "puxadas de tapetes". Aparentemente todos me respeitam publicamente, pelo menos é como os vejo, muito embora "precisamos evitar a paranoia e a presunção" 39 .

Por outro lado é fundamental não perder de vista que, nesse ambiente acadêmico, alguns querem ver mesmo você fora do jogo, fora da disputa dos editais de fomento, da seleção do mestrado e doutorado, das bolsas de iniciação científica, fora da possibilidade de dizer o que é a pesquisa a partir de seu olhar e, sobretudo, da política institucional. Querem te ver fora da vida acadêmica porque acham que só eles têm o direito de estar ali, entre os livros, as ideias, a ciência e o poder.

Num ambiente como esse, em que um outsider ${ }^{40}$ como eu tem plena consciência de seu papel social, conhece a si mesmo e os seus adversários, os preconceituosos também sofrem em me ter por perto e ver que a cada dia eu cresço enquanto pessoa, ampliando os meus horizontes e o de todos que estão comigo no laboratório ou linha de pesquisa, que eu cresço e ressignifico a minha trajetória, como estou fazendo neste exato momento. Então, ter um negro nos jornais, sem ser na página policial, deve ser mesmo angustiante para o preconceituoso, para o racista-safado de plantão.

Contudo, de volta à imagem registrada por Paulo Paiva, é interessante notar a forma como eu quis aparecer num dos mais importantes veículos de imprensa do país; inclusive, o mais antigo da América Latina. A fotografia que compõe a matéria foi produzida exclusivamente para a composição da entrevista e mostra o meu caminhar pelo campus universitário, entre o Centro de Ciências Sociais Aplicadas e o Colégio de Aplicação da UFPE. Foi praticamente um ensaio fotográfico. Eu gostei tanto que fiz um recorte da foto e coloquei como capa da minha página no Facebook. ${ }^{41}$

\footnotetext{
${ }^{39}$ A frase entre aspas foi proferida por telefone pelo professor Lepê Correia, em 2018, no exato momento em que eu construía o referido parágrafo. A conversa se prolongou ao ponto de "irmos" várias vezes à África e tratarmos, entre outras coisas, sobre o discurso da Servidão voluntária, de Etienne de La Boétie, publicado em 1576. Uma explícita relação com o momento político do Brasil, em que mais de 50 milhões de brasileiros votaram num presidente que desferiu várias vezes palavras discriminatórias e racistas contra os afrodescendentes.

40 Para melhor compreensão desse conceito ver Os outsiders e estabelecidos, de Norbert Elias (2000).

${ }^{41}$ Para visualizar a página: https://www.facebook.com/eedilsonfernandes.
} 
A entrevista publicada no Diário de Pernambuco veio num momento muito importante, da mesma maneira que a crônica $O$ homem que orienta paixões, ${ }^{42}$ porque eu tinha acabado de sair de uma eleição para reitor da UFPE. Foi uma eleição muito difícil, pois, mesmo tendo levado pela primeira vez a eleição para o segundo turno, terminei muito abatido e enfraquecido emocionalmente. Durante a campanha, passei por momentos muito dolorosos com a divulgação de fake news que colegas apoiadores de outros candidatos propalaram a meu respeito e, obviamente, com a anuência dos próprios candidatos.

Quando a matéria foi publicada eu estava em Caicó, no Rio Grande do Norte, apresentando um trabalho no Congresso de História e Sensibilidades e achei muito bacana e carinhosa a forma como o jornal fez a matéria. Na versão impressa, não sei se por deslize ou outro motivo, o jornalista escreveu que eu estaria trabalhando na Universidade de São Paulo. Isso fez com que alguns colegas me ligassem para saber o porquê da minha transferência para a USP.

A matéria dá ênfase a dois aspectos que julgo importantes no campo das minhas lembranças, de um negro em terras de branco. O primeiro diz respeito a meu pai, Rinaldo Fernandes de Souza, porque desde criança eu era bastante autônomo, levava a marmita do almoço de domingo para ele, que era portuário no Cais do Recife, no Marco Zero. Como vi em vários momentos o trabalho braçal e árduo que ele fazia ao embarcar os sacos de açúcar, sempre pensei em tirá-lo de lá, e a única forma era continuar estudando para que ele recebesse o bolsa-escola, que exibia com orgulho no contracheque, e eu galgar outro tipo de profissão. No entanto, sempre tive a sensação de que não consegui tal intento. Papai se aposentou em 1975-1976.

De qualquer maneira, aprendi muito com o meu pai, especialmente a leitura. Aos domingos, sentado numa cadeira de balanço, ele sempre lia os jornais e tecia um ou outro comentário sobre política, economia e esporte. Aliás, as melhores passagens eram sobre o time do coração, o Santa Cruz, considerado pela imprensa especializada como o mais querido.

Às vezes, quando vejo réplicas de um dos quadros de Cândido Portinari, Homens do campo trabalhando, lembro-me do meu pai no Cais do Porto do Recife. Era, e é assim como o vejo até hoje, nos lampejos de lembrança, porque ele faleceu há 23 anos. Quando penso, lembro dele participando de uma resumida configuração de três ou quatro trabalhadores, cooperando por meio da força de seus braços para movimentar a economia, ainda que o produto de seu trabalho fosse e ainda seja desvalorizado.

Papai era portuário e o discurso que normalmente ouço ou lembro era seu sussurro se dirigindo aos amigos do trabalho ou do futebol da seguinte forma: Nêgo veio!. Certamente, uma das formas carinhosas de trato mútuo entre os considerados iguais na negritude, na força de trabalho e na esperança de uma vida melhor.

Para outro aspecto, trago o excerto da matéria do Diário de Pernambuco: "Com a bagagem dada pelos pais, Edilson foi assumindo o comando da própria história" (Paz, 2015, p. 1). De fato, é assim mesmo que me vejo, dono do meu próprio destino,

42 Crônica escrita por Maria Helena Câmara Lira, em alusão aos primeiros anos de orientação que teve comigo no curso de Licenciatura em Educação Física, no blog Entre o Inseto e o Inseticida, 2015. Disponível em: https://gargalhadaslagrimas.wordpress.com/2015/04/25/o-homem-que-orienta-paixoes/. 
construído a cada momento em meio aos obstáculos da vida. Mesmo driblando os obstáculos, com astúcia proveniente de um indivíduo fraco, considerando Certeau (1998), sempre procurei respeitar os mais velhos, os analfabetos e todos aqueles e aquelas que, por alguma razão, têm o trabalho braçal como sustento, que sustentam as universidades públicas, por exemplo.

Com essas lembranças, é bom mesmo sempre ter por perto reflexões que asseguram nossos princípios, conforme Bourdieu (2005) diz, a "auto-análise não pode deixar de lado a formação das disposições associadas à posição de origem, das quais se sabe que, em relação aos espaços sociais em cujo interior elas se atualizam, contribui para determinar as práticas" (p. 109). Assim, as nossas práticas são representações das disposições iniciais e, de alguma maneira, são modeladas pelo que aprendemos por meio das experiências de vida em diferentes ambientes sociais, e isso talvez seja captado ou capturado por vários indivíduos com os quais interagimos no cotidiano, respeitando-nos ou depreciando-nos para garantir seus privilégios históricos.

Infelizmente, alguns colegas que têm a mesma origem que tenho ou talvez origem mais complexa, por não terem conhecido o próprio pai pelas circunstâncias da vida, buscam insistentemente oprimir o semelhante. Ou seja, ao tentar defender os privilégios de serem professores universitários, por mérito, convicção de classe ou ousadia, oprimem aqueles que não tiveram as mesmas oportunidades e, às vezes, criam tensões com os parceiros de origem no afã de disputar o espaço e o poder com os semelhantes. Contudo, não tenho o direito de tripudiar com a privação parental alheia, mas aqui faço valer as observações de Paulo Freire (2005) que diz que, em determinadas circunstâncias, o oprimido vira opressor.

Nesse contexto sempre penso que as pessoas me veem de uma forma diferente do que realmente sou no meu cotidiano. Talvez e certamente, essas pessoas me vejam como um grandioso, um cara enorme, porque no fundo eu quero e preciso me mostrar assim, seja em casa, com a minha família, minha esposa, meus filhos, seja especialmente no trabalho, com os estudantes de graduação e de pós-graduação, gestores da universidade e colegas técnico-administrativos.

Sempre tenho a impressão de que as pessoas me veem muito maior ou menor do que realmente sou. Muito mais importante do que realmente me sinto, muito mais feliz do que realmente sou e com muito mais possibilidades do que tenho. Todavia, entendo que até certo ponto contribuo significativamente para essa representação. Talvez, eu realmente queira mesmo que elas me vejam dessa forma, para me manter no campo, lutando e criando condições de sobrevivência.

Então, não é tarefa fácil a reafirmação da grandeza que se pretende ter num campo como uma instituição de ensino superior, historicamente, criada e desenvolvida para indivíduos oriundos das classes sociais abastadas. É como se esse ambiente em que vivemos não nos pertencesse por origem de sangue, mas por teimosia ou astúcia, ou as duas coisas juntas. Por isso é importante permanecer no jogo e fazer a diferença entre os pesquisadores do CNPq, os que desejam um laboratório mais equipado ou que apenas ministram 'porcamente' suas aulas, e a sua própria condição de docente político-científico preocupado com que mais gente de sua origem adversa também possa entrar e permanecer na instituição. 
Contudo, mesmo na condição de outsider, com o sentimento que lhe é próprio e, talvez, por essa razão ainda é possível se diferenciar de forma muito salutar entre as tantas tensões, mesmo tendo adquirido também o habitus da representação desse campo intelectual-acadêmico.

Sempre tive o cuidado ao apresentar as oportunidades que a universidade pode oferecer ao estudante e, às vezes, quando eu menos esperei, recebi de volta um pouco do que construí. Foi o que aconteceu em 2015, durante a campanha para reitor da UFPE, num momento muito difícil da minha campanha, em que Maria Helena Câmara Lira, exestudante de graduação, mestrado e atualmente doutora, docente da Universidade Federal Rural de Pernambuco, escreveu uma crônica endereçada a mim numa de suas redes sociais.

Assim, a percepção que Maria Helena tem de mim é a seguinte: "ele faz isso não porque ele é bom, solidário e caridoso, mas porque sabe o lugar que ocupa na universidade" (Lira, 2015). É exatamente isso, sei do lugar estratégico que ocupo na instituição universitária e, por isso, preciso me manter firme nas orientações dos temas e problemas de pesquisa, para que, no futuro, o egresso seja capaz de desenvolver suas pesquisas de forma autônoma, com qualidade e impacto positivo na sociedade.

A crônica da Maria Helena foi muito importante, não só em virtude do que eu estava vivendo naquele momento como agora, ${ }^{43}$ entristecido na condição de outsider, expurgado pelo grupo que advogava o mesmo sentimento, e isso contarei no penúltimo capítulo. Mais do que nunca, tenho a percepção do impacto das minhas falas dirigidas aos estudantes, é muita responsabilidade que precisamos ter em relação ao nosso comportamento na sala de aula. De qualquer modo, esse é um bom feedback, até porque, em certa medida, a percepção da Maria Helena em relação ao meu comportamento, à minha imagem, também é um pouco de como eu quero ser visto pelos estudantes, pela comunidade acadêmica.

O início da crônica é um tanto inusitado. Embora a autora pretendesse falar sobre o meu perfil acadêmico e, especialmente, o meu jeito particular de existir no mundo, ela começa situando o leitor acerca das controvérsias da própria área da Educação Física, indicando, inclusive, que é uma formação profissional que, na maior parte das vezes, negligencia as Ciências Humanas e Sociais, ao tempo que também é negligenciada por essas áreas.

$\mathrm{Na}$ percepção da cronista eu não deixei passar ao largo as Ciências Humanas e Sociais, mesmo estando num curso que, historicamente, de norte a sul do país, está voltado para as Ciências da Saúde. Em certa altura do texto, ela chega a ser muito generosa e cuidadosa ao me descrever como o homem que orienta paixões, que deu origem ao título da crônica.

Ao ler as palavras generosas da Maria Helena, realmente senti um grande conforto, especialmente pelo momento difícil que eu estava vivendo, como disse. As palavras foram reconfortantes por me mostrar que contribuí e contribuo para que mais e mais estudantes, como a cronista, naquela época já docente da UFRPE, de origem popular pudessem ter a formação acadêmica que receberam a partir das minhas simples orientações, de um

43 Os detalhes dessa situação conto no texto: Largaram as minhas mãos!, penúltimo capítulo, escrito um ano após a redação desse parágrafo. 
professor de Sociologia do Esporte, quando fiz a discussão de dois textos simultaneamente, $A$ águia e a galinha, de Leonardo Boff, e $A$ busca da excitação, de Norbert Elias.

Nas palavras de Helena ela havia me procurado no Departamento de Educação Física da UFPE porque eu the transmitia "sensibilidade, historicidade, humanidade". Penso que é pura gentileza da cronista, embora eu tenha me esforçado para corresponder a esse tipo de representação.

Contudo, no fundo, o meu comportamento, à época, como ainda é hoje, tenta mostrar a consciência de que sou negro, de origem das classes populares, assim, tenho a obrigação e compromisso de não reproduzir os valores da negligência, da exclusão histórica, pois, como outsider, sei da minha responsabilidade em transmitir ou dar significado a outras pessoas do que faço e, consequentemente, tentar reverberar o sentimento de pertencimento, da mesma maneira quando era artista, que fazia o possível e impossível para que o espectador sentisse o pertencimento étnico por meio da prática mimética que eu desenvolvia com a dança afro.

De qualquer modo, a crônica de Maria Helena foi importantíssima na época. Hoje, volta e meia, leio para me revigorar de falas e olhares feitos por um determinado colega da universidade em relação à eleição para reitor de 2015, quando me disse que não havia votado em mim porque eu não tinha produção acadêmica. Na verdade, isso é expressão do ranço preconceituoso de quem não aceita um negro disputar o cargo mais alto da instituição e parte do princípio de que o candidato negro não poderia ter produção acadêmica compatível com o cargo.

Como o território pretensamente é de branco, pelo menos é assim que muitos enxergam a universidade, esse colega caucasoide só expressa seus preconceitos em momentos muito específicos, como o momento da nossa conversa, e jamais em público. Ao dizer que não votou em mim por conta da produção científica, ele mesmo se esqueceu de olhar para o seu Currículo Lattes e de seu candidato, e verificar que eu não sou o espelho da sua inércia investigativa. Aliás, assisti com muito prazer à sua defesa de professor titular, mesmo depois de sua fala guiada por preconceitos, e vi como se desculpava por não ter feito nenhuma tese, nenhum memorial descritivo à altura, compatível com seu tempo de serviço e com a banca seleta que eu mesmo havia ajudado a montar, convidando alguns amigos de profissão.

Posso chamá-lo de Narciso Segundo, justamente, porque toda sua devoção é calcada num outro igualmente sutil e perigoso, travestido de intelectual supremo, que não admite de forma alguma que nós, negros e indígenas, sejamos sequer chamados de professores. Para este, o Narciso Primeiro, a escória não só está entre os negros universitários, docentes e eventualmente doutores. Para ele, a escória também está resguardada entre brancos originários das classes populares que eventualmente tenham chegado à universidade.

Apesar dessa minha fala, em relação aos Narcisos, eu os admiro em suas interpretações, mesmo equivocadas, pois sempre conseguem disfarçar bem os seus reais interesses na manutenção de seus status e privilégios históricos. De qualquer modo, tudo isso é perceptível aos olhos de quem está de fora da universidade, pelo menos, gente da imprensa consegue identificar personagens negros em territórios brancos. É o caso do jornalista Inaldo Sampaio que acompanhava a disputa eleitoral em 2015 e escreveu a 
seguinte matéria: "Professor de origem negra entra na disputa pela Reitoria da UFPE [...]. Caso venha a ser eleito, Edilson Fernandes seria o primeiro reitor negro da história da UFPE" (A Política..., 2015).

Como o leitor pode conferir, o jornalista destaca o fato de eu ser negro num território em que seria o primeiro dessa origem a ocupar o cargo máximo da instituição universitária. Apesar das dificuldades enfrentadas, estar nesse território também tem suas pequenas vantagens, pois é um lócus de disputa de narrativas e de onde ainda posso construir possibilidades de transformações sociais. É assim como me vejo e me posiciono, aliás, alguns estudantes ainda tentam se inspirar não apenas nos meus ensinamentos, mas também na minha postura, nos meus gestos, conforme a fotografia que se segue, num dia comum de debate de projetos na pós-graduação.

Figura 552 -

Aula na pós-graduação em Educação, 2018.

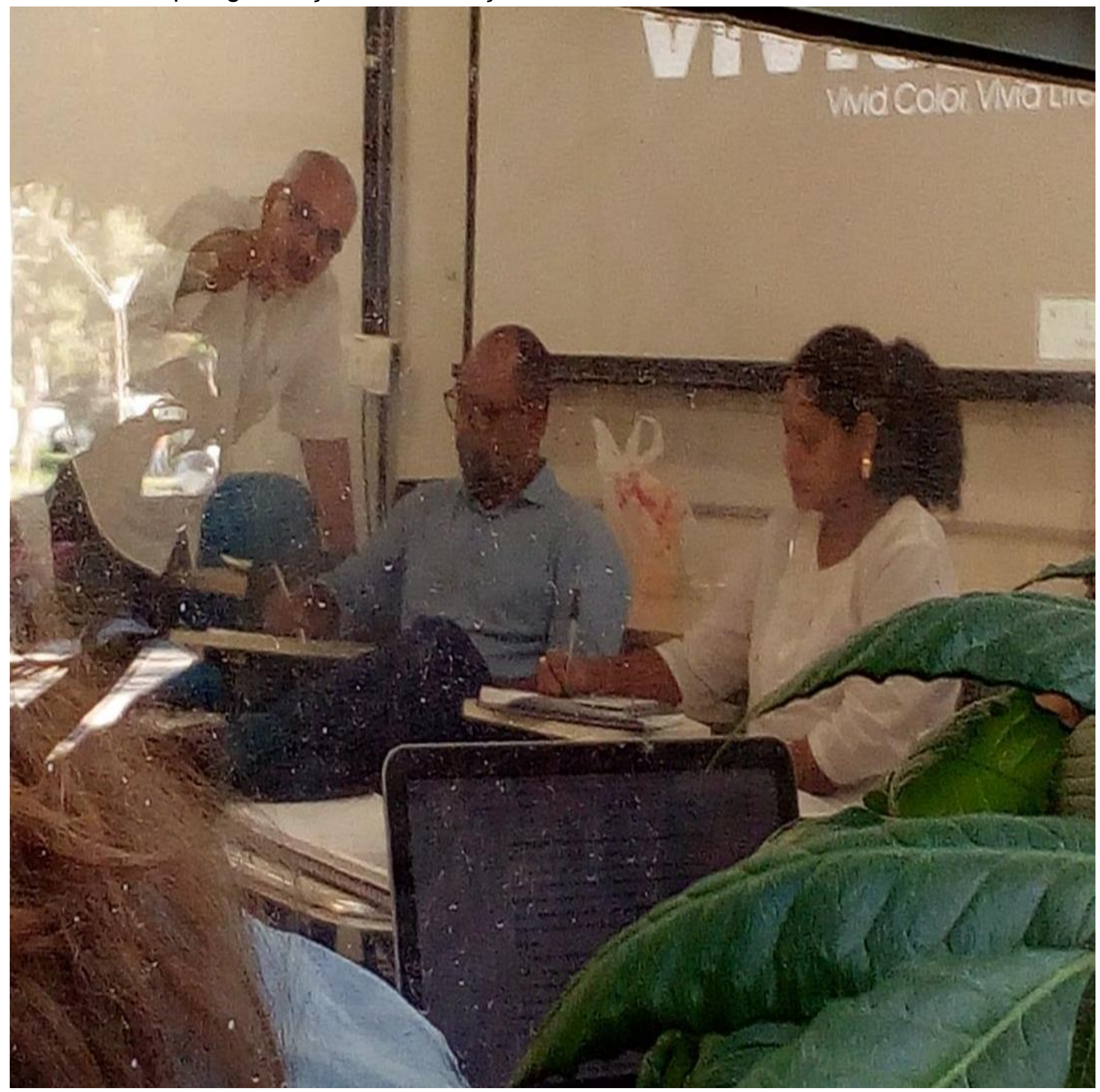

Fonte e fotografia: Paulo Pergentino, em 20 de abril de 2018.

\begin{tabular}{|l|l|l|l} 
Regae: Rev. Gest. Aval. Educ. & Santa Maria & v. 10 & n. especial
\end{tabular}

e66773, p. 1-325

2021 
A fotografia é um flagrante de um ex-estudante de mestrado e agora doutorando, o Paulo Pergentino, que registrou um dos momentos da disciplina Seminário de Pesquisa em Teoria e História da Educação II. Segundo o autor do registro a ideia era fotografar e usar como trabalho a ser apresentado num evento dentro do próprio Centro de Educação da UFPE, numa exposição de fotografias de intelectuais e estudantes negros. Como pode ser visto na imagem, estou no centro; à esquerda de quem olha, está JJC, e, à direita, Gina Guimarães. A imagem foi capturada na parte externa da sala, separada por tijolos e janelas de vidro, por isso a foto tem partículas de poeira sobrepostas.

A ideia de flagrante é perceptível no gesto de JJC de apontar para a janela tentando me despertar para o momento. O registro foi bastante sugestivo em virtude do debate que fazíamos acerca do projeto de tese da própria Gina Guimarães, Os saberes do afoxécandomblé de rua nas cidades de Olinda e Recife, década de 1980. Estávamos muito concentrados revisando conceitos e possibilidades metodológicas, pois a discussão já havia terminado e deveríamos apreciar outro projeto, talvez o do próprio JJC, que parecia se preparar com o datashow.

Debater projetos de forma coletiva realmente é um dos aspectos fundamentais no processo de formação de pesquisadores, é sempre bom mantermos essa prática, especialmente quando estamos diante de temas de tamanha complexidade, que envolvem saberes e questões étnico-raciais, como ocorreu no dia deste registro de Paulo Pergentino. Aprendi isso na Unicamp, no meu doutoramento. O Pergentino foi defensor, na ocasião, de trabalho intitulado Os saberes da Escola Gigante do Samba. Aliás, até o presente momento, sou identificado como um docente que escreve e orienta acerca da temática afrodescendente, embora, nos últimos tempos, tenha orientado outros objetos relacionados às instituições escolares.

Nesse contexto, nem sempre tive a consciência de que a universidade tinha esses meandros delimitados em território de não negros, mas uma vez despertado para isso, sempre tentei provocar mudanças nesse ambiente. Penso que a primeira vez foi ao criar, na Universidade Federal de Uberlândia, em 1993, o Grupo de Dança Afro da UFU e depois a disciplina, no curso de Licenciatura em Educação Física, Teoria, Prática e Metodologia da Dança Afro. Essas duas atividades docentes na mesma instituição me permitiam mexer com algumas estruturas político-ideológicas entre os colegas professores, técnicos e estudantes, mas também possibilitavam que outros indivíduos afetos à afrodescendência pudessem ter um encontro identitário e realçar artisticamente sua criatividade nos espetáculos e, às vezes, na sala de aula.

Considero que esses dois projetos, o de ensino e o de extensão, eram inovadores para o ambiente acadêmico e para a própria cidade de Uberlândia. Então, saber o território onde se está pisando é fundamental para galgar sucesso em ações inovadoras. Penso também que tive de aprender a duras penas, por meio de alguns percalços experimentados no cotidiano universitário, especialmente, na UFU, com o processo de sindicância impetrado contra as minhas "atitudes e procedimentos pedagógicos" em sala de aula. Contudo, é fundamental um registro mais objetivo do que consegui fazer enquanto detentor desse meu habitus negro em território controverso de branco, facilmente verificável no quadro a seguir. 
Quadro 187 -

Consolidação da produção acadêmica acerca das questões étnico-raciais.

\begin{tabular}{|c|c|c|c|}
\hline Título da produção & Suporte de circulação & Natureza & Ano \\
\hline A dança afro primitiva & $\begin{array}{l}\text { Faculdade de Filosofia, } \\
\text { Ciências e Letras de } \\
\text { Arapongas, Paraná }\end{array}$ & $\begin{array}{l}\text { Trabalho de } \\
\text { conclusão de } \\
\text { curso }\end{array}$ & $1991 \mathrm{a}$ \\
\hline $\begin{array}{l}\text { Resgatar a dança afro-primitivo } \\
\text { dentro do contexto sócio-cultural }\end{array}$ & $\begin{array}{l}\text { Revista Brasileira de } \\
\text { Ciências do Esporte (CBCE) }\end{array}$ & Resumo/anais & $1991 b$ \\
\hline A dança afro primitiva & Revista Sprint & Artigo & 1991c \\
\hline $\begin{array}{l}\text { A dança afro primitivo: uma proposta } \\
\text { humanista }\end{array}$ & $\begin{array}{l}\text { Encontro Nacional de } \\
\text { Recreação e Lazer (Enarel) }\end{array}$ & Resumo/anais & 1991d \\
\hline A expansão da dança afro na UFU & $\begin{array}{l}\text { Revista Brasileira de } \\
\text { Ciências do Esporte (CBCE) }\end{array}$ & Resumo/anais & 1993 \\
\hline $\begin{array}{l}\text { A Reinvenção da tradição afro- } \\
\text { brasileira através do movimento } \\
\text { humano }\end{array}$ & $\begin{array}{l}46^{\underline{a}} \text { Reunião Anual da } \\
\text { SBPC }\end{array}$ & Resumo/Anais & 1994 \\
\hline $\begin{array}{l}\text { Representações sociais da cultura } \\
\text { negra através da dança de seus } \\
\text { atores }\end{array}$ & $\begin{array}{l}\text { Pós-graduação em } \\
\text { Educação Física } \\
\text { Universidade Gama Filho, } \\
\text { Rio de Janeiro }\end{array}$ & $\begin{array}{l}\text { Dissertação de } \\
\text { mestrado }\end{array}$ & 1995 \\
\hline $\begin{array}{l}\text { Dança afro e representações } \\
\text { sociais: relatório de um estudo para } \\
\text { subsidiar proposta de conteúdo em } \\
\text { Educação Física }\end{array}$ & $\begin{array}{l}3^{\circ} \text { Congresso Latino- } \\
\text { Americano de Esporte, } \\
\text { Educação e Saúde no } \\
\text { Movimento Humano }\end{array}$ & Resumo/anais & 1996 \\
\hline $\begin{array}{l}\text { Dança dos mitos: um estudo sobre a } \\
\text { dança afro e o controle das } \\
\text { emoções no desenvolvimento da } \\
\text { sociedade brasileira }\end{array}$ & $\begin{array}{l}\text { Congresso Mundial de } \\
\text { Educação Física. AIESEP. } \\
\text { Artus, Revista de Educação } \\
\text { Física e Desportos }\end{array}$ & $\begin{array}{l}\text { Resumo } \\
\text { expandido }\end{array}$ & 1997 \\
\hline $\begin{array}{l}\text { Entre o fogo e o vento: as práticas } \\
\text { de batuques e o controle das } \\
\text { emoções }\end{array}$ & FEF - Unicamp & $\begin{array}{l}\text { Tese de } \\
\text { doutorado }\end{array}$ & 1998 \\
\hline $\begin{array}{l}\text { Proibição de batuques no século } \\
\text { XIX: a etiqueta religiosa presente } \\
\text { em seu discurso }\end{array}$ & $\begin{array}{l}\text { Revista Brasileira de } \\
\text { Ciências do Esporte (CBCE) }\end{array}$ & $\begin{array}{l}\text { Resumo } \\
\text { expandido }\end{array}$ & 1999 \\
\hline $\begin{array}{l}\text { Etnografia e história da dança } \\
\text { litúrgica e artística no Rio de } \\
\text { Janeiro. }\end{array}$ & $\begin{array}{l}\text { VII Congresso Brasileiro de } \\
\text { História da Educação } \\
\text { Física, Esporte, Lazer e } \\
\text { Dança }\end{array}$ & $\begin{array}{l}\text { Resumo } \\
\text { expandido }\end{array}$ & 2000 \\
\hline $\begin{array}{l}\text { Entre o fogo e o vento: as práticas } \\
\text { de batuques e o controle das } \\
\text { emoções }\end{array}$ & Editora Universitária - UFPE & $\begin{array}{l}\text { Livro } \\
\text { Três edições }\end{array}$ & $\begin{array}{l}2001- \\
2010\end{array}$ \\
\hline $\begin{array}{l}\text { Os outsiders afro-brasileiros e suas } \\
\text { danças ancestrais. }\end{array}$ & Revista ArtCultura & Artigo & 2002 \\
\hline $\begin{array}{l}\text { Representações de afro-brasileiros; } \\
\text { depoimentos de dançarinos-atores }\end{array}$ & Editora Universitária - UFPE & Livro & 2008 \\
\hline
\end{tabular}

Fonte: autor (2019). 
Como o leitor pode perceber, são 15 produtos com suportes de circulação nacional e local bem diferentes, sendo livros, artigos, resumos, resumos expandidos, monografia, dissertação e tese. Na cor mostarda, linhas 1, 7 e 10, estão as produções que resultaram em trabalhos finais, em cursos de pós-graduação lato e stricto sensu. Não considero que esses produtos de trabalho de conclusão de curso sejam os mais importantes, mas são, seguramente, aqueles que me exigiram exposição mais densa no campo acadêmico, sobretudo, porque houve a necessidade de compartilhar as ideias iniciais com outros personagens da academia, professores e orientadores.

Com um breve olhar sobre o quadro, é perceptível a utilização de congressos como um dos importantes suportes para veiculação dessas produções, especialmente numa época em que havia, de minha parte, a necessidade de ser visto pela comunidade acadêmica e, quem sabe, ministrar algum curso para os universitários em congressos. Infelizmente, isso nunca aconteceu, mas a reafirmação da negritude continuou sendo expressa por meio das publicações, sobretudo em 1991, em que é notável a concentração do maior número de trabalhos, até porque foi o ano em que concluí a graduação e o curso de pós-graduação lato sensu, início da transmigração de campo e de onde parte a construção da hipótese desta tese.

À medida que ponho esses produtos num quadro para leitura, percebo que alguns títulos se repetem ou parecem tentar indicar o mesmo sentido na reafirmação de um lugar de fala, de um habitus até então mantido num campo artístico. Entretanto, vejo também que alguns produtos foram confeccionados após algum tempo longe desse universo artístico da dança, mas que possuem a mesma força e intencionalidade com que foram pensados. Digo isso porque a dissertação de mestrado e a tese de doutorado, bem como outros produtos criados a partir de 1995, mesmo impulsionados por uma estética africana, já não contavam com a minha participação artística como dançarino-ator naquele momento.

Em linhas gerais, esse quadro 18 representa a marca de uma trajetória, na medida em que se tem produtos específicos relacionados às questões étnico-raciais, sobretudo, à dança africana, numa perspectiva de formulação de um novo conteúdo para a Educação Física brasileira. Essa produção, obviamente, tem um impacto na minha trajetória enquanto uma de minhas marcas e na minha formação de pesquisador-autor. Aliás, esses textos produzidos vão servir, mais adiante, para uma modelagem de um constructo, que será objeto de verificação desta tese.

Nesse contexto, por um lado, uma análise cuidadosa sobre o conteúdo na temporalidade desses produtos pode revelar as preocupações que eu tinha acerca da técnica corporal e os aspectos relacionados à ancestralidade. Por outro, pode revelar os avanços e retrocessos com que fui registrando as ideias acerca da estética africana em forma de dança.

Avanços, porque é perceptível a elaboração teórica e empírica própria de uma formação intelectual em desenvolvimento, isso é visto quando me debruço sobre entrevistas de atores sociais que também têm a dança afro como expressão artística e, em outros momentos, passo a perscrutar documentos históricos para a elaboração das pesquisas. Retrocessos, justamente pelo meu afastamento físico-corporal da arte, objeto das reflexões. O distanciamento necessário e inevitável para produzir ciência, que Elias (2001) chama de autodistanciamento, ou seja, a minha objetivação. 
Dessa maneira, o quadro de referência não é apenas uma representação gráfica para efeito de ilustração, também é, em síntese, uma tentativa de proferir um discurso a partir de um lugar determinado, com uma linguagem e códigos próprios, uma cultura que faz circular outras intencionalidades, ainda que seja uma produção do conhecimento pautado nas teorias eurocêntricas.

No entanto, o leitor pode perceber que é a partir dessa linguagem e teorias aqui criticadas que vou me reafirmando enquanto intelectual negro, onde a escrita sobre a dança vai adquirindo outros contornos, ao tempo em que eu atravesso a média da formação profissional por meio da elaboração da monografia, da dissertação e da tese de doutorado.

De qualquer forma, onde quer que estejamos, nós, negros, precisamos aproveitar as brechas e, com alguma astúcia, as fissuras estruturais dos preconceitos, bem como os erros do sistema, como dizem alguns. Então, quando fui pró-reitor de extensão na Universidade Federal de Pernambuco, entre 2011 e 2014, pude aproveitar esse espaço estratégico e lançar um edital em nível nacional sobre a temática das relações étnicoraciais.

Foi realmente um grande projeto, conseguimos publicar 32 títulos de pesquisadores de vários lugares do Brasil. Fico realmente muito orgulhoso em ter colaborado significativamente com esses produtos, tão necessários e urgentes para um Brasil onde ainda insistem com a intolerância religiosa e onde direitos aos bens e serviços ainda são para poucos.

A imagem a seguir é apenas um pequeno trecho no qual estão descritos todos os títulos publicados pelo projeto e reflete, sem sombra de dúvida, não apenas o trabalho de uma gestão, mas o trabalho incansável de muita gente que pretende ter e fazer um país melhor, sobretudo, pesquisadores que ainda acreditam no que produzem acerca da negritude, da afrodescendência.

Não vou comentar todos os títulos, até porque esse procedimento fugiria ao escopo desta tese, mas é realmente importante registrar a grandeza da série na perspectiva da diversidade temática e no que concerne às questões postas da alteridade, do cotidiano religioso e processos educacionais, bem como os desafios da construção da identidade afrodescendente. Segue a imagem de um dos títulos da série Étnico-Racial: 
Figura 1553 -

Contracapa da Série étnico-racial, livro 20, UFPE, 2013.

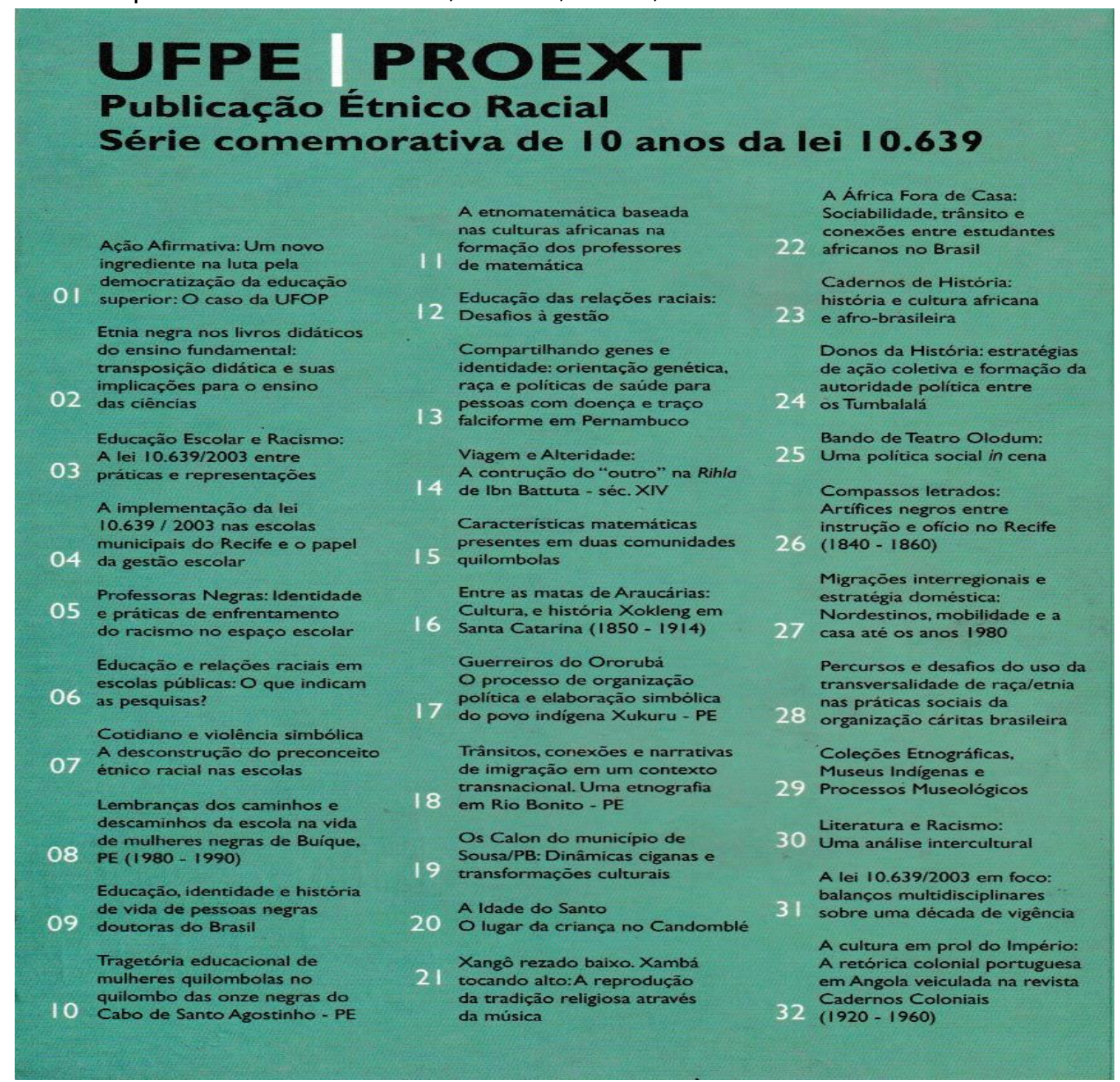

Fonte: acervo da biblioteca do autor.

O exemplar acima, que serve de inspiração neste momento, trata do lugar que a criança ocupa na religião de matriz africana. A autora fez um estudo etnográfico entrevistando adultos e crianças e observando a dinâmica em que se estabelece o cotidiano do terreiro (Falcão, 2014), espaço de troca de saberes e de crença religiosa. Pela leitura do texto, é possível observar a riqueza de detalhes do cotidiano do terreiro, cuja etnografia nos faz enxergar a cosmovisão africana e seu impacto no Brasil.

Com muito orgulho, por onde passo, tenho dito que essa foi uma das principais marcas da minha gestão. Consegui juntar num só momento 32 títulos relacionados ao tema, o que resultou numa coleção que é um patrimônio imensurável para a sociedade brasileira. É evidente que a gente só faz coisas como essas com uma equipe. Assumi como um dos meus trabalhos técnicos, na coordenação geral junto com a Maria Christina de Medeiros Nunes, mas também tivemos a participação da professora Margarida Correia de Lima, no projeto gráfico; Isabela Freire e Filipe Neri, na diagramação, e Ayodê França, na ilustração da capa. 
$\mathrm{Na}$ verdade, aproveitei o momento em que se comemorava $1 \mathrm{dez}$ anos da lei $\mathrm{n}$. 10.639/2003 e lancei o edital para motivar a demanda. Além disso, o lançamento foi coletivo, investimos em passagens e diárias dos pesquisadores para a realização de um debate acerca de suas publicações num evento institucional da Pró-Reitoria de Extensão, o Enext, que aconteceu na UFPE.

O que estava posto naquele momento, como ainda permanece, é a produção científica que emerge de editais das instituições universitárias, como foi o caso, e outros órgãos de fomento quase sempre investindo em objetos consagrados das áreas de Humanas e principalmente de Exatas e Tecnológicas. Entretanto, debate científico à parte, consegui impulsionar a Série étnico-racial e também a coleção Brasil-África, esta publicada pela editora da UFPE sob a coordenação do professor Marco Mondaine, do Departamento de Serviço Social.

Faço esse registro porque somente com um 'pé afro' ou uma disposição afrodescendente é que fazemos coisas dessa natureza, que enfrentamos muitos desafios, especialmente as limitações orçamentárias, em que normalmente são travadas algumas pequenas batalhas para considerarmos as prioridades. Esse foi um dos trabalhos que assumi como desafio e, por essas e outras razões, acabei recebendo uma homenagem. Trata-se de um certificado do Fórum dos Diretores das Unidades Acadêmicas da UFPE, em agradecimento pelos estímulos às ações extensionistas e o trabalho que eu desenvolvi quando estive à frente da Pró-Reitoria de Extensão. Confesso que fiquei surpreso e bastante preocupado. O Preito de Reconhecimento foi entregue numa das sessões do Conselho Universitário, penso que uma das primeiras reuniões de 2013.

Figura 54 -

Certificado do Fórum de Diretores da UFPE, 2013.

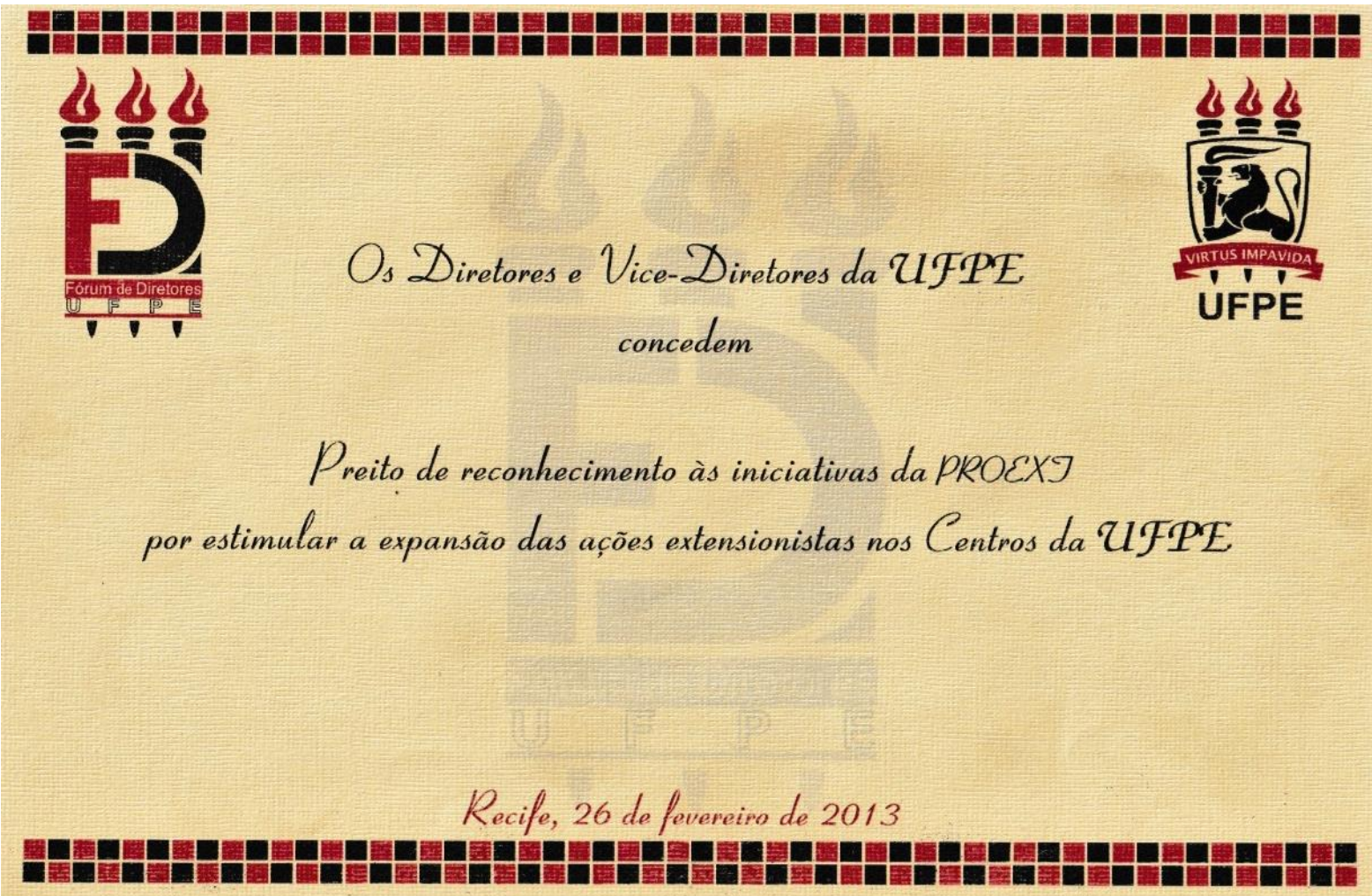

Fonte: acervo do autor. 
Fiquei surpreso ao receber essa honraria porque não imaginava que o meu trabalho como gestor estava tendo tanta visibilidade entre os diretores de centro a ponto de me diferenciar dos demais pró-reitores, daí a preocupação. Logo após esse reconhecimento a minha permanência na gestão ficou um tanto abalada. Provavelmente a ciumeira foi geral. A partir daquela data, a minha participação nas reuniões passou a ser um pouco restrita, colegas da gestão começaram a ver com desconfiança os movimentos que eu fazia para prestar um bom serviço.

Contudo, gostaria de destacar o fato de que as distinções institucionais revelam um tipo de capital simbólico fundamental para a integridade das relações de um campo e demonstram um potencial quase irrefutável, uma infinidade de possibilidades, nesse caso específico, possibilidades institucionais. O capital simbólico também pode servir como alerta para uma espécie de 'destituição do poder', na medida em que os detentores de prestígio, até aquele momento, ainda não tivessem sido confrontados com outros atores igualmente competentes para o estabelecimento da referida distinção. De modo que me senti um outsider, um excluído às avessas. Estava definitivamente na vitrine prestes a quebrar.

Essa 'destituição do poder' também tem impacto político-administrativo, uma vez que atores de relativo prestígio institucional passaram a me apontar como de um outro grupo, como na verdade o era, em colaboração, mas, nesse caso, com o intuito de que a distinção recebida depusesse contra a administração geral da universidade. Assim, internamente, ou seja, no ambiente da Reitoria, os olhares de outros gestores e, sobretudo, pró-reitores passaram a ser de reprovação e de distanciamento; pelo menos, essa foi a minha percepção ou, talvez, apenas um olhar de dupla desconfiança.

Agora, mais do que nunca, consigo compreender seus olhares de 'destituição do poder', aprofundarei mais adiante o tema da política, mas já posso afirmar que os documentos recebidos durante a trajetória, seja por ordem da prática institucional, seja por agraciamento, como este é o caso, têm impacto nas futuras decisões para realçar, muitas vezes, o prestígio alcançado no próprio campo em disputa, o que tentarei analisar no penúltimo capítulo.

Contudo, essa não foi a única vez que fui lembrado pelos serviços prestados como gestor nessa unidade administrativa. Na verdade, em 2017, recebi o Troféu Berimbau de Ouro, agraciado pelo Centro Cultural da Câmara Municipal de Salvador em conjunto com a Associação de Capoeira do Mestre Máximo. Essa premiação é concedida em valorização e reconhecimento aos homens e mulheres que realizaram algum trabalho de destaque em função das questões étnico-raciais em diferentes setores da economia, da cultura na gestão pública ou privada. Assim, mesmo já não mais gestor da Pró-Reitoria de Extensão, o trabalho da Série étnico-racial foi lembrado, bem como outros incentivos diretos e indiretos que fiz a grupos da capoeira, às vezes patrocinando eventos ou pautando matérias no meu programa de televisão Cabeça de área: penso, logo assisto, exibido pela TV Universitária da UFPE. 
Figura 556 -

Recebimento do Troféu Berimbau de Ouro, Salvador, 2017.

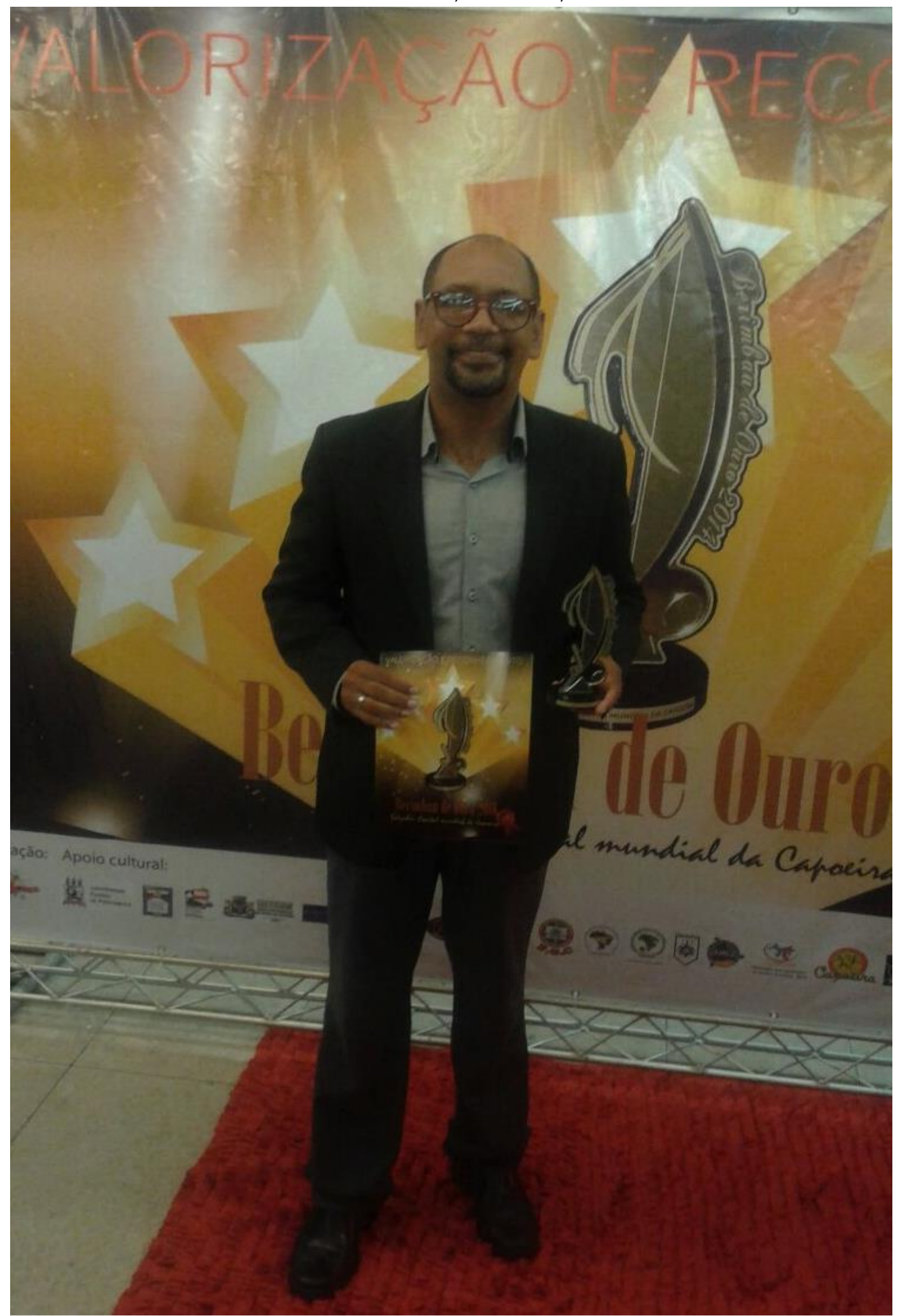

Fonte: Acervo pessoal - fotografia do professor Henrique Gerson Kohl. 
Pela fotografia, pode se constatar que a premiação é revestida de pompa e circunstância, pois já era a $5^{\underline{a}}$ edição e já haviam sido homenageadas 70 personalidades de destaque das artes plásticas, da música, da capoeira, da intelectualidade e da gestão pública. Então, fiquei muito orgulhoso de ter recebido a distinção em virtude do que eu havia feito como gestor da unidade administrativa considerada a mais pobre da universidade.

Ao lembrar essa premiação do Berimbau de Ouro, outro registro que há bastante tempo tenho como uma das importantes experiências é o Prêmio Zumbi dos Palmares, que recebi da Câmara Municipal de Uberlândia, em 1995. Naquela ocasião, certamente, a distinção foi em virtude dos projetos de dança afro que eu desenvolvia na Universidade Federal de Uberlândia junto aos estudantes da instituição e pessoas das comunidades circunvizinhas. Passado todo esse tempo, fica a certeza do dever cumprido na defesa, estímulo e visibilidade da cultura afro-brasileira, tão necessária e importante para o conjunto da nossa sociedade e o futuro das novas gerações de artistas e intelectuais.

Nesse contexto, quando o assunto é pesquisa científica e circulação do saber, seja na graduação, pós-graduação ou outro ambiente da universidade, há disputas de narrativas sobre este ou aquele ser o conhecimento necessário à sociedade brasileira. Há, por vezes, disputa pelo financiamento dos projetos, pela aquisição de equipamentos para laboratórios e pelo poder institucional; inclusive, são as disputas de poder que tratarei no próximo capítulo de maneira mais explícita.

\section{Capítulo 7 - 0 campus em disputa: da ciência à política institucional e as teias do poder}

Os intelectuais exercem sua influência sobre o poder estando fora dele, elaborando propostas que poderão ou não ser acolhidas, mas que eles próprios consideram úteis para melhorar as relações de convivência presididas pela atividade política, ou fornecendo informações históricas, econômicas e técnicas aos políticos para facilitar as suas deliberações ou para torná-las menos causais e arbitrárias. (Bobbio, 1997, p. 104)

Essas reflexões do Bobbio (1997) são fundamentais para se entender que o intelectual sempre manteve e manterá uma relação política. Quando um intelectual não é um político na acepção do termo aqui empregado, ele mesmo estará diretamente ou indiretamente mantendo relações técnico-científicas com aqueles que têm a política como sua atividade principal. Aliás, em última instância, somos todos políticos, vivemos numa polis moderna, mas uma polis. E, como em qualquer outro lugar, há relações de poder, quando não, as próprias relações caracterizam-se pelo poder que uns exercem sobre os outros.

A partir dessas considerações este capítulo tem por objetivo apresentar e analisar a minha participação na política institucional nas duas instituições de ensino superior em que trabalhei, a Universidade Federal de Uberlândia e, especialmente, a Universidade Federal de Pernambuco. Confesso que é um capítulo que relutei em escrever, tanto a primeira seção, que trata de forma amena sobre as questões relacionadas à UFU e depois as particularidades da coirmã nordestina, assim como, em caráter muito particular, as duas outras seções, onde exponho aspectos relacionados às eleições para a Reitoria em 2015 e 2019 na UFPE. 
Com a evidência própria da experiência de vida, percebo que esses aspectos relacionados à política só têm sentido se considerarmos a minha inserção institucional nos diferentes ambientes acadêmicos em que frequentei ativamente, circunscritos ao próprio campo de produção ou, de maneira mais complexa, à configuração social, onde mantive ligações afetivas e políticas mais extensas. Caso não se tenha esses elementos presentes na narrativa, poderia passar a ideia de se tratar apenas de picuinhas, conforme mensagem popular.

Então, nesse contexto da minha inserção institucional, em que exponho algumas nuances por entre as relações interpessoais com colegas das universidades em questão deve, inevitavelmente, ser compreendida no plano simbólico e, ao mesmo tempo, num chão que custa muito caro para todos nós que vivemos nesse ambiente, onde sofremos pressões e tensões de toda ordem. É óbvio que essas tensões ocorreram e ainda ocorrem, em certa medida, porque fazemos parte do mesmo campo, onde são travadas disputas de diferentes níveis e graus de responsabilidades. Tais disputas podem ser em relação ao controle e domínio do conhecimento, pelos fundos setoriais e editais internos à instituição, e, no caso mais específico, a disputa política, pelo poder institucional.

Destarte, essas seções da política só terão validade nesta autobiografia se forem considerados esses e outros elementos de análise. No mais, se não fizesse essas considerações, poderia comprometer a identidade na narrativa e, sobretudo, transgrediria uma de suas mais importantes regras, que é o direito à privacidade, segundo Eakin (2019). Logo, na medida em que trago para a narrativa personagens importantes para a compreensão do próprio enredo, de alguma forma, libero para a exposição as identidades de meus colegas, ainda que o faça por meio de pseudônimos surreais e engraçados.

Desse modo, este é um capítulo que cabe bem a ideia do envolvimento e alienação, assim como de ligações afetivas e políticas para uma valência aberta como eu, que vivi numa configuração institucional, algo próximo com que Elias (1998) trata para definir os níveis de controle dos impulsos e certa dose de tensão nas múltiplas situações-perigo em que indivíduos e grupos passam no cotidiano. Parece que a política é um desses campos de tensão constante, aberto e minado.

\section{Para voar mais longe!}

Nós, intelectuais, somos realmente muito engraçados. 'Odiamos a política. Muitas vezes vemos esse aspecto da condição humana como uma aberração da natureza. Lidamos com os eventos e momentos políticos como se nada tivéssemos a ver com eles. No entanto, não nos damos conta de que, pelo menos, entre os professores das universidades federais, foi uma política pública de expansão das IES que permitiu o ingresso de muitos colegas doutores desempregados ao ensino superior.

Além disso, a própria condição que me vejo neste momento, a de pleiteante ao cargo de professor titular, por promoção na carreira docente, deve-se às lutas e greves travadas entre o Governo Federal, na representação de Dilma Rousseff, e o movimento docente. Na verdade é uma reivindicação antiga, já ouvíamos murmurinhos sobre isso desde 1993, quando entrei na Universidade Federal de Uberlândia, mas até 2012 ter essa titularidade só era possível por concurso público. A luta política permitiu a nossa ascensão na carreira. Às vezes, só a política permite voar como águia. 
Numa excelente conferência proferida na Universidade Federal de Pernambuco, a meu convite, em 2017, Saviani, ${ }^{44}$ em sua exposição e também em artigo publicado, disse que "os intelectuais se sentem como uma categoria social à parte", eles se enxergam como se estivessem para além da política. Pelo menos, é assim que eles tentam se mostrar à sociedade, adversos à política. Tentam passar a ideia de que política e ciência não se misturam, ainda que aqui e ali se percebam defendendo uma política para ciência, inovação e tecnologia no Brasil.

A relação entre o intelectual e a política é realmente instigante, não cabendo aqui um debate aprofundado pela natureza deste estudo, cabe, no entanto, refletir por meio do que expressa Saviani (2016), ou seja, "assim, se os intelectuais orgânicos gozam de uma autonomia relativa em relação à classe dirigente a que estão vinculados, os intelectuais tradicionais se sentem portadores de uma autonomia por assim dizer absoluta" (p. 146). Essa autonomia vai muito além de um partido político ou de uma associação docente, por exemplo. Chega, às vezes, aos extremos das relações interpessoais, ao ponto de alguns colegas dizerem que não gostam de política, mesmo praticando-a todos os dias nos corredores da universidade, tentando encontrar um lugar na administração central da instituição em que atuam como docentes.

Desse modo, sei que um docente pode participar da vida político-administrativa da instituição de várias maneiras, como, por exemplo, coordenando um curso de licenciatura ou bacharelado, chefiando um departamento, dirigindo um centro acadêmico, um órgãos suplementar ou uma pró-reitoria ou ainda ocupando o cargo mais alto da universidade, o de reitor. Muito embora a maioria dos colegas que ocupam esses cargos não admitam que jogam o jogo da política institucional, sempre haverá uma relação política mais ou menos estreita com as forças hegemônicas desse campo, onde as teias das relações são inevitavelmente tensas, centro das quais revigora a disputa pelo poder.

Assim, desde quando entrei na Universidade Federal de Uberlândia, em 1993, tenho participado dos debates em torno das disputas de poder exercidas na instituição universitária. Acho que foi uma troca sutil de campo artístico para o político-institucional e só me percebi neste momento, ao relembrar meus itinerários. Em Uberlândia, por exemplo, ocupei meu primeiro cargo, o de chefe de setor. Na verdade, o chamado 'chefe de mim mesmo', pois não tinha nenhum funcionário para que eu coordenasse. Era um cargo pertencente à Diretoria Estudantil, este sim disputado entre os professores e de grande visibilidade institucional.

Nunca entendi direito qual era a função do chefe de setor, mas estava sob minha responsabilidade a organização da entrada de estudantes, sua permanência e saída do Centro Esportivo Universitário, que era uma espécie de clube para estudantes e funcionava aos sábados, domingos e feriados, onde os estudantes tinham acesso a piscina, pista de atletismo, quadras poliesportivas, campo de futebol etc. Às vezes, aproveitava esse momento de chefe para ler um pouco o material da dissertação, pois, na época, eu ainda era professor auxiliar I. Fui esse chefe até 1996, momento da minha ida para o doutorado na Unicamp.

\footnotetext{
${ }^{44}$ Refiro-me à conferência Os intelectuais, memória e política, que aconteceu no Centro de Educação, Universidade Federal de Pernambuco, em 12 de junho de 2017. Compareceram ao evento aproximadamente 1.700 pessoas. Para acomodar tanta gente foi preciso utilizar a quadra poliesportiva do Colégio de Aplicação da UFPE.
} 
Bem, eu cheguei da Unicamp após a realização do meu doutorado, no final de 1998, em dezembro. Naquele mesmo ano, me apresentei no Departamento de Educação Física para a surpresa de todos, pois havia feito o doutorado em dois anos. Passei o ano de 1999 trabalhando normalmente, ministrando, inclusive, as disciplinas Rítmica e Dança e Teoria, Prática e Metodologia da Dança Afro.

Além das disciplinas retomei o projeto de extensão Grupo de Dança Afro da UFU, mas sem o mesmo entusiasmo de antes. Chegando nas proximidades do ano 2000, a UFU estava passando por uma reestruturação em seu estatuto, e o que antes era denominado de Departamento de Educação Física passaria a ser Faculdade de Educação Física. Então, todas essas mudanças requereriam também a necessidade de eleição para a direção dessa unidade administrativa. Portanto, seria a primeira eleição para o primeiro diretor da Faculdade de Educação Física da UFU.

Uma das minhas colegas, a Dinah Vasconcellos Terra, uma pessoa que tenho em boa conta, em virtude de ter sido ela quem me estimulou a prestar o concurso público para a UFU em 1992, ventilou a possibilidade de eu concorrer à direção da Faculdade que se iniciava. $\mathrm{Na}$ época, eu era um dos poucos doutores, acho que naquela ocasião só éramos eu, o Silvio Soares, a Rossana Valéria e o Apolônio Abadio do Carmo, e o doutorado era um dos critérios para a candidatura. Então, sob a coordenação da professora Dinah Terra, me candidatei. Foi a primeira vez em que experimentei essa façanha de disputa na universidade.

A comissão eleitoral, não lembro agora seus membros, pensou em duas possibilidades para a eleição: fazê-la dentro do próprio pleno do antigo Departamento de Educação Física, onde participavam os professores, um técnico-administrativo e um representante discente ou estendê-la para o conjunto do corpo docente, discente e todos os técnicos. Penso que, na primeira alternativa, ganharia com certa folga, pois, curiosamente, após meu retorno da Unicamp, havia adquirido um certo respeito junto aos docentes, mas, na hora da decisão, pensei duas coisas. Primeiro, seria a eleição para o diretor da Faculdade que estava iniciando, um marco na história institucional, portanto, era muito importante que o processo fosse democrático, afinal seria a inauguração de um novo ambiente para a Educação Física, a 'Educa', como todos a chamam carinhosamente por lá. Segundo, pensei em testar a minha popularidade e defendi, entre os professores, a ideia de uma eleição mais democrática, o que acabou sendo a proposta vencedora.

Então, levamos a eleição para a comunidade da faculdade. E a Dinah Terra, enquanto coordenadora da minha campanha, me perguntou se eu gostaria de fazer algum cartaz, panfleto etc. Foi aí que tive a ideia de fazer um banner com mais ou menos três metros e colocar numa das paredes da faculdade, com o meu lema: O voo da águia 2000, Edilson diretor! Isso lembrava um pouco um dos textos que gostava de trabalhar com os estudantes, $A$ águia e a galinha, escrito por Leonardo Boff.

Fomos dois candidatos para concorrer ao cargo, eu e o professor Silvio Soares. E, para acalorar a discussão, foi promovido um debate. Neste, o Silvio me fez uma pergunta interessante e desconcertante, provocado pelo meu próprio lema. A pergunta foi: se você, Edilson, é a águia, quem é a galinha? Fiquei embaraçado com a possibilidade de responder àquela pergunta, porque estavam presentes vários estudantes, professores, técnicos. Naquele momento a quadra esportiva estava lotada e eu não queria, obviamente, dizer que ele era a galinha, até porque não era isso que eu pensava. Então, 
respondi que eu era a águia, mas ele insistiu com a pergunta e foi quando eu percebi que a tática do Silvio foi realmente eficaz e, ao mesmo tempo, engraçada, para que pudesse refletir um pouco mais a respeito.

Recebi aquela pergunta do Silvio como uma das melhores saídas que ele encontrou para o contra-ataque à exposição do banner. Por outro lado, a minha intenção não era, em momento algum, chamar alguém de galinha, apenas era de tentar puxar a memória dos meus ex-alunos, para que eles lembrassem das minhas aulas e a discussão do texto de Leonardo Boff. Assim, eles poderiam lembrar das coisas boas e interessantes discutidas por meio da metáfora do autor e, consequentemente, votar em mim, é óbvio.

Houve a eleição e, na apuração, quando já tinham sido registrados os votos de um terço dos segmentos, percebi que ia perder, então fui para casa. À noite a Dinah ligou dizendo que realmente tínhamos perdido a eleição. Como isso aconteceu em dezembro de 1999, havia planejado passar férias aqui no Recife, então aproveitei, peguei o carro e viajei de férias.

Foi nessa ocasião que visitei o Departamento de Educação Física da UFPE com a minha amiga pedagoga, a Jaraine Neves, que tinha vindo de Ariquemes, Rondônia, para passar férias com a família. A Jaraine foi quem questionou o professor Laranjeiras sobre a possibilidade de uma transferência de um professor doutor da UFU para a UFPE. Laranjeiras respondeu positivamente, mas informou que seria importante conversar com o chefe de Departamento, o professor Jorge Rocha, e entregar um ofício para solicitar a transferência.

Nessa ocasião, entreguei no Departamento o primeiro exemplar da revista Conexões: educação física, esporte e lazer, publicada até hoje pela FEF, da Unicamp, onde eu tinha um artigo sobre Norbert Elias e Max Weber. É bom registrar que a criação dessa revista foi proveniente de uma discussão e decisão política entre os orientandos de doutorado do Ademir Gebara, que ficaram de fora do Congresso/Encontro Nacional de História do Esporte, edição da Gama Filho, em 1998. Ou seja, eu, Ricardo Lucena, Wanderley Marchi Jr. Cleber Sacramento, Fernando Mezzadri, Luiz Alberto Pilatti e Marcelo Proni. A revolta virou revista.

Mas de volta à UFU, foi a perda dessa eleição na Faculdade de Educação Física que impulsionou a minha vinda para o Recife. Aliás, não apenas isso, também havia recebido uma resposta negativa do Programa de Pós-Graduação em Educação Brasileira da UFU sobre meu ingresso como docente do mestrado. A alegação foi um tanto desconexa. O parecer dizia que, apesar de uma produção razoável, os temas que pretendia trabalhar não se adequavam às linhas de pesquisa existentes. Desse modo, mesmo coordenando a minha primeira bolsa de iniciação científica, o desestímulo era total. Assim, aliei todos esses elementos aos problemas pessoais que estava passando com a minha filha mais velha do primeiro casamento e resolvi investir na transferência para a UFPE. Na próxima seção, abordarei as minhas relações políticas na referida instituição de ensino.

\section{SomosTodosUFPE de mãos dadas!}

Ao chegar na Universidade Federal de Pernambuco passei alguns meses sem atividade por conta de alguns arranjos que o Departamento de Educação Física deveria fazer para me acomodar em seu quadro docente. Uma vez resolvida essa pendência, 
passei a ministrar aulas na disciplina Sociologia do Esporte, aliás, criei um laboratório com o mesmo nome para alimentar o espírito acadêmico e enveredar por outras áreas de intervenção e pesquisa.

Todavia, depois de ter sido chefe na Universidade Federal de Uberlândia, só voltei a ter cargo administrativo na Universidade Federal de Pernambuco em 2002, o que foi um bom momento para aprender a lidar com os estudantes e resolver algumas questões relacionadas ao processo de ensino-aprendizagem, visibilidade do curso, além de adentrar no universo burocrático da instituição.

Embora tenha participado da primeira eleição para coordenador do curso de licenciatura em Educação Física, em 2002, e tenha sido coordenador administrativo e diretor do Núcleo de Educação Física e Desportos, o mais inusitado na minha carreira é o fato de ter concorrido ao cargo máximo da instituição, o de reitor, em 2015. É essa disputa eleitoral que mais me impulsiona a falar nesta parte da autobiografia, apesar da relutância em escrever a respeito.

Sem a devida estrutura financeira, conseguimos apresentar um projeto bastante interessante naquele momento, especialmente pelas ideias inovadoras contidas em aproximadamente 48 páginas, construídas a partir da interlocução junto a professores, estudantes e técnicos. Foram três meses intensos, de muitos debates nos departamentos, nos quais aprendi muito sobre a instituição universitária.

A UFPE não é uma ilha como pode parecer à primeira vista. Ela está, obviamente, interconectada por diferentes setores da sociedade; aliás, como todas as instituições de ensino superior. Então, as pessoas têm interesse em saber o que está acontecendo entre seus muros. Dessa forma, chama especial atenção o título da matéria no Blog Inaldo Sampaio, A Política com "P" Maiúsculo, para anunciar um pouco do cotidiano institucional, principalmente, o debate político que estava se iniciando em fevereiro de 2015. Assim, trago um excerto de sua matéria, agora na íntegra:

Professor de origem negra entra na disputa pela Reitoria da UFPE

Em que pese o favoritismo de [DBDA] para ser reconduzido ao cargo de reitor da Universidade Federal de Pernambuco, a campanha ficou mais animada neste final de semana com a entrada de mais um candidato na disputa. Trata-se do professor Edilson Fernandes, que lidera o movimento "Somos todos UFPE". Com ele, agora são cinco os candidatos ao cargo de reitor da maior universidade de Pernambuco. Caso venha a ser eleito, Edilson Fernandes seria o primeiro reitor negro da história da UFPE. ( $A$ Política..., 2015)

Como está explícito, o jornalista reafirma o favoritismo do DBDA, reitor na época, que acabou realmente ganhando a eleição para mais quatro anos, e enfatiza minha origem afrodescendente como um dos diferenciais entre os candidatos. Confesso que o nosso material de campanha não ressaltava esse aspecto étnico-racial, afinal sempre pensei que o principal era debater o projeto de universidade e modelo de gestão. Entretanto, esse destaque dado pelo Inaldo Sampaio serviu para embasar algumas críticas de apoiadores de outros candidatos que quiseram me atribuir o estigma de vitimização. Se não me falha a memória, foi a primeira crítica que recebi de um dos professores, o Túrbido, do Departamento de Genética, embora vários colegas dessa unidade tenham pensamento exatamente contrário e, consequentemente, depositaram apoio e confiança no projeto que eu apresentava. 
Guardadas as devidas proporções o texto também reposicionava um elemento histórico no contexto institucional, era o fato de que se eu fosse eleito, seria o primeiro negro a dirigir uma das maiores universidades do país. Aliás, sempre ouvi de um colega bem próximo que a UFPE é o terceiro orçamento do Estado, ou seja, quem a dirige é o "terceiro homem mais poderoso de Pernambuco". A fala dele sempre remeteu ao preconceito, como se um negro não fosse capaz de gerir um orçamento de 1,3 bilhão ou não tivesse liderança para conduzir a universidade. Não sei se ele diz isso porque acha mesmo que o reitor é de fato poderoso ou porque acha que esse lugar de poder não me caberia por ser negro, ou as duas coisas juntas.

Voltando à matéria, eu liderava um movimento bastante significativo nesse contexto de injustiças, preconceito e discriminação e isso fazia e fez muita diferença quando percorríamos os três campi e disseminávamos as ideias contidas no documento produzido pelo movimento SomosTodosUFPE, que conseguiu chegar ao segundo turno, pela primeira vez na história da Universidade Federal de Pernambuco.

Figura 567 -

Propaganda eleitoral para reitor, 2015

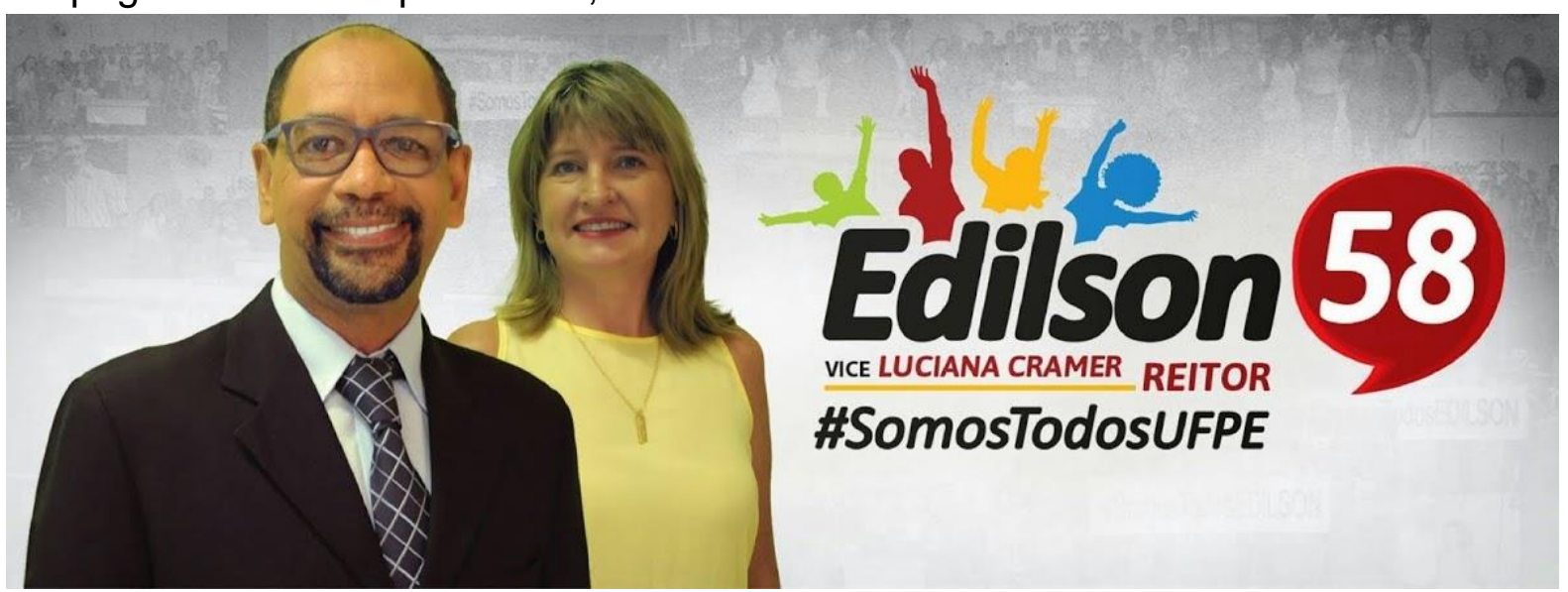

Fonte: http://somostodosufpe.blogspot.com/.

O movimento tinha como pressuposto a equidade como uma condição essencial para o desenvolvimento de uma das mais importantes universidades brasileiras e a maior e mais importante instituição do Norte e Nordeste. Nosso crescimento político foi inevitável, até chegamos ao segundo turno, embora tivéssemos passado por muitas humilhações desnecessárias em virtude da disputa pelo poder. Alguns jogaram baixo e muito sujo.

No fundo, todos que fazíamos parte desse momento éramos mesmo outsiders e sabíamos disso. O nosso sentimento era, como ainda é para alguns, que embora sejamos docentes, ocupamos uma 'categoria um pouco abaixo' do que realmente deveríamos ocupar dentro da universidade. Percebemos que negros doutores, oriundos das classes populares, professores de Educação Física, e com articulação estreita na área de Humanas, ainda são mal vistos em alguns setores da instituição.

Como pude experimentar no meu próprio lombo esse campo acadêmico resguarda uma infinidade de símbolos, que não devem ser ameaçados por alguém que ainda está por construir seu habitus científico. Muitos colegas intelectuais diziam que eu não tinha produção suficiente para submeter uma candidatura daquela envergadura. Entretanto, um

\begin{tabular}{|l|l|l|l|l|l|} 
Regae: Rev. Gest. Aval. Educ. & Santa Maria & v. 10 & n. especial & e66773, p. 1-325 & 2021 \\
\hline
\end{tabular}


dos nossos apoiadores, o professor Wellington Pinheiro, que considero um dos mais inteligentes da nossa turma, na época, tratou de fazer uma pesquisa a partir do Currículo Lattes dos cinco candidatos.

Os resultados foram surpreendentes. Dos cinco candidatos naquela ocasião eu era o responsável pelo maior número de artigos, livros, capítulos de livros, orientações de mestres e doutores etc. Portanto, o preconceito se fazia circular livremente entre os acadêmicos, muitos dos quais apontados como progressistas, mas, na verdade, estimulados e estimuladores do racismo institucional. Contudo, em meio às disputas pelo poder e a possibilidade de ocupar o cargo mais alto da instituição, consegui, junto com os apoiadores, chegar ao segundo turno, um acontecimento inédito.

Frente a esse resultado parcial, a UFPE não seria mais a mesma desde a sua criação, a partir da Faculdade de Direito, em 1827. Assim, por meio do movimento que representei, foi acrescida a uma das mais importantes universidades do país fontes de relativa visibilidade, onde os outsiders, como eu, passaram a ter registro histórico na disputa pelo poder institucional.

Figura 57 -

Matéria de jornal sobre disputa ao cargo de reitor, 2015.
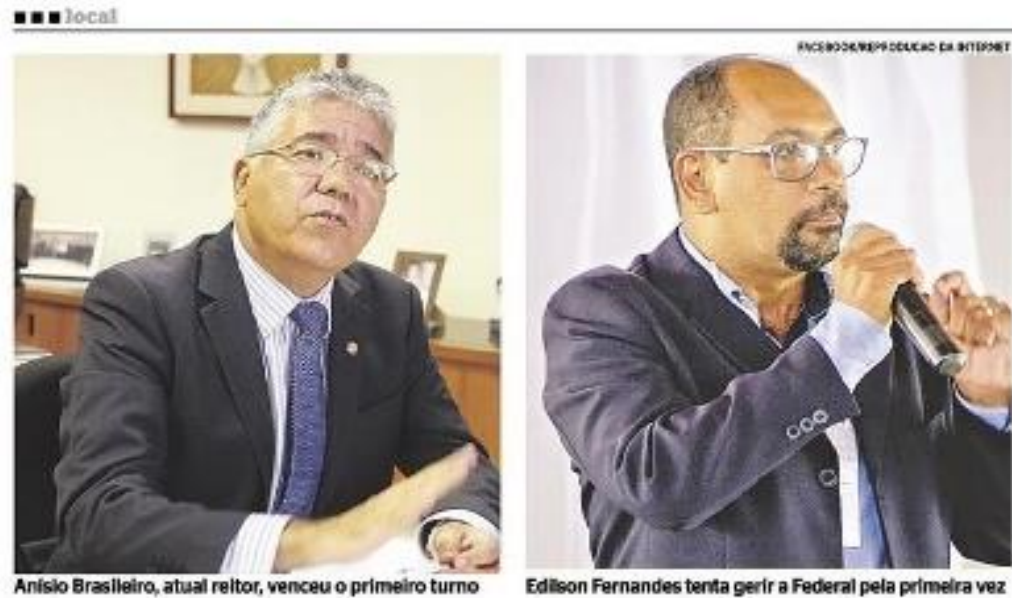

\section{UFPE tem disputa histórica pelo cargo de reitor}

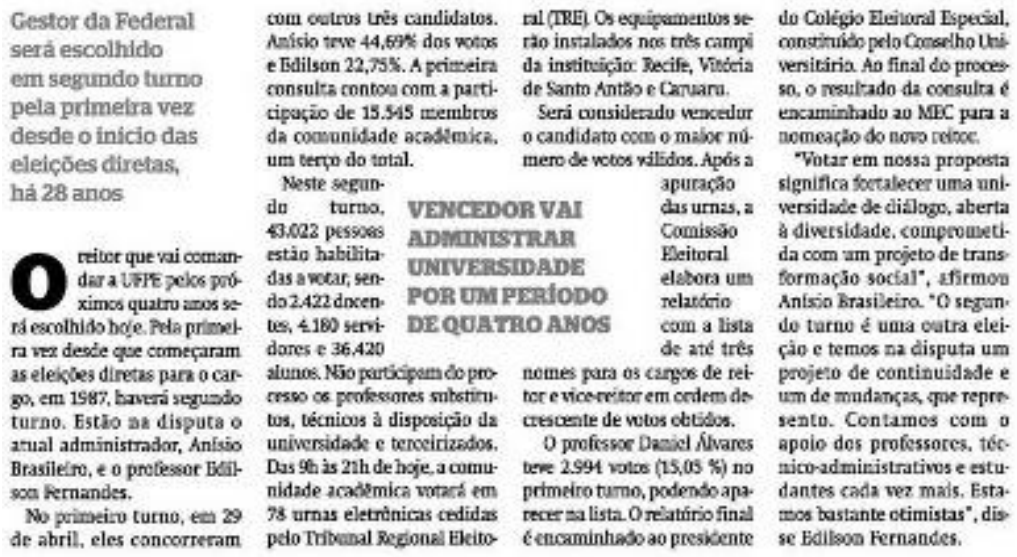

DIARIO IEPRNAMBUCO

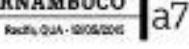

\begin{tabular}{|c|c|}
\hline A UPPE em nümero & \\
\hline 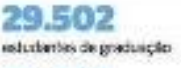 & \\
\hline 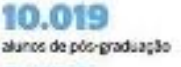 & \\
\hline $\begin{array}{l}2.590 \\
\text { protansers }\end{array}$ & aromede gratingto \\
\hline $\begin{array}{l}4.184 \\
\text { senidoss therico. } \\
\text { sominetrotine }\end{array}$ & $\begin{array}{l}134 \\
\text { carcos de psanjocuspso } \\
\text { striobo serse }\end{array}$ \\
\hline 3 & $\begin{array}{l}56 \\
\text { arom de pis gastiscter into } \\
\text { sersu }\end{array}$ \\
\hline 12 corrses sessemicos & 464 \\
\hline
\end{tabular}

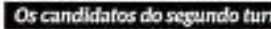

Chapa 56 Anscas einorrmes Viso resitona Foribel: Cimpes

Ankosanstens

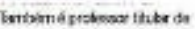
oresnoara inm plestoutant rolsborstive Tolnous. tomilbens e: Sociktt (fFrig

Hogseraciupos

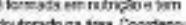
a criecte do carous de vintists

Peopostne:

- Nortera inkeditos pano irstivesso de soblide podutsado

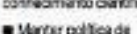
reveon parmatrazed

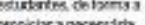
pecpiciranoressirs.

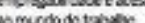

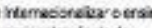

incievmentros

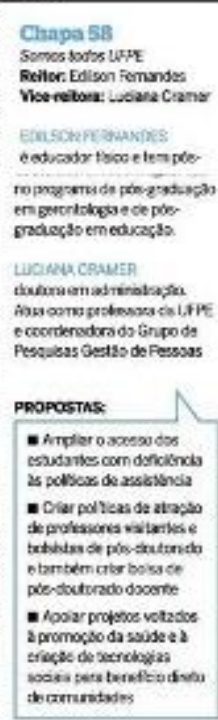

Clrapa 58 Feitor Edison Fom notretora: Woan Cans coprestade gradersto emeducasts. LOUR CRMER Lamasmadnatapas ecrortensatrade finproda Pesajeas Gestis de Fessoss

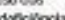
collsex de rescisondia

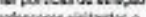

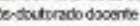
momoso da soudes 2

Fonte: Agência de Notícia/UFPE/Clipping/Diario de Pernambuco, 2015, p. a7. 
Nessa disputa histórica a qual se refere o título da matéria, ocorreram vários debates acerca da instituição, mas, pelos corredores e por onde margeavam esse campo aberto, foram muitas notícias falsas, tal qual uma eleição majoritária em qualquer prefeitura ou governo estadual. Confesso que mesmo há algum tempo participando da política institucional, tanto na UFU, quanto na UFPE, colaborando com candidatos ou como espectador, eu nunca havia presenciado tamanhos absurdos pelo poder, ao ponto que até um senador da República, do PT, se envolveu na campanha contra a minha candidatura, ou seja, a disputa pela Reitoria da UFPE virou problema nacional. Era o que se ouvia nos bastidores.

Como dizem na política, a máquina trabalhou muito para ganhar do SomosTodosUFPE. Eram visíveis o empenho e o envolvimento de muitos colegas que ocupavam cargos de confiança do reitor no cotidiano da campanha, em seu horário de expediente. Muitos deles, anteriormente meus incentivadores, estavam acovardados pelo poder da máquina. Muitos até ensaiavam vaias contra mim durante os debates.

O resultado político foi satisfatório para o meu grupo de apoiadores, mas, pessoalmente, o desgaste físico e mental foi sem precedentes. Emagreci uns dez quilos. Só consegui me recuperar depois de uns sete meses, com alimentação bem à moda da mamãe: feijão, arroz, ovo frito, carne de boi, salada de rúcula e duas ou três garrafas de Malzebier por dia. Acabei engordando mais do que deveria. Porém, superada a tormenta eleitoral e as sequelas de emagrecimento, voltei às atividades normais de docente.

Outro aspecto que eu gostaria de registrar é a minha participação na gestão da Universidade Federal de Pernambuco. Reconheço que é um salto razoável na narrativa, considerando o que tenho dito até o momento, mas gostaria de comentar um pouco sobre minhas decisões em ser candidato a reitor num momento em que eu estava fazendo uma excelente gestão à frente da Pró-Reitoria de Extensão. Pelo trabalho desenvolvido nessa unidade administrativa, algumas pessoas diziam que eu era uma espécie de líder servidor, que estava sempre pronto e preparado para ajudar a comunidade acadêmica, chegando até a receber um certificado de agradecimento pela gestão que estava desenvolvendo.

De certa forma, eu me envolvi tanto com essa experiência na gestão que, como paradoxo, isso me levou a não querer mais continuar com o trabalho. Resisti o quanto pude para não ser candidato a reitor. Nessa época eu tinha bastante visibilidade e ficava feliz pelos elogios recebidos por vários membros da comunidade acadêmica. Além disso, tinha uma remuneração razoável, uma gratificação significativa, assim podia viajar pelo Brasil e outros países representando a instituição. Estava vivendo intensamente a vida institucional e isso reverberava positivamente. Evitei o máximo que pude, cerca de dois anos, mas os colegas do meu grupo político insistiam como num mantra: você tem que ser candidato, você tem que ser candidato. Então, passei a considerar e, em seguida, aceitei a ideia.

Ao ser candidato, várias pessoas que me incentivaram durante um bom tempo acabaram sumindo antes e durante a campanha. Eu diria que, até hoje, algumas continuam sumidas e outras tragadas pelo poder. Não sei o que houve. Inclusive, algumas, na época, apareceram com a camisa dos adversários, vai entender a cabeça 
desse povo. Aliás, campanha na UFPE é exatamente igual a de qualquer vereador ou deputado. Às vezes, quem dá mais, leva! Todavia, para um ambiente de intelectuais, isso parece muito estranho.

Algumas pessoas que considerava parceiras da política, até partidária, participaram da inscrição da chapa, mas sumiram também, não fizeram campanha, e só retornaram depois de dois meses do pleito, para fazer a bendita avaliação. Então, eu como candidato a reitor, passei por momentos muito difíceis, por vezes me senti sozinho com minhas angústias de candidato, especialmente quando voltava para casa. As críticas que recebia eram muito pesadas e infundadas, inclusive, eu me sentia sem o respaldo de uma orientação política e partidária, ao contrário de outras campanhas que dissimulavam o partido, mas eram financiadas por ele.

Digo isso porque eu era de um partido político, embora não seja necessário ter filiação partidária para ser reitor da universidade. No entanto, como vários colegas meus que eram de um partido e participaram da tomada de decisão da candidatura, eu esperava que o partido que eu era filiado, no mínimo, pudesse me ajudar no início da construção da carta-programa, das táticas políticas eleitorais, na divulgação da nossa candidatura e na defesa da candidatura do ponto de vista externo da universidade. Infelizmente, isso nunca aconteceu.

Entretanto, ganhei uma participação mais ativa da Associação Nacional de PósGraduandos no segundo turno, quando alguns colegas vieram de São Paulo e se instalaram no Recife. Aqui eles passaram as duas semanas que antecederam o segundo turno e fizeram um excelente trabalho.

Um outro dado que eu gostaria de deixar registrado é a capacidade hipócrita de alguns colegas defenderem publicamente uma coisa e nos bastidores fazerem outra totalmente diferente, sobretudo, do ponto de vista de preconceito étnico-racial e acadêmico-científico. Tentaram levantar falsas celeumas, porque sou de Educação Física e atuo nos programas de pós-graduação em Educação e de Gerontologia, mas muitos pareciam não entender a interdisciplinaridade presente nessa relação, bem como a capacidade de um intelectual como eu tem de pesquisar e escrever sobre vários assuntos.

Num debate político como estive envolvido, há de se ter muito cuidado porque percebi a tentativa de alguns colegas provocarem meu desequilíbrio emocional para que eu perdesse a razão no trato com os outros candidatos. No fundo, em minha percepção, quiseram me usar de bode expiatório ou balão de ensaio para lograr êxito no futuro muitas vezes, incentivados por interesses escusos - e nem sempre eu percebi; outros colegas me incentivaram para proveito próprio. Esses elementos são muito complicados, vivi-os nesse momento eleitoral, mas outras pessoas poderiam passar por isso também.

Nesse processo encontrei vários colegas que me ajudaram, alguns sem interesse aparente, até mesmo sem terem sido formalmente convidados. No entanto, por vezes, essas colaborações voluntárias se excederam e cometeram erros, provavelmente genuínos, mas que levaram, por exemplo, à explicitação da nossa tática de campanha. Um desses erros foi coletivo. Nessa época de campanha fotografávamos tudo e todos, em qualquer lugar por onde passávamos. Depois, percebemos que, consequentemente, os adversários vinham juntos, sobretudo o detentor da máquina, o próprio reitor, candidato à época, e acabavam convertendo nossos votos. 
De modo que aconteceu de alguém chegar querendo ajudar e nós colocarmos seu nome na internet como um de nossos apoiadores. A partir daí, a equipe do outro candidato, que tinha uma máquina muito pesada, ia conversar com essa pessoa, questioná-la a ponto de ela retirar seu apoio à nossa campanha. Considero que foram cometidos erros táticos como esse e ainda outros relacionados à publicidade das propostas do nosso projeto de gestão.

Tínhamos um texto com quarenta e poucas páginas, com várias propostas que fomos acrescentando ao longo desse trajeto de três meses. As propostas iam surgindo e publicávamos quase que simultaneamente, só que boa parte dessas propostas acabavam sendo contestadas pelos outros candidatos, porque, no fundo, eles não tinham propostas e viam uma alternativa de esconder essa realidade criticando as nossas. No entanto, como não tínhamos tempo de elaborar uma boa argumentação, perdíamos apoio e tempo.

Um bom exemplo foi a proposta de que as refeições do Restaurante Universitário custassem $\mathrm{R} \$ 1,00$. Até hoje essa é uma proposta exequível, várias universidades brasileiras, inclusive aqui no Nordeste, têm refeições no $R U$ por $R \$ 1,00$. Às vezes, por $R \$ 1,50$. Essa ideia surgiu numa das nossas conversas com estudantes, fizemos um levantamento das universidades, vimos que havia possibilidade para aplicação e pedimos segredo à nossa turma, mas um colega, simplesmente, resolveu publicar porque achava que era uma excelente proposta para os estudantes. O resultado foi que, por isso, levamos muita porrada.

Outra proposta que recebeu uma avalanche de questionamentos, até pela internet, foi o kit para estudantes de Odontologia, que seria uma maleta com instrumentos e insumos dentários, para estágios e acompanhamentos das aulas. Inclusive, depois, resolvemos estender essa ideia a outros cursos, como, de Arquitetura, para equipamentos de desenho e pintura, de Medicina etc. Mas fomos severamente combatidos pelos adversários e perdemos muito tempo rebatendo as críticas em vez de nos concentrarmos na campanha. Além disso, também tivemos problemas com nossa proposta para a iluminação pública da universidade. Nós pensamos em instalar painéis solares, para termos economia de energia e, como benefício, uma energia limpa, mas, em virtude dos altos custos dessa tecnologia, as pessoas questionaram bastante de onde viria 0 financiamento.

Nesse contexto um de nossos piores erros táticos, foi nossa falta em colocarmos em xeque a gestão que o DBDA já estava fazendo como reitor. É verdade que tive minhas razões, uma vez que eu estava saindo da gestão para concorrer com aquele candidato que era meu ex-chefe. Inclusive recebi críticas por isso. Também não quis ressaltar, em nenhum momento, o excelente trabalho que fiz na Proext, porque, talvez, o argumento que seria utilizado fosse o de que tudo o que foi realizado estava sob a sua anuência. Embora soubéssemos que não foi nada disso que aconteceu, sempre atuei de forma autônoma na administração central e isso foi o motivo de ter dado certo. Então, não confrontei a gestão do DBDA, as minhas únicas críticas pesadas foram duas, sendo: a gestão do improviso e o estorno de $\mathrm{R} \$ 290$ milhões aos cofres do Governo Federal.

A ideia da gestão do improviso foi apresentada no campus de Vitória de Santo Antão e foi interpretada equivocadamente, porque, segundo o vice-diretor na época, eu estava ofendendo todo o campus de Vitória de Santo Antão. Claramente, não era essa minha 
intenção, eu estava falando que a gestão do DBDA era do improviso porque não conseguia aplicar os planos institucionais como elaborados. Inclusive, esse debate que lembro ocorreu na quadra do curso de Educação Física, onde havia muitos papelões pregados para proteger da chuva e do sol, como se ali fosse um casebre, como ainda parece estar até hoje.

Sobre o estorno, comentamos no segundo turno que o DBDA havia devolvido em três anos cerca de $\mathrm{R} \$ 290$ milhões de reais. Essa crítica, em particular, gerou um rebuliço grande dentro de nossa equipe, porque muitos não sabiam qual era o fundamento dessa afirmação. $O$ fato é que esse dado foi colhido do Portal da Transparência Brasil, que trata da gestão pública, e apenas um dos nossos apoiadores teve acesso.

De qualquer forma, isso também deve ter causado um certo transtorno à campanha do DBDA. Imagino, inclusive, que a campanha tenha ficado ameaçada para o segundo turno. De posse desses dados citei esse possível estorno do erário em alguns debates, inclusive na TV Universitária e no Centro de Artes e Comunicação.

Considerando todas as dificuldades, conseguimos fazer uma excelente campanha. Enquanto candidato sempre estive ciente do que estava fazendo. Naquele momento eu era um conhecedor dos problemas da universidade, primeiro, pelo fato de conhecê-la quando estava no cargo de pró-reitor; segundo, porque me preparei bastante, estudei para ser um candidato. Apesar disso e de me sentir um candidato forte e de grande visibilidade, eu também me senti injustiçado, porque queria fazer um debate em torno da gestão pública de ensino superior, desde a concepção de universidade, a internacionalização e a interiorização até os problemas cotidianos dos projetos e programas de pesquisa e extensão, o ensino e captação de recursos por meio das patentes. Era tudo isso que gostaria que fosse debatido.

Contudo, o debate foi puxado para baixo, para a minha desconstrução enquanto candidato. É inegável que você vê muita desonestidade numa eleição para governador, deputado, prefeito ou presidente da República, mas eu nunca esperava que isso fosse acontecer dentro da universidade, principalmente porque eu tinha participado de outras eleições e apoiado candidatos na UFU. Inclusive, já havia apoiado, na UFPE, o ex-reitor AHPL, mas em sua candidatura isso não aconteceu.

$\mathrm{Na}$ verdade, apoiei o AHPL na segunda e terceira vez em que ele foi candidato. Eu o apoiei fortemente na primeira gestão, no momento em que ele trouxe para a UFPE o Projeto Reuni. Naquela época, 2007, o grupo do DDR, alguns professores, que dirigiam a Adufepe, estudantes e técnicos foram contra esse projeto de expansão da universidade e acabaram ocupando a Reitoria por vários dias, um mês e meio ou dois meses.

Em virtude dessa ocupação, o AHPL passou a despachar numa das salas do Centro de Convenções da UFPE, então, eu e o professor Arguto Silvério articulamos junto com o Movimento Estudantil Secundarista e a União da Juventude Socialista uma passeata no eixo central da Universidade, na Av. Professor José Rêgo, bem próximo à rotatória da BR101. Com um megafone, gritávamos que queríamos estudar na melhor universidade do Nordeste. Era um contraponto a aqueles que ocupavam a Reitoria naquele momento. Trago essa lembrança para explicar que o apoio não foi apenas no período eleitoral, foi durante toda a gestão. 
Curioso é que a ocupação ocorreu um dia antes da posse do AHPL na segunda gestão. Assim, a posse foi suspensa até que o impasse fosse resolvido, o que demorou vários dias. Inclusive, a polícia federal foi chamada e, para acompanhar essa situação, estiveram presentes alguns políticos renomados e a Secretaria dos Direitos Humanos da OAB.

O projeto Reuni visava promover a expansão da universidade; como consequência, teríamos mais vagas para professores e técnicos, para estudantes, abertura de novos cursos etc. Foi com esse projeto que a UFPE construiu os campi de Caruaru e de Vitória de Santo Antão. No entanto, o grupo mais à esquerda, dirigido pelo DDR e EVVM, mostrou-se contrário a tudo isso, sob o argumento de que não teria havido, como realmente não lembro de ter, um amplo debate no Conselho Universitário e na comunidade acadêmica sobre a importância e impactos do Reuni em nossa instituição.

De todo o modo, eu e o Arguto Silvério atuamos no contraponto ao movimento de ocupação da Reitoria. Na época, ele era recém-chegado à UFPE, mas já estava bastante envolvido com a política institucional. Então observe que nosso trabalho na universidade é propositivo, trabalho acadêmico e político. É irrefutável que exercemos uma certa liderança, mas eu não encaro como liderança única, porque, obviamente, não somos os únicos líderes.

Sei das nossas dificuldades, mas, de algum modo, também sei que nós estamos sempre na vanguarda de alguns movimentos em defesa da UFPE, defendendo os interesses do professor e aquilo que a sociedade brasileira precisa e merece, porque, além de professores e pesquisadores, somos também políticos, ainda que a maior parte da comunidade acadêmica não queira enxergar ou admitir a política entre os intelectuais.

Nesse contexto, gostaria de registrar que, além de ter apoiado o AHPL, também apoiei o DBDA, que ganhou na primeira vez em que se candidatou, e ocupei o cargo de pró-reitor de extensão por conta da minha atividade na campanha do DBDA. De qualquer modo, ao me lançar candidato a reitor, nunca tinha visto uma situação como aquela, a tentativa de destratar o outro e desconstruir o ser humano. Então, com isso, apesar de me sentir aviltado, tentava não demonstrar publicamente, mesmo que meu sentimento fosse de revolta e de vergonha pelo outro, que me destratava nas redes sociais.

Foram dias muito complicados, mas eu não pensei em desistir, apenas busquei algo que pudesse contornar os problemas que circundavam a campanha, especialmente as fake news. Na época, eu já conseguia ver que tudo estava fora do meu controle. No entanto, algo apareceu no final do túnel, um alento, a crônica da Maria Helena, já referida anteriormente. A fotografia que exponho a seguir acompanhava o texto elogioso sobre o meu profissionalismo. É o registro do último debate do primeiro turno em 2015, no Colégio de Aplicação da UFPE. 
Figura 58 -

Fotografia como candidato a reitor, debate no Colégio de Aplicação, 2015.

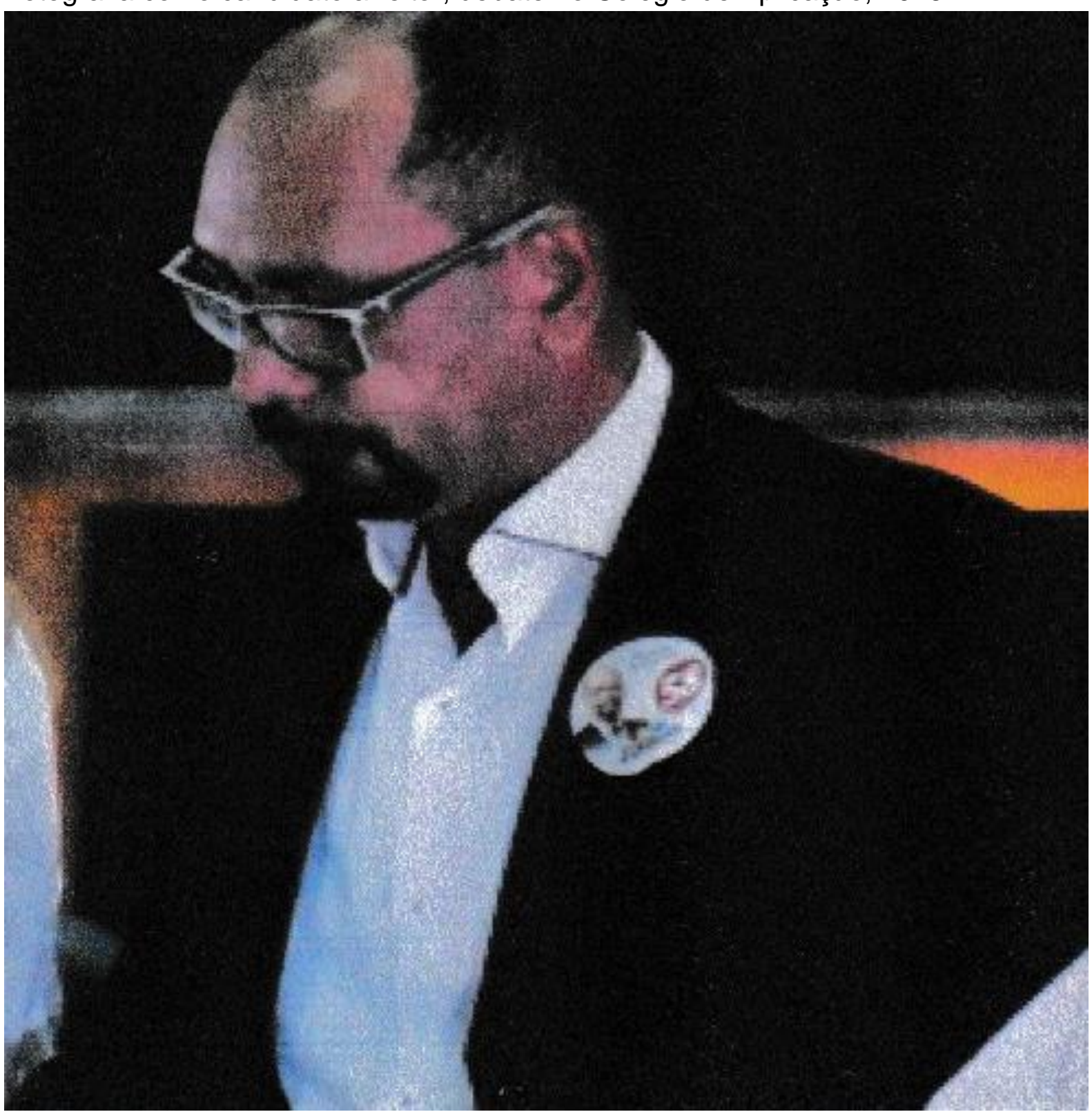

Fonte: https//gargalhadaslagrimas.files.wordpress.com/2015/04/edilson-souza.png

Talvez não seja possível ver em meu semblante, mas, naquele momento, eu já sabia que algo de ruim estava por acontecer em relação à candidatura. Passei por instantes complicados e, em momento algum, chamei a atenção pública para o que estava vivendo, experimentando o ódio alheio. Acho que é a primeira vez que estou falando abertamente sobre isso, mas, na época, fiquei muito abalado psicologicamente e não conseguia falar sobre o assunto. Acho que superei; inclusive críticas de pessoas que jamais poderia imaginar que teriam a capacidade de levantar falso testemunho, destilar seu ódio e preconceito sobre minha candidatura.

Eu até devotava certa admiração por algumas dessas pessoas, pensava que eram realmente amistosas e civilizadas, mas, inevitavelmente, elas estavam mesmo expondo seus sentimentos mais negativos, ódio e preconceito racial. Algumas dessas pessoas se revelaram hipócritas. Contudo, passado esse tempo, mais ou menos quatro anos, depois 
desse relativo distanciamento, vejo que isso não é novidade dentro da instituição, afinal é um ambiente constituído por pessoas que fazem parte da sociedade, a qual construímos todos os dias. Eu e você, leitor. Todos nós, até mesmo os hipócritas. Todos nessa rede de relações confusas.

A universidade não é um simples espelho da sociedade, é a própria sociedade em movimento dentro de um determinado ambiente, é a sociedade nas interrelações sociais, educacionais e políticas. Por isso, a universidade, ou melhor, as pessoas que vivem nesse ambiente acabam produzindo e reproduzindo valores sociais dos mais diversos. Guardadas as devidas proporções, tenho muita clareza hoje que não é porque o cara é intelectual, que é um pesquisador renomado, que não tem sentimentos menos nobres. Muitas vezes, num cenário de tensão como o mencionado, um momento de disputa pelo poder institucional, na luta pelo domínio e controle do simbólico ou de um ambiente propício a aquisição de capital cultural, as pessoas se revelam os piores dos monstros.

É num contexto de disputa pelo território institucional que alguns intelectuais deixam fluir a monstruosidade que tem dentro de si, tentando destruir o outro na tentativa de controle do espaço, na disputa não só pelo conhecimento e saber científico, mas pelo poder da instituição, o domínio pelo poder da hierarquia institucional ou, pelo menos, pelo controle histórico construído pela instituição ao longo de sua existência.

Assim como outras universidades federais, a UFPE também surgiu a partir de famílias tradicionais, por pessoas abastadas, da elite econômica oligárquica. Há um elemento de crise profunda dos detentores desse poder em mantê-lo a qualquer custo, ainda que seja a distância e por incentivo aos que melhor se assemelham em comportamento e interesse.

Curioso é ter a certeza de que pessoas que agora são intelectuais e gozam de certo prestígio acadêmico, já foram humildes e também se arvoram no direcionamento do ódio e preconceito, é como se eu servisse de espelho para aquele indivíduo que não quer se ver. A UFPE surgiu a partir da Faculdade de Direito, em 1827, depois temos as Faculdades de Farmácia, Medicina, Engenharia etc., ou seja, foi a elite econômica que criou tudo isso, não foi o cidadão comum, desprovido de recursos, um proletário, gente do povo.

Embora toda a tentativa de criação que envolve a UFPE ter um pensamento autônomo em relação à Igreja, como constata a historiografia das instituições com as mesmas características, foi a elite religiosa quem a criou. Então, acredito que os preconceituosos e racistas de plantão pensam: 'como um negro, vindo de um curso sem expressão acadêmica, defende ideias inovadoras numa Universidade tradicional como a nossa?'. E foi esse sentimento que acabou aflorando no contexto eleitoral, alguns desses desejos e impulsos violentos que estavam reprimidos, guardados, acabaram por aflorar naquela disputa política.

Todavia, vou repetir, até mesmo pessoas oriundas das classes populares, professores e técnicos, egressos de escola pública, também se revoltaram contra a minha candidatura, e isso é interessante do ponto de vista psíquico-social, porque é como se eles se vissem e não quisessem ser vistos no 'espelho que reluzia' em meio ao debate político institucional. De qualquer modo, as urnas mostraram que fizemos uma boa 
campanha, tivemos visibilidade e me projetei ainda mais na UFPE. O resultado político foi excelente e o eleitoral também, com mais ou menos 5.650 votos, com aproximadamente 2.000 votos de diferença do primeiro colocado.

Contudo, numa disputa como essa, há sempre a necessidade de se preparar física, psicológica e espiritualmente. Caso contrário, acaba-se no meio do caminho, no meio do campo vazio da instituição, com o seu habitus extremamente exposto.

Após quatro anos, uma nova eleição se apresenta na peleja da Reitoria. Como me posicionei frente a esse desafio? Como os colegas que contribuíram com o projeto em 2015 se comportaram em relação ao projeto SomosTod@sUFPE, a ser defendido em 2019? É o que veremos na próxima seção.

\section{Largaram as minhas mãos!}

As experiências dentro e fora da instituição universitária são realmente muito interessantes quando observamos o comportamento das pessoas frente a algumas situações, assim como verificamos as nossas próprias iniciativas diante dos desafios. Então, o que aconteceu comigo em 2019, do ponto de vista político, dentro da UFPE, foi algo que eu considero um tanto inusitado. Talvez, por ser um acontecimento muito recente, ainda não me sinta à vontade para falar sobre o assunto ou até mesmo registrar a experiência.

De qualquer maneira, cabe algumas reflexões acerca do meu comportamento e posicionamento político dentro da instituição universitária, bem como as tensões que entremeiam o possível enredo nesse ambiente, onde vivem os expertos que produzem conhecimento. Logo, a emergência de estudos sobre trajetórias acadêmicas pode ser uma excelente oportunidade para se dizer ou contar algo sobre a vida cotidiana que, sem nenhum aporte teórico, seria praticamente impossível.

Estudos como os de Franklin (2009) corroboram a assertiva de que as narrativas de docentes, por exemplo, constroem um espaço de liberdade para tratar assuntos mais tensos do que os de costume. Assim,

uma das contendas centrais [de seu livro] é que as memórias fornecem insights cruciais sobre a política acadêmica porque, numa oferta de espaços que são mais flexíveis que as ofertadas pelas teorias, [os professores] podem exibir contradições entre o pessoal e o político sem ter que conciliá-las. (Franklin, 2009, p. 2) ${ }^{45}$

Essas reflexões da autora são importantes no conjunto das memórias de professores e o seu ambiente acadêmico, entretanto, concordo só parcialmente com a sua fala, visto que a conciliação existirá na medida da própria narrativa, onde balizamos informações acerca deste ou daquele personagem. Então, há de se conciliar sempre, até na medida da quantidade e qualidade da informação a respeito dos eventos políticos e sua trama. Semelhante à minha percepção sobre a experiência que vivi publicamente ou nos bastidores da política institucional.

\footnotetext{
45 One of this book's central contentions is that memoirs afford crucial insights into the academy because, in offering spaces that are more musing and pliable than those afforded by theory, they can display contradictions between the personal and political without having to reconcile them (Franklin, 2009, p. 2).
} 
Nesse sentido, a conciliação existirá na composição de cenários e personagens reais, mesmo que seus nomes sejam fictícios, como faço aqui, e na reconstrução da narrativa, contada de forma escrita, mediada por códigos linguísticos. Assim, a percepção do que ocorreu comigo na eleição para reitor da UFPE em 2019 é regada por um misto de sentimento de dever cumprido, autoconfiança e descuido da teia das relações políticas.

Foi emocionante uma das reuniões que participei com um professor e seus alunos, no Centro Acadêmico de Vitória de Santo Antão, cheguei até a chorar quando os vi, num dia de sábado, ensaiando a peça Rei Leão em Língua Brasileira de Sinais. Confesso que a emoção foi mais em virtude de eu ter lembrado dos muitos finais de semana e feriados que ensaiava no Rio de Janeiro que do momento político que estava por vir. Além de gostar do que fazia naquela ocasião, entre 1985 e 1992, havia a necessidade de sobrevivência. Por isso, chorei. Entretanto, percebi que precisava me recompor e falar de política, razão da minha visita àquele campus acadêmico.

A forma como vou abordar o assunto parece filme ou coisa de novela. Pelo menos, é assim que penso. A minha percepção a respeito disso, gira um pouco em torno da teoria da conspiração, da categoria conspiratória que subjaz os elementos ou a experiência vivida recentemente. É impressionante como determinadas pessoas próximas a mim, ou que compartilharam comigo o mesmo grupo de pesquisa, que precisaram do meu nome ou do meu Currículo Lattes para captação de recursos públicos e galgar um certo espaço acadêmico, não me acompanharam nesse novo projeto em 2019.

Algumas delas já haviam dito que iriam me apoiar, ainda que não o fizessem publicamente. Porém, iriam votar, pelo menos. Contudo, essas mesmas pessoas, umas três ou quatro, não me apoiaram, conforme haviam dito, mas fizeram publicamente campanha contra o projeto que eu defendia. Não apenas fizeram campanha para o outro candidato, para o JBS Santo, não mais parceiro, diga-se de passagem, mas também fizeram campanha contra mim, inclusive, no próprio Departamento em que atuo no momento.

As fake news também foram divulgadas por esses colegas, que disseram absurdos nas salas de aula do curso de Educação Física. Propalaram a ideia de que a candidatura que eu defendia era oportunista, um projeto pessoal e inclusive que, caso eu fosse eleito, não seria nomeado pelo Governo Federal. Ou seja, fizeram o contrário do que haviam me dito e, consequentemente, tentaram distanciar o projeto ${ }^{46}$ que eu defendia desde 2015 da comunidade universitária. Acho que conseguiram.

Mesmo quem assistia de longe à movimentação eleitoral na UFPE percebia o meu isolamento às margens de um grupo que havia trabalhado comigo fortemente na eleição de 2015. Contudo, não me deixei abater. Contei com a minha experiência, relativamente bem-sucedida de quatro anos atrás e me mantive firme em todos os debates. Aliás, no primeiro deles, que ocorreu no Centro Acadêmico do Agreste, já deu para se ter uma vaga ideia da tragédia eleitoral que estava por vir.

${ }^{46}$ Os marcos centrais do projeto de universidade defendido podem ser encontrados num artigo publicado nos anais do II Congresso da Associação dos Docentes da Universidade Federal de Pernambuco (Adufepe), em outubro de 2018. 
Nesse primeiro debate, cheguei uns cinquenta minutos atrasado. Achei legal os outros candidatos esperarem para começarmos a discussão. $O$ atraso foi em virtude de uma agenda em busca de apoio, que não se consolidou. Quando anunciaram os candidatos a reitor e seus respectivos vice-reitores, apareci sozinho, pois o Sandro Sayão, a quem agradeço enormemente a confiança no projeto, em razão de outra agenda, não pôde comparecer. Então, quando chamaram a chapa SomosTod@sUFPE, algo interessante aconteceu, só estavam comigo uma jornalista e mais três apoiadores, que não eram da universidade e nem faziam parte da minha família. Nessa ocasião, os outros candidatos já se mostravam fortes com, pelo menos, quinze a vinte apoiadores, sendo professores, estudantes e técnicos.

De cima do palco conseguia enxergar ex-apoiadores do projeto anterior, inclusive pessoas que estiveram no posto de comando em 2015, apoiando outros candidatos. Não me intimidei, tratei a todos com muito respeito e firmeza, característica de um político experiente, mas estava consciente de que a campanha seria muito dura e, provavelmente, teria resultado trágico.

Neste momento, agarrei-me ao pouco conhecimento que dispunha sobre a universidade e tentei mostrar que estava preparado para dirigi-la, caso fosse eleito. Logo nas falas iniciais, mostrei que havia feito uma boa gestão à frente da Proext. Mesmo com os argumentos apresentados, sentia que a plateia não respondia positivamente a tais apelos. De qualquer forma, apresentei as ideias, o meu posicionamento, e o curioso foi que ainda consegui receber vários aplausos, inclusive, dos apoiadores de três candidatos, menos do pessoal do JBS Santo. Acho que estavam com raiva de mim, e ainda continuam. Não consigo afirmar.

Nesse primeiro debate precisei contar com a minha própria segurança acadêmica e científica, com o pouco conhecimento que dispunha dentro da universidade e o conhecimento que possuía sobre a instituição, além das relações profissionais que sempre devotei confiança. Ainda que alguns conhecidos tenham feito apostas em outros projetos, estava convicto do importante papel a ser desempenhado para a democracia interna da instituição.

Contudo, em meio a tantos atropelos, eu me vi sufocado e pensei na ideia de conspiração. Acho que várias pessoas, amigos antes próximos, voltaram-se contra o projeto e contra a ideia de eu ser candidato. Alguns foram ao meu Departamento fazer campanha para desconstruir a minha candidatura e a minha imagem. Aliás, um determinado candidato fincou trincheira por lá, com o objetivo de esvaziar um pouco dos votos que eu tinha, pelo menos, os que eu pensava que ainda tinha.

$\mathrm{O}$ discurso difundido era o de que, se eu fosse eleito, não tomaria posse porque eu era filiado a um partido político e o Governo Federal não faria minha nomeação em virtude de o presidente Bolsonaro ser de extrema-direita. Vejo que há uma racionalidade nesse discurso, porque eu realmente fazia parte de um partido político naquele momento, mas o curioso é que os propagadores desse discurso também eram filiados ao PT. Inclusive, participantes de um grupo antifascista da UFPE. 
Não obstante, não era isso que estava em jogo, o que eu queria debater era o projeto de universidade, modelo e concepção de gestão de uma instituição de ensino superior: as propostas para a internacionalização, expansão da universidade etc. Era isso que eu queria verdadeiramente debater, era para isso que eu me sentia preparado, com as mesmas ideias da eleição de 2015.

Outra questão que gostaria de registrar diz respeito ao segundo turno das eleições. Eu apoiei o candidato do então reitor, o DBDA, adversário de 2015. E essas mesmas pessoas que defendiam outro candidato, que também havia chegado a esse turno, acabaram intensificando as críticas dirigidas a mim sob a alegação de que eu teria virado um membro da direita. Alguns chegaram a dizer que eu não era mais negro, que havia perdido a cor e a identidade de raça.

No fundo, esses indivíduos pensavam que o apoio ao projeto defendido pelo JBS Santo, no segundo turno, aconteceria por osmose. Muito pelo contrário, esperei que os candidatos me procurassem e discutissem as propostas por mim defendidas, mas o único a conversar comigo, no dia seguinte ao primeiro turno, foi o candidato apoiado pelo reitor na época.

Contudo, vejo que essa ideia da teoria de conspiração pode ser apenas um impulso de revolta da minha parte, algo como um desabafo de um perdedor. Mas cabe como um registro acerca dos meandros da política no interior de uma das maiores universidades do país, pois talvez alguém pense que isso não acontece dentro de uma instituição como a nossa. Porém, tudo é possível, porque a universidade é uma construção social a longo prazo, intrinsecamente dinamizada pelos atores sociais e suas idiossincrasias.

Passado esse processo eleitoral, eu me vejo de certa maneira sozinho, sem grupo e sem força política. A força política existente foi fragmentada e dizimada. A propósito, ainda penso que o episódio da Adufepe, da eleição em junho de 2018, criou um fosso intransponível entre os camaradas apaixonados pela política partidária e institucional. Tudo começou quando dois colegas entraram em disputa, o Arguto Silvério e o TCLT Quintas. Foi uma luta pelo controle das ideias de um grupo ou instituição, pelo menos a princípio. Mas, na minha modesta forma de pensar, principalmente, foi uma disputa intergeracional que, por motivos particulares, levou a um grande e grave problema político entre nós.

As consequências dessa disputa levaram à divisão do grupo, com duas chapas concorrentes ao mesmo espectro político-ideológico. Na minha avaliação os dois estavam certos e igualmente equivocados, dependendo do ângulo de visão. Isso porque, pela ótica de um projeto pensado estrategicamente entre nós, um deles deveria disputar a eleição de deputado, e só isso. E outro equívoco foi a possibilidade de esse mesmo indivíduo ter exercido o cargo de presidente e devesse deixar outros assumirem tal responsabilidade, ainda que não muito confiáveis.

Por outro lado, pode ser por tentar limar alguém pela liderança já demonstrada em épocas anteriores ou, ainda, pelo fato de não deixarmos a instituição nas mãos de alguém mal-intencionado como aconteceu em 2015, em que o cidadão jogou todo o nosso trabalho político-eleitoral no lixo, como já mencionando na seção anterior.

Visão romântica à parte, o fato é que um simples desentendimento virou uma tragédia político-eleitoral que incluiu todo um grupo; consequentemente, fiquei em cima do muro e não tive condições de descer. Se fosse julgar só pela questão política, numa 
decisão atropelada, como foi a última reunião que participei, onde se tomou a fatídica decisão, na verdade, desse arroubo de duas chapas, ficaria com a chapa 1, mas, se considerado os aspectos pessoais, pela amizade, ficaria e fiquei nos bastidores com a 2 . É óbvio que sempre alguém ganha quando tem família brigando. Infelizmente.

Assim, mediante a disputa instalada nesse campo, alguém teria estimulado a divergência para manipular os sentimentos e, notoriamente, aproveitar a contenda em prol de um projeto mais justo e democrático para a eleição de reitor na UFPE. Certamente, quem mais se beneficiou dessas discórdias foi o JBS Santo, que estratégica e sorrateiramente conseguiu aprofundar ainda mais a crise, afastar velhos amigos e construir sua história política dentro da universidade. Logo, não fossem esses e outros aspectos, talvez o resultado eleitoral tivesse sido outro, mas isso nunca saberemos.

A meu ver, foi isso o que aconteceu: uma briga pessoal entre um idoso e outra pessoa mais jovem, o Arguto Silvério, numa conjuntura particular em que se pretendia 'colocar o mais jovem em seu devido lugar'. Um cara muito impulsivo, diga-se de passagem, que não se rendeu aos caprichos de outrem, levou todos nós à dissolvência. Todos perdemos, inclusive o Arguto Silvério, que pretendia disputar a eleição para deputado estadual e o projeto que ele estava trabalhando há muito tempo não deu em nada.

Entre uma decisão de força política e a minha relação pessoal, não consegui ir a público para apoiar ninguém mas, nos bastidores, todos sabem que apoiei o Arguto Silvério. Mesmo sem demonstração pública investi alguns trocados e impulsionei a chapa na internet, dei alguns telefonemas para colegas e tratei de arrumar mais alguns recursos com o Neves de Arruda, principalmente no segundo turno. Eu não estava trabalhando diretamente na campanha, mas todos viram minha filha e minha esposa no meu lugar, ajudando-o na disseminação das propostas. Naquela altura, a minha preocupação era saber de que maneira o Arguto Silvério sairia daquela situação-problema, pois estava cercado por tensões desfavoráveis e provavelmente não seria mais candidato a deputado estadual.

Essa eleição da Adufepe passou para o segundo turno. Nesse momento a chapa 2 perdeu com razoável número de votos de diferença e o Arguto ficou revoltado com a força política, com várias pessoas, inclusive comigo. Passados alguns dias tentei reaproximá-lo da força política estadual com o objetivo de mostrar que aquele tinha sido um momento difícil, mas que ele era visto por nós como uma liderança importante. Muito embora, sem nenhum demérito, eu reconheça que os fatos ocorridos tenham sido em virtude da sua impulsividade e energia própria de um político juvenil.

O que quero realmente dizer é a posição de Arguto Silvério na eleição para reitor em 2019. Inicialmente ele não tomou nenhuma posição de imediato, somente acompanhou o processo durante quase todo o primeiro turno, sem definir de que lado estaria, talvez estivesse preocupado em manter a amizade. Porém, faltando quatro dias para o primeiro debate, ele me telefonou dizendo que teria três propostas para me apresentar. Aliás, três propostas capciosas. 
$\mathrm{Na}$ primeira delas, segundo ele, eu deveria desistir da candidatura, faríamos um evento com ele coordenando e passaríamos a apoiar publicamente o JBS Santo. Na segunda proposta, eu deveria desistir da candidatura, apoiaria o JBS Santo, mas não faria evento nenhum e não haveria a necessidade de fazer campanha. Na terceira proposta, eu simplesmente retiraria a candidatura.

Diante das três questões colocadas respondi que, na verdade, só estava em jogo apenas uma proposta, qual seja eu retirar a candidatura em detrimento do JBS Santo. Mediante o que escutei, apresentei a contraproposta de que ele me apoiaria num evento público com bastante visibilidade e partiríamos para a campanha de reitor, ele ficou de pensar. Passadas umas duas semanas disse que havia tomado uma decisão importante: apoiaria o JBS Santo, porque ele iria para o segundo turno, tinha totais condições, logo, iria ajudar aquela candidatura. Diante do que ouvi, disse a ele que eu tinha por princípio sempre ajudar as pessoas que precisavam e eu, naquele momento, estava necessitando ser ajudado, para superar os desafios de uma campanha como aquela. Então, nos despedimos e fomos embora.

Nesse contexto, posso registrar que ele fez uma opção política. Talvez, mais correta, segundo seus parâmetros. Assim, mesmo falando com certa tranquilidade, com a calma aparente com que gosto de me mostrar, fiquei muito triste e chateado. Sentia que estaria naquele instante perdendo uma amizade. Comecei a refletir profundamente a atitude que tomei lá atrás, numa conjuntura em que a amizade havia pesado mais forte na minha decisão ou no muro em que fiquei pendurado.

Neste momento, sinto-me solitário. Isolado e politicamente sozinho tento me encontrar academicamente a partir da minha produção científica, dos meus orientandos de mestrado e doutorado, mesmo que alguns tenham largado as minhas mãos ou não tenham feito muita questão de estar ao meu lado durante a campanha e depois dela. Por isso, esta gravação de hoje, exatamente às 10h50min., do dia 19 de julho de 2019, está sendo muito emblemática. É um dia chuvoso e, conforme todas as outras ocasiões em que gravei, quem está do meu lado é o Spike, meu cachorro. De qualquer forma, essa gravação, que trago como registro para materializar esta minha escrita, reproduz um pouco do meu sentimento durante toda a campanha.

Num dos momentos mais críticos da conjuntura nacional, quando a fala dos movimentos sociais e das forças progressistas propalavam o discurso 'ninguém solta a mão de ninguém', soltaram exatamente as minhas. Aliás, além de me soltarem as mãos deram-me as costas e ainda tentaram me empurrar do abismo. Isso não é um efeito de linguagem, mas é como me senti e o que percebi pelos gestos de muitos colegas, que, até aquela ocasião, eu ainda os tinha em alguma conta.

É bem provável que eu também tenha contribuído com esse feito da soltura das mãos embora, verdadeiramente, não tenha pensado na possibilidade de afastamento de vários colegas num dos momentos que mais precisava. Inclusive, num momento em que perdi minha mãe para o câncer, um desses colegas que largou a minha mão, o Manuel Bilontra, ligou no dia do sepultamento para desejar os pêsames e ainda pediu que eu recuasse. Ou seja, a preocupação dele estava centrada mais na política do que no sofrimento do amigo. Lamentavelmente, isso tudo é coisa da vida, da própria política em dissonância com os sentimentos alheios. 
Ademais, o Manuel Bilontra, durante muito tempo, andou ensaiando a derrocada de alguns colegas da universidade, falava muito mal, inclusive, do JBS Santo, mas depois, nesse momento fatídico da eleição, uniu-se a favor de um projeto, de certa forma, legítimo, no entanto, mirando a minha possível derrocada, no afã de consegui algum espaço na futura gestão.

O fato é que não preparei o campo político como deveria. Confiei no recall 2015 e no grupo que me levou ao segundo turno naquela época. Confiei na amizade. Ledo engano. É preciso estimular e cultivar o campo, da mesma forma que é importante expor, com propriedade, o habitus sob o qual você se expressa para manter a chama política sempre acesa. Por vezes, não me sinto traído ou injustiçado, o sentimento é o de que perdi a adesão do grupo pelo excesso de confiança na história recente, que me permitia pensar na vitória política que tive em 2015.

Por outro lado, também é importante uma análise mais densa sobre o que de fato aconteceu para o mesmo grupo que esteve comigo ter se afastado e feito campanha contra o projeto SomosTod@sUFPE, criado juntamente com eles em 2015. A propósito, alguns não só soltaram as minhas mãos como também passaram a me repudiar, parecia coisa de ordem pessoal e não por defesa de um projeto a ser debatido na instituição.

Nesse sentido, a pergunta que tenho insistentemente me feito é a seguinte: por que esses colegas me disseram não? Por que foi mais fácil dizer não para mim de diferentes formas, em vez de recusar a aliança com outro candidato, sendo que eu também era "amigo" e, ainda, da composição de quatro anos atrás? Na época disseram um não de forma muito clara, muitas vezes constrangedora, pelo menos, essa foi a impressão que tive, e ainda tenho, ao lembrar dessa situação. Com tudo isso acontecendo, tinha a sensação de que eu havia saído do grupo, mas, na verdade, o grupo havia me retirado de seu núcleo de articulação e aglutinação de forças. Resolveram repassar o poder para outro personagem e atribuir a ele a possibilidade de defender suas ideias frente à comunidade universitária. Realmente, o poder mudou de mãos e, consequentemente, eles me transformaram num outsider de um grupo que ajudei a construir e fomentar a esperança. Ao menos, esse foi o meu sentimento ao perceber o que estava acontecendo naquele momento.

Talvez nunca consiga encontrar as respostas para tantos nãos recebidos naquela época, mas, para meu próprio conforto, acredito que, ao longo da minha trajetória, consegui desenvolver a capacidade de ouvir essa palavra indigesta e perturbadora. Penso, inclusive, que consegui construir uma espécie de ferramenta ou armadura, algo fartamente presente na literatura da autoajuda chamado de: inteligência emocional.

Ao inverter a questão tudo parece ser mais fácil, pois é taticamente mais confortável achar que tenho mais capacidade emocional de ouvir um 'não' do que outros colegas igualmente partícipes da política universitária. É, portanto, deveras simples pensar que tenho algo realmente especial, um ouvido mais bem-treinado. Desse modo, também consigo submeter, como o faço neste momento, todo esse material ao crivo de uma narrativa como parte intrínseca da minha identidade, no processo de biografização.

Agora, mais do que nunca, preciso aprender a lidar com essa realidade da cultura do 'não'. Outrossim, depois de tanto ouvir essa palavra, acabei exercitando e dizendo também os meus. Por uma questão de incompatibilidade de projeto e também de convivência, precisei ensaiar os meus 'nãos' e distribuí-los a quem merecia por direito. A 
prudência exigiu esse comportamento porque não teria a menor condição em coordenar uma determinada pesquisa científica ou ser 'administrado' por alguém que tenha exercitado de forma redonda um 'não' frente aos desafios que eu tinha ao representar um projeto de universidade naquele momento.

Nesse contexto, sempre disse que o meu principal compromisso era com o sucesso. No entanto, considerando os últimos acontecimentos políticos e, especialmente, o resultado eleitoral de 2019, a partir desse momento, preciso conviver com a derrota, os reveses da vida. Preciso coexistir com a desilusão e o fechamento de um ciclo político na instituição universitária. Assim, aproveitei o ensejo para me retirar de duas pesquisas coordenadas pelos colegas que largaram a minha mão, principalmente os de estudos focados nas relações étnico-raciais, temática que sempre defendi, inclusive na orientação de mestrandos e doutorandos, alguns hoje professores da UFPE, que igualmente me largaram.

Curiosamente, as primeiras pessoas a largarem as minhas mãos foram exatamente a Agualinda Viva e a Santana do Agreste, que provavelmente alimentavam o campo comigo. Tenho a certeza de que perdi muito do capital político que me restava dos afrodescendentes, sobretudo, alguns chamados afrocentrados, estudantes e, em particular, docentes que militam com esse assunto. Mas é óbvio que há exceções. Dois colegas que também sustentam a temática étnico-racial continuaram na minha defesa da História e da Educação.

Em todo o caso, não me rendi facilmente às turbulentas tentativas de desconstrução da minha candidatura. Participei ativamente de todas as reuniões e debates quando chamado; inclusive, o que aconteceu no Centro de Ciências Jurídicas, local que sempre achei elitista. Isto é, sempre tive o sentimento de que, historicamente, esse ambiente não me pertencia.

Informes do CCJ

Debate dos Candidatos a Reitor da UFPE

O Diretório Acadêmico Demócrito de Souza Filho em parceria com a Direção do Centro de Ciências Jurídicas promoverá um debate com os candidatos a reitor da UFPE para o Quadriênio 2019-2023. O debate ocorrerá no dia 20 de maio de 2019 às $19 \mathrm{~h}$ no Anfiteatro IV da Faculdade de Direito do Recife. As Cinco chapas que concorrem no pleito confirmaram presença no Debate. Convidamos todos os membros da comunidade acadêmica do CCJ para participarem deste importante evento (UFPE, Ascom, 2015). Mesmo com um grupo muito pequeno de militantes, estive presente em todos os debates, inclusive o mais desafiador, o da Faculdade de Direito, a mais antiga instituição das Ciências Jurídicas do país. Então, como de costume, revisei todos os pontos que provavelmente cairiam nas perguntas feitas pelos professores, estudantes e técnicos. Durante a revisão do projeto, na Pousadinha, pensei de forma intrigante que deveria fechar a discussão daquela noite, nas considerações finais, com algo mais envolvente ou que desse o impulso à autoestima que estava precisando naquele momento. Por levar em conta esses aspectos, passei a ensaiar a poesia de Solano Trindade, repeti várias vezes até chegar no tempo que provavelmente dispúnhamos, eu e o Sandro Sayão, algo em torno de cinco minutos. Combinei com o nosso candidato a vice-reitor que ele falaria primeiro uns dois 
minutos e meio e eu completaria o resto do tempo com um poema. Antes da poesia, eu disse que aquela noite eu dedicava a minha fala ao Tobias Barreto, ao Joaquim Nabuco, à Escola do Recife e a todos os afrocentrados ali presentes: sou negro, contam que os meus avós vieram de Luanda como mercadoria de baixo preço. O meu avô brigou como um danado nas terras de Zumbi, na capoeira e na faca escreveu não leu o pau comeu. Ele não foi nenhum pai João humilde e manso. Mesmo vovó, vovó não foi de brincadeira, na guerra dos Malês ela se destacou, e na minha alma ficou o samba, o bamboleio, o batuque, a capoeira, o ataque e o desejo de libertação. (Trindade, 2011)

Foi um sucesso, todos aplaudiram, exceto o candidato a vice-reitor do JBS Santo, o Virgulino Olinda, que fez gracinha dizendo que ele era negro, mulher, travesti etc., tudo isso para tentar desviar o impulso emotivo que consegui despertar nas pessoas naquele instante.

Contudo, até agora falei apenas de um dos lados dos que me largaram as mãos, mas tem mais gente do outro lado. Alguns camaradas passaram todo o tempo da campanha escamoteando-se, tentando driblar as decisões da força política, mas, sem se conter, acabaram apoiando publicamente um dos meus concorrentes. Esses camaradas estiveram, durante quatro meses, num debate quase interminável, apenas para decidir se eu seria candidato ou não. Vejo que foi simples perda de tempo. Inclusive, nesses meses, entre novembro 2018 e fevereiro 2019, passei por muitos problemas pessoais, como o falecimento da minha mãe, como já disse.

Apesar de toda essa tormenta pessoal, não fugi ao debate. Mesmo minha mãe na UTI, não arredei o pé da discussão política. Na verdade, à noite, eu rezava e pedia perdão a Deus por ainda insistir naquela discussão interminável, sem futuro, enquanto minha mãe agonizava no hospital. Sei que não tenho justificativa, mas também não queria ser enquadrado da mesma forma que o Arguto Silvério teria sido por ocasião da eleição da Adufepe, por isso redobrei a paciência para ouvir todas as grosserias próprias de uma disputa política.

Vários camaradas, ainda que tendo participado da discussão e deliberação pela candidatura, refugiaram-se nos compromissos sem fim, deram as mais variadas desculpas esfarrapadas para não buscarem os votos, pelo menos comigo, mas, certamente, também com outros candidatos concorrentes. No fundo, centrei até agora a narrativa num determinado grupo de interesse temático, mas a coisa foi realmente generalizada. O apoio não veio nem de quem havia decidido pela candidatura. Da força política mesmo, apenas dois ou três ajudaram com alguma coisa. Deram um "suporte" por meio das palavras, até porque nem faziam parte da comunidade universitária. Apenas um professor filiado colaborou mais ativamente, tentando angariar fundos, sem muito sucesso, como o Neves de Arruda.

$\mathrm{Na}$ verdade, muitos sumiram do meu horizonte, seja enquanto militantes das causas sociais, seja porque tentaram resguardar seus interesses pessoais, e a minha candidatura, certamente, contrariava tais interesses. Muita gente, inclusive, mentiu ao dizer que iria se dedicar à vida acadêmica, mas, na prática, envolveu-se com outras candidaturas, até mesmo andou sendo candidato a algum cargo num determinado centro acadêmico. Contudo, não há santo de nenhum dos lados. Não posso atribuir o sumiço geral apenas aos que propositadamente quiseram e largam as mãos. Provavelmente, eu 
tenho minha parcela de contribuição nessa dissidência geral. Todavia, em certa medida, procurei me distanciar das emoções que tentavam pairar sobre a campanha, tentei agir de maneira alienada, conforme as reflexões de Elias (1998).

Vejo que, até certo ponto, colaborei para o que aconteceu, mesmo não desejando os fatos ocorridos. Eu poderia ter sido enérgico ao perceber que havia a possibilidade de dissidência de um ou de outro e que isso prejudicaria, como prejudicou, a minha campanha. Poderia, inclusive, ser mais incisivo com o JBS Santo, nas primeiras evidências de seu desejo em protagonizar parte da eleição a reitor em 2019 na UFPE.

Penso que não fiz o dever de casa, não cultivei e cativei publicamente aqueles e aquelas que hipoteticamente poderiam colaborar com o projeto de 2019. Devo mesmo ter pisado feio na bola ou no orgulho de alguns. No entanto, se cometi erros, não foi por falta de caráter, deve ter sido por displicência política ou por não ter observado mais de perto o jogo que estava em andamento no campo naquele momento. De qualquer modo, mesmo de mãos soltas, cumpri o papel intelectual de defender o projeto de universidade que acreditava.

A minha percepção geral sobre o que aconteceu é que, em algumas situações, eu me via como um incômodo. Um bode no meio da sala. Um bode barbudo no meio da sala. $\mathrm{E}$ esse bode barbudo interagia com todos os indivíduos nesse ambiente, mas não conseguia influenciar absolutamente ninguém. Então, fui perdendo lenta e progressivamente um pouco do poder que eu pensava ter. A percepção é a de que aconteceu comigo um fenômeno que na política se chama de desidratação.

Assim, esse processo de desidratação chegou ao ponto de eu não ter ou não querer participar de nenhum grupo atualmente. Externamente, as pessoas me veem como membro de um grupo político, mas o próprio grupo dentro da universidade não existe mais e, mesmo que ainda existisse, eu não me sentiria partícipe dele. Tudo isso é em virtude de que as relações de confiança dos membros dessa força política se esvaíram. Não existe mais confiança mútua. Um grupo é fortalecido por essa relação de confiança e objetivos comuns que os regulam. Fortalecido, de certo modo, pelas relações de hierarquia e poder, ainda que frouxas e latentes.

Nesse contexto, pensando na perspectiva de Elias (1994), no que diz respeito ao processo de individualização, que expressa a singularidade de um ser humano, eu construo o entendimento de que necessito fortalecer a minha trajetória acadêmica e refazer os meus caminhos; inclusive, o político, ainda que eu compreenda que esse círculo político tenha se encerrado. Necessito reconstruir as relações interpessoais. Alguns colegas do meu Departamento disseram que seria prudente a recriação de algumas pontes, até com alguns que me abandonaram. Nesse momento, acho que não é uma boa ideia, visto que a relação amistosa pode ser um pouco difícil, pelo menos a curto prazo. Digo isso porque um dos personagens, o Manuel Bilontra, chamou-me de canalha num dos momentos que nos encontramos na entrada da universidade, na panfletagem do segundo turno, quando estávamos pedindo votos, obviamente, para candidatos diferentes.

Posso dizer que a força política que construímos por algum tempo dentro da UFPE foi deteriorada. Não existe mais. Será preciso um outro conjunto de fatores para que retorne a dinâmica relativamente normal de um grupo que pense e faça política, ainda que erre na análise de conjuntura e não se esconda por trás dos votos alheios. Será 
necessário estabelecer outros jogos em meio às forças que andam atuando dentro e fora da universidade, especialmente no que diz respeito ao avanço de forças retrógradas, conservadoras, nesses tempos nebulosos. Principalmente nesse momento em que se comenta, entre os progressistas, da importância de não largar as mãos - apesar que as minhas, largaram.

Quem convive comigo mais de perto está acostumado a ouvir um dos meus lemas: "Vamos sempre para frente e para cima!". Entretanto, considerando os últimos acontecimentos da política, estou mesmo "para trás e para baixo". Assim, não resta outra tática de sublimação a não ser escrever o máximo possível para, pelo menos, responder a uma demanda institucional e profissional da carreira docente, algo que ainda está ao meu alcance. Escrever esta tese na perspectiva do constructo do 'eu' fonte.

Considerando o meu sentimento, o peso da política incorre na parte mais negativa do processo eleitoral, mas preciso deixar registrado que alguns, ainda que poucos, continuaram com as mãos dadas. Seja qual tenha sido o motivo, uns ainda continuaram comigo; pelo menos, no primeiro turno. Posso listá-los de uma maneira muito carinhosa e respeitosa. Apesar de todos os problemas, acho que a política também tem muito de afeto e companheirismo. Lembro-me bem das reuniões que fizemos aos sábados, um dia complicado para a maioria. Alguns levavam seus filhos para a rápida discussão que fazíamos sobre as táticas a serem assumidas na semana seguinte.

Desse modo, estiveram de mãos dadas comigo e com 0 projeto SomosTod@sUFPE2019, nos debates e panfletagens, nas discussões, articulação e comunicação: Dicró do Norte, Amada Convicta, Lopes Filho, Pazzi de Andrade, Udia do Patrimônio, Josué Pena Branca, Manu Magri e Sosimpatia. Além desses, ainda pude contar, durante a campanha e após o desfecho do segundo turno, com Jomo do Samba e Estrela Flamejante, que estavam muito preocupados com a minha situação na universidade nesse período pós-eleição; além disso, também queriam saber como deveríamos encaminhar as questões importantes acerca das relações étnico-raciais, uma vez que alguns focados no debate afrodescendente, como Dacruz e Dalua, não só largaram as mãos como também tripudiaram da nossa posição política, considerando-se mais negros e negras do que aqueles que fizeram opção por outro projeto.

Além dos abnegados e abnegadas que continuaram de mãos dadas, não poderia deixar de registrar a participação da minha família, especialmente, minha esposa Roseane e minhas filhas Alice Lidiane, Viviane, Tatyane e Tulane, que estiveram comigo em vários momentos dessa importante atividade política-institucional em 2019, seja nos debates, nas panfletagens, seja nas críticas aos que soltaram minhas mãos. Talvez, essa tenha sido a razão pela qual não me destruí na angústia e desespero ao me perceber um candidato sem apoio político, colocado como outsider dos outsiders pelo grupo que ajudei a formar.

Este é o meu ponto de vista, é apenas uma das possíveis versões dos acontecimentos. É a minha percepção pessoal intransferível sobre alguns acontecimentos, sobretudo, da política-institucional. São as minhas experiências, obviamente, conectadas às experiências de outros membros desse campo. Assim, essa percepção pessoal tem impacto num tipo específico de compreensão acerca do que foi 
possível alcançar até o presente momento, mas alguém que também viveu o que estou tentando relatar pode ter uma visão diametralmente oposta, por isso é preciso relativizar o que vemos, sentimos e dizemos.

Destarte, frente a esse rascunho de memória recortada sobre a luta pelo poder institucional na UFPE, passei a refletir um pouco mais sobre esses acontecimentos recentes e tentar reduzir "ao terreno da luta no interior do campo uma análise cuja finalidade era objetivar essa luta e, ao mesmo tempo, dar ao leitor um domínio dessa luta" (Bourdieu, 2004, p. 117). Passados cinco meses da eleição em 2019 o Neves de Arruda me procurou para um diálogo e saber como eu estava lidando com as questões da universidade, ou seja, qual o meu sentimento em relação ao que havia acontecido.

$\mathrm{Na}$ conversa, durante um cafezinho meio amargo, argumentei que precisava mergulhar na elaboração desta tese, para deixar algo digno de um trabalho acadêmico e de qualidade. Ele percebeu que eu não queria participar de nenhuma reunião e me disse que uma pessoa sozinha e que não consegue juntar um grupo de pessoas, não tem valor na política. Na ocasião, respondi que não queria juntar pessoas, apenas fazer esta tese.

Mesmo com essa resposta, é sempre bom termos em mente as 'boas teorias' sociais, aquelas que discutem acerca das relações de poder e o pêndulo da balança, que, neste caso, pendeu para outro lado. Além, é óbvio, de ter a convicção de que "a vida social dos seres humanos é repleta de contradições, tensões e explosões. $O$ declínio alterna-se com a ascensão, a guerra com a paz, as crises com os surtos de crescimento. A vida dos seres humanos em comunidade certamente não é harmoniosa" (Elias, 1994a, p. 20); assim como a minha vida não tem sido, nesses últimos tempos. Pensando em tudo o que vivi naquele momento e no momento da escrita deste parágrafo, meu sentimento é de total solidão, mesmo com a minha família próxima ou ainda que eu estivesse contando com alguns poucos amigos que ligavam vez ou outra para uma cerveja ou um favor, o que era mais comum.

Não obstante o sentimento que durante um bom tempo me tomou conta, de posse da teoria para lidar com os dados empíricos e, parafraseando Elias (1994a), percebi que ainda tinha alguns amigos e inimigos, um bom sinal sobre estar vivo. Tinha conhecidos perdidos ou mortos que ainda estavam na minha memória, tão necessária para a construção desta autobiografia.

Nesse contexto, o leitor pode achar estranho e talvez pensar que eu esteja supervalorizando os bastidores da política-institucional ou que minhas reflexões não passam de revanchismo ou até mesmo desabafo de um perdedor. No entanto, mesmo que tudo isso represente neste momento essa narrativa, num projeto autobiográfico como este, é necessário um significativo envolvimento e distanciamento para um relato pessoal consistente e somente de posse de uma massa documental abrangente ou da experiência vivida é que será possível ser "autorizado" a dizer o que está sendo dito no presente trabalho.

Contudo, os ciclos se abrem e se fecham continuamente; então, já no primeiro semestre de 2020, recebi um convite para coordenar a campanha de diretor do Centro de Ciências da Saúde. Achei um tanto inusitado por parte de quem me convidou, o Simpático Docente, a quem agradeci, mas não aceitei. Havia um bom tempo em que eu e o referido professor não conversávamos, estivemos em lados opostos em virtude de outras eleições. Mesmo em lados opostos, posso garantir que sempre tive uma certa admiração 
por esse profissional devido a sua sinceridade, humildade e educação no tratamento com os demais colegas. Sua experiência de vida e como gestor revela uma liderança, ainda que não enfatize e não demonstre com ousadia.

Para finalizar este capítulo, na verdade, tudo o que foi dito até aqui não passa de uma percepção, como já referido. Portanto, de um ponto de vista, ou a vista de um ponto, conforme Leonardo Boff (2014), essa percepção dos acontecimentos, bem como seu relato fundamentam-se no próprio modelo de pesquisa com todos os riscos que se têm em fazer ciência a partir da valorização de uma razão narrativa de si, ou seja, de episódios que marcaram o indivíduo que fala, tornando-se ele mesmo sujeito e objeto de seu estudo.

Considerando que nesse capítulo abordei uma parte específica da políticainstitucional, sobretudo dos bastidores, que, de algum modo, só foi alcançado por quem viveu mais de perto; no próximo capítulo, vou em busca dos objetos dispersos acerca do que produzi durante a minha trajetória, mesmo que seja também uma percepção muito particular do vivido. Dessa forma, tentarei abordar como um constructo se desenvolve e se apresenta num determinado itinerário, onde há transmigração de campo. Logo, ainda carregado de subjetividade e manuseando objetos de uma experiência de vida, 0 constructo do 'eu' fonte será analisado no próximo capítulo enquanto possibilidade de explicitação da hipótese desta tese e possível ponto de partida para outros estudos semelhantes ao que o leitor tem em mãos.

\section{Capítulo 8 - 0 campo autobiográfico e o constructo do 'eu' fonte}

Foram esses os erros e crimes da minha mocidade. Narrei a história deles com uma fidelidade que me satisfaz o coração. Se, mais tarde, honrei a idade madura com algumas virtudes, hei de dizê-las com a mesma franqueza, pois esse é o meu desígnio. Mas é preciso parar aqui. O tempo pode erguer muitos véus. Se minha memória chegar à posteridade, talvez ela um dia saiba o que eu tinha a dizer. Há de saber-se então porque me calo. (Rousseau, 2008, p. 258)

Conforme está explícito em Rousseau (2008), o tempo pode de fato erguer muitos véus e são esses véus que pretendo descortinar e reafirmar neste último capítulo da tese. Farei isso com o objetivo de demonstrar, mais uma vez, que a construção histórica de um indivíduo se faz a partir de muitas clivagens, algumas das quais devotamos muito orgulho e prazer em tê-las na trajetória, outras nem tanto. Porém, todas contribuem para a compreensão que temos de nós mesmos, de nossa subjetividade.

Essa compreensão é, inevitavelmente, ancorada na objetivação e subjetivação do agente social, inclusive, pela razão narrativa, como uma tomada de consciência de uma dispersão evidente, como tentarei demonstrar neste capítulo a partir da minha busca em reunir o que foi por mim disperso durante a trajetória. Isso tem a ver com a posição que ocupo no campo intelectual-acadêmico, com impacto direto no meu ponto de vista, na minha percepção.

Concordo também com Rousseau (2008) ao tratar das questões da posteridade e da memória, da liberação ou interdição do que é dito num projeto autobiográfico, por exemplo; ou seja, a sensação de que a memória não pode ou não quer liberar tudo num ato de protesto ou de proteção durante a autonarrativa. Assim, o objetivo deste capítulo é 
reafirmar os questionamentos e a hipótese desta tese no que diz respeito à percepção que tenho da minha trajetória entre a escola, a vida acadêmica e o constructo do 'eu' fonte, na temporalidade autobiográfica entre 1975 e 2020.

A título de lembrança, essa temporalidade está sendo analisada na perspectiva da hipótese segundo a qual houve em minha vida a transmigração de um campo artístico para o acadêmico, na qual sofri, entre outras, alterações linguísticas significativas, mais expressivas entre as clivagens do meu itinerário. No entanto, percebi que, a partir da tomada de consciência do desenvolvimento de um habitus num campo específico, tais mudanças resultaram no que chamo de constructo do 'eu' fonte.

\section{Aspectos gerais do constructo}

Conforme Bourdieu (1989) o campo é uma construção simbólica onde se produz e reproduz objetos e valores e onde diferentes agentes ou indivíduos legitimam representações, classificam signos e lutam pelo poder. É um ambiente onde se joga de forma específica a partir de determinadas crenças e do domínio da linguagem, que, em certa medida, sustentam as interrelações dos próprios indivíduos no campo.

Todavia, as linhas que atravessam determinados campos ou, em última instância, todos os campos estão irremediavelmente numa região limítrofe, especialmente os campos onde vigoram a produção artística, literária, científica e política, conforme capítulo anterior, onde é preciso um descortino contínuo dos subcampos aos quais estão envolvidos diferentes agentes, o que é extremamente complexo e necessário para a relação do indivíduo e os grupos sociais de onde partem sua produção e circulação de sentido:

Objetivar o sujeito objetivante, objetivar o ponto de vista objetivante, é uma coisa que se pratica correntemente, mas isso é feito de um modo aparentemente muito radical, mas na verdade muito superficial. Em outros termos, pensa-se que se objetivou o sociólogo, ou em geral um produtor de bens culturais, ao objetivar sua "posição de classe". Esquece-se de que é preciso ainda objetivar sua posição neste subuniverso, onde estão envolvidos interesses específicos, que é o universo da produção". (Bourdieu, 2004, p. 114)

Nesse contexto, para melhor compreensão desta tese, tomei como base empírica vários campos em que atuei, como o campo escolar, o artístico e o acadêmico-científico, que se desdobra também na política institucional. Esses campos são facilmente verificados na minha trajetória em instituições distintas e complementares para efeito do processo de individualização alcançado como ser humano e profissional. Parafraseando Bourdieu (1989), poderia chamar de 'meus campos', onde travei as tensões na busca e nas relações de poder, na afirmação do meu ego e explicitação das minhas vontades.

Considerando essas vontades, percebo que todo campo tem características muito peculiares, sobretudo no espaço em que residem as tensões. Há campos mais abertos; outros, fechados; uns sublimados e outros minados. O campo da arte, por exemplo, identifico como sublimado e menos tenso em relação a outros, principalmente quando comparado ao acadêmico, que se revigora na tensão e no solo minado que cultiva. Por 
outro lado, a percepção que tenho do campo político é que ele é aberto e simultaneamente minado, onde você entra e sai com certa facilidade, mas com a possibilidade de que algo estoure a qualquer momento, ou seja, mude de rumo em poucos minutos.

Contudo, foi no campo institucional acadêmico onde foi possível adquirir o que Bourdieu (1989) chamaria de capitais totais, onde aprendi a jogar, disputar e transformar os capitais adquiridos em outros capitais igualmente simbólicos e necessários para a sobrevivência no campo e no jogo. Foi a aquisição e aprimoramento da linguagem acadêmico-científica que me possibilitou a transmigração de um campo a outro.

Nesse contexto, de todos os capitais ao qual pertenço - econômico, como renda; patrimônio cultural, como os diplomas, certificados e qualificações intelectuais; social, nas transformações dos recursos nas redes sociais etc. -, o capital linguístico foi decisivo não só para usar e incorporar a linguagem técnica da minha formação profissional, mas também para jogar com as palavras acadêmicas exigidas e apropriadas nesse campo, como faço neste momento.

E esse "meu" campo acadêmico-científico foi estruturante na construção de minha identidade profissional docente, pois foi onde passei por uma transição de conflito e mudança de artista profissional autônomo, no Rio de Janeiro, para funcionário público federal numa instituição de ensino superior, que depende de muitos profissionais de várias especialidades e com a responsabilidade de cumprimento de horários, planos de curso, balizamento dos gestos e da fala. E, ainda, com a necessidade de imprimir no estudante - ou pelo menos tentar - a ética profissional e o desejo de transformação social.

Além da perspectiva teórica acima apresentada, tentei seguir criteriosamente as orientações de Certeau (2002), que compreende que em História tudo começa com o gesto de separar, selecionar objetos dispersos culturalmente e, com essa atitude de ordem prática de ofício, recompor os objetos para dar significado social em outro lugar, que não o originalmente determinado. Essas orientações serviram como uma espécie de lente de aumento, para enxergar quais objetos estiveram na minha trajetória e quais poderiam ser mudados de lugar para realçar o que eu pretendia dizer:

Em história, tudo começa com o gesto de separar, de reunir, de transformar em documentos certos objetos distribuídos de outra maneira. Esta nova distribuição cultural é o primeiro trabalho. Na realidade, ela consiste em produzir tais documentos, pelo simples fato de recopiar, transcrever ou fotografar estes objetos mudando ao mesmo tempo o seu lugar e o seu estatuto. (Certeau, 2002, p. 81)

Com essas orientações, me senti mais seguro no desenvolvimento deste estudo, sobretudo, ao perceber que aqui estava também um pouco de como realizo minhas pesquisas e como oriento meus estudantes, a despeito de suas paixões temáticas. Ou seja, ao escrever minha trajetória, percebo que escrevo sobre como faço e oriento pesquisas, bem como trato com o envolvimento e o distanciamento com que é possível produzir conhecimento científico, na perspectiva de Elias (1998).

$\mathrm{Na}$ verdade, neste estudo faço uma análise a partir do interior, cuja profundidade tnum viés bastante significativo, uma carga emocional densa, o que requer do leitor um razoável desconto interpretativo. No entanto, tenho plena consciência de que estou fazendo um trabalho de investigação científica e não um romance. Desse modo, resolvi 
escrever o momento em que me constituo enquanto fonte, bem como quando levanto as fontes que me autorizam enquanto membro de um campo específico, especialmente 0 que se articula com a ciência.

Uma visão interna, com todo o envolvimento que requer entradas e permanências, é uma visão privilegiada dos acontecimentos, embora reconheça que a carga emocional da narrativa possa extrapolar o bom senso e, consequentemente, dificultar ou não enxergar a periferia dos próprios acontecimentos. Outrossim, o envolvimento pode ainda diminuir a capacidade de ouvir mais atentamente o discurso dos atores sociais envolvidos no próprio enredo a ser representado, sobretudo, ao falar da política institucional. Logo, o envolvimento permite a capacidade de enxergar os meandros que um personagem de fora não conseguiria traduzir os sentimentos, mas também, com igual proporção, estando por dentro, pode-se ofuscar tendências, expectativas etc.

Desse modo, no mesmo dia que tomei a decisão em escrever a tese usando o método autobiográfico, tratei de fazer um pequeno roteiro do que pretendia gravar na autonarrativa. Lembrei, inclusive, de um autor que conheci quando ainda era estudante de doutorado, entre 1996 e 1998, na Universidade Estadual de Campinas. No livro $A$ imaginação sociológica, Wright Mills (1982), entre outras coisas, fala dos arquivos que os pesquisadores têm e vão abrindo durante toda uma vida. Retirando desses arquivos as experiências, os temas e os problemas de seu interesse, de acordo com as necessidades teóricas ou empíricas, o pesquisador vai construindo sua carreira. Eu ainda acrescentaria que o pesquisador vai constituindo-se também enquanto fonte.

Nesse contexto, esta tese representa um pouco dessas reflexões, o ato de retirar do meu arquivo não apenas os problemas de pesquisa que fui lentamente acumulando, mas, sobretudo, acrescentar, descrever e refletir sobre as experiências que surgiram na minha trajetória de vida. Vejo que são muitos arquivos ou subarquivos que teria de abrir para separar os vestígios dessa temporalidade autobiográfica, mas, mesmo com essa consciência, é preciso dar limites para prosperar numa investigação com essas características.

Além disso, está presente nesta tese uma questão epistemológica importante, especialmente para as Ciências Humanas e Sociais, que desenvolvem pesquisas qualitativas utilizando entrevistas, história oral, história de vida ou biografia. No entanto, a autobiografia, por exemplo, tenta eliminar um aspecto ético preocupante na utilização de fontes orais. Isso diz respeito à utilização de minha própria narrativa sem a mediação de um outro pesquisador-entrevistador, posto que não me sinto usado enquanto objeto de pesquisa, não sou usado por um pesquisador que se apropria da minha fala, do meu discurso e se projeta profissionalmente e academicamente, sem sequer dar retorno em algum dia dos resultados de sua investigação.

Então, quando construo essa minha fala, eu tenho plena consciência de que essa enorme quantidade de material de pesquisa será utilizada para fins teóricos e práticos, cuja finalidade servirá para mim no primeiro momento, mas também, como resultado final, constará no repositório institucional e, possivelmente, servirá para outras pesquisas relacionadas ao mesmo tema. 
Assim, o êxito numa investigação em que os arquivos precisam aparecer à luz de um método está em não querer enganar os próprios instintos ou astúcias de pesquisador autônomo e relativamente experiente, mas se permitir errar pelos excessos a partir da compreensão do próprio método, ao qual está subordinado desde a sua justificação:

Além disso, a ordem cronológica com que se organizam biografias imprime à vida uma lógica retrospectiva e prospectiva, preocupada em dar um sentido à existência. O nome próprio, a individualidade biológica e a assinatura asseguram a constância e alimentam a ilusão de unidade, quando, na verdade, o eu é fracionado e múltiplo. (Alberti, 2015, p. 169170)

Ao analisar essas reflexões de Alberti (2015) acerca da cronologia que organiza os aspectos biográficos, todo esse material adquirido pelas minhas buscas em função do que precisava escrever na narrativa pessoal a partir de registros, serve bem ao que posso chamar de fonte, na perspectiva de Saviani (2006), que compreende uma fonte como algo que "indica uma base, o ponto de apoio, o repositório dos elementos que definem os fenômenos cujas características se busca compreender" (Saviani, 2006, p. 28-29). Então, sou aqui este repositório, carregado de sentimentos e emoções, único responsável pelas lembranças dos avanços e retrocessos da minha trajetória.

Considerando essas reflexões feitas pelo autor supracitado, é óbvio que as fontes históricas são construídas e constituídas a partir dos problemas levantados pelo pesquisador, na medida em que se encontram disponíveis em arquivos públicos, privados ou pessoais, uma relação inesgotável de documentos produzidos para finalidades diversas.

O que se verifica, no entanto, é que há muitos registros ou vestígios deixados por várias gerações, e esses documentos podem servir como fontes de pesquisa. Contudo, essa infinidade de documentos dispersos pode ser reorganizada pelo pesquisador em forma de fontes, além de servir de exemplo quando estamos diante de um projeto autobiográfico, conforme aqui aplicado. Assim, é necessário ter uma representação razoável de si mesmo para avançar nas evidências postas pelos documentos produzidos ao longo de uma trajetória.

Segundo Albuquerque Júnior (2007), as evidências são resultado dos questionamentos feitos pelo pesquisador aos documentos, ou seja, é o fruto da construção, em certa medida, do próprio pesquisador em suas ações de ofício, que, ao manusear os arquivos, pode encontrar uma infinidade de documentos aos quais realizará suas perguntas de interesse anteriormente ajustadas à finalidade de seu projeto. Entretanto, eu entendo que as reflexões do autor estão colocadas tomando por base os documentos escritos, embora essas evidências também possam ser tomadas de exemplo para as fontes orais.

Todavia, o autor não hierarquiza os tipos de fontes, muito pelo contrário, ele sinaliza uma relação íntima entre essas duas peças que podem revelar a trama. Assim, "o oral não deve ser oposto dicotomicamente ao escrito, como duas realidades de um espaçotemporal distintas e distantes, mas como formas plurais que se contaminam permanentemente, pois haverá sempre um traço de oralidade riscando a escritura e as falas sempre carregarão pedaços de textos" (Albuquerque Jr., 2007, p. 230). 
Compreender essa conexão entre a oralidade e o texto é fundamental para uma pesquisa que possui esses dois tipos de fontes, uma vez que não será possível a hierarquização ou valorização das evidências decorrentes de seus manuseios.

É pensando nessa construção híbrida que é possível também me colocar como um constructo de fonte, com possibilidades reais de me interpor nas evidências que surgem a partir da pergunta inicialmente colocada neste projeto autobiográfico, ou seja: qual é a percepção que tenho da minha trajetória de vida desde as séries iniciais à universidade em relação aos campos artístico e acadêmico-científico e as disposições políticas decorrentes entre 1975 e 2020 ?

Contudo, o detalhamento que trago neste capítulo foi fundamental para que eu fosse aprofundando a minha familiaridade com o método autobiográfico e, consequentemente, constituindo-me enquanto fonte de pesquisa. Tais procedimentos também foram me permitindo avançar para o interior do próprio estudo do objeto deste relatório. Assim, fui tendo o cuidado em me manter sempre no limite tênue entre a licença poética, a arte e a investigação científica. Dessa forma, fui organizando os tais "objetos da cultura material: fotos, objetos pessoais, a biblioteca etc., o que alguns chamam de teatro da memória" (Borges, 2015, p. 214).

Nesse teatro da memória, tentei mobilizar o que dispunha sobre o que eu havia escrito e dito em entrevistas para jornais ou para algum pesquisador. Assim, resolvi utilizar trechos do depoimento concedido ao Laboratório de História Oral e da Imagem da UFPE, em 2009, apenas em alguns momentos da tese. Essa decisão deve-se ao fato de que, embora eu tenha relatado temas semelhantes ao que trato aqui, especialmente no capítulo À guisa das memórias, minha fala naquele momento estava submetida às provocações de dois entrevistadores e, obviamente, outra emoção tomava conta a partir de suas intervenções. De qualquer modo, ao receber gentilmente as transcrições em 2019, percebi que detalhes do que foi dito foram úteis para o esclarecimento de alguns pontos relativos à construção do meu habitus de artista ou, parafraseando Bourdieu (1989), de uma disposição num campo específico.

Por outra parte, também recorri ao que foi possível mobilizar no contexto dos meus discursos, de modo que "o falar de si recobre, por sua vez, formas diversas que têm relação com a pluralidade dos objetivos enunciativos e dos tipos de discurso: descritivo, explicativo, argumentativo, avaliativo etc." (Delory-Momberger, 2012, p. 525). A autora reconhece, inclusive, que o caráter do discurso narrativo é um dos mais apropriados pela sua especificidade temporal, ou seja, por recorrer à temporalidade biográfica, muito comum no ato da fala do indivíduo.

De qualquer modo, o objetivo é mostrar empiricamente como uma fonte se constitui para efeito de análise, ainda que a relação sujeito-objeto esteja intimamente imbricada, e se confirme como uma autobiografia ou, como está previsto nas reflexões de Costa (2016), haja a possibilidade de ser uma auto-hermenêutica, ou seja, a interpretação que o autobiógrafo pode fazer de seus próprios discursos, mesmo como efeito colateral de seu cotidiano, onde mantém as relações interpessoais num determinado lugar, especialmente institucional. 
Nesse caso específico, o constructo do 'eu' fonte tem base empírica na perspectiva do levantamento da documentação da trajetória de vida em vários campos e, sobretudo, no registro da minha fala, seja espontaneamente, a partir de um roteiro criado por mim, seja nas entrevistas que concedi a órgãos de imprensa ou pesquisadores. Sendo assim, eu sou o constructo documental em ação, em movimento, me constituo e me sinto documento na acepção de um repositório possível de liberação de informações mediante questionamentos. Aliás, não apenas sou esse constructo, mas todos nós somos um pouco. Então, nessa perspectiva, o que eu revelo nesta tese é que as evidências aqui verificadas e apresentadas são reposicionadas a partir dos questionamentos feitos no início deste projeto autobiográfico.

Esse constructo documental é importante pelo fato de me colocar em constante ação e em evidência, simultaneamente. Em ação, porque preciso responder aos diferentes questionamentos ou indagações a partir e conjuntamente de uma trajetória, afinal ao fazer este trabalho também construo caminhos e destruo outros. Em evidência, porque preciso liberar e, às vezes, interditar informações dessa própria trajetória. Logo, esses dois constructos têm conexão entre a ação e a evidência.

Esses elementos se conjugam na elaboração mental e, consequentemente, num discurso, é o que Calligaris (1998) chamaria de ato biográfico. Ao mesmo tempo, as evidências, que são as liberações das informações relacionadas aos questionamentos considerando a sociabilidade, os aspectos econômicos, culturais, ou seja, a temporalidade autobiográfica, parafraseando Delory-Momberger (2016).

Nesse contexto, a base fundamental de um 'eu' constructo de uma fonte está na composição do repositório que represento; nesse caso, repositório das minhas angústias, táticas, desejos e expectativas, assim como das decisões que lograram êxito e das que resultaram em algumas perdas. Então, conforme pensa Saviani (2006), considerando, obviamente, a construção de uma fonte, sou esse repositório. Logo, os registros estão, irremediavelmente, na minha memória e no meu corpo. Portanto, dessa maneira que me constituo fonte.

É compreensível que essa fonte que constituo possa ser colocada em suspeição, aliás, como todas as fontes de diferentes naturezas. Como toda fonte historiográfica, o constructo da fonte que constituo nesta autobiografia também está sujeito à crítica, bem como a um histórico de sua integridade e autenticidade. Por isso, também é fundamental pensar nesse constructo do 'eu' fonte semelhante ao que Eakin (2019) fala a respeito da identidade narrativa e a sinceridade do autobiógrafo.

Ainda que se possa colocar a fonte que constituo em suspeição, numa crítica acerca da veracidade narrativa, por exemplo, eu me constituo fonte. Inclusive, todos os seres humanos podem se constituir enquanto fontes, desde que haja um entendimento do pesquisador de que aquele indivíduo seja um repositório importante para a elucidação de alguns fenômenos ou problemas sociais. Basta pensar na perspectiva da fonte oral, onde há uma clivagem significativa para se retirar dali informações importantes sobre o passado e o presente.

Entretanto, no meu caso específico, eu estou revelando e liberando as informações a partir dos meus próprios questionamentos, inclusive, da hipótese que construí. Então, tento resolver as próprias questões por mim levantadas e simultaneamente narradas por 
tramas que eu vivi, experimentei e, em alguns casos, criei o enredo e as tensões juntamente com os personagens elencados na estrutura narrativa deste estudo, mesmo que, para isso, tenha optado pelo uso de nomes fictícios.

Nessa perspectiva, o constructo do 'eu' fonte se revela em vários aspectos, não apenas a partir da minha fala registrada espontaneamente para a elaboração desta tese, mas também quando sou entrevistado por um pesquisador ou jornalista mediante algum movimento ou evento que eu tenha participado em algum momento de minha trajetória; sobretudo, quando desenvolvo a capacidade de mobilizar um conjunto de documentos ou coisas que escrevi para alguma instituição, em minha residência ou em outros lugares, além de fotografias ou objetos onde me faço conteúdo.

Considerando esses elementos, a minha memória também é uma fonte privilegiada. Aliás, eu sou a memória. E o 'eu' fonte é esse conjunto documental disperso em casa, entre amigos, na universidade e em outras instituições que, de alguma maneira, resguardam algo sobre minha existência. Assim, o resultado desta tese "diz respeito ao biografado enquanto dimensão constitutiva da gênese e de tornar-se socioindividual" (Delory-Momberger, 2016, p. 136).

Dessa forma, o constructo desse 'eu' fonte se firma a partir do que chamo de autonarrativa, ou seja, as minhas falas gravadas e registradas, minha temporalidade demarcada por episódios no campo das artes, ciência e política e entre cenários e instituições formadoras e transformadoras da realidade social. O que esse relato tenta explicitar é a minha maneira particular de agir e pensar frente aos desafios, assim como a minha percepção durante o próprio percurso intercambiante em vários ambientes.

Essa constatação é fundamental em pesquisas dessa natureza, porque um dos aspectos epistemológicos nesse jogo de tensões autobiográficas "é justamente a configuração singular de fatos, de situações, de relacionamentos, de significações, de interpretações que cada um dá a sua própria existência e que funda o sentimento que tem de si próprio como ser singular" (Delory-Momberger, 2012, p. 526). Esse é um processo que se revela não apenas durante a produção dos registros ou dos procedimentos da investigação, mas também enquanto evidência documental.

Nesse contexto, percebi que lentamente fui me constituindo uma fonte na medida em que pude construir outras fontes para a própria investigação. Isso aconteceu, por exemplo, ao arrolar a massa documental a meu respeito, a partir da minha escrita, ao redigir o meu primeiro trabalho acadêmico, a monografia de conclusão do curso de pósgraduação lato sensu. Incluo também alguns trabalhos para congressos, o meu trabalho de mestrado, a dissertação, o projeto e tese de doutorado e quando comecei a escrever outros trabalhos relacionados à minha experiência corporal, a dança afro.

O constructo do 'eu' fonte parte da minha experiência enquanto artista, porque todos os escritos inicialmente foram relacionados a esse tema, que envolve as questões corporais e a etnicidade afrodescendente. Assim, todas as narrativas inicialmente construídas foram fundamentadas e orientadas por essa matriz de interesse étnico. Passei a escrever outras coisas, mas essa temática foi seguramente o ponto de partida, é o que me insere no campo acadêmico, porque, parafraseando Delory-Momberger (2016), essa foi a maneira que encontrei para minha razão narrativa, o que expressa também a minha biografização. 
Considerando essa racionalidade, todo o indivíduo constrói uma representação de seu tempo e espaços vividos cumulativamente, seja por meio de episódios curtos ou mais longos, seja por apenas um dia. Assim, "de acordo com essa lógica, o indivíduo humano vive cada instante de sua vida como o momento de uma história: história de um instante, história de uma hora, de um dia, história de uma vida" (Delory-Momberger, 2016, p. 136). Eu diria que vivemos continuamente a história de muitas histórias.

Se a minha história é um ponto importante para o meu constructo enquanto fonte, até onde minha memória alcança, os rabiscos desse trabalho de monografia foram resultados de uma decepção, um momento tenso em que tive que reagir ao que considerei como preconceito pela técnica da arte que eu desenvolvia no Rio de Janeiro. Então, o que originou esses escritos iniciais foi uma participação num Festival de Dança Contemporânea, no Teatro João Caetano, no Rio de Janeiro, em 1988 ou 1989, como já falei anteriormente. De todo modo, a razão da minha narrativa expressa uma dimensão bastante interessante no que diz respeito ao impacto do que foi devidamente contado enquanto episódio e, sobretudo, no momento em que percebi que a utilização desses elementos, textos e intertextos, servia para o que estou chamando de constructo do 'eu' fonte, ao que posso expressar como internarrativas da memória.

O constructo do 'eu' fonte é modelado pelo conjunto de documentos que são mobilizados na compreensão de um indivíduo na sua relação com os diferentes grupos sociais. Essa individualidade, singularidade constitutiva do 'eu' fonte, tem uma relação direta com os diferentes grupos e instituições. Mas essa modelagem do próprio constructo é fundamentalmente carregada de muitas ações anteriores sob as quais reside a evidência da própria singularidade.

Esse conjunto documental possui uma coerência interna que sofre pressão do ambiente externo a partir de sua historicidade. Nesse sentido, toda a produção bibliográfica juntamente com a entrevista concedida ao Lahoi e os áudios que gravei, por exemplo, resguardam em si uma coerência interna, constitui a essência do constructo do 'eu' fonte que, se for submetido à alguma análise, será possível identificar seu núcleo de significação. Portanto, é esse núcleo que tento trazer à prova.

Por outro lado, é razoavelmente aceitável que outro conjunto documental, ou seja, aqueles documentos que foram construídos por algumas instituições ao meu respeito, como, por exemplo, ofícios, processos e outros registros, não tenha nenhuma relação direta com que estou falando do ponto de vista desse constructo, mas tenha a ver indiretamente com a sua composição geral, na sua complexidade, na medida em que trata sobre algumas ações ou atividades por mim desenvolvidas. Isso ocorre porque todos esses elementos também passam a compor a minha singularidade, a minha individualidade, e por meio disso é comprovada minha relação com os outros membros da sociedade mais geral.

Desse modo, "cada pessoa só é capaz de dizer 'eu' se e porque pode, ao mesmo tempo, dizer 'nós'. Até mesmo a ideia 'eu sou', e mais ainda a ideia 'eu penso', pressupõe a existência de outras pessoas e um convívio com elas - em suma, um grupo, uma sociedade" (Elias, 1994a, p. 57). Logo, é preciso compreender que o método autobiográfico, que tem como pressuposto a construção de uma fonte primordial - a fala, o 
discurso do indivíduo sobre si mesmo -, mantém uma coerência, visto que a percepção do indivíduo tem uma relação estreita com os grupos sociais que fazem parte de sua experiência na trajetória.

Nesse contexto, é preciso dizer que meus planos e minhas ações ocorrem em virtude dos processos sociais mais amplos e corroboram as transformações sociais em curso, sem isso o movimento que faço não teria sentido para ser realizado, sem a devida interrelação com tais transformações cegas a longo prazo ou, às vezes, perceptíveis. Em outras palavras, os planos e ações individuais são possíveis em virtude da conjuntura mais geral que the permite a movimentação.

Considerando esses elementos, o constructo do 'eu' fonte, esse amálgama de códigos linguísticos, e outros que possam atingir a percepção humana, ou pelo menos a minha percepção nessa trajetória, é produto e processo de várias ações e acontecimentos cumulativos, que expressam irremediavelmente a minha temporalidade autobiográfica. Com efeito, esse constructo também é carregado de emoções, pelo fato de que numa trajetória várias relações históricas e sociais são estabelecidas, afinal é por meio disso que aprendemos e desenvolvemos determinados sentimentos uns com os outros.

Nessa relação interpessoal e no processo de objetivação e subjetivação, o indivíduo passa a ser um repositório, esperando a oportunidade para servir enquanto fonte. Desse modo, o constructo do 'eu' fonte se materializa quando, por exemplo, sou convidado a expor minhas lembranças e concepções de arte e movimento artístico no Recife, na década de 1980. Aliás, é o que faço no tópico Um parêntese na memória: arte e ciência, na primeira parte desta tese. A gravação que fiz, em particular, exemplifica bem a ideia central do que estou chamando de constructo do 'eu' fonte, isso porque a fala exposta indica uma concepção estética e uma posição especial que ocupei no campo artístico durante considerável parte da minha trajetória.

Nesse enquadramento sócio-histórico até aqui apresentado, há uma complexidade que envolve esse constructo em relação a sua aplicação na autobiografia, justamente porque, como diz Velandia Mora (2010), há nesse tipo de pesquisa uma relação imbricada em que o narrador é a fonte de pesquisa, o tema é o autor daquilo que se escreve. $O$ autobiógrafo, portanto, é o protagonista do projeto e traz para sua escrita a sua concepção da trajetória, sua forma particular de ver e sentir o próprio trajeto, isso revela a maneira de se modelar um caminho, de pensar e agir diante dos desafios encontrados e superados na temporalidade de sua concepção.

Por outro lado, o construto do 'eu' fonte parte do reconhecimento do outro sobre a possibilidade de ouvir ou ver o que você tem a dizer e a forma como agir em relação aos eventos-crise durante a trajetória. Quando um pesquisador, por exemplo, reconhece em você uma "liderança" ou personagem que pode falar sobre determinados assuntos de seu interesse e que pretende elucidar. É dessa forma que você passa a ser um repositório em potencial no constructo de uma fonte.

Considerando esse constructo, compreendemos o mundo por meio da nossa memória e a partir do que conseguimos "ordenar" do passado, viver o presente e projetar o futuro. Assim, o constructo do 'eu' fonte representa o conjunto dos registros de uma atividade ou das atividades proeminentes de um determinado momento ou espaço da temporalidade autobiográfica. Ou seja, o constructo de minha referência nesta tese é o 
resultado daquilo que consegui e quis resguardar na memória, as minhas diversas atividades profissionais em tempos vividos e agora devidamente registradas e públicas, o que mostrarei na próxima seção.

\section{Do constructo às fontes}

Na seção anterior fiz uma breve análise das questões relacionadas ao meu itinerário e a possibilidade de um constructo na conexão com diferentes tipos de fontes, em que foi possível refletir sobre o meu processo de objetivação e subjetivação. Dessa maneira, esses aspectos do constructo me fazem lembrar de Bosi (1994) ao tratar das questões relacionadas à memória, sobretudo, o que o passado reserva enquanto aprendizado, incorporado de forma automatizada, com todas as características próprias do que é costumeiro em seu cotidiano ou, pelo menos, aquilo que foi devidamente exercitado enquanto rotina. Diz ela:

O passado conserva-se e, além de conservar-se, atua no presente, mas não de forma homogênea. De um lado, o corpo guarda esquemas de comportamento de que se vale muitas vezes automaticamente na sua ação sobre as coisas: trata-se da memória-hábito, memória dos mecanismos motores. De outro lado, ocorrem lembranças independentes de quaisquer hábitos: lembranças isoladas, singulares, que constituiriam autênticas ressurreições do passado. (Bosi, 1994, p. 48)

Conforme Bosi (1994) as lembranças tratam-se de ocorrências das memórias efetivadas no corpo do indivíduo, nos comportamentos costumeiros, quando fazemos ressurgir lembranças isoladas ou conectadas aos sentimentos e emoções de um passado mais ou menos distante que, pela força da vontade, emergem nos vestígios que registro nessa minha temporalidade autobiográfica e na razão desta narrativa, por exemplo. Assim, mesmo as lembranças isoladas ou em conexão com os sentimentos de outros indivíduos constituem, em seu conjunto, o constructo de uma fonte.

Para além da reflexão da autora, o constructo do 'eu' fonte se expressa de várias maneiras, seja do arquivo institucional que resguarda documentos e objetos de minha Pasta de Assentamento Funcional da UFPE, seja do meu arquivo pessoal, o mais provável, onde surgem documentos dos mais inusitados aspectos, se considerarmos suas tipologias.

Ao escarafunchar a minha pequena biblioteca na sala que ocupo na universidade, encontrei uma relíquia que não lembrava. Trata-se de impresso com letras marcadas pela antiga impressora oitenta colunas, só os mais antigos sabem do que estou falando. Considero esse texto como uma espécie de proto-escrita da minha dissertação e da tese, que viraram livros. Esse documento histórico expressa uma temporalidade de muitas convicções sobre a dança afro e a vontade de fazer algo que fosse mais atrativo do ponto de vista artístico.

Esses escritos foram produzidos em 1991, para conclusão do curso de pósgraduação em Psicomotricidade e Pedagogia do Movimento Humano. Após a entrega do trabalho final, resolvi colocar meu nome artístico e vender o texto entre meus alunos da Escola Estadual de Dança Maria Olenewa, antiga Escola do Teatro Municipal do Rio de Janeiro. 
Posso adiantar que o resultado financeiro da venda desse material foi muito aquém do esperado, penso que só tive cerca de dez compradores, numa turma de 60 alunos. Porém, do ponto de vista da imersão, da reflexão sobre a técnica corporal, objeto da arte afrodescendente, os resultados seguiram a longo prazo, com impacto até o presente momento, pela concepção e visão de mundo, bem como pela própria força dos estudos que consegui aprofundar.

Figura 59 -

Capa da monografia desenhada à mão por Mônica, Rio de Janeiro, 1991.

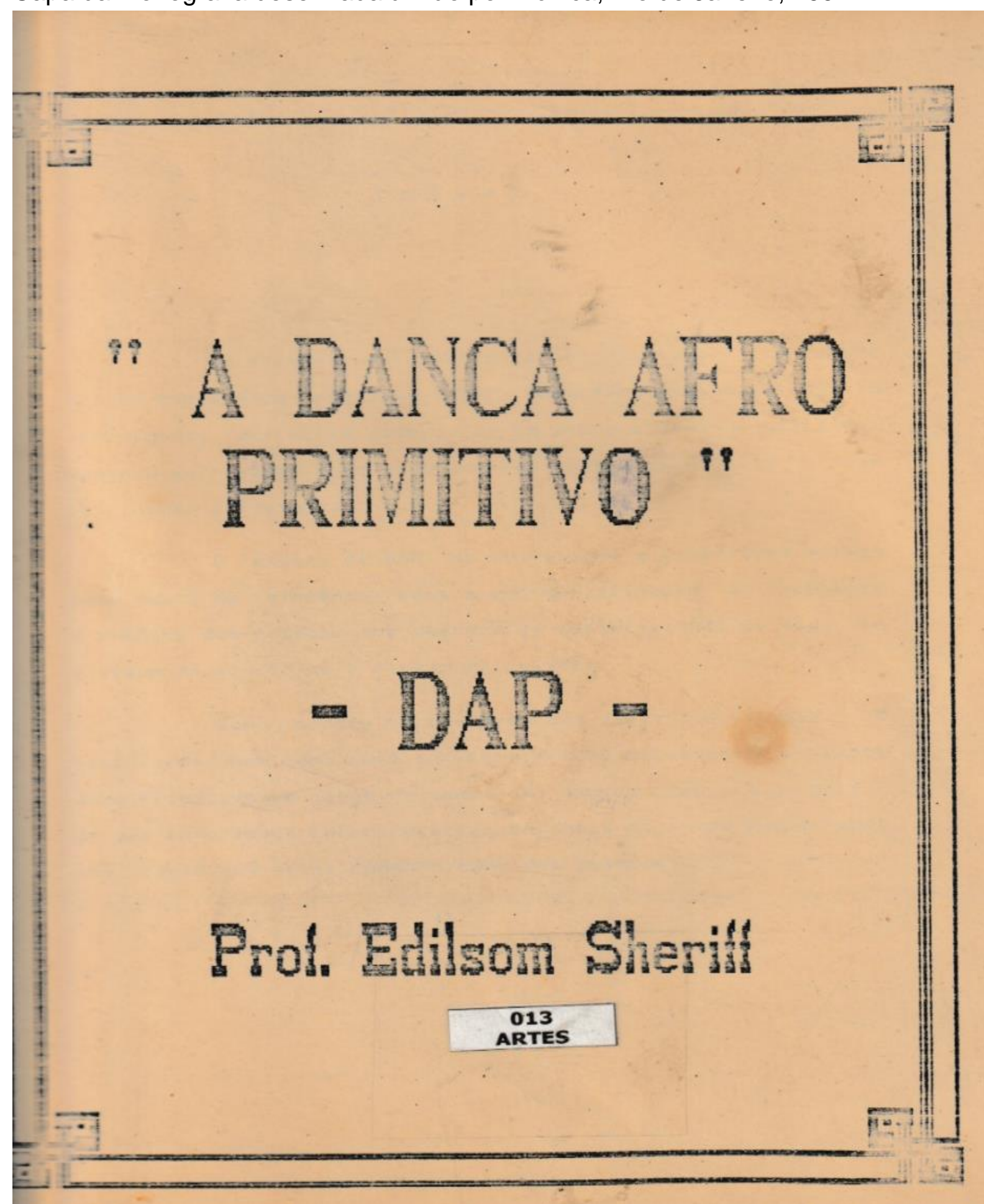

Fonte: acervo da biblioteca do autor. 
O referido texto tenta recuperar o sentido e origem da Dança Afro Primitivo - DAP -, uma espécie de resgate histórico, e traz algumas reflexões acerca do grupo ao qual participei e foi responsável por fazer com que eu desenvolvesse trabalhos dessa técnica de expressão artística. Assim, segue minhas modestas reflexões naquela ocasião: "O grupo nasceu em 1979, [no Sesi de Sítio Novo] entre Olinda e Recife, com apenas 12 componentes e o nome Zumbi Bahia. Em 1980, as experiências do Teatro Experimental do Negro do Recife ocasionaram a fusão e o batismo do Balé Primitivo de Arte Negra de Pernambuco" (Sheriff, 1991a, p. 12).

Como o leitor pode perceber, o título da monografia em tela está entre aspas, o que demonstra certa dúvida não apenas na grafia, mas também se a dança realmente seria primitiva. Entretanto, a minha assinatura de autor é essa mesma, com exceção do erro da letra ' $m$ ' na palavra 'Edilson', mesmo assim grafada em pleno vigor, como também foi o trabalho artístico desenvolvido no Rio de Janeiro. O texto em tela reflete muito bem esse momento da arte de dançar e a perspectiva de minha transmigração do campo artístico para o acadêmico. No fundo, eu pretendia também intensificar a ideia de que a DAP era uma dança cuja técnica era não ter técnica, pois acreditava que se revestia apenas de emoções.

O texto foi vendido no formato A4, encadernado com folha transparente na frente e contracapa vermelha. Para ilustrar os escritos que seriam comercializados entre os amantes da referida expressão artística, lembro que recorri a uma de minhas alunas na época, a Mônica, que era jornalista, e ela traçou alguns rabiscos desenhados a lápis grafite.

A marca logo abaixo do meu nome enquanto autor diz respeito ao número 13 e à Arte, uma referência ao arquivamento na prateleira do Laboratório de Sociologia do Esporte UFPE/CNPq, feita por um dos bolsistas. Considerando que eu pretendia, de alguma forma, trazer à discussão os escritos de uma época, incorporei essa fonte ao arquivo pessoal, do mesmo modo como estou fazendo com outros textos que havia esquecido.

Percebo que 1991 foi um ano emblemático para o processo de transmigração de campo, que pretendo reafirmar enquanto hipótese e constructo de uma fonte. Naquela ocasião, eu estava realmente inquieto com a ausência de literatura sobre a arte que desenvolvia, foi um período que escrevi muitas coisas aparentemente desconexas, mas hoje vejo que eram apenas protótipos de pesquisas mais avançadas, como a dissertação de mestrado e a tese de doutorado. Para se ter uma ideia, entre os textos esparsos, deve constar um registro na Biblioteca Nacional do Rio de Janeiro, algo escrito genericamente com o título $A$ dança afro no Brasil, com isso pretendia apresentar a diversidade e submodalidades dessa técnica corporal. Vejo que essas ideias acabaram se fortalecendo no último capítulo da minha tese de doutorado (Souza, 1998).

Contudo, no arquivo pessoal, como foi referido nos procedimentos, podemos intercruzar várias fontes que servem como análise do constructo, como, por exemplo, a carta de aceite do primeiro trabalho que enviei ao Congresso Brasileiro de Ciências do Esporte, no primeiro ano de docência na Universidade Federal de Uberlândia, em 1993. Ao me deparar com esse documento, lembrei de que havia escrito um outro texto para 0 mesmo congresso, na edição de setembro de 1991, ano em que concluí o curso de 
Especialização em Psicomotricidade e Pedagogia do Movimento Humano, que foi o mesmo período dos escritos vendidos para os alunos da Escola Estadual de Dança Maria Olenewa e dos registros na Biblioteca Nacional.

O texto é bem coerente em relação à intermitência entre a escrita de um artista e um futuro professor universitário, mostra, inclusive, algumas confusões conceituais, embora reconheça uma certa originalidade nas linhas centrais dos argumentos. Com esse trabalho, tive a minha primeira apresentação pública num congresso. Posteriormente, apresentei-o também numa sessão de comunicações coordenadas, que era submetida a um debatedor. Lembro bem da apresentação em que fui sabatinado pelas novidades deste conteúdo na área de Educação Física, sobretudo naquele congresso, onde os resumos eram impressos numa moldura.

Figura 60 -

Primeiro trabalho apresentado em congresso sobre a dança afro, Conbrace, 1991.

RESGATAR A DANCA AFRO-PRIMITIVO DENTRO DO CONTEXTO SOCIO-CULTURAL

Prof.: EDILSON SHERIFY (Rio de Janeiro, RJ)

\begin{abstract}
A problemática central do assunto se basela na busca de conceltos, res gạte a origem e histórico da dança afro-primitivo, bè como, sua situaçảo nó cámo das danças teatrais.

0 que me levou a escrever este trabalho, inicialmente fol a necessida de de registrar meus 11 (onze) anos de experiência prática e en segundo lugar, os diversos questionamentos dos meus alunos, a respelto de uma literatura es pectallzada.

O tema propōe, desenvolver os mals diferentes conceitos sobre a danç afro-primitivo, que particularmente criel a sigla bAP.

A DAP existe no tempo sob o domínio de qualquer povo, porém sua "sis temat1zaçäo", longe de preconceltos estét1cos, e sua prätica teatral se deu aqui no Brasil, pelo balé príntîvo đe arte negra-PE.

o terao primitivo aparece como un ponto fundamental e natural na ma neíra de cada individuo se expressar, da primetra expressão, portanto, pura que cede condisão às expressōes gestuals futuras com um sentido úntco e uni versal que possiblilta a expansäo dos novos motivos.

A danca afro-primitivo (DAP) necessita de um tratamento alnda mais profundo no que se refere ao resgate cultural e sua base fllosöfica; e que não seja descartada a possiblildade co conhecimento da religiâo afrombrasilei ra e interpretação dos orixás.

E, além dos aspectos mencionados no que diz respelto às suas caracteristicas físicas psicossocials, poderíanos situá-1a dentro do aspecto tera pêut1co.
\end{abstract}

Fonte: http://revista.cbce.org.br/index.php/RBCE/issue/view/60. 
Com o título Resgatar a dança afro-primitivo dentro do contexto sócio-cultural, eu estava intermitente entre dois campos, a arte e a ciência. Naquele momento, o principal desejo enquanto indivíduo, artista autônomo no Rio de Janeiro, era de me fazer conhecer no ambiente da Educação Física e ministrar alguns cursos dessa técnica-dançante para estudantes e professores nos congressos, mas, infelizmente, isso nunca aconteceu.

Ao analisar essa fonte, adquirida on-line entre os anais de todas as edições do Congresso Brasileiro de Ciências do Esporte, percebi que ali aparecem importantes traços autobiográficos. Digo isso porque os objetivos do texto eram os de "registrar meus 11 (onze) anos [na época] de experiência prática" e responder "aos questionamentos dos meus alunos a respeito de uma literatura especializada" (Sheriff, 1991b, p. 199), provavelmente na referida técnica de dança.

Com esses objetivos, eu pretendia dizer que havia algo a ser contado sobre uma atividade desenvolvida digna de ser apresentada num dos maiores e melhores congressos acadêmicos-científicos naquele momento, cujo tema era produção e circulação do conhecimento em educação física, esporte e lazer. Então, a intenção do meu resumo era despertar uma produção que correspondesse à necessidade dos meus alunos que cobravam de mim uma literatura compatível com a prática desenvolvida na época.

A figura revela que a ideia principal deste trabalho era a busca de conceitos para situar a origem e a história da dança-primitiva, ou seja, não era uma preocupação com os estilos de dança afro existentes e já do meu conhecimento, mas uma preocupação para uma técnica muito específica, a primitiva, uma vez que eu reafirmava sua origem e desenvolvimento aqui no Brasil.

Outro aspecto bastante interessante são os anúncios que faço nessa comunicação acadêmica, ou seja, se o termo dança afro-primitiva já era de algum conhecimento enquanto dança teatral, o termo DAP, a sigla que indica a referida dança foi criada por mim para dar mais visibilidade à técnica sistematizada pelo grupo que fazia parte. Além disso, eu mesmo tentava conceituar aquela expressão artística e buscava apoio na religião afro-brasileira, inclusive, com a interpretação da ancestralidade. Um dos apelos feitos no texto de aproximadamente 22 linhas era de que aquela expressão artística possuía fortes "características físicas e psicossociais, [assim] poderíamos situá-la dentro do aspecto terapêutico" (Sheriff, 1991b, p. 199).

O leitor pode se perguntar sobre a necessidade de diferenciação estética e conceitual entre as danças afro. Então, só a título de curiosidade, o afro era primitivo porque contrapunha a dança afro-brasileira, afro jazz, afro contemporâneo e a ginástica afro-brasileira, que foi desenvolvida pelo José Anchieta. Com o avanço das minhas elucubrações, oito anos depois, devido a minha tese de doutorado, consegui distinguir as técnicas corporais aplicadas na dança afro e as razões pelas quais havia a necessidade de diferenciação conceitual (Souza, 1998).

Desse modo, a distinção se faz na perspectiva do distanciamento da origem de matriz africana, da ancestralidade, e da polidez das condutas individuais que se refletem na técnica da dança, o que pode ser facilmente observado empiricamente quando diretores-coreógrafos e dançarinos-atores se apresentam com ritmos percutidos diretamente com os tambores e atabaques ou eletronicamente, com os pés descalços, corpos nus ou seminus, além da aplicação de piruetas, conforme a utilização técnica. 
Nesse contexto, no momento em que tento interpretar o que escrevi em 1991, percebo que a proposta de conceituar a dança objeto da minha experiência, infelizmente, não se cumpriu. Tudo ficou mesmo no anúncio e desejo de divulgar academicamente algo que ainda estava no campo da arte. Aliás, a própria assinatura do texto ainda foi feita com o pseudônimo artístico. Entretanto, é importante assinalar que o conhecimento é cumulativo e, à medida que as leituras avançam e a participação em outros campos vai se aprofundando, vou paulatinamente apontando outros desafios para a arte-dançante de meu interesse. Assim, vou construindo e me constituindo enquanto fonte.

Há de se perceber, no entanto, que o VII Congresso Brasileiro de Ciências do Esporte naquele ano tinha como tema a produção e veiculação do conhecimento na educação física, esporte e lazer no Brasil: análise crítica e perspectivas, ou seja, era um momento propício para mostrar o que eu havia produzido em termos de novo conhecimento acerca de um dos conteúdos da área, no caso, a dança; especialmente, como poderia e deveria fazer circular essa produção acadêmica. Além disso, a proposta do evento também corroborava as minhas intenções; no caso, fazer uma crítica ao que havia sido produzido até o presente momento e apontar outros encaminhamentos para escoar essa produção.

Em 1993, já docente da Universidade Federal de Uberlândia, apresentei um trabalho com um título bem sugestivo, $A$ expansão da dança afro na UFU: uma proposta política pedagógica. Esse título expressava bem o meu desejo de promover dentro da instituição universitária a estética afro-brasileira. Assim, a publicação desse trabalho num dos maiores congressos da nossa área seria um bom encaminhamento para a divulgação e, ao mesmo tempo, mais um indicativo de que aquela arte se constituiria como objeto de investigação científica; pelo menos, esse era o meu pensamento.

Além dos aspectos científicos, havia a intenção de fortalecer os elementos políticopedagógicos que emergiam dessa arte de matriz africana. Naquela ocasião, primeiro ano de docência num curso superior, eu pretendia, como está no resumo dos anais, ${ }^{47}$ desdobrar as ações em projeto de ensino, pesquisa e extensão.

${ }^{47}$ Anais do VIII Combrace, Belém do Pará, 1993, p. 44. 
Figura 61 -

Segundo trabalho apresentado sobre a dança afro, Conbrace, 1993.

44

VIII CONBRACE

\title{
EXPANSÃO DA DANĢA AFAO NA UFU: UMA PROPOSTA POLITICA PEOAGOGICA
}

\author{
AUTOR: PROFS GDILSONDE SOUZA
}

UNIVERSIDADE FEDERAL OE UBERLȦNDIA

CENTAO OE CIENCIAS BIOMEDICAS

DEPARTAMENTO OE EOUCAÇÁO FISICA E ESPORTES

\begin{abstract}
A dança Afro no Brasil, apesar de ser priviègio de aiguns grandes centros, tern sido vista apenas como algo festivo exótico, desvinculada do ámbito académico e nảo sendo objeto de preocupação pedagógica dos estudiosos.

O presenie artigo lam por objetvo relletir sobre a Expansảo da Dança Alro - DAF em Uberiandia, bem como. verificar a sua importáncia sócio-cuhural para o povo uberiandenso. Portanto, o projeto de expansấo corresponde a quatro projetes menores, sendo: a) Projelo de Ensine; b) Projeto grupo cultural de bança Arro da UFU; c) Projeto Comunitario e d) Projeto de Pesquisa.

O pressuposto básico é de que, urna vez a DAF nảo se encontrando na Universidade, na cultura extra-universitaria na cultura popular, trabainar no sentido da subjetividade coletiva, parece ser o marco fundamental na construçăo de um novo Ethos - uma nova visáo de mundo para a populaçāo envolvida no processo.

Assim sendo, este projeto represemta um grande desalio na tentativa de estabelecer uma outra perspectiva estética e existencial e que, a Universidade possa se comprometer junto à comúnidade em ger al, como sendo um espaço qualitativamente importante na troca de saberes.
\end{abstract}

Fonte: http://revista.cbce.org.br/index.php/RBCE/issue/view/67.

A partir dessa fonte, junto com a anterior, posso localizar uma das evidências do processo de transmigração que eu estava iniciando, tentando dar um sentido acadêmicocientífico a uma expressão artística cuja técnica eu já dominava por muito tempo. Era também um bom ensaio acadêmico para o que estava pretendendo desenvolver enquanto pesquisa de mestrado e para a disciplina eletiva que criaria posteriormente.

Contudo, naquele momento, eu já havia entrevistado vinte dançarinos-atores no Rio de Janeiro para escrever a pesquisa de mestrado e, embora tivesse o material que serviria como objeto de estudo, ainda não sabia o que deveria fazer com as transcrições das fitas. A falta de experiência impedia a compreensão para constituir as fontes que estavam sob a minha própria responsabilidade, ainda que eu mesmo fosse uma dessas fontes. Como consequência disso, não conseguia me desvencilhar de falsos pressupostos científicos para ascender no processo de análise e defender a dissertação.

Os falsos pressupostos dizem respeito ao tipo e procedimentos de investigação que pudessem atender aos pré-requisitos de uma pesquisa ao nível de mestrado: naquela época eram quase inexistentes os cursos de pós-graduação stricto sensu em Educação Física, boa parte do que se tinha de investigação nessa área eram, como ainda hoje, pesquisas voltadas para a área da saúde. Dessa forma, o meu trabalho fugia um pouco dessa vertente por abordar os aspectos das representações sociais, portanto, uma pesquisa voltada para a área de humanas.

De volta ao resumo apresentado no congresso em 1993, eu afirmava que a dança afro já estava consolidada em alguns centros urbanos e já possuía status de privilégio cultural, mas ainda não era uma preocupação de pedagogos e estudiosos em ambientes acadêmicos. Então, um dos objetivos daquela comunicação era "refletir sobre a expansão 
da Dança Afro - DAF - em Uberlândia, bem como verificar a sua importância sócio-cultural para o povo uberlandense" (Souza, 1993, p. 44). Desse modo, está explícito que eu intentava promover a dança afro dentro da universidade e mostrar a importância que aquela arte deveria ter para uma cidade do interior de Minas Gerais, inclusive, uma outra sigla foi criada para facilitar a compreensão, DAF, ou seja, dança afro.

Naquela ocasião, primeiros meses de docência na universidade, ainda não tinha muita noção de que havia um movimento social negro bastante expressivo em Uberlândia. $\mathrm{Nm}$ bairro tradicional da cidade, o Patrimônio, que se configurava como um quilombo urbano. $E$ isso foi fundamental para que o projeto de expansão dessa arte se consolidasse dentro da instituição e adquirisse um valor acadêmico e cultural significativo, embora esse reconhecimento tivesse vindo com certo olhar de desconfiança por parte de alguns professores e estudantes.

Agora sob análise, eu pretendia desenvolver vários projetos dentro da universidade, como: o Grupo de Dança Afro da UFU; a disciplina eletiva Teoria, Prática e Metodologia da Dança Afro e a pesquisa de mestrado, defendida na Universidade Gama Filho, quando fui aprovado com louvor. No entanto, mais do que uma promessa, o trabalho pretendia sugerir e exigir outra postura acadêmica, especialmente da própria Universidade Federal de Uberlândia, pois o último parágrafo do resumo tinha o seguinte excerto:

Assim sendo, esse projeto representa um grande desafio na tentativa de estabelecer uma outra perspectiva estética e existencial, e que a Universidade possa se comprometer junto à comunidade em geral, como sendo um espaço qualitativamente importante na troca de saberes. (Souza, 1993, p. 44)

Com essas palavras eu também estava tentando estabelecer um diálogo e fazer política com a instituição no sentido de ter os projetos aprovados, mesmo que, naquele momento, a única ferramenta para isso fosse o próprio texto apresentado no congresso. Inclusive, nessa ocasião, a assinatura do resumo já era como professor universitário e com o meu sobrenome de batismo.

Para o leitor ter uma ideia mais concisa daquele momento, em 1993, eu estava provocando a produção de fontes sem ter muita noção dos possíveis impactos que isso poderia causar em minha carreira docente, sobretudo, no campo da arte. Além disso, já havia algum indício de que eu estava mudando de campo, não porque pretendia de fato fazer essa transmigração, afinal nunca pensei em deixar algo que havia me sustentado durante tanto tempo e ainda me apresentava artisticamente nos teatros e dentro da própria universidade, mas já estava no horizonte, levando em conta minhas produções e interesses na época.

Nesse contexto, a minha participação no VIII Congresso Brasileiro de Ciências do Esporte: Que ciência é essa? Memória e tendências era provocativa no sentido de evocar uma memória ancestral no campo das ciências que a Educação Física e Esporte pretendiam se estabelecer. Havia naquela ocasião uma questão epistemológica a ser resolvida entre os estudiosos da área, a busca pelo objeto de nossas investigações para reafirmação no ambiente acadêmico. Dessa forma, eu acreditava que, em virtude das incertezas do campo indefinido, isso favorecia o que estava pretendendo fazer. 
Neste momento, ao ir em busca de um constructo da fonte que me constituo, percebo com mais clareza que as ideias sinalizadas em pequenos rabiscos apresentados como resumo nos congressos científicos e as promessas da década de 1990 se materializaram, pelo menos, uma parte dos desejos. Assim, os resumos enfraquecidos pelas inconsistências teóricas e conceituais daquele momento foram fortalecidos pela memória do tempo presente, revigoraram-se em alguns trabalhos científicos, como, por exemplo, a defesa da minha dissertação de mestrado, Representações sociais da cultura negra através da dança e de seus atores (Souza, 1995).

Além de ser produto de um pequeno acúmulo das discussões elaboradas e refletidas nos eventos acadêmicos a partir dos textos dos congressos, esse trabalho reflete um dos momentos mais importantes da minha transmigração do campo artístico para o acadêmico. Ele representa uma dupla satisfação. Primeiro, porque a ideia central do texto foi a de interpretar as histórias de vida de atores sociais que praticavam a dança afro no Rio de Janeiro e de que maneira essa técnica de dança construiu a identidade e consciência social desses atores. Logo, consegui expor num documento acadêmicocientífico parte da percepção de muitos colegas artistas sobre a arte que desenvolvíamos com muito afinco e que, inclusive, serviu como forma de sustento de muitas famílias, ou seja, uma fonte construindo outras fontes.

Segundo, de posse daquele conteúdo, era possível ofertar, como acabei fazendo, uma disciplina eletiva num curso superior de Educação Física, o que me parecia inusitado, considerando as tensões presentes naquele campo institucional acadêmicocientífico regrado pelas exigências, pelo preconceito étnico e também pelas diferenças das áreas dos saberes. Dessa maneira, eu compreendi com aquele estudo que o principal subsídio que dispunha enquanto literatura tinha origem nos conteúdos abordados por meio das histórias de vida dos atores sociais, dançarinos-atores, que colaboraram com aquela investigação. Com a referida pesquisa, eu defendia os seguintes objetivos:

Descobrir as representações sociais de atores da dança afro em torno dessa atividade corporal, verificando quais as principais construções presentes no conteúdo de seu discurso. Verificar como atores de diferentes experiências sociais constroem a sua identidade e consciência social ao praticarem essa atividade de dança; Subsidiar uma proposta de inclusão da dança afro no currículo da licenciatura em Educação Física, discutindo criticamente o papel dessa arte na expressão da cultura negra representada na sociedade brasileira. (Souza, 1995, p. 4)

Como o leitor pode perceber, havia a necessidade de encontrar as razões que justificassem não somente o estudo pretendido, mas a importância identitária dos indivíduos no seu fazer artístico a partir de suas relações sociais. Além desses elementos, eu pretendia tornar possível a compreensão de que havia a necessidade de uma arte de matriz africana ser ou fazer parte indissociável da formação técnica e humana de estudantes de um curso superior, principalmente dos discentes do curso de Licenciatura em Educação Física.

Essas ideias posicionadas no trabalho de mestrado estavam bastante avançadas naquele momento, somente oito anos depois é que sua propositura entrou em consonância com o debate mais geral devido à emergência da Lei 10.639/2003, que trata da obrigatoriedade do ensino da história da África e história da cultura afro-brasileira. No 
entanto, já no final de 1994, consegui criar a disciplina eletiva e ministrá-la para estudantes de diferentes cursos da Universidade Federal de Uberlândia, embora a minha recordação dê conta de que a primeira turma só teve sete estudantes matriculados, e a segunda, 22.

Situação geral e epistemológica à parte, era muito difícil, entre os idos de 1995, pensar em parar de dançar ou me desvencilhar da arte, embora o campo acadêmico tivesse se apresentado com bastante força, especialmente pelas inúmeras reuniões em que era convocado a participar. É compreensível também que, para um artista em transição, tudo aquilo não passava de simples evocação do vazio, pois a ordem e o sentido prático da vida pareciam que ainda não havia chegado por lá. Reunião para chamar outras reuniões.

Com isso, quero dizer que já faz tempo que busco um constructo do 'eu' fonte. Sem me dar conta, evidentemente, vou cambaleando na trajetória, tentando encontrar brechas para reafirmar o conteúdo identitário e ressignificar essa história incorporada como elemento fundamental de uma disciplina acadêmica. Se no trabalho de mestrado a ideia posta era a da reafirmação identitária e uma propositura acadêmica; o objetivo era uma disciplina num curso superior. Na segunda pesquisa, na tese de doutorado (Souza, 1998), a energia se concentrou em tentar traduzir a teoria de processos civilizadores a partir do controle das emoções dos ajuntamentos de negros e pretos livres em suas práticas de batuques, desenvolvidas na cidade de São Sebastião do Rio de Janeiro, no século XIX.

Como pode ser percebido, de forma mais amadurecida e em conformidade com o que preceitua um doutoramento, fui em busca de uma literatura que pudesse explicitar alguns pontos, que eram ofuscados pelas emoções que eu devotava na dança, mesmo que já tivesse parado de dançar definitivamente no campo profissional. Então, comecei a pensar que deveria tentar aplicar uma teoria mais robusta e que pudesse alimentar meu espírito inventivo, já devidamente sublimado e transmigrado do campo artístico para o acadêmico-científico.

Nesse sentido, o leitor sabe que Norbert Elias desenvolveu sua síntese teórica centrada na Europa, mas, a partir de uma boa leitura junto aos colegas que iniciaram e ainda continuam no Grupo de Pesquisa de Processos Civilizadores/CNPq, especialmente da turma de doutoramento da Faculdade de Educação Física da Unicamp, em 1996, foi possível aplicar para o desenvolvimento da tese os marcos conceituais, tais como: mimeses, individualização e sublimação (Elias, 1992, 1994, 1995); e outros constantes no escopo geral de uma síntese, como: envolvimento e alienação, outsider e processos sociais (Elias, 1998, 2000, 2006).

No fundo, fui buscar na teoria eliasiana os elementos comuns e irrefutáveis presentes na diversidade das sociedades que compunham a África negra ou subsaariana. Logo, encontrei os seguintes aspectos comuns: a crença no poder da fala e dos gestos, dos cânticos e das danças; a relação de parentesco da família nuclear e ampliada; a crença na ancestralidade mítica (Souza, 1998). Assim, foi um estudo de grande densidade teórico-empírica pela própria natureza de sua problemática e intercruzamento de Sociologia e História.

Com os marcos conceituais eliasianos, foi possível interpretar à luz dessa teoria um dos níveis de controle exercidos sobre os ajuntamentos de negros e pretos livres a partir de suas práticas de batuques desenvolvidas no século XIX e de que maneira o controle 
imposto pelos 'homens bons', por meio das posturas municipais publicadas na cidade de São Sebastião do Rio de Janeiro, teve impacto no desenvolvimento de uma polidez das condutas dos praticantes dessas expressões, cotejadas pela emoção da ancestralidade do panteão africano (Souza, 1998).

É evidente que as pesquisas defendidas na Universidade Gama Filho e na Unicamp foram esboçadas em trabalhos mais modestos que tiveram início na década de 1990, sobretudo, por meio de resumos apresentados em congressos científicos, como 0 Encontro Nacional de Recreação e Lazer, em 1991 e o Congresso Brasileiro de Ciências do Esporte, 1991 e 1993. Em alguns desses resumos, ainda é possível observar a minha assinatura como artista, ou seja, Edilson Sheriff, e em outros com o meu nome de batismo. Esse é um período bastante interessante por representar um aspecto fundamental da minha razão autobiográfica, ou seja, episódio de mudança de lugar de fala e de ambiente de escrita.

Mesmo de forma sutil, os textos dos congressos evidenciam o que se pode chamar de transmigração configuracional da Arte para a Ciência, especialmente no momento da minha saída do Rio de Janeiro para a Universidade Federal de Uberlândia. No conjunto, os escritos mostram uma coerência de discurso de reivindicação de uma arte de matriz africana a ser valorizada no meio artístico pelos pares (Sheriff, 1991a, 1991b; Souza, 1991a, 1991b, 1991c), bem como no processo de mudança e reivindicação acadêmica (Souza, 1993).

Outras publicações também se somam a trabalhos que vieram posteriormente, dessa vez com mais maturidade acadêmica-científica, como minha própria tese de doutorado (Souza, 1998) e demais produtos veiculados em artigos e livros (Souza, 1999, 2000, 2001). Aliás, o ano de 2000 foi a última vez em que apresentei trabalho em congresso com essa temática e marca, talvez, a fase decisiva de transmigração do campo artístico para o campo científico, não só no plano simbólico, mas, sobretudo, no plano territorial, quando passei a ministrar aulas na Universidade Federal de Pernambuco.

De qualquer maneira, para dar um sentido mais próximo possível do que estou tentando reafirmar num constructo do 'eu' fonte, vou escarafunchando o que dispunha no meu arquivo pessoal e institucional, bem como num dos aportes mais importantes da atualidade, as plataformas on-line, onde é possível encontrar fontes que evidenciam o que estou tentando provar enquanto hipótese. Então, boa parte do que estou tratando neste momento foi desenvolvida a partir de um modesto manuscrito apresentado na II Jornada de Estudos Eliasianos (Uneb/IFBA) em 2019, quando identifiquei de maneira ainda incipiente o processo de transmigração que fiz do campo artístico para o acadêmico. Inclusive, a minha percepção de autobiógrafo identifica nesse processo o constructo do 'eu' fonte.

Para compreender a transmigração de um campo a outro, bem como o que me impulsionou a escrever sobre esse assunto específico, é importante que o leitor saiba que fui filiado ao Sindicato dos Profissionais da Dança do Estado do Rio de Janeiro, em 1985, isso porque só poderia atuar e receber algum financiamento estatal se tivesse o registro profissional. Então, orientado pelo Celso Cardoso, diretor do Instituto Nacional de Artes Cênicas na época, fiz o registro para poder ministrar aulas num curso financiado pelo Governo Federal em 1986. 
Nesse contexto, eu era um dançarino afro, outsider e percebia que artistas oriundos de expressões mais conhecidas, especialmente "artistas clássicos", observavam o que eu fazia como um produto de subcultura, como se isso fosse possível, "embora já tivéssemos desde de 1953 com Mercedes Baptista, ${ }^{48}$ no Rio de Janeiro e no Brasil, uma razoável circulação dessa técnica corporal nos teatros, nas academias de ginástica e dança" (Souza, 2019, p. 3). Contudo, o sentimento outsider também vinha da defesa de uma técnica corporal desenvolvida no Recife com o Balé Primitivo de Arte Negra de Pernambuco, na década de 1980.

Como o leitor pode compreender, a técnica corporal que levei e defendi no Rio de Janeiro era primitiva, em contraposição ao que já se praticava, como a dança afrobrasileira, a dança afro-contemporânea e o afro-jazz (Souza, 1998). Assim, "eu me constituía personalidade outsider no território carioca, bem como da configuração da arte negra nessa localidade em virtude dos procedimentos adotados no meu fazer artístico" (Souza, 2019, p. 3).

Apesar de todo o vigor que sentia na execução dessa arte de matriz africana, muitas vezes me sentia enfraquecido nos eventos que participava. Isto foi latente num festival ocorrido no Teatro João Caetano, no qual o resultado não foi nada favorável ao espetáculo que produzi, conforme narrado na seção No Rio de Janeiro: teatro, academia de dança. Contudo, ao olhar o percurso trilhado, vejo que, naquela condição de artista enfraquecido pelo sentimento outsider em processo de transmigração, passei a escrever vários rabiscos que agora ganham outro sentido ao serem analisados nesta tese e que estão sendo visitados por outros pesquisadores, embalados por conceitos que possam expressar uma técnica corporal mais ou menos aprimorada na perspectiva das relações étnico-raciais.

Nesse contexto, nos meus escarafunchados entre arquivos, bibliotecas e outras plataformas, acabo por encontrar pesquisadores, na atualidade, que me trazem em citações ao cenário acadêmico para defenderem seus trabalhos em forma de dissertações, monografias e teses, a exemplo de Sales (2015), bem como em artigos científicos publicados que têm como referência minhas produções da década de 1990, a exemplo de Corrêa (2012), Oliveira (2016), Ferreira et al. (2019) ou ainda Santiago e Franco (2015), que citam dois textos publicados no início do meu processo de produção e transmigração do campo artístico para o acadêmico, momento em que assinei como Sheriff (1991) e como Souza (1993). Assim, Santiago e Franco (2015) tinham como objetivo mapear os artigos sobre dança na Revista Brasileira de Ciências do Esporte e, provavelmente, devem ter percebido as nuances pelas quais eu estava passando naquele momento.

Além disso, ainda é possível identificar partes dos meus escritos em livros, como está presente em Lima (2013). É curioso que eu sou citado num dos capítulos desse autor e, nos meus trabalhos mais recentes (Souza, 2018), citei-o como uma de minhas referências. Assim, só me dou conta agora de que um autor, ou seja, um constructo do

48 Governo do Estado de São Paulo. Secretaria de Cultura e Economia Criativa. Museu AfroBrasil. Disponível em: http://www.museuafrobrasil.org.br/pesquisa/hist\%C3\%B3ria-e-mem\%C3\%B3ria/historia-ememoria/2014/07/17/mercedes-baptista. Acesso em: 17 set. 2019. 
'eu' fonte, também se constitui a partir de autores. Então, como o leitor pode perceber, é essa perspectiva autor-fonte-autor em que vou me constituindo e redefinindo trajetórias teóricas, além de redefinir e ressignificar os sentidos da própria escrita.

Em linhas gerais, o próximo quadro resume o que foi discutido até aqui, quando os autores buscam referências em meus textos e, às vezes, resumos que publiquei e apresentei na década de 1990. Outros, porém, buscam produções mais recentes, encontram minha tese e as publicações dela decorrentes, mas com o mesmo propósito de indicar um sentido para as questões étnico-raciais que envolvem a arte, a corporeidade e a educação contemporânea.

Quadro 18 -

Textos citados por autores.

\begin{tabular}{|l|l|l|}
\hline \multicolumn{1}{|c|}{ Autores/ano } & \multicolumn{1}{|c|}{ Produção e ano da produção citada } & Suporte da citação \\
\hline Corrêa (2012) & $\begin{array}{l}\text { Etnografia e história da dança litúrgica e } \\
\text { artística no Rio de Janeiro, 2000. }\end{array}$ & Artigo \\
\hline Oliveira (2016) & $\begin{array}{l}\text { 1. A dança afro primitiva, 1991a; } \\
\text { 2. A dança afro-primitiva, 1991b; } \\
\text { 3. A dança afro primitivo: uma proposta } \\
\text { humanista, 1991. }\end{array}$ & Dissertação \\
\hline Ferreira et. al. (2019) & $\begin{array}{l}\text { 1.Dança Afro-primitiva, 1991; } \\
\text { 2. Etnografia e história da dança litúrgica } \\
\text { e artística no Rio de Janeiro, 2000. }\end{array}$ & Artigo \\
\hline Sales (2015) & $\begin{array}{l}\text { Entre o fogo e o vento: as práticas de } \\
\text { batuques e o controle das emoções, } \\
\text { 2001. }\end{array}$ & Tese \\
\hline Santiago e Franco & $\begin{array}{l}\text { 1.Resgatar a dança afro primitivo dentro } \\
\text { do contexto sociocultural, 1991; } \\
\text { (2015) }\end{array}$ & Artigo \\
& $\begin{array}{l}\text { Uma proposta política pedagógica, } \\
\text { 1993. }\end{array}$ & \\
\hline Eima (2013) & $\begin{array}{l}\text { Entre o fogo e o vento: as práticas de } \\
\text { batuques e o controle das emoções, } \\
\text { 2005 }\end{array}$ & Livro \\
\hline
\end{tabular}

Fonte: autor (2019).

Ao olhar com certo orgulho para esse quadro, passado todo esse tempo, chega à consciência que estou inevitavelmente construindo fontes. $\mathrm{E}$ o despertar desse fato devese muito ao que agora consegui fazer a partir de vários procedimentos, inclusive, eliasianos, como o autodistanciamento, "que se suba o degrau seguinte da escada em espiral que é a consciência de si” (Elias, 2001, p. 148). Então, a minha consciência permite dizer que a construção da fonte que sou se dá à medida que os meus repositórios são aqui apresentados institucionalmente ou por meio do acervo pessoal, seja 
documentos que aparecem em arquivos particulares ou de familiares que contenham informações ao meu respeito. Ou ainda de maneira tática, na própria confecção desta tese que se consolida como uma fonte privilegiada, discutida e analisada, quiçá, aprovada pelo leitor.

Em última instância, esta tese reposiciona a minha biografia institucional e acadêmica, na medida em que construo novos conceitos, como o próprio constructo do 'eu' fonte, e ressignifico conceitos antigos sobre os temas aqui defendidos. Então, a percepção que tenho dessa fonte que constituo é composta por um amálgama e recorrência; amálgama pelo resultado dos pequenos registros da minha trajetória, que dão um sentido mais geral do que foi dito ou escrito. E recorrência é onde a própria autonarrativa tem reaparecimento episódico; ou melhor, o próprio contexto da autonarrativa, para ser compreensível em sua temporalidade (auto)biográfica, faz aparecer momentos significativos com certa frequência. Afinal, sempre haverá uma história contada por fios de outras histórias.

Nesse contexto, percebo que nós temos uma forma especial de autonarração, do ponto de vista do episódio, que envolve fatos e eventos mais intensos e densos, carregados de emoção, como a política, por exemplo. Há, de toda forma, uma recorrência episódica no ato de contar os momentos da vida. Então, a memória é amálgama e recorrência. Por outro lado, o constructo do 'eu' fonte resguarda a integridade subjetiva do indivíduo/narrador e, por meio desse resguardar da subjetividade, é possível encontrar elementos importantes da identidade do agente social que narra sobre si.

Considerando o que diz Saviani (2006) sobre a política de fonte, este constructo do 'eu' fonte se fortalece na perspectiva da preservação e socialização de seu conteúdo, expresso por um conjunto documental de diferentes naturezas. Desse modo, resguardo um saber e um poder intrínsecos no campo de uma experiência humana singular e plural simultaneamente. Um saber que pode ter acumulado muitas evidências de um itinerário e, por essa e outras razões, tenho interesse em preservá-lo e dar a devida visibilidade.

É evidente que isso de alguma forma é cotejado pelo ambiente em que desenvolvi minhas atividades e tomei minhas decisões, pelo campo em que atuei e mantive minhas relações interpessoais, onde desenvolvi o que Bourdieu (2004) chamaria de habitus; no caso específico, o sentido da minha existência, minha história incorporada, a qual resolvi descortinar certos meandros das minhas interrelações, minhas interdependências.

Desse modo, o constructo do 'eu' fonte serve a um dos aspectos importantes dos processos sociais, das transformações e mudanças, pois é nele que está contida a memória à espera da recordação. Digo isso porque guardamos e recordamos aquilo que para nós tem um significado especial, o que é singular e plural ao mesmo tempo, aquilo que desejamos que os outros indivíduos possam um dia usufruir como exemplo. E a liberação do que está guardado nos porões dessa memória só é possível mediante o despertar do indivíduo para sua própria existência, firmando-se em sua subjetividade ou no seu constructo.

Destarte, o constructo do 'eu' fonte são descobertas que precisam ser operadas, escarafunchadas entre os objetos dispersos e que precisam manter-se protegidos e guardados. Ao operar o que está disperso, organiza-se de outra maneira a dispersão para Ihe conferir sentido (Certeau, 1998). Assim, ao reorganizar a minha própria dispersão, fui 
percebendo também o que já havia dito, escrito sobre algo ou alguém. Logo, paulatinamente, fui trazendo à recordação os episódios dos itinerários onde o manuseio de fontes escritas e iconográficas, on-line ou físicas, dão um sentido muito especial à própria trajetória enquanto símbolo de aquisição de capital. Daí a simples descoberta de que não sou outra coisa senão eu mesmo nessa dispersão por mim causada.

Contudo, esses meus procedimentos de descoberta me fizeram pensar algo próximo ao que Certeau (2002) entende "como história esta prática (uma "disciplina"), o resultado (o discurso) ou relação de ambos sob a forma de uma 'produção'. Certamente, o termo história está relacionado à ciência e ao seu objeto - a explicação que se diz e a realidade daquilo que se passou ou se passa" (p. 32).

Nas reflexões do autor a instituição e lugar são dois pontos importantes de partida para a construção do discurso do historiador a partir de uma teoria. No entanto, é preciso compreender que tanto a instituição como o lugar ocupam irremediavelmente um dos espectros sociais que vive o próprio historiador, ou no seu tempo ou em casos especiais em tempos remotos, mas, a despeito da organização da disciplina em torno de um método, é possível acessar o não dito a partir dos vestígios deixados por gerações anteriores e encontrados nos objetos durante a operação de que se vale o pesquisador.

Diante do que foi exposto até o presente momento, escrever a história pressupõe estar sob as condicionantes de determinadas regras sociais e institucionais, as quais a disciplina histórica e a pessoa do historiador estão inevitavelmente associadas. Dessa maneira, o discurso elaborado pelo pesquisador está condicionado à permissão do ambiente em que vive, cujo trabalho é historicizar os objetos de que dispõe em sua atividade.

Considerando esses aspectos teóricos e empíricos aludidos por Certeau (2002), há um papel a ser cumprido por um constructo em que o 'eu' se torna fonte, semelhante ao que refere Silva (2015) acerca dos docentes no interior das universidades, onde produzem seu próprio material bibliográfico para seus estudantes numa disciplina de graduação e pós-graduação, cujo conteúdo é o seu pensamento sobre os problemas sociais, políticos ou outros conteúdos de seu interesse e formação. Normalmente, o material produzido diz respeito ao objeto de estudo de seu interesse no momento, seja em virtude do cumprimento de metas a serem apresentadas aos órgãos de fomento de pesquisa, seja pelo simples interesse sobre determinado tema.

Dessa forma, o constructo do 'eu' fonte expõe a minha relação com os outros indivíduos e grupos sociais e, às vezes, com as instituições por onde passei, na perspectiva de estabelecer uma comunicação acerca de diferentes assuntos, da ciência à política, bem como outras informações de interesses pessoais e acadêmicos-científicos.

Diante da análise apresentada, posso afirmar que constam no constructo conteúdos empiricamente passíveis de verificação, mediante os diferentes arquivos produzidos e relacionados com o indivíduo (auto)biografado.

Essas unidades de conservação pressupõem também uma propriedade constituída durante uma trajetória, que pode ser verificada em dois tempos (auto)biográficos, os quais existem conexões fundamentais para a compreensão da trajetória em análise. Assim, é fundamental uma tipologia que sintetize graficamente as abordagens aqui descritas, conforme o diagrama a seguir: 
Figura 62 -

Diagrama do constructo.

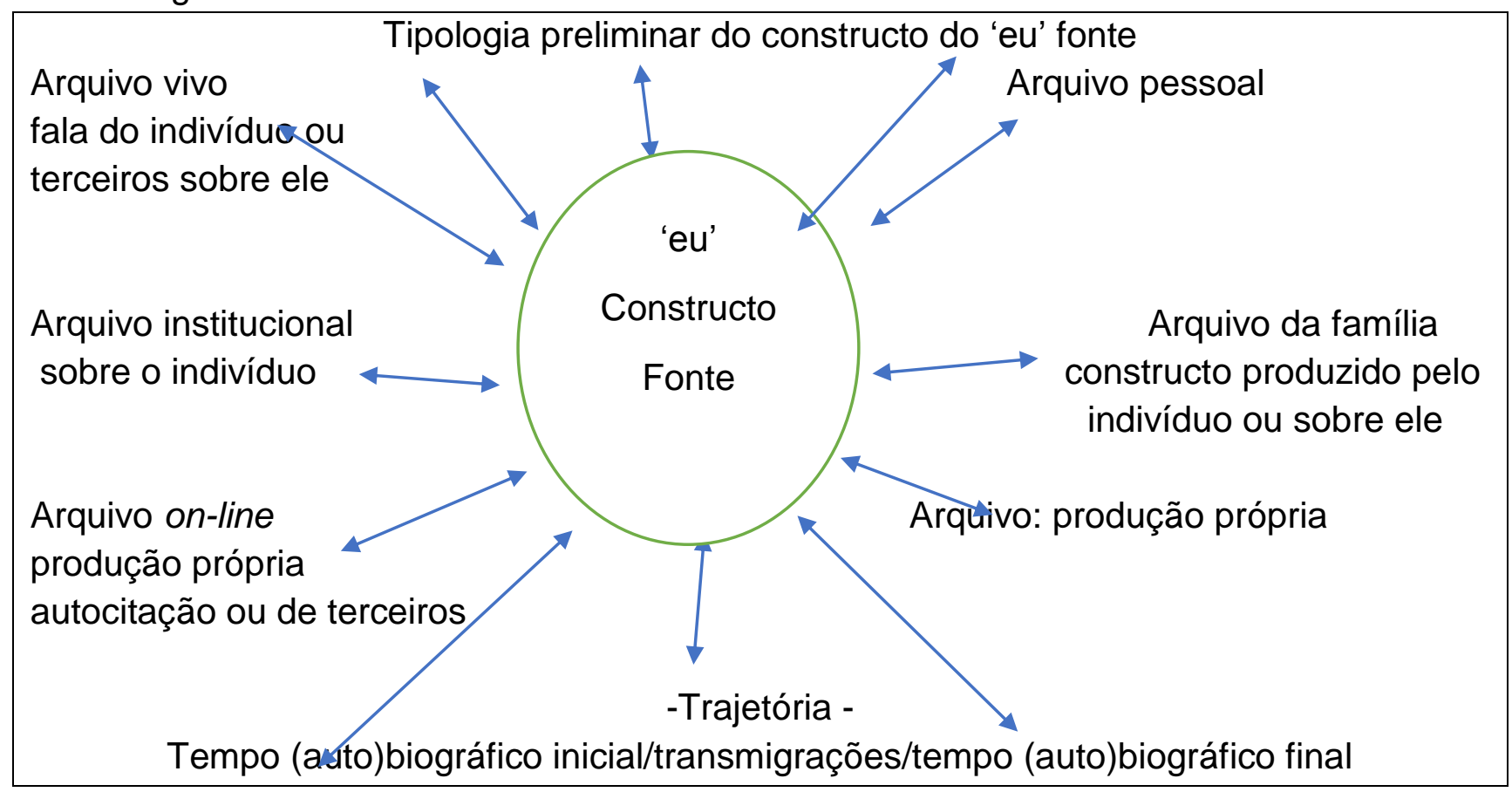

Fonte: autor (2019).

Essa é uma representação gráfica preliminar de como percebo o constructo. $O$ desenho construído exatamente no centro do diagrama é em virtude de uma das minhas lembranças sobre o meu teste de alfabetização na escolinha de Dona Lilia, minha primeira professora, devidamente lembrada no capítulo À guisa das memórias. Para recordar o leitor, o teste consistia em fazer um furo, em forma de círculo, no meio de uma folha de papel em branco e, a partir dessa abertura, mostrar as letras do alfabeto, uma após outra, de $\mathrm{A}$ à $Z$, com o objetivo de avaliar os meus conhecimentos abecedários. Esse foi o primeiro e grande teste da minha vida. É em homenagem à minha professora Dona Lilia que pensei em representar o constructo dessa maneira, onde tudo parece estar em volta de uma prova.

No aspecto geral dessa tipologia, é preciso compreender que, em seu centro, está o proprietário, fonte do constructo, sem o qual não há pesquisa ou composição da narrativa de si, ou seja, a (auto)biografia. É preciso também que o proprietário tenha despertado para o tipo e a lógica de seu constructo e identifique as transmigrações pelas quais passou ou está passando de um campo de produção de seu conteúdo, assim como os territórios de afirmação da trajetória.

Conforme é possível perceber para efeito de uma tipologia inicial, do arquivo vivo, saem as gravações espontâneas ou provocadas por outros pesquisadores sobre temas de domínio do proprietário do constructo, objeto de estudo. As informações podem ser recolhidas a partir de um roteiro prévio sem, no entanto, estar preso à obrigatoriedade de tratar deste ou daquele tema. Desse arquivo, também é possível a utilização ou reutilização de entrevistas feitas por pesquisadores sobre temas de domínio do "proprietário" do constructo, podendo, inclusive, ter sido ou não publicadas com outras finalidades, mas, sendo utilizadas, servem para a compreensão geral da fonte objeto do constructo. 
Em última instância, esse arquivo vivo também pode ser compreendido como um texto escrito pelo proprietário sobre si mesmo ou sobre outros e que foi utilizado por algum pesquisador na composição da (auto)biografia. É o que normalmente tem acontecido com as pesquisas que se utilizam desse método, ou seja, pesquisadores escrevendo sobre o que determinados personagens, intelectuais ou artistas, escreveram sobre pessoas, poemas, músicas etc.

Do arquivo pessoal, pode ser utilizada toda a massa documental relativa à vida do proprietário do constructo, desde que devidamente processada para efeito de compreensão do tema principal ou corolário da escrita de si. Porém, arquivos pessoais costumam abrigar uma infinidade de documentos de todos os domínios da vida cotidiana, desde extratos bancários, registros de nascimento, carteiras estudantis, de identificação profissional, certificados e diplomas, que podem ser do "proprietário" do constructo ou de terceiros. Há de se tomar o cuidado no momento de separar o que serve para a compreensão do constructo do 'eu' fonte daquilo que apenas ocupa o lugar de uma documentação dispersa de outros indivíduos, membros da família ou amigos.

Já o arquivo institucional é, por sua natureza, o menos controlável pelo proprietário do constructo. Embora as informações tratem direta ou indiretamente de sua vida ou de seus dependentes diretos, como filhos e cônjuge, sempre haverá um intermediário para sua localização, acesso e disponibilização; inclusive, em alguns casos, sua posse será realizada a partir de requerimento próprio. Assim, instituições escolares, acadêmicas e empresas guardam esses acervos de maneira impessoal, o que requer do "proprietário" do constructo um certo cuidado na solicitação desses documentos. É importante ter acesso a toda a pasta funcional para se escarafunchar o que irá colaborar com o tema em que se pretende discorrer.

$\mathrm{O}$ arquivo on-line, por sua vez, é o maior e mais abrangente dos ambientes que possibilitam a compreensão do constructo. No entanto, deve-se tomar o devido cuidado para buscar nesse arquivo o que de fato tem a ver com o seu proprietário. Embora tudo possa estar disponível nesse tipo de arquivo, às vezes, sua identificação requer um tempo razoável para que os pesquisadores e outros curiosos possam iniciar sua produção e veiculação. Esse é o tipo de arquivo que um elemento puxa necessariamente outros de uma cadeia quase infinita de documentos sobre o proprietário do constructo.

Por fim, o arquivo científico é relativamente o mais controlável, pois ele é formado pela produção do proprietário do constructo, que ele mesmo escreve - seus artigos, livros, dissertações, teses etc. - e pela natureza da produção, também controlada pelo indivíduo. Esse arquivo demonstra um certo grau de racionalidade em torno das problemáticas desenvolvidas. No entanto, é necessário analisar com certa acuidade, para identificar transmigrações de campo e de interesse do proprietário para, em seguida, indicar mudanças ou permanência de trajetória (auto)biográfica.

Não obstante a importância do conjunto de arquivos para a consolidação do constructo do 'eu' fonte, considero que dois desses arquivos são essenciais para essa ocorrência, sem eles não há possibilidade de se iniciar a verificação empírica de uma trajetória. O primeiro é o arquivo vivo, de onde emergem as memórias do próprio (auto)biografado, sua fala e recordações, ou a fala e recordações de outras pessoas sobre o indivíduo, em que pode haver comentários acerca de suas aspirações, desejos, expectativas, tensões e os campos por onde eventualmente passou. O segundo é o 
arquivo pessoal, onde, de alguma forma, o (auto)biografado guardou informações referentes a sua vida, suas relações interpessoais, fotografias, cartas, e-mails, projetos, processos e outros artefatos que evidenciam a trajetória num determinado campo. Esses dois tipos de arquivos precisam estar disponíveis e em consonância mútua para efeito de uma análise preliminar do constructo.

Por outro lado, na base da tipologia se encontram a trajetória respaldada pelo tempo (auto)biográfico inicial, as transmigrações e o tempo (auto)biográfico final. A trajetória pode ser compreendida pelas nuances e sinuosidades realizadas pelo indivíduo em toda sua existência; inclusive, compreendida pelo tempo inicial da (auto)biografia, quando o (auto)biógrafo elege o momento de onde deve partir suas primeiras falas sobre os episódios que lhes marcam no constructo. As transmigrações são as mudanças de rumo, de itinerário e até mesmo de abordagens realizadas pelo indivíduo, culminando com o tempo (auto)biográfico final, que corresponde com a finalização dos episódios demarcados ou delimitados na trajetória indicada.

Parafraseando Elias (2005), o constructo do 'eu' fonte pode representar um fator importante acerca do que o autor chama de um indivíduo enquanto valência aberta; ou seja, o tipo, a qualidade e a quantidade de ligações afetivas, emocionais, políticas, religiosas, profissionais etc., que esse indivíduo manteve em seu itinerário. Então, esse constructo pode representar essas ligações sociais por onde o indivíduo passou, deixando, portanto, evidências de sua passagem. Assim, quando digo que esse diagrama é a composição de meu constructo, estou dizendo que são as minhas evidências, minhas ligações sociais em meu itinerário. Logo, as minhas evidências estão reposicionadas nesse diagrama, a partir do qual me represento enquanto unidade.

Considerando todos esses aspectos, a trajetória, as transmigrações e a (auto)biografia inicial e final, é possível também que tudo isso seja compreendido como a historicidade do indivíduo (Elias, 1994a). No meu caso em particular, foi aquilo que consegui construir em meu processo de individualização, desde os meus registros iniciais da minha existência à vida adulta. Tudo isso somente foi perceptível quando foi feito uma unidade a partir do que antes estava disperso, por isso que as evidências do que constam dos arquivos são fundamentais para a compreensão do indivíduo e suas relações com os outros e diferentes grupos sociais de seu itinerário.

Nesse contexto, embora um constructo se refira a um indivíduo em especial, a unidade da dispersão de que faz parte não se deve exclusivamente a seu proprietário como único responsável pelas evidências. É provável que, nas relações interdependentes do indivíduo, a dispersão que trata seu constructo tenha sido realizada por outros de maneira direta ou indireta. No entanto, a unidade dependerá sempre dos esforços do (auto)biógrafo na construção da narrativa num processo contínuo de aprendizagem, é o que Alheit (2011) chama de biografização, produto, sentido e formas de aprendizagens. Um constructo é o processo contínuo de observação, admiração e possível análise. É o jogo de tensão e reconhecimento pelo seu proprietário ou por outros que dele devotam algum interesse de verificação e estudo.

Todavia, é preciso lembrar que não há perfeição num constructo do 'eu' fonte, da mesma maneira em que a trajetória de vida não segue em linha reta. No entanto, um constructo da forma como está aqui representado é a unidade do que antes estava disperso e só no processo de busca de seu sentido, de sua intencionalidade que consigo 
ressignificar o meu passado ou o passado do biografado. Esse meu constructo é a minha percepção e análise acerca dos acontecimentos materializados em objetos, grafados e deixados nos vestígios das múltiplas relações interpessoais e institucionais que mantive até o presente momento. Portanto, o seu real sentido só se consolida na unidade e singularidade com o que tento expressar aqui, por este instrumento de tese.

\section{O desfecho das memórias}

Ao caminhar para a finalização desta tese, gostaria de salientar que as coisas aqui escritas foram cotejadas, em todo o trato metodológico, pelas lembranças que trago de campos distintos e complementares, que impactaram significativamente na minha formação profissional e humana, no sentido de responder ao seguinte questionamento: qual a percepção que tenho da minha trajetória de vida desde as séries iniciais à universidade, envolvendo o campo artístico, acadêmico-científico e as disposições políticas daí decorrentes entre 1975 e $2020 ?$

Todavia, quando iniciei este estudo, dois desafios estavam colocados: primeiro, o processo de objetivação, ou seja, como me tornar objeto da minha própria pesquisa científica, interpretar minhas falas, meus gestos e as evidências presentes nos documentos por mim produzidos ou produzidos por terceiros sobre a minha vida; segundo, como compreender a minha subjetivação, mediante as evidências por mim provocadas ou identificadas, a produção de sentido por mim encaminhada a uma determinada comunidade de destino, meus campos de produção, especialmente o campo intelectual-acadêmico.

Frente a esses desafios construí a hipótese segundo a qual transmigrei do campo artístico para o acadêmico-científico e, consequentemente, desenvolvi o habitus peculiar ao novo campo, isto é, a mudança da linguagem e a sublimação dos impulsos arteciência, que culminaram com a consciência de dispersão durante a trajetória e a minha compreensão do constructo do 'eu' fonte enquanto unidade.

Assim, para confirmar a hipótese da transmigração dos campos, estabeleci dois eixos intercruzados, sendo um teórico-metodológico, de revisão e aplicação da literatura; e outro empírico, de busca das memórias por meio dos registros das minhas falas e manuseio de diferentes tipologias de fontes. A partir desses eixos, todos os objetivos foram devidamente alcançados, como a minha modesta contribuição ao debate acerca do método (auto)biográfico enquanto instrumento de pesquisa e o seu impacto em memoriais discursivos; a construção e análise da autonarrativa focada nas ações que perpassaram pela minha ambientação escolar, artística, acadêmica, científica e política, entre 1975 e 2020, e o levantamento e análise de diferentes tipologias documentais, que evidenciaram a minha mudança de trajetória, a imersão nas atividades acadêmico-científicas e a participação na política institucional.

Considerando a minha razão narrativa, a memória registrada e a documentação consultada, confirmo a hipótese da transmigração que sofri do campo artístico para o acadêmico-científico com a aquisição de um habitus, no qual a linguagem foi devidamente ressignificada e materializada em ações do capital cultural-escolar. O habitus desse campo, uma vez incorporado às práticas que lhes conferem estatuto, ainda tem avançado substancialmente em direção a um constructo que se define numa fonte a partir das dispersões experimentadas durante a minha trajetória. 
Nesse sentido, hoje falo e escrevo porque algo me move em direção aos múltiplos significados que foram possíveis construir nesse meu percurso, sobretudo ao procurar incansavelmente a formação acadêmica e tê-la como minha principal atividade e sustento, além de ser uma fiel aliada para superar os percalços encontrados nos diferentes campos por onde passei. Essa formação acadêmica só se tornou possível porque encontrei na arte os elementos suficientes para me levar ou trazer ao nível mais alto da formação educacional, ao título de mestre e de doutor. E cheguei nessa formação escrevendo e falando sobre técnica corporal, que foi objeto de meus interesses durante muito tempo.

Contudo, ao recordar e escrever da forma como está aqui explicitado, as dúvidas eram constantes durante o manuseio da documentação que fui levado a produzir e a levantar acerca das minhas evidências. Por isso, procurei fazer uma breve discussão de autores clássicos da Sociologia e História com o objetivo de estabelecer modelos de estudos e perspectivas procedimentais na relação entre indivíduo e sociedade e pesquisador enquanto sujeito-objeto de pesquisa, buscando facilitar a interpretação das minhas próprias evidências.

Nesse contexto, autores como Norbert Elias, Pierre Bourdieu e Michel de Certeau me ajudaram a pensar mais efetivamente sobre uma pesquisa científica modelada por pressupostos até então diferentes do que eu estava acostumado a fazer na relação sujeito-objeto, mas bem próximo das discussões que envolviam conceitos empregados para mitigar as dicotomias e, sobretudo, as posições assumidas pelos pesquisadores na produção do conhecimento. Além disso, com base em seus modelos teóricos e empíricos, esses autores me trouxeram mais conforto e segurança diante do objeto a ser analisado. Assim, se em algum momento deixei de imprimir sentido à narrativa junto a esses modelos, foi mais em virtude das minhas defecções do que propriamente pelas limitações dos teóricos apresentados.

$\mathrm{Na}$ busca dos procedimentos mais corretos para esta pesquisa, procurei fazer uma revisão de literatura que apontasse convergências e divergências de conceitos relativos aos estudos com abordagem ou características (auto)biográficas, para oferecer ao leitor algumas opções teóricas e metodológicas no trato do conhecimento sobre o tema em pauta. Na verdade, foi mais uma questão epistemológica, pontos de vista que eu precisava explicitar na perspectiva do método da narrativa de si.

A revisão de literatura neste estudo mostra, inclusive, a infinidade de entradas e abordagens pelas quais esse método pode ser revestido, com a diversidade de interesses acadêmicos e institucionais de um campo bastante profícuo de construção de fontes para a historiografia da educação, por exemplo. Esse aspecto ficou esclarecido quando o levantamento de pesquisas realizadas no conjunto das instituições brasileiras, revelou uma diversidade significativa de temas e procedimentos investigativos nesse campo do conhecimento.

Frente à revisão de literatura, encontrei ainda o método da narrativa de si, grafado de duas maneiras, (auto)biografia com parênteses e sem parênteses. Decidi que, ao escrever com esse sinal de pontuação, com essa inserção no discurso, estou indicando que se trata da escrita de um indivíduo sobre si mesmo ou de um pesquisador sobre determinado personagem. No entanto, ao grafar essa palavra sem os parênteses, estou 
dizendo que a narrativa de si foi abordada por um método científico e realizada pelo próprio pesquisador enquanto sujeito-objeto. Nessa relação imbricada, o pesquisador foi, concomitantemente, sujeito e objeto da investigação, escreveu e divulgou seus resultados, como o faço neste momento.

Normalmente, um estudo com as características (auto)biográficas pretende verificar a relação do indivíduo com os diferentes grupos sociais em que houve uma interdependência funcional, buscando compreender em que condições as tensões ou conflitos sociais e individuais foram resolvidos. Porém, a partir de um estudo dessa natureza, também é possível a compreensão do modelo de sociedade que forja indivíduos com determinadas características ao resolverem seus problemas de uma maneira em detrimento de outras, é como esse agente se percebe no processo de objetivação e subjetivação em seu tempo histórico.

Considerando esses aspectos, posso garantir que consegui, até certo ponto, me objetivar enquanto agente social, artista, intelectual e acadêmico, inclusive, meus pensamentos sobre o campo e a minha posição de classe. Entretanto, caberá outra pesquisa para objetivar o pensamento dos subcampos em que passei, pois é algo deveras complexo, em virtude das múltiplas interrelações existentes nos processos de transformações e mudanças em que esses subcampos estão sujeitos. Dito de outra forma, enquanto valência aberta, são múltiplas as ligações sociais possíveis e imagináveis de um indivíduo, e elas variam desde naturezas emocionais e afetivas às esferas estéticas e políticas, em todas suas nuances e densidades.

Desse modo, no cômputo geral, a principal dificuldade encontrada na confecção desta tese foi transformar a fala em texto. Ou seja, escrever o dito a partir das lembranças contadas na autonarrativa. $O$ procedimento de transcrição da fala revela também aspectos importantes na elaboração e reelaboração do pensamento com resultado na linguagem acerca de determinados episódios. Assim, por meio desse procedimento, é possível reafirmar posições, refutar ideias e rever o significado das coisas e objetos em determinado contexto, para oferecer ao leitor algo mais plausível de compreensão.

Nesse sentido, a (auto)biografia não pode ser pensada como uma história linear, direta e sem as devidas interconexões sociais. A (auto)biografia sempre deverá ser compreendida como uma história reversa, uma história dentro de outras histórias, numa narrativa do indivíduo sobre si mesmo ou sobre os outros agentes de seu campo ou de seu interesse. Por vezes, um pesquisador busca o relato ou o que está disponível, enquanto evidência, sobre um outro; por vezes, trata-se de um procedimento sociológico e histórico em que o sujeito é o próprio objeto das suas interpretações, nas suas mais variadas e multifacetadas relações sociais. Nesse processo, como um de seus produtos, pode se constituir uma fonte para a historiografia.

É essencial, portanto, registrar que as dimensões socioeducativas enquanto aspectos da historicidade do indivíduo são bastante aproveitadas ou comentadas nas (auto)biografias até aqui consultadas. As narrativas confirmam que seus autores querem deixar evidente que os impulsos criativos, dos afetos e desejos, são moldados pela educação recebida dos pais e, em alguns casos, por instituições por onde passaram. É a educação que vai moldando o impulso ou direcionando para um comportamento mais 
desejável socialmente, ainda que o (auto)biografado relute em admitir seus efeitos. Eu, por exemplo, sei que a educação escolarizada, a que foi proporcionada pela minha família, bem como a que recebi dos diferentes grupos sociais em que participei, foi imprescindível na minha historicidade.

Neste trabalho, procurei oferecer ao leitor elementos gerais de uma trajetória intercambiante na escola, na arte e na vida acadêmica, com suas peculiaridades da política institucional. Entretanto, se na minha razão narrativa meus episódios foram marcados por tensões, angústias, afetos e desafetos, uma outra pesquisa também pode corroborar o sentido da trajetória a partir das disciplinas escolares e seus resultados enquanto impacto numa formação educacional.

Com isso, quero dizer que a (auto)biografia ou uma narrativa de si podem ser pautadas apenas por um dos aspectos da vida do indivíduo, focando apenas nos processos de ensino-aprendizagem e a socialização de determinados conhecimentos, na relação com as instituições educacionais e os acervos documentais por elas conservados. Podem também focar nos aspectos culturais, ou mesmo na vida econômico-financeira de um agente social no interior de sua família e como isso tem impacto em suas decisões no contexto mais amplo de seu campo de atuação.

Considerando esses aspectos, posso dizer que essa autobiografia é a minha sociologia e a minha história. É parte significativa de uma percepção que adquiri a partir de fontes de informações produzidas por mim e por terceiros durante a minha trajetória no recorte temporal aqui compreendido. Por essa razão, procurei aproveitar integralmente todo tipo de fonte disponível sobre o meu itinerário, especialmente as fotografias, que revelam mais do que um momento, revelam, por vezes, sentimentos e estado de espírito em diferentes territórios.

Em seu conjunto, os registros fotográficos dão um tom muito especial em relação aos territórios por onde passei, seus habitus específicos, minhas intencionalidades. Desde as primeiras exposições com os meus pais, as minhas fotografias $3 \times 4$ e outras do ambiente artístico, pude perceber mais concretamente a cara étnica de agentes agindo em muitos campos. Foi a partir da seleção dessa iconografia que senti o autobiógrafo destravando o seu processo de subjetivação, foi concomitantemente no manuseio desses objetos que pude compreender também que serei sempre o mesmo no continuum de um outro.

Muito embora os registros da época de artista explicitem a hipótese da minha transmigração desse campo, é a imagem em que apareço com os meus pais na cerimônia de formatura do curso de licenciatura em Educação Física que destaco como uma das mais importantes do meu sentimento em relação às mudanças de rumo e de campo da esfera da arte. Mesmo de maneira tímida, a partir daquele momento, comecei a perceber que havia algumas alterações na minha forma e conteúdo da expressão corporal de matriz africana.

Nesse contexto, todo o aporte iconográfico influenciou significativamente a análise e interpretação da autonarrativa, porque as imagens, especialmente aquelas em que figuro enquanto um de seus personagens principais, denotam, por vezes, um tributo às minhas transformações corporais, bem como me apresento socialmente nos diferentes campos por onde mantive o itinerário num processo de permanente aprendizagem. Assim, esse aporte reflete de maneira expressiva na minha percepção e no próprio ato autobiográfico. 
Ainda sobre os documentos analisados, gostaria de destacar que os livros por mim publicados compõem um dos objetos mais significativos para compreender meu itinerário no campo acadêmico e interlocução com outros intelectuais. Entretanto, mesmo tendo essa percepção, reconheço a fragilidade na exploração dessa fonte, cabendo, no futuro, talvez, um estudo mais aprofundado acerca dos temas, problemas e abordagens teóricas e metodológicas no processo com que me inscrevi e subscrevi minhas intencionalidades nesse tipo específico de circulação do conhecimento. É que a análise dos livros poderia cobrir desde o projeto gráfico e plano de redação aos elementos acima descritos para identificar as minhas preocupações de autor, bem como a evidência de um autobiógrafo no processo de construção enquanto fonte, o que demonstra a complexidade desse tipo de documento para efeito das interpretações pretendidas neste estudo.

Desse modo, a cada encontro e manuseio de uma das minhas fontes orais, iconográficas ou escritas, uma descoberta, onde móveis, utensílios e papéis aparentemente desconexos à saudade de um ambiente, mostram uma direção seguida ou interditada. Logo, foi na recorrência da memória e seu registro que pude ter a certeza de que o exercício da autonarração é ato político, igualmente necessário à formação humana de um cientista e de um profissional da educação, na tomada de sua consciência em busca da unicidade.

Essa foi a razão pela qual procurei incessantemente um conjunto de documentos a meu respeito que pudesse subsidiar a análise e interpretação de meu itinerário desde a escola à universidade, passando, inclusive, pelo campo artístico, de onde partiu a exclusividade da minha biografização, minha forma de aprender como se aprende. Boa parte dos documentos foram incorporados indissociavelmente na escrita da tese; outra parte, em menor proporção, está apresentada como apêndice e nos anexos, onde o leitor pode visitar e complementar suas conclusões acerca das inúmeras possibilidades de um autobiógrafo em seu processo de objetivação.

No apêndice, destaco o roteiro ao qual construí e submeti minha fala, meus gestos e minhas recordações, ou seja, minhas memórias autonarradas, que serviram como base para a construção de toda a tese. Embora a autonarração tenha essas características, não se trata de associação livre, conforme pode preceituar a psicanálise, trata-se de o indivíduo historicizar seu próprio itinerário. Essa foi a razão pela qual também expus o meu primeiro trabalho acadêmico, escrito inicialmente para um concurso na universidade e, posteriormente, para atender às exigências de um curso de pós-graduação lato sensu.

Todas essas evidências corroboraram o fortalecimento da hipótese desta tese, sobretudo ao identificar com mais precisão que eu havia feito algo pela arte de matriz africana, por onde escorriam os saberes até então desenvolvidos pela estética corporal espetacularizada e pela ciência enquanto objeto científico em processo de formatação; além de ser minha única maneira de enxergar a vida, pelo menos durante um bom tempo. Se no apêndice destaco esse documento que serviu de inspiração para a maior parte dos trabalhos que escrevi no início da minha carreira docente, no anexo, destaco o certificado de conclusão de série.

Esse documento faz referência à $4^{a}$ série do antigo $1^{\circ}$ grau e é um dos mais importantes registros que encontrei sobre a minha passagem por essa escola já extinta, o Centro Educativo Operário Agamenon Magalhães, em 1976. Não bastasse o bom sentimento que tenho pela instituição, lá pude construir alguns argumentos de defesa em 
virtude de ter sido transformado, momentaneamente, em outsider num passeio no dia 7 de setembro daquele ano. Também há fortes evidências de que meu pai fez constar sua assinatura dando ciência da minha frequência e avaliação no referido certificado, o que me trouxe grande satisfação. Fiquei surpreso e grato, afinal papai nunca tinha demonstrado interesse por essas questões "administrativas" e de meu acompanhamento na escola, certo de que eu corresponderia às expectativas de um bom aluno.

Contudo, é importante frisar ainda que a documentação das instituições escolares é uma das formas biográficas que expressam o capital cultural a quem dele possa fazer uso como direito. E a aprovação identificada pelos registros numéricos e conceituais, costumeiramente chamados de histórico escolar, é uma forma específica de acompanhamento e síntese dos progressos alcançados por um determinado indivíduo no itinerário educacional.

Nesse contexto, considerando esse tipo de registro referente a todos os indivíduos escolarizados, enquanto professor universitário, vivo autobiograficamente, aliás, como todos de meu campo, onde somos obrigados a anotar na Plataforma Lattes todas as atividades realizadas de ensino, pesquisa, extensão e gestão. Tais anotações são evidências incontestes da entrada e permanência no campo acadêmico, lócus das disputas pelo saber-poder. Dessa maneira, esse viver autobiograficamente remete a todos nós, intelectuais, e o meu sentimento assim o assegura às formas específicas de lidar com outros agentes sociais e instituições da mesma natureza. Assim, o Lattes figura ao mesmo tempo suporte, entrada e permanência no campo, bem como fonte (auto)biográfica para revelar o status do indivíduo em seu itinerário. É por meio desse instrumento que organizamos por ordem cronológica uma série de atividades realizadas em diferentes espaços-temporais e de interesses temáticos, o que nos torna explicitamente ligados a alguma instituição.

Dessa maneira, na descoberta do constructo do 'eu' fonte, por exemplo, parti do princípio de que todos nós somos dispersos e nos dispersamos por territórios, ambientes transitados e transitáveis, compreendidos como o campo escolar, o acadêmico, o artístico, o político, sujeito a registros no Lattes. Em cada campo, num processo de interdependência funcional com outros agentes sociais, travei algumas lutas pelo poder, pelo saber-poder, seja por sua conservação e ou transformação.

Considerando o conjunto de evidências que trago neste estudo, posso afirmar que todos os agentes sociais constituem fontes a partir das lutas travadas no interior dos campos de onde emergem seus respectivos habitus. No entanto, a questão que se coloca não é se um indivíduo é ou não fonte, mas como se constituiu fonte em seu itinerário e a partir de qual momento despertou a consciência ou a subjetivação de assim ser constituído. Logo, foi no decorrer da luta travada em diferentes campos e na tomada de consciência da minha subjetivação que se consolidou o meu constructo de fonte.

Foi também no momento em que produzi sentido num discurso falado ou escrito por mim documentado em alguns momentos, às vezes, por outros indivíduos das minhas relações sociais, num espaço-temporal determinado, em que o constructo de que trato foi estruturado pela tomada de consciência de uma dispersão e em busca da própria unicidade. Logo, o constructo do 'eu' fonte é a unidade dessa dispersão e, quando me constituo unidade, reúno num só lugar o que antes estava disperso na trajetória. 
Essa foi a razão pela qual o diagrama do constructo foi elaborado, para dar mais visibilidade aos procedimentos requeridos neste estudo e tornar conhecida uma das minhas mais importantes descobertas que, agora óbvias, somente percebi na operação e manuseio dos documentos deixados em diferentes campos no meu itinerário, como, por exemplo, arquivos pessoais e, especialmente, os institucionais, que resguardam uma singularidade no conjunto dos acervos por mim visitados. Foi muito emocionante voltar às escolas após 45 anos. Esse é um exercício que recomendo aos meus colegas intelectuais, para que não esqueçam suas disposições de origem.

No fechamento desta tese, sinto-me muito honrado e desejo uma vida melhor às futuras gerações de intelectuais que, porventura, estejam vivendo um momento semelhante a esta experiência. Mesmo com alguns contratempos, tenho a percepção de que a minha vida pode traduzir uma história de sucesso. Saliento que não pretendi mostrar como me transformei num ser humano melhor, mas sim mostrar de que maneira me transformei nesse ser humano que sou a partir de minha trajetória, dos meus percalços no processo de recordação.

Alguns podem dizer que a memória é falha, e esta é a razão pela qual não devemos confiar em suas revelações. Eu diria que a memória não é simplesmente falha, pois a julgar pela proximidade dos fatos ou eventos ocorridos, se o espaço-tempo está muito presente, a memória pode tentar proteger o indivíduo de suas possíveis revelações, principalmente quando os personagens das lembranças ainda fazem parte do convívio social de quem recorda. Assim, às vezes, falhei ao tentar recordar, mas procurei proteger a privacidade de vários personagens da minha autonarrativa, sem que para isso meus argumentos da exposição do enredo perdessem a força dos meus sentimentos. Essa ocorrência foi mais em virtude da fala sobre a política, algo não digerido pelo tempo ainda muito presente.

Dessa maneira, todos esses percalços por mim experimentados fazem parte não apenas da minha trajetória enquanto indivíduo, mas também de outros agentes sociais, que corroboraram a minha formação humana no interior da própria docência no ensino superior, ainda que os meandros da política possam parecer inacreditáveis nesse ambiente de expertises. Em função disso, falo das pequenas derrotas que vão se confirmando e, às vezes, ressignificando a própria maneira com que trago à recordação em minha razão narrativa, nos meus episódios. No entanto, é preciso redefinir os planos e as ações para a retomada do rumo, não esmorecer e seguir sempre em frente.

Ao olhar para trás, com o distanciamento próprio de quem procura as recordações, reconheço que foi no campo acadêmico onde tive muito sucesso e algumas impossibilidades momentâneas. O sucesso aparece quando alcanço o maior nível de escolaridade e titulação no âmbito da carreira docente, já algumas impossibilidades surgem no momento que resolvo fazer política na própria instituição universitária. Nesse campo, em particular, conheci pessoas muito inteligentes, e outras, que pensam ser inteligentes. Também tive contato com alguns líderes carismáticos, outros, vaidosos, mentirosos contumaz e hipócritas. Porém, todos, inevitavelmente, seres humanos em suas singularidades, importantes para a compreensão mais geral do próprio campo sempre em disputa. 
De algum modo, expresso nesta tese um discurso sobre as diferentes formas de sociabilidades educacionais requeridas na minha trajetória para contornar as situaçõesperigo, modeladas pelos percalços encontrados na infância e na vida adulta. A essa altura do fechamento deste trabalho científico, percebo que, de um lado, meu capital cultural está objetivado nos meus livros adquiridos e por mim produzidos, minha dissertação e minhas teses. A esses produtos, devo meus progressos escolares, que é uma outra forma de capital cultural adquirido a longo prazo, expresso, inclusive, por meio de certificados e diplomas. Por outro lado, nada disso seria possível se eu não tivesse ingressado no campo artístico; sobretudo, na arte de matriz africana, que eu chamaria de capital cultural mais denso e significativo, de onde tudo parece ter originado como herança étnica.

Todavia, não é exagero afirmar que este trabalho resguarda em seu conjunto razoáveis lacunas e imperfeições. As lacunas são próprias de um trabalho onde não conseguimos, como na maioria das vezes, a apreensão do todo social de uma vida, ainda que disponhamos dos instrumentos objetivos e subjetivos para a realização da pesquisa. As imperfeições estão na ordem da própria relação sujeito-objeto aqui imposta, está na ocorrência das inferências exageradas e aligeiradas com que realizei a discussão sobre a autonarrativa, por exemplo. Mesmo assim, tenho clareza de que ao finalizar este trabalho estou deixando uma possível fonte para a interpretação de vários aspectos de uma vida e que pode ajudar na modelagem de outros trabalhos científicos.

Chegando ao final desta conclusão, espero ter cumprido uma parte significativa da minha trajetória, especialmente ser aprovado neste processo de promoção na carreira, e que esses escritos sirvam de inspiração para outros intelectuais que almejam a titulação por mim defendida. Além disso, espero que os aspectos teóricos e os procedimentos apresentados joguem um pouco mais de luz aos elementos empíricos da (auto)biografia enquanto método de pesquisa, tudo isso porque o estudo em tela reflete uma trajetória de transformações importantes, notadamente a maneira como um intelectual se forma desde as séries iniciais do processo de escolarização. É nesse aspecto onde o método aqui empregado confere significativo contributo, uma vez que é possível entender a formação humana e formação profissional de maneira indissociável.

Nessa perspectiva autobiográfica, é possível compreender também como sei o que aprendi. Quais foram os parâmetros da aprendizagem e modelos de referência para que eu acumulasse os saberes que possuo e, inevitavelmente, como construí o conhecimento que tenho e a minha identidade profissional enquanto docente? Esses aspectos são importantes porque têm impacto na minha formação humana, bem como na maneira como compreendo e faço ciência na sociedade brasileira, afinal sempre entendi que estudar não era uma questão de inteligência, apesar de quando criança imaginar que a inteligência passava, necessariamente, pelas mãos. Logo cedo comecei a compreender que estudar era uma questão de disciplina, de responsabilidade para com os meus desejos, as tarefas e atividades a mim atribuídas. Atividades que eu deveria cumprir. E a minha biografização assim o indica.

Considerando tudo o que foi dito nestes escritos, estou oficialmente me apresentando e dando espaço para que a instituição, a qual estou vinculado no momento, conheça minhas origens e intencionalidades; inclusive, para que conheça minha percepção sobre meu itinerário durante os 27 anos de atividades docentes. $E$ ainda consiga conhecer a minha percepção sobre a vida e o meu balanço provisório dessa 
experiência. E a julgar pelo exame aqui exposto, é importante que tudo isso possa ser absorvido como tema de investigação nos Programas de Pós-Graduação em Educação e no Mestrado em Gerontologia, locais onde tenho orientado algumas pesquisas, no âmbito da Universidade Federal de Pernambuco.

Por fim, para os desfechos pretendidos, afirmo que chegar a ser professor titular de uma das melhores universidades do país é, a meu ver, um privilégio fora da curva histórica com que vários dos meus contemporâneos estão às margens. É ter também muita dedicação e sorte na vida. Dedicação porque sistematizar os estudos pede isso. Sorte, porque é preciso um clima político, social, cultural e econômico propício ao êxito da astúcia. É aproveitar integralmente as brechas deixadas pela sociedade racista e preconceituosa, que não dá as mesmas condições de oportunidade para todos e, por fim, desenvolver táticas de sobrevivência em meio às múltiplas e tensas relações interpessoais, mesmo tendo nascido à luz de um candeeiro.

\section{Referências}

A POLÍTICA com "P" maiúsculo. Blog Inaldo Sampaio, 23 fev. 2015. Disponível em: http://www.inaldosampaio.com.br/professor-de-origem-negra-entra-na-disputa-pelareitoria-da-ufpe/ 23/02/2015. Acesso em: 15 dez. 2018.

ALMEIDA, João Ferreira de; PINTO, José Madureira. A investigação nas ciências sociais. Lisboa: Presença, 1995.

ALHEIT, Peter. "Biografização" como competência-chave na modernidade. Educação e Contemporaneidade, Salvador, v. 20, n. 36, 2011, p. 31-41.

ARÓSTEGUI, Júlio. A pesquisa histórica: teoria e método. Bauru: Edusc, 2006.

ALBUQUERQUE JR., Durval Muniz de. História, a arte de inventar o passado: ensaio de teoria da história. Bauru: Edusc, 2007.

ALBERTI, Verena. História dentro da história. In: PINSKY, Carla Bassanezi (org.). Fontes históricas. São Paulo: Contextos, 2015.

BOFF, Leonardo. A águia e a galinha: uma metáfora da condição humana. Petrópolis: Vozes, 2014.

BORGES, Vavy Pacheco. Fontes biográficas: grandezas e misérias da biografia. In: PINSKY, Carla Bassanezi (org.). Fontes históricas. São Paulo: Contextos, 2015.

BOSI, Ecléa. Memória e sociedade: lembranças de velhos. São Paulo: Companhia das Letras, 1994.

BOURDIEU, Pierre. O poder simbólico. Lisboa: Difel, 1989.

BOURDIEU, Pierre. Campo de poder, campo intelectual: itinerario de un concepto. Buenos Aires: Montressor, 2002.

BOURDIEU, Pierre. Coisas ditas. São Paulo: Brasiliense, 2004.

BOURDIEU, Pierre. Esboço de auto-análise. São Paulo: Companhia das Letras, 2005.

BOURDIEU, Pierre. A ilusão biográfica. In: FERREIRA, Marieta de Moraes; AMADO, Janaína (org.). Usos e abusos da história oral. Rio de Janeiro: FGV, 2006.

BOURDIEU, Pierre. A economia das trocas simbólicas. São Paulo: Perspectiva, 2007.

BOURDIEU, Pierre. A distinção: crítica social do julgamento. São Paulo: Edusp; Porto Alegre, Zouk, 2007a. 
BOURDIEU, Pierre. Razões práticas: sobre a teoria da ação. Campinas: Papiros, 2011.

BOBBIO, Norberto. Os intelectuais e o poder: dúvidas e opções dos homens de cultura na sociedade contemporânea. São Paulo: Unesp, 1997.

BRIÃO, Gabriela Félix. Eu, uma professora de matemática em jornada narrativa em busca de meus eus-professores em autoformação. Rio Claro: Unesp, 2017. 321f. Tese (Doutorado em Educação Matemática). Universidade Estadual Paulista Júlio de Mesquita.

BRITTO, Augusto César Luiz; CORRADI, Analaura. Considerações teóricas e conceituais sobre arquivos pessoais. Ponto de Acesso, Salvador, v. 11, n. 3, 2017, p. 148-169.

BUENO, Belmira Oliveira. O método autobiográfico e os estudos com histórias de vida de professores: a questão da subjetividade. Educ. Pesqui., São Paulo, v. 28, n. 1, 2002.

CAFFAGNI, Carla Wanessa do Amaral. Pelos olhos de Alice: ancestralidade afroameríndia, ambientalismo e formação - uma tese de ficção autobiográfica. São Paulo: USP, 2016. 351f. Tese (Doutorado em Educação). Universidade de São Paulo.

CALLIGARIS, Contardo. Verdades de autobiografias e diários íntimos. Revista Estudos Históricos, v. 11, n. 21, 1998, p. 44-58.

CARINO, Jonaedson. A biografia e sua instrumentalidade educativa. Educ. Soc., Campinas, v. 20 n. 67, 1999.

CERTEAU, Michel de. A invenção do cotidiano: artes de fazer. Petrópolis: Vozes, 1998.

CERTEAU, Michel de. A escrita da história. Rio de Janeiro: Forense Universitária, 2002.

CIDADE NEGRA. A estrada. Youtube, 8 nov. 2017 Disponível em: https://www.youtube.com/watch?v=01QP2IHsgPk. Acesso em: 20 jun. 2020.

CORRÊA, Ana Maria Maciel. A trajetória de uma educadora e sua produção didáticopedagógica: Ester Nunes Bibas e a educação do Pará. Curitiba: CRV, 2018.

CORRÊA, Ivan Livindo de Senna. Cultura corporal afro-brasileira na escola: resistência e perspectiva de estudantes do Ensino Médio. Cadernos do Aplicação, Porto Alegre, v. 25, n. 1, 2012, p. 81-105.

COSTA, Alex Augusto Mesquita. Atuação de um guitarrista em salvador: pesquisa autobiográfica docente. Salvador; UFBA, 2017. 403f. Tese (Doutorado em Música Popular). Universidade Federal da Bahia.

COSTA, Marcos André Nunes; SOUZA, Edilson Fernandes de. Memória da copa do mundo em Pernambuco: os documentos e o monumento. Recife: Cepe, 2018.

COSTA, Patrícia Cláudia da. Auto-hermenêutica em entrevistas autobiográficas. Revista Brasileira de Pesquisa (Auto)Biográfica, Salvador, v. 1, n. 1, 2016, p. 75-88.

CUNHA, Djenane Sichieri Wagner. Escrita autobiográfica e autoria em memoriais de professores de língua portuguesa. São Paulo: PUC, 2013. 189f. Tese (Doutorado em Língua Portuguesa). Pontifícia Universidade de São Paulo.

CUNHA, Jorge Luiz da. Escrever histórias para convencer os outros: memórias, diários e cartas de imigrantes. Revista Brasileira de Pesquisa (Auto)Biográfica, v. 3, n. 7, 2018, p. 235-256.

DELORY-MOMBERGER, Christine. Abordagens metodológicas na pesquisa biográfica. Revista Brasileira de Educação, v. 17, n. 51, 2012, p. 523-740.

DELORY-MOMBERGER, Christine. A pesquisa biográfica ou a construção compartilhada de um saber do singular. Revista Brasileira de Pesquisa (Auto)biográfica, Salvador, v. 1, n. 1, 2016, p. 133-147. 
DENDASCK, Carla Viana; LOPES, Gileade Ferreira. Conceito de habitus em Pierre Bourdieu e Norbert Elias. Revista Científica Multidisciplinar do Conhecimento, v. 3, n. 1, 2016, p. 1-10.

DUNNING, Eric. Prefacio. In: ELIAS, Norbert; DUNNING, Eric. Deporte y ocio en el proceso de la civilizacion. Fondo de Cultura Económica, 1995.

EAKIN, Paul John. Vivendo autobiograficamente: a construção da identidade na narrativa. São Paulo: Letra e Voz, 2019.

ECO, Umberto. Como se faz uma tese. São Paulo: Perspectiva, 1994.

ELIAS, Norbert; DUNNING, Eric. A busca da excitação. Lisboa: Difel, 1992.

ELIAS, Norbert. O processo civilizador: formação do Estado e civilização. Rio de Janeiro: Jorge Zahar, 1993.

ELIAS, Norbert. A sociedade dos indivíduos. Rio de Janeiro: Jorge Zahar, 1994a.

ELIAS, Norbert. O processo civilizador: uma história dos costumes. Rio de Janeiro: Zahar, 1994b.

ELIAS, Norbert. Mozart, sociologia de um gênio. Trad. de Sérgio Góes de Paula. Rio de Janeiro: Jorge Zahar, 1995.

ELIAS, Norbert. Os alemães: a luta pelo poder e a evolução do habitus nos séculos XIX e XX. Rio de Janeiro: Zahar, 1997.

ELIAS, Norbert. Envolvimento e alienação. Rio de Janeiro. Bertrand Brasil, 1998.

ELIAS, Norbert. Norbert Elias por ele mesmo. Rio de Janeiro: Jorge Zahar, 2001.

ELIAS, Norbert. Introdução à sociologia. Lisboa: Edições 70, 2005.

ELIAS, Norbert; SCOTSON, John L. Os estabelecidos e os outsiders: sociologia das relações de poder a partir de uma pequena comunidade. Rio de Janeiro: Zahar, 2000.

ESPÍRITO SANTO, Antônio Carlos Gomes do; SOUZA, Edilson Fernandes de; MOREIRA, Rafael da Silveira (org.). Tópicos em gerontologia. Curitiba: CRV, 2018.

EFS-LATTES. (Edilson Fernandes de Souza). Plataforma Lattes. CNPq. Disponível em: http://lattes.cnpq.br/3329563140947244. Acesso em 24 nov. 2018.

FALCÃO, Christiane Rocha. Ele já nasceu feito: o lugar da criança no Candomblé. Recife: UFPE, 2014.

FERREIRA, Luiz Carlos Pinheiro. Mo(vi)mentos autobiográficos: historiando fragmentos narrativos de experiências de vida docente e discente em artes visuais. Goiânia: UFG, 2015. 329f. Tese (Doutorado em Arte e Cultura Visual). Universidade Federal de Goiás.

FERREIRA, Francisco Renato Silva et. al. Processos de ensino e aprendizagem: um estudo sobre a aplicação da dança afro-brasileira no espaço das aulas de ginástica em Juazeiro do Norte. Id On Line Rev. Mult. Psic., v. 13, n. 45, 2019, p. 462-488.

FONSECA, Elisabete Martins da. Imaginário e formação de educadores: a narrativa de si. São Paulo: USP, 2016. 183f. Tese (Doutorado em Educação) Universidade de São Paulo.

FRANCHI, Ana Paula. O Discurso panegírico e a legitimação do poder no século IV D.C. Revista Vernáculo, n. 19 e 20, 2007, p. 99-108.

FRANKLIN, Cynthia G. Academic lives: memoir, cultural theory, and the university today. Georgia, London: The University of Georgia Press Athens, 2009.

FREIRE, Paulo. Pedagogia do oprimido. Rio de Janeiro: Paz e Terra, 2005. 
GOODSON, Ivor F. Narrativas em educação: a vida e a voz dos professores. Porto: Porto Editora, 2015.

GOFFMAN, Erving. Manicômios, prisões e conventos. São Paulo: Perspectiva, 1974.

GOFFMAN, Erving. A representação do eu na vida cotidiana. Petrópolis: Vozes, 1985.

GUERRA FILHO, Raulito Ramos. FLORianópolisNOSãojoséodosCAMPOS. Na mala, autobiografemas: sonoro, imagético e verbal. Campinas: Unicamp, 2016. 289f. Tese (Doutorado em Educação). Universidade Estadual de Campinas.

HALBWACHS, Maurice. A memória coletiva. São Paulo: Vértice, 1990.

HASS DA SILVA, Eduardo Cristiano; DUARTE, Ariane dos Reis; GRAZZIOTIN, Luciane Sgarbi Santos. Um ensaio biográfico: memórias do professor Sven Robert Schulze. Reflexão e Ação, Santa Cruz do Sul, v. 27, n. 3, 2019, p. 109-127.

HOLANDA, Lourival. Batuque: entre som e seu sentido. In: SOUZA, Edilson Fernandes de. Entre o fogo e o vento: as práticas de batuques e o controle das emoções. Recife: UFPE, 2010.

HOLLY, Mary Louise. Investigando a vida profissional dos professores: diários biográficos. In: NÓVOA, António (org.). Vida de professores. Porto: Porto Editora, 2013.

LANZI, Lucirene Andréa Catani. A autobiografia como metodologia para uma história da disciplina arte no Brasil: vida e formação de uma arte/educadora. Marília: Unesp, 2016. 305f. Tese (Doutorado em Educação). Universidade Estadual Paulista.

LEITE, Leni Ribeiro; CARVALHO, Luiza Helena Rodrigues de Abreu. O panegírico como proposta de redação e seu caráter argumentativo. Acta Scientiarum. Language and Culture, v. 40, 2018.

LEVI, Giovanni. Usos da biografia. In: FERREIRA, Marieta de Moraes; AMADO, Janaína (Org). Usos e abusos da história oral. Rio de Janeiro: FGV, 2006.

LIMA, Augusto. Samba, história e a questão racial e social. In: BRAZ, Marcelo (org.). Samba, cultura e sociedade: sambistas e trabalhadores entre a questão social e a questão cultural no Brasil. São Paulo: Expressão Popular, 2013.

LIRA, Maria Helena Câmara. O homem que orienta paixões. Blog Gargalhadas e Lágrimas: entre o inseto e 0 inseticida, 25 abr. 2015. Disponível em https://gargalhadaslagrimas.wordpress.com/2015/04/25/o-homem-que-orienta-paixoes/. Acesso em 25 ago. 2019.

LOPES, Laryssa Grazielle Feitosa; SOUZA, Edilson Fernandes de. A violência contra a pessoa idosa: entre paradigmas e agravos de notificação. In: ESPÍRITO SANTO, Antônio Carlos Gomes do; SOUZA, Edilson Fernandes de; MOREIRA, Rafael da Silveira (org.). Tópicos em gerontologia. Curitiba: CRV, 2018.

MALATIAN, Teresa. Narrador, registro e arquivo. In: PINSKI, Carla Bassanezi; LUCA, Tania Regina de (org.). O historiador e suas fontes. São Paulo: Contexto, 2015.

MARQUES, Valéria; SATRIANO, Cecília. Narrativa autobiográfica do próprio pesquisador como fonte e ferramenta de pesquisa. Linhas Críticas, Brasília, v. 23, n. 51, 2017, p. 369386.

MAUAD, Ana Maria. Através da imagem: fotografia e história interfaces. Tempo, Rio de Janeiro, v. 1, n. 2, 1996, p. 73-98.

MAUSS, Marcel. Sociologia e antropologia. São Paulo: Edusp, 1974.

MILLS, C. Wright. A imaginação sociológica. Rio de Janeiro: Zahar, 1982. 
MUNANGA, Kabengele. O Universo cultural africano. In: MUNANGA, Kabengele. ÁfricaBrasil; história, política, economia. Belo Horizonte: Fundação João Pinheiro, 1984.

NÓBREGA, Terezinha Petrúcia da. In: SOUZA, Edilson Fernandes de. Entre o fogo e o vento: as práticas de batuques e o controle das emoções. Recife: UFPE, 2005.

NÓVOA, António (org.). Vida de professores. Porto: Porto Editora, 2013.

OLIVEIRA, Vânia da Silva. Ara-İtàn: a dança de uma rainha, de um carnaval e de uma mulher. Salvador: UFBA, 2016. 182f. Dissertação. (Mestrado em Dança). Universidade Federal da Bahia.

PASSEGGI, Maria da Conceição; SOUZA, Elizeu Clementino de; VICENTINI, Paula Perin. Entre a via e a formação: pesquisa (auto)biográfica, docência e profissionalização. Educação em Revista, Belo Horizonte, v. 27, n. 1, 2011, p. 369-386.

PAZ, Jailson. Menino negro e pobre tornou-se doutor quando afrodescendentes não entravam no ensino superior. Diário de Pernambuco, Recife, 17 de nov. 2015. Disponível em: http://www.diariodepernambuco.com.br/app/noticia/vidaurbana/2015/11/17/interna_vidaurbana,610680/menino-negro-e-pobre-tornou-se-doutorquando-afrodescendentes-nao-entravam-o-ensino-superior.shtml. Acesso em: 06 dez. 2018.

PEREIRA, Lígia Maria Leite. Algumas reflexões sobre histórias de vida, biografias e autobiografias. História Oral, v. 3, 2000, p. 117-127.

PERELMAN, Chaim; OLBRECHTS-TYTECA, Lucie. Tratado da argumentação: a nova retórica. São Paulo: Martins Fontes, 1996.

PIMENTA, João Paulo. Memorial acadêmico (concurso de livre-docência) - Faculdade de Filosofia, Letras e Ciências Humanas, Universidade de São Paulo, São Paulo, 2012. Disponível em: https://www.fflch.usp.br/sites/fflch.usp.br/files/201711/Joao_Paulo_Garrido_Pimenta.pdf. Acesso em: 23 jul. 2019.

PICHILINGA, Elcio. Canto negro. [Poema]. (mimeogr.). Recife, 1983.

ROCHA, Yuri Tavares. Memorial: monografia (para o nível de professor doutor 2) Departamento de Geografia, Faculdade de Filosofia, Letras e Ciências Humanas, Universidade de São Paulo, São Paulo, 2011. Disponível em: https://www.fflch.usp.br/sites/fflch.usp.br/files/2017-11/Yuri_Rocha.pdf. Acesso em: 23 jul. 2019.

ROSENTHAL, Gabriele. A estrutura e a gestalt das autobiografias e suas consequências metodológicas. In: FERREIRA, Marieta de Moraes; AMADO, Janaína (org.). Usos e abusos da história oral. Rio de Janeiro: FGV, 2006.

ROUSSEAU, Jean-Jacques. Confissões. Bauru: Edipro, 2008.

SANTIAGO, Bruna Gomes e FRANCO, Neil. Dança na revista brasileira de ciências do esporte (1979-2014). Motrivivência, v. 27, n. 45, 2015, p. 189-208.

SAVIANI, Dermeval. Breves considerações sobre fontes para a história da educação. Revista HISTEDBR on-line, Campinas, n. especial, 2006, p. 28-35.

SAVIANI, Dermeval. Intelectuais, memória e política. Revista HISTEDBR on-line, Campinas, n. 67, 2016, p. 141-153.

SALES, Jonas de Lima. Corporeidades negras em cena - um processo cênico-pedagógico em diálogos com a tradição e a contemporaneidade. Brasília: UNB, 2015. 255f. Tese (Doutorado em Arte). Universidade de Brasília. 
SETTON, Maria da Graça Jacintho. A teoria do habitus em Pierre Bourdieu: uma leitura contemporânea. Rev. Bras. Educ., Rio de Janeiro, n. 20, 2002, p. 60-70.

SETTON, Maria da Graça Jacintho. Socialização de habitus: um diálogo entre Norbert Elias e Pierre Bourdieu. Rev. Bras. Educ., Rio de Janeiro, v. 23, 2018, p. 1-23.

SILVA, Haike Roselane Kleber da. Considerações e confusões em torno de história oral, história de vida e biografia. Métis: História e Cultura, Caxias do Sul, v. 1, n. 1, 2002, p. 2538.

SILVA, José Bento Rosa da. Do semba ao samba: um jeito de ser no mundo. In: SOUZA, Edilson Fernandes de. Ensaios da civilização no samba. Curitiba: CRV, 2018.

SILVA, Patrícia Petitinga. Estudei a vida e a vida ofereceu-me o ensino: trajetórias identitárias de uma professora-pesquisadora que ensina ciências. Salvador: UFBA/Feira de Santana/UEFS, 2017. 133f. Tese (Doutorado em Ensino, Filosofia e História das Ciências). Universidade Federal da Bahia; Universidade Estadual de Feira de Santana.

SILVA, Wilton Carlos Lima. A vida, a obra, o que fala, o que sobra: memorial acadêmico, direitos e obrigações da escrita. Revista Tempo e Argumento, Florianópolis, v. 7, n. 15, 2015, p. 103-136.

SILVEIRA, Éder da Silva. Por que ele? Reflexões sobre o percurso e os bastidores de uma biografia histórica. Revista Brasileira de Pesquisa (Auto)biográfica, Salvador, v. 1, n. 3, 2016, p. 467-479.

SOUSA, Vera Luísa de. Histórias de vida e narrativa como possibilidades da escuta de si. Presidente Prudente: Unesp, 2016. 204f. Tese (Doutorado em Educação). Universidade Estadual Paulista.

SHERIFF, Edilson. (Edilson Fernandes de Souza). A dança afro primitivo - DAP. Rio de Janeiro, (mimeogr.), 1991 a.

SHERIFF, Edilson. Resgatar a dança afro-primitivo dentro do contexto sócio-cultural. CONGRESSO BRASILEIRO DE CIÊNCIAS DO ESPORTE, 13, 1991. Anais ... Uberlândia: UFU, 1991b. Disponível em: http://revista.cbce.org.br/index.php/RBCE/issue/view/60. Acesso em: 2 set. 2019.

SOUZA, Edilson Fernandes de. A dança afro primitiva. Arapongas: FFCLA, 1991a. $30 f$. Monografia (Especialização em Pedagogia do Movimento Humano). Faculdade de Filosofia, Ciências e Letras de Arapongas.

SOUZA, Edilson Fernandes de. A dança afro primitiva. Sprint, Rio de Janeiro, v. 10, n. 53, 1991b, p. 31-22.

SOUZA, Edilson Fernandes de. A dança afro primitivo: uma proposta humanista. ENCONTRO NACIONAL DE RECREAÇÃO E LAZER, 1, 1991c, Brasília. Anais... Brasília: GDF/SCE, 1991C.

SOUZA, Edilson Fernandes de. A Expansão da dança afro na UFU. CONGRESSO BRASILEIRO DE CIÊNCIAS DO ESPORTE, 15, 1993. Anais ... Belém: Uepa, 1993. Disponível em http://revista.cbce.org.br/index.php/RBCE/issue/view/67. Acesso em: 2 set. 2019.

SOUZA, Edilson Fernandes de. A Reinvenção da tradição afro-brasileira através do movimento humano. REUNIÃO ANUAL DA SBPC, 46, 1994. Anais ... Vitória: Ufes, 1994.

SOUZA, Edilson Fernandes de. Representações sociais da cultura negra através da dança e de seus atores. Rio de Janeiro: UGF, 1995. 183f. Dissertação (Mestrado em Educação Física). Universidade Gama Filho. 
SOUZA, Edilson Fernandes de. Dança afro e representações sociais: relatório de um estudo para subsidiar proposta de conteúdo em Educação Física. CONGRESSO LATINOAMERICANO DE ESPORTE, EDUCAÇÃO E SAÚDE NO MOVIMENTO HUMANO, 3, 1996. Anais ... Foz do Iguaçu: Unicamp/Unioest, 1996.

SOUZA, Edilson Fernandes de. Dança dos mitos: um estudo sobre a dança afro e o controle das emoções no desenvolvimento da sociedade brasileira. CONGRESSO MUNDIAL DE EDUCAÇÃO FÍSICA, 1, 1997. Anais ... Rio de Janeiro: Aiesep/UGF, 1997.

SOUZA, Edilson Fernandes de. Entre o fogo e o vento: as práticas de batuques e 0 controle das emoções. Campinas: Unicamp, 1998. 247f. Tese (Doutorado em Educação Física) Universidade Estadual de Campinas.

SOUZA, Edilson Fernandes de. Proibição de batuques no século XIX: a etiqueta religiosa presente em seu discurso. Revista Brasileira de Ciências do Esporte, ano 21, v. 1, 1999, p. 1329-1334.

SOUZA, Edilson Fernandes de. Etnografia e história da dança litúrgica e artística no Rio de Janeiro. CONGRESSO BRASILEIRO DE HISTÓRIA DA EDUCAÇÃO, ESPORTE, LAZER E DANÇA, 7, 2000. Anais ... Porto Alegre: Ufrgs/Esef, 2000.

SOUZA, Edilson Fernandes de. Os outsiders afro-brasileiros e suas danças ancestrais. ArtCultura, v. 4, n. 5, 202, p. 46-55.

SOUZA, Edilson Fernandes de. Representações de afro-brasileiros: depoimentos de dançarinos-atores. Recife: UFPE, 2008.

SOUZA, Edilson Fernandes de; SIMÕES, José Luís; LUCENA, Ricardo Figueiredo (org.). Escritos a partir de Norbert Elias. Recife: UFPE, 2009.

SOUZA, Edilson Fernandes de. A Arte de orientar no uso dos métodos e das fontes. In:SOUZA, Edilson Fernandes de (org.). Histórias e memórias da educação em Pernambuco. Recife: UFPE, 2009a.

SOUZA, Edilson Fernandes de. Edilson Fernandes de Souza (depoimento, 2009). Entrevista concedida a Isabel Guillen e Ivaldo Marciano. Projeto Ritmos, Cores e Gestos da Negritude Pernambucana. 22 jun. 2009b. Disponível em https://www3.ufpe.br/negritude/index.php?option=com_content\&view=article\&id=332\%3Ae dilson-fernandes-de-souza\&catid=30\&ltemid=244. Acesso em 06/12/2018, às 07h30.

SOUZA, Edilson Fernandes de. Norbert Elias: uma teoria desconectada à realidade brasileira - balançando o chicote. In: SOUZA, Edilson Fernandes de; SIMÕES, José Luís; LUCENA, Ricardo Figueiredo (org.). Escritos a partir de Norbert Elias. Recife: UFPE, 2009c

SOUZA, Edilson Fernandes de. Entre o fogo e o vento: as práticas de batuques e o controle das emoções. Recife: UFPE, 2010.

SOUZA, Edilson Fernandes de; SIMÕES, José Luís; LUCENA, Ricardo Figueiredo (org.). Mozart e seu habitus maníaco-depressivo em Viena: uma análise sócio-educacional da depressão. In: SOUZA, Edilson Fernandes de; SIMÕES, José Luís; LUCENA, Ricardo Figueiredo (org.). Escritos a partir de Norbert Elias. Recife: UFPE, 2010. v. 2.

SOUZA, Edilson Fernandes de; FIGUEIREDO, Haroldo Moraes de; CAVALCANTE, Márcio Eustáquio Lopes. Violência e lazer nos bairros do lbura e Nova Descoberta. Recife: UFPE, 2012.

SOUZA, Edilson Fernandes de; SENA, Izabel Adriana Gomes de; SIMÕES, José Luís (Org.). Histórias e memórias da educação em Pernambuco. Recife: UFPE, 2014. v. 2. 
SOUZA, Edilson Fernandes de; SIQUEIRA; Marcos Roberto C. de; MALTA, Jonathas Eduardo Luna. Memórias de um autodidata: Carmelo de Castro e o culto ao corpo em Pernambuco. In: SOUZA, Edilson Fernandes de; SENA, Izabel Adriana Gomes de; SIMÕES, José Luís (org.). Histórias e memórias da educação em Pernambuco. Recife: UFPE, 2014.

SOUZA, Edilson Fernandes de. Ensaios da civilização no samba. Curitiba: CRV, 2018.

SOUZA, Edilson Fernandes de. Minha arte de artista outsider na sublimação de cientista e constructo do 'eu' fonte. JORNADA DE ESTUDOS ELIASIANOS, 2, 2019. Anais ... Boipeba: Uneb/IFB, 2019.

SOUZA, Edilson Fernandes de. Quais desafios resguardam o projeto de Universidade que atenda a sociedade brasileira? In: PORTO, Zélia Granja et al. (org.). Memória do congresso UFPE em debate. Recife: Nectar, 2019a.

SOUZA, Edilson Fernandes de. Tese autobiográfica: os procedimentos para o constructo do 'eu' fonte. Revista Brasileira de Pesquisa (Auto)Biográfica, Salvador, v. 5, n. 14, 2020, p. 777-795. Disponível em https://revistas.uneb.br/index.php/rbpab/article/view/7815. Acesso em 20 de jun. 2020.

SOUZA, Elizeu Clementino de. (Auto)Biografia, identidades e alteridade: modos de narração, escritas de si e práticas de formação na pós-graduação. Revista Fórum Identidades, ano 2, v. 4, 2008, p. 37-50. Disponível em: https://seer.ufs.br/index.php/forumidentidades/article/view/1808. Acesso em: 7 ago. 2019.

SOUZA, Elizeu Clementino de; PASSEGGI, Maria da Conceição. Apresentação. Educação em Revista, Belo Horizonte, v. 27, n. 1, 2011, p. 327-332. Disponível em: http://www.scielo.br/scielo.php?script=sci_arttext\&pid=S0102-

46982011000100014\&Ing=en\&nrm=iso. Acesso em: 31 jul. 2019.

SUASSUNA, Dulce Figueira. Prefácio à terceira edição. In: SOUZA, Edilson Fernandes de. Entre o fogo e o vento: as práticas de batuques e o controle das emoções. Recife: UFPE, 2010.

THOMPSON, Paul Richard. A voz do passado: história oral. Rio de Janeiro: Paz e terra, 1992.

TRINDADE, Solano. Sou negro. [Poema]. Vermelho: a esquerda bem informada. 18 nov. 2011. Disponível em: https://vermelho.org.br/2011/11/18/sou-negro/. Acesso em: 6 maio 2018.

UFPE. Resolução 3/2014. Recife: UFPE, 2014.

UNWIN, Maria del Pilar Troncoso. Linguagem autobiográfica na construção da identidade: de falante nativa a educadora. Taubaté: Unitau, 2008. 105f. Dissertação (Mestrado em Linguística Aplicada). Universidade de Taubaté.

VELANDIA MORA, Manuel Antônio. De la autobiografia a la autoetnografia como herramienta para el estudio de sí mesmo. España: Universidad del País Vasco, 2010. 159f. Tesis (Douctorado em Psicopedagogía). Universidad del País Vasco.

\section{Arquivos institucionais}

Universidade Federal de Pernambuco/Progepe. Pasta de assentamento funcional. Edilson Fernandes de Souza. Vários documentos. UFU-UFPE, 1993-2020.

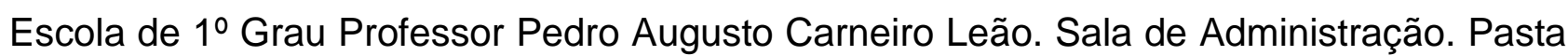
Individual de Aluno. Letra E, 1977-1979. Requerimento de matrícula (5 $\left.5^{\mathrm{a}} 8^{\mathrm{a}}\right)$, histórico 
escolar, ficha individual de aluno e documentos da Escola Centro Educativo Operário Agamenon Magalhães, 1976.

Escola de Referência em Ensino Médio de Beberibe. Livro ata dos resultados finais da $8^{\mathrm{a}}$ série "B" do turno $2^{\circ}$ do $1^{\circ} \mathrm{Grau}$. Recife/PE

Escola Epitácio Pessoa. Sala arquivo de documentação. Caixa -64, de 3902 a 3969 Arquivo 3945. E-05. Vários documentos. Cabo de Santo Agostinho/PE

Escola Técnica Estadual Almirante Soares Dutra. Sala de apoio técnico. Ata de resultados finais do rendimento escolar do ano de 1983. $3^{a}$ série. Auxiliar de Enfermagem "E". Turno da Tarde do $2^{\circ}$ Grau. Recife/PE.

Escola Santo Inácio de Loyola. Arquivo permanente. Ficha individual curso de $2^{\circ}$ Grau. Vários documentos, 1981-1982.

Escola Municipal de 1ํ Grau Marechal Arthur da Costa e Silva. Registro de frequência, Classe 3 ${ }^{a}$. novembro, 1975. Jaboatão dos Guararapes/PE.

\section{Arquivo pessoal}

Procuração ao Sr. Ademir Schimidt para realizar matrícula no Programa de Pósgraduação em Educação Física Estudos do Lazer da Unicamp. Americana/SP. 1997.

Diploma de Graduação em Educação Física. Universidade Castelo Branco/RJ. 1998.

Diploma de Doutorado em Educação Física/Estudos do Lazer. Universidade Estadual de Campinas, 1999.

Declaração de Término do Curso com Disciplinas Cursadas. Grupo Palestra Sport. Faculdade de Educação Física de Arapongas/PR, 1991.

Portaria de Nomeação de Chefe de Setor. Universidade Federal de Uberlândia/MG, 1993.

Certificado de Conclusão do Mestrado em Educação Física. Universidade Gama Filho/RJ, 1995.

Declaração de Conclusão do Estágio Pós-Doutoral. Faculdade de Letras. Universidade do Porto, 2010.

Crachá da Associação dos Cronistas de Pernambuco (ACDP), 2010.

Monografia de Dança Afro Primitivo (DAP). Edilson Sheriff. Rio de Janeiro. (mimeogr.), 1991.

Carteira de estudante da Associação Pernambucana de Serviços Educacionais. Escola Santo Inácio de Loyola. $2^{\mathrm{a}}$ Série "C" do $2^{\circ} \mathrm{Grau}, 1982$.

Fotografia Dança Afro. Edilson Sheriff (Fernandes de Souza). Fotógrafa Cleidimar do Studio Baila. Apresentação Pública. Praça Rui Barbosa- Uberaba/MG, 1989.

Fotografia Dança Afro. Edilson Sheriff (Edilson Fernandes de Souza). Fotógrafo Desconhecido. Apresentação no Painel de Dança. Faculdades Integradas Castelo Branco/RJ, 1989.

Fotografia de Formatura. Licenciatura em Educação Física. Fotógrafa Dulcinéa Silva. Teatro João Caetano, Rio de Janeiro/RJ, 1991. 


\section{Fontes orais}

Edilson Fernandes de Souza. Autonarrativa. Gravação em 30 de dezembro de 2018, na residência, cidade do Recife. Captação do áudio realizado pelo autobiógrafo. Título: Primeira gravação. Tempo de 00:52:08,16.

Edilson Fernandes de Souza. Autonarrativa. Gravação em 31 de dezembro de 2018, na residência, cidade do Recife. Captação do áudio realizado pelo autobiógrafo. Título: Biografia, fala 2. Tempo de 00:44:11,34.

Edilson Fernandes de Souza. Autonarrativa. Gravação em 02 de janeiro de 2019, na residência, cidade do Recife. Captação do áudio realizado pelo autobiógrafo. Título: Biografia, fala 3. Tempo de 00:53:05,47.

Edilson Fernandes de Souza. Autonarrativa. Gravação em 11 de janeiro de 2019, na residência, cidade do Recife. Captação do áudio realizado pelo autobiógrafo. Título: Escola, gravação 1. Tempo de 00:55:18,71.

Edilson Fernandes de Souza. Autonarrativa. Gravação em 12 de janeiro de 2019, na residência, cidade do Recife. Captação do áudio realizado pelo autobiógrafo. Título: Escola e política. Tempo de 00:41:13,73.

Edilson Fernandes de Souza. Autonarrativa. Gravação em 23 de janeiro de 2019, na residência, cidade do Recife. Captação do áudio realizado pelo autobiógrafo. Título: Para Inaldete Pinheiro - Memória da Negritude Pernambucana. Tempo de 00:42:25,62.

Edilson Fernandes de Souza. Autonarrativa. Gravação em 19 de julho de 2019, na residência, cidade do Recife. Captação do áudio realizado pelo autobiógrafo. Título: Largaram a mão 1. Tempo de 00:13:57,82.

Edilson Fernandes de Souza. Autonarrativa. Gravação em 24 de julho de 2019, na residência, cidade do Recife. Captação do áudio realizado pelo autobiógrafo. Título: UFU, Eleição diretor. Tempo de 00:10:08,00.

SOUZA, Edilson. Edilson Fernandes de Souza (depoimento, 2009). Recife, Laboratório de História Oral e da Imagem - Lahoi. Entrevistadores: Isabel Guillen e Ivaldo Marciano. Gravação realizada no Núcleo de Educação Física e Desportos/NEFD/UFPE. Tipo da entrevista: história oral de vida/temática. Tempo de 02:14:13,00.

\section{Fontes escritas}

Edilson Fernandes de Souza. Currículo Lattes. http://lattes.cnpq.br/3329563140947244. print realizado em 24/11/2018.

Edilson Fernandes de Souza. Entrevista à Isabel Guillen e Ivaldo Marciano. Projeto Ritmos, Cores e Gestos da Negritude Pernambucana. 22/06/2009. Disponível em https://www3.ufpe.br/negritude/index.php?option=com_content\&view=article\&id=332\%3Ae dilson-fernandes-de-souza\&catid=30\&ltemid=244. Acesso em 06/12/2018, às 07h30.

Blog Inaldo Sampaio. A Política com "P" Maiúsculo. Disponível em: http://www.inaldosampaio.com.br/professor-de-origem-negra-entra-na-disputa-pelareitoria-da-ufpe/ 23/02/2015. Acesso em 15/12/2018. Às 6h37

PAZ, Jailson. Menino negro e pobre tornou-se doutor quando afrodescendentes não entravam no ensino superior. Diário de Pernambuco, Pernambuco, 17 de nov. 2015. Disponível em: http://www.diariodepernambuco.com.br/app/noticia/vidaurbana/2015/11/17/interna_vidaurbana,610680/menino-negro-e-pobre-tornou-se-doutorquando-afrodescendentes-nao-entravam-o-ensino-superior.shtml. Acesso em 06/12/2018. 
Agência de Notícia/UFPE/Clipping/Diário de Pernambuco. UFPE tem disputa histórica ao cargo de reitor. 2015, p. a7. Disponível em: https://www3.ufpe.br/agencia/clipping/index.php?option=com_content\&view=article\&id=21 764:ufpe-tem-disputa-historica-pelo-cargo-de-reitor\&catid=732\&ltemid=228. Acesso em 22/07/2019.

\section{Fontes iconográficas}

Ritmos, cores e gestos da negritude pernambucana. Laboratório de história oral e da imagem. Lahoi/UFPE. Balé Primitivo de Arte Negra. Várias fotografias. Disponível em: https://www3.ufpe.br/negritude/images/galeria/bale_primitivo/foto\%2027.jpg. Acesso em: 09/08/2019. Dessa plataforma utilizei as fotografias de número 27, 31, 48 e 50.

Fotografia Solo de dança afro. Painel de Dança. Faculdades Integradas Castelo Branco. Rio de Janeiro, 1998. Acervo pessoal.

Fotografia de Formatura em Educação Física. Teatro João Caetano/RJ, 1991. Acervo pessoal.

Fotografia com professores no pátio das Faculdades Clarentianas, Batatais/SP, 1991. Acervo pessoal.

Fotografia no campus da UFPE. Fotógrafo Paulo Paiva. 2015. Acervo do Diário de Pernambuco.

Fotografia na sala de aula da Pós-Graduação em Educação, 2018. Fotógrafo e acervo Paulo Pergentino.

Fotografia de apresentação de dança afro. Praça Rui Barbosa, Uberaba/MG, 1989. Fotógrafa Cleidimar Studio Baila. Acervo pessoal.

Fotografia/retrato dos meus pais - Montagem de 2002. Fotógrafo desconhecido. Acervo de Lídia Pinto de Souza.

Fotografia aos 12 anos de idade, 1977. Fotógrafo desconhecido. Acervo da Escola de $1^{\circ}$ grau professor Pedro Augusto Carneiro Leão.

Fotografia aos 17 anos de idade, 1982. Fotógrafo desconhecido. Acervo da Escola Epitácio Pessoa.

Fotografia no estúdio. Ensaio. Rio de Janeiro, 1986. Acervo pessoal.

Edilson Fernandes de Souza é professor na Universidade Federal de Pernambuco. Orcid: https://orcid.org/0000-0002-8842-4304.

Endereço: Rua Presidente Washington Luiz, 85 - 50.720630 - Recife - PE - Brasil. E-mail: edilson.souza@ufpe.br.

Critérios de autoria: Edilson Fernandes de Souza concebeu o texto na sua integralidade.

Recebido em 19 de julho de 2021.

Aceito em 12 de agosto de 2021.

(c) (1) $\Theta(\Theta$ 